\title{
LINGUA MONTENEGRINA
}

časopis za jezikoslovna, književna i kulturna pitanja

LINGUA MONTENEGRINA

the magazine of linguistic, literary and cultural issues

God. VIII, sv. 1, br. 15

Izdavač

FAKULTET ZA CRNOGORSKI JEZIK I KNJIŽEVNOST

\author{
Redakcija \\ Josip Silić (Zagreb) \\ Vukić Pulević (Podgorica) \\ Milorad Nikčević (Osijek) \\ Amira Turbić-Hadžagić (Tuzla) \\ Aleksandra Nikčević-Batrićević (Podgorica) \\ Przemyslaw Brom (Katowice) \\ Milica Lukić (Osijek) \\ Jakov Sabljić (Osijek) \\ Vanda Babić (Zadar) \\ Ljudmila Vasiljeva (Lavov) \\ Čedomir Drašković (Cetinje) \\ Aleksandar Radoman (Podgorica) \\ Goran Drinčić (Podgorica) \\ Glavni i odgovorni urednik \\ Adnan Čirgić \\ Sekretar Redakcije \\ Nikola Popović
}

Cetinje, 2015. 



\section{Илија ВЕЛЕВ (Скопје)}

UDK 930.85:929Ćirilo, sveti 930.85:929Metodije, sveti

Pregledni rad

Универзитет „Св. Кирил и Методиј“ - Скопје

ilijavelev@yahoo.com

\section{СВ. КОНСТАНТИН-КИРИЛ И МЕТОДИЈ КАКО АФИРМАТОРИ НА СЛОВЕНСКАТА ЦИВИЛИЗАЦИЈА, КУЛТУРА И ПИСМЕНОСТ}

Научните проследувања се зановувани врз изворните истражувања на процесите што ја поттикнале афирмацијата на словенската цивилизација и култура, проникнати од периодот на големите преселби на народите од втората половина на VI век и се́ до заживувањето на кирилометодиевската традиција - кога се афирмирала третата христијанска цивилизација во Европа словенската (веднаш по римолатинската и византискогрчката).

Посебен акцент се посветува на проникнувањето на феноменот на словенската цивилизација и култура којшто го мотивирал процесот на симбиоза на повеќ ето основоположувани цивилизации и култури, при што како своевиден супстрат се рафинирал и словенскиот културноисториски колективитет и идентитет. Во таа насока клучна улога одиграла мисионерската и просветителската дејност на сесловенските просветители и рамноапостоли св. Константин-Кирил и Методиј.

Клучни зборови: Словенска цивилизација и кулӣу ра, Кириломейодиевски извори, Панонски легеенди, св.

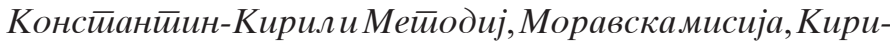

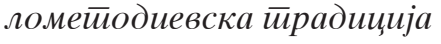

\section{Воведни напомени за проникнувањето на феноменот на словенската цивилизација и култура}

Проследувањето на словенскиот културноисториски идентитет во глобалниот контекст на човековото опстојување од неговото

* Predavanje održano 20. 2. 2015. godine na Fakultetu za crnogorski jezik i književnost na Cetinju povodom 21. februara - Dana maternjega jezika. 
историско проникнување, па се́ до современиот оформен колективитет, едноставно мора да се сообразува со феноменот на процесот на цивилизациското прелевање од една во друга епоха, или од еден до друг социолошки и културноисториски амбиент во времињата што поминале. Всушност, во која и да е географска средина назад низ вековите се премостувале повеќе основоположени цивилизации и култури, а притоа словенската самата од себе оставала своевиден супстрат како непресушен извор од кој современите словенски традиции (меѓу кои и јужнословенските - македонската, бугарската, српската, хрватската, словенечката, секако и црногорската) го напојуваат сопствениот културноисториски и национален идентитет. Конкретно на Балканот и пошироко во Југоисточна Европа овој процес на цивилизациско прелевање имал историски континуитет од антиката, преку римолатинското и византиско-христијанското глобално општество, па се́ до втемелувањето и афирмацијата на словенската цивилизациска свест за духовно и културно себеидентификување со словенскиот колективитет.

Обично во историографијата проникнувањето на словенската цивилизација и култура почнува да се анимира од периодот на т.н. голема преселба на народите (односно словенската колонизација), која се реализирала во раниот Среден век - од 80-тите години на VI и низ целиот VII век. Треба да се нагласи дека настанатата духовна и културна симбиоза на домородните (домицилни) населенија со доселените словенски племиња настапила под силното влијание на византиската глобализација. Притоа во актуелниот социолошко-културолошки амбиент станале мобилни два важни фактори: словенизирањето и христијанизацијата. Имено, процесот на словенизирање ги зафатил домородните населенија од колонизираните средини, а од друга страна пак, процесот на христијанизација ги истиснувал паганските традиционални духовни искуства на доселуваните словенски племиња како резултат на осмислената и функционална политичка доктрина, која требало да ја обезбеди лојалноста за интеграција на Словените во византискиот глобален свет.

Произнесената од наша страна историско-цивилизациска проекција најилустративно ја докажуваме преку исклучително сложените процеси што се одвивале на просторот на Македонија, зашто нивното недоволно социолошко или културолошко дообјаснување влијаеше, а и се́ уште влијае да се притемнува или да се оттуѓува македонското историско препознавање - па дури и се позајмуваат делови од нејзиниот идентитет и истите се вградуваат како приспо- 
Св. Константин-Кирил и Методиј...

собено искуство во современите темели на туѓите соседни национални традиции. Па така, словенскиот миграциски наплив предизвикал влијателни етнички промени на просторот на Македонија и пошироко на Балканот. Домородното (домицилно) македонско население, кое дотогаш било сообразено со византискиот духовен, културен и административно јазичен амбиент, дошло во ситуација да се вклучува во новата етничка симбиоза со словенските доселени племиња и по извесно време станало билингвално (односно трилингвално). Оттогаш на општествената сцена во Македонија почнало да стапува на сила надвладејувачката социолошка позиција на словенството како колективен идентитет. Овие глобални процеси биле сложени и се одвивале со забавено темпо во период од скоро три века. Имено, словенските колонизатори лесно ќе се адаптирале на христијанскиот духовен и културен свет под влијанието на контактите со домородното македонско население и со духовната библиска традиција, што била присутна на тлото на Македонија како ранохристијанско апостолско и византиско искуство. Но таа интеркултурна цивилизациска функција лесно не можела да се реализира, зашто доселеното паганско население тешко го совладувало восприемањето на византискогрчката јазична и писмена комуникација. Требало да се сочекаат функционално созреаните социолошки и културолошки фактори кои го поттикнале феноменот на историското проникнување на стандардизацијата на старословенскиот книжевен јазик, на словенската писменост, на книжевно-творечките процеси, како и на словенското богослужење. Финалето на ваквата историска епизода на словенско цивилизациско прелевање било завршено со политичкото активирање на Кирилометодиевската сесловенска мисионерска и просветителска дејност.

\section{Изворите за проследување на сесловенското просветителско дело на св. Константин-Кирил и Методиј}

Во палеославистиката и во медиевистиката е пишувано многу и мошне опширно за истакнатите византиски мисионери и сесловенски просветители св. Константин-Кирил и Методиј. Но во секое научно излагање остануваат бројни дилеми и се покренуваат мноштво претпоставки во врска со нивното потекло, карактерот на нивната дејност и нивното реално место во историската рамка при профилирањето на словенскиот цивилизациски систем. Тоа е така зашто природата на досега идентификуваните извори за дејноста на 
св. Константин-Кирил и Методиј главно имаат легендарен или култен (житиен) карактер, а тие како посредни историски соопшувања поттикнуваат различни импресивни, па дури и романтичарски научни толкувања и интерпретации. Станува збор за житијните, химнографските или за ораторско-прозните текстови составувани за св. Браќа, во кои над се́ доаѓа до израз книжевната импресија, како и воспоставувањето и афирмацијата на нивните светителски култови. Затоа, при односот кон ваквите култно-книжевни текстови во функција на историски извори треба да се пристапува строго критички кон произнесената фактографија, а истата да се сообразува со актуелните за тоа време општествени, политички, духовни или културни процеси. Дополнително треба да се има предвид и тоа дека нивните содржини не се сочувани во оригиналните форми, туку до нашата современост се имаат на увид преписи од подоцнежни периоди. Тоа овозможувало оригиналните содржини да трпат и извесни интервенции, во смисла на дополнувања, скратувања, преформулирања, па дури и преосмислувања. Самата природа на тие извори не ја гарантираат прецизната историска податливост, зашто често нивните содржини биле приспособувани на црковно-политичките интереси од местото и од времето каде и кога се создавале.

Кон ваквата ситуација го надоврзуваме и фактот што во периодот кога на општествената сцена активно се појавиле интелектуалните и мисионерски потенцијали на првите словенски просветители, тогаш едноставно се́ уште не било вообичаено да се составуваат автобиографии од страна на истакнати дејци, па дури не се пишувале и биографии за нив. Ако се претпостави дека постоела каква и да е изворна документација во која се регистрирале актуелните настани поврзани со св. Браќа, таа не е сочувана зашто веројатно била изложена на уништување.

Отсуството на историската изворна документираност има уште и поконкретна условеност. Имено, се има предвид фактот дека мисионерската дејност на св. Константин-Кирил и Методиј до крај не ги реализирала политичките, црковните и културните очекувања на византискиот Константинопол и на папата во Рим, па следствено и настаните поврзани со нив не се сметале како одлучувачки за развојот на историската епоха. Токму и причината што словенското просветителско дело на овие мисионери за Византија не резултирало во задоволителна мерка како стратешка дипломатска доктрина, тие како историски личности отсуствувале од содржините на средновековните византиски историско-лето- 
Св. Константин-Кирил и Методиј...

писни, хронографски и друг вид напишани документации. Но и во словенските преводи или преписи на византиските хроники ниту еден од средновековните книжевни дејци не се одважил да ги надополни нивните содржини со настани од дејноста на светите Браќа. Веројатно за таквата состојба било пресудно сфаќањето дека тие се сесловенски просветители, протагонисти на екуменската христијанска идеја, чиишто духовни и културни рефлекси станале општи цивилизациски вредности - надвор од интересите на византискиот протекторат. Исто така не било вообичаено светителскиот спомен за св. Константин-Кирил и Методиј да има свое место во литургискиот и во богослужбениот живот на византиската црква. Затоа и не се составувале византиски книжевни состави, што ќе го крепат нивниот светителски култ.

Досега се евидентирани и неколку сочувани римолатински извори за св. Константин-Кирил и Методиј, што претставуваат индиректни или посредни сведоштва со документаристичко-епистоларен карактер од времето на Моравската мисија по смртта на св. Кирил Филозоф. Овие сочувани пишувани сведоштва треба да се набљудуваат како извор на историски информации предадени од дистанца на римопапските црковно-политички интереси. На прв план се имаат предвид манастирско-поменички, епистоларни и подоцнежни спомени или култно легендарни писмени извори.

Имајќи го предвид фактот дека св. Константин-Кирил и Методиј биле сесловенски просветители и нивната мисионерска дејност се втемелила во афирмацијата на идната словенска цивилизациска свест, тогаш е и логично што се најбројни т.н. словенски извори пишувани на старословенски јазик. Станува збор за хагиографски (житијни), химнографски, проповедно-поучни и пофални ораторско-прозни книжевни дела посветени на св. Константин-Кирил и Методиј, но и за нивните засведочени авторства на различни книжевни творби, како и за текстови напишани во центрите на нивните ученици и следбеници. Сепак, примарно место меѓу нив го имаат познатите Панонски легеенди, што претставуваат текстолошка целина на двете пространи житија за св. Константин-Кирил и Методиј. Популарниот заеднички назив го добиле во науката поради афирмацијата на тезата на рускиот славист А. Горски изнесена уште од 1863 година, дека тие книжевни состави биле напишани во Панонија.

За оваа пригода сакаме да нагласиме дека, до скоро во палеославистиката се одеше и до таа крајност што кон двете пространи житија се градеше митологизиран научен однос како кон “единстве- 
ни” извори за проучување на кирилометодиевистиката, што треба да се прифаќаат како најблиски до историската вистина. Во тој однос опоменуваме дека мора и треба да се има предвид природата на составите како култно-легендарни содржини, приспособувани - структурно на творечкото клише на хагиографскиот (житиен) жанр, а текстуално на формата да се воспоставува и да се развива култ кон личностите (светителите) протагонисти на главната култна манифестираност. Во секој случај самата содржина нема да се дистанцира од поткрепувањето на претставата за историскиот формат на рамноапостолската и сесловенската просветителска дејност на светителите, но начинот на кој тоа се прави излегува од границите на реалистичкиот систем на произнесување. Но што е најважно, творечката перфекција во овие книжевни текстови ја будат доживуваната импресија за духовните и културните искуства од минатото како за општоцивилизациски придобивки, а тоа треба да го поткрепуваат современиот глобален процес за културно прелевање меѓу народите.

Долго време во палеославистиката и во медијавистиката беа актуелни прашањата за периодот и за местата кога и каде биле составени двете пространи житија. Преовладува мислењето дека тие се составиле уште во втората поливина на IX век, веднаш по смртта на светите Браќа - на св. Константин-Кирил во 869 и на св. Методиј во 885 година. Но понекогаш се актуелизираа и ставовите за подоцнежното потекло на овие словенски оригинални житијни состави, а пред се́ - имајќи го предвид фактот за отсуството на протографите и за подоцнежното потекло на нивните преписи. Последните ставови често се изолирани во науката и се сметаат како хипотетички и доволно неаргументирани, па дури и се квалификуваат како "непатриотски” (од сесловенскиот аспект на произнесување). Сепак, ако се имаат предвид познатите воено-политички и духовно-културни процеси што се одвивале во кирилометодиевскиот период и тие да се сообразат со историските податливости преточени во содржините на преписите од двете пространи житија, тогаш нужно ќе се остави простор за своевидна научна реконструкција по однос на прашањето за потеклото на сочуваната содржинска форма на т.н. Панонски легеенди.

Едноставно, лесно се доаѓа до констатацијата дека во сочуваните содржини од преписите на двете нивни пространи житија историските настани се приспособувани според црковно-политичките интереси на Византија. Таквата согледба дава доволен аргумент за 
да се претпостави дека текстуалните варијанти на овие две житијни творби не биле составени во периодот веднаш по смртта на св. Константин-Кирил и Методиј - некаде до крајот на IX век. Историски е засведочено дека по смрта на сесловенските просветители и по завршувањето на Моравската мисија не се истакнувал значаен интерес за нив и за нивната поранешна дејност од страна на византиската државна политика и на цариградската патријаршија. Сличен бил и односот на папата во Рим, кој политички го толерирал прогонството на кирилометодиевите ученици од страна на германското римолатинско духовништво. Двата моќни духовни центри допуштиле прогонетите Кирилометодиеви ученици да станат политички инструмент за реализација на стратешките интереси на Првото бугарско царство. Но на бугарските владетели не им биле целосно прифатливи изворните идеи на Моравската мисија спроведувани во функција на византиските или на римопапските политички очекувања, но и на екуменскиот баланс меѓу едните и другите. Лојалноста кон изворните идеи од Моравската мисија на Кирилометодиевите ученици св. Климент и св. Наум била пресудна тие да не ги прифатат новите форми на словенското просветителство, што требало да функционира согласно актуелните интереси на бугарските владетели. Затоа тие се повлекле во Светиклиментовата словенска епархија - главно на територијата на Македонија и таму ја формирале Охридската духовна и книжевна школа, со неутрален статус дури и во однос на Константинопол. Афирмацијата на изворната кирилометодиевска дејност од страна на нивните ученици во Охридската духовна и книжевна школа (спротивно на Преславскиот духовен центар) придонела таму да се сочува и да се развива култот на св. Кирил и Методиј, како на сесловенски просветители и рамноапостоли. Нивниот светителски култ се документира во црковните календари од месецословите на најстарите сочувани ракописни книги, што произлегле од Охридската книжевна школа. Таков е примерот со месецословот на Асемановойо г̄лаг̄олско евангеллие од крајот на $\mathrm{X}$ век, што денес се чува во Ватиканската библиотека во Рим (Цод. Ват. Слав. 3 глаг.). Затоа пак, во византиските или во постари бугарски ракописи не се среќаваат застапени календарските вести за сесловенските просветители. Тоа сведочи дека во периодот до крајот на X век култот на св. Кирил и Методиј веќе бил воспоставен во богослужбената практика на Охридскиот духовен центар и тие биле официјално канонизирани за светители од црквата. Ваквиот светителски статус дозволувал за нив да се составуваат житијни, 
химнографски и ораторско-прозни книжевни состави, како дел од книжевниот облик за воспоставување и ширење на нивниот култ.

Не треба изречно да се негира дека постои веројатност првите житија за св. Браќа да биле составени од нивните современици. Затоа пак, не се исклучува можноста врз основа на содржините од двете изворни стари житија за сесловенските просветители подоцна да се компилирале нови пространи хагиографски состави со приспособени содржини на тогашните актуелни црковно-политички интереси на Византија.

Нашите најнови истражувања покажаа дека историските и политичките околности да се стори тоа биле најсоодветно поттикнати во првата половина на XI век и во Охридскиот духовен и книжевен центар, кога по пропаста на Самуиловото словенско владетелство Византија го повратила црковниот и политички протекторат на македонските простори - а со тоа и на диецезата на Охридската архиепископија. Отсуството на директната изворна податливост за ваквиот историографски последователен став и натаму ќе ги остави отворени научните прашања: од кои автори биле преработени првобитните житијни состави за св. Константин-Кирил и Методиј како содржински компилации; дали биле напишани на византискогрчки јазик како што наложувале тогашните византиски антисловенски тенденции, а подоцна се превеле на старословенски јазик; дали текстуалната компилација се извела изворно на старословенски јазик од книжевник или од книжевници на Охридскиот книжевен центар, а требало со популарноста на култот за светите Браќа да ја придобијат локалната христијанска паства кон византискиот духовен протекторат; итн, итн.

\section{Мисионерската дејност на св. Константин-Кирил и Методиј во функција на афирмација на словенската цивилизација и култура}

Пошироко во науката обично толкувањето и интерпретациите на сочуваните кирилометодиевски извори онакви какви што се нудат крајно ангажирани, па дури и политички тенденциозни проследувања. Ваквиот научен однос се градеше, а и се́ уште се гради во интерес на идејата во истражувачките презентирања да се приспособуваат актуелните современи потреби за истакнување на определена национална превласт над глобалниот историско-развоен словенски цивилизациски контекст. Ваквите ограничени претстави за 
историски престижните глобални вредности само ја осиромашуваат општата цивилизациска придобивка за сите словенси народи и им се скратува нивниот културноисториски влог во актуелните европоцентристички тенденции за културно прелевање меѓу народите. Но таквите истражувачки дефекти ќе станат неактуелни и провидни само кога прецизно ќе се набљудува феноменот кирилометодиевска традиција. Затоа и напоменуваме дека е време палеославистите и медиевистите да се ослободат од романтичарските страсти и да се прекине со импровизацијата кога се тврди дека светите Константин-Кирил и Методиј биле Словени, византиски Грци - дури и со патриотски набој дека биле Бугари, Македонци и сл.

Имено, историските сообразувања од времето во кое тие живееле потврдуваат една друга вистина, ослободена од канонското клише на житијниот модел на преосмислување на личните биографии. Потемелните истражувања покажуваат дека веројатно тие биле потомци на старото домородно население на просторот на Македонија, кое по скоро тривековниот процес на словено-домородната симбиоза знаело словенски јазик и веќе живеело сродно со другите народи во Византија и со Словените. Затоа и византискиот двор нив ги користел за посредници да ја наметнуваат политичката и духовната волја над Словените. Особено поткрепата за таквиот став може да се побара и во содржината на познатите Панонски легеенди. Впрочем, при предавањето на должноста за Моравската мисија не било случајно обраќањето на византискиот император Михаил III кон св. Константин-Кирил: Друг̄ не може да г̃o найрави

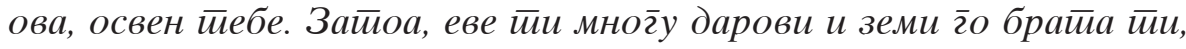

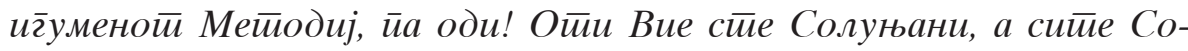
луњани чистио словенски зборуваай (Панонски легеенди, Житие за св. Методиј, глава 5 - превод: Јован Таковски, Скопје 2001).

Впрочем, тие биле родени во Солун - македонски град кој бил втор административен и културен византиски центар по Константинопол. Но високото образование го стекнале во византиската престолнина, близу до највисоките општествени, политички, научни, културни и над се́ духовни кругови. Следствено во тој контекст историографската последователност ќе биде конкретна кога ќе се истакне дека св. Константин-Кирил и Методиј се пред се́, и над се́, византиски мисионери - израснати во високиот слој на византиската општествена хиерархија, реализатори на афирмацијата на словенската духовна и културна традиција, т.е. словенски просветители во функција на византиските и делумно на римопапските политички 
и црковни интереси. Основната заложба во нивната дејност била емисарството со политичка, црковна и дури на секундарен план - со културно-просветителска задача. Главниот инструмент за реализација на политичките и на црковните мисионерски идеи првовремено му бил подреден само на хрисиичјанскиой, а подоцна истовреме-

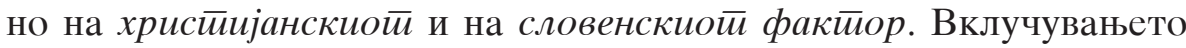

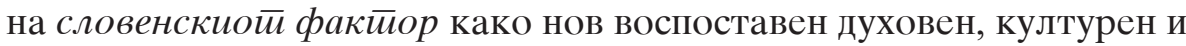
писмен феномен требало да ја интегрира словенската цивилизациска свест во глобалниот византиски, а посредно и во римопапскиот свет на интереси. При политичкото проектирање на нивната мисионерска ангажираност биле вклучени највисоките државни и црковни авторитети, од чиишто резултати посредно требало да зависат и спроведувањата на највисоките византиски стратешки интереси. Затоа и честопати св. Браќа биле поставувани во функција на своевиден политички или црковен инструмент за спроведување на високите византиски цели. Ако во првичните мисионерски ангажирања главното политичко средство им било ширењето и афирмацијата на христијанството како врата низ која ќе се влезе во суштината на глобалниот византиски свет на влијание, новите околности ја наметнувале потребата да се балансираат односите на секој план со се́ поактивниот словенски фактор на териториите каде што словенското население веќе било доминантно. Тоа политички и црковно било детектирано од страна на Византија и на источноправославната црква во Константинопол, но нешто подоцна и папата со западната римолатинска црква ги насочиле сопствените политички средства на влијание кон истата цел. Токму и на планот за афирмација на словенската духовна и културна свест на просторите со доминантно словенско население св. Браќа најревносно ги спровеле своите мисионерски задачи, истовремено заживувајќи го историскиот процес на афирмација на третата христијанска цивилизација и култура во Европа - словенскайа, веднаш по византискогрчката и по римолатинската. Тоа им обезбедило историска гаранција да бидат сочувани во духовната и во културната меморија како сесловенски просветители, но и како своевидни општохристијански рамноапостоли. На историските крстопати низ вековите нивниот култ остави траен белег за поистоветување со словенското самопрепознавање и самоидентификување.

Светите Браќа ги стекнале славата и историското значење со нивната мисионерска дејност, спроведувана при т.н. Брег̄алничка мисија, како и при култно-засведочените во Панонските легенди - 


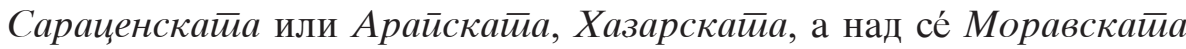
мисија. Само првата Брегалничката во 855 година и последната Моравската мисија меѓу 863 и 885 година политички биле поставени во функција на словенското просветителство, додека другите две Сараценската (Арапската) во 851 или 855/856 година и Хазарската во 860/861 година политички го манифестирале христијанскиот богословско-догматски примат над паганството, јудеизмот и исламот.

Индиректните податоци за функционирањето на првата Брегалничка кирилометодиевска мисија се среќаваат во повеќе сочувани пишани извори, пред се́ со легендарно-хагиографски содржински карактер. ${ }^{1}$ Но отсуството на податоци за нејзиното постоење во популарните Панонски лег̄енди предизвика во палеославистиката да се поделат мислењата за нејзиното историско постоење. Сепак, крајното негирање за постоењето на Мисијата не може да се засновува единствено врз аргументот дека за неа не постојат сведоштва во Панонските легенди, зашто и овој извор има легендарно-хагиографски карактер со приспособувана црковно-политичка содржина. Обично Брегалничката мисија не ја признаваат дека постоела истражувачите чиишто погледи се поблиску до палеобугаристиката, од причина што во политичката и во воената основа таа имала антибугарски карактер, а со тоа се коси со нивните "патриотски" научни интереси. Затоа и кај дел од истражувачите е хипотетично постоењето на т.н. Брег̄алничка мисија, којашто св. Константин-Кирил и Методиј ја спроведувале во историски посведоченото локално владетелство - Словенската архонтија (кнежество) во Стримонската склавинија (брегалничко-струмичката област во Македонија), каде што Византија го испратила св. Методиј да управува во периодот меѓу 845 и 855 година. Следствено, византиско-словенското кнежество во брегалничко-струмичкиот крај на Македонија било иницирано од страна на високите политички и црковни авторитети на Византија со цел да се придобие тамошното домородно и словенско население во борбата против бугарското военото навлегување. Но во тој период на привиден воен мир меѓу Византија и Бугарија словенското население во Македонија покажувало низок морал и

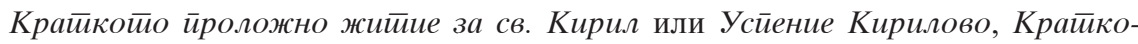

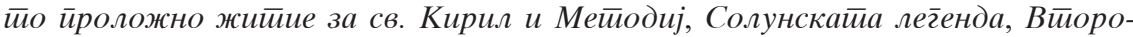
$\bar{u} о$ словенско житиие за св. Наум Охридски, староруското книжевно дело

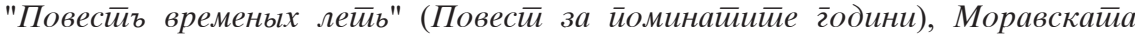

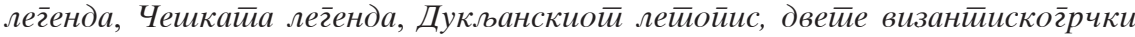

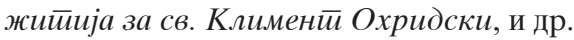


недисциплина поради отпорот кон византиското подаништво. Ваквата состојба била непосредниот повод св. Константин-Кирил да биде вклучен како мисионер во кнежеството на брата си.

Правовремено, за да се неутрализира ваквата непогодна ситуација за Византија во Македонија првпат политички се активирал авторитетот на словенскиот фактор. Притоа св. Методиј изготвил Воен судебник (Закон за судење на луѓейо). Овој книжевно-правен акт се напишал на словенскиот јазик што го зборувале македонските Словени, а писмото било византискогрчко (зашто се́ уште не постоело устроено словенско писмо). Се смета дека мисионерскиот ангажман на св. Константин-Кирил бил насочен кон дефинитивното воспоставување на христијанството меѓу Словените, за да го избалансира нивното цивилизациско прелевање во византискиот свет. Ваквиот политички, духовен и културен чин можел да се реализира само преку сообразувањето на византискиот и на словенскиот социолошки амбиент. Тоа би можело да е историската побуда за првпат св. Браќа да се најдат во улога на словенски просветители. Во некои пишувани извори (легендарно-хагиографски) се споменува дека тогаш и таму св. Браќа ја создале и првата словенска азбука во 855 година. Еден дел од поранешните палеослависти сериозно ги зедоа предвид податоците од легендарно-култните извори и афирмативно ја нагласуваа улогата на Брегалничката мисија при воспоставувањето на словенската писменост. ${ }^{2}$ Само со доза на претпоставеност може да се констатира дека, всушност станувало збор за првите обиди да се примени една “неустроена словенска азбука” врз основа на византискогрчката, па и на римолатинската ортографија. Тоа би можело да е првиот облик на старословенската кирилица, којашто се доустроила и правно се официјализирала подоцна во Бугарија на Преславскиот собор во 893 година. Поради политичкиот и воен крах на Методиевото словенско кнежество во 855 година, а со тоа и на Брегалничката мисија, овој словенски просветителски процес останал недореализиран. Со тоа и кирилицата не може да се смета како прво словенско писмо, туку ваквата квалификација ја има глаголицата - устроена во 863 година за потребите на Моравската мисија.

При кирилометодиевската мисонерско-просветителска дејност Моравскайа мисија имала клучно обележје за натамошните

2 Меѓу нив беа имињата на: А.Куник, А.Гилфердинг, М.Погодин, В.Билбасов, Н.Туницки, К.Куев, В.Истрин, Е.Георгиев, Б.Панов, Б.Алексова, Бл.Ристовски и др. 
Св. Константин-Кирил и Методиј...

цивилизациски проекции во Европа, со кои се профилирала третата по важност христијанска цивилизација - словенската, веднаш по византискогрчката и по римолатинската. Затоа останува мошне важно да се истакне прашањето: Шйо ја условило истиорискайа и

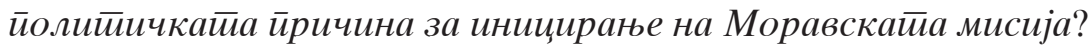

За да се почне со научното разјаснување на односново прашање истражувачката анализа треба да се засновува врз посебното проследување на трите историско-развојни и идеолошки

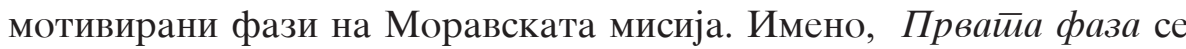
врамува во периодот меѓу 863 и 867 година и имала чисто визан-

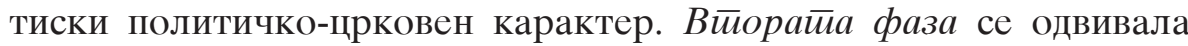
во функција на црковно-политичките интереси на папата во Рим и траела меѓу 867 и 869 година - до смртта на св. Константин-Кирил

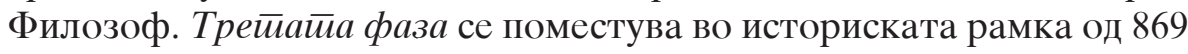
до 885 година, значи по враќањето на св. Методиј од Рим во Моравија - но овојпат како реализатор на христијанската екуменска тенденција за балансирање на односите меѓу византискиот Исток и римолатинскиот Запад.

Воено-политичката состојба во западнословенските кнежества се попречувала пред политичките амбиции на моравскиот кнез Ростислав да ги обедини западнословенските народи од целата среднодунавска област во независен сојуз и да создаде самостојна словенска христијанска црква. Всушност западнословенските кнежества веќе биле под воена, политичка и црковна колонизација на средновековната Франечка (Германска) држава, која го оддржувала својот протекторат преку црковните управни инструменти на римолатинската христијанска хиерархија. Папата Николај I го одбил барањето да испрати епископ во Моравија за прогласување на црковна независност, па Ростислав се обратил со истата молба до византискиот православен Константинопол. Ваквиот политички пресврт нашол плодно тло во актуелната ситуација дека Византија и Моравија имале заеднички непријател во франечкиот (германски) воен сојузник Бугарија, но и цариградската патријаршија имала политички тенденции да го истисне римолатинското влијание и да го наметне сопственото. Тоа било доволно како историски мотив за да почне Моравската мисија на св. Константин-Кирил и Методиј, чијашто подвижна основа и́ била антигерманска и антибугарска, а посредно и антиримолатинска. Со тоа во Моравија остро се вкрстиле конфронтираните интереси на источниот и на западниот црковен центар. 
Прифаќањето словенски белег на Мисијата во Моравија од страна на Византија било добро осмислена стратегија од страна на патријархот Фотиј и на воениот стратег кесарот Варда. Тие мошне добро знаеле дека само со политика на толерантност кон словенските народи можела да се придобие нивната лојалност. Во случајов улогата на византискиот император Михаил III била само политички номинална. Особено новопоставениот патријарх Фотиј ја користел можноста да се поттикне самостојноста на словенската богослужба и на словенската писменост како средство за привлекување на западните Словени кон закрилата на Источната црква. Затоа и се определиле како предводници византиски мисионери со форматите на св. Константин-Кирил и Методиј, а не биле земени предвид учени луѓе од словенскиот род. Првенствено се имало предвид нивното мисионерско искуство, како и високиот степен на нивната афирмација во кариерата - првиот како филозоф и хартофилакс, а вториот како архонт на Словенска архонтија (кнежество) во брегалничко-струмичкиот крај од Македонија.

Во политичката основа Моравската мисија била респективно словенска, зашто главните стратешки тенденции требало да се реализираат преку застапеноста на словенскиот јазик во богослужењето, книжевноста и во писменоста. Тоа било едно од главните политички средства на западнословенските владетели за да го централизираат своето владеење, на што силно им пречело влијанието на средновековната франечка држава и на тамошното свештенство. Таму христијанскиот црковен живот бил управуван од франечкото свештенство, кое проповедувало и вршело богослужба на неразбирлив римолатински јазик.

Мошне сложената политичка и догматско-идеолошка црковна поставеност на суштината на Моравската мисија барала подолг период за да се извршат подготовки за нејзиното успешно реализирање. Постојат претпоставки дека задачата за сложената Мисија св. Браќа ја добиле уште во летото 862 година, а заминале да ја реализираат во наредната 863 година. Но за успешното спроведување на мисионерскиот чин за словенско просветителство првовремено се испречил проблемот што се́ уште немало устроени словенски букви. Дури и да имало некаков поранешен обид за устројство на словенска азбука при евентуалната порано изведена Брегалничка мисија во 855 година, таквиот ортографски чин останал недореализиран поради воениот и политичкиот крах на Брегалничкото словенско кнежество, со коешто управувал св. Методиј. Затоа следела 
Св. Константин-Кирил и Методиј...

приоритетната обврска да се устрои словенско писмо, да се стандардизира книжевен старословенски јазик, а и да се преведат од византискогрчки нужните богослужбени и проповедно-поучни книги.

Без конкретна изворна аргументација некои тенденциозни истражувачи се обидуваа подготовките за сесловенското просветителство да го лоцираат во манастирскиот амбиент на Олимп во Мала Азија, каде што претходно - по падот на Брегалничкото словенско кнежество во 855 година, св. Методиј се замонашил и заедно со брата си активно се посветиле на книжевно-творечката дејност. Следствено, тие и тврдат дека во манастирот Полихрон на Олимп се устроило првото словенско писмо - глаголицата за потребите на Моравската мисија и дека таму се стандардизирал книжевниот старословенски јазик. Се тврдеше дури и дека таму се превеле на старословенски јазик првите богослужбени книги.

Сепак, последователноста на проследувањето на процесите што претходеле јасно ја демистифицира таквата теза за притемнување на историската слика. Веќе потврдениот успешен византиски мисионер св. Константин-Кирил не можел да се подготвува изолиран во манастирскиот амбиент на Олимп за исклучително сложените обврски, што му претстоеле при идното сесловенско просветителство и воведувањето на словенското богослужење. Политичкиот и културниот статус на тогашниот македонски град Солун бил престижен, како еден од посилните византиски центри веднаш по Цариград. Токму во родниот град св. Константин-Кирил имал идеални услови да ги спроведува подготовките за заживување на словенската писменост, но и успешно да ги спроведува контактите и консултациите со најголемите византиски авторитети. Над cé, на самиот терен од околината на Солун можел изворно да ги користи јазичните словенски говорни искуства, за врз основа на нив да устрои компететна - фонетски устроена словенска азбука и да стандардизира (да кодифицира) општ словенски книжевен јазик.

Во палеославистиката секогаш е актуелно прашањето, како св. Константин-Кирил ја устроил словенската азбука, а истовремено и го стандардизирал старословенскиот јазик? Пред се́, кон ваквата задача тој се однесувал одговорно и пристапил да ја реализира со високо стручно ангажирање. Не треба да се исклучува можноста св. Браќа да зеле и свои учени соработници од словенскиот род, кои добро го познавале словенскиот мајчин јазик и во голема мерка им помогнале во прецизирањето на диференцијацијата на одделни словенски гласови. Секако, тие биле од околината на Солун - од родот 
на македонските Словени. Тие станале нивни ученици и следбеници во ширењето на словенската цивилизациска свест. Во таквиот случај во прилог оди и претпоставката за можноста дека св. Климент и Наум Охридски биле едни од тие нивни соработници и доследни спроведувачи на кирилометодиевската традиција. Во секој случај нужно треба да се напоменува дека, ваквите тези имаат само доза на претпоставка.

Веќе во славистиката е сигурно дека за потребите на Моравската мисија св. Константин-Кирил го устроил словенскиот азбучен систем на г̄лаг̄олицайа. Оваа прва стандардно устроена словенска азбука настанала како резултат на стручна филолошка работа, при која се имале предвид искуствата од писменото функционирање на повеќе туѓи азбуки. Но устроеното и стандардизирано глаголско словенско писмо по форма било оригинално и во него немало механички позајмени графеми од друга азбука, иако во извесна смисла ги поддржувало основните методолошки пристапи од византискогрчкото или од еврејското ортографско искуство.

Паралелно со устројството на првата словенска азбука - глаголицата се извршила и кодификацијата на сесловенскиот книжевен јазик (старословенскиот или црковнословенскиот), во чијашто основа влегле македонските словенски говори од околината на Солун. Со тоа се создале услови за да се почне со преведување на нужните црковни богослужбени книги, а се напишале и првите оригинални словенски творби. Токму подготовките за Моравската мисија го активирале процесот на словенско книжевно создавање и на словенско преведување.

Уште од самото доаѓање на словенските рамноапостоли во Велеград, престолнината на Моравија, дошло до израз словенојазичното спроведување на богослужбената и на проповедната дејност, зашто за краток период се превел на старословенски јазик целиот богослужбен чин (за утрената, часовите, малата и големата вечерна, литургијата), кој веќе во моравската црква почнал да се практикува според источно-православниот типик. Во своите проповеди на словенски јазик ги просветувале христијаните да не ги прифаќаат остатоците од паганството, но истовремено посредно ја афирмирале теолошката доктрина блиска на источната црква. Затоа, уште во почетокот од нивната дејност се судриле со интересите на франечкото латинско духовништво, кое постепено почнало да ја губи духовната доминација. Тие биле непријателски настроени кон примената на црковнословенскиот јазик во богослужбата и во 
писменоста. Св. Константин-Кирил бил обвинет дека ги нарушува светите позиции на традиционалната духовна и писмена цивилизација во христијанскиот свет да се пишува и да се проповедува на трите јазици: еврејски, латински и византискогрчки. Ваквата тријазична доктрина не била продукт на времето во кое дејствувал св. Константин-Кирил и брат му св. Методиј. Идејата е постара и влече корења уште од далечниот IV век, кога настанало Источното ромејско царство - Византија. Но официјално тријазичната идеја ја афирмирал книжевникот Исидор Севилски (570-636), повикувајќи се дека на тие три јазици, Пилат заповедал да се напише натписот на крстот на којшто бил распнат синот господов Исус Христос. Тријазичната теорија се ширела низ вековите како во римската, така и во источната црква, а секое богослужење на сопствениот јазик се квалификувало за еретичко дело. Освен т.н. официјални богослужбени јазици јазиците на другите народите служеле само како говорно средство за меѓусебна комуникација, а византискогрчкиот или римолатинскиот биле практично средство во црквата, дипломатијата, науката и во книжевноста. Токму во втората половина од IX век тријазичната доктрина се нашла пред јавна демистификациja, на која жестоко и́се спротивставиле токму св. Константин-Кирил и Методиј при реализацијата на Моравската мисија. Св. Константин-Кирил ги нарекувал приврзаниците на учењето за трите јазици

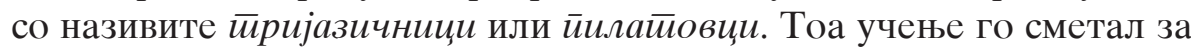
нехумано, за што и со огромен ентузијазам се впуштил во борба против тријазичниците - проектирајќи го новиот хуманизам во духовниот и во културниот однос за рамноправноста на јазиците и за еднаквоста меѓу народите.

Мисионерските активности во Моравија течеле континуирано се́ до 867 година, кога во Византија настанале нови политички и црковни состојби. Имено, по убиствата на императорот Михаил III и на кесарот Варда, а и со отстранувањето на патријархот Фотиј, од византиската јавна сцена исчезнале клучните иницијатори на Моравската мисијата. Новооснованата Василиева македонска династија на престолот на Византија и повторното враќање на патријархот Игнатиј, спроведувале пофлексибилен политички и црковен однос кон папата во Рим, при што се создале сериозни причини св. Браќа да се вратат во Византија на некакви консултации. Со тоа завршила првата провизантиска фаза од одвивањето на Мисијата. Веројатно повратниот пат тие го избрале преку Венеција, па минувајќ́ преку Панонското словенско кнежество на Коцељ и таму го вткаиле 
словенското просветителство - манифестирајќи го веќе кодифицираниот старословенски јазик и устроената словенска глаголица. Во тие историски рамки некои истражувачи сметаат дека настанале и првите контакти на ученици по род Хрвати и Словенци со словенската писменост и со глаголицата, а преку јадранското крајбрежие проникнувањето на словенските просветителски идеи се најавиле уште во босанските и во црногорските средини. При својот престој во Венеција св. Константин-Кирил и Методиј уште еднаш жестоко биле нападнати и обвинувани од страна на тријазичниците за правото да се богослужбува на словенски јазик. Тогаш св. Кирил ја постигнал и највисоката кота на сопствената аргументација за еднаквоста на сите јазици и писма: Не врне ли дожд од Бог̄а еднакво за сийе? Зар не дишеме воздух сийе еднакво? Тог̄аш, како не се срамийе да

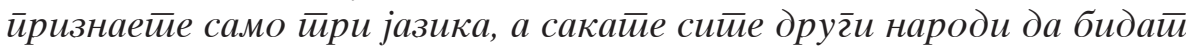
слейи и г̃луви? (Панонски легеенди, Житие за св. Кирил, глава 16).

Одгласот за брилијантната одбрана на св. Браќа против тријазичниците во Венеција стигнал и до папата Николај I, којшто ја согледал можноста со истите духовни средства на источната црква во Цариград да ги реализира интересите на западната црква во Рим. Затоа им испратил покана на словенските просветители да го посетат папскиот престол во Рим. Веројатно на папата му била позната и актуелната позиција на св. Браќа при новонастанатата политичка ситуација во Византија, па затоа сметал дека може да ги привлече на своја страна за да го зацврсти влијанието меѓу западнословенските христијани. Не е познато дали следела нивна консултација со византискиот двор, а не се знае и тоа дали во името на добрата волја за помирувачки однос меѓу двете христијански цркви Византија го удоволила нивното заминување во Рим?

Во Рим ги пречекал лично новоизбраниот папа Адријан II, кој им приредил голема свеченост. Причина за нивниот свечен дочек била веста дека со себе тие ги носат моштите на светиот папа Климент Римски (ок. 89 - ок. 97-101), што во претходната своја мисија од 860 година ги пронашле во Херсон. Вештите мисионери и овојпат се послужиле со дипломатска умешност, зашто знаеле дека култот на св. Климент Римски е многу почитуван во Рим и во Западната црква. Откривањето на неговите мошти и донесувањето во Рим биле поводот подоцна св. Константин-Кирил и Методиј да бидат канонизирани за светители од страна на Римската црква. Папата Адријан II се зафатил да ги реализира и политичките намери, при што ги благословил словенските преведени книги што со 
себе ги носеле светите Браќа, а словенската богослужба се стекнала со официјално одобрение од Римската црква. Исто така папата им доделил свештенички чинови на некои од Кирилометодиевите ученици. Преку одобрениот чин за словенско богослужење папата очекувал западните Словени да го прифатат суверенитетот на апостолската литургиска традиција. Но поважно од тоа било што со овој чин дошло до историското духовно и културно подместување во кое се профилирала третата по важност христијанска цивилизација во Европа - словенската (веднаш по римолатинската и по византискогрчката). Нивната поставеност при ваквата позиција им наложувала во иднина да ја протежираат мисијата на христијанското екуменство, зашто тие и самите се стремеле во Моравија да ја сообразат византиската литургија со латинската миса. Нивниот престој во Рим траел околу една година. Особено бил активен св. Константин-Кирил, којшто контактирал со најобразованите личности и со нив ги споделувал сопствените филозофски и теолошки знаења. Но набргу тој тешко се разболел. Претчувствувајќи ја смртта го примил монашкиот образ, добивајќи го името Кирил. По 50 денови тој умрел на 14 февруари во 869 година.

Веднаш по смртта на св. Константин-Кирил, панонскиот кнез Коцељ писмено побарал од папата да го испрати св. Методиј да ја продолжи дејноста што ја вршел со брата си пред две години. Папата испратил специјално послание до моравскиот кнез Ростислав, до нитранскиот кнез Светополк и до панонскиот кнез Коцељ со кое им соопштил дека во нивните земји им го испраќа свети Методиј како папски легат (пратеник): да ве учи како шйо баравйе, и да ви

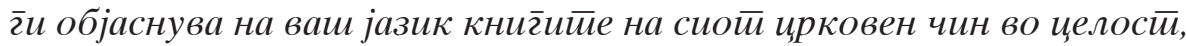

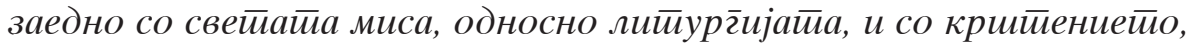

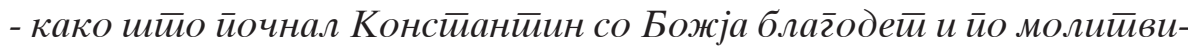

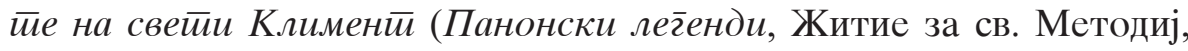
глава 8 - превод: Јован Таковски, Скопје 2001). Како што се гледа од житијниот извор, папата се согласил да се манифестира екуменската христијанска чест во словенската богослужба, а претходно тоа го поткрепил и со нагласувањето дека - иако св. Браќа мисионери најпрво биле испратени во овие словенски земји од Византија и од патријаршијата во Константинопол, тие не сториле ништо против каноните на апостолскиот престол и дури дошле во Рим со моштите на св. Климент Римски. Но сепак, тој бил претпазлив во однос на задоволувањето на сопствените интереси, па ќе нагласи: Пазейе г̄o

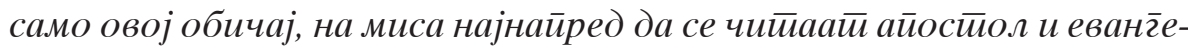


лие на римски (лайински), йойоа на словенски“ (Панонски лег̄енди, Житие за св. Методиј, глава 8).

Со повторното испраќање на св. Методиј во Моравија и во Панонија се ослабнало влијанието на германо-баварското духовништво, но затоа пак се очекувало конкретно поврзување на тамошното словенско население кон Римската црква. Св. Методиј ја продолжил просветителската дејност и го спроведувал воведувањето на словенската богослужба. Сепак, главната намера на западнословенските владетели била да се стекне црковна автономија. Затоа Коцељ повторно го пратил св. Методиј во Рим заедно со 20 придружници за да биде ракоположен за епископ на Панонија. Папата го удоволил барањето ракоположувајќи го св. Методиј за архиепископ на сите словенски области, а тоа морал да го стори поради претпазливоста повторно да не се вмешаат интересите на византиската источна црква. Затоа пак, баварските епископи широкоградо не го прифаќале ваквото решение, зашто се донело без нивна согласност, а и тоа се косело со нивните духовни аспирации.

Нашите претпоставки се дека и самата Византија била запознаена за повторното ангажирање на св. Методиј од папата како словенски просветител меѓу Западните Словени, за што и словенскиот првоучител се обратил за извесен совет до византискиот император Василиј I Македонец и до повратениот патријарх Фотиј (од кого првобитно и бил испратен со брата си како мисионер во Моравија). Секако дека државната политика на Византија, а и духовната стратегија на патријархот Фотиј во континуитет пројавувале активен интерес за дејноста на св. Методиј. Изворно е засведочено тогашното незадоволство на византискиот император поради отстапките на св. Методиј кон папата, за да го добие архиепископскиот престол во Моравија. Сепак, за историографијата е важно тоа што е документирана поканата до св. Методиј од Византиската Империја да ја посети својата татковина по 20 години странствување во Моравија. Св. Методиј бил пречекан во Цариград со високи почести, а се пофалило и неговото учење. Како сведоштво за тоа служи останувањето на двајца негови ученици (свештеник и ѓакон) во Цариград, но и задржувањето на словенски книги во византиската престолнина. Тој се вратил во Моравија, каде што останал се́ до својата смрт (6 април 885 година) - повторно изложуван на непрекинати притисоци од латинското духовништво, зашто веќе ја изгубил поткрепата од Рим и бил оставен сам на себеси. 
Св. Константин-Кирил и Методиј...

Интересно е да се напомени каков бил црковно-политичкиот статус на св. Методиј за време на неговото мисионерство во т.н. трета фаза од Моравската мисија. Следствено на тоа, како што ќе се затоплиле политичките односи меѓу вселенската патријаршија и папата во Рим, така и дејноста на св. Методиј добивала сила на значење. Но и откако ќе дошло до заладување на тие односи, нагло се влошувале условите за неговата дејност и често се наоѓал во заточеништво.

По смртта на св. Методиј неговите ученици биле прогонети од Моравија, со што и дефинитивно згаснала Моравската мисија. Но основните идеи за ширење на словенска цивилизациска свест од таа Мисија не згаснале и биле продолжени од Кирилометодиевите ученици св. Климент, св. Наум и Константин Презвитер, кои натаму доследно ги реализирале назад во нејзиниот извор на политичко протекување - во Македонија. Доколку не заживеала Охридската духовна и книжевна школа со изворните идеи од Моравската мисија, тогаш и самата Мисија ќе останала притемнета во историскиот заборав на времињата што следеле до нашата словенска национална и културна современост.

\section{Послесловие за кирилометодиевската традиција}

Поддржувањето на словенскиот јазичен и културен идентитет од страна на Византија, а подоцна и од папата во Рим, се покажало како функционална политичка доктрина и за бугарските средновековни владетели Борис и Симеон. Чинот на словенското просветителство во бугарската држава го поттикнал до неговата завршна фаза владетелот Симеон на Преславски собор во 893 година. Тогаш официјално се воспоставил старословенскиот јазик во богослужбената и во книжевната практика на бугарската држава, во чијшто состав бил завладеан и поголемиот дел од Македонија. Сепак, од политички причини се направил компромис во однос на примената на словенското писмо, при што се заменила глаголицата со новоустроеното словенско писмо - кирилицата. Св. Климент и Наум не се помириле со отстапувањата од основните изворни идеи на словенското просветителство, што го спроведувале нивните учители св. Константин-Кирил и Методиј. Затоа целосно се изолирале во Македонија, т.е. во Климентовата епархија, формирајќи ја Охридската духовна и книжевна школа наспроти Преславскиот центар - со примената на изворните словенски просветителски идеи од 
Моравската мисија и на глаголицата во писмената практика. Со тоа се реализирал историскиот процес на дисперзија меѓу средновековната бугарска и македонска духовна и културна традиција, натаму развивајќи ги посебните културноисториски идентитети - бугарскиот наспрема македонскиот. Афирмацијата на Охридската книжевна школа потпирана врз изворните идеи на Кирилометодиевото епохално дело придонела да се интензивира развојот и на останатите средновековни словенски традиции, а пред се́ јужнословенските и руската. Активниот творечки растеж на Кирилометодиевите ученици на македонскиот простор значително придонел да се подреди статусот на Преславскиот книжевен центар во своевидна периферна позиција на влијание во останатите словенски средини. Всушност, перманентното воено и политичко слабеење на Првото бугарско царство го довело истото до вазалска позиција во однос на Византија и се́ до негово згаснување, при што по нецел век на траење Преславскиот книжевен центар исчезнал од духовната и културната сцена на Балканот. Престижниот статус на Охридската книжевна школа станал уште поактуелен при идниот развој на кирилометодиевската традиција во Македонија, Црна Гора, Србија, Хрватска, Украина и во Русија.

\section{Ilija VELEV}

\section{ST. CYRIL AND METHODIUS AS PROPONENTS OF SLAVIC CIVILIZATION, CULTURE AND LITERACY}

In this paper, the scientific results are presented of original research processes that have contributed to the affirmation of Slavic civilization and culture, starting with the great migration of peoples in the second half of the sixth century until the development of St. Cyril and Methodius tradition, which affirmed the third Christian tradition in Europe, Slavic one (in addition to the Roman or Latin and Byzantine-Greek).

The author pays particular attention to the phenomenon of Slavic civilization and culture created in the process of symbiosis with the native civilization and culture, from which Slavic cultural-historical collectivism and identity emerged. In this process, a key role was played by the missionary and enlightening activity of St. Constantine-Cyril and Methodius.

Key words: Slavic civilization and culture, Saint Cyril and Methodius, Pannonian legends, Saint Cyril and Methodius tradition 


\section{Miomir ABOVIĆ (Tivat)}

UDK 811.163.4'367.633

Izvorni naučni rad

Fakultet za crnogorski jezik i književnost - Cetinje

miomir.abovic@fcjk.me

\section{EKSTENZIJA ZNAČENJA KOD PRIJEDLOGA; NEPRIMARNO ZNAČENJE PRIJEDLOGA OSIM; PORED, KOD, KRAJ, MIMO I PRIJEDLOGA DO U B/CG/H/S JEZIKU}

U radu ćemo se baviti neprimarnim značenjem, u smislu pravca semantičkog razvoja, određenih prijedloga i grupa prijedloga u B/CG/H/S jeziku. Nastojaćemo opisati mehanizme nastanka neprimarnih značenja kod tih prijedloga (i grupa prijedloga), značenja koja konstatuju manje-više svi relevantni gramatički priručnici $\mathrm{B} / \mathrm{CG} / \mathrm{H} / \mathrm{S}$ jezika, ali ne pokušavaju objasniti njihov nastanak.

Ključne riječi: prijedlozi, značenje, semantički razvoj, genitiv, eksceptivnost, aditivnost, aditivnost, koncesivnost

Prijedlozi se kao vrsta riječi svrstavaju u takozvane suznačne riječi koje su karakteristične po tome ,što im je značenje u manjoj mjeri leksičko, a u puno većoj mjeri gramatičko ili pragmatičko, uopćeno, ovisno o značenju drugih riječi s kojima se te riječi pojavljuju u sklopu većih sintaktičkih jedinica“ (Pranjković 2013: 172). O relacionom karakteru prijedloga kao vrste riječi govori i D. Klikovac: „Predlozi su, kako je to dobro poznato, relacione reči: pokazuju odnos između dvaju ili više objekata“ (Klikovac 2000: 19). Suznačnost prijedloga, međutim, posebnog je tipa: „Oni (prijedlozi, prim. M. A.) načelno pripadaju suznačnim riječima, ali se njihova suznačnost ne sastoji u neodređenosti i(li) nedostatnosti leksičkoga značenja (kao npr. kod zamjenica), nego je izrazito sintaktičke naravi jer prijedlozi služe za konkretizaciju pojedinih kosih padeža, pa su u tom smislu vezani za kategoriju padeža, mogu se čak smatrati svojevrsnim potpadežima. Oni su, moglo bi se reći, u leksičkom smislu potpuni utoliko što manje ili više jasno naznačuju tip prostornoga (npr. po, u, pod, nad), vremenskoga (npr. prije, poslije, nakon, uoči) ili nedimenzionalnoga odnosa (npr. zbog, glede, usprkos, poput), ali se njihova suznačnost sastoji u tome što takvih odnosa nema bez jedinica kojima se ozna- 
čuju predmeti (tj. bez padežnih oblika)“(Pranjković 2013: 176). S obzirom na to da su prijedlozi „u leksičkom smislu potpuni“, a da je njihova suznačnost „sintaktičke naravi“ i da se „,ne sastoji u „neodređenosti i(li) nedostatnosti leksičkog značenja“" njima je, kao i bilo kojoj drugoj punoznačnoj vrsti riječi, imanentan transfer značenja. Upravo taj fenomen, transfer značenja kod pojedinih prijedloga i grupa prijedloga u B/CG/H/S jeziku u okviru određenih prijedložno-padežnih konstrukcija, biće i predmet ovog rada.

Prvi prijedlog kojim ćemo se u ovom radu pozabaviti jeste prijedlog osim u prijedložno-padežnoj konstrukciji osim + $\mathbf{G}$ u značenju koje taj prijedlog ima u primjerima poput sljedećih: Rukopis, osim tekstova koji su objavljeni u Crnogorskom književnom listu... sadrži i nove važne priloge...(Vijesti, 7. 4. 2011, 35), Osim sporova, u tom periodu je bila žestoka finansijska kriza...(Vijesti, 12. 10. 2011, 7), Osim termoelektrane, trebala bi se graditi $i$ prateća tvornica bioetanola...(Jutarnji list, 20. 12. 2014, 4), ...a osim uživanja u engleskoj prestonici, pjevačica je završavala i poslovne obaveze. (Dan, Šarena strana, 27. 12. 2014, 22). Upotrebu prijedložno-padežne konstrukcije osim + G u ovom značenju registrovao je već M. Stevanović u svojoj Sintaksi: „Ne više sa značenjem izuzimanja, već za označavanje pridruživanja drugome čemu...predlog osim, s genitivom naravno, imamo u primerima tipa: osim toga je dovoljno poznavao prošlost svoga jezika (T. Maretić, Gramatika i stilistika, 9) - Osim španskog naroda samo je francuski narod mogao dati...(J. Dučić, Dela 5, 34)“ (Stevanović 1974: 287-288). Prijedložno-padežnu konstrukciju osim + G u značenju tzv. aditivnog (komitativnog) genitiva pominju i autori kolektivne monografije Sintaksa savremenoga srpskog jezika - prosta rečenica. Za aditivni (komitativni) genitiv (ko)autori ove monografije kažu da je u pitanju ,genitiv sa značenjem pridruživanja (dodavanja, uključivanja) jedne pojave (osobe, predmeta, apstraktnog pojma) drugoj“ (Piper et alt. 2005: 173). Zanimljivo da neki drugi gramatički priručnici savremenog jezika ne pominju prijedložno-padežnu vezu osim $+\mathbf{G}$ u aditivnom značenju. Tako npr. autori (iz štampe nedavno izašle) Kognitivne gramatike hrvatskoga jezika navode da je za konstrukciju osim $+\mathbf{G}$,karakteristično značenje isključivanja. Sami orijentiri isključeni su iz označenoga scenarija, pa se s obzirom na to profilirani situacijski okvir u odnosu na njih također ostvaruje kroz predodžbu prostorne udaljenosti“ (Belaj, Tanacković-Faletar: 355-356). Ni autori Gramatike hrvatskoga jezika za gimnazije i visoka učilišta ne registruju aditivno značenje prijedložno-padežne konstrukcije osim + G, već samo eksceptivno: „Genitivu s prijedlogom osim izuzimanje je osnovno značenje“ (Silić, Pranjković 2005: 216). Prijedložnu-padežnu konstrukciju osim + G kao osnovni i najbitniji model eksceptivnog genitiva, tj. genitiva „sa značenjem izuzimanja (isključivanja) jedne pojave (osobe, predmeta, apstraktnog pojma) 
iz mnoštva ostalih prisutnih ili odsutnih istovrsnih pojava" navode i autori Sintakse savremenoga srpskog jezika (Piper et alt. 2005: 172). Iz navedenog se kao bitne mogu izdvojiti dvije činjenice: a) značenje izuzimanja (isključivanja) je osnovno značenje prijedložno-padežne konstrukcije osim $+\mathbf{G}$ i b) ni u jednom od pomenutih gramatičkih priručnika (a ni u široj literaturi, koliko je nama poznato) ne uočava se i ne objašnjava veza između eksceptivnog značenja prijedložno-padežne konstrukcije osim + G kao za nju primarnog, sa jedne strane, i njenog aditivnog značenja, kao izvedenog, sa druge. A ta veza postoji iako su ova dva značenja, eksceptivno i aditivno, obuhvaćena jednom te istom prijedložno-padežnom konstrukcijom, naizgled potpuno suprotna $\mathrm{i}$ međusobno isključujuća. Koncept izuzimanja, isključivanja leži u osnovi oba značenja ove prijedložno-padežne konstrukcije. Razlika se tiče konteksta u kojem se realizuje značenje isključivanja. U značenju koje se u Sintaksi savremenoga srpskog jezika markira kao eksceptivno, genitivom s prijedlogom osim, kako smo već naglasili, jedan entitet izuzima se iz „mnoštva ostalih prisutnih ili istovrsnih pojava“. U drugom značenju ove prijedložno-padežne konstrukcije, značenju koje se nominuje kao aditivno, koncept isključivanja (izuzimanja) se, ako je tako moguće reći, vezuje za mentalni prostor enkodera poruke, $\mathrm{tj}$. tiče se hijerarhizacije informativnog značaja rečeničnih članova $u$ umu kreatora datoga iskaza. Pojam s imenom u genitivu je, naime, presuponirani pojam, pojam koji se podrazumijeva u okviru skupa određenih entiteta mišljenih u umu kreatora iskaza. Isključivanje (izuzimanje) tiče se upravo podrazumijevajuće prirode pojma s imenom u genitivu u konstrukciji s prijedlogom osim. Drugim riječima, pojam sa imenom u genitivu ,isključuje se“, „izuzima“ u smislu da u hijerarhizaciji informativne vrijednosti rečeničnih članova od strane pošiljaoca poruke taj pojam odstupa u drugi plan. Isključivanje se, dakle, tiče isključivanja pojma sa imenom u genitivu iz centralnog informativnog plana iskaza, iz fokusa obavijesti koja se iskazom želi prenijeti; u tome se, kad je ova upotreba prijedložno-padežne konstrukcije osim + G iscrpljuje značenje isključivanja (izuzimanja). Pojam $\mathrm{s}$ imenom u genitivu u konstrukciji s prijedlogom osim, međutim, iako u pozadini kad je informativni plan iskaza u pitanju, sastavni je dio date misaone konstrukcije enkodera poruke. Upravo ta komponenta sastavnosti, činjenice da je pojam s imenom u genitivu sastavni dio date misaone konstrukcije, i omogućava da se kod te prijedložno-padežne konstrukcije $u$ ovom slučaju razvije aditivno značenje. Priroda konstrukcije osim $+\mathbf{G}$ u ovim primjerima, konstrukcije koja se u svijesti pošiljaoca poruke tretira kao nosilac podrazumijevane informacije, tj. konstrukcije koja u obavijesnoj strukturi datog iskaza kao takva ima informativno manji značaj, najbolje se vidi iz perifraze iskaza s prijedložno-padežnom konstrukcijom osim $+\mathbf{G}$, konstrukcijom s vezom koordinativnih veznika 
a i- ... a osim uživanja u engleskoj prestonici, pjevačica je završavala i poslovne obaveze > pjevačica je završavala poslovne obaveze, a i uživala je u engleskoj prestonici...; Osim termoelektrane, trebala bi se graditi i prateća tvornica bioetanola ... > Trebala bi se graditi prateća tvornica bioetanola a i (naravno) termoelektrana. Mada u lingvističkoj literaturi nema saglasnosti oko funkcionalne i značenjske prirode iskaza s jednovremenom upotrebom veznika a i i ${ }^{1}$ mi prihvatamo mišljenje da se „katkada ova dva veznika kom-

Tako npr. M. Stevanović tu vezu vidi kao spoj dva koordinativna veznika i razlog njenog nastanka objašnjava ovako: „Ako je potrebno označiti i sastavnost i suprotnost dveju neposredno uzastopnih rečenica koje su jednim elementom suprotne, a drugim sastavne, onda se upotrebe oba veznika i a i i, i to uvek na prvom mestu a, kao u primeru: Nad svom tom žurbom i krikom sjalo je sunce, a i zemlja bjelinom zasenjivala" (Stevanović 1974: 804). M. Kovačević, pak, u svom radu o diferencijaciji partikula i homoformnih (djelova) veznika tvrdi da su „ta dva spoja (a i, ali i, prim. M. A.) zaista specifična, ali ni to nisu spojevi dva nezavisna veznika (...) jer jednostavno u srpskom standardnom jeziku nikad nije moguće 'kombinovati' dva sintaksički istovrsna (nezavisna ili zavisna) veznika u 'složeni veznik'. Specifičnost ovih spojeva prvenstveno je u tome što, za razliku od ostalih 'spojeva', najčešće nije moguće eliptirati i a da rečenica ostane gramatički ovjerena, što posredno upućuje na zaključak da je u ovom spoju i veznik a ne partikula. Najčešće je, međutim, moguća redukcija prvog elementa, tj. a ili ali. Ta činjenica upućuje na alternativne hipoteze kao objašnjenje: ili je prvi dio spoja (tj. a odnosno ali), budući da je izostavljiv, partikula (iz čega onda nužno proističe zaključak da partikule mogu stajati ispred nezavisnog veznika i), ili dva nezavisna veznika mogu tvoriti 'složeni' nezavisni veznik... Ni jedna od hipoteza ne može se, međutim, potkrijepiti čvršćim naučnim argumentima“ (Kovačević 1998: 255-256). U nastavku svog rada Kovačević dokazuje da se, pošto se nikad u kontaktnom položaju ne mogu realizovati bilo koji homoformni veznik i partikula, u spoju *i i jedna od te dvije jedinice mora supstituisati nekom drugom jedinicom. Po njemu, ,zamjena partikule i gotovo da nije moguća, jer ona među partikulama nema nijednog relativnog sinonima... Ostaje, dakle, jedina mogućnost da se zamijeni veznik i. Kad taj veznik povezuje vremenski sukcesivne ili kauzalne sadržaje koordiniranih klauza, i je moguće zamijeniti veznicima pa ili te, tako da se tada često i i realizuje kao pa/te i; ali kad se veznikom i povezuju vremenski simultani sadržaji klauza, mogućnost supstitucije bilo kojim sastavnim veznikom izostaje. I prioritetno tada dolazi do zamjene i i sa a/ali i. Izbor a ili ali kao supstituenta nije slučajan, nego je podržan činjenicom da se u srpskom jeziku i a i ali pojavljuju i u nevezničkoj funkciji gramatičkih 'osamostaljivača' rečeničnih članova... Veznik a/ali pri takvoj supstituciji uz vezničku i sam dobija intenzifikatorsku funkciju, tako da rečenici daje status stilistički markirane (posebno u odnosu na onu sa samim sastavnim veznikom). Tako u navedenom spoju a/ali ima ulogu koordiniranog veznika, a i ulogu intenzifikatorske partikule..." (Kovačević 1998: 256). Navedeno Kovačevićevo objašnjenje nastanka spoja a (ali) i prilično je neuvjerljivo iz više razloga - tačno je da je, kad povezuje vremenski sukcesivne sadržaje koordiniranih klauza, veznik i moguće zamijeniti veznicima pa ili te; ali ne može se kao tačna prihvatiti Kovačevićeva konstatacija da „kad se veznikom i povezuju vremenski simultani sadržaji klauza, mogućnost supstitucije bilo kojim sastavnim veznikom izostaje“. Jer, kako je dobro primijetio i oprimjerio I. Pranjković „veznik te može povezivati i elemente u vremenskoj usporednosti (naglasio M. A.) i elemente u sukcesivnosti. Međutim, taj veznik vrlo često služi kao 'rezerva' (prije svega) vezniku 
Ekstenzija značenja kod prijedloga...

binuju da istaknu izdvojenost sadržaja konstrukcije koju uvode iz opšte celine, uz održanje čvrste veze s njom“ (Simić, Jovanović: 762). Izdvojenost iz cjeline sadržaja koji se uvodi uz istovremeno održanje veze s tom cjelinom sugeriše specifičnost sintaktičko-semantičkog statusa tog sadržaja; specifičnost koja je, po našem mišljenju, najprije za enkodera, a onda i dekodera datog iskaza, u manjem informativnom značaju tog dijela iskaza (Simić, Jovanović 2002: 431). U prvobitno sastavnu konstrukciju markiranu veznikom i umeće se, dakle, veznik a, koji unosi značenje dispariteta i taj dio rečenice po nečem (u našim primjerima po sekundarnosti informativnog značaja njenog sadržaja) izdvaja od njenog ostatka.

Druga činjenica koju ćemo notirati u ovom radu je da se niz prijedloga kojima se uz genitiv primarno označava prostorni odnos među predmetima upotrebljava u konstrukcijama sa koncesivnim značenjem. Riječ je o prijedlozima pored, kod, kraj i mimo: I pored nezavidne situacije $u$ protekloj godini...odolijevamo teškoćama koje nas prate...(Dan, Kultura, 27. 12. 2014, 12), Kod tolike rodbine, ipak je umro napušten i sam. (razg.), Kraj tolikih problema, ipak se ne predaje (razg.), ,, Avala “ je šest godina dograđivana bez građevinske dozvole, a $i$ mimo odobrenja arhitekte Vladislava Plamenca. (Vijesti, 3. 1. 2015, 35). Ono što je zajedničko svim ovim prijedlozima je „da uz genitiv označuju odnos među predmetima kojemu je svojstvena blizina“ (Silić, Pranjković 2005: 212). Upotrebu ovih prijedloga u konstrukcijama s

i, tj. upotrebljava se zato da se veznik i ne bi prečesto upotrebljavao. To osobito dolazi do izražaja onda kad bi veznik i trebalo da se u okviru jedne strukture upotrijebi na različitim razinama (npr. za povezivanje i pojedinih klauza i rečeničnih članova)“ (Pranjković 1984: 54). Iz rečenog je jasno da nema nikakvih zapreka da veznik $\mathbf{i}$ bude supstituisan i veznikom te, a ne jedino i samo veznicima a/ali koji su vezani za drugo funkcionalno-semantičko polje. Sa druge strane, moguća supstitucija veznika i veznicima a/ali nužno datim koordiniranim strukturama pored komponente sastavnosti pridaje i komponentu neke (pod)vrste suprotnosti. Mi se zbog svega toga, kad je spoj a i u pitanju, opredjeljujemo za rješenje iznijeto u glavnom tekstu, tj. stav da je ovdje riječ o kombinaciji dva veznika. Mišljenja smo da su ove koordinirane konstrukcije primarno sastavne; kod njih je, naime, moguće elipsirati veznik a, a da konstrukcija ostane gramatična, ali to isto nije moguće uraditi sa veznikom i, npr. Rukopis sadrži i nove važne priloge, a i tekstove koji su objavljeni $u$ „Crnogorskom književnom listu" > Rukopis sadrži i nove važne priloge i tekstove koji su objavljeni u „Crnogorskom književnom listu", ali ne *Rukopis sadrži i nove važne priloge, a tekstove koji su objavljeni $u$ „Crnogorskom književnom listu“. Moglo bi se reći da je veznik a naknadno dodat, i da u ovim konstrukcijama on vrši svoju centralnu funkciju koja se ispoljava u tome da se njim „obeležava izuzimanje izvesnih grupa fakata iz celine, i to na taj način što se među njima stvara disparitet po nekom svojstvu, funkciji ili odnosu, ali uz zadržavanje osećaja pripadnosti celini u opštem smislu, van istaknute perspektive. Važno je dodati da je objedinjavajuća perspektiva samo stvar 'osećaja', i da je u semantičkoj pozadini, kao neka opšta perspektiva. A da je disparitet u prvom planu...Veznikom a, može se reći, označava se delimičan unutrašnji disparitet neke globalno jedinstvene celine“" (Simić, Jovanović: 2002: 431). 
koncesivnim značenjem konstatuju sve bitnije gramatike srpskohrvatskog, srpskog i hrvatskog jezika. ${ }^{2}$ Postavlja se pitanje zašto su se baš prijedlozi s genitivom koji označavaju odnos među predmetima kojem je svojstvena blizina pojavili u sklopu onog dijela koncesivne konstrukcije koji denotira na zadovoljeni uslov. Da bismo to objasnili napravićemo ekskurs u dva pravca - u pravcu takozvane lokalističke teorije i u pravcu dubljeg pojašnjenja semantičke kategorije dopusnosti. M. Kovačević u svojoj studiji o uzročnom semantičkom polju, govoreći o učešću prostih kategorija u formiranju kategorije uzroka u jeziku, kaže da je „lokalnost (...) produkt još mitskog mišljenja; kategorija koja se zasniva na neposrednom opažanju momenata naporednosti, supostojanja objekata. Za označavanje i izražavanje lokalnosti gotovo svi jezici su stvorili efikasna sredstva, koja će dalje, zavisno od toga koliko je bilo učešće ove u formiranju drugih kategorija - biti korištena za izražavanje mnogih drugih značenja“ (Kovačević 2013: 31). Kako vidimo, sredstva za izražavanje lokalnosti koriste se i u konstrukcijama s dopusnim značenjem; budući da su u razvoju jezika najranije oformljena, sasvim je razumljiv i njihov prodor u semantičku sferu koncesivnosti. Da bismo objasnili odakle i zašto su se baš prostorni prijedlozi za izražavanje odnosa blizine pojavili kao sredstvo za izražavanje prvog dijela koncesivnih konstrukcija, moramo se detaljnije pozabaviti i semantičkom prirodom koncesivnosti. Egzegezu je pri tome, privremeno, najbolje prenijeti na teren zavisnosloženih rečenica s veznikom iako kao tipičnog izraza i predstavnika semantičke kategorije koncesivnosti u B/CG/H/S jeziku. Zanimljiva zapažanja o koncesivnim rečenicama daju R. Simić i J. Jovanović u svojoj, u ovom radu već citiranoj knjizi: „Veznik 'iako'

„U prirodi je našeg jezika i upotreba genitiva s predlogom kod s permisivnim (dopusnim) značenjem, kakvo imamo u primerima: Sramota bi bila da Turci dođu u moju kuću, pa $i$ kod tolike slave i imena moga da u njoj ništa ne nađu...“(Stevanović 1974: 308). „Dakle, i genitiv s predlogom kraj (...) upotrebljava se s koncesivnim (dopusnim) značenjem, npr.: Kraj sve nedaće $u$ životu bijaše svojoj djeci dobar i predobar..." (Stevanović 1974: 317). „A od ovoga (značenja zajednice pojma s imenom u genitivu s prijedlogom pored sa onim od čega se taj pojam na izvjestan način izuzima, prim. M. A.) opet nije daleko koncesivno značenje upotrebe genitiva s predlogom pored, u kojem su „obični i predlozi kod i kraj... Ta tri romana, i pored zastarele forme, moderna su po zamisli..." (Stevanović 1974: 325). „Genitiv s prijedlogom kod relativno se često upotrebljava i u dopusnome značenju, npr. $N i$ kod tolikih problema oni se ne predaju. U tome značenju javljaju se i prijedlozi kraj, npr. Kraj tolikih djevojaka on se ne ženi, i pored, npr. I pored takvih susjeda treba sačuvati živce i živjeti normalno" (Silić, Pranjković 2005: 214). Autori Sintakse savremenog srpskog jezika - prosta rečenica kao modele za realizaciju koncesivnog genitiva navode prijedložno-padežne konstrukcije s prijedlozima pored, mimo, bez, protiv, preko i kod (Piper et alt. 2005: 170-172). „Dopusni genitiv upotrebljava se s predlozima mimo, pored, kraj, bez, protiv, preko ili kod u adverbijalnoj ili u atributskoj funkciji, sa značenjem prevladavanja prepreke za ostvarivanje onoga što se apstraktnom imenicom u dopusnom genitivu određuje“ (Piper 2013: 335). 
u stvari je stegnuta sekvenca 'i ako’ = 'ako i’. Poslednja se može shvatiti kao granični slučaj uslovne implikativnosti sa opštim značenjem: 'u svim slučajevima, pa i u tome da': - Ići ćemo na izlet iako bude padala kiša = Ići ćemo na izlet bez obzira na sve, pa i na kišu = Svakako ćemo ići na izlet. Iz uslovne sfere, $\mathrm{tj}$. iz sfere kondicionalne presupozitivnosti, značenje konstrukcije na taj način migrira u oblast bezuslovne presumptivnosti. Koncesivnost nije ništa drugo do dalja razvojna forma bezuslovnosti“ (Simić, Jovanović 2002: 1358). „Semantička podloga koncesivnosti slična je onoj kod suprotnih naporednih rečenica. Razlika je u načinu sintaksičkog uobličenja ekskluzije: tamo su kontradiktorne činjenice stavljene jedna kraj druge kao ravnopravne, a ovde je za polazište uzeta jedna, pa je sa njenoga gledišta ocenjena druga kao neočekivana, a ipak 'dopuštena'“ (Simić, Jovanović 2002: 1359). Pored udruživanja sa semantičkom kategorijom uslovnosti [J. Silić i I.Pranjković ovaj tip dopusnih rečenica nazivaju uvjetnodopusnima (Silić, Pranjković 2005: 349)], dopusne rečenice nastaju i udruživanjem sa uzročnošću ,pa su takve dopusne rečenice u relaciji prema uzročnima...(i) nazivaju se uzročnodopusnima“ (Silić, Pranjković 2005: 349). No, bez obzira na koji način nastaju dopusne rečenice, da li udruživanjem sa semantičkom kategorijom uslovnosti ili udruživanjem sa semantičkom kategorijom uzročnosti, važno je konstatovati sljedeće - sadržaji zavisne klauze i glavne klauze jedne dopusne rečenice povezani su dubljom zavisnošću, određenim vidom zakonomjernosti. Tako npr. u rečenici Otišli smo u šetnju iako je padala kiša između radnje šetanja i padanja kiše postoji imanentna veza i unutarnja zakonomjernost u smislu da se po kiši (najčešće) ne ide u šetnju. Koncesivno značenje prijedloga kojima se označava blizina među entitetima najvjerovatnije je poteklo iz konteksta u kojima se ovi prijedlozi upotrebljavaju u njihovom primarnom značenju, značenju prostorne blizine; npr. Pored obilne večere, ostao je gladan (Ostao je gladan u blizini obilne večere); Iz ovakvih konteksta, u kojima je značenje prostorne blizine primarno, a koncesivno tek latentno, upotreba prijedloga pored, kod, kraj, mimo s genitivom proširila se i u kontekste u kojima se blizina shvata metaforički: I pored nezavidne situacije u protekloj godini...odolijevamo teškoćama koje nas prate (u navedenom primjeru pojam blizine manifestuje se kao simultanost odolijevanja teškoćama i nezavidne situacije, uklopljenost prvog sadržaja u drugi). U takvim kontekstima pored metaforički shvaćenog odnosa blizine između sadržaja na koji referiše prijedložno-padežna konstrukcija pored, kod, kraj, mimo + G i sadržaja na koji referiše ostatak klauze, u prvi plan dolazi i odnos vremenskog paralelizma između ta dva sadržaja. Na bazi vremenskog paralelizma i metaforički shvaćene blizine između pomenuta dva sadržaja klauze stvara se podloga za nastanak koncesivne semantike kod prijedložno-padežnih veza pored, kod, kraj, mimo + G; prijedlozima kojima 
se denotira blizina uz pojam u genitivu, uz vremenski paralelizam sadržaja koji se, sa jedne strane, iskazuje prijedložno-padežnom konstrukcijom, a sa druge, ostatkom klauze, naglašava se tijesna logičko-smisaona povezanost tih sadržaja. Tijesna logičko-smisaona povezanost sadržaja ostatka klauze sa pojmom u genitivu sa pomenutim prijedlozima implikuje i nameće očekivanje da bi sadržaj tog dijela klauze po unutarnjoj zakonomjernosti, diktiranoj semantikom pojma u genitivu, trebalo / ne bi trebalo da se realizuje (npr. Pored nezavidne situacije u protekloj godini ne uspijevamo da odolijevamo teškoćama koje nas prate). Međutim, dešava se upravo suprotno. I upravo u tome otkriva se konačni razlog (opstanka) upotrebe prijedloga pored, kod, kraj, mimo sa genitivom (i) u koncesivnom značenju - naglašavanjem, putem metaforičke upotrebe primarno prostornih prijedloga za denotiranje odnosa blizine među entitetima, tijesne unutarnje, logičko-smisaone veze među konstituentima koncesivne konstrukcije posmatrane kao cjelina, impliciranjem na taj način da semantika pojma u genitivu zahvaljujući toj tijesnoj logičkoj-smisaonoj povezanosti sa ostatkom sadržaja klauze nužno mora izazvati (ne)realizaciju ostatka sadržaja klauze, što se ipak ne dešava, postiže se krajnji efekat - oformljenje značenja bezuslovne presumptivnosti klauze u cjelini (npr. u već pomenutom primjeru Svakako uspijevamo da odolimo teškoćama koje nas prate). Riječju, prijedlozi koji primarno funkcionišu kao pokazatelji relacije konkretne blizine među određenim entitetima pokazali su se, kroz opisani semantički proces, kao efikasno jezičko sredstvo za izražavanje jedne apstraktne kategorije, kategorije koncesivnosti.

$\mathrm{U}$ ovom radu pozabavićemo se i upotrebom prijedloga do s genitivom u značenju izuzimanja. Eksceptivni genitiv se definiše kao ,genitiv sa značenjem izuzimanja (isključivanja) jedne pojave (osobe, predmeta, apstraktnog pojma) iz mnoštva ostalih prisutnih ili odsutnih istovrsnih pojmova" (Piper et alt. 2005: 172). Autori ove monografije ističu da je prijedlog do sa genitivom u eksceptivnom značenju arhaičan (Piper et alt. 2005: 173), dok za upotrebu genitiva sa ovim prijedlogom u istom značenju J. Silić i I. Pranjković u svojoj knjizi kažu da je u savremenom hrvatskom jeziku obilježena (Silić, Pranjković 2005: 206). Ni u jednom od ovih priručnika nema međutim naznake od ukazivanja na moguću povezanost primarnog značenja veze genitiva s prijedlogom do i eksceptivnog značenja ove prijedložno-padežne konstrukcije. Primarno značenje genitiva sa prijedlogom do ,vezano je za adlokalnost (...) s tim da je tomu prostornom odnosu svojstveno kretanje jednoga predmeta prema drugome kao granici kretanja (riječ je o graničnoj direktivnosti)“" (Silić, Pranjković 2005: 205). Semantički bitan u konstrukciji genitiva sa prijedlogom do je, dakle, pojam granice pri čemu, kad je riječ o spacijalnom značenju, tu granicu predstavlja pojam sa imenom u genitivu. Granica se, međutim, može aper- 
cepirati ne samo kao nešto prema čemu je usmjereno kretanje nekog entiteta ili nešto uz što supostoji neki drugi entitet nego i kao nešto što odvaja pojam sa imenom u genitivu od situacije na koju referiše ostatak iskaza; upravo ta činjenica je omogućila pojavu eksceptivnog značenja prijedložno-padežne konstrukcije do + genitiv .

Rezimirajući, možemo reći da je semantička evolucija ne samo prijedložno-padežnih konstrukcija nego jezičkih jedinica uopšte veoma zanimljivo i korisno područje za istraživanje budući da objedinjuje izučavanje izražajnih sredstava jezika, sa jedne strane, i mentalnih procesa, sa druge, omogućavajući dublje uvide $\mathrm{u}$ funkcionisanje ljudskog uma. Utoliko je čudnije da $\mathrm{u}$ literaturi o $\mathrm{B} / \mathrm{CG} / \mathrm{H} / \mathrm{S}$ jeziku nema mnogo radova s ovom tematikom. Ovaj rad smatramo skromnim doprinosom u pravcu popunjavanja praznine na polju izučavanja semantičkog razvoja jezičkih jedinica u B/CG/H/S jeziku; izučavanja koje će u budućnosti, nadamo se, postati mnogo intenzivnije, što će kao rezultat imati temeljniju proučenost $\mathrm{B} / \mathrm{CG} / \mathrm{H} / \mathrm{S}$ jezika i temeljnija saznanja o semantičkim procesima koji su aktivni ili su bili aktivni u njemu.

\section{Izvori}

- Vijesti - dnevni list iz Podgorice

- Dan - dnevni list iz Podgorice

- Jutarnji list - dnevni list iz Zagreba

\section{Literatura}

- Belaj, Branimir, Faletar Tanacković, Goran. Kognitivna gramatika hrvatskoga jezika. Zagreb: Disput, 2014.

- Klikovac, Duška. Semantika predloga. Beograd: Filološki fakultet, 2000.

- Kovačević, Miloš. Sintaksa složene rečenice u srpskom jeziku. Beograd: Raška škola, 1998.

- Kovačević, Miloš. Uzročno semantičko polje. Beograd: Jasen, 2012.

- Piper, Predrag et alt. Sintaksa savremenoga srpskog jezika. Prosta rečenica. Beograd: Institut za srpski jezik SANU, Beogradska knjiga, Matica srpska, 2005.

- Piper, Predrag, Klajn, Ivan. Normativna gramatika srpskogjezika. Novi Sad: Matica srpska, 2013.

- Pranjković, Ivo. Gramatička značenja. Zagreb: Matica hrvatska, 2013.

- Pranjković, Ivo. Koordinacija u hrvatskom književnom jeziku. Zagreb: Hrvatsko filološko društvo, 1984. 
- Silić, Josip, Pranjković, Ivo. Gramatika hrvatskoga jezika za gimnazije i visoka učilišta. Zagreb: Školska knjiga, 2005.

- Simić, Radoje, Jovanović, Jelena. Srpska sintaksa 1-2. Beograd: Jasen, 2002.

- Stevanović, Mihailo. Savremeni srpskohrvatski jezik 2. Sintaksa. Beograd: Naučna knjiga, 1974.

\section{Miomir ABOVIĆ}

\section{EXTENSION OF MEANING OF PREPOSITIONS: NON-PRIMARY MEANINGS OF PREPOSITIONS OSIM, PORED, KOD, KRAJ, MIMO AND DO IN THE BOSNIAN, MONTENEGRIN, CROATIAN AND SERBIAN LANGUAGE}

In this paper, the author deals with non-primary meaning, in terms of the direction of semantic development, of certain prepositions and groups of prepositions in the Bosnian, Montenegrin, Croatian and Serbian language. The author aims to describe the mechanisms of development of non-primary meaning of these prepositions (and groups of prepositions), meaning that is ascertained by more or less all the relevant grammatical manuals in the relevant languages, but with no attempt made to explain their formation.

Key words: adverbs, meaning, semantic development, genitive case, additivity, concessionality 
UDK 811.163.4(497.16)'282'374

\section{Novica VUJOVIĆ (Nikšić)}

\section{Pregledni rad}

Fakultet za crnogorski jezik i književost - Cetinje

novica.vujovic@fcjk.me

\section{DIJALEKATSKI RJEČNICI I NJIHOV ZNAČAJ}

- povodom Biblioteke Lexicographia-

Autor ovoga priloga polazi od činjenice da dobro urađen rječnik predstavlja preśek leksičkog fonda jednoga jezika, odnosno nekog dijalekatskoga područja jednoga jezika. S obzirom na to, možemo reći da rječnici povodom kojih je nastao ovaj tekst, odnosno sabrani leksički fond, otkriva pravo bogatstvo crnogorskoga jezika. Predstavljeni rječnici iz Biblioteke Lexicographia Instituta, odnosno danas Fakulteta za crnogorski jezik i književnost - dragocjen su prilog montenegristici.

Ključne riječi: crnogorski jezik, dijalekatski rječnici, leksikologija, dijalektologija

Institut za crnogorski jezik i književnost, danas Fakultet za crnogorski jezik i književnost - Cetinje, objavio je u Biblioteci Lexicographia pet rječnika, i to po knjigama ovim redom: Rječnik veličkoga govora, ${ }^{1}$ Njeguški rječnik, Rječnik plavsko-gusinjskoga govora, ${ }^{3}$ Rožajski rječnik ${ }^{4}$ te Rječnik osmanske leksike barskoga kraja. ${ }^{5}$ Odmah da kažemo: čini se da je pojavljivanje tih rječnika kod nas prošlo gotovo nezapaženo.

Vrijedno je primijetiti da knjige kao recenzenti potpisuju naši ugledni naučnici: Radoslav Rotković i Božidar Šekularac (knj. 1), Čedomir Draško-

1 Branko Jokić, Rječnik veličkoga govora, Institut za crnogorski jezik i književnost, Podgorica, 2012.

2 Dušan Otašević, Njeguški rječnik, Institut za crnogorski jezik i književnost, Podgorica, 2012.

3 Ibrahim Reković, Rječnik plavsko-gusinjskoga govora, Institut za crnogorski jezik i književnost, Podgorica, 2013.

4 Ibrahim Hadžić, Rječnik rožajskoga govora, Institut za crnogorski jezik i književnost, Podgorica, 2013.

5 Sead Šlaković, Rječnik osmanske leksike barskoga kraja, Institut za crnogorski jezik i književnost, Podgorica - Bar, 2013. 
vić i Radoslav Rotković (knj. 2), Jašar Redžepagić, Alija Džogović i Zuvdija Hodžić (knj. 3), Adnan Čirgić (knj. 4) i Jasmina Đorđević (knj. 5).

Branko Jokić je prikupljao riječi veličkoga govora s ambicijom da u prezentaciji (dijela) osnovne stare leksike (riječi) podśeti na velički govor i pomogne njegovu očuvanju, ali i da ukaže kako je ona u dobroj mjeri i dalje živa. ${ }^{6}$ Velička leksika ispitivana je mnogo više u radovima koji su se odnosili na govor suśednih sela ili plemena. Autor naglašava da govor Velike karakteriše, između ostaloga, prisustvo specifičnoga alternanta poluglasnika, kao i veliko prisustvo riječi s fonemom $s ́$. U predgovoru se govori i o slojevitosti veličke leksike. Kao primjer autorove posvećenosti prikupljanju leksike čitamo navođenje 94 (u govoru ih je sigurno još koje nijesu ušle u registar) riječi kojima se određuje karakter, odnosno moralni profil čovjeka. Veoma dragocjen prilog izučavanju jezika toga dijela Crne Gore svakako je registar toponima koje autor navodi u predgovoru (iz Velike - 144 i u Nokšićima/Novšićima/Novšiću 74 toponima).

Njeguški rječnik djelo je Dušana Otaševića koji zbog bolesti nije mogao dovršiti posao oko rukopisa, pa je sve materijale predao Institutu, odnosno Adnanu Čirgiću da ih pripremi za štampu. Otašević u predgovoru čitaoce upoznaje s geografskim, istorijskim, privrednim, saobraćajnim i kulturnim prilikama njeguškoga plemena, što je u vezi i s dijalektološkim karakteristikama oblasti. Plemenski naziv se prvi put pominje 1420, a ranije je postojao naziv Ledinac (Njeguško polje - Lužina). Toponim je izveden prema hidronimu Nelgoše. Kaže se da je potok nestao poslije jakoga zemljotresa koji je tokom četvrte decenije XVI vijeka pogodio oblast Lovćena i okoline.

Publikovana građa je akcentovana i data s uobičajenim leksikografskim odrednicama. O govoru Njeguša autor veli: „Njeguški govor pripada takozvanim starocrnogorskim govorima. Tu su se slile osobine bokeljskoga govora i govora cetinjskoga tipa, te se može reći da je riječ o prelaznome govoru. I pored toga, po najbitnijim svojstvima njeguški govor uklapa se u opštecrnogorski jezički sloj."

Rječnik plavsko-gusinjskoga govora rezultat je dugogodišnjega rada slikara Ibrahima Rekovića. Na prigovore da to nije posao za njega, autor je lijepo odgovorio konstatujući da za tim poslom nijesu pošli ljudi kojima je to struka i koji su plaćeni da to rade. Reković je prikupio riječi, akcentovao ih, ${ }^{8}$ dao objašnjenja („Objašnjenja su uglavnom ispravna, ali pogdede nepotpuna. ${ }^{\left({ }^{9}\right.}$ ), kao i primjere iz upotrebe. Uz ponuđeni znatan fond leksike zabi-

Branko Jokić, n. d., str. 17.

Dušan Otašević, n. d., str. 15-16.

Akcentovao ih je Adnan Čirgić u skladu s izgovorom Ibrahima Rekovića.

Akademik Jašar Redžepagić, „Prilog proučavanju plavsko-gusinjskog duhovnog nasljeđa“, u: Rječnik plavsko-gusinjskoga govora, str. 382. 
Dijalekatski rječnici i njihov značaj

lježene su i fraze, kletve, blagoslovi, poslovice i izreke. Sabrana građa nosi pečat govora Plava i okoline. „Ti izrazi i reči sastavni su deo komunikacije muslimanskog, a delimično i pravoslavnog mesnog stanovništva. U tom govoru susrećemo se s nizom staroslovenskih i praslovenskih termina, takođe sa mnoštvom turskih, arapskih i persijskih reči, ili sa posuđenicama iz albanskog, grčkog, italijanskog i jezika susednih i drugih naroda." ${ }^{\text {"10 }}$

Rekovićevu knjigu kao recenzent potpisuje i Alija Džogović, dijalekto$\log$ i onomastičar, koji se više decenija bavio toponimijom i govorima plavsko-gusinjske dijalekatske zone. U njegovoj je recenziji posebno naglašena polisemičnost leksičkoga materijala.

Autor rječnika govora Rožaja i okoline je Ibrahim Hadžić. I on navodi kako je vođen željom da zabilježi i sačuva od nestanka rijetke ili gotovo iščezle riječi toga područja. Da se zaključiti da je rječnik profesionalno urađen. Centralni dio knjige čini registar, no značajno je spomenuti da se u knjizi nalazi i prilog iz narodnih govora s kraćim usmenim tvorevinama i tumačenjima nekih riječi i izraza. O primjerima koje autor naziva lokalizmima rečeno je u predgovoru da se može pretpostaviti da su dominantno slovenskoga porijekla. Hadžić oblike zasvjedočene u govoru Rožaja i okoline poredi sa stanjem u Rečniku srpskohrvatskog književnog jezika Matice srpske i Rečniku srpskohrvatskog književnog i narodnog jezika Srpske akademije nuka i umetnosti (podśećamo da je nedavno objavljena 19 knjiga). Pozivajući se na neujednačenost akcenatske slike u govoru rožajskoga kraja, autor uz primjere ne stavlja znake za obilježavanje akcenata. Pitanja koja dijalektolozima nameće građa o kojoj je riječ naznačio je Adnan Čirgić u recenziji. ${ }^{11} \mathrm{Na}$ kraju, podśećamo čitaoce i proučavaoce govora Rožaja i okoline da ovu knjigu prati CD s fonozapisima izvornih govornika, uglavnom snimljenih 70-ih godina XX vijeka i to s govornicima starije dobi, tako da je riječ o izuzetno vrijednoj građi.

Rječnik osmanske leksike barskoga kraja „sadrži riječi koje je koristio obični narod u svakodnevnoj komunikaciji. Dat je i manji broj riječi albanskoga i romanskoga porijekla, koje su se često mogle čuti u govoru." ${ }^{\prime 2}$ Turci su dolaskom na ove prostore veliki trag ostavili ne samo u sferi kulturnoga i vjerskoga života nego su, čini se, ništa manje uticali i na jezike osvojenih naroda. Ne smetnimo s uma da orijentalizmi čine znatan dio našega leksičkog fonda. Prisutni su i u jeziku crnogorskih pisaca: podśećamo da od 14.100 ri-

10 Akademik Jašar Redžepagić, n. d., str. 382.

11 Adnan Čirgić, „Iz recenzije“, Rječnik rožajskoga govora, Institut za crnogorski jezik i književnost, Podgorica, 2013, str. 559-561.

12 Sead Šlaković, Rječnik osmanske leksike barskoga kraja, Institut za crnogorski jezik i književnost, Podgorica - Bar, 2013, str. 9. 
ječi Njegoševa Gorskoga vijenca na orijentalizme „otpada oko $400 “{ }^{13}$ dok ih je u Svobodijadi (prema Pecovu brojanju to djelo ima oko 26.000 riječi) oko 1000, odnosno „turcizmi učestvuju sa $4 \%$ “. ${ }^{14}$

U rječnik je Šlaković unio i nazive naselja i ulica, kao i izraze, izreka i pjesme Bara i okoline. Dodajmo da su uz rječnik štampana muslimanska imena i prezimena Bara i okoline XIX vijeka. Važno je napomenuti da nije riječ o adaptiranim orijentalizmima u crnogorskome jeziku, već o „petrificiranoj“ osmanskoj leksici budući da je riječ o leksici ljudi koji su komunicirali i turskim jezikom.

Podśećamo na ovome mjestu da prvi leksikografski radovi u Crnoj Gori nastaju tokom posljednje četvrtine XIX vijeka. Radovi iz toga perida objavljeni su u crnogorskim časopisima, a svim autorima je kao uzor poslužio rad Vuka Stefanovića Karadžića. ${ }^{15}$ „Ne donosi se, dakle, leksika u svoj cjelovitosti književnoj, regionalnoj ili bilo kojoj drugoj već samo diferencijalna gdje se u stvari diferencira zabilježeni leksički fond u odnosu na Vukov Rječnik i književni jezik."16

Svima koji se bave kulturom, tradicijom i istorijom našega naroda rječnici iz Biblioteke Lexicographia nude dragocjene materijale. Riječ je, dakako, o rječnicima koji su višestruko značajni ne samo za montenegristiku. „Dijalekatski rečnik, više nego drugi tip rečnika, ne definiše reč sa lingvističke strane, nego definiše stvarnost koju ta reč označava. On, dakle, počiva, i opstaje, na kulturnoj semiotici pa bi njegova kulturološka vrednost bila u mogućnosti rekonstrukcije kulturne semiotike ‘čitanjem' to jest, upotrebom rečnika. ${ }^{\text {"17 In- }}$ formativna vrijednost dijalekatskoga rječnika, dakle, nije primarno usmjerena na govornike toga dijalekta, već prije svega čini bazu širokih mogućnosti naučnoga, prosvjetnoga i drugih pristupa tome sadržaju..$^{18}$

13 Asim Peco, „Turcizmi u Njegoševom Gorskom vijencu“, Pisci i njihov jezik, Prosveta, Beograd, 1995, str. 91. U knjizi u kojoj su objavljeni Pecovi radovi o turcizmima u Gorskome vijencu i Svobodijadi nalazimo i ovo: „Proces islamizacije, pak, bio je tijesno povezan upravo sa dolaskom Turaka na naše jezičko područje. Ali, ponavljam, to nikako nije bio i čin deslovenizacije onih koji su primili vjeru koju su nosili Turci i koji su znatno doprinijeli njenom širenju. Riječju, islamizacija nije povlačila za sobom i deslovenizaciju. To najbolje potvrđuje jezik. Na našem tlu jezik i onih koji su prihvatili islam bio je i ostao slovenski“ (str. 101).

14 Asim Peco, „Turcizmi u Njegoševoj Svobodijadi“, Pisci i njihov jezik, Prosveta, Beograd, 1995, str. 128.

15 Detaljnije u: Branislav Ostojić, „Vuk Karadžić i prvi leksikografski radovi u Crnoj Gori“, O crnogorskom književnojezičkom izrazu III, Univerzitet Crne Gore, Podgorica, 2003, str. 103-119.

16 Branislav Ostojić, n. d., str. 107.

17 Nedeljko Bogdanović, „Kulturološki značaj dijalekatskih rečnika“, Istraživanja srpskog jezika na Kosovu i Metohiji, zbornik radova, knj. 1, Univerzitet u Prištini - Filozofski fakultet, Kosovska Mitrovica, 2008, str. 16.

18 Viđeti: Nedeljko Bogdanović, n. d. 
Mi ovđe svakako polazimo od činjenice da dobro urađen rječnik predstavlja preśek leksičkog fonda jednoga jezika, odnosno nekog dijalekatskoga područja jednoga jezika. Rječnik nam olakšava opis nekog govora ili rukopisa koji je nastao u toj govornoj zoni. S obzirom na to, možemo reći da rječnici povodom kojih je nastao ovaj tekst, odnosno sabrani leksički fond, otkriva pravo bogatstvo crnogorskoga jezika. Da bismo načinili valjanu analizu crnogorskoga leksičkog materijala moramo biti sigurni u autentičnost likova, kao i tačno bilježenje akcenata. Ovđe imamo na umu grešku koja se potkrala Dragu Ćupiću, dugogodišnjem direktoru Instituta za srpski jezik u Beogradu, koji je konstatovao da „u Velestovu, Markovini i Zagredi nema uzlaznih akcenata, a u Zagredi bi se mogli i očekivati - i zbog etničke veze sa Čevom i zbog blizine Bjelopavlića (čiji govor ima sva četiri akcenta)“. ${ }^{19}$ Pomenuta konstatacija zaista iznenađuje s obzirom na to da se Ćupić decenijama bavio dijalektologijom te da je rođen samo desetak kilometara od pomenutih čevskih sela $\mathrm{i}$ sigurno je više puta bio u prilici da čuje izvorne govornike iz tih sela. Uz takve materijalne greške montenegristika se sve vrijeme suočavala i s činjenicom da su crnogorski govori decenijama bili dio plana dijalektoloških istraživanja srpskoga jezika te da je pristup registrovanim materijalima negirao postojanje crnogorskoga jezičkog identiteta. Prirodno je da i leksikografija toga doba prati kretanja oficijelne serbistike, pa se djelovalo tako da je „bilo značajnije opisati govore kao cjeline nego davati i njihovu kompletniju leksiku“، ${ }^{20}$

Bogatstvo crnogorskoga jezika očuvano je i pored permanentnoga nastojanja jezičke politike i planiranja da se „lokalni“ $i$,,arhaični“ elementi istisnu iz jezika. Jasno je da je sve što je crpljeno iz narodnih govora zaobilazilo brojne elemente karakteristične za crnogorske govore, a kako je to istiskivanje „lokalnih“ osobina u praksi izgledalo svjedoči citat: „Ovo, razumije se, nije posao pojedinca, već svih nas. Učiteljima, profesorima, svim nastavnicima našeg jezika pripada veliki dio posla na ovom polju. Dužnost je svakoga od njih da u mjestima svog rada tačno odredi odnos narodnog govora prema književnom jeziku, da tačno utvrdi neknjiževne elemente u govoru svojih učenika i da onda intenzivno dejstvuje u pravcu književnog jezika (... $)^{\text {‘21 }}$ itd.

19 Drago Ćupić, „Petar Pejović, Ozrinići - pleme Stare Crne Gore, Beograd, 2004, 552 str. B5 formata +7 karata“, Onomatološki prilozi, knj. XVIII, SANU, Beograd, 2005, str. 484. Ćupić pravilno navodi da je uz silazne akcente na prostoru čevskih sela zasvjedočen i „drugi uzlazni“, međutim za govor stanovništva Markovine nije u pravu kad veli da nema uzlaznih akcenata (taj prostor smo obišli više puta, snimali govor informatora i bilježili onomastičku građu). Da je Drago Ćupić pogriješio u određivanju akcenta u govoru Zagrede potvrdio nam je dijalektolog Adnan Čirgić.

20 Drago Ćupić, „Dijalekatski (regionalni) rečnici srpskoga jezika“, Srpski jezik, br. 5/1-2, Naučno društvo za negovanje i proučavanje srpskog jezika, Beograd, 2000, str. 703.

21 Milija Stanić, „Pitanje razvitka narodnih govora“, Stvaranje, br. 7-8, Titograd, str. 373-380. 
Treba ipak dodati da dijalekatski rječnici moraju imati mnogo važniju ulogu u osnovnoškolskom i srednjoškolskom obrazovanju današnjeg crnogorskoga obrazovnog sistema. Mislimo da je zadatak nastavnika i sastavljača programa za osnovnu i srednju školu da đake detaljnije upoznaju s našom dijalekatskom leksikom. Naravno, to ne znači da će izučavanje tih govornih osobina ići na štetu standarda, već da će učenici razvijanjem ośećaja za crnogorsko jezičko nasljeđe s kojega je nastao standardni crnogorski jezik - izgrađivati jezičku kulturu uopšte. Dodajmo i to da je Akcenatski savjetnik ${ }^{22}$ već urađen i da je nezaobilazan na časovima crnogorskoga jezika.

Značajno je na osnovu sabranih materijala ispitati uticaj riječi stranoga porijekla na našu leksiku. Tako ćemo, na primjer, konstatovati da je romanizam burilo zasvjedočen u rožajskome, plavsko-gusinjskom i veličkome govoru, kao i u njeguškom barelo. Njeguški govor inače karakteriše „daleko više romanizama od bilo kojega drugog dijela podlovćenske Crne Gore“" ${ }^{23}$ pojašnjava autor Njeguškoga rječnika. Orijentalizam baglama nalazi se u Rječniku rožajskoga govora i Rječniku plavsko-gusinjskoga govora. Germanizam kredenac zasvjedočen je u Njeguškom rječniku u obliku kredenca. I tako redom slijedeći višedisciplinarni pristup tom dijelu naše leksike. Ovđe je značajno dodati da su brojne riječi preuzimane iz drugih jezika te da su vremenom postale apsolutno uklopljene u sistem crnogorskoga jezika i govorni predstavnici ih ne ośećaju kao strane riječi.

Vrijedno je, uza sve navedeno, sačiniti rječnik opscene leksike, odnosno vulgarnih riječi koje su čak i onomastičari nerijetko zaobilazili i pored činjenice da je zasvjedočena u crnogorskoj toponimiji, a nekad i u nadimcima i porodičnim nadimci (ogranci, ,zagranci“) itd. Onomastički aspekt naznačenoga pitanja podrazumijeva izradu crnogorskoga prezimenika rječničkog tipa, no više je od svega značajno raditi na kompletiranju registra naših toponima i izradi dijelekatske karte. ${ }^{24}$ Nadalje, malo je pažnje posvećeno prikupljanju i proučavanju natpisa na nadgrobnim spomenicima (a oni dakako nose intimni porodični pečat) na starijim grobljima u Crnoj Gori. Ne treba zaboraviti terminologiju kuće i pokućstva, terminologiju poljoprivrede, religije, običaja i obreda koji žive u našem narodu. Dijalekatski rječnici pružaju uvid u antropografsku leksiku. Kako se može proučavati i klasifikovati antropografska

22 Adnan Čirgić i Jelena Šušanj, Akcenatski savjetnik, Ministarstvo prosvjete, Podgorica, 2013.

23 Dušan Otašević, Njeguški rječnik, Institut za crnogorski jezik i književnost, Podgorica, 2012, str. 13.

24 Moramo spomenuti da je tome poslu čvrste temelje udario Vukić Pulević, crnogorski biologbotaničar, koji je uz brojne radove priredio (koautorski rad s Novicom Samardžićem) monografski leksikon Fitonimi i zoonimi u toponimiji Crne Gore, Dukljanska akademija nauka i umjetnosti, Podgorica, 2003. 
leksika pokazao je Nedeljko Bogdanović u osvrtu na takve riječi u govoru Zagarača. ${ }^{25}$ Nudeći detaljnu sistematizaciju primjera (po biološkom statusu, tjelesnoj aktivnosti, djelatnosti, karakteru osobe, srodničkom statusu, nacionalnosti i mnogim drugim) Nedeljko Bogdanović konstatuje: „U tvorbi, kao i figurativnom značenju prednjače reči, neretko i tabuisane, sa područja analija i genitalija (preko 20 reči!), a iz animalnog sveta osnovu više izvedenica sa figurativnim značenjem ima pas: pašče, paščadija, psoglav, psoglavile (kao i: podvirep, požmirep).“26

Dijalekatska leksikografija podrazumijeva bilježenje svih riječi (ukoliko nije riječ o terminološkom rječniku) mjesnoga govora u kojima će se svakako naći i nestandardni likovi, kao i akcenat koji odstupa od akcenatskoga sistema crnogorskoga standardnog jezika. Uspješan rad na rječnicima najčešće se može razumjeti kao koautorski zadatak. Obrada leksičkoga materijala zahtijeva odgovarajući pristup i metodološku ujednačenost. Sve se to postiže „kombinovanim delovanjem kadrovske sekcije, smišljene podele posla i postepenim sazrevanjem autorskog kolektiva, zapravo stvaranjem leksikografske škole“ ${ }^{27}$ Međutim, u našem primjeru vrlo je slikovita činjenica da su se u posao izrade rječnika upustili ljudi kojima leksikologija i leksikografija nije struka. Iako u leksikografiji nije nepoznata pojava da rječnike rade nelingvisti, ${ }^{28}$ između ostaloga to može biti odgovor na neaktivnost najznačajnijih naših institucija.

Crnogorski leksikografi, dijalektolozi i onomastičari mogu se naslanjati na iskustva kolega istraživača sa šire štokavske teritorije. Nama se čini da će mladi istraživači, recimo i to ovđe, najviše doprinijeti obradi tema o

25 Nedeljko Bogdanović, „Antropografska leksika u Rečniku govora Zagarača Draga i Željka Ćupića“, Zbornik Instituta za srpski jezik SANU I, posvećeno dr Dragu Ćupiću povodom 75-godišnjice života, Institut za srpski jezik SANU, Beograd, 2008, str. 71-79.

26 Nedeljko Bogdanović, n. d., str. 76. Može nam ovđe biti interesantan dio zaključka urađen na osnovu poređenja ispitivane leksike sa stanjem u govorima jugoistočne Srbije. Bogdanović veli da se u tom dijelu Srbije

„ne javljaju (se) obrazovanja tipa -onja / -ota: posronja / posrota, plećonja / plećota; ne postoji tvorba nastavkom -ile: praznoglavile, praznotrbile, proglavile;

nema obrazovanja na -o: posro, prco;

nema obrazovanja na -ov: poganov;

u Zagaraču mnogo je više obrazovanja na -uša: povukuša, potrkuša, premiguša, premizguša, prosjakuša (u Timoku nema ni jedne od ovih reči, ali ima namiguše!)“ (str. 76). Dužni smo ispraviti autorovu grešku načinjenu pri navođenju primjera jer u govoru Zagarača, pa i u Ćupićevu Rječniku - postoji samo prośakuša.

27 Mitar Pešikan, „Nevolje rada na našim opisnim rečnicima“, Naš jezik, knj. XVI, sv. 3, Institut za srpskohrvatski jezik, Beograd, 1967, str. 197.

28 U izvještajima o radu na dijalekatskim rječnicima srpskoga jezika, a u njih su ubrajani i crnogorski jezički materijali, stoji da su polovinu radili ljudi kojima lingvistika nije struka (uzeto je stanje do 2000. godine). Viđeti: Drago Ćupić, navedeno djelo. 
kojima je riječ ako se u diplomskim, magistarskim i doktorskim radovima budu usmjeravali na originalne jezičke spomenike, te materijale iz jugoistočnih i śeverozapadnih crnogorskih govora prikupljene u saradnji s izvornim informatorima. Na ovome mjestu, a povodom objavljenih rječnika govora crnogorskoga jezika u Biblioteci Lexicographia Fakulteta za crnogorski jezik i književnost vrijedi podśetiti na značajno pitanje - Postoji li danas u Crnoj Gori leksikografski kadar i koliko zaista dijalektolozi rade na terenu i bilježe autentične materijale?

Publikovana građa u rječnicima koje je objavio Institut, odnosno današnji Fakultet za crnogorski jezik i književnost nosi sliku života ljudi, njihovoga trajanja kroz vjekove na prostoru koji im je nametao način života i privređivanja, đe su živjeli u stalnome dodiru s kulturama i jezicima naroda koje su zatekli, kao i onih koji su kasnije na bilo koji način dolazili u kontakt s njima. Sve što je bilo dio svijeta crnogorskoga čovjeka ugrađeno je u jezik i potvrđeno kroz bogatstvo leksike i izražajnih mogućnosti crnogorskoga jezika.

\section{Literatura}

- Bogdanović, Nedeljko: „Kulturološki značaj dijalekatskih rečnika“, Istraživanja srpskog jezika na Kosovu i Metohiji, zbornik radova, knj. 1, Univerzitet u Prištini - Filozofski fakultet, Kosovska Mitrovica, 2008, str. 16.

- Bogdanović, Nedeljko: „Antropografska leksika u Rečniku govora Zagarača Draga i Željka Ćupića“, Zbornik Instituta za srpski jezik SANU I, posvećeno dr Dragu Ćupiću povodom 75-godišnjice života, Institut za srpski jezik SANU, Beograd, 2008, str. 71-79.

- Čirgić, Adnan: „Iz recenzije“, Rječnik rožajskoga govora, Institut za crnogorski jezik i književnost, Podgorica, 2013, str. 559-561.

- Ćupić, Drago: „Petar Pejović, Ozrinići - pleme Stare Crne Gore, Beograd, 2004, 552 str. B5 formata +7 karata“, Onomatološki prilozi, knj. XVIII, SANU, Beograd, 2005.

- Ćupić, Drago: „Dijalekatski (regionalni) rečnici srpskoga jezika“, Srpski jezik, br. 5/1-2, Naučno društvo za negovanje i proučavanje srpskog jezika, Beograd, 2000.

- Hadžić, Ibrahim: Rječnik rožajskoga govora, Institut za crnogorski jezik i književnost, Podgorica, 2013.

- Jokić, Branko: Rječnik veličkoga govora, Institut za crnogorski jezik i književnost, Podgorica, 2012.

- Otašević, Dušan: Njeguški rječnik, Institut za crnogorski jezik i književnost, Podgorica, 2012. 
- Ostojić, Branislav: „Vuk Karadžić i prvi leksikografski radovi u Crnoj Gori“, O crnogorskom književnojezičkom izrazu III, Univerzitet Crne Gore, Podgorica, 2003, str. 103-119.

- Peco, Asim: „Turcizmi u Njegoševom Gorskom vijencu“, Pisci i njihov jezik, Prosveta, Beograd, 1995, str. 90-118.

- Peco, Asim: „Turcizmi u Njegoševoj Svobodijadi“, Pisci i njihov jezik, Prosveta, Beograd, 1995, str. 119-129.

- Pešikan, Mitar: „Nevolje rada na našim opisnim rečnicima“, Naš jezik, knj. XVI, sv. 3, Institut za srpskohrvatski jezik, Beograd, 1967, str. 193-204.

- Redžepagić, akademik Jašar : „Prilog proučavanju plavsko-gusinjskog duhovnog nasljeđa“, u: Rječnik plavsko-gusinjskoga govora, Institut za crnogorski jezik i književnost, Podgorica, 2013, str. 381-384.

- Reković, Ibrahim: Rječnik plavsko-gusinjskoga govora, Institut za crnogorski jezik i književnost, Podgorica, 2013.

- Stanić, Milija: „Pitanje razvitka narodnih govora“, Stvaranje, br. 7-8, Titograd, str. 373-380.

- Šlaković, Sead: Rječnik osmanske leksike barskoga kraja, Institut za crnogorski jezik i književnost, Podgorica - Bar, 2013.

\section{Novica VUJOVIĆ}

\section{DIALECT DICTIONARIES AND THEIR SIGNIFICANCE}

- On Lexicographia book edition -

The author of this paper starts his analysis from the premise that a well-made dictionary is a cross section of the lexicon of a language or a dialect of a language. In this context, we can say that the dictionaries which provoked this paper, or the gathered lexicon, reveal the true wealth of the Montenegrin language. The dictionaries published within the Lexicographia book edition of the former Institute and now Faculty for Montenegrin Language and Literature are a valuable contribution to the study of the Montenegrin language.

Key words: Montenegrin language, dialect dictionaries, lexicology, dialectology 

UDK 811.163.4'367.634((091)(497.16)

Pregledni rad

\title{
Miloš KRIVOKAPIĆ (Podgorica)
}

Filozofski fakultet Nikšić

krivokapicmilos@yahoo.com

\section{UPOTREBA VEZNIKA U JEZIKU SERDARA I GUVERNADURA RADONJIĆA (1706-1828) I U CRNOGORSKIM GOVORIMA}

\begin{abstract}
Većina karakteristika crnogorskih govora uglavnom su i osobenost pisama serdara i guvernadura Radonjića. Pisma Radonjića u znatnoj mjeri oslikavaju situaciju u svojoj dijalekatskoj bazi - starocrnogorskim, ali i u drugim crnogorskim govorima. U pismima Radonjića češće su složene rečenice čiji su djelovi međusobno povezani veznicima od onih bez veznika. Veznici u tim rečenicama nosioci su određenih sintaksičkih odnosa. U ovim pismima manifestuju se razne mogućnosti upotrebe istih veznika u odnosima djelova složene rečenice, kao i upotreba raznih veznika u istoj funkciji.

Ključne riječi: veznici, uzročno značenje, suprotnost, inverzija, iskazna rečenica, poredbena rečenica
\end{abstract}

\section{Uvod}

Pisma serdara i guvernadura Radonjića (1706-1828) većinom oslikavaju situaciju u svojoj dijalekatskoj bazi - starocrnogorskim, ali i u drugim crnogorskim govorima. U pismima Radonjića registrujemo znatno veći broj složenih rečenica čiji su djelovi međusobno povezani veznicima od onih bez veznika. U tim rečenicama veznici su nosioci određenih sintaksičkih odnosa. U ovim pismima se manifestuju razne mogućnosti upotrebe istih veznika u odnosima djelova složene rečenice, ali i upotreba raznih veznika u istoj funkciji.

\section{Upotreba veznika/e/}

Poznata je osobina crnogorskih govora da se veznik /e/ javlja u uzročnom značenju. ${ }^{1}$ Prema istraživanjima starocrnogorskih govora M. Pešikana,

1 M. Stevanović kaže da se veznik /e/ javlja u kučko-bratonožićkoj grani (up. Stevanović 
veznik /e/ se upotrebljava dvojako, i to: na početku uzročne i na početku iskazne rečenice (Pešikan 1965: 293). Veznik /e/, koji se u pismima Radonjića naporedo upotrebljava sa drugim veznicima u istoj funkciji, zabilježen je i u jeziku vladike Danila (Mladenović 1973: 183), vladike Petra I (Ostojić 1976: 248), crnogorskim govorima (Stevanović 1933-1934: 126; Miletić 1940: 571; Pešikan 1965: 293; Vujović 1969: 293). M. Pešikan smatra da je uzročno /e/ isto što i književno /jer/ (koje se ne upotrebljava u starocrnogorskim govorima) i neće se nikad upotrijebiti u inverziji (Pešikan 1965: 293). Veznik /e/ upotrebljava se u ovim pismima i na početku uzročne i na početku iskazne rečenice. Na početku uzročne rečenice registrujemo ga umjesto veznika $/ j e r / 2$ : No, gospodaru, čini pušti ni svakoga, zašto će mirnije biti, e ako pođoše u tursku zemlju, neće biti mira među njima (VIP3);

Zato molimo Vaše preuzvišeno gospostvo da ni činite to dijete pustiti e smo ga na riječ $i$ vjeru dali Vašeg preuzvišenog gospostva (VIP5);

Oni ih molili i kumili da ih ne pačaju, e njima ništa ne čine (SP4);

Molismo g-na governadura (...) da prenoćimo u ednu kuću u grad e bijesmo veoma trudni (SP6);

Srči se na mene serdar e sam ubio onoga Lacmana (SP28);

G-ne preuzvišeni molim Vas za ovo pismo da se u mnozine ne čuje e sam među mačem i nakovanjom (SP40).

Upotrebu veznika /e/ na početku iskazne rečenice u pismima Radonjića registrujemo u funkcije veznika/da/, što potvrđuju sljedeći primjeri:

Sada čujemo e nas Rišnjani zaskaču da ne sijeku kako su naučili (VIP3a);

Ma smo im i mi pisali poradi Vaše zapovijedi da ne rečete e ve ne oćemo obslužit (VIP18);

Ako bi se ko naša da se za svoju sramotu javi da ne rečete e su naši vijeru prevrgli (SP30);

Ako velite e e more vaše, mi znamo da est (JP2).

Navedeni primjeri pokazuju da pisma Radonjića oslikavaju situaciju u svojoj dijalekatskoj bazi - starocrnogorskim govorima. Tako M. Pešikan objašnjava da u starocrnogorskim govorima iskazno /e/ odgovara književnom /da/, koje se takođe upotrebljava. On navodi da se /e/ u rečenicama u kojima ima izražavanja namjere ili želje neće upotrijebiti (rekli su mu da dođe a ne

1933-1934: 126). B. Miletić prezentuje nekoliko primjera takođe sa istim značenjem (Miletić 1940: 571); B. Ostojić navodi da Petar I pored veznika/zašto/ ne upotrebljava veznik /e/ u uzročnom značenju (up. Ostojić 1976: 248).

2 Primjeri su ekscerpirani iz doktorske disertacije Miloša Krivokapića (2009): Jezik u pismima serdara i guvernadura Radonjića, Filozofski fakultet u Novom Sadu. Pri navođenju primjera date su skraćenice: VI (pop i serdar Vuko Radonjić); S (serdar i guvernadur Stanislav (Staniša) Radonjić); VII (guvernadur Vukale (Vukolaj) Radonjić); J (guvernadur Jovan Radonjić); VIII (guvernadur Vukolaj Radonjić); P (pismo). 
„e dođe“), napominjući da je u obje ove službe /e/ porijeklom od anaforske zamjenice (Pešikan 1965: 293).

\section{Upotreba veznika /ma/}

U frekventne veznike spada i veznik /ma/ (tal. $m a$ ) koji se često koristi umjesto veznika /ali/ ${ }^{3}$ u pismima Radonjića, dok su veznici /ama/ i /ema/, koji se javljaju u starocrnogorskim govorima (Pešikan 1965: 210-212) i jeziku vladike Petra I nepoznati Radonjićima ${ }^{4}$. U savremenom književnom jeziku „rečenice s veznikom /ma/ u predikatu uvek imaju krnji perfekat (...) ispred veznika /ma/ srećemo i veznik /pa/. Dopusne rečenice s veznikom $/ \mathrm{ma} / \mathrm{su}$ različne još i po tome što su uvek hipotetične, što tj. nijesu indikativne ili relativne već modalne dopusne rečenice“" (Stevanović 1969: 875). Ovaj veznik u ulozi suprotnog veznika /ali/ registrujemo u sljedećim primjerima:

Vladajte se kako znate, ma se ne nađite prevareni ka i priđe (VIP8);

Da mene nije bilo stid od vas (...) i dosad bi platio, ma će bit posada ako bog da (SP15);

Bijehu mi pisali da pođem preko vode niz rijeku pod grad, ma mi poć ne kćesmo (SP17);

I to im pasa (...) pak jošte prijete ma ne znam hoće li im svaka pasat (SP22);

Odista sam i dosad (...) bio nuđen da vi se piše knjiga, ma ja nijesam ktio (SP27);

Mi bez suda ne idemo, ma naše puštit nećemo kudijen naše knjige pišu (SP31);

Neka se pravi prikažuju, ma ako otvorih da govorim svu istinu, neće me sram biti (SP43).

\section{Upotreba veznika/no/}

„Suprotne su jedne drugima i rečenice od kojih se drugom kazuje da se nešto drugo ili drukčije (iz)vrši, zbiva ili jest, a ne ono što se konstatuje prvom od tih rečenica, i između kojih se kao spoljni znaci veze upotrebljavaju veznici

\footnotetext{
3 Ali je kao veznik suprotnih rečenica rijedak u jeziku Petra I jer su ga potisli veznici stranog porijekla /ma/ (tal) i /ama/ (tur). On se obično upotrebljava u disjunktivnom značenju - umjesto veznika /ili/, što odgovara stanju u savremenim crnogorskim govorima (up. Ostojić 1976: 247; Stevanović 1933-1934: 123; Miletić 1940: 566, Pešikan 1965: 203, Vujović 1969: 345; Vušović 1927: 67), kao i u jeziku P. P. Njegoša (up. Stevanović, Bošković 1967: 8,105; Vušović 1930: 172).

4 Tuđeg je porijekla i veznik /ema/ (tur) - (Ostojić 1976: 247-248).
} 
/već/, /nego/, /no/ i dr. Funkcija i značenje veznika /već/, /nego/, /no/ potpuno su isti; sve tri ove reči u njima su suprotni veznici u funkciji spoljnih oznaka veze međusobno adversativnih naporednih rečenica. Oni su tu, dakle, sinonimi. Veznik/no/ se, posebno, upotrebljava kao opozicija vezniku /ali/“ (Stevanović 1969: 767-768). Veznik /no/ najčešće bilježimo umjesto veznika/već/, / nego/, /ali/, što je osobina i starocrnogorskih govora (Pešikan 1965: 212):

To ostavit nećemo zaisto, no ćemo se š nekima obist (SP8);

Ne umijem što no dati na znanje Vašoj preuzvišenosti (SP9);

I to im dosta nie, no su se pošli tužiti (SP11);

On njima ne moga ništa no skoči na mene i veliko mi zlo i sramotu učini (SP12);

Mi ne bismo radi da se učini koja nesklada (...) no da svaka stvar ide po načinu (SP34);

Zašto mi ovi siromasi počinut ne dadu, no su i danas svi dohodili (SP39); Ma za mnogo ovo trpijet neću ni mogu, no ću radit s mojom fameljom naći mijesto (SP40).

\section{Upotreba veznika /ali/ i /oli/}

„Suprotnosti istovetne za datu priliku vezuju se poglavito veznikom / ili/ (...) Po intonaciji rastavnih rečenica može se utvrditi da li se njima jače ističe suprotnost ili istovetnost“" (Stevanović 1969: 784). Suprotni veznici /ali/ i / oli/, koji se javljaju umjesto /ili/ u crnogorskim govorima (Pešikan 1965:211), kod Petra $\mathrm{I}^{5}$ upotrebljavaju se u disjunktivnom značenju, u pismima Radonjića, takođe, umjesto veznika /ili/:

A kad dođemo $k$ Vašem preuzvišenom gospostvu, bliže ćemo zborit ali ću biti vjeran ali nevjeran (VIP14);

Pisao sam Ozrinićima ali da se zatvore od Hercegovine ali ćemo mi njih (VIP23);

Ćerali su ih puškama i veće ednoga ranili, a petini ali šestini balote pasale proz haljine (SP3);

Pravijem sam reka ali da one neposlušne kastigaju ali da ću iskraj njih poć sa svom fameljom (SP27);

I vas naš zbor plačući su zaklinjali ali za njihovo da im se nađe način da imaju svoje ali da im ne branimo nakužat njihovo (SP34);

5 Umjesto veznika/ili/ stoji u većini slučajeva /oli/ (up. Ostojić 1976: 211-212). 


\section{Upotreba veznika /pak/}

Veznik /pak/ ima u pismima Radonjića značenje veznika /pa/, /i/, dok u savremenom govoru njihovog rodnog kraja nije registrovan (up. Pešikan 1965: 212). Ovaj veznik, koji je zastupljen i u jeziku vladike Petra I (Ostojić 1976: 252), nije u upotrebi u starocrnogorskim govorima (Pešikan 1965:212):

Ta ista kuća koja e to učinila pedeset glavah e š nje palo u našu zemlju, pak hoće jošt toliko (VIP2);

Crnogorci svadiše se is pašom is aračlijom, pak se rasrčiše i pođoše u Skadar (VIP3);

Oni dan pođoh doma, a već nijesam ulazio u grad, pak sam razumio da ot takoga milostiva i bogata g-ra (gospodara) hoće se i drugi dar (SP13);

I to im pasa, pak poklaše rečene ovnove, pak jošt prijete (SP22);

Pak sam pisao (...) da otvore oko da se ne bi Turčin odselio oli u Crnu Goru oli u primorje (JP12).

Ovakva upotreba veznika/pak/ poznata je i današnjem mrkovićkom govoru (up. Vujović 1969: 290). Upotreba ovog veznika, iako donekle zastarjela, pripada i današnjem književnom jeziku (up. Stevanović 1933-1934:123; Ostojić 1976: 252).

\section{Upotreba veznika/tek(teke)/}

Upotreba veznika /tek(teke) $/{ }^{6}$ u crnogorskim govorima (Stevanović 1933-1934: 127; Miletić 1940: 580; Pešikan 1965: 212; Vujović 1969: 291) ne odudara od upotrebe u današnjem književnom jeziku ni tada kada se javlja umjesto veznika /čim/ u ovim pismima. U ovim pismima veznik/tek/ rijetko registrujemo umjesto veznika /čim/7 :

Teke sam se nadiga, činio sam te se skupilo ovo naše selo (SP2);

Teke čujem da ste došli u Kotor, Vašoj zapovijedi pristupiću da Vi skute cijelivam (JP1).

6 U savremenom književnom jeziku veznik /tek/ je u funkciji označavanja suprotnosti, isključivanja, spoljni znak veze vremenskih rečenica sa upravnim (Stevanović 1969: $778,779,782,843,844,858)$.

7 Veznik/tek(teke)/ rijetko se sreće u jeziku Petra I; upotrebljava se u funkciji naglašenog vremenskog veznika sa značenjem /čim/ (up. Ostojić 1976: 252; Pešikan 1965: 212). 


\section{Upotreba veznika /kako/ i /ka/}

U pismima Radonjića, kao što je i Njegoševom i jeziku Petra I, veznik /kako/ često se javlja u načinskim i/ili poredbenim rečenicama ${ }^{8}$ umjesto današnjeg $/ \mathrm{kao}$ što/ i $/ \mathrm{kao} /{ }^{9}$, a kontrahovana forma $/ \mathrm{ka} /$ umjesto $/ \mathrm{kao} /$ :

Pošto su sišli dolje, neka ispune Grbljani kako su obećali, ka bismo i $m i$ (VIP2);

Preporučujem se Vašemu preuz. g-stvu kako mome principu za svaki moj posa (SP21);

Tu sam sinoć ostao kako smeten, znajući da će Vaše p.g. biti naijeđeno za te nesklade (SP26);

No da budu vijerni svom principu i da Vaše zapovijedi obsluže kako pravi suditi (SP42).

Hoće činiti da ne puštaju crnogorski žitak između sebe kako su i vazda (VIP3);

I toliko puka imali pobit, kako će bit śedočeno ot Đura Franova iz Špiljarah (SP4a);

Već mu nikakva zuluma, ni zla, ni sramote bilo nije (...) kako će lijepo znat $i$ Vaše preuz. g-vo (SP11);

Ma se bojim pošto se makne životinja iz primorja ovog proljeća pri planini izviše Trojice, kako e užanca, da ne sucedi među njima koje veliko zlo (SP31).

Upotreba načinskog i poredbenog veznika /kako/, koji u ovim pismima registrujemo umjesto današnjeg književnog / kao/, /kao što/, ali i veznik / $\mathrm{ka} /$, kao što se vidi iz navedenih primjera, odstupa od stanja u savremenom književnom jeziku. Ovaj veznik zastupljen je i u jeziku vladike Petra I u istoj funkciji, dok se u starocrnogorskim govorima javlja veznik $/ \mathrm{kao} / \mathrm{u}$ formi $/ \mathrm{ka} /$, /ki/ (Ostojić 1976: 250; Pešikan 1965: 212).

\section{Upotreba veznika /a kamoli/ i /makar/}

„Poredbene rečenice za izuzetnu nejednakost imaju više spoljnih znaka veze s upravnim rečenicama. Ti su znaci: /kamoli/ i /a kamoli/, /nekmoli/ i /a

8 „Kada način vršenja i izvršenja jedne rečenice objašnjavamo radnjom druge, mi smo, određujući tako način vršenja glavne rečenice, uporedili ono što se njome kazuje s radnjom zavisne rečenice. A iz toga je jasan zaključak da su načinske rečenice i poredbene u isto vrijeme" (Stevanović 1969: 848).

9 U jeziku Petra I umjesto veznika /kao/ stoji redovno /kako/ (up. Stevanović, Bošković 1967: 88; Ostojić 1976: 250). 
nekmoli/, /toli/ i /a toli/ (...)“ (Stevanović 1969: 850-851). Veznike /a kamoli $/{ }^{10}$, /makar $/{ }^{11}$, u pismima Radonjića veoma rijetko bilježimo:

A ne bih se promijenio ni za onu svinju njihova principa a kamoli za njih (VIP15);

A iz doma ako će makar sutradan poć (VIP5).

U starocrnogorskim govorima veznik /makar/ nije registrovan, /a kamoli/ rijetko, češće umjesto ovog veznika /a ne/.

\section{Ostali veznici}

Radonjićima su nepoznati veznici stranog, turskog porijekla /ama/, / ema/, koji su, kako je već napomenuto, zabilježeni u jeziku vladike Petra I i srednjokatunskim i lješanskim govorima, kao i veznici /mada/ i /premda/, u čemu se ogleda podudaranost sa starocrnogorskim govorima ${ }^{12}$. U pismima Radonjića javljaju se, pored pomenutih, i veznici: /i/, /pa/,/te/,/ni/,/niti/, / već/, /nego/, /jer/, /iako/ i dr. ali oni nijesu ni po čemu karakteristični.

\section{Zaključak}

Prepoznatljive crte crnogorskih govora karakteristika su i ovih pisama. Rečenice u pismima serdara i guvernadura Radonjića nijesu reprezent korespondencijskog stila. Naprotiv, one su često duge, glomazne, sa mnogo umetnutih djelova, raznih inverzija u nizanju rečeničnih konstituenata. Međutim, nije istovjetna situacija kod svih pisara. Razlike su najočiglednije između prvog pisara s početka XVIII i posljednjih guvernadura s početka XIX stoljeća. U ovim pismima češće registrujemo složene rečenice čiji su djelovi međusobno povezani veznicima od onih bez veznika. U tim rečenicama veznici su nosioci određenih sintaksičkih odnosa. U pismima Radonjića manifestuju se razne mogućnosti upotrebe istih veznika u odnosima djelova složene rečenice, kao i upotreba raznih veznika u istoj funkciji. Radonjićima su nepoznati veznici turskog porijekla /ama/, /ema/, koji su zabilježeni u jeziku vladike Petra I Petrovića i srednjokatunskim i lješanskim govorima, kao i veznici /mada/ i / premda/, u čemu se ogleda podudaranost sa starocrnogorskim govorima.

10 Kamoli, a kamoli - oznaka za vezivanje poredbenih rečenica za izuzetnu nejednakost (Stevanović 1969: 850-851).

Znak veze dopusnih rečenica s upravnim (Stevanović:1969: 875-876).

12 U starocrnogorskim govorima nijesu registrovani veznici /mada/ i premda/ (up. Pešikan 1965: 212). 


\section{Literatura}

- Vujović, Luka (1969): „Mrkovićki dijalekat“, Srpski dijalektološki zbornik, knj.XVIII, str. 77-368.

- Vušović, Danilo (1927): „Dijalekat istočne Hercegovine“, Srpski dijalektološki zbornik, knj. III, str. 3-70.

- Krivokapić, Miloš (2009): Jezik u pismima serdara i guvernadura Radonjića (doktorska disertacija), Filozofski fakultet u Novom Sadu.

- Miletić, Branko (1940): „Crmnički govor“, Srpski dijalektološki zbornik, knj.IX, Beograd, str. 211-663.

- Mladenović, Aleksandar (1973): Jezik vladike Danila, Novi Sad: Matica srpska.

- Ostojić, Branislav (1976): Jezik Petra I Petrovića, Titograd: CANU.

- Pešikan, Mitar (1965): „Starocrnogorski srednjokatunski i lješanski govori“, Srpski dijalektološki zbornik, knj.XV, str. 1-294.

- Stevanović, Mihailo (1933-1934): „Istočnocrnogorski dijalekat“, Južnoslovenski filolog, XIII, str. 1-128.

- Stevanović, Mihailo (1969): Savremeni srpskohrvatski jezik, II, Beograd: Naučno delo.

- Stevanović, Mihailo, Bošković, Radosav (1967): Rečnik uz celokupna dela P.P. Njegoša, Beograd.

\section{Miloš KRIVOKAPIĆ}

\section{USE OF CONJUNCTIONS IN THE LANGUAGE OF SERDARS AND GUBERNATORS RADONJIĆ (1706-1828) AND IN MONTENEGRIN SPEECH PATTERNS}

In this paper, the author shows that characteristics of Montenegrin speech patterns generally correspond to those of the letters of serdars and gubernators Radonjić. The analyzed letters substantially reflect the situation in their dialectal basis - old Montenegrin, but also other Montenegrin speech patterns. Compound sentences whose parts are connected to each other with conjunctions are more frequent than those without conjunctions given that conjunctions in these sentences are the holders of certain syntactic relationships.

Key words: conjunctions, causal meaning, inversion, declarative sentences, comparative sentences 


\section{Milica LUKIĆ (Osijek)}

UDK 003.349.2(497.5)"18““

Izvorni naučni rad

Filozofski fakultet Sveučilišta J. J. Strossmayera u Osijeku mlukic@ffos.hr

\section{Vera BLAŽEVIĆ-KREZIĆ (Osijek)}

Filozofski fakultet Sveučilišta J. J. Strossmayera u Osijeku vblazevic1@ffos.hr

\section{PARČIĆEVA KONCEPCIJA OBNOVE STAROSLAVENSKIH LITURGIJSKIH KNJIGA U XIX STOLJEĆU}

Neosporno je danas da vodeća uloga u obnovi staroslavenskih liturgijskih knjiga u XIX. st. pripada Dragutinu Antunu Parčiću. Taj je devetnaeststoljetni homo universalis u paleoslavističkoj / paleokroatističkoj literaturi poznat kao onaj koji je glagoljskim misalom spasio starodrevnu hrvatsku povlasticu - glagoljicu od neminovne propasti koja joj je prijetila u drugoj polovici XIX. stoljeća. Njegov glagoljski Misal, kojim se u liturgijsku uporabu vraća crkvenoslavenski jezik, izlazi 1893. u svom prvom izdanju i predstavlja krunu ćirilometodskih obnoviteljskih nastojanja ne samo među Hrvatima nego i među Slavenima uopće. U vrijeme kada glagoljica na hrvatskome nacionalnom prostoru živi svojim potisnutim životom valjalao je osigurati da se glagoljski Misal može bez poteškoća upotrebljavati, stoga D. A. Parčić izdaje Mali azbukvar za pravilno i jednolično čitanje glagoljice (autor Ivan Broz, 1894) te priređuje staroslavensku gramatiku i rječnik: Grammatica paleoslavico-latina i Rječnik latinsko-glagolski, koji su ostali u rukopisu. U radu će se stoga opisati dva navedena priručnika i pokazati kako je ono što opisuju (i propisuju) u skladu s Parčićevom koncepcijom jezičnoga oblikovanja (obnavljanja) staroslavenskih liturgijskih knjiga, napose Misala iz 1893. Također će se potvrditi da Parčić sudbinu svojih liturgijskih izdanja nije želio prepustiti slučaju, već je promišljeno i s jasnom koncepcijom pristupio obnovi staroslavenskih liturgijskih knjiga.

Ključne riječi: hrvatski crkvenoslavenski jezik, XIX. stoljeće, Misal 1893, pomoćna liturgijska izdanja 


\section{Uvod: u svjetlu jezične politike - novocrkvenoslavenski varijeteti u dodiru (iscl. i hcsl. jezik) ${ }^{1}$}

Prije nego odredimo mjesto pomoćnih liturgijskih izdanja (jezičnih priručnika) koje je D. A. Parčić oblikovao (uz temeljne liturgijske knjige), a koji opisuju i propisuju odrednice obnovljenoga hcsl. jezika i pisma u XIX. stoljeću, naš je zadatak skicirati i unutarnju strukturu procesa istočnoslavenizacije litrugijskih knjiga koji, među ostalim, uključuje:

- jezičnu politiku i jezično planiranje

- istočnoslavenizirane gramatike kao normativne priručnike

- kodifikaciju novo(crkveno)slavenskoga jezika pri Rimu

Valja ga dovesti u složeniji odnos s procesom uređivanja i objelodanjivanja novih knjiga u XIX. stoljeću po obnovljenoj hcsl. recenziji, a koji je temeljen i na afirmativnim pretpostavkama. Suodnos je najprije definiran vanjskojezičnim, političkim razlozima - daljnjim unionističkim težnjama Cyrillomethodiane kao pokreta ${ }^{2}$ te prilagođenošću iscl. prijevodnih izdanja normiranim latinskim uzorima (Vulgata) - tako da isti i ne može počivati tek na odstupanju i suprotnostima, a ocjene filologa o kulturocidnom razdoblju istočnoslavenizacije koje smjenjuje preporodno hrvatskoglagoljsko XIX. stoljeće danas se drže pretjeranima, točnije korisnijim se čini uspostaviti problemski pristup posljednjim etapama aktivnoga razvoja glagoljaštva i glagolizma, čemu bi i poglavlja ovoga rada mogla pridonijeti.

S obzirom na to da je proces slijedio određenu pravopisnu i gramatičku normu (grafija i jezik) s kojom je hrvatsko glagoljaško svećenstvo bilo malo upoznato, slovenska slavistica Vanda Babič smatra kako je termin istočnosla-

\footnotetext{
Sociolingvistika radije operira točnije određenim i jače omeđujućim pojmom jezičnog varijeteta, koji je povezan s izvanjezičnim činiteljima, nego pojmom jezika u smislu jednog autonomnog, globalnog i monolitnog sustava. Novocrkvenoslavenski jezici / jezični varijeteti o kojima se raspravlja jesu hrvatski crkvenoslavenski i istočnoslavenski jezik hrvatskih liturgijskih knjiga u XVII. i XVIII. stoljeću. U tekstu rada označeni su kraticama: hesl. i iscl. jezik.

2 Milica Lukić ističe kako je vatikanski Zbor za širenje vjere ustanova koja postupa u skladu s ekumenskim nastojanjima i poticanjem crkvenoga jedinstva između Katoličke i Pravoslavne crkve, a nakon što su se Brestovskom unijom Kijev i sva Rutenija sjedinili s Rimom, hrvatske glagoljske liturgijske knjige postale su sredstvo kojim se ima postići kohezija među raskoljenim Slavenima, tim više što su rusku redakciju staroslavenskoga jezika rabili i novopridošli ukrajinski grkokatolici (u Poljskoj i u Ukrajini), držeći je pravim liturgijskim jezikom (2010: 79-80). Formalna dopusnica za uporabu nelatinskoga jezika u liturgiji izrečena je još 1215. godine na Lateranskom koncilu, a četiri stoljeća kasnije ekumenske su težnje kroz nove liturgijske jezike i dalje ostale zaštitnim znakom Rima i djelovanja Kongregacije.
} 
Parčićeva koncepcija obnove staroslavenskih liturgijskih knjiga u XIX stoljeću

venizacija (usp. 2000: 17-29) precizniji od termina rusifikacija (temelji se na gramatikama Lavrentia Zizania 1596. i Meletia Smotrickoga $1619^{3}$ ). To isto tako znači da su bila potrebna i pomoćna liturgijska izdanja za ovladavanje novim pravopisnim i jezičnim pravilima, ponajprije bukvari: Levakovićev Bukvar u trima izdanjima $(1629,1693$. te 1763. pod uredništvom Antuna Juranića), Karamanov Bukvar slavenskij pismeny Veličajšago Učitelja B. Jeronima Stridonskago Napečatan. V Rime; Tipom Svetoga Sobora ot razmnoženija Very u dvama izdanjima (1739. i 1753). Izdana je potom i mrtvačka misa u dvama izdanjima Ivana Paštrića: Misse za umervšie samo iz missala rimskoga izvadjene svojim zakonom kako se v isti služi. Za službu i način svih crikav (!), Romae, Anno 1707. te izdanje iz 1767. godine (za tisak priredio o. A. Juranić, usp. Bolonić 1980: 23), a tu su i Molitvi Prežde, i poslije Misse glagolimija, iz Messala Romeskago, Injehže mjest izvedene, ninježe iz latinskoga na Slavinski jezik privedene iz 1765. godine.

$\mathrm{S}$ obzirom na to da je riječ o novocrkvenoslavenskom razdoblju, vremenu u kojem se csl. jezični varijeteti javljaju u određenoj sredini usporedo s književnim jezikom kojemu je osnova „domaći“ idiom (kod Hrvata to je hrvatski crkvenoslavenski jezik od XVI. stoljeća, usp. Damjanović 2005: 11), razvija se svijest tadašnjih članova komisije za uređivanje liturgijskih knjiga (pri Kongreaciji u Rimu) o razlici vulgarnih dijalekata ili govornih slavenskih idioma (koji ulaze i u jezik knjige, doduše nižega registra od liturgijskog) i općeslavenskoga književnog jezika (izvornim takvim jezikom u XVII. i XVIII. stoljeću drži se iscl. jezik čija je norma kodificirana gramatikama M. Smotrickoga i L. Zizania ${ }^{4}$ ).

U knjizi o jeziku hrvatskih glagoljaša Stjepan Damjanović (1984b: 9-42) već u uvodnim poglavljima naglašava razlikovnu povijest narodnoga jezika (dijalekta) i povijest književnoga jezika te ističe probleme s kojima se pri takvoj podjeli susrećemo. Povijest nas književnoga jezika stavlja pred dvojaku zadaću: s jedne strane opisujemo povijest njegova ustrojstva na svim jezičnim razinama (fonologija, morfologija, sintaksa, leksik), a s druge strane opisujemo povijest njegova normiranja i uporabe (vanjska povijest jezika, izvanjezični činitelji poput društveno-političke strukture društva, jezičnih kontakata, prosvjetnih, crkvenih prilika i političkih poteza i dr). Književni je

3 Gramatika Slovenska s'veršennago iskustva osmi častij slova i inych nuždnych Lavrentia Zizania (Vilno 1596), Gramatiki Slavenskija pravilnoe sintagma Meletia Smotrickog (Jevje blizu Vilna 1619).

4 Koliko su maloruski unijati pri Rimu uistinu malo (ili nimalo) poznavali te gramatike odnosno iscl. normu, svjedoči Emanuela Sgambati u članku Udio Rusina u izdavanju hrvatskih glagoljskih knjiga u XVII. stoljeću (1983: 103-122). Gramatiku M. Smotrickoga otkriva tek Paštrić kao novitet, a svi unijati u Propagandinoj jezičnoj komisiji nisu primarno bili filolozi / jezikoslovci. 
jezik normiran i kodificiran, a to podrazumijeva zakonitosti jezika i njihovu prihvaćenu uporabu, te postojanje propisa i pravila u rječnicima, gramatikama i drugim priručnicima. U povijesnim jezicima norma se ponekad očituje i kao odsutnost norme (L. Ščerbe, prema Damjanović 1984b: 14), odnosno variranje norme, a u povijesti hrvatskoga jezika (pritom treba razlikovati povijesni jezik od funkcionalnoga ${ }^{5}$ ) u srednjem vijeku književni su jezici i latinski i općeslavenski književni jezik. Oba su jezika čvrsto normirana što znademo jer oni koji se njima služe dobro razumiju što se u tom jeziku može, a što ne može. Tako shvaćena norma (u variranju) pokazuje i postojanje čakavskoga književnog jezika. Uz latinski dakle, jezik je knjiga našega (razvijenog) srednjovjekovlja hrvatski crkvenoslavenski jezik. Međutim, taj jezik nije nikada zadovoljavao sve potrebe koje bi jedan književni jezik morao zadovoljavati. Uz njega su postojala dva niže rangirana jezika koja su također imali područja primjene čakavsko-crkvenoslavenski (-kajkavski) amalgam te čakavski, narodni jezik. U nekim područjima su se međusobno i preklapali, ali nikada nisu imali funkciju koju je imala visoka varijanta - crkvenoslavenski jezik hrvatske redakcije, a to je liturgija. Problem je tek u činjenici da norma tih jezika nije kodificirana (izrada gramatika i rječnika, prihvaćanje i odbacivanje iz jezičnoga temelja / dijalekta, usp. Mićanović 2006: 22-23). Pisci i priređivači naših srednjovjekovnih liturgijskih djela dobro su poznavali crkvenoslavensku normu. Tako, između ostalih, tvrde i Hercigonja (usp. 1984: 28), Josip L. Tandarić (1993: 33), Damjanović (1984b: 12-13, 2008: 14-15). Ipak, događalo se da je ta norma nekada zanemarivana. Prelaženje na neki drugi kôd ili njihovo miješanje, posuđivanje izraza iz jednoga sustava u drugi, što je jedna od bitnih diglosijskih odlika, uvijek je bilo svjesno i s određenom svrhom (Tandarić 1993: 87). To Damjanović naziva prema Ščerbeu variranjem norme. Glagoljaši su u hrvatskoglagoljskim tekstovima pomlađivali jezik i to je bilo isključivo pitanje njihova stava. Prema Peteru Trudgillu (1995: 98-99), važno bi bilo utvrditi da je niska diglosijska varijanta standardizirana do određenoga stupnja kao što je to kod čakavskoga jezika. Mada nepisana, njegova je norma uočljiva, tako ističu i Lozić Knezović i Galić Kakkonen (2010: 211-226), a Damjanović tvrdi da nije kodificirana (1984b: 12-13, 2008: 14). ${ }^{6}$ Potom, sve varijante

$5 \quad$ Povijesni jezik postoji kao kulturni proizvod i priznat je kao jezik od vlastitih govornika i govornika drugih jezika; on je sklop različitih jezičnih sustava koji se razlikuju trojako: u prostoru (oblikuju različite dijalekte $>$ dijatopijska različitost), društveno-kulturno (konstituiraju različite jezične slojeve i jezične razine $>$ dijastratička različitost (u izražajnom pogledu - jezični stilovi > dijafazijska različitost). Funkcionalni jezik je u svakom pogledu jedinstven (za razliku od povijesnog jezika), tj. istodobno je sintopijski, sinstratički i sinfazijski i on je kao jedinstveni jezični sustav predmet gramatike (Mićanović 2006: 12-14).

6 Andrew R. Corin drži da uistinu sva društva, pismena ili ne, poznaju neku endogenu, intuitivnu komunikacijsku normu. To znači da se ne slaže do kraja s u nas posve prihvaćenim 
hrvatskoga jezika imaju svoj naziv i razlikuju se jedna od druge. Situacije u kojima se svaka varijanta upotrebljava društveno su vrlo dobro definirane. Hrvatskoglagoljski liturgijski tekstovi očuvali su normu hrvatskoga tipa crkvenoslavenskoga jezika do danas. Na temelju istraživanja i opisa jezičnoga stanja na svim jezičnim razinama u tim spomenicima (od XI. do XVI. st), moguće je apstrahirati značajke varijetetne norme hrvatskoga crkvenoslavenskog jezika na svim jezičnim razinama (usp. Mihaljević - Reinhardt 2005: 31-82). Na temelju te spomeničke baštine, metodološki također pristupajući hcsl. jeziku kao podsustavu općeslavenskoga književnog jezika, Ivan Berčić i Dragutin A. Parčić u jeku ćirilometodske obnove XIX. stoljeća „vraćaju“ hcsl. jezik u liturgijske knjige (Tandarić 1993: 70-72, Lukić 2012b: 317-337). Da ne nastavljaju ondje gdje je zaustavljen prirodan razvoj toga jezika u XVI. stoljeću, dobro je poznato (Žagar, Zaradija Kiš 2006: 153-189), ali valja rasvijetliti koji su čimbenici uvjetovali taj smjer. Jedan je od njih je svakako želja da se vrate na početak redakcijskoga formiranja kako bi osigurali što veću razumljivost i kohezivnost književnoga jezika u općeslavenskom (ekumenskom) pokretu. Drugi jest isticana činjenica o istočnoslavenizaciji liturgijskih knjiga - taj 260 godina dug proces ostavio je neizbrisiv trag u povijesti hrvatskoga jezika i nikako nije mogao biti zanemaren, što zbog izvanjezičnih činitelja (politika Rima, jezik koji je također imao namjeru zbližiti istočne i zapadne Slavene, Tridentski sabor i sravnjenost s Vulgatom), što zbog uskojezičnih (normiranost i kodificiranost iscl. književnog jezika, uporabna vrijednost (uzus) čak i u hrvatskim glagoljskim župama). Treći proizlazi iz drugoga, a tiče se činjenice da norma hcsl. jezika u vrijeme Berčića i Parčića nije (o)pisana, odnosno ne postoje gramatike, rječnici i drugi priručnici hcsl. jezika. Mali azbukvar, Parčićeva rukopisna gramatika, rječnik i druga pomoćna izdanja (koja prate njegov Misal iz 1893. i jezičnu koncepciju) prvi su takav pokušaj koji se obilato temelji na interferiranju dvaju postojećih književnih podsustava općeslavenskoga književnog jezika - hcsl. i iscl. sustava, jednoga s nepisanom i drugoga s pisanom normom. Analizom tih priručnika, ali i komparativnom analizom samoga jezika Parčićevih liturgijskih izdanja, moguće je konkretnije

shvaćanjem da uz hcsl. jezik supostoje i dva niže rangirana jezika (ali uređena, od čega jedan zasigurno i normiran) sa svojim područjima primjene - čakavsko-crkvenoslavenski (-kajkavski) amalgam (hrvatsko-staroslavenski) te čakavski, narodni jezik. Latinski (u okviru kojega je vernakularni čakavski) i glagoljski kompleks (hcsl. jezik i amalgamni jezik) za Corina su dva sociolingvistička organizma drukčije strukture. Nekada su se ta dva kompleksa dodirivala, uglavnom u djelovanju srednjovjekovnoga intelektualca koji poznaje i i latinski i glagoljski kompleks. To će reći da Corin ne prihvaća organsko jedinstvo hrvatske srednjovjekovne tropismenosti i trojezičnosti, premda se slaže da su utjecaji, obilati i značajni, među kompleksima pismenosti postojali (1993: 155-196). 
ustanoviti o kakvoj je zamisli novoga liturgijskog (književnog) jezika riječ te kako se izvanjezični činitelji koji oblikuju Cyrillomethodianu u njem zrcale, kao i norma dvaju liturgijskih književnih jezika koji su mu prethodili, a sve prema nadređenu općeslavenskom književnom jeziku. Taj novi liturgijski jezik hrvatskocrkvenoslavenskoga je tipa, ali funkcionira još onako kako je to Šimun Kožičić postavio u načelima vlastite jezične koncepcije (za termin hrvatski) - kao nadacionalan općeslavenski književni jezik (usp. Žagar 2012: 111-124). Jezična osnovica u tom smislu nije govorni (organski) idiom, već tip knjižnoga jezika čija norma je ostala nepisana. I to su ćirilometodijanci u XIX. preuzeli kao naslijeđe iz vremena istočnoslavenizacije (usp. Mihaljević 2009: 289). Tim se odabirom u XVII. zaustavio prirodan razvoj hcsl. jezika i poremetio se odnos triglosije između hrvatskoga crkvenoslavenskog jezika i njegovih podsustava (nižih registara: amalgamnoga hrvatsko-staroslavenskoga i starohrvatskog, čakavskoga narodnog jezika) te odnos bilingvizma prema latinskom jeziku (usp. Wardaugh 2006: 88-119, Mihaljević 2009: 289, Damjanović 2000: 7-43, 2005: 48-55). Zaključuje se kako se u dobu istočnoslavenizacije prvi jezični varijetet (hcsl. jezik) nasilno zamijenio istočnoslavenskom redakcijom i time je ugrožen odnos triju do tada postojećih jezičnih varijeteta. Sociolingvistički gledano, odnos novocrkvenoslavenskoga (iscl. tipa, književnog) jezika i narodnoga (čakavskog) jezika tada je postao odnos bilingvizma jer je riječ o dvama jasno odijeljenim jezičnim sustavima koji ne utječu jedan na drugoga. Osim toga, norma iscl. jezika više se nije temeljila na organskom idiomu, već je postala umjetna (knjiška) i strana izvornim hrvatskim govornicima (na taj će način normu temeljiti i hcsl. jezik XIX. st. u viziji Berčića i Parčića). To je uvjetovalo potpuno odvajanje spomenutih jezičnih sustava i diglosijski (triglosijski) odnos pretvorilo u odnos bilingvizma (usp. Mihaljević 2009: 289). Dakako da je stanje s novocrkvenoslavenskim u XVII. stoljeću u Rusiji drugačije nego u nas. Kevin Roth (2013: 171-183) piše o latinskoj gramatici govornoga ruskog jezika Heinricha Ludolfa Grammatica Russica iz

7 Također i koja mu je uloga u određivanju kvalitativnih i kvantitativnih odrednica "indigene" hrvatske redakcije (Hamm 1963: 65). Uz to, Ivana Eterović pisala je o novim metodološkim pristupima ranosrednjovjekovnim hrvatskim glagoljskim (liturgijskim) spomenicima ističući kako se shema starih i novih jezičnih elemenata ne može održati (2012: 33-39) te kako je potrebno promišljati o izvanjezičnim činiteljima (funkcija, uporaba i dr) koji su odredili raslojavanje književnoga jezika (i preko liturgije) i njegovu elastičnost koja ide u prilog širenju i razumljivosti. Nova istraživanja osim toga trebaju ukazati na kontinuiranost hrvatske redakcije, a uključiti valja i nepravedno zapostavljeno razdoblje istočnoslavenizacije (usp. Golubova svjedočenja o Hercigonjinu pozivanju da se revidira uloga Ivana Paštrića u obnovi liturgijskih knjiga iz paleoslavističke perspektive, 1996: 134). 
Parčićeva koncepcija obnove staroslavenskih liturgijskih knjiga u XIX stoljeću

1696. godine ${ }^{8}$ i zaključuje kako su govorni jezik (vernakularni ruski) i pisani (književni) crkvenoslavenski jezik u XVII. st. u odnosu diglosije i distrubirani su prema visokom (pisana riječ) i niskom registru (svakodnevna govorna komunikacija $)^{9}$.

Postavlja se pitanje kako u XIX. stoljeću i organizirati učenje hrvatskoga crkvenoslavenskog jezika kada je dijelom njegova sustava postala i 260 godina duga povijest istočnoslavenizacije, kojoj je narod naposlijetku ipak priučen? Kako jezično planirati obnovu liturgijskih knjiga na hesl. jeziku i uvođenje toga književnog jezika u liturgijsku praksu kada njegova norma nije opisana, već je bila usmenoga tipa, i u stalnoj interakciji s dvama nižim jezičnim registrima koji su svršena etapa povijesnoga razvoja hrvatskog jezika? Kolebanja su to kojima je Parčić pokušao stati na kraj savršenom ravnotežom raznorodnih jezičnih elemenata kojima je raspolagao, zato se jezik njegova Misala (1893) i nazivao hiperkorektnim i artificijelnim (Tandarić 1993: 82). Još je više kolebanja pokazao u rukopisnoj staroslavenskoj gramatici koja je pratila novo izdanje Misala - u njoj hcsl. i iscl. staroslavenska jezična i pravopisna norma interferiraju, ali se teško može uočiti pravilnost i funkcionalnost u tom procesu. Dakako, u obzir valja uzeti i činjenicu da je riječ o nedovršenoj gramatici (i rječniku). No činjenica je da su ga njegovi prethodnici, Paštrić, Sović i Karaman, čak i u vanjskom, metodološkom smislu inspirirali (uz pripremu novih liturgijskih knjiga pripremaju se i pomoćna (kodifikacijska) sredstva: slovopisi i pravopisi, gramatike, rječnici i dr). Moguće je zaključiti i to da su se riječi J. Hamma (1971: 217) o nepovratnosti procesa koji je Levaković 1631. započeo u velikoj mjeri pokazale istinitima.

Sociolingvistici je u novije vrijeme sve više zanimljiv fenomen jezične politike Rima glede hrvatskih crkvenoslavenskih knjiga u XVII. i XVIII. stoljeću. Štoviše, postupci unijata pri Rimu bez zadrške se nazivaju jezičnim planiranjem (osnovno lingvističko sredstvo jezične politike, usp. Samardžija 2006: 117-126 ${ }^{10}$, Mićanović 2006: 26). U Zborniku Jezična politika i jezična

8 Knjižica je pisana latinskim jezikom i objavljena je u Engleskoj, a autor joj je Nijemac koji je bio u diplomatskoj službi danskoga kralja. Potreba autora da latinskim jezikom piše razlikovnu rusku gramatiku svjedoči o važnosti toga jezika i njegovu presudnom utjecaju krajem XVII. odnosno početkom XVIII. stoljeća. U prvim poglavljima knjižice donose se razlikovna obilježja ruskoga i crkvenoslavenskog jezika (primjer csl. riječi segodnya/danas, današnji/ i ruske sevodni). Potreba da se latinskim jezikom pišu csl. priručnici također je naslijeđe istočnoslavenskoga jezičnopolitičkog razdoblja koje će Parčić preuzeti i dalje razvijati.

9 Odnos među csl. jezičnim varijetetima (točnije csl. jezik i vernakular) kao diglosiju i inače su prvi prepoznali znanstvenici u okviru istočnoslavenske situacije - Ferguson 1959, potom Uspenskij 1976, 1983. i 1984, Worth 1978. i dr. (usp. Corin 1993: 163-164).

10 Jezično planiranje nije samo posao jezikoslovaca nego u njem svjesno sudjeluju brojni i različiti izvanjezični, dotično društveni čimbenici (Škiljan 1988: 8). Definira se kao skup 
stvarnost rad autorice Maje Matasović (2009: 51-60) o pitanju liturgijskoga jezika u hrvatskim župama između XVII. i XIX. stoljeća donosi se u poglavlju Planiranje statusa jezika, čime se potvrđuje osvježena dijakronijska perspektiva jezične politike i planiranja jezika. Da su nastojanja biskupa J. J. Strossmayera i Franje Račkoga oko novoga, obnovljenog liturgijskoga jezika u hrvatskim glagoljskim knjigama pitanje jezične politike, točnije planiranja statusa jezika također je dobro poznato (usp. Petrović 1979: 47-99, Damjanović 1991: 155-172, Lukić 2010: 75-107). Cilj je ovoga rada, između ostalih, pomnije predstaviti kako se nastavio planirati korpus novocrkvenoslavenskoga jezika hrvatskoga tipa te kojim se priručnicima taj liturgijski jezik pokušao opisati i normirati, odnosno kako je planirano usvajanje i uporaba obnovljenoga hrvatskoga crkvenoslavenskog jezika. Tako se čini djelatan napor u povezivanju vanjske i unutarnje povijesti jezika, a jezično stanje u Misalu (1893) u službi je istaknutih načela. O tim je pitanjima, igrom slučaja, umjesto čitavoga Odbora za uređenje liturgijskih knjiga u drugoj polovici XIX. stoljeća odlučivao jedan čovjek - Dragutin Antun Parčić - i to ne bez ugledanja na rješenja koja je ponudilo istočnoslavensko višestoljetno razdoblje (planiranje statusa i korpusa jezika ${ }^{11}$ - priručnici i rasprave o književnom slavenskom

racionalnih i uglavnom institucionalnih postupaka kojima neko društvo utječe na jezične oblike javne komunikacije i na formiranje svijesti svojih sudionika o tim oblicima (Samardžija 2008: 34-36). Da je Crkva izvršila golem utjecaj na standardizaciju i širenje vernakulara ističe i Sue Wright u knjizi Jezična politika i jezično planiranje - od nacionalizma do globalizacije (2010). Protestanti su osporavali Katoličku crkvu u raspravama i traktatima o vjerskim pitanjima koji su u prvo vrijeme bili na latinskom, u tradiciji svih učenih vjerskih tekstova, ali se uskoro pojavila potreba da se učine općedostupnima, pa je uslijedilo njihovo prevođenje na vernakulare. Budući da se izum tiskarstva podudario s rastućim ineteresom za vjerska pitanja, protestanti, koji su u biti trajno bili u ofenzivi, novonastalu su situaciju dobro iskoristili da svoju poruku prošire posredstvom cvatućeg tržišta tiskovina na vernakularu (Anderson 1983), pa je prvi put u Europi nastala masovna čitateljska publika (Febvre i Martin 1976). Ta je praksa imala dubinsku jezičnu propagandu koja se odrazila i na politiku Katoličke crkve (normiranje crkvenoslavenskoga jezika).

11 Heinz Kloss (1904-1987) mijenja tzv. Haugenov model nastajanja standardnih jezika (četiri aspekta jezičnog razvoja koji dijalektu daju status jezika, a vernakularu status standarda: selekcija, kodifikacija, elaboracija, prihvaćanje) i uvodi pojmove planiranje statusa (selekcija kod Haugena) i planiranje korpusa (kodifikacija i elaboracija kod Haugena). Uzimajući u obzir dvojnu narav jezičnog planiranja (planiranje korpusa i planiranje statusa), postaju očite razlike s obzirom na mjesto koje ove dvije sastavnice zauzimaju unutar jezične politike. Planiranje statusa nesumnjivo pripada jezičnoj politici. Ono uvijek obuhvaća izbor jednog jezika ili varijeteta koji zadobiva određeni status. Planiranje statusa obuhvaća, osim odluke o izboru koja ima politički aspekt, i plan izvedbe procesa kojim se jezik uvodi u uloge koje su za njega planirane, ali i planiranje mogućeg moderniziranja, proširivanja, standardiziranja i kodificiranja jezičnog korpusa. Planiranje korpusa također se smatra dijelom jezične politike, i to dijelom koji je "najlingvističkiji" aspekt jezične politike, što implicira da je planiranje statusa samo djelomično lingvistički postupak. Unutar planiranja korpusa, 
Parčićeva koncepcija obnove staroslavenskih liturgijskih knjiga u XIX stoljeću

jeziku (Paštrić, Karaman), metodologija rada, konkretna jezična rješenja na svim jezičnim razinama - slovopis i pravopis do sintakse i leksika).

S obzirom na sadržajna ograničenja ovoga rada, kao i želju autorica da makar skiciraju elemente hcsl. pravopisne, fonološke (i morfološke) norme propisane devetnaestostoljetnim pomoćnim liturgijskim izdanjima, samo će se nabrojiti eventualna popudbina iscl. razdoblja koju Parčić uzima za temelj u vlastitoj jezičnoj koncepciji.

\section{Iscl. norma - pravopisni, gramatički i rječnički priručnici}

Još u prvogom valu istočnoslavenizacije najavljene su težnje za oblikovanjem csl. gramatike i rječnika (Levaković, Terlecki). Potom, u svojoj sumi glagoljaštva (De Missalis, Breuirarij Illyrici Romani et similium diuinorum offioiorum origine, charaetere, oontinuatiome, scriptdone, impressione, usu et locis, ac modo imtelligemdi scripta, et impressa, officiaque noua uertendi 1700, usp. Golub 1971: 379) Ivan Paštrić koncepcijski je popratio drugi val iscl. liturgijskih knjiga, a u devet je glava problematizirao odnos književnoga (crkvenog) slavenskog jezika i narodnih idioma, povijest toga jezika i dviju azbuka kojima se izražava, rasprostranjenost i povijest slavenske liturgije i temeljnih liturgijskih knjiga itd. Osobito su nam u Paštrićevu pisanju važne definirane zadaće koje je uputio budućim, novim priređivačima glagoljskih knjiga (na osobit način to se odnosi i na Parčića). Pozitivan transfer zasigurno ostvaruje i treći val iscl. liturgijskih knjiga, i to u užem smislu, odnosno i s utjecajem na samu hcsl. normu u XIX. st:

a) Do kraja se polarizira odnos slavenskoga književnog i vulgarnog, narodnog jezika Karamanovim i Sovićevim raspravama (usp. Stojković 1930: 120-131).

b) Oblikuje se prvi latinski (Sovićev) prijevod gramatike M. Smotrickoga namijenjen štićenicima Urbanova kolegija u Rimu. Soviću je papa Benedikt XIV. 1742. godine povjerio katedru za slavenski liturgijski jezik ua Urbanovu kolegiju) (usp. Babič 2008: 31-47). Slovnica, koju

koje je prije svega jezično kultiviranje u širem smislu, razlikuje se elaboracija i kultiviranje u užem smislu, tj. skrb o jeziku. Elaboracija obuhvaća razvitak gramatike, uključujući tvorbu složenca i leksik, različite registre i stilove, na takav način da jezik može udovoljiti novim komunikacijskim potrebama. Kultiviranje se sastoji prije svega u stabilizaciji standarda i ono je u određenom stupnju nužno (usp. Trudgill 2010: 143-158, Mićanović 2006: 23-26). U Haugenovoj koncepciji jezično planiranje širi je pojam od procesa standardizacije, čija je jezgra kodifikacija; jezično planiranje započinje selekcijom kao prvim korakom u planiranju statusa, a nastavlja se kodifikacijom kao prvim korakom u planiranju korpusa (tj. jezično planiranje nadređeno je standardizaciji, odnosno selekcija ne pripada standardizaciji). 
je Sović preveo na latinski jezik godine 1756. za slušatelje crkvenoslavenskoga jezika u Karamanovu glagoljskom kolegiju (Collegium illyricum), ostala je u rukopisu kao dio Zoisove ostavštine u ljubljanskoj Knjižnici. Inače je Sović prijateljevao i s Albertom Fortisom, s kojim se i dopisivao te raspravljao o slavenskim jezikoslovnim pitanjima. Za njega je ćirilicom prepisao Hasanaginicu (usp. Strohal 1912: 43).

c) Berčićeva izdanja, kao i Parčićeva domisalska izdanja ${ }^{12}$ slijede iscl. slovopis i pravopis normiran Karamanovim Bukvarom 1739. Prema tom Bukvaru određuje se u mnogome i Azbukvar 1894, a prema Karamanovu Misalu 1741. Parčićev Misal 1893 (usp. Tandarić 1993: 71-72), zbog sravnjenosti s Vulgatom, ali i zbog težnje da se oblikuje nadnacionalan sveslavenski csl. književni jezik.

12 I. Berčić: 1. Chrestomathia linguae veteroslovenicae charactere glagolitici (Prag 1859), 2. Ulomci sv. Pisma (Prag 1865-1871). D. A. Parčić: 1) obrazac mise za Kêsara i Kralja našego i Decretum - litografija, Zadar prije 1863,2) obrazac mise Misi za umr'šee s koralnim napjevom - litografija, Galevac 1860, 3) napjev za kor, iza glavnoga oltara, u crkvi Sv. Marije na Glavotoku Vsa lêpa esi, Marie s koralnim notama, 4) obrazac mise na blagdan Bezgrešnoga začeća - litografija, Krk 1. prosinca 1864, 5) prijevodi himna - Jam lucis orto sidere, naslov: PESSAN, prvi stih: Se svita zvizdi v'sijavši, te Adoro te devote latens Deitas Tome Akvinskoga, naslov: SLOG sv. Tomi iz' Akvina $k^{\prime} s v$. Evharistii, prvi stih. Nic' ti se klanam, Božestvo tajnoe - tiskani u Serafinskoj tiskari u Glavotoku 1870-ih godina, 6) Čin i Pravilo misi ošće že i molitvi pre i po mise iz' Rim'skago misala, Rim 1881, 7) Prilog' slovên'skim' ezikom' v' nem'že misi v'seob'ĉee vr'k've, za nêkaê mêsta i v' tretiem' činê sv. Fran'čiska služimie s'dr'žet'se, Rim 1881. i dr. (usp. Badurina 1993b: 155-182). 
Parčićeva koncepcija obnove staroslavenskih liturgijskih knjiga u XIX stoljeću

Tablica 1. Udio iscl. razdoblja u hesl. razdoblju XIX. stoljeća

\begin{tabular}{|c|c|}
\hline \multicolumn{2}{|c|}{$\begin{array}{l}\text { ŠTO PREUZIMA PARČIĆ IZ ISCL. RAZDOBLJA } \\
\text { (vanjskojezični okvir + odraz na csl. normu u XIX. st) }\end{array}$} \\
\hline Levaković i prvi val iscl. knjiga & $\begin{array}{l}\text { Levakovićev bukvar Azbukividnjak slo- } \\
\text { vinskij u trima izdanjima (1629, 1693. te } \\
\text { 1763. pod uredništvom Antuna Juranića) } \\
\text { - najavljuje se nastajanje kodificiranih } \\
\text { priručnika (gramatika i rječnik) } \\
\text { (Jagić 1913: 48): Nije dosta, što se pri- } \\
\text { govara nedosljednostima u jeziku; to je } \\
\text { tek jedna neuspjela strana njegove rad- } \\
\text { nje, koja pokazuje, da ne treba mnogo } \\
z \check{a l i t i, ~ s ̌ t o ~ s e ~ n i j e ~ i s p u n i l o ~ n j e g o v o ~ o b e c ́ a-~} \\
\text { nje, da će napisati još i rječnik i grama- } \\
\text { tiku crkvenog jezika. }\end{array}$ \\
\hline $\begin{array}{l}\text { Paštrić i drugi val iscl. knjiga } \\
\text { Suma glagoljaštva (De Missalis, Breu- } \\
\text { irarij Illyrici Romani et similium diui- } \\
\text { norum offioiorum origine, charaetere, } \\
\text { oontinuatiome, scriptdone, impressione, } \\
\text { usu et locis, ac modo imtelligemdi scrip- } \\
\text { ta, et impressa, officiaque noua uerten- } \\
\text { di) } 1700 \text {. }\end{array}$ & 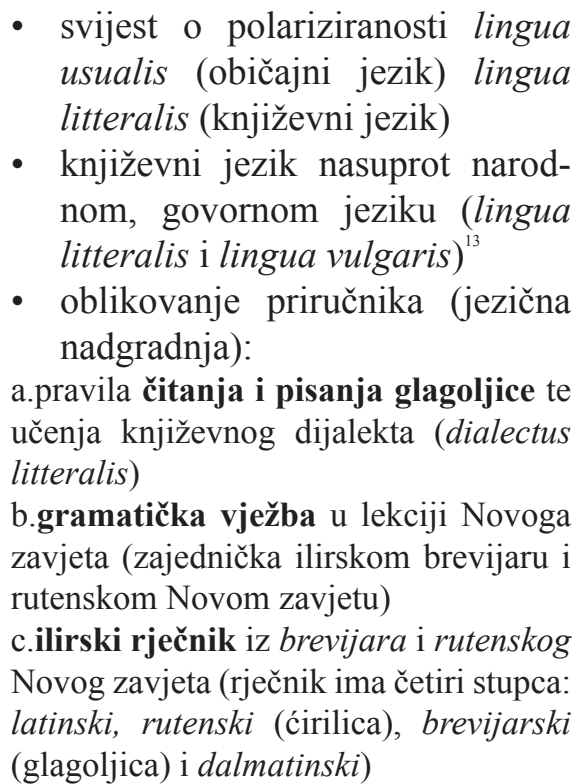 \\
\hline
\end{tabular}

13 Ta će polarizacija ostaviti golem utjecaj na povijest hrvatskoga književnog jezika i današnji hrvatski jezični standard koji nedovoljno čuva hcsl. tradiciju. Tu će razliku u polemikama svjesno oživljavati i ćirilometodijanci XIX. stoljeća prilikom izdavanja Misala (1893) u obnovljenoj jezičnoj redakciji, pa će i don Frane Bulić i Ivan Danilo, potpisnici Spomenice, a i sam Dragutin A. Parčić u kritičkom odgovoru na Spomenicu (Za obstanak glagolice) spominjati Stjepana Rozu i njegove jalove pokušaje za uvođenjem narodnog jezika u liturgijske knjige. 


M. Karaman i M. Sović - treći iscl. val
1753. Identita della lingua litterale slava
e necessita di conservarla ne libri sacri.
1787. Rifflessioni sull' ignoranza della
lingua slava letterale in Dalmazia
M. Sović prevodi iscl. gramatiku M.
Smotrickoga na latinski jezik

- teza o jedinstvenom općeslavenskom književnom jeziku (za Karamana i Sovića u iscl. knjigama, za Parčića u hcsl. knjigama, uz zadržano staroslavensko zvučanje, npr. jerovi)

- latinski prijevod gramatike Smotrickoga namijenjen polaznicima ilirskih glagoljskih sjemeništa u hrvatskim biskupijama, kao i dalje (Loreto, Rim i dr)

- po treći put nastojalo se oko priređivanja gramatike i rječnika (te drugih pomoćnih liturgijskih sredstava) koji će pomoći hrvatskim glagoljašima u ovladavanju staroslavenskim jezikom i pismom, kakvi se nalaze u liturgijskim knjigama; to se moglo učiniti tek prema iscl. uzorima jer je jedina staroslavenska gramatika toga vremena, ona M. Smotrickoga (1619, 1648), načinjena na temelju ruskih, rusinskih $i$ srpskih spomenika, ističe Stojković (1930: 120)

Karamanov Bukvar slavenskij pismeny Veličajšago Učitelja B. Jeronima Stridonskago Napečatan. V Rime; Tipom Svetoga Sobora ot razmnoženija Very u dvama izdanjima (1739. i 1753)

Novocrkvenoslavenski jezik i u XIX. stoljeću bilo je važno normirati prateći načela koja su uspostavili provoditelji iscl. norme, osobito Karaman i Sović. Ideja o crkvenoslavenskom (sveslavenskom) općem književnom jeziku zadržana je i u vrijeme Cyrillomethodiane, kao i diferencija prema govornom jeziku, odnosno vulgarnim dalmatinskim dijalektima (govorima) - nepodobnima za crkvenu uporabu. Svojevrsna Karamanova pobjeda ovjekovječena je 
Parčićeva koncepcija obnove staroslavenskih liturgijskih knjiga u XIX stoljeću

u konstituciji pape Benedikta XIV. Ex pastorali munere od 15. kolovoza 1754. Nju spominje i Parčić rečenicom:

Glagolski misal preštampan je šest puta, pak se nije nikada (?) podigao glas za promjenu slova, samo (?) preosta žalostni spomen dubrovačkoga svećenika Stjepana Roze, koji se je bio drznuo zaiskati, da se sav misal preobrne i izda u pučkom jeziku; nu tu njegovu drzovitost pobi $i$ sjajno obrani staroslovjenštinu nadbiskup zadarski Karaman....(citirano prema Milčetić 1883: 281-282)

Milčetić dakako nije istoga mišljenja, pozdravlja narodni jezik u crkvi, ističe djelatan primjer protestanata i ne razumije što točno Parčić u toj ideji drži drzovitošću. Jasno je da Milčetić i Parčić ne stoje pri istim političkim i jezičnopolitičkim načelima, jer Parčić nastupa, kako i sam na kraju rasprave Za obstanak glagoljice ističe, kao glasnik Rima, dobro su mu poznati dekreti kojima politika Sv. Stolice ograničuje glagoljsko bogoslužje i činjenica da će se, i ono malo što ga je po našim biskupijama ostalo, rasuti ne budu li se odredbe štovale. Već konstitucija pape Benedikta XIV. Ex pastorali munere 1754. ističe obvezu služenja slavenskim literarnim jezikom i pismenima, jeronimovskima (glagoljicom) u popisanim biskupijama. Pritom najstrože zabranjuje uporabu govorenoga slavenskog jezika (Slavo vulgari sermone) i latinice (šćavet i hrvatski obrednik) (usp. Fućak 1975: 122). Biskupijama s tradicijom glagoljskoga bogoslužja propisane su knjige koje je tiskala ili će tiskati Kongregacija za širenje vjere s prikladnim revizijama i odobrenjima. Milčetić dakle iznosi stavove o narodnom jeziku u liturgiji neopterećen, a Parčić posve oprezan prema političkim potezima Rima. O izlasku njegova Misala (1893) ta se politika odjelotvorila u novim dekretima (13. veljače 1892. i 5. kolovoza 1898) kojima je Kongregacija dala odgovor na sumnje glede staroslavenskoga jezika u bogoslužju. Prvi je dostavljen zagrebačkom, goričkom i zadarskom metropolitu s odlukama: 1) da staroslavenski jezik u bogoslužju ostaje staroslavenski, a ne moderni ili pučki, i to samo ondje gdje on zakonito postoji, 2) misa se dvojako (latinski i slavenski) ne smije služiti, 3) privilegij glagoljanja vezuje se uz crkvu, a ne uz osobe. Time se crkva vraća 150 godina unatrag na odredbe Benedikta XIV. S obzirom na žestoke pobune i odgovore, Kongregacija 1898. šalje dodatna pravila o tumačenju odredaba iz 1892. između ostalih da knjige u staroslavenskim biskupijama moraju biti ostisnute glagoljicom, da je staroslavenski jezik u bogoslužju realna povlastica, a ne osobna i da je usko vezana uz crkve, a ne svećenike itd. Tako se odvijalo planiranje statusa novocsl. jezika (odluka o izboru, koja ima politički aspekt, i planu izvedbe procesa kojim se jezik uvodi u uloge koje su za njega planirane, plan izvedbe kontrole i prosudbe tijeka kojim se jezik uvodi u nova područja, a i planiranje mogućeg moderniziranja, proširivanja, standardiziranja i kodi- 
ficiranja jezičnog korpusa). Planiranje korpusa pak smatra se „najlingvističkijim" aspektom jezične politike i prije svega jest jezično kultiviranje $u$ širem smislu te obuhvaća razvitak gramatike, uključujući tvorbu složenca i leksik, različite registre i stilove, na takav način da jezik može udovoljiti novim komunikacijskim potrebama. Kultiviranje se sastoji prije svega u stabilizaciji standarda i ono je u određenom stupnju nužno (usp. Trudgill 2010: 143-158). Tu se podrazumijeva i kodificiranje jezika priručnicima kao što su pravopis, gramatika i rječnik. I to su Paštrić, Karaman i Sović (prijevod gramatike) ostavili u naslijeđe kao čvrstu metodu koju je slijedio Parčić.

Važan korak u danom smjeru jest i obrazovanje ilirskoga klera. Još nakon Tridentskoga sabora razvija se među našim biskupima svijest o važnosti glagoljskih sjemeništa. Potkraj XVII. st. to uspijeva Paolo Naldini. Dekrete za izobrazbu ilirskoga klera izdaje i splitski nadbiskup Sforza Ponzonio (1620), pa onda splitska sinoda za nadbiskupa Stefana Cosmia (1688), a nadbiskup Stefano II. Cupilli početkom XVIII. stoljeća najprije dovodi glagoljaše u Split da kod upućenih svećenika nauče najpotrebnije, a onda za poljički kler osniva ilirsko sjemenište u predgrađu Lučac. Zadarski nadbiskup Vinko Zmajević 1725. traži pomoć za gradnju ilirskoga sjemeništa od Venecije. Ona ga upućuje na Rim. Sjemenište se otvara 1729. ovlašću pape Benedikta XIII. i neposredno je podvrgnuto Svetoj Stolici. Nadbiskup Mateo Karaman daje mu 1748. statute. Na tom tragu i Parčić se u prepisci sa Strossmayerom i Račkim bori za pravilnu izobrazbu glagoljaša svećenika. Oni bi morali biti upućeni u neiskvaren općeslavenski književni jezik za koji je odabran hcsl. književni temelj i zato mu je cilj izraditi priručnike koji će tomu služiti. Gramatiku i rječnik stoga i oblikuje na latinskom jeziku jer su namijenjeni svećenicima glagoljašima koji se školuju u Rimu, a prema Apostolskom pismu Zavodu sv. Jeronima Slavorum Gentem koje je 1. kolovoza 1901. uputio papa Leon XIII. (usp. Lukić 2012a: 382-401).

O tim temeljnim priručnicima, točnije Azbukvaru i Gramatici, kao i devetnaestostoljetnoj hcsl. normi koja se njima kodificira, više u sljedećim dvama poglavljima.

\section{O pravopisnoj (i pravogovornoj) te fonološkoj normi obnovljenoga hcsl. jezika - Mali azbukvar za pravilno i jednolično čitanje glagoljice} (1894)

Priređivanje i uređivanje Misala (1893) u novoj jezičnoj i pismovnoj redakciji podrazumijevalo je dakle i oblikovanje jezičnih i pismovnih priručnika koji kodificiraju normiran hesl. jezik liturgijskih knjiga. Ta je popratna izdanja oblikovao, razumije se iz dosada istaknutoga, slijedeći metodologiju 
svojih prethodnika u Rimu (ponajprije Paštrića, Sovića i Karamana) Dragutin A. Parčić. Tijekom rimskoga razdoblja razmjenjivao je pisma s Vatroslavom Jagićem, Strossmayerom i Račkim, a u njima nemalo apostrofira spomenike koji čine korpus novoga csl. jezika, pravopisna i jezična rješenja koja odabire te prijepore do kojih u međuvremenu dolazi. U pismu 5. srpnja 1869. V. Jagiću Parčić piše:

Meni se čini da nam se nije držati posve čisto staroslavenskoga jezika, koji bi strogo sliedio idealnu i pravilnu slovnicu, takva jezika nećemo naći u nijednom crkvenom spomeniku glagoljskom. Vi dobro znate da svaki codex ima svoje osebine, a odkad se počelo uglatu glagoljicu rabit za crkvene knjige uvele su se i ondje njekoje osebine koje uprav razlikuju našu hrvatsku recenziju od satrobugarske, ruske itd. a opet ine knjige glagoljicom pisane od knjiga cirilskih. (Jagić 1910: 294)

Kada je već nekoliko godina radio u Rimu na pripremanju Misala i kada je pravopisnu i jezičnu normu u određenoj mjeri proveo u probnim domisalskim otiscima ${ }^{14}$, pisao je 21 . siječnja 1880. Jagiću s molbom (...) da me slovinski učenjaci upute imam li tim istim pravcem prirediti i sav Misal (...) (Jagić 1910: 295-296).

Također iz Rima 2. studenoga 1881. Parčić piše o odabiru hcsl. jezika, o spomenicima prema kojima je sravnjivao normu, o razlozima daljnjih konzultiranja Karamanova Misala te o nadnacionalnom poslanju biranoga liturgijskog jezika (Jagić 1910: 297), a 25. rujna 1893. po izlasku Misala Jagiću konačno piše o vlastitoj jezičnoj koncepciji:

(...) Vidjet ćete da u odlomcih Evangjelja upotrebio sam ponajveć Assemanovo Evangjelje, pak i Marijansko, pridržao sam, gdje sam ih našao, i stare aoriste; nu na više mjesta bilo mi nuždno, jer je tako zahtievala rimska cenzura, da se prilagodim prievodu Vulgate. Žao mi bilo, što u Apostolu nisam mogao imati pri ruci drugo osim Šišatovačkoga, a u odlomcih staroga uvieta morao sam upotriebiti Brčićeve odlomke; odlomke Psalama po Sinaitskom psaltiru Geitlerovu, a molitve prema prvom izdanju Misala. Uobće držao sam se hrvatske recenzije (...). Pak još suviše imao sam urediti matice za lievanje pismena, i pročaja, a napokon kakovu sam nagradu dobio? Nepovoljne su okolnosti za one koji se bave slavenskom knjigom. (Jagić 1910: 298-299)

14 Da se jezik tih otisaka i konačnoga izdanja Misala (1893) razlikuje, upozorio je Tandarić (1993: 81-84). 
U prvoj polovici 1894. godine, prema želji senjsko-modruškoga biskupa Jurja Posilovića (od 1894. do 1914. zagrebački biskup), Parčić je priredio Mali azbukvar za pravilno i jednolično čitanje glagoljice u novih crkvenih knjigah po hrvatskoj recenziji (redakciji, op. a). U impresumu stoji: U Rimu. - Tisak sv. Sbora 'de Propaganda Fide' 1894.

Alojz Jembrih (2002: 19) napominje kako je već naslovom istaknuto da knjižica ima poslužiti čitanju knjiga priređenih po hrvatskoj redakciji, odnosno redakciji D. A. Parčića. Koraci u procesu kodificiranja ortografske i fonološke (ali i ortoepske) norme novocrkvenoslavenskoga jezika hrvatskoga tipa oblikovani su već u prepisci s Vatroslavom Jagićem (gore doneseni dijelovi prepiske). Nemoguće ih je razumjeti bez usporedbe s rješenjima iscl. razdoblja, tim više što početna obnova hcsl. jezika u Berčićevu radu podrazumijeva očuvanu ortografsku (u nekoj mjeri i ortoepsku) normu iscl. izdanja (usp. Tandarić 1993: 80-81). Krešimir Mićanović (2004: 122) u vezi sa suvremenim pitanjima jezičnoga planiranja i (re)standarizacije ističe kako je problem kodificirane ortoepske norme dobar primjer napetosti između kodificiranoga standardnog varijeteta i jezične upotrebe. Nerijetko se kao primjer različitog statusa normi s obzirom na stupanj obveznosti i ujednačenosti navode ortografska i ortoepska norma, pri čemu se potonja opisuje kao varijabilna, podložna utjecaju regionalno i socijalno izdiferencirane jezične zajednice (izgovor manje podložan standardizaciji). Kako su pak glagoljaši rabili iscl. knjige, odnosno jesu li poštovali ortoepsku normu propisanu primjerice Karamanovim Bukvarom (1739), ne možemo sa sigurnošću znati ni potvrditi. Tandarić napominje da suditi možemo tek prema žuntama, rukopisnim dodacima misa i oficija, kako iscl. izdanja nisu među domaćim svećenstvom bila prihvaćena te da je vladala neujednačenost. Jezična osnovica u takvim prijevodnim rukopisima ostaje crkvenoslavenska, ali ortoepska i i morfološka norma naglašeno su hrvatskočakavske a ne ruskoslavenske (1993: 80). Ivan Berčić, profesor biblijskih znanosti i staroslavenskoga jezika na zadarskoj bogosloviji, u prvom izdanju Čitanke staroslavenskoga jezika (1859, također na latinskom jeziku) tiskao je tekstove Staroga i Novog zavjeta prema Karamanovu Misalu (1741) i Brevijaru (1791), ali s promjenama (čišćenje od rusizama). I u Bukvaru (1862/63) se pronalaze takvi tekstovi. Tandarić zaključuje kako je Berčić hcsl. redakciju vratio na razini glasova (grafemička razina, dakle u odnosu na izgovor), ali je zadržao Karamanovu rusificiranu grafiju (pitanja slovopisa i pravopisa, konkretno slovnoga inventara / grafetička razina, usp. Žagar 2013: 15-16). Rječnik nije dirao. I Parčić je u domisalskim izdanjima (Mrtvačka misa 1860. i dr) proveo hrvatsku redakciju na fonološkoj razini, ali je zadržao staru iscl. grafiju s dijakritičkim znacima. Njih napušta tek u pokusnim tiskanim izdanjima i u samome Misalu. Već u citiranom pismu Jagiću od 5. srpnja 
1869. pitanja slovopisne i pravopisne te fonološke (i ortoepske) norme Parčić je do u tančine apostrofirao (ali i morfološke norme - dativ, imperfekt):

Opredjelimo dakle oćemo li kadgod taj poluglasnik 1 zamieniti s punim samoglasnikom? s kojim? pak onda budimo dosljedni u svoj kolikoj radnji. S gosp. kan. Brčićem nisam jošte ništa pobliže o tomu zaključio zato treba nam i vaše važno mnenje. (...) A šta ćemo s jerom na kraju rieči gdje ne zastupa nijednoga samoglasa? Da ne smeta u štivenju najbolje bi ga bilo po svema izostaviti. Nakon c, $\check{c}, \check{s}, \hat{c}, \check{z} d$ pisat ćemo pravilnije u (a ne ju?). Što se forma tiče: Dativ na omu, mjesto umu (i uumu). Imperfekt na aah, êah, $\hat{e}^{15}$ ah (ili na ah, êh, êh)? (Jagić 1910: 294-295)

U domisalskim (probnim) otisnutim izdanjima pravopisna su i fonološka norma već uglavnome uređene, a ta su Misi vlašćee v'Tretiem 'čine Svetago Ot'ca Framciška i in'de apostol'skim' izvoleniem'služimie (Rim 1881), Mise svetih'v'seob'ćee Cr 'kve i inie v'nekih'mêstêh'izvoleniem 'apostol'skim služimie. Prilog Rim skomu Misalu lêta MDCCXLI (Rim 1881), Čin'i Pravilo misi ošće že i molitvi pre i po mise iz’ Rim’skago misala (Rim 1881). O njima Jagiću piše 15. srpnja 1881:

Kako vidite, osobito iz odlomaka Evangelja, moja je bila nakana držati se po prilici naše hrvatske recenzije zapadn. obreda, kakova je u knjigah od XII vieka unapried. Za to sam pridržao samo I (gdje bi imalo biti i jery), samo jedno $\hat{E}$, i jedno l svagdje, gdje mu je mjesto po Miklošićevu Rječniku, te još pisao A umjesto Ê iza l, n (zemla i t.d.) prema našim glagoljskim spomenikom. Nu nijesam upotrebio stezanja dvaju I, nego oboje napisao (o učenii i slična); niti njihove dissimilacije u EI (Ijudei ni Ijudi) nego samo samo pravilno ljudii (u gen. pl.); hvaleĉii (a ne hvaleĉei) i t.d. Ovdje desivši se presv. Rački odobrio je sa svim moj postupak, i naložio mi da istim smjerom obavim svu svoju radnju za Misal; očekivat ću ipak $i$ od vas dotično i za me prevažno mnienje. (Jagić 1910: 296)

Kako je na kraju odlučeno urediti ta pitanja u izdanju Misala (1893), svjedoči u pismu Jagiću od 25. rujna 1893:

U obće držao sam se hrvatske recenzije, zadržao samo $\hat{E}$, (zamieniv ga sa A poslie l, n, r, kako je to obično u naših starih), a poluglase uredio prema Miklošićevu Rječniku. (1910: 299)

$15 \mathrm{~S}$ točkom. 
Prvi priručnik kojim se kodificira norma (osobito slovopisna i pravopisna te fonološka, dakle i ortoepska) jest Mali azbukvar za pravilno i jednolično citanje glagoljice iz 1894. Njegov je pretisak donio 2002. godine, povodom obilježavanja stoljetnice smrti D. A. Parčića Alojz Jembrih u knjizi Ex libris Kezele, a Stjepan Damjanović već godinu poslije (2003: 1-8) opominje kako hrvatska filologija uporno knjižicu pripisuje Parčiću koji ju je samo uredio za tisak, a njezinim autorom je Ivan Broz, kako stoji na 10. stranici knjižice:

Svakomu svoje. Ove bilježke sgotovio je bio malo prije smrti Dr. I. Broz po želji presv. bisk. Posilovića, pak se evo sad objelodanjuju uz male promjene veleuč. Radetića sjemeništnoga profesura u Senju, čemu sam ja još uz koju opazku i razjašnjenje nješto pridodao.

Damjanović donosi i kratak opis knjižice koja ima 11 stranica i podijeljena je ovako: A. Glagoljska azbuka B. Tumačenje glagoljskih slova, C. Tumačenje brojeva, D. Primjer čitanja. Na samom početku nalazi se tablica s glagoljičnim i ćiriličnim slovima i njihovim brojevnim vrijednostima te latinična transliteracija, točnije latinicom zabilježen izgovor. Za slova đerv, jat, jer izgovor nije u tablici komentirao, već je uputio na poglavlje B. U poglavlju B. tumači se čitanje pojedinih slova, a temeljna je metoda pozivanje na suvremeni hrvatski izgovor. Damjanović ocjenjuje korektnima objašnjenja primjera ostvarivanja $l, n, r$ i njihovih mekih parnjaka te ostvarivanja jerova. Kod uputa u čitanju đerva Broz ističe samo pojavu u tuđicama, ali takvom je stvarnost tek prvih redakcijskih spomenika ističe Damjanović (2003: 7) ${ }^{16}$, već od XII. st. potvrđuju se i primjeri rojenie, meja i danas ih ostvarujemo kao /j/ jer je riječ o čakavskom glasu koji stoji na mjestu štokavskoga /d/ (a oba su prema praslavenskom *dj). Autor Azbukvara preporučuje dakle štokavski izgovor. Zanimljivo je i tumačenje glagoljičnoga slova šta. Prema Damjanoviću Broz ispravno tvrdi da se on u staroslavenskom uvijek ostvarivao kao /št/, pa tako preporuča i za nove hrvatske crkvene knjige sa zanimljivom preporukom osim da gdjegod, osobito gdje ih dolazi više u istoj rieči, ne sili lasnoća izgovora jedno zamieniti sa ć prema današnjem hrvatskom izgovoru, n. pr zaĉicenie / zaštićenije/ (2002: 56). Tek kod riječi kojih nema u hrvatskom jeziku zasigurno u izgovoru ostaje/št/. Damjanović ističe da dosjetku ne treba Brozu

16 Valja napomenuti da su upravo istaknuta mjesta za nas potvrdom kako je riječ o konstruiranu jeziku, artificijelnoj normi hcsl. jezika XIX. stoljeća koja funkcionira tako da se, gdje je bilo nemoguće jednoznačno provesti hesl. normu koja se očituje u svojoj nestabilnosti (primjer bilježenja jata ili đerva, dakle grafemička razina), Parčić vraćao staroslavenskim osnovama, ali hiperkorektnom provedbom rješenja koja nije karakteristična ni za spomenike kanona, kao ni za najstarije hcsl. (redakcijske) spomenike do XIII. st. Gdje je Broz pokušao (pr)opisati normu u skladu s Misalom (1893), a Parčiću se činilo da (pr)opis nije dostatan, dodavao je vlastite komentare i pojašnjenja. 
strogo zamjeriti jer ni dugo poslije njega nisu jezikoslovci razlikovali normu klasičnoga staroslavenskoga od norme idioma koji tradicionalno zovemo hrvatskom redakcijom staroslavenskoga jezika ili naprosto hrvatskostaroslavenskim jezikom. U njemu se šta ostvaruje kao /ć/ i kao /šć/. Za slovo jat predlažu se dva čitanja: /e/ (iza suglasnika) i /ja/ (iza samoglasnika i na početku riječi). Ali donosi se i dodatno objašnjenje: nebi bilo baš ni protivno predaji da se čita, gdje je običaj, i kao $i$. Moglo bi se očekivati da je ovu napomenu unio Parčić ili Radetić. Broz se i u svojoj csl. gramatici dosljedno držao Leskienova tumačenja da se jat iza suglasnika realizirao kao zatvoreno /e/. Sve je potom oprimjereno pjesmom Pjesan Svetomu Duhu.

Glede slovnih matrica i slovnoga inventara (32 slova), bez sumnje je da Parčićev Misal (i Azbukvar) ima glagoljska slova prema Prvotisku Misala (1483). Također, slova zêlo, iže i ôtb imaju samo brojevnu vrijednost $(8,10$, 700). Uporaba slova đerv, jat, šta, jer (poglavlje B) dade se odmjeriti o stanje $\mathrm{u}$ Misalu, s povremenim usporednim osvrtom prema rabljenim i primjernim hcsl. misalima (Vat. Illir. 4 XIV. st, Prvotisak 1483). Istaknuta je slova i sam Broz posebno izdvojio u tumačenju pa ćemo tako učiniti i mi, ali s novim napomenama i uspostavljanjem poveznica:

Tablica 1. Uspostavljanje odnosa između izvorne i konstruriane hcsl. slovopisne i pravopisne norme (konkretno: grafemička razina)

\begin{tabular}{|l|l|l|}
\hline $\begin{array}{l}\text { Primjerni oblici knjiške } \\
\text { hcsl. grafemičke norme u } \\
\text { mijeni }\end{array}$ & $\begin{array}{l}\text { Provedba hcsl. norme } \\
\text { XIX. st. }\end{array}$ & $\begin{array}{l}\text { (Pr)opis hcsl. norme XIX. } \\
\text { st }\end{array}$ \\
\hline $\begin{array}{l}\text { XIV. st. -Vat. Illir. } 4 \\
\begin{array}{l}\text { XV. st. (1483) - } \\
\text { Prvotisak }\end{array}\end{array}$ & 1893. Misal (Parčić) & $\begin{array}{l}\text { 1894. Mali azbukvar } \\
\text { (Broz i Parčić) }\end{array}$ \\
\hline
\end{tabular}

Đerv (̂ิ). U hrvatskoglagoljskim fragmentima iz XII. i XIII. stoljeća đerv je rabljen samo na mjestu gr. $/ \mathrm{Y} /$, odnosno latinskoga $/ \mathrm{g} /$ pred prednjim vokalom, dakle u tuđicama. Od XIII. stoljeća započeo se pojavljivati i na mjestu prasl. *d' (*dj). Od XIV. stoljeća pak na mjestu svakoga /j/ bez obzira na njegovo postanje. U Prvotisku misala (1483) slovo $\hat{j}$ rabi se na mjestu grčkoga

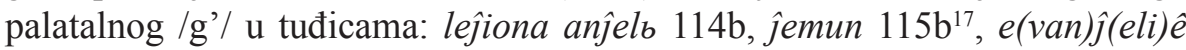
118a, a na početku riječi đerv za gr. $\Upsilon$ se i ispušta: emunomb (115b). U Prvotisku ipak nalazimo i variranje skupine $\check{z} d$ i suglasnika $j$ markirana đervom

17 Primjeri su preuzeti iz dijela Temporala Vat. Illir. 4 (Muka po Mateju: 74a-77d), Prvotiska (Muka po Mateju: 112a-118a) i Misala 1893. (Muka po Mateju: 129b-134a). 
(roždstvomb 7b : rojeniê 1a, usp. Damjanović 1984a: 69). U Vat. Illir. 4 dobro je očuvana skupina $\check{z} d$, a đerv je prisutan samo u tuđicama: ev(a)nj(e)lie 74b, lejiona anj(e)lb 75b, jemunu 76c, ali također može ispasti u incijalnoj poziciji: et'simaniju 74d). U Misalu (1893) se slovo đerv rabi samo za bilježenje grčkoga palatalnog /g'/ (jednako kao u kanonu i Vat. Illir. 4): Evanbjeliê 133b, lejeona Anbjelb 131a; slovo $\hat{j}$ na mjestu gr. $\Upsilon$ na početku riječi ne ispušta se kao u Prvotisku: Setbsimaniju 130b. Zaključuje se da je na taj način iskonstruiran povratak na početak redakcijskog formiranja: prvi hcsl. spomenici do XIV. st. (pr. Vat. Illir. 4), baš kao i općeslavenski kanonski tekstovi, imaju đerv samo u tuđicama za gr. / /, odnosno latinski /g/ pred prednjim vokalom, što je također odraz čuvanja staroslavenske tradicije (usp. Damjanović 1984b: 72) i samih početaka redakcijskoga formiranja.

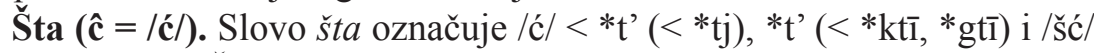
$<\left({ }^{*} \mathrm{sk}^{\mathrm{c}},{ }^{*} \mathrm{skj},{ }^{*} \mathrm{stj}\right)$. Šta je bio na hrvatskom glagoljskom području (čakavskom i kajkavskom) slovo za /šć/ i /ć/, na ćiriličnom (štokavskom) za /šć/, /ć/ i / št/. U Vat. Illir. 4 i Prvotisku ne susrećemo bilježenje dvaju slova za /šć/ (tzv. fonetizacija: slovo $\check{s}+$ slovo šta). Slovo šta i u Parčićevu je Misalu (1893) označavalo /ć/ i /šć/, nikako nije uporabljena sveza dvaju slova (slovo $\check{s}+$ slovo šta): hoĉeši 130a, skrbbeĉe 130a, glagoljuce 131b, aĉe 131b, otbpuĉu 132b. Slovo šta do XV. je stoljeća u hrvatskoglagoljskim tekstovima označavalo i /ć/ i /šć/ i /šst/ (Damjanović 2008: 59). Od XV. stoljeća nadalje glagoljaši nerijetko skupinu /šć/ bilježe kombinacijom $\breve{s}+\hat{c}$ jer dodatno žele upozoriti da nije riječ o /ć/. Između tih dvaju slova znaju stoga staviti i apostrof: $\check{s}^{\prime} \hat{c}$. No u liturgijskim tekstovima pisanje je slova $\breve{s} t a$ uz pomoć dvaju znakova $(\breve{s}+\hat{c}$ ili $\breve{s}+t$ ) rijetkost (usp. Mihaljević 1992: 12; Šimić 2000: 41; Jučević 2002: 92). To znači da je Parčić u Misalu preuzeo, u ovom slučaju opravdano bi bilo istaknuti i nastavio tradiciju hrvatskoglagoljskih liturgijskih tekstova (XV. i XVI. st) koji tradicionalno slovom šta bilježe /ć/ i /šć/.

Jat (ê). Slovo se rabi za zapis skupina /je/ i /ja/ i u Vat. Illir. 4 i u Prvotisku $^{18}$. Za Parčića se pak može zaključiti da slijedi pravilo iz gramatike

18 Dakako imamo u vidu činjenicu da se slovo jat moglo izgovarati i prema ekavskom odnosno ikavskom refleksu, ali gdje u pismu nije zabilježena ta promjena, bez obzira na konzervativnost pisma, ne može se zaključivati o refleksima. Također, znademo i to da je riječ o liturgijskom tekstu (i to dijelu Temporala, Muka po Mateju) te da se u takvima fonemska vrijednost jata čuvala i u XV. st. Slovo jat prevladava u odnosu na pismom potvrđene ekavizme i ikavizme u Vat. Illir. 4. i Prvotisku. Pritom Vat. Illir. 4, kao najstariji cjeloviti hcsl. misal, najbolje čuva ocsl. normu, a bilježi i neke ekavizme (pr. $v^{\prime}$ vsem ${ }^{\prime}$ 74b). Prvotisak pak bilježi također prevladavajući jat, uz ekavizme ali i značajniji broj ikavizama: skudelniču 115b, pogrebenie $115 \mathrm{~b}$, zavedeovu $117 \mathrm{~b}$, te smišano $116 \mathrm{~b}$, zadiše 116b (usp. Šimić 2000: 19, 26). 
Parčićeva koncepcija obnove staroslavenskih liturgijskih knjiga u XIX stoljeću

Dobrovskoga o pozicijski uvjetovanom izgovoru jata (1822: 24-26) ${ }^{19}$, a ne iz Leskienove poput Broza (zatvoreno /e/, usp. 1922: 5-6). Slovo jat u Misalu (1893) bilježi se/ja/ na početku riječi, u postvokalnom i međuvokalnom položaju, iza slova za palatalne suglasnike. Jatom se u hcsl. jeziku mogla bilježiti i skupina /ja/ postala od *ę (Vat. Illir. 4 êše i 75b, Prvotisak êše i 114a), no u Parčićevu Misalu (1893) tomu nije tako: refleks je staroslavenskoga prednjega nosnoga samoglasnika beziznimno /e/, protezom proširen prednji nazal reflektira se katkad $\mathrm{u} \hat{e}^{20}$, ali nepravilno jer imamo uglavnom primjere poput: ese $i$ 131a (Ma jęse $i$, usp. Jagić 1960: 102), etb me 131a, ne este mene 131a (Ma jęti mę, ne jęste mene, usp. Jagić 1960: 102). U Misalu (1893) jat je zamijenjen slovom $a$ iza $/ 1$ '/, /n'/, /r'/ odnosno umekšanost nije obilježena (pred vokalima /a/ i /e/): zemla 133b (z(e)mla 77b, z(e)mla 117b). Izuzetak je primjer povbtorêetb (ali ne iz Muke), usp. Babič 2000: 114) ${ }^{21}$. U samome Malom azbukvaru ističe se da je to pitanje kolebljive norme: $N u$ jer su riedki ovi potonji slučajevi, (a o tom naosob odlučuje Slovnica uz Rječnik) manja će bit pogreška, ako se ra, re svagdje čita kao /ral, /rel. Za izgovor rju ima pak glagoljica predjotovano slovo, te piše morju, borju se (2002: 56). Zaključuje se kako je riječ o rješenju hcsl. norme XIX. stoljeća koje teži početku redakcijskog formiranja i naslijeđenoj staroslavenskoj pisarskoj praksi: slovo jat na položaju prasl. jata prevladavajuće u odnosu na slova $e$ i $i$ (usp. Mihaljević 2009: 299), ali se dopušta izgovor /e/ i /i/ gdje nije protivno predaji ${ }^{22}$. Opravdano je postaviti pitanje je li Broz ovdje drugačije normirao izgovor nego što je to zamišljeno u preučenoj Parčićevoj koncepciji, kojoj učenost zamjera čak i Jagić 1894. godine?

Jerovi. U Parčićevu Misalu ne bilježi se razlika između tvrdoga i mekoga jera. I jedan i drugi označeni su štapićem: vb ono 129b, človếčski 129b, mьnоju 130a itd. Izgovor /a/ na mjestu zabilježenoga štapića (nekadašnja jaka pozicija) pretpostavlja se prema pravilima iznesenima još u Parčićevu pismu 1869. godine, a kada se na razini pisma bilježi vokalizacija,

19 U Parčićevu Misalu jatom označuju skupine /je/ i /ja/ (a Broz napominje izgovor /e/): sinb človêčbski prêdanb budetb 129b; vbzliê na glavu emu 129b. Prepoznaju se ocsl. normirane pozicije, ali Broz napominje izgovor/e/ uz izgovor/ja/.

20 M. Žagar i A. Zaradija Kiš (2006: 176) navode primjer êsti za inicijalni (prejotirani) prednji nazal reflektiran u $\hat{e} / \mathrm{ja} /$. Mi nismo potvrdili takvoga primjera u tekstu Muke.

21 Jedino kada je dopušteno pretojiranim glagoljičnim slovom ju: glagoljuĉems 132a (glagoljuĉi 76c, g(lago)ljuĉu se 114a), sbtvorju 132b, no u Vat. Illir. 4 i Prvotisku Misala ovdje je neobilježena umekšanost: stvoru 76c, stvoru (116a). Još jednom se potvrđuje hiperkorektna hcsl. norma XIX. stoljeća, ali i njezino nasljedovanje hcsl. norme XIV. i XV. stoljeća glede bilježenja umekšanosti /1/, /n/, /r/, nasuprot običnijem povratku redakcijskim počecima do XIII. st.

22 Dokaz da je ortoepska norma manje podložna standardizaciji. 
bilježi se prema iscl. uzorima, što Parčiću zamjera i Jagić u kritičkom osvrtu na Misal 1894. Stanje dakle s jerovima u nekadašnjem jakom položaju u Misalu izgleda ovako:

Tablica 2. Jerovi u nekadašnjem jakom položaju

\begin{tabular}{|l|l|}
\hline & Misal (1893) \\
\hline graf (slovna višestrukost) & I (ne razlikuju se jor i jer) \\
\cline { 2 - 2 } & e, a (niže i tanje otisnuta slova) \\
\hline grafem & $\begin{array}{l}\text { osobitost hrvatskoglagoljskih spomenika i u XIV. st. } \\
\text { (pr. Vat. Illir. 4, Prvotisak) - bilježenje nevokaliziranih } \\
\text { jakih jerova }\end{array}$ \\
\cline { 2 - 2 } & iscl. i hcsl. norma (ali i općesl. vokalizacija) \\
\hline
\end{tabular}

Sve će to nagnati Jagića (1894: 210-216) da zaključi kako Parčićev Misal uistinu jest previše učen za praktičnu primjenu (odnosno da je takvom jezična norma u njem provedena i kodificirana trima priručnicima: rukopisnom gramatikom i rječnikom te Malim azbukvarom), a osobito su nestabilna pitanja izgovora. Prije svega, to se za Jagića odnosi na na umetanje štapića I (za ь i ь) jer obrazovani urednik teksta ipak je trebao misliti na to da Misal na glagoljici nije namijenjen filolozima nego duhovnicima, od kojih većina crkvenoslavenski jezik koristi više u praksi nego u teoriji. Bezbrojni vokali I u svojem bi sadašnjem obliku mogli zbuniti čitatelje tako da ne znaju gdje ga trebaju čitati, a gdje ne. Ne nedostaje samo grafička razlika u pojedinim slučajevima, nego i uputa za korištenje, nešto u obliku pravila praktičnog izgovaranja, da bi se prilikom izgovora vokala I bilo moguće ravnati prema „živućem“ idiomu - ponavljao je Jagić. To pravilo doduše ne bi vrijedilo za sve slučajeve, no ipak bi bilo dostatno za mnoge. Smatrao je da bi sretnije rješenje bilo i ono nadahnuto iscl. slovopisnom i pravopisnom normom (ponešto preobraženom): slučajeve u kojima se i čita kao vokal, i to kao /a/, razlikovati od drugih po dijakritičkom znaku, primjerice kao í. Takvo označavanje bi u slučajevima

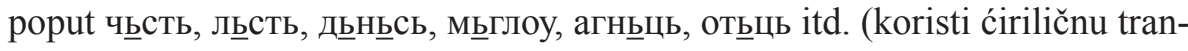
skripciju, dijakritički štapić na označenoj poziciji), duhovnicima služilo kao uputa da trebaju čitati часть, ласть, данась, маглоу, агнаць, отаць. Parčić to

23 Tip vokalizacije $b>e$ posredovan je Misalu (1983) preko iscl. norme i njezine provedbe u Karamanovu Misalu (1741), premda je riječ o vokalizaciji prisutnoj u Assemanijevu evanđelistaru te drugim bugarsko-makedonskim spomenicima kanona staroslavenskih spisa (usp. Soldo 1990: 173, Žagar, Zaradija Kiš 2006: 176). 
ne prihvaća, već kako je i sam isticao u pismu od 15. srpnja 1881. (jerovi na svim etimološkim pozicijama prema Miklošićevu staroslavenskom rječniku). Najveću nejasnoću glede jerova Jagiću predstavljaju dionice za pjevanje (nadopunjene notama) u kojima Parčić sasvim nepotrebno razlikuje $a$ i $e$ (umjesto drevnog ъ umeće $a$, a umjesto ь umeće $e$ ), te zahtijeva da se pjeva (dakle $\mathrm{i}$ čita): /božestvenim/, /vladičestvija/, /denes/, /konec/, /istinen/ itd.

U Azbukvaru pak stoji objašnjenje koje može još više zbuniti glede izgovornih vrijednosti nekadašnjih jakih i slabih jerova. Pitanja su to oko kojih je norma ostala kolebljiva, kako se vidi i iz pisama koje je Parčić Jagiću slao 1869. pa 1881, a odgovor očigledno nije bio dostatan za stabilan dogovor. Sve se u Azbukvaru tumači glasovnom harmonijom i spregom sa suvremenim hrvatskim izgovorom jer mnogi su koji niesu po svema vješti toj uporabi u staroj slovienštini:

Kad se može rieč i bez l izgovoriti onda se sasvim izostavlja; ovo valja osobito na kraju i u sredini višeslovčanih rieči, gdje slovka sa samoglasom završuje na suglas, kao n. pr. Bogı /Bog/, višsni /višnji/, pravıda / pravda/, vidêviše /vidjevšel.

Kad se rieč inače da izgovoriti, jer postaje bezglasna ili sasvim mukla, onda se 1 može zamieniti s punim, nu kratkim, glasom a ili e; a to valja samo u sredini rieči, gdje slovka bez samoglasa svršuje na $\imath$, kao člstı, vıplı, dvıri, tımını, sıšsdı, tımiênı i t. $d$.

Opazka ${ }^{24}$. Pravilnije bi bilo da se tvrdi jer (l) izgovara kratkim a/u; a meki kratkim e/i: nu. Jer u naših knjigah nema te razlike, a mnogo ih je, koji niesu po svema vješti toj uporabi u staroj slovienštini, najbolje je, kako su jur od pamtivieka naši stari hrvatski spomenici običavali, izgovarati samo a, nu prekratko, kao a malko prislonjeno na e, na pr. čitati gorje navedene rieči ovako: čast, vaplj, dvari, tamn, sašd, tamijan (2002: 57).

\section{Kratko o Parčićevoj rukopisnoj csl. / hcsl. gramatici}

Parčićevu rukopisna i nedovršena staroslavenska gramatika dosada je javnosti bila poznata samo preko sporednih, marginalnih bilježaka Parčićevih biobibliografa (usp. Bonefačić 1902: 28, Badurina 1993a: 19, Badurina 1993b: 179, Derossi 1993: 39, Ćosić 1993: 53, Soldo 1990: 176²5, Jembrih

24 S obzirom na to da je Parčić u pjevnim dionicama bilježio vokalizaciju jakoga jera prema iscl. normi (slovom e), što mu Jagić zamjera, vjerojatno je ovu Opazku dodao baš on kako bi opravdao postupak u Misalu.

25 U jednom trenutku Soldo pogrešno naziva njegovu gramatiku hrvatskoga jezika Grammatica della lingua Slava (illirica) iz 1873. staroslavenskom (1990: 172). 
2002: 20-21). Uvijek se isticalo kako iz njegove rukopisne ostavštine znademo da je pripremao školske učbenike iz staroslavenskoga jezika (rukopisni Rječnik latinsko-glagoljski i Gramatica paleoslavica-latina), a očigledno su isti namijenjeni svećenicima glagoljašima koji se školuju u Rimu, što je potvrđeno i Apostolskim pismom Zavodu sv. Jeronima Slavorum Gentem koje je 1. kolovoza 1901. uputio papa Leon XIII. (usp. i Lukić 2012a: 382-401). Parčić je rukopisnom gramatikom također pokušao kodificirati hcsl. normu XIX. st. Primjeri u njoj ispisani su glagoljicom, a morfološka norma jest uglavnom očuvana staroslavenska (/pr/opisana prema Dobrowskom, Leskienu i Miklošiću). Već je karakteristično provedena slovopisna i pravopisna reforma: prema hrvatskoj redakciji, ali sa zadržanim iscl. dijakritičkim znacima ponad slova, čak i u transliteriranim primjerima. Uputni jezik bio je latinski (metodološka praksa uspostavljena radom Paštrića, Sovića i Karamana, usp. i latinskim jezikom pisanu rusku gramatiku Heinricha Ludolfa Grammatica Russica iz 1696. godine). Anđelko Badurina ističe da se ta latinska gramatika čuva u Arhivu samostana Sv. Marije na Glavotoku, ima 32 lista pisana latinskim jezikom, dok su staroslavenski primjeri (drugačije nego u Solde) pisani ćirilicom i latinicom. Tu se nalazi i koncept Latinsko-staroslavenskoga rječnika pisanoga glagoljicom. Jedan je dio u bilježnici od 90 listova pisan abecednim redom, a srugi dio na 9 araka folio formata, ali nije poredan abecednim redom (Badurina 1993b: 179). Primjerak staroslavenske gramatike koji nam je ustupljen u Arhivu Provincije franjevaca trećoredaca u Zagrebu (Ksaver) istoga je opsega i jednakih podnaslova koje spominje u vezi s latinskom Badurina, ali je pisana hrvatskim jezikom (tako je i s primjerima) ${ }^{26}$.

Da je riječ o nedovršenoj rukopisnoj gramatici, svjedoči već činjenica da gramatika započinje morfologijom ili oblikoslovljem (premda se to može razumjeti i definicijom gramatike u užem smislu koja se dijeli na morfologiju, u kojoj se proučavaju najmanje značenjske jedinice (morfemi), oblici, ustrojstvo i vrste riječi, te sintaksu, koja obuhvaća proučavanje odnosa među sastav-

26 Gramatika je isrcpnije opisana i predstavljena na simpoziju Glagoljska tradicija u povijesti slavenske pismenosti (21. - 27. listopada 2013) u organizaciji Staroslavenskoga instituta iz Zagreba, Instituta za slavistiku Ruske akademije znanosti iz Moskve te Odsjeka za kroatistiku i Odsjeka za istočnoslavenske jezike i književnosti Filozofskoga fakulteta Sveučilišta u Zagrebu. Zbog sadržajnih ograničenja ovoga rada i već uspostavljenih istraživačkih ciljeva, osvrnut ćemo se samo na ona mjesta iz gramatike koja na primjeru slovopisne / pravopisne i fonološke (te ortoepske) norme pokazuju kako je proces normiranja i kodifikacije norme hcsl. jezika u XIX. stoljeću (Parčićeva koncepcija) otvoren kanonu stsl. spisa (X. i XI. st), hcsl. srednjovjekovnoj knjiškoj tradiciji (XIV. i XV. st. - Vat. Illir. 4, Prvotisak Misala), ali i iscl. uzorima (osobito Karamanov Misal 1741). 
Parčićeva koncepcija obnove staroslavenskih liturgijskih knjiga u XIX stoljeću

nicama nizova i funkcija tih sastavnica u složenijim jezičnim jedinicama ${ }^{27}$ ), a Parčićeva terminologija jasno ukazuje na njegovu pripadnost Zagrebačkoj ili Ilirskoj školi. Navedeno osnažuje i znanje o Parčićevu autorstvu Gramatike hrvatskoga jezika (1873) koja izlazi iste godine kao i Slovnica hervatska za srednja učilišta Adolfa Vebera (Tkalčevića), a pisana je u tradiciji jezika tzv. Zagrebačke ili Ilirske škole (Anić 1993: 93).

Nadalje, Parčićeva je gramatika pregledna sinkronijska gramatika (predstrukturalistička), započinje morfologijom i ne ide predaleko u dijakroniju. Točnije ne uspostavlja vezu s rekonstruiranim oblicima u prajeziku preko jezika srodnika i izoglosa, a osvrće se samo na one komponentne u općeslavenskom jeziku i njegovim redakcijskim podsustavima koje su izravno povezane (pr. denazalizacija nosnika ili bilježenje vokalizacije jerova i sl).

Parčić se kod primjera u gramatici služio, premda u transliteracijskim vrijednostima, istočnoslaveniziranim tipom slovopisa i pravopisa koji je kanoniziran Karamanovim Bukvarom (1739) i kasnijim misalskim i brevijarskim izdanjima. Glede zabilježenih fonoloških promjena (denazalizacija, bilježenje vokalizacije nekadašnjega jakog jera, slovo šta, đerv i dr) riječ je o hcsl. primjerima (obnovljen jezični tip XIX. st). Primjernosti radi, posebnosti istočnoslavenske grafije u početnim Parčićevim navodima ovdje ćemo donijeti u slikovnim prilozima. Takvi su primjerice štapić za jor i štapić s dijakritičkim znakom za jer, slovo $i$ s dijakritičkim znakom za glas /j/, jat s točkicom za glasovnu vrijednost /je/ i sl.

Premda Parčić donosi primjere iz kanona stsl. spisa (Assemanijevo, Zografsko evanđelje, Suprasljaski zbornik), kao i iz hrvatskih redakcijskih spomenika (senjski Lobkovicov kodeks, vrbnički misali i brevijari itd), a citira i Berčićevu Chrestomatiu - prema pisarskoj praksi koja u odnosu na grafetičku i grafemičku razinu analize ukazuje na postojanje slova za jerove (štapić i štapić s dijakritičkim znakom), slovima $u$ i $e$ zabilježenu denazalizaciju jusova (prednji nazal denazaliziran $\mathrm{u} e$ prema hcsl), slovom $y$ (transliteracijska vrijednost, prema iscl. uzorima) zabilježeno čuvanje jerya zaključujemo da je riječ i o oslonjenosti na tada 200 godina dugu istočnoslaveniziranu tradiciju liturgijskoga jezika i spomenika, kao i postojećih slovnica Zizania (1596) i Smotrickoga (1619), ali i da je riječ o svojevrsnoj gramatici koja pro(o)pisuje hr-

27 Tek gramatika i gramatički priručnici u širem smislu obuhvaćaju i fonologiju, u kojoj se proučavaju glasovni sustav jezika i razlikovna obilježja pojedinih glasova (fonema) u sastavu jezičnih jedinica kojima je svojstveno značenje (tj. morfema), te dijelove semantike (proučavanje značenja riječi i drugih jezičnih jedinica), leksikologije (proučavanje rječničkog sastava nekog jezika) i stilistike (proučavanje jezičnih jedinica s obzirom na uporabno raslojavanje). Također, sustav i raspodjela gramatičkih sadržaja na ortografiju, etimologiju (morfologiju), sintaksu i prozodiju naslijeđen je iz tradicionalnih grčkih i latinskih gramatika. 
vatski crkvenoslavenski jezik (novocsl. tipa), dakako ukoliko se on shvaća kao podsustav staroslavenskoga jezika prilagođen liturgijskim potrebama Crkve u XIX. st. Na taj se način uspostavlja afirmativan tip odnosa prema iscl. razdoblju, u vanjskojezičnom (metodološkom) smislu (oblikovanje priručnika), ali i samim pravopisnim i jezičnim rješenjima (usp. Parčićevo bilježenje jerova s dijakritičkim znacima, kao i Jagićeve napomene u kritici Misala 1894).

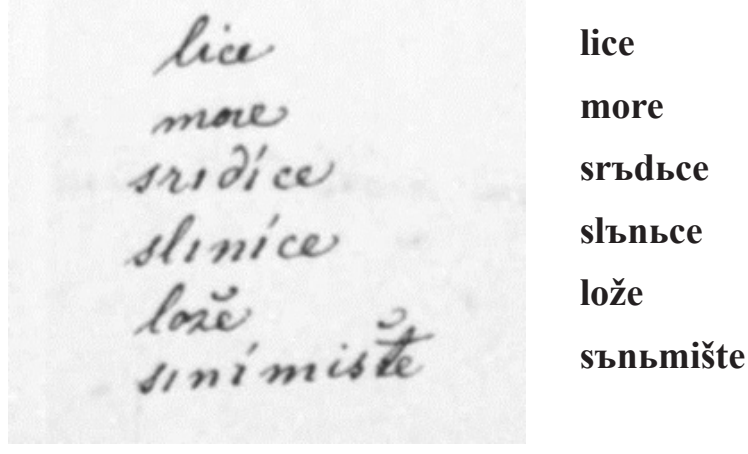

Slika 1. Znakovi za jerove prema iscl. pravopisnoj normi

Na drugom mjestu Parčić sam komentira iscl. slovopis i pravopis pri bilježenju izgovorne vrijednosti slova $i=/ \mathrm{j} /$. Poznato mu je dakle da se već u Levakovićevu Brevijaru (1648) već pojavljuje slovo $i$ s dijakritikom za/j/, a i u Karamanovu Misalu, ali to je već XVIII st.

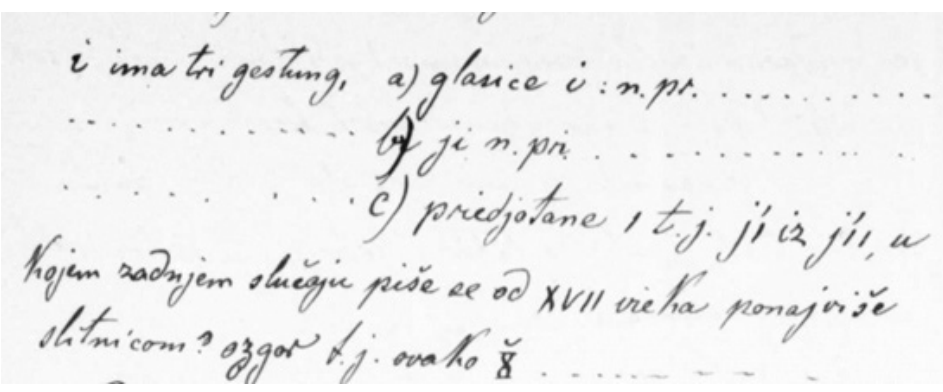

Slika 2. Parčićev komentar o iscl. slovopisu i pravopisu u Gramatici

Jezične su definicije afirmativne i u sprezi s vodećim staroslavenskim gramatikama Parčićeva vremena (Dobrovsky, Leskien, Miklošič), ukoliko su poglavlja ispunjena primjerima (gdjegdje u ovoj nedovršenoj gramatici stoje upražnjena mjesta za paradigmatske nizove deklinacija ili konjugacija, ali 
bez ispisa), oni su reprezentativni i potvrđeni izvornikom (spomenici kanona staroslavenskih spisa, istočnoslavenizirani spomenici i hrvatskostaroslavenski spomenici). Naslonjenost na tradiciju Zagrebačke škole prepoznaje se najprije u terminologiji i drugim detaljima (pr. poredak padeža), ali se ona ne slijedi bespogovorno, što je Sanda Ham zaključila i u odnosu na Parčićevu talijansku gramatiku hrvatskoga jezika (Grammatica della lingua slava (illirica) 1873). U tom smislu mogu se uspostaviti i veze sa tzv. sestrinskom staroslavenskom gramatikom, točnije udžbenikom staroslavenskoga jezika Ivana Broza, inače vukovca, iz 1889. godine (primjerice, izostanak terminologije za glasovne promjene). Tomu je tako jer se nekoliko temeljnih svojstava usporedbe kod ovih dvaju gramatičara ispostavljaju zajedničkima - vrijeme djelovanja (druga polovica, točnije kraj XIX. stoljeća), zanemarena jezičnopovijesna komponenta njihove jezikoslovne djelatnosti, tip knjige - udžbenik / priručnik / pomoćno liturgijsko sredstvo, zajednički rad na pripremama pomoćnih knjiga za čitanje i uporabu novih staroslavenskih liturgijskih knjiga - pr. Mali azbukvar 1894. itd.

Nadalje, Parčićeva metodološka korektnost očituje se u pozivanju na izvore - postojeće gramatike kojima se služio i od koje je primjere odmjerio, kao i u dijelovima jezičnih opisa u kojima se poziva uvod, točnije daje naslutiti da je rukopis imao uvodno poglavlje u tipu vanjske povijesti jezika - u kojem su opisane povijesne okolnosti nastanka staroslavenskoga jezika i dviju azbuka, vjerojatno su donesene tablice s azbučnim poretkom slova glagoljice i ćirilice, njihovim brojevnim vrijednostima i imenima, predstavljeni su temeljni spomenici kanona staroslavenskih spisa, kao i spomenici za koje već, kako ističe i Lunt (2001: 10-12), postoji jasna klasifikacijska oznaka redakcije / recenzije, odnosno jasno je da je riječ o spomenicima koji ne oprimjeruju više općeslavenski književni jezik, već neki od podsustava. Za Parčića je dakako osobito bitan hrvatski tip ckrvenoslavenskoga jezika, onaj koji je i prema vanjskim dokumentima (papinski dekreti, rad Odbora za izdavanje liturgijskih knjiga, članci u glasilima poput najpoznatijega Za obstanak glagoljice 1882. i dr) odabran za jezik novih staroslavenskih liturgijskih izdanja uz ustavnu glagoljicu. Što čini u spomeničkom, jezičnom, pismovnom i spacijalno-temporalnom kriteriju hrvatski crkvenoslavenski jezik, Parčić u nedovršenom gramatičkom rukopisu daje naslutiti, a mi znademo i potvrditi činjenicom da je na njegovoj „obnovi“ surađivao još s Ivanom B(e)rčićem pri izdavanju Chrestomathie linguae veterslovenicae 1859. Sve je spomenute informacije Parčić zasigurno namjeravao uvrstiti u gramatiku jer ih je svejednako uvrštavao u prepisku s Josipom Jurjem Strossmayerom, Franjom Račkim, Vatroslavom Jagićem i drugima, u članke i prikaze kojima se javljao u glasilima svoga vremena, a rabio ih je i kao argumente u sada već proslavljenim jezično-pismovnim polemikama. 


\section{Zaključak}

U radu se uspostavlja afirmativan odnos između novocrkvenoslavenskih jezičnih varijeteta u dodiru - istočnoslavenskoga s (o)pisanom normom (XVII. i XVIII. st) te hrvatskoga crkvenoslavenskog XIX. stoljeća, čija je norma (pr)opisana temeljnim priručnicima koje je priredio Dragutin Antun Parčić (uz I. Broza Mali azbukvar 1894, rukopisna csl. gramatika i rječnik), kao pomoćna izdanja uz hcsl. Misal iz 1893. godine. Nakon sociolingvističkoga (vanjskojezičnopovijesnoga) uvoda, u drugom dijelu rada istaknuti su elementi slovopisne / pravopisne (i ortoepske) hcsl. norme XIX. stoljeća. Na temelju kratke komparativne analize stanja u primjernim hcsl. spomenicima XIV. i XV. stoljeća te u Misalu (1893) i Azbukvaru (1894), moguće je zaključiti kako je nova jezična koncepcija obilježena demokratičnim stavom D. A. Parčića (i I. Broza) - preuzimaju se rješenja iz izvorne hcsl. norme, čas s početka (uporaba slova đerv), čas s vrhunca redakcije (bilježenje umekšanih $/ 1 /, / \mathrm{n} /, / \mathrm{r} /$ ), potom iz iscl. norme (Karaman, Bukvar 1739. i Misal 1741: bilježenje vokalizacije jakoga jera slovom $e$, pretpostavljeni izgovor svakoga jakog jera kao /e/i/). Kratkim propitivanjem izvora i priručnika potvrdila se i vanjskojezičnopovijesna teza o hcsl. jeziku XIX. stoljeća kao nadnacionalnom, općeslavenskom jeziku liturgije, sukladno politici Rima i ekumenskim težnjama Cyrillomethodiane.

Kratak osvrt na rukopisnu csl. gramatiku potvrđuje Parčićevu eklektičnu jezičnu koncepciju u uređivanju liturgijskih knjiga i težnju za normiranjem svih razina novoga hcsl. jezika. Naposljetku, valja istaknuti i metodičko-didaktičke doprinose slovničkoga štiva i Azbukvara, osobito jer je Parčić naglasio komu je slovnički rukopis namijenjen - studentima bogoslovije, svećenicima i laicima glagoljašima - i u koje svrhe - učenje staroslavenskoga jezika za praktičnu primjenu u staroslavenskoj liturgiji. 
Parčićeva koncepcija obnove staroslavenskih liturgijskih knjiga u XIX stoljeću

\section{Literatura}

- Anić, Vladimir. 1993. „Dragutin Parčić kao hrvatski gramatičar“. U Zbornik radova sa znanstvenoga skupa Život i djelo Dragutina A. Parčića (Zadar-Preko 18. i 19. listopada 1992), ur. Julije Derossi, 92-102. Zadar: Matica hrvatska - Ogranak Zadar.

- Babič, Vanda 2000. Vpliv vzhodne cerkvene slovanščine na hrvaške glagolske tekste v 17. in 18. stoletju. Ljubljana: Razprave Filozofske fakultete.

- Babič, Vanda. 2008. „Matej Sovič in ohranjeni rokopis njegovega latinskega prevoda slovnice Meletija Smotrickega (1619) iz leta 1773 v rokopisni zbirki NUK Ljubljana“. U Zbornik referatov za štirinajsti mednarodni slavistični kongres, Ohrid, 10-17. september 2008, ur. Aleksandra Derganc, 31-47. Ljubljana: Slavistično društvo Slovenije.

- Badurina, Anđelko. 1993b. „Nepoznati Parčić“. U Zbornik radova sa znanstvenoga skupa Život i djelo Dragutina A. Parčića (Zadar - Preko 18. i 19. listopada 1992), ur. Julije Derossi, 155-182. Zadar: Matica hrvatska - Ogranak Zadar.

- Badurina, Antun. 1993a. „Uz otkrivanje spomen-ploče o. A. D. Parčiću“. U Zbornik radova sa znanstvenoga skupa Život i djelo Dragutina A. Parčića (Zadar - Preko 18. i 19. listopada 1992), ur. Julije Derossi, 14-16. Zadar: Matica hrvatska - Ogranak Zadar.

- Bolonić, Mihovil. 1980. „Tiskane glagoljske knjige krčkih glagoljaša“. Croatica Christiana Periodica 4 (5): 1-40.

- Bonefačić, Kvirin Klement (Daroslav). 1902. Dragutin A. Parčić. Krk: Kurykta.

- Broz, Ivan (ur. D. A. Parčić). 1894. Mali azbukvar za pravilno i jednolično čitanje glagoljice u novih crkvenih knjigah po crkvenoj recenziji. Rim: Congr. de Propaganda Fide, Ex typographia polyglotta.

- Corin, Andrew R. 1993. „Variation and norm in Croatian Church Slavonic“. Slovo (41/42): 155-196.

- Ćosić, Vjekoslav. 1993. „D. A. Parčić, život u djelu“. U Zbornik radova sa znanstvenoga skupa Život i djelo Dragutina A. Parčića (Zadar - Preko 18. i 19. listopada 1992), ur. Julije Derossi, 45-58. Zadar: Matica hrvatska Ogranak Zadar.

- Damjanović, Stjepan. 1984a. „Jezik prvotiska u kontekstu književnojezične prakse hrvatskih glagoljaša“. Slovo (34): 63-80.

- Damjanović, Stjepan. 1984b. Tragom jezika hrvatskih glagoljaša. Zagreb: Hrvatsko filološko društvo. 
- Damjanović, Stjepan. 1991. Jedanaest stoljeća nezaborava. Osijek - Zagreb: Izdavački centar Revija, Međunarodni slavistički centar Republike Hrvatske.

- Damjanović, Stjepan. 2000. Filološki razgovori. Zagreb: Hrvatska sveučilišna naklada.

- Damjanović, Stjepan. 2003. „Brozovo poznavanje slavenske i hrvatske jezične starine". Fluminensia 15 (1): 1-8.

- Damjanović, Stjepan. 2005. Staroslavenski jezik. Zagreb: Hrvatska sveučilišna naklada.

- Damjanović, Stjepan. 2008. Jezik hrvatskih glagoljaša. Zagreb: Matica hrvatska.

- Derossi, Julije. 1993. „Antun Dragutin Parčić (1832-1902)“. U Zbornik radova sa znanstvenoga skupa Život i djelo Dragutina A. Parčića (Zadar - Preko 18. i 19. listopada 1992), ur. Julije Derossi, 33-44. Zadar: Matica hrvatska - Ogranak Zadar.

- Dobrovsky, Josef. 1822. Institutiones linguae slavicae dialecti veteris, Vindobonae: Sumptibus et typis Antonii Schmid.

- Eterović, Ivana. 2012. „Poredbena metoda i filološke analize ranonovovjekovnih hrvatskoglagoljskih liturgijskih tekstova“. U Zbornik radova Petoga hrvatskog slavističkog kongresa, ur. Marija Turk, Ines Srdoč-Konestra, 33-39. Rijeka: Filozofski fakultet.

- Fućak, Jerko. 1975. Šest stoljeća hrvatskoga lekcionara. Zagreb: Kršćanska sadašnjost.

- Golub, Ivan. 1971. „Rad Ivana Paštrića na izdavanju glagoljskih liturgijskih knjiga“. Slovo (21): 377-387.

- Golub, Ivan. 1996. „Ivan Paštrić u maticama Arkadije“. Croatica - prinosi proučavanju hrvatske književnosti 26 (42/43/44): 133-140.

- Hamm, Josip. 1963. „Hrvatski tip crkvenoslavenskog jezika“. Slovo (13): 43-67.

- Hamm, Josip. 1971. „Ruska redakcija u glagoljskim spomenicima“. Slovo (21): 213-222.

- Hercigonja, Eduard. 1971. „Odabrane perikope evanđelja iz Prvotiska“. U Misal po zakonu rimskoga dvora. Zagreb: LIBER.

- Hercigonja, Eduard. 1984. „Povijesni, društveni i kulturnoambijentalni uvjeti nastanka i razvoja hrvatskoga glagoljaškog tiska (u povodu 500. obljetnice prvotiska Misala 1483)“. Slovo (34): 17-62.

- Jagić, Vatroslav. 1894. „Kritischer Anzeiger: Missale Romanum slavonico idiomate ex decreto sacrosancti concilii tridentini restitutum (...)“. Archiv für slavische philologie (16): 210-216. 
- Jagić, Vatroslav. 1910. „Erinnerrungsblätter an Ivan Berčić und Dragutin Parčić". Archiv für slavische philologie (31): 288-300.

- Jagić, Vatroslav. 1913. „Hrvatska glagolska književnost“. U Povijest hrvatske književnosti, knjiga I, Branko Vodnik, 9-60. Zagreb: Matica dalmatinska.

- Jagić, Vatroslav. 1960. Codex marianus glagoliticus. Graz: Akademischen Druck- und Verlagsanstalt.

- Jembrih, Alojz, Mladen Kezele. 2002. Ex libris Kezele. Zagreb: Hrvatski studiji Sveučilišta u Zagrebu.

- Jučević, Ivan. 2002. Jezik hrvatskoglagoljskih tiskanih brevijara. Osijek: Sveučilište J. J. Strossmayera u Osijeku.

- Leskien, August. 1922. Handbuch der Altbulgarischen (Altkirchenslavischen) Sprache (Grammatik - Texte - Glossar). Heidelberg: Carl Winters Universitätsbuchhandlung.

- Lozić Knezović, Katarina i Gordana Galić Kakkonen. 2010. „Odnos crkvenoslavenskoga jezika i govornoga jezika u hrvatskome srednjovjekovlju“. Časopis za hrvatske studije 6 (1): 211-226.

- Lukić, Milica, Marina Pilj Tomić. 2010. „Staroslavenske liturgijske knjige na hrvatskom nacionalnom prostoru u XIX. stoljeću“. Lingua Montenegrina 3 (6): 75-107.

- Lukić, Milica. 2012a. „Korespondencija đakovačkoga biskupa Josipa Jurja Strossmayera i sarajevskog nadbiskupa Josipa Stadlera“. U Zbornik radova VI. međunarodnog znanstvenog simpozija Muka kao nepresušno nadahnuće kulture, 382-402. Zagreb: Udruga Pasionska baština.

- Lukić, Milica. 2012b. „Dragutin Antun Parčić i njegov Rimski misal slavenskim jezikom (Rim, 1893.) - (u povodu 100. obljetnice Parčićeve smrti i pretiska njegova glagoljskog Misala u Crnoj Gori)“. Lingua Montenegrina 5 (10): 317-337.

- Lunt, Horace G. 2001. Old Church Slavonic Grammar, Berlin - New York: Mouton de Gruyter.

- Matasović, Maja. 2009. „Svećenici između latinskog i hrvatskog jezika (17-19. st.)“. U Jezična politika i jezična stvarnost, ur. Jagoda Granić, 51-60. Zagreb: Hrvatsko društvo za primijenjenu lingvistiku.

- Mićanović, Krešimir. 2004. „Hrvatski s naglaskom“. Rasprave Instituta za hrvatski jezik i jezikoslovlje 30 (1): 121-130.

- Mićanović, Krešimir. 2006. Hrvatski s naglaskom - standard i jezični varijeteti. Zagreb: Disput.

- Mihaljević, Milan, Johannes Reinhart. 2005. „The Croatian Redaction: Language and Literature“. Incontri Linguistici 28: 31-82. 
- Mihaljević, Milan. 1992. „The Phonological System of the Croatian Redaction of Church Slavonic". Slavic and East European Journal 36 (1): 1-16.

- Mihaljević, Milan. 2009. „Hrvatski crkvenoslavenski jezik“. U Povijest hrvatskoga jezika - 1. knjiga: Srednji vijek, ur. Josip Bratulić i drugi, 283-349. Zagreb: Croatica.

- Miklošič, Franc. 1875. Vergleichende Grammatik der slavische Sprachen. Beč: Wilhelm Braumüller.

- Milčetić, Ivan. 1883. „O novom izdanju hrvatskih liturgičkih knjiga“. Vienac (17): 281-282.

- Parčić, Dragutin Antun. ? (rukopis). Gramatika staroslavenska. Rim.

- Parčić, Dragutin Antun. 1893. Rimbski Misalb slavênbskimb ezikomb prêsv. G. N. Urbana Papi VIII povelêniemb izdanb Missale romanum slavonico idiomate es decreto sacrosancti Concilii Tridentini. Rim: Congr. de Propaganda Fide, Ex typographia polyglotta.

- Petrović, Ivanka. 1979. „Franjo Rački - otac hrvatske Cyrillo-Methodiane“. Zbornik zavoda za povijesne znanosti Istraživačkog centra JAZU 9: 47-99.

- Roth, Kevin. 2013. „Learning Russian via Latin in the 17th century“. Graeco-Latina Brunensia 18 (1): 171-183.

- Samardžija, Marko. 2008. Hrvatski jezik, pravopis i jezična politika u $N D H$. Zagreb: Hrvatska sveučilišna naklada.

- Sgambati, Emanulea. 1983. „Udio Rusina u izdavanju hrvatskih glagoljskih knjiga u XVII. stoljeću“. Slovo (32/33): 103-122.

- Soldo, Antun Josip. 1990. „Antun Dragutin Parčić i njegov glagoljski misal“. Slovo (39-40): 167-181.

- Stojković, Marijan. 1930. „Pokušaji uvođenja ruskoslavenske gramatike Meletija Smotrickoga kod Hrvata katolika“. Nastavni vjesnik 38: 120-131.

- Strohal, Rudolf. 1912. Hrvatska glagolska knjiga. Zagreb: Tiskara Merkur.

- Šimić, Marinka. 2000. „Jezik Muke po Mateju u hrvatskoglagoljskim misalima“. Slovo (50): 5-117.

- Škiljan, Dubravko. 1988. Jezična politika. Zagreb: Naprijed.

- Tandarić, Josip Leonard. 1993. Hrvatska glagoljska liturgijska književnost - Rasprave i prinosi. Zagreb: Kršćanska sadašnjost.

- Trudgill, Peter. 1995. Sociolinguistics: an introduction to language and society. Michigan: Penguin.

- Wardhaugh, Ronald. 2006. An Introduction to Sociolinguistics. Malden (MA, USA): Blackwell Pub.

- Wright, Sue. 2010. Jezična politika i jezično planiranje - od nacionalizma do globalizacije. Zagreb: Fakultet političkih znanosti. 
Parčićeva koncepcija obnove staroslavenskih liturgijskih knjiga u XIX stoljeću

- Žagar, Mateo, Antonija Zaradija Kiš. 2006. „Muka po Mateju u Parčićevu misalu (1893): kulturološke, jezične i grafijske odrednice (nacrtak)“. U Zbornik radova 5. Međunarodnog znanstvenog simpozija s temom: Boka kotorska - jedno od izvorišta hrvatske pasionske baštine, ur. Jozo Čikeš, 153-189. Zagreb: Udruga Pasionska baština.

- Žagar, Mateo. 2012. „Zadaci i perspektive istraživanja jezika glagoljskih tisanih izdanja Šimuna Kožičića Benje (uz pripremanje kritičkog izdanja Misala hruackoga)“. Fluminensia 24 (1): 111-124.

- Žagar, Mateo. 2013. Uvod u glagoljsku paleografiju. Zagreb: Institut za hrvatski jezik i jezikoslovlje.

\section{Milica LUKIĆ \& Vera BLAŽEVIĆ-KREZIĆ}

\section{PARČIĆ'S CONCEPT OF RECONSTRUCTION OF OLD-SLAVIC LITURGICAL BOOKS IN THE $19^{\mathrm{TH}}$ CENTURY}

It is indisputable today that the leading role in the reconstruction of Old Church Slavic liturgical books in the $19^{\text {th }}$ century belonged to Dragutin Antun Parčić. This $19^{\text {th }}$ century's homo universalis in paleoslavic / paleocroatistic literature is known as the one who saved, through the Glagolitic Missal, an archaic Croatian privilege - Glagolitic script from impending doom threatening it in the second half of the $19^{\text {th }}$ century. His Glagolitic Missal, which returns Church Slavic language to the liturgical use, came out in 1893 and is the culmination of St. Cyril and Methodius's rebuilding efforts not only among the Croats, but also among the Slavs in general. At the time when Glagolitic script was suppressed in the Croatian national area, proper use of the Glagolitic Missal had to be provided, and therefore D. A. Parčić issued an Alphabetic manual for proper and uniform reading of the Glagolitic script (authored by Ivan Broz, 1894) and edited the Old Slavic grammar and dictionary: Grammatica Paleoslavico-Latina and Latin-Glagolitic Dictionary, which remained in manuscript. The paper therefore describes the two mentioned manuals and shows that what they are describing (and prescribing) is in accordance with Parčić's conception of language design (reconstruction) of old Slavic liturgical books, especially the Missal of 1893. It also confirms that Parčić approached the reconstruction Slavic liturgical books deliberately and with a clear concept.

Key words: Croatian Church-Slavic language, $19^{\text {th }}$ century, Missal of 1893, auxiliary liturgical books 



\section{Loretana FARKAŠ (Osijek)}

UDK 811.163.4'28(497.5)

Izvorni naučni rad

Filozofski fakultet Sveučilišta u Osijeku

1farkas@ffos.hr

\section{Silvija ĆURAK (Osijek)}

Filozofski fakultet Sveučilišta u Osijeku

scurak@ffos.hr

\section{KLAIĆEVO BIZOVAC̆KO NARJEČJE I DANAŠNJI PODRAVSKI GOVORI SLAVONSKOG DIJALEKTA}

Doktorski rad Adolfa Bratoljuba Klaića, Bizovačko narječje, napisan je 1939. godine. Iako ga je Klaić doradio i priredio za tisak 1959. godine, otisnut je tek 2007. godine. Nastao je na poticaj Ivšićevih radova o šaptinovačkom govoru i posavskim govorima u kojima je Ivšić prikazao jezične odlike u dijelu istočnohrvatskih štokavskih govora, a i pokrenuto je važno pitanje predmigracijskog jezičnog stanja slavonskog dijela hrvatskog jezičnog područja. Rad prikazuje metodologiju Klaićeva proučavanja bizovačkog govora te usporedbu s podravskim govorima slavonskog dijalekta, točnije šaptinovačkog govora.

Ključne riječi: slavonski dijalekt, podravski poddijalekt, bizovački govor, akcentuacija, fonologija, morfologija, sintaksa, tvorba riječi, leksik

\section{Uvod}

Klaić je svoj doktorski rad Bizovačko narječje napisao još 1939. godine. Doradio ga je i priredio za tisak 1959. godine, no tek je nakon više od šezdeset godina dostupan u tiskanom obliku ${ }^{1}$.

U uvodnom dijelu studije Klaić navodi da je građu za svoj rad počeo skupljati još 1929. godine, a u rukopisnom ju je obliku posudio Josipu Hamu koji je također istraživao i opisao slavonske podravske govore Valpovštine. (Ham 1949: 5-70)

Klaić, Adolf Bratoljub. 2007. Bizovačko narječje. Matica hrvatska-Ogranak Bizovac. Bizovac. 
Klaić je u svom opisu obuhvatio govore sljedećih sela: Bizovac, Brođanci, Habjanovci, Petrijevci, Satnica, Šag, Nard, Ladimirevci, Valpovo, Bistrinci, Ivanovci, Marjanci, Marjančaci, Vinograci, Harkanovci, Zelčin, Tiborjanci, Gat, Bocanjevci, Bočkinci, Veliškovci, Črnkovci, Podravski Podgajci, Sveti Đurađ, Čamagajevci, Lacić, Beničanci, Kunišinci, Šljivoševci, Radikovci, Rakitovica, Poreč i Donji Miholjac. Ističe da je od svih navedenih sela bizovački govor najkarakterističniji za to područje, a i njegov je materinski govor pa ga najsustavnije opisuje. Posebne jezične osobitosti govora ostalih sela namjeravao je iznijeti u studiji Govor slavonskopodravskih ekavaca, no nažalost to nikada nije učinio. (Klaić 2007:11)

Klaićev je rad nastao na poticaj Ivšićevih radova o šaptinovačkom govoru (Ivšić 1907) i posavskim govorima (Ivšić 1913) u kojima Ivšić prikazuje jezične odlike dijelaistočnohrvatskih štokavskih govora te je otvorio i pitanje predmigracijskog stanja slavonskog dijela hrvatskog jezičnog područja. Pri tome utvrđuje da je Ivšić svojim istraživanjima po posavskom govoru učinio $i$ velik dio posla za podravski govor, jer po rezultatima, koje je on iznio, i po rezultatima, koje imam i iznosim ja, možemo zaključiti, da je u pogledu glasova, a i u drugim osobinama, posavski i podravski govor veoma bliz, karakteristike jednog i drugog govora nisu dakle samo posavske odnosno podravske, nego općeslavonske. (Klaić 2007:1)

Zbog tih razloga Klaić opis bizovačkoga govora u cijelom radu uspoređuje s Ivšićevim opisom posavskih govora i šaptinovačkog govora. Također, naglašava da je bizovački govor organski nastavak posavskog govora, osobito u odnosu na akcentuaciju, a ekavštinom se veže uz neka posavska sela i uz ekavski Šaptinovac. Upravo ćemo zbog toga poneke dijelove iz Klaićeva Bizovačkoga narječja usporediti s današnjim šaptinovačkim govorom koji je opisan u okviru istraživanja o govorima našičkog kraja. (Ćurak 2012)

Bizovački je govor Klaić opisao na svim jezičnim razinama: fonološkoj, morfološkoj, sintaktičkoj, tvorbenoj i leksičkoj. U prikazu ćemo slijediti Klaićev prikaz te opisati rezultate njegovih istraživanja i usporediti ih s rezultatima do kojim smo došli istražujući današnji šaptinovački govor.

\section{Bizovačko narječje}

\section{Fonologija \\ 1.1. Naglasak}

Naglasni je sustav i uvodno poglavlje Klaićeve studije o bizovačkom govoru, ali naglasnom je sustavu dosta pozornosti posvetio i u kasnijim poglavljima. Po Klaićevu mišljenju bizovački govor ima pet naglasaka: 
- kratkosilazni (vöda) i dugosilazni (rêc) odgovaraju književnim naglascima, a mogu stajati na svakom mjestu u riječi,

- naglasak koji je prijelazan između akuta i dugosilaznoga i pojavljuje se samo na jednosložnim riječima $(k r a ̂ ̃ l j)$,

- naglasak koji se pojavljuje samo na prvom slogu naglašenih dvosložnih riječi na kojima je u standardnom jeziku dugouzlazni naglasak (rûेka): „Akcenat koji označujem znakom ầ stoji samo na prvom slogu u dvosložnih rieči knjiž. tipa rúka. On je silazan, ali opet različito od akc. na pr. prâvda, a osim toga ima svojstvo da u stanovitim prilikama prelazi u na pr. rūkä je, što se riečima tipa prâvda ne može nikada dogoditi. (Klaić 2007:19)

- akut, kojeg Klaić naziva "Ivšićev posavski akcenat" (Klaić 2007: 20), a koji se sve više gubi u bizovačkom govoru i zamjenjuje drugim naglascima, npr. junãk $>$ jünã $k$ : „Akcenat Ivšićev je "posavski akcenat", o kojem je izcrpljivo govoreno u radnji S. Ivšić, "Prilog za slavenski akcenat" (Rad 187), gdje mu je razložena fiziologija, postanak i razvoj. Već ovdje ću spomenuti da taj akcenat u stanovitim prilikama pokazuje težnju, da se izgubi, a osobito to biva u riečima posavskog tipa junãk, gospodãr, koje imaju u B. akc. jünãak, göspodã r. Naglašavam, da taj akc. kadkada stoji mjesto drugih knjiž. akc. (na pr. põsloška, zãdruga, svilẽni, crkva), a bilježim ga i u prilikama šũti pored šû̂ti (imperativ), dãdete pored dādête, Gospojĩne pored Göspojîne, dovezẽmo pored dovezēmô, snũje pored snūjê, nĩje pored nījê, prẽdem pored prēdêm, podorãno pored pödorâno, većĩnom pored vëcî̀nom, raspẽla pored räspêla, oltãri pored öltâิri i t. d. (Klaić 2007:20)

Novoštokavskih uzlaznih naglasaka u bizovačkom govoru nema.

Za razliku od Klaića, Josip Ham u odnosu na naglasni sustav najprije komentira Ivšićevo tumačenje posavskog akuta i uspoređuje ga sa čakavskim i kajkavskim akutom. Naglašava Ivšićevu nepreciznost u određivanju razlike između posavskog i kajkavskog akuta, pogotovo stoga što neki jezikoslovci smatraju da su današnji podravski štokavci potomci nekadašnjih kajkavaca koji su se prije turskih invazija poštokavili pa su lako mogli sačuvati tu stariju (kajkavsku) naglasnu osobinu osobinu. (Ham 1949: 15)

Podravski akut, ističe Ham, pripada uzlaznim naglascima. I u podravskog je akuta, kao i u posavskog akuta, ekspiratorna sila jača u drugom dijelu nego u prvom, i jača je od sile kojom se izgovara sljedeći slog. Ham navodi da se uz akut i dugouzlazni u nekim govorima pojavljuje poseban naglasak koji je po intonaciji srodan akutu, a Ivšić takav naglasak zove tromim (") i bilježi ga za neke kajkavske i posavske govore. Nadalje, Ham navodi da zbog 
razmjerno kraćeg početnog dijela naglaska i višeg tonaliteta sloga iza njega taj naglasak ima posebno obilježje lakoće i skakutavosti pa ga zbog toga naziva saltans, a budući da je kraći od akuta proširuje naziv takvog naglaska u poludugi saltans ('), primjerice u riječima: pojảta, nedẻlja. (Ham 1949: 29) Zanimljivo je što Ham ističe da je taj naglasak češći u govoru žena nego muškaraca, kao i u mlađih nego u starijih ljudi. Cijelo je područje donje Podravine i podijelio s obzirom na poludugi saltans na istočni, zapadni i središnji dio. (Ham 1949: 17)

Današnji šaptinovački naglasni sustav, kao i većina govora slavonskog dijalekta, poznaje pet naglasaka: kratkosilazni ("), dugosilazni (^), zavinuti ( $)$, kratkouzlazni ( ' ) i dugouzlazni ('). Naglaske zabilježene u današnjem šaptinovačkom govoru bilježimo u sljedećim primjerima:

a) kratkosilazni: örej, pletënice, naprävimo, kaparïsano, dukäta, poköjni

b) dugosilazni: cêli, nâs, ît (ići), znô, pôdne

c) zavinuti: dõjde, peškir ispãde, kasnẽje, decẽ

d) kratkouzlazni: sramòta, òtac, zèmlja, nòga

e) dugouzlazni: lótre, fárba, mládi, proživila, podlévati.

Prema Moguševoj naglasnoj klasifikaciji naglasni sustav Šaptinovaca i Bokšića pripada novijoj akcentuaciji koju obilježava djelomično pomicanje akcenatskog mjesta i to uglavnom kratkosilaznoga naglaska s posljednjeg sloga za jedan slog naprijed, primjerice: zemljä > zèmlja, nāröd > národ. ( Moguš 1977:53)

\subsection{Ostala fonološka obilježja}

U fonološkom opisu Klaić naglašava da je bizovački govor ekavski kao u primjerima: sêno, čövek, pëvati. I današnji je šaptinovački govor uglavnom ekavski, i u kratkim i u dugim slogovima: ïspoved, nëdjelja, pëvalo cêli, béljiti. Osobito je to izraženo kod starijih ljudi. Ponekad se u govoru $e$ još uvijek izgovara malo zatvorenije u naglašenim slogovima, ali ne onako kako je to opisao Stjepan Sekereš (Sekereš 1982). Osim ekavskog odraza jata rijetko se mogu čuti ikavizmi: prožívila, smïla, dìci, döli. Ivšić također navodi najčešće ikavizme u govoru: pripäst se, prid, di, trpit, divôjka. (Ivšić 1907:114) Ponekad se u govoru pojavljuje i jekavski odraz jata, osobito kod mlađih ljudi, što je utjecaj standardnog jezika: zvijézda, djëca, bijéle.

Osim ekavskog odraza jata i Klaić bilježi rijetke ikavizme: divōjka, sïtiti se, mïjur. Česte su i kontrakcije vokala kao i u većini današnjih govora slavonskoga dijalekta: rëko, sōnïce, dvānêst, kao i gubljenje vokala u primjerima poput: mäzat, kāzät, õnd, väko. Slični su primjeri i danas u Šaptinovcima. 
U opisu suglasnika Klaić navodi primjere protetičkog $v$ koje se javlja ispred glasa $u$...prilično često pogotovu u starijih ljudi upravo kao u kajkavaca i u Šaptinovcu. (Klaić, 2007:39) Bilježi primjere: vujo, vüsne, vüžina itd. Danas u šaptinovačkom govoru više ne pronalazimo takvih primjera, iako Ivšić navodi da se fonem $/ v /$ pojavljuje u riječima vûzal, vûsne, vúže, vüjak (Ivšić 1907:116).

Budući da slavonski dijalekt ne pozna glas $h$, Klaić i u bizovačkom govoru pronalazi mnoštvo primjera u kojima se glas $h$ gubi ili zamjenjuje glasovima $j, v, k$ : öću, rën, aljïna, näjero, mäceja, strâj, pärok, vr̈pa, sûv. Slične je primjere zabilježio i Ivšić u Šaptinovcima, a i danas se u šaptinovačkom govoru glas $h$ ne izgovara.

Klaić opisuje i ostale suglasničke osobine, poput „palatalizacije konsonanata $l$ i $n$ ", što je i inače obilježje podravskih govora, ali i nekih drugih govora slavonskog dijalekta: moljïti, dëteljina, naslonjïti. U istraživanju smo zabilježili slične primjere, a analogijom je prema obliku mòljit u šaptinovačkom govoru nastala imenica mòljba. Umekšano se l govori i u imenicama dëteljina, ljubënica, kao i u glagolu pëljati. Potvrdu toga pronalazimo i u Ivšića. (Ivšić 1097:115) koji navodi da suglasnik $l$ može stajati umjesto $n$ u riječima $m l o ̈ g o$, mlóštvo (Ivšić 1907:115), no nismo pronašli takve disimilirane oblike.

\section{Morfologija}

Iz morfološkog je opisa bizovačkoga govora razvidno da se u imenica a-vrste čuva staro morfološko stanje. To se prije svega očituje u nesinkretiziranom izrazu gramatičkih morfema u dativu, lokativu i instrumentalu množine. Klaić navodi da je dativ množine na -om, -em dosta čest, ali da se pronalaze $\mathrm{i}$ primjeri s „novim“ gramatičkim morfemom -ima. Evo nekoliko primjera: dâj prascẽm, podãjte tïma ranjenīkôm. U lokativu je množine najčešći gramatički morfem -i: na automobĩli su döšli, u onïma ganjkovĩ. I u instrumentalu se množine javlja stari gramatički morfem -i: s könji, käblica s kumpẽri. Ivšić je također zabilježio stare gramatičke morfeme u navedenim padežima, no nažalost u današnjem su šaptinovačkom govoru ti padeži jednaki standardnima.

Prema imenicama e-vrste, navodi Klaić, sklanjaju se i neka osobna muška imena kao Mârko, Pâvo, Jôzo: Tô je kïjer näšeg Mârke, glëđi Pāvî da ödeš. To je obilježje većine govora slavonskog dijalekta. U genitivu je množine imenica e-vrste običan gramatički morfem -a: rūkâ, slūgâ, dok dativ, lokativ i instrumental množine imaju samo gramatički morfem - $a m a$, a gramatički morfemi -am i -ami potpuno su nepoznati: svinjäma, šaragljäma. Takav je gramatički morfem i u nekih imenica i-vrste: ceväma, kapljäma. Takvi se primjeri i danas bilježe $u$ šaptinovačkom govoru. 
U opisu pridjeva ističe da se ne može točno odrediti upotreba neodređenog i određenog oblika pridjeva, a komparativ se pridjeva, osim oblika düžji, tëžji, vǐšji, götji, šìrji, tvori morfemom -eji: čistẽji, sitẽeji, siromašnẽji, lošẽeji, gustẽji, dobrẽji, prvẽji. Isto je i danas u Šaptinovcima, ali i u ostalim govorima podravskog poddijalekta.

Iz opisa zamjeničkih oblika izdvojit ćemo primjer genitiva jednine u kojem se umjesto posvojne zamjenice njezin rabi genitiv osobne zamjenice: vïdio sam njẽ brata, sëstru njẽ üzo. Takvu pojavu pronalazimo i u ostalim govorima podravskog poddijalekta i u današnjem šaptinovačkom govoru: Döšli su njẽ ròditelji. Tô je bïo brät njẽ. Potvrdu takvog oblika nalazimo i u Ivšića: Posvojne zamjenice nézin ili nên nema uopće u šaptinovačkom govoru, već se svagda nadomješta genitivom sg. lične zamjenice ńê (od óna); govori se na pr. ńê je ótac döšo, - to je nê rubïna, - s neê sa sestrôm divánio i t. d. (Ivšić 1907:138) Usporedo s tim oblikom danas se može čuti i standardni oblik njézin.

U sklonidbi se broja jedan obično gubi glas $d$ ispred $n$ pa glasi: jëna, jëno, jenõga i sl.

Navodimo i neke oblike priloga koje Klaić spominje: nâjpöslam, danâski, ozgõra, usvuzdûž.

Pri opisu glagolskih oblika Klaić navodi da bizovački govor nema imperfekta, pluskvamperfekta, glagolskog priloga prošlog, a aorist je vrlo rijedak. I u ostalim govorima slavonskog dijalekta prošla se radnja uglavnom izriče perfektom: òbrali smo vìnograda, nísam smëla dõć käsno. U govoru se često čuje i krnji perfekt, primjerice: bíla mlâda i lûda, kopäla kukùruz po céle dâne.

U konjugaciji ističe važno obilježje bizovačkog govora, a to je nastavak -eju u 3. lice množine prezenta: jëdeju, pletējî, izađẽju, iako se u novije vrijeme javljaju i standardni oblici. Prema Klaićevu su mišljenju takvi oblici ostatak nekadašnjeg kajkavskog utjecaja. Osim tih oblika, glagoli na -am, kao köpam, čũvam, stežu u 3. lice množine nastavak -aju u -u: köpu, čũvu. Ham je također za područje donje Podravine naveo dulje i kraće oblike za 3. lice množine prezenta: -u, -eju, -iju: kradu / kradeju, vozu /voziju. (Ham 1949: 45) Nastavci za 3. lice množine prezenta -eju, -iju karakteristični su i za kajkavsko narječje: vežeju, misliju (Lončarić 1996: 109), no Ham, nakon opisa razvoja tih nastavaka naglašava: da ni podravsko -eju, -iju nisu morali biti ropski odraz kajkavskih oblika, već su se na tom području mogli i samostalno razviti,

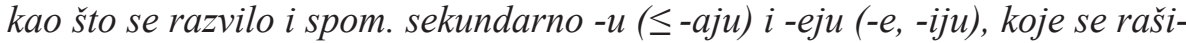
rilo u jugoistočnom dijelu, a dolazi i u središnjem govoru i u $\breve{S} N$ (Šaptinovci). (Ham 1949: 58)

Nastavak -eju zabilježili smo u današnjim Šaptinovcima: držéju, ležéju, trčéju, sedéju. 


\section{Sintaksa}

Na početku poglavlja o sintaksi Klaić upozorava da taj dio opisa nikako nije potpun jer Nije naime moguće bez vezana govora pohvatati sve sintaktičke karakteristike, a ako one i dođu u nevezanom govoru, onda su možda akcenatske, morfološke ili fonetske osobine upadljivije i u prvi se momenat čine važnije, pa sintaksa ostane po strani. (Klaić 2007: 143)

Od sintaktičkih obilježja navodi upotrebu besubjektnih rečenica: ne vïdje ji se; često izostavljanje pomoćnoga glagola u perfektu: mĩ već večërali; atribut se nalazi iza imenice: Õnda nastäne nedëlja päčistā. Slični se primjeri mogu čuti i danas u Šaptinovcima.

\section{Tvorba riječi}

U poglavlju o tvorbi riječi Klaić najviše opisuje tvorbu hipokoristika muškog i ženskog roda. Pri tome navodi da vlastita imena muškog roda dobivaju sufiks -eta i -oš: Ivëta, Jozëta, Ïvoš, Pävoš. U današnjem šaptinovačkom govoru hipokoristici muškog roda najčešće se tvore sufiksima -o, - $a$ : Frânjo, Mírko, Józo, Tüna. Nismo zabilježile oblike hipokoristika koji se tvore sufiksima -ica, -an, -en, -eta, -oš, iako Ivšić u rječniku navodi hipokoristik za muško ime Grga: Grgëna, ne navodeći u kojem se značenju upotrebljava takav hipokoristik. (Ivšić 1907:156) Pretpostavka je da je u vrijeme Ivšićeva istraživanja sufiks -en(a) bio češći u tvorbi hipokoristika muškog roda. U današnjem smo govoru zabilježili hipokoristično ime Grgëna jedino u obiteljskom nadimku: Gr̈genovi.

Hipokoristici ženskog roda, navodi Klaić, često se tvore sufiksom -ača: Maräča, Rezäča, no u današnjem smo šaptinovačkom govoru zabilježili hipokoristike ženskog roda sa sufiksima -ica, -ka, -a: Märica, Slävica, Kätica, Ânka, Îvka, Rúža, Mára, Káta. Nismo pronašli oblike koji se tvore sufiksima -ena, -ača, -ara, dok se u Ivšićevu poglavlju o rječniku pronalaze oblici hipokoristika ženskog roda sa sufiksom -ena: Cecëna, Lucëna, Katëna, Mandëna. (Ivšić 1907:154) Iz tih se primjera može zaključiti da je u Šaptinovcima sufiks -ena bio čest u tvorbi hipokoristika ženskog roda.

\section{Rječnik}

Opis bizovačkog govora Klaić završava rječnikom u kojem abecednim redoslijedom navodi nekoliko stotina riječi. Sve je navedene riječi usporedio s Akademijinim i Broz-Ivekovićevim rječnikom, a i sa šaptinovačkim rječnikom kojeg je naveo Ivšić (Ivšić 1907:154) Pri tome naglašava da je pronašao 
dosta usporednih odrednica bizovačkog i šaptinovačkog leksika. Ivšić je u rječniku naveo preko 450 riječi prema abecednom kriteriju, posebno je naznačio ako je pojedina riječ oblikom ili izgovorom drukčija, a u zagradama navodi njihovo značenje i etimologiju. Pregledom obaju rječnika (Klaićeva i Ivšićeva) uočljivo da su obojica zabilježili dosta riječi koje označavaju pojedine predmete ili aktivnosti koje se više ne koriste pa ih nema ni u današnjem šaptinovačkom govoru, primjerice: bâdal (gore račvasto drvo, što se zabije u zemḷu, kad se pletu uža, pa se uže zatiče za zub), dëdak (na polici u kola, na što se natiče stramica), pamučnênica (košuḷa lanom snovana, a pamukom tkana). (Ivšić 1907:154)

Slijedi popis nekoliko Klaićevih riječi, a koje se i danas mogu čuti u šaptinovačkom govoru:

- äpa, äpe, otac, àpa stãri, djed

- dvorìna, dvorìne, augm. dvor, dvorište

- kasìna, kasìne, poljska staza

- kästrôla, kästrôle, u Šaptinovcima kastróla, kuhinjska posuda s dugačkom drškom u kojoj se prže jela i začini; tava

- kijjễr, kijëra, u Šaptinovcima kïjer, mala kuća koja se obično sastojala od jedne prostorije

- krstopũće, krstopũće, u Šaptinovcima krstopúće, raskrižje

- lësa, lëse, drvena kapija na plotu

- örej, orëja, orah

Na kraju knjige Klaić donosi i nekoliko oglednih primjera bizovačkog govora.

\section{Zaključak}

Adolf Bratoljub Klaić u Bizovačkom je narječju detaljno opisao bizovački govor polovice 20. stoljeća i time otvorio put kasnijim proučavanjima podravskog poddijalekta, ali i ostalih govora slavonskog dijalekata. To se osobito odnosi na prozodijska obilježja koja opisu mjesnog govora daju posebnu vrijednost. Uočava se da se njegovo bilježenje naglasaka razlikuje od Hamova. Istraživanjem i usporednom analizom zapazili smo da je današnji šaptinovački govor sačuvao većinu podravskih obilježja. Promjene su, u odnosu na Klaićev opis bizovačkog govora, najviše zahvatile morfološku razinu.

Objavljivanje Klaićeve studije o bizovačkom govoru vrijedan je prinos proučavanju podravskih govora jer ...se tim činom sretno odužuju dva duga: davnašnji Klaićev prema bizovačkom zavičaju i današnji zavičaja prema Klaiću. (Samardžija 2007:202) 


\section{Literatura}

- Brozović, Dalibor. 1985. Suvremeno štokavsko narječje kao plod konvergentnoga jezičnog razvoja, Hrvatski dijalektološki zbornik 7/1. str. 59-71.

- Curak, Silvija. 2012. Današnji govori u okolici Našica. Doktorski rad. Filozofski fakultet Sveučilišta u Osijeku. Osijek.

- Farkaš, Loretana; Pilj, Marina. 2008. Govor Brođanaca, Šokačka rič 5. Ur. Anica Bilić. Zajednica kulturno-umjetničkih djelatnosti Vukovarsko-srijemske županije. Vinkovci. str. 113-125.

- Ham, Josip. 1949. Štokavština Donje Podravine. Rad JAZU 275/2. Zagreb. str. 5-70.

- Ivšić, Stjepan. 1907. Šaptinovačko narječje. Rad JAZU 168. Zagreb. str. 113-162.

- Klaić, Bratoljub. 1936. O podravskom akcentu i kvanitetu. Južnoslavenski filolog 15. Beograd. str. 181-183.

- Klaić, Bratoljub. 2007. Bizovačko narječje. Matica hrvatska - Ogranak Bizovac. Bizovac.

- Kolenić, Ljiljana. 1997. Slavonski dijalekt. Croatica str. 45-46. 101-116.

- Kolenić, Ljiljana. 2003. Slavonski dijalekt prema ostalim hrvatskim dijalektima. Zbornik Zagrebačke slavističke škole. Ur. Stipe Botica. Filozofski fakultet, Zagrebačka slavistička škola - Hrvatski seminar za strane slaviste. Zagreb. str. 175-183.

- Lisac, Josip. 2002. Osnovne značajke štokavske prozodije. Fluminensia 14/1. str. 85-88.

- Lisac, Josip. 2003. Hrvatska dijalektologija 1, Hrvatski dijalekti i govori štokavskoga narječja i hrvatski govori torlačkoga narječja. Golden marketing. Zagreb

- Lončarić, Mijo. 1996. Kajkavsko narječje. Školska knjiga. Zagreb

- Moguš, Milan. 1977. Čakavsko narječje. Školska knjiga. Zagreb

- Samardžija, Marko. 2010. Adolf Bratoljub Klaić i istočnoslavonski govori. Šokačka rič 7. Ur. Anica Bilić. Zajednica kulturno-umjetničkih djelatnosti Vukovarsko-srijemske županije. Vinkovci. str. 21-26.

- Sekereš, Stjepan. 1966. Govor našičkog kraja. Hrvatski dijalektološki zbornik 2. Zagreb. str. 209-301.

- Sekereš, Stjepan. 1974. Govor slavonske Podravine. Zbornik za filologiju i lingvistiku 17/2. Novi Sad. str. 125-166.

- Sekereš, Stjepan. 1975. Govor slavonske Podravine. Zbornik za filologiju i lingvistiku 17/1. Novi Sad. str. 185-221

- Sekereš, Stjepan. 1981. Odnos govora slavonske Podravine prema kajkavskom narječju. Zbornik za filologiju i lingvistiku 24/1. Novi Sad. str. 75-88. 
- Znika, Marija. 1996. Leksik govora donje Podravine u Ivšićevu opisu i danas. Zbornik radova sa znanstvenoga skupa održanoga u Orahovici od 29. travnja do 1. svibnja 1994. godine o 110. obljetnici rođenja profesora Stjepana Ivšića Zagreb, Ur. Finka, Božidar. HAZU. Matica hrvatska - Ogranak Orahovica. Orahovica. str. 177-185.

\section{Loretana FARKAŠ \& Silvija ĆURAK}

\section{KLAIĆ'S BIZOVAČKO NARJEČJE AND CONTEMPORARY PODRAVA'S SPEECH PATTERNS OF THE SLAVONIAN DIALECT}

The paper discusses the book Bizovačko narječje (Bizovac's Dialect), written by Adolf Bratoljub Klaić, originally as his $\mathrm{PhD}$ dissertation in 1939. Having been revised, the dissertation was ready to be published in 1959; however it took more than 60 years for the publication to occur. Klaić's work was inspired by Ivšić's works on the speech patterns of Šaptinovci and the Posavina region. Ivšić dealt in detail with the synchrony in a part of the Štokavian speech patterns in Eastern Croatia but also addressed an important issue of the pre-migration state of the Slavonian part of the Croatian language area. The present paper deals with the methodology of Klaić's study of the speech pattern of Bizovac and compares it with the study of the speech patterns of the Slavonian dialect, in particular to the speech of Šaptinovci in the Podravina region.

Key words: Slavonian dialect, sub-dialect of Podravina, speech pattern of Bizovac, accentuation, phonology, morphology, syntax, word formation, lexicon 


\title{
Tanja BREŠAN-ANČIĆ (Split)
}

UDK 811.163.4'354(497.5Dalmacija)

Pregledni rad

Filozofski fakultet Sveučilišta u Splitu

bresant@ffst.hr

\section{PRAVOPISNA PREVIRANJA U DALMACIJI 60-IH I 70-IH GODINA 19. STOLJEĆA}

\begin{abstract}
Autorica u radu analizira pojedine pravopisne probleme koji se javljaju tijekom 60-ih i 70-ih godina 19. stoljeća u dalmatinskoj publicistici. Analizirani tekstovi ekstrahirani su iz dviju dalmatinskih novina, Narodnog lista i Zviezde. Odabrani su novinski tekstovi koji upravo zbog svojeg javnog karaktera, ostavljaju mogućnost utjecaja na javnost koji je u tom jezično turbulentnom vremenu od presudne važnosti. S obzirom da je riječ o periodu u kojem utjecaj vukovaca i novoštokavskih inovacija još nije toliko jak, kreće se od pretpostavke da će rješenja pravopisnih problema češće biti u skladu s normom zagrebačke filološke škole, kao i to da će, usprkos djelovanju zadarskog filološkog kruga, utjecaj dalmatinske jezične tradicije biti sveden na minimum.

Ključne riječi: Dalmacija, etimološki pravopis, fonološki pravopis, zagrebačka filološka škola, zadarski filološki krug, hrvatski vukovci
\end{abstract}

\section{Uvod}

Nakon narodnoga preporoda koji je istim nacionalnim nabojem povezao sjever i jug Hrvatske, započinje vrlo buran period u jezičnoj povijesti kako Hrvatske, tako i Dalmacije. Druga polovica 19. stoljeća u Hrvatskoj i Dalmaciji period je ispunjen jezikoslovnim raspravama pristaša različitih filoloških škola i pravaca. Prvenstveno, riječ je o zagrebačkoj filološkoj školi koja na čelu s Vjekoslavom Babukićem, Antunom Mažuranićem, Adolfom Veberom Tkalčevićem i Bogoslavom Šulekom nasljeđuje ilirske jezičnonormativne postavke. Drugim putom kreću riječka filološka škola na čelu s Franom Kurelcem, zalažući se za ponešto starija rješenja u hrvatskom jeziku preuzeta većinom iz staroslavenskog jezika, te zadarski filološki krug na čelu s Antom Kuzmanićem koji neuspješno brani dalmatinsku ikavicu 
i kulturni primat što ga je čakavsko narječje nekoć imalo. Nadmoćna nad ostalima, zagrebačka filološka škola nakon književnog dogovora u Beču 1850. godine dobiva vrlo jakog oponenta u Vuku Stefanoviću Karadžiću i njegovim sljedbenicima Đuri Daničiću, Peri Budmaniju, Arminu Paviću, Tomi Maretiću i drugima koji čine najmlađi jezični smjer u Hrvatskoj druge polovice 19. stoljeća - hrvatske vukovce. Hrvatski su vukovci, ugledajući se na mladogramatičarsku lingvistiku zagovarali ideju „da jezik ima svoj život i svoje zakone bez obzira na književnost i da se u njoj samo primjenjuje s više ili manje uspjeha" (Samardžija, 2001: 205), a potkrjepu toj teoriji tražili su Karadžićevim i Daničićevim djelima. ${ }^{1}$ Jasno je kako su se u drugoj polovici 19. stoljeća, a naročito od početka 80 -ih godina suočile dvije gotovo suprotne jezične koncepcije, ,jedna zasnovana na jeziku čija je jezgra probrana štokavština (bez provincijalnih i drugih 'osebunjakah'), a iz čakavštine i kajkavštine u književni jezik idu sve one pravilne riječi, oblici i fraze koje štokavština ne pozna“" (Samardžija, 2001: 19), a druga pobornica književnog jezika utemeljenog na ,novoštokavskom ijekavskom dijalektu, onakvom kakav je zabilježen u djelima Karadžićevim i opisan u djelima Daničićevim“ (Samardžija, 2001: 19).

Iz neravnopravne su borbe kao pobjednici izašli vukovci ne toliko poradi lingvističkih razloga koliko zbog mnogobrojnih nadmetanja unutar zagrebačke filološke škole koja su rezultirala raznim pravopisnim komisijama, ali ne i jedinstvenim pravopisnim priručnikom ${ }^{2}$, te još više zbog političke situacije koja je na vlast dovela unioniste, a među njima vukovce Armina Pavića (revizora koji je odobrio Brozov fonološki pravopis) i Tomu Maretića (zastupnika unionističke mađaronske stranke). Pobjeda hrvatskih vukovaca zaključena je izlaskom Hrvatskog pravopisa Ivana Broza 1892., Gramatike i stilitike hrvatskoga ili srpskoga jezika Tome Maretića 1899. i Rječnikom hrvatskoga jezika Franje Ivekovića i Ivana Broza 1901. pa je tako vukovska

1 Vukovci su gotovo isključivo koristili jezik Karadžićevih djela, što Tomo Maretić u predgovoru svojoj gramatici otvoreno i govori „Svi ljudi, koji o toj stvari mogu pravo suditi, slažu se u tome, da je Vuk Stefanović Karadžić do danas prvi naš pisac, što se tiče pravilna i dobra jezika. Da je on za književni naš jezik ono, što je Ciceron bio i jest za književni latinski jezik“" (Samardžija, 2001: 205).

2 Još 1862. godine Dvorska je kancelarija dvjema naredbama propisala da se u hrvatskim školama ima upotrebljavati jedan pravopis i to onaj: „(...) koji se onamo od god. 1836. držao u glavnome za književni (věra, děte; pèrst; bratja...)“ (Samardžija: 2001: 122). Godine 1877. održala se pravopisna komisija koja je propisala, između ostalog, jekavski refleks kod kratkih i iekavski refleks kod dugih slogova, slogotvornost fonema /r/ no pravi se, jedinstveni pravopisni priručnik javlja tek 1892. godine u vidu fonološkog Brozova pravopisa, nakon što je 1889. godine vlast odlučila ,da je od prijeke potrebe za škole jedan pravopis, a taj treba da je osnovan na načelima fonetičkoga pisanja“" (Samardžija, 2001: 123). 
koncepcija početkom 19. stoljeća jezičnim priručnicima ojačala položaj tada dominantnog jezičnog pravca u Hrvatskoj.

Iako je Dalmacija bila na marginama jezikoslovnih polemika, pitanje službenog jezika se u pogodnom trenutku nametnulo kao pitanje nacionalnog interesa.

S obzirom da je politički i kulturno bila odvojena od ostatka Hrvatske, Dalmacija je bila i izvan glavnih jezičnih rasprava. Tadašnji najveći dalmatinski jezični autoritet, Ante Kuzmanić te zadarski filološki krug ${ }^{3}$ ustrajali su na obrani dalmatinske grafije te ikavice koja je imala dugu tradiciju na ovim prostorima. Nekoliko je razloga za takve jezične stavove. Prvi je zasigurno prestiž ikavice koji je imala u dalmatinskim kao i slavonskim djelima fra Andrije Kačića Miošića, Antuna Kanižlića, Matije Antuna Relkovića i drugih. Napuštanjem najrasprostranjenijeg dijalekta Dalmaciji su, kolijevci hrvatske kulture, nametnuta jezična rješenja, genetski joj neprirodna. Primat što ga je dalmatinska ikavica imala u prošlosti sve je više slabio; neki su članovi zadarskog filološkog kruga postupno napuštali svoje stavove, a čak i Zora dalmatinska, časopis zadarskog filološkog kruga, 1850. godine počinje izlaziti pisana ilirskom grafijom. ${ }^{4} \mathrm{~S}$ druge strane, dalmatinsku je grafiju diskretno omogućavala i austrijska uprava kako bi na taj način onemogućila nacionalno ujedinjenje razdvojenih hrvatskih krajeva. Izvan zadarskog jezičnog kruga, svaki sa svojim jezičnim stavovima ostaju dalmatinski gramatičari poput Parčića, Danila te Budmanija ${ }^{5}$ koji zastupaju različita stajališta o hrvatskom standardu. Usprkos već spomenutim težnjama za očuvanjem dalmatinske jezične tradicije utjelovljene prvenstveno kroz dalmatinsku grafiju i uporabu ikavice, malo je novina slijedilo takvu praksu. One službenog karaktera ${ }^{6}$ bile su prevođene s njemačkog jezika te su tiskane u Beču pa se jači utjecaj dalmatinske jezične tradicije i nije mogao očekivati. S druge je strane u Dalmaciji jačala želja za ujedinjenjem kao i otpor višestoljetnoj uporabi talijanskog jezika pa su određena pravopisna rješenja, koja i nisu imala potvrdu u dalmatinskoj pismenosti, preuzimana kao zalog zajedništvu, i onom nacionalnom i jezičnom.

3 Neki su od članova zadarskog filološkog kruga bili: Šime Starčević, Ignjat Alojzije Brlić i Stjepan Ivičević (Pranjković: 5).

4 Do tada je bila pisana dalmatinskom grafijom reformiranom 1820. godine (Vince, 1873: 71).

5 Parčić je zastupao načela zagrebačke filološke škole, Budmani vukovska, iako njegova gramatika sadrži „,pomirljivija“ gramatička rješenja. Danilo u svojim gramatikama drastično mijenja svoja jezična stajališta. Dok u svojoj gramatici iz 1855. zastupa koncepciju zagrebačke filološke škole, u drugoj se gramatici iz 1873. u potpunosti priklanja vukovcima.

6 Riječ je o brojnim novinama i listovima koji su donosili prijevode zakona i naredbi iz Vlade u Beču, a koji su se ticali pojedinih kraljevina Austro-Ugarske monarhije (Pokrajinski list, Državna lista zakona, Prevodi ilirski naredba(h) i zakona(h) za Kraljevinu Dalmaciju i drugi). 
60-e su godine tako uvod u eskalaciju jezičnih sukoba koji su ostavili traga i na pismenost u Dalmaciji te doveli do jezika kakvoga danas poznajemo. Razdoblje 60-ih i 70-ih godina u ovom je radu odabrano jer predstavlja period prije jačanja vukovske jezične koncepcije. Naime, taj je period obilježen snažnijim utjecajem zagrebačke filološke škole, nasljednice ilirskih jezičnih postavki. Uz to, jezično pitanje u Dalmaciji pravi preokret i poticaj doživljava 1870. godine pobjedom narodnjaka u Dalmatinskom saboru. Pobjeda Narodne stranke na izborima za Dalmatinski sabor potpuno je onemogućila da ikavica postane osnovicom za nadgradnju hrvatskog standardnog jezika, ali je označila prekretnicu u njegovu statusu. Naime, rasprave se u saboru počinju voditi na hrvatskom jeziku te se barem u teoriji pokušava izjednačiti status hrvatskoga i talijanskoga jezika. U praksi je to, ipak, bilo teže provedivo jer su učitelji, kao i javni službenici mahom bili obrazovani na talijanskim učilištima pa su hrvatski jezik jako slabo poznavali.

Narodnjaci rješavaju i pitanje naziva jezika koji je u Dalmaciji varirao od novinskih naziva hrvatsko-srpski, hrvatski ili srpski, slavodalmatinski, slavjanodalmatinski, dalmatinski, ilirsko-dalmatinski, a među pukom najčešće hrvacki jezik, arvacki jezik (Vince, 2002: 550) i u svome mu programu 1869. godine daju hrvatsko ime. Izborna pobjeda Narodne stranke stvorila je uvjete da već na drugome zasjedanju 14. rujna 1871. Sabor prihvati prijedlog da se: „1.) Podnesci imadu rješavati na jeziku na kojem su pisani; 2.) Hrvatskim jezikom mogu se služiti stranke i njihovi zastupnici; 3.) Grbovi i pečati javnih ureda, osim vojnih, mogu imati samo hrvatski natpis“" (Maštrović, 1972: 174).

Bečka je vlada tada zaustavila ove prijedloge obrazlažući svoju odluku time kako je jezično pitanje stvar središnje vlade, a ne Sabora. U travnju 1872. godine na snazi je naredba o uvođenju ,zemaljskih jezika“ u vanjskoj službi političko-upravnih vlasti, sudova i državnih odvjetništava u Dalmaciji (Bulat 1900: 7) prema kojoj hrvatski jezik u Dalmatinskome saboru postaje ravnopravan talijanskome (Samardžija, 2001: 15), te se nastava na oba jezika (tzv. utrakvizam) zauvijek ukida u školama ${ }^{7}$. Sve većom afirmacijom hrvatskog jezika u javnom životu raste i nesnošljivost među jezikoslovcima kako na hrvatskoj tako i na srpskoj strani.

Tek se 80-ih godina 19. stoljeća u Dalmaciji počinju događati konkretne promjene u jezičnoj strukturi koje sugeriraju kako novoštokavska norma ima sve veći utjecaj na književni jezik (Brešan, 2012.). Talijanski jezik 1883. godine prestaje biti službenim u Dalmatinskom saboru i Zemaljskom odboru

7 Treba napomenuti kako su se u praksi ovi zakoni vrlo rijetko provodili jer se talijanski obrazovano činovništvo ovakvim odlukama osjetilo direktno pogođeno. 
pa to postaje ,narodni jezik hrvatski i srbski“"8, a lex Bulat, odnosno prijedlog Gaje Bulata koji propisuje da se pravni zastupnici i stranke moraju služiti jezikom koji je u zemlji običajan, biva prihvaćen. Vlada tijekom 80-ih godina provodi ponarođenje srednjih škola u Splitu, Dubrovniku i Kotoru, a po uzoru na sjevernije krajeve Hrvatske u škole se uvodi fonološki pravopis.

\section{Normativna djela druge polovice 19. stoljeća u Dalmaciji}

Jezičnoj i gramatičkoj neujednačenosti u Dalmaciji nije pomogla ni neujednačenost kodifikacijskih rješenja u dalmatinskim gramatikama. Kao što su se na sjevernom dijelu Hrvatske normativni priručnici podijelili na one koji slijede naputke zagrebačke filološke škole ${ }^{9}$ i one koji idu tragom Vuka Stefanovića Karadžića, ${ }^{10}$ i u Dalmaciji se pristup rješavanju određenih pravopisnih i gramatičkih rješenja razlikovao od autora do autora. Rasprave o jeziku najčešće su dolazile iz pera Ante Kuzmanića i Šime Starčevića koji su istupali u dostupnim im dalmatinskim novinama, a najčešće su to bili Zora dalmatinska (Zadar, 1844. -1849.), Glasnik dalmatinski (Zadar, 1849. - 1866.) ili nešto kasnije Narodni list (Zadar, 1862. - ).

Jezičnu situaciju nije razriješila ni pojava nekoliko gramatika u Dalmaciji. Ivan Danilo još je 1855. u Zadru tiskao gramatiku pod nazivom Grammatica illirica koja se jezičnim postavkama u potpunosti razlikuje od sljedećeg njegova uratka Praktične gramatike iz 1873. godine. Prva je gramatika još uvijek bila pisana ilirskim pravopisom; još su uvijek bili prisutni stariji padežni oblici; koristi se ě slijedeći najvjerojatnije Babukićevu slovnicu (Vince, 1971: 291). Svoje jezične stavove Danilo u potpunosti mijenja u Praktičnoj gramatici. Pisana je fonološkim pravopisom, (i)jekavskim refleksom jata te $u$ množinskim padežima ima uporabu novoštokavskih nastavaka. Nekako u isto

8 U „predlogu“ koji su „,̌astni zastupnik Pavlinović i družina podnieli“ Saboru piše: ,Jezik Sabora i Zemaljskog odbora jest narodni jezik hrvatski ili srbski. Hrvatski se razpravlja, pišu saborski zapisnici, glasuju zakoni, predlozi i zaključci, i dopisuje se svakom Vlasti. Uz Sabor, Zemaljski odbor uredjuje unutrenje knjige, sve poslove, rješitbe, oglednice i dopise. Zastupnicim ostaje prosto u Saboru govoriti, podnositi predloge i talijanski“" (Hitropisna izvješća, 1883: 527).

9 Jezične smjernice zagrebačke filološke škole propisivale su Ilirska slovnica (1854.) Vjekoslava Babukića, Slovnica hèrvatska (1859.) Antuna Mažuranića, Slovnica hèrvatska za srednja učilišta (1871.) i Skladnja ilirskoga jezika (1859.) Adolfa Vebera Tkalčevića i dr. te Pravopis jezika ilirskoga (1850.) Josipa Partaša.

10 U „vukovske“ se normativne priručnike ubrajaju: Gramatika i stilistika hrvatskoga i srpskoga književnog jezika (1899.) Tome Maretića, Osnove srpskoga ili hrvatskoga jezika (1872.) Đure Daničića, Hrvatski pravopis (1892.) Ivana Broza i dr., Rječnik hrvatskoga jezika (1901.) Franje Ivekovića i Ivana Broza. 
vrijeme nastaje Parčićev Hrvatsko-talijanski rječnik s gramatikom ${ }^{11}$ koja je pisana umjereno etimološkim pravopisom te je koncipirana pretežito prema naputcima zagrebačke filološke škole. Ta je gramatika nastala kao kompilacija prethodno napisanih gramatičkih opisa (Stolac, Vlastelić, 2005: 2).

Možda najutjecajnija gramatika za Dalmaciju druge polovice 19 stoljeća, Grammatika della lingua serbo-croata (illirica) Pietra (Pere) Budmanija izlazi 1867. godine. Iako u javnosti percipirana kao gramatika vukovsko-daničićevskog tipa jer u samome naslovu nosi naziv srpsko-hrvatski, pisana je fonetskim pravopisom te je propisivala novoštokavske nastavke u sklonidbama, ne treba je promatrati isključivo u takvom kontekstu. Pero Budmani u svojoj gramatici ne može zanemariti tradiciju koja živi na ovim prostorima. Gramatika je djelo koje češće opisuje, no što propisuje pa je nužno morao uz novoštokavske inovacije prikazati i jezik koji je zaista u uporabi. Ne treba zaboraviti, njegova je gramatika izašla u šezdesetim godinama kada utjecaj hrvatskih vukovaca nije na vrhuncu, a razvoj hrvatskoga jezika još je uvijek mogao krenuti u nekom drugom smjeru. Stoga ne čudi kada Budmani svoju gramatiku naziva i ilirskom jer je takav naziv bio uobičajen u Dalmaciji (Tafra, 1995: 163). Imeničke deklinacije određuje po nastavku u genitivu jednine, zadržava dubletne nastavke za $\mathrm{D}, \mathrm{L}$ i I množine kao i razliku između sklonidbe neodređenog i određenog pridjeva. Uz takve, načelno morfološke kategorije, Budmani zadržava i digrame $d j$ i gj za /d/ te $t j$ za $/ c ́ c /{ }^{12}$ Tako najvažniji normativni priručnik za Dalmaciju nije u potpunosti definiran s obzirom na svoju koncepcijsku orijentiranost. S jedne je strane okrenut hrvatskoj tradiciji, dok se s druge strane okreće novim težnjama vukovsko-daničićevskog tipa.

Veze među dalmatinskim jezikoslovcima bile su vrlo snažne. Mihovil Pavlinović i Dragutin Parčić bili su školski kolege, a međusobno su pomagali jedan drugome i u leksikografskom radu. Pavlinović je također surađivao i s Natkom Nodilom. Ipak, druga polovica 19. stoljeća za Dalmaciju znači pristup jeziku s različitih strana. Parčić u potpunosti prihvaća jezična rješenja zagrebačke filološke škole te svoju gramatiku piše etimološkim pravopisom. Etimološkim se pravopisom služi i Mihovil Pavlinović koji poput Ante Kuzmanića zagovara uporabu ikavice. Sličnost se Kuzmanića i Pavlinovića s vukovcima može uočiti u njihovu zagovaranju korištenja narodnoga, gotovo pučkoga jezika (Vince, 1972-1973: 147). S druge se strane nalaze Danilo i Budmani sa svojim gramatikama pisanim fonološkim pravopisom u kojima, načelno, zagovaraju vukovsku koncepciju jezika. Uzmemo li u obzir da su te gramatike izašle relativno rano, 60-ih i 70-ih godina, kada je još uvijek jaka je-

11 Grammatica della lingua slava (illirica), izdana 1873. u Zadru.

12 Više se o komparativnoj analizi Budmanijeve gramatike s ilirskom i novoštokavskom normom može pronaći u članku Branke Tafre O hrvatskim vukovcima iz drugoga kuta (1993). 
zična koncepcija zagrebačke filološke škole može se zaključiti kako su upravo ove dvije gramatike uvele i učvrstile vukovsku jezičnu doktrinu u Dalmaciji.

Osim ovih gramatika i Parčićeva rječnika nije se u Dalmaciji sve do Brozova pravopisa iz 1892. godine i Maretićeve gramatike iz 1899. godine pojavilo veće leksikografsko djelo. Ni ova dva djela nisu bila napisana od strane Dalmatinaca niti su slijedila hrvatsku jezičnu tradiciju, ali su, uz Broz-Ivekovićev rječnik iz 1901., zatvorili jedno veliko poglavlje ispunjeno brojnim raspravama i neslaganjima te i službeno uveli novoštokavsku normu u hrvatsku jezičnu zbilju.

\section{Metode rada i ciljevi istraživanja}

Dosadašnja istraživanja jezika druge polovice 19. stoljeća upućuju na velika kolebanja u smjerovima kojima je hrvatski pravopis, a i jezik općenito, trebao ići. Ovaj će rad, na primjeru dviju novina, Narodnog lista ${ }^{13}$ (Zadar, 1862. - ) i Zviezde ${ }^{14}$ (1863) aktualizirati neka pravopisna pitanja tijekom 60ih i 70-ih godina 19. stoljeća. Publicistički su tekstovi uvijek dobar predložak za jezične rekonstrukcije jer svojim javnim karakterom omogućuju jezično obrazovanje šire javnosti. Upravo zato, u ovom je radu važan karakter korpusa jer prikazuje jasnu sliku jezičnoga stanja u tome periodu. Ostale su novine većinom bile upravno-službenog karaktera ${ }^{15}$ te su donosile zakone proglašavane u Beču. ${ }^{16}$

Cilj je ovoga rada rasvijetliti koje jezične koncepcije prevladavaju u periodu prije, za Dalmaciju, ključnih 80-ih godina, može li se osjetiti utjecaj dalmatinske jezične tradicije te koliko se već tada može zamijetiti utjecaj novoštokavskih inovacija.

Analiza će se temeljiti na primjerima iz dviju navedenih novina koji će se usporediti s jezičnim priručnicima koji su izlazili u tom periodu.

Kreće se od pretpostavke da će rješenja pravopisnih problema češće biti u skladu s normom zagrebačke filološke škole, kao i to da će, usprkos

13 Narodni list počinje izlaziti 1. ožujka 1862. godine pod nazivom Il Nazionale. Bio je pisan talijanskim jezikom, s hrvatskim dodatkom: Prilog $k$ Narodnom listu koji se analizira u ovome radu. Tek od 1869. godine Narodni list počinje u cijelosti izlaziti pod tim nazivom te je pisan hrvatskim jezikom.

14 Novine će u analizi biti označene kraticama: Narodni list: NL, Zviezda: ZV.

15 Riječ je o Pokrajinskom listu, Državnoj listi zakona, Prevodima ilirskim naredba(h) i zakona(h) za Kraljevinu Dalmaciju i drugima. Klasifikacija je preuzeta iz Maštrović, Jadertina Croatica, 1954.

16 Većim su dijelom te novine sadržavale zakone prevođene s njemačkoga jezika iz Državne liste zakona koji bi se potom uređivali u Beču. Redaktori su također bili nedalmatinskog podrijetla pa je utjecaj dalmatinske jezične tradicije bio sveden na minimum. 
djelovanju zadarskog filološkog kruga, utjecaj dalmatinske jezične tradicije biti sveden na minimum.

Tako postavljena hipoteza vodi k sljedećoj, a to je da će takav nestabilan sustav biti bolje propustan za nova jezična rješenja koja jače nadiru tijekom 80-ih godina.

Na odabir pravopisnih problema koji se analiziraju u ovome radu utjecala je činjenica da su se upravo u njima najjasnije ocrtavale pravopisne dvojbe jezičnih koncepcija u tome periodu. Oko tih su se pravopisnih problema vodile jezične rasprave, a jezikoslovci suprotstavljenih jezičnih škola imali su o njima oprečne stavove. Stoga u radu nisu uključeni svi pravopisni problemi, već samo oni koji su u tom trenutku bili aktualni. To su prvenstveno refleks jata te asimilacije, a potom i pisanje pojedinih fonema te sastavljeno i rastavljeno pisanje riječi.

\section{Pravopisna analiza}

Pravopisna će analiza uključivati prikaz nekoliko problema. Prvenstveno će biti riječi o refleksu jata. Asimilaciju po zvučnosti, kao i asimilaciju po mjestu tvorbe promatrat će se kroz njihovu realizaciju u pismu, s time da će se posebna pozornost posvetiti onim primjerima u kojima bi, kao posljedica nemogućnosti pravopisa da zabilježi određeni glas, barem u pismu, moglo doći do izostanka asimilacije. Također, opisat će se bilježenje fonema /ć/, /ź/, $/ \check{\zeta} / \mathrm{i} / \mathrm{h} /$ te sastavljeno i rastavljeno pisanje riječi.

\subsection{Refleks jata}

Jedno od najvažnijih pravopisnih pitanja 19. stoljeća bilo je upravo pisanje jata. Ilirski je pravopis prvenstveno propisivao $\check{e}$, međutim vrlo brzo takav se način pisanja napušta te se prihvaća pisanje ie u dugim slogovima te je u kratkim (Malić, 1992: 123). Babukić u svojoj Ilirskoj slovnici iz 1854. još uvijek koristi ě iako navodi da se ,ima izgovarati kao je kada je slovka po naravi kratka (...) ako li pisme ě po naravnome glasu zastupljuje oštar iliti dugačak naglasak to se onda izgovara kao jé, ie ili ije“ (Babukić, 1854: 7). Budmani, pak, razlikuje dijalektalne posebnosti različitih krajeva koji koriste refleks jata pa navodi: „za dialetto orientale (istočni dijalekt) refleks je ekavski, za dialetto occidentale (zapadni dijalekt) ikavski, a za dialetto meridionale (južni dijalekt) potrebno je razlikovati tri refleksa jata: 
a) ako je vokal jat u ostalim dvama dijalektima kratak, refleks je je (vjera),

b) ako je vokal u druga dva dijalekta dug, refleks je ije (dijete), ${ }^{17}$

c) ispred vokala /e/, /a/, /j/, /ě/ postaje /i/: dio, sijati, isti oblik ima i ispred /j/, /dj/ ili /gj/ ako je kratak i vokal u ostala dva dijalekta. Npr. sidjeti ili sigjeti umjesto sjedjeti ili sjegjeti.“ (Budmani, 1867: 6).

Danilo u svojoj prvoj gramatici (1855), a u tome ga slijedi i Parčić (Ham, 2006: 120), bilježi rogato e (ě) i u skladu s Babukićevom Slovnicom preporučuju različit izgovor: ikavski, ekavski i (i)jekavski.

U analiziranom korpusu zabilježeni su različiti refleksi jata. Najčešće se bilježi iekavski i u dugim i u kratkim slogovima. Tako se bilježe primjeri: rieč uvriedi (3.1.1863. NL), nedospievaju (31.10.1863. NL), zviezda (2.4.1863. ZV), mnienje (27.1.1869. NL), nariečjah (9.4.1863. ZV), dieli (21.6.1879. NL), promienio (13.8.1879. NL), sriedom (2.1.1875. NL). Iako Partašev Pravopis jezika ilirskoga iz 1850. godine još uvijek bilježi ě te propisuje da ga se izgovara „kao ie jednim otvaranjem ustah, n. p. cvět, děl, slěp“ (Partaš, 2002: 7) ${ }^{18}$, a taj grafem bilježe i slovnice zagrebačke filološke škole; vidljivo je da se grafijski prijelaz iz ě u ie u potpunosti dogodio. Doduše, Partaševa napomena o pojedincima koji refleks jata pišu jekavski i ijekavski sugerira kako se javlja nova jezična struja kojoj se javnost sve više priklanja. To će potvrditi i javna glasila u Dalmaciji u sljedećim desetljećima. U 70-im i 80-im godinama još se dijelom osjeća iekavska usmjerenost dok će u 90-im godinama pravopis u potpunosti postati (i)jekavski (Brešan, 2012).

Jekavski se refleks češće javlja u kratkim slogovima što pokazuju primjeri poput: povjerenja (17.4.1863. NL), mjeri (16.4.1863. ZV), djelovanja (3.1.1863. NL), povjestnica (27.1.1869. NL), mjeseca (21.6.1879. NL), djelatne (13.8.1879. NL), bježi (28.7.1875. NL). Sve učestalija pojava jekavskog refleksa rezultirala je i pravilima donesenima na sastancima Školskoga odbora održanima 1877. i 1879. na kojima je zaključeno: „Gdje je slovka duga piši ie, a gdje je kratka je“ (Mrazović, 1877: 218), uz napomenu kako bi trebalo napraviti mali rječnik s popisom riječi koje imaju dugi, a koje kratki slog. Ipak, velik broj primjera s iekavskim refleksom u kratkim slogovima sugerira uredničku nesigurnost u tome koji refleks odabrati. Jekavski je refleks prilično čest i kod primjera pokrivenog $r$ poput: naprjedka (13.5.1868. NL), po srjed (6.11.1869. NL), osrjedotočivaju (6.11.1869. NL), najprječe (15.9.1869. NL).

17 Uvažavajući tradiciju drugih filoloških škola, Budmani napominje kako „hrvatski autori pišu ije bez j: ie" (Budmani, 1867: 6).

18 Partaš se u svojem Pravopisu vrlo oštro obračunava s onima koji umjesto ě pišu je ili ije navodeći kako „ovakovi osebnici malo mariju za slogu, i zato se neimaju niti naslědovati“ (Partaš, 2002: 8). 
$\mathrm{U}$ dugim se slogovima, jekavski refleks rijetko javlja: navjestili (17.4.1863. NL), obavjestiti (3.1.1863. NL), povjedati (25.8.1869. NL), povjesti (26.2.1879. NL), ne smje se (21.3.1874. NL). Zabilježeni primjeri, doduše potvrđuju kako se taj refleks jata i u kratkim i u dugim slogovima javlja od početka dok su nešto rjeđi primjeri u kojima se u dugim slogovima koristi ije kao u primjeru prije (8.4.1863. NL), zavijena (3.1.1863. NL), vapijemo (3.1.1863. NL), grijeh (25.8.1869. NL), nijedna, ljudskijeg (25.10.1879. NL), najmilijeg (21.3.1874. NL). Dugi slogovi, načelno, najdulje zadržavaju upravo iekavski refleks.

S obzirom na vremensko i prostorno određenje analiziranih tekstova moglo se očekivati da će se bilježiti i ikavski refleks jata, pošto je tada još uvijek bio jak utjecaj Ante Kuzmanića i zadarskog filološkog kruga, kao i na činjenicu da su urednici ovih izdanja mahom bili Dalmatinci poput Natka Nodila, Jurja Biankinija, Lovre Matića, Ivana Danila i Mihe Klaića.

Ipak, ikavica se vrlo rijetko bilježi: $d v i$ godine (13.2.1869. NL), posli, nigdi (13.8.1879. NL), pripoznaje (21.3.1874. NL) te se može zaključiti kako dalmatinska ikavica nije imala dovoljno jak utjecaj u javnim glasilima.

Očito nesnalaženje u pravilima o refleksu jata pokazuju i primjeri u kojima se različiti refleksi bilježe unutar iste rečenice: o mnogijem raznovrstniem stvarniem zaprekam (30.5.1874. NL).

Iako se tijekom proučavanog perioda iekavski refleks pokazao dominantnim refleksom, smjer u kojem će se razvoj refleksa jata odvijati najzornije već tada pokazuje ,jekaviziranje“ toponima koji su u svojem izvornom obliku zapisani ikavicom. Ta se pojava javlja sredinom stoljeća pod sve većim utjecajem hrvatskih vukovaca. Takav je slučaj i u analiziranim tekstovima. Ime grada Splita javlja se u obliku Spljet, Spljetom, Spljeta u objema novinama (14.5.1863. ZV, 5.3.1863. NL, 4.2.1874. NL, 1.2.1879. NL). Unatoč jakom protivljenju dalmatinske javnosti ovakva se praksa provodila sve do 1912. godine kada Boranić donosi pravilo da „mjesna imena i prezimena u ekavskom i ikavskom području čuvaju $e$ i $i$ “ (Šimunović, 2008: 11).

\subsection{Asimilacije}

Pitanje jednačenja po zvučnosti imalo je posebnu težinu jer je, možda više od drugih pravopisnih pitanja, predstavljalo opredjeljenje između etimologije koju su zagovarali pristaše zagrebačke škole i eufonije koju su proklamirali vukovci. Budmanijeva gramatika propisivala je fonološko načelo, ${ }^{19}$ što

19 „Se nella formazione o nella flessione de' vocaboli vengono a star vicine due consonanti mute l'una media e l'altra tenue, quella che precede si assimila alla seguente, cioe diventa media o tenue, secondo che quest' ultima è media o tenue: per cui, dinanzi a una consonante 
se s obzirom na to da je i inače naginjao rješenjima koja su propisivali vukovci bilo i očekivano, međutim uvažavajući razlike dvaju jezika koje normira ${ }^{20}$, bilježi kako Hrvati zadržavaju etimološko načelo ${ }^{21}$. Ta nam natuknica daje opis zatečenog stanja, ali ne propisuje nikakvo pravilo. Slično su tom problemu pristupali i ilirci. Mažuranić u svojoj Slovnici Hèrvatskoj iz 1859. godine navodi kako su „dva načela po kojih se obično u hèrvatskom jeziku opreděljuje pravòpis: blagòglasje i bližnji izvor iliti koren rěči“ (Mažuranić, 1859: 26), međutim za oba slučaja daje i prednosti i mane te donosi pravilo: „Piši onako, kako te najlakše mogu razuměti, ako ne svi, a ono barem većina onih za koje pišeš‘. To bi pravilo značilo da se etimologiju slijedi dok ona olakšava razumijevanje poput primjera koje navodi ljubko, redko, gospodski, a fonološko načelo gdje etimologija smeta razumljivosti: štovati, nigda, vazda. Iz ovoga je jasno kako Mažuranić u većini riječi slijedi etimološko načelo. S obzirom da iz tadašnjih gramatika ipak nije jasno propisano koje načelo slijediti, u ovome korpusu bile su očekivane neujednačenosti u pravopisu.

Usprkos tomu, analiza pokazuje kako se asimilacija po zvučnosti vrlo dosljedno ne provodi te je u ovom razdoblju očita dominacija etimološkog pravopisa koji su propisivale gramatike zagrebačke filološke škole: neizpravna, razsuda, zastupničtva (3.1.1863. NL), sborom, razprostraniti (10.9.1863. ZV), srbsko (1.8.1868. NL), neizkvareni (26.2.1879. NL), podpunije (21.6.1879. NL), obsluži (20501874. NL). Rijetki su primjeri asimilacije po zvučnosti kao u primjeru poispušćana (10.9.1863. ZV) jer je dalmatinski tisak, barem u ovom pitanju, sve do kraja 19. stoljeća njegovao etimološki pravopis ${ }^{22}$.

Primjeri u kojima se provodi asimilacija po zvučnosti iznimno su rijetki: istok (21.4.1869. NL), zgoda (15.9.1869. NL), ispiti (25.8.1869. NL), ali oni ipak potvrđuju kako tendencije za bilježenjem asimilacije već postoje.

Asimilacija po mjestu tvorbe, promatrana je isključivo s pravopisnog stajališta. Fonemi /ć/ i /d/ nastali jotacijom, zapisivani su dvojako, grafemima $c$ i $d$ te digramima $t j, d j$ i gj. U primjerima u kojima je grafem $c ́$ prisu-

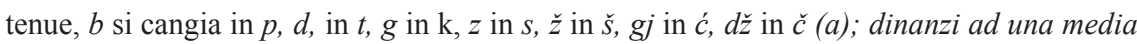
viceversa $p$ si cangia in $b$, $t$ in $d$, ecc. (Ako pri tvorbi ili pak fleksiji riječi dođu u dodir dva bezvučna suglasnika, jedan srednji, a drugi napeti, ovaj koji prethodi se asimilira onome koji slijedi tj. postaje srednji ili napeti, ovisno o tome da li je taj suglasnik koji slijedi srednji ili napeti. Pri tome, dakle, ispred napetog suglasnika $b$ se mijenja u $p, d \mathrm{u} t, g \mathrm{u} k, z \mathrm{u} s, \check{z} \mathrm{u} \check{s}, g j$

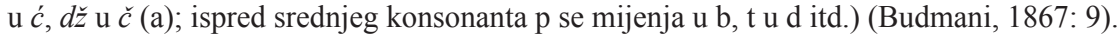

20 Riječ je o srpskom i hrvatskom jeziku.

${ }^{21}$ „I Croati scrivono sempre secondo il principio etimologico (Hrvati uvijek pišu prema etimološkom principu): srbski, sladko, bogca, izkopati, družtvo, žedjca, topdžija, svatba, nikda, sbor, zadušbina, svjedočba, ljudski, ecc. (Budmani, 1967: 9).

22 Potvrđuju to istraživanja na drugim korpusima službeno-upravnih novina koje su izlazile tijekom druge polovice 19. stoljeća te početkom 20. stoljeća (Brešan, 2012). 
tan, asimilacija po mjestu tvorbe u pismu se provodi dosljedno: poispušćana (10.9.1863. ZV), samostalnošću (3.1.1863. NL), svečanošć (31.10.1863. NL), žešće (29.1.1868. NL), najžešće (21.4.1869. NL), Tršćanski (30.5.1873. NL), kršćanski (30.5.1874. NL), izvješće (13.8.1879. NL). S druge strane, moglo se pretpostaviti da će se u primjerima u kojima jotacija nije zabilježena u pismu izostaviti i jednačenje po mjestu tvorbe, ipak analiza je pokazala kako pravopis i u takvim slučajevima zadržava jednačenje po mjestu tvorbe: moždjena (10.1.1863. NL), krštjanstva (7.5.1863. ZV), groždje (25.10.1879. NL). Samo se jednom bilježi primjer krstjani (5.3.1863. NL).

\subsection{Pisanje fonema /ć/, /ź/ i / ̌̌̉}

Problem zapisivanja pojedinih fonema u dalmatinskoj, ali i hrvatskoj jezičnoj tradiciji proizlazio je iz činjenice da je latinica kao pismo prvenstveno bila namijenjena neslavenskim jezicima, pa su najveći problem u njezinu prilagođavanju predstavljali upravo palatalni glasovi (Holjevac, 2013: 119). Dopreporodno razdoblje uključuje postojanje barem četiriju različitih grafija: kajkavske, slavonske, dubrovačke i čakavske (Holjevac, 2013: 120). Slavonska je grafija u tom periodu bila najrazvijenija dok je na jugu Hrvatske na usustavljivanju grafije radila pravopisna komisija u Zadru, osnovana 1820 .

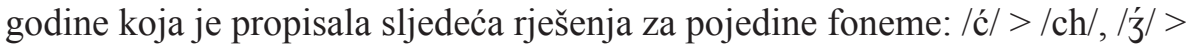
/dj/ i /gj/ ovisno o tome je li fonem nastao jotacijom ili ne.

Gajeva pravopisna reforma započinje već 1830. godine izlaskom njegove Kratke osnove hrvatsko-slavenskoga pravopisanja koja je sadržavala grafeme s tildama. Gaj poslije odstupa od takve reforme te tildu zamjenjuje kvačicama pa od slova s dijakritičkim znakom ostavlja samo $\check{c}, \check{z}, \check{s}$ i ě te uvodi $l j, n j, d j, d \check{z}$, dok ć piše dvojako, kao ć i kao digram tj (Malić, 1992: 121).

Fonem /ć/ se, u ovome istraživanju, analizirao samo u primjerima u kojima je rezultat jotacije. Iako Budmani u svojoj gramatici navodi kako „Hrvati u riječima u kojima je $c$ nastalo od $t$ pišu $t j$ (Budmani, 1967: 2), takva se napomena ne bilježi kod Mažuranića (1869: 6), a čak i Stazić u svojoj gramatici iz 1850. godine preporuča pisanje grafema $c$ u slučajevima jotacije (Stazić, 1850: 15). S obzirom da u ovom pitanju ondašnje gramatike imaju poprilično ujednačen stav iz kojeg je vidljivo da se u većini slučajeva digram tj zamjenjuje grafemom $c ́$ ne iznenađuje da se i u korpusu većinom bilježi grafem ć: osramoćene, žešć $i^{23}$ (10.1.1863. NL), podplaćeni (8.4.1863. NL), plaća (27.6.1868. NL), braću (1.8.1868. NL), upliće (30.5.1873. NL), naj-

23 U navedenom primjeru uz jotaciju provodi se i asimilacija po mjestu tvorbe. 
žešći ${ }^{24}$ (4.2.1874. NL), iako se još ponegdje bilježi digram tj kao u primjeru krštjanski (17.1.1863. NL).

Fonem / $/ 3$ / bilježio se digramima $d j$ i $g j$. Digram $d j$ napušta Đuro Daničić kada 1878. u Akademijinu rječniku počinje upotrebljavati grafem đ. Unatoč tomu, u Dalmaciji se taj grafem teško prihvaćao ${ }^{25}$. Fonem /ź/ Partaš u svojem pravopisu zamjenjuje digramima $d j$ i gj (Partaš, 2002: 6) kao i Budmani u svojoj gramatici (1867: 3). Ipak, obojica bilježe grafem $d z ̌$ te ga vezuju uz uporabu turcizama (Partaš, 1850: 8, Budmani, 1867: 3). Takvu praksu u svojoj gramatici slijedi i Danilo (1873: 2), kao i analizirani korpus pa se bilježe primjeri poput: Tamadžin, Džingis-kan (7.5.1865. ZV), džebanom (25.10.1879. NL).

Analizirani tekstovi pokazuju kako u slučaju fonema /ź/ prevladava uporaba digrama dj: vidjamo, mladjarije, rdju (10.1.1863. NL), gradjevinske (29.10.1863. ZV), medjutim (27.6.1868. NL), dogadja se (19.9.1868. NL), pogrdjena (30.5.1873. NL), govedjoj (25.10.1879. NL), dogadjajim (21.6.1879. NL), nesudjen (2.6.1874. NL), te vrlo rijetko gj: Gjorgu Rajkovića (29.10.1863. ZV), Magjari (6.11.1869. NL), magjarski (1.8.1868. NL), Gjurgjeva (1.8.1868. NL). Razloge prevlasti digrama dj možemo pronaći u Budmanijevoj gramatici u kojoj se navodi da Hrvati ne koriste gj osim u riječima stranoga podrijetla kao angjeo (1867:2) što se potvrđuje i u ovom korpusu.

\subsection{Pisanje fonema $/ h /$}

Fonem $/ \mathrm{h} /$ javlja se kao dio suglasničkog inventara proučavanoga korpusa u nepromijenjenom obliku što je u skladu s onodobnom normom pa Partaš navodi kako „h imade jednaki glas sa latinskim i němačkim, n. p. halja" (Partaš, 2002: 8). Bilježi ga se na početku riječi u primjerima harnost (4.1.1868. NL), hlepio je (21.4.1869. NL), htješe (21.3.1874. NL), u sredini riječi: vrhovne (5.3.1863. NL), gluha (17.1.1863. NL), zahtiev (21.4.1869. NL), svrha (4.2.1874. NL), te na kraju, najčešće kao dio ilirskog nastavka -ah/-ih za genitiv množine imenica: poduzećah, novacah (14.5.1863. ZV).

Rjeđe se, tijekom 60-ih godina gubi kao u primjeru svatio (3.1.1863. $\mathrm{NL})$, da ji odciepe (31.10.1863. NL) ili se zamjenjuje grafemom k: paroki (3.1.1863., 15.9.1869. NL), monarkije (6.11.1869. NL).

Iznimno se javlja u riječima gdje mu po etimologiji nije mjesto: polahko (5.3.1863. NL), lahak (17.4.1872. NL) što je obilježje Babukićeve Slovnice (1854: 5).

24 Isto.

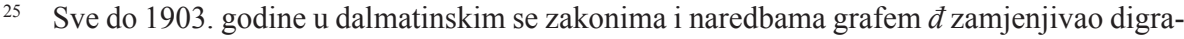
mima dj ili gj (Brešan, 2012). 


\subsection{Sastavljeno i rastavljeno pisanje riječi}

Pitanje sastavljenog i rastavljenog pisanja riječi uključuje pravila o pisanju upitne i niječne čestice. Gramatike se i u tome pitanju razilaze pa Babukić niječnu česticu u svojoj Slovnici piše zajedno s glagolom-nositeljem radnje dok Danilo (1873.) takvu praksu mijenja te niječnicu spaja s glagolom tek kod modalnih glagola, te glagola biti i htjeti dok ostale glagole piše odvojeno poput ne dadu ili ne spada.

Analiza nijekanja glagola pokazala je kako postoji jasna vremenska uvjetovanost u pisanju niječne čestice. Naime, tijekom 60 -ih godina većina se niječnica piše zajedno s glagolom pa bilježimo: nebi, neljubi, nebole (17.1.1867. NL), nemislimo (13.5.1866. NL), nemogu, nebi (3.1.1863. NL), nemože (10.1.1863. NL), nebi (25.6.1863. ZV), netreba $(9.4 .1863 . \mathrm{ZV})$, nevidi (10.1.1863. NL), nekaže, (25.6.1863. ZV), neostane (4.1.1868. NL), nepovratimo (16.5.1868. NL), nedade (10.7.1869. NL).

70-e godine donose veliki zaokret te se bilježe, gotovo isključivo, primjeri nijekanja u kojima je niječna čestica odvojena: ne dopušća (9.3.1872. $\mathrm{NL})$, ne zauzimlju (28.2.1872. NL), ne susretamo (18.3.1874. NL), ne stoji (4.2.1874. NL), ne smije (30.5.1873. NL), ne kasni (31.7.1875. NL). Usprkos vidljivoj promjeni pravopisne prakse još se, mada iznimno rijetko, mogu pronaći primjeri u kojima je niječnica spojena s glagolom: nebi (20.2.1873. NL), a takva se pojava pojačava tijekom 1878. i 1879. kada je većina niječnica zapisana zajedno s glagolom: nevidi (19.3.1879. NL), nebismo (23.4.1879. NL). Ipak, već se i tijekom 60-ih bilježe primjeri odvajanja čestice koji sugeriraju u kojem će se smjeru to pravilo razviti u kasnijim godinama: ne vidjamo, ne imamo, ne ljubimo (10.1.1863. NL), ne dajmo (4.4.1869. NL).

Pisanje niječnog oblika glagola htjeti tijekom 60-ih i 70- ih godina bilo je vrlo ustaljeno pa se niječnica uvijek piše zajedno s glagolom: nećemo (16.4.1863. ZV), neće (14.5.1863. ZV, 5.2.1873. NL, 18.3.1874. NL, 30.5.1874. NL), nećeš (9.3.1872. NL).

Potvrdu za spajanje čestica s glagolom, može se pronaći i kod upitne čestice $l i$. Ona je zabilježena zajedno s glagolom tijekom 60-ih godina: moželi (9.3.1863. ZV), misleli se (6.11.1869. NL) iako Budmani (1967: 228-229) propisuje odvajanje čestice. Ipak, to se pravilo počinje provoditi u 70-im godinama pa se bilježe: okrenu li (9.3.1872. NL), ne bi li se (30.5.1874. NL), uzmemo li, nije li (18.3.1874. NL), bude li (5.2.1879. NL), ne bi li (15.3.1879. NL). Još se uvijek mogu pronaći ostatci pravila iz slovnica zagrebačke filološke škole: jesmoli (20.2.1873. NL), hoćeli (30.4.1879. NL).

Razlika između etimološkog i fonološkog pravopisa vidljiva je i u tvorbi futura 1. Babukić u svojoj Ilirskoj slovnici navodi kako se futur 1. tvori „iz 
pomoćljiva glagolja hoću, hoćešs, hoće i iz infinitiva dotičnoga trajućega ili minućega glagolja“ te se oni pišu odvojeno kada pomoćni glagol dolazi iza infinitiva (Babukić, 1854: 308). Ipak, navodi kako se upravo u ovom pitanju vidi razlika između „blagoglasja“ i „,rěčoslovja“ jer V. S. Karadžić u svojoj gramatici (1818.) spaja infinitiv i pomoćni glagol u jednu riječ: platićemo, kupiće (Babukić, 1854: 309). Takvi se primjeri mogu zabilježiti i u analiziranim tekstovima: znaćete, dopustiće, znaće (15.9.1869. NL). Ipak, češće se bilježe futuri u kojima je pomoćni glagol odvojen od infinitiva: primijetiti ću (13.5.1868. NL), doći će (16.5.1868. NL), osvetit će se (24.1.1872. NL), biti će (18.3.1874. NL), ustrojiti će se (12.4.1879. NL).

\section{Zaključak}

Dalmatinska je pismenost tijekom 19. stoljeća, pogotovo u njegovoj drugoj polovici bila opterećena prvenstveno nacionalnim nejedinstvom $\mathrm{s}$ ostatkom Hrvatske koje je u konačnici rezultiralo i jezičnom i pravopisnom razjedinjenošću. Hrvatski je jezik u tome periodu iz nekoherentnog i nekodificiranog sustava na kraju stoljeća prerastao u standardiziran polifunkcionalan idiom koji je tako usustavljen i normiran mogao zadovoljiti sve potrebe javnoga komuniciranja. Nakon ilirskoga preporoda koji je snažno odjeknuo i u Dalmaciji prirodni je tijek jezika brojne neujednačenosti koje su do tada postojale ujednačio i na kraju trima jezičnim priručnicima vukovskoga karaktera i propisao.

Analiza ovih dviju novina pokazala je kako, na samom početku velikoga sukoba jezičnih koncepcija koji će u 80-im godinama eskalirati, pravopis u Dalmaciji slijedi pravila propisana normativnim priručnicima koji slijede jezične stavove zagrebačke filološke škole, iako u svakom analiziranom aspektu postoji vidljiv utjecaj jezične doktrine hrvatskih vukovaca. Refleks jata dominantno je iekavski. Ipak, u kratkim se slogovima u svakome članku javlja, poprilično neujednačeno, jekavski refleks, dok se u dugim slogovima ijekavski primjenjuje vrlo rijetko. Provođenje asimilacije po zvučnosti u pismu se provodi iznimno rijetko. Takva se situacija zadržava sve do početka stoljeća te se može reći kako je ta promjena gotovo posljednja ušla u hrvatski pravopis u Dalmaciji.

Fonem /ź/ se ne bilježi grafemom $d$, zamjenjuju ga digrami $d j$ i gj dok je /亏̌/ grafemom $d \check{z}$ prisutan u posuđenicama orijentalnog predznaka. Čakavski refleks /j/ nije zabilježen, što uz izostanak ikavskoga refleksa svjedoči o tome kako jezična tradicija dalmatinskoga područja, sačuvana u doktrini zadarskog filološkog kruga, kao i lokalni govori nisu imali većega utjecaja na jezik javnih tiskovina toga perioda. Takvi su rezultati razumljivi naročito ako bolje promotrimo Narodni list. Riječ je o glasilu Narodne stranke koja se zalagala 
za ujedinjenje sa sjeverom Hrvatske pa je potpuno opravdano što su jezična rješenja češće svoju potvrdu pronašla u normi zagrebačke filološke škole pa čak i hrvatskih vukovaca. Vezivanje za jezičnu tradiciju zadarskog filološkog kruga te inzistiranje na dalmatinskim jezičnim značajkama na neki bi način značilo i jačanje dalmatinske autonomije što u trenucima intenzivnih pokušaja ujedinjenja narodnjacima nikako nije bilo u interesu.

/Ć/ se bilježi i digramom $t j$, iako vrlo rijetko, a /h/ se javlja nepromijenjeno u svim pozicijama u riječi.

Niječna se i upitna čestica tijekom 60 -ih godina češće pišu zajedno s glagolom dok se u 70-im godinama takva praksa mijenja te se one odvajaju od glagola.

Ovakvo jezično stanje pokazuje kako su se u dominantno etimološkom pravopisu već počeli zamjećivati veći otkloni poput ijekavskog refleksa jata te naznaka asimilacije po zvučnosti. U desetljećima koja dolaze, do kraja 19. stoljeća jezik će u Dalmaciji u potpunosti promijeniti svoj smjer. 80-e godine 19. stoljeća pokazat će se prijelomnima. Veliki zaokret u politici, a i jeziku, napravit će drastične promjene i u pravopisu. Od toga će trenutka iekavski refleks u dalmatinskim tiskovinama postati tek rudiment, ostatci ilirskih jezičnih nastojanja nazirat će se tek u zadržavanju etimologije u pisanju riječi sve do početka 20. stoljeća.

Analiza ovoga korpusa pokazuje kako dalmatinski tisak, unatoč postojanju dviju različitih normi u tom periodu, jedne propisane Parčićevom i prvom Danilovom gramatikom koje slijede postavke zagrebačke filološke škole te one druge koju propisuju Budmanijeva i druga Danilova gramatika još uvijek prednost daje rješenjima zagrebačke filološke škole. Ipak, relativno rano normiranje novoštokavskih inovacija, kroz Budmanijevu i drugu Danilovu gramatiku unosi nemir u do tada prilično stabilno jezično stanje. Pojava tih dviju gramatika zasigurno je utjecala na promjenu uredničkih stavova te se u cijelom korpusu primjećuju jezični elementi koje unose hrvatski vukovci, poput ijekavskog refleksa, rijetkih primjera provođenja asimilacije te pisanja niječnice zajedno s glagolom. Iz današnje je pozicije vrlo teško sa sigurnošću pretpostaviti kako bi analizirana pravopisna rješenja izgledala da su te gramatike izašle koje desetljeće kasnije. Ipak, već je u uvodu navedeno kako gramatike češće opisuju zatečeno stanje, no što ga propisuju pa se može zaključiti kako su novoštokavske inovacije u hrvatski jezik u Dalmaciji ušle i ranije. U interesu je ovoga, a i drugih istraživanja koja rekonstruiraju jezik u prošlosti Dalmacije da se analize prošire i na pravopis drugih tipova tekstova, naročito onih koji nisu svjesno uređivani, poput različitih pamfleta, oporuka ili pisama koji bi nam pokazali kako je izgledao jezik tadašnje javnosti. Tako bi jezična slika Dalmacije zasigurno bila bogatija. 
Period druge polovice 19. stoljeća, do 80-ih godina pokazuje da u Dalmaciji novoštokavske inovacije još nisu dominantne, ali njihova pojavnost u ovom periodu sugerira kako će 80-te godine donijeti promjene te će se jezični stavovi hrvatskih vukovaca sve više implementirati na hrvatski jezik u Dalmaciji.

\section{Literatura}

- Babukić, Vjekoslav (1854) Ilirska slovnica, Zagreb, Bèrzotiskom nar. tiskarnice Dra. Ljudevita Gaja.

- Baković, Matijas (2011) „Pokušaj grafijske reforme Đure Augustinovića“, Fluminensia, 23, 1, 39-52.

- Brešan, Tanja (2012) Jezik službeno-upravnih novina za kraljevinu Dalmaciju u razdoblju od 1867. do 1903., doktorska disertacija, Filozofski fakultet Sveučilišta u Zagrebu.

- Budmani, Pietro (Pero) (1867) Grammatica della lingua serbo-croata (illirica), Vienna, autorova naklada.

- Bulat, Gajo (1900) Jezično pitanje u Dalmaciji. Beč.

- Ham, Sanda (2006) Povijest hrvatskih gramatika, Zagreb, Nakladni zavod Globus.

- Holjevac, Sanja (2013) „Grafijska rješenja u dopreporodnim izdanjima riječke tiskare Karletzky“, Fluminensia, 25, 1, 119-134.

- Malić, Dragica (1992) „Pravci razvoja hrvatskoga književnog jezika od ilirskog razdoblja“, Rasprave ZHJ, 18, 119-130.

- Maštrović, Vjekoslav (1954) Jadertina Croatica 2, Zagreb, JAZU.

- Maštrović, Vjekoslav (1972). Uvođenje hrvatskog jezika u Dalmatinski sabor. Zbornik Dalmacija 1870. Zadar.

- Mažuranić, Antun (1859). Slovnica hèrvatska za gimnazije i realne škole. Zagreb: Tiskom spisateljevim.

- M[razović], L[adislav] (1877) „Ob ustanovi hrvatskog pravopisa“, Vienac 9, 11, 176-179, 13, 210-211, 14, 217-221.

- Narodni list (1862. - ) serijska publikacija, Zadar.

- Partaš, Josip (2002) Pravopis jezika ilirskoga, Zagreb, Institut za hrvatski jezik i jezikoslovlje (Čakovec: ,Zrinski“"), (pretisak).

- Pranjković, Ivo, Hrvatski jezik u 19. stoljeću, Zagrebačka slavistička škola. www.hrvatskiplus.or, posjet 4. ožujka 2014.

- Samardžija, Marko (2001). Franjo Iveković, Ivan Broz, Tomo Maretić, Vatroslav Rožić, Milan Rešetar, Antun Radić, Dragutin Boranić: Jezikoslovne rasprave $i$ članci. Zagreb: Matica hrvatska.

- Stazić, Andrija (1850). Gramatica della lingua illirica ad uso degli amatori nazionali e stranieri. Zadar: Tipografia dei fratelli Battara. 
- Stolac, Diana, Vlastelić, Anastazija (2005). Sintaksa u Parčićevoj gramatici hrvatskoga jezika iz 1873. godine. Fluminensia, god. 17., br. 1, 1-11.

- Šimunović, Petar (2008) „Ranosrednjovjekovna toponimija splitskog poluotoka“, Archaelogica Adriatica, 2, 587-599.

- Tafra, Branka (1995) Jezikoslovna razdvojba, Zagreb, Matica hrvatska.

- Zviezda (1863) književni list za prosvjetu, poduku i zabavu, Zadar.

- Vince, Zlatko (1971) „Gramatike zadarsko-dalmatinskog jezičnog kruga“, Zadarska revija, 20, 4, 285-300.

- Vince, Zlatko (1972 - 1973) „O nekim jezično-kulturnim problemima u Dalmaciji 70-ih godina XIX. stoljeća“, Historijski zbornik, 25-26, 135-161.

- Vince, Zlatko (1973) Odnos Ante Kuzmanića prema Ljudevitu Gaju. Radovi Instituta za hrvatsku povijest. Sveučilište u Zagrebu - Institut za hrvatsku povijest. br. 3. 65-91.

- Vince, Zlatko (2002) Putovima hrvatskoga književnog jezika. Lingvističko-kulturnopovijesni prikaz filoloških škola i njihovih izvora, Zagreb, Nakladni zavod Matice hrvatske.

\section{Tanja BREŠAN-ANČIĆ}

\section{ORTHOGRAPHIC TURMOIL IN DALMATIA IN 1860s and 1870s}

The author of the present paper analyzes certain orthographic issues occurring during the $60 \mathrm{~s}$ and 70 s of the $19^{\text {th }}$ century in Dalmatian publications. The analyzed texts have been extracted from two Dalmatian newspapers, Narodni list and Zviezda. The author opted for newspaper articles because of their public character, leaving the possibility of influencing the public, which is of crucial importance in this linguistically turbulent time. Given that this is a period in which the influence of Vuk's followers and new Štokavian innovations is still not so strong, the author starts the analysis from the assumption that the solution to orthographic problems would often be in accordance with the standard of the Zagreb's philological school, as well as that, in spite of the action of the Zadar's philological circle, the impact of Dalmatian linguistic tradition would be kept to a minimum.

Key words: Dalmatia, etymological orthography, phonological orthography, Zagreb's philological school, Zadar's philological circle 


\section{Marijana TERIĆ (Nikšić)}

UDK 091:929Kujačić J.

Preliminarno saopštenje

Fakultet za crnogorski jezik i književnost - Cetinje marijana.teric@fcjk.me

\section{RUKOPIS DR JOVANA KUJAČIĆA IZ 1950. GODINE}

U ovome radu ukazali smo na postojanje rukopisa dr Jovana Kujačića iz 1950. godine koji se čuva u Zavičajnome muzeju u Nikšiću. Analitičkim sagledavanjem rukopisa opisali smo proces nastajanja prijevoda Ilijade na crnogorski jezik. U tome pogledu uradili smo komparativni pristup toga rukopisa sa izdanjem Ilijade iz 2003. godine (DANU, Podgorica) i opisali određene sličnosti i različitosti u njihovome koncipiranju. $\mathrm{Na}$ kraju istraživačkoga zadatka skrenuli smo pažnju na zavidnu kreativnu energiju dr Jovana Kujačića kao i na specifinost njegova rukopisa.

Ključne riječi: dr Jovan Kujačić, rukopis, Ilijada (2003), prevodilačka djelatnost, komparativni pristup

Kad se 2003. godine u izdanju DANU pojavio prvi crnogorski prijevod Ilijade ${ }^{1}$, čitalačka javnost upoznala se s rukopisom dr Jovana Kujačića (1869-1958), staroga gotovo pola vijeka. Pomenuti prijevod, kako nam opisuje Balša Brković u uvodnome dijelu štampanoga izdanja, sačuvan je kao rukopis u ogromnoj svesci uredno koncipiranoj od predgovora, uvoda i fusnota sa većim brojem starogrčkih riječi i preciznim datumom završetka rada: „Herceg Novi, 15. I 1951. svega - 24, 417 stihova“. Ocjenjujući rukopis „kapitalnom vrijednošću crnogorske kulture “, ${ }^{2}$ Balša Brković otkriva da je riječ o integralnome prijevodu Ilijade, utemeljenom na crnogorskome jezičkom standardu. ${ }^{3}$ Ono što, takođe, saznajemo jeste da je taj dragocjeni rukopis sačuvan od uništavanja za vrijeme rata u Mostaru, zahvaljujući prijatelju porodice Kujačić, koji ga je 1999. godine poklonio Dukljanskoj akademiji nauka i umjetnosti i

1 Prvo pjevanje Ilijade s ruskoga prijevoda na crnogorski preveo je Njegoš u desetercu, a 80ih godina XIX vijeka Labud Vrbica u Crnogorki i Novoj Zeti objavio je prijevode s grčkoga prva četiri pjevanja Ilijade, u četrnaestercu.

2 Balša Brković: „O prvom crnogorskom prijevodu kapitalnog starohelenskog epa o padu Troje, Homerove Ilijade“, u: Homer: Ilijada, DANU, Podgorica, 2003, str. 18.

3 Isto, str. 17. 
time dozvolio da prevodilački poduhvat Jovana Kujačića, zajedno s ljudima na čelu ove institucije, ugleda svjetlost dana.

Publikovanje prijevoda jednoga od najstarijih književnih djela evropske književnosti (Homerove Ilijada i Odiseja) značajan je projekat Dukljanske akademije ali i Kujačićeva stvaralačkoga angažmana. Ono što danas znamo o ovom autoru jeste činjenica da je kao ljekar i prevodilac, još u studentskim danima, pokazao interesovanje za prevodilačku djelatnost ne samo radova iz oblasti medicine. U tome pogledu, poznati su njegovi prijevodi s različitih jezika: ruskoga - Društveni položaj u Rusiji, Šta je umjetnost i U čemu je moja vjera Lava Tolstoja, s kojim je bio i prijatelj, latinskog - Aristotelova Politika, starogrčkoga - Homerova Ilijada, francuskoga i njemačkoga - studije I. Ilića Mečnikova O prirodi čovjekovoj i Odlomci iz filozofije optimizma i dr. Sa još 23 monografije iz više medicinskih grana i 146 stručnih i naučnih radova u raznim časopisima i publikacijama, kao i 13 prevedenih djela, Kujačić se tretira kao „najproduktivniji medicinski pisac i prevodilac u istoriji crnogorske medicine do sredine prošlog vijeka“. ${ }^{4}$ Sve to jasno govori o ozbiljnosti kreativnoga angažmana Jovana Kujačića, čiji rukopis analitički sagledava Novak Kilibarda, ukazujući na brojne specifičnosti prevedenoga strohelenskog epa kao i intelektualne sposobnosti njezina autora. Iako je takvom kritičkom opservacijom današnji čitalac upoznat s pravom vrijednošću, kako se vjeruje, jedinoga sačuvanog rukopisa koji se nalazi u Dukljanskoj akademiji, naša dužnost je da ukažemo na postojanje još jednoga, čini se zaboravljenog rukopisa toga djela, koji se sad čuva u Zavičajnome muzeju u Nikšiću. ${ }^{5}$.

Prije nego što pristupimo analitičkom determinisanju pronađenoga rukopisa, prenosimo kratak dio teksta iz intervjua s poznatim slikarom Mirkom Kujačićem, sinom dr Jovana Kujačića, koji o svome ocu iznosi ovo:

„Moj otac (...) maturirao je u Sremskim Karlovcima u narodnoj nošnji, crnogorskoj bjeljaci (to je onaj bijeli gunj) i opancima. U Sremskim Karlovcima se učio grčki od trećeg razreda, a latinski još od prvog. I tako je mogao on da prevede i prepjeva Homerovu ILIJADU sa grčkog. Očeva knjiga sjećanja, kao i prevod ILIJADE i sada su u rukopisu vrlo lijepo ukoričeni njegovom rukom, jer je otac volio da se bavi nekim ručnim radom. ${ }^{\text {" }}{ }^{6}$

4 Preuzeto sa: www.medicinabar.com 24. 10. 2014; 19:04 h.

5 Nažalost, ne postoje precizni podaci o vremenu i načinu prispijeća toga rukopisa u muzejski fond. Posredno se može zaključiti da je do toga došlo šezdesetih godina prošloga vijeka. U to vrijeme rukopis nije imao muzejsku vrijednost, pa je postao dio muzejske biblioteke, za čiji su inventar vezane signature na njegovim koricama.

6 „U ateljeu Mirka Kujačića“ (četvrtak, 20. mart 2008). Ovaj intervju je objavljen 1982. u mostarskom MOSTU br. 51-52, časopisu za kulturu i društvena pitanja. Preuzeto sa: www. divninitekstovi.blogspot.com 28. 10. 2014; 11:21 h. 
Ovaj podatak iz navedenoga intervjua potvrđuje i prijevod koji je dospio u naše ruke, a radi se o ručno ukoričenoj svesci koju je Kujačić vrlo pedantno uredio.

Kad uzmemo u obzir godinu nastanka pronađenoga rukopisa, moramo naglasiti da je sačuvan u izuzetno dobrom stanju. O prohujalim godinama svjedoče požućeli listovi i zastarjeli miris papira koji se ośeća prilikom prelistavanja. $\mathrm{Na}$ osnovu informacija kojima raspolažemo iz pronađenoga rukopisa, započetog 20. IX 1949, a završenog 20. VII 1950. godine u Herceg Novom, sa 24.999 stihova, zanimljivo je zapažanje da je do nastanka drugoga rukopisa (15. I 1951) prošlo svega pola godine. Iako je rukopis sačuvan u veoma obimnoj svesci koja sadrži 1378 strana, on ne pośeduje uvod, predgovor i fusnote poput drugog. Međutim, na uvodnoj stranici rukopisa, nalazi se iśečena i nalijepljena slika autora čuvenoga spjeva Ilijade, Homera, dok je ispod prijevoda svakoga pjevanja, zabilježen i starogrčki natpis, pri čemu nam tako strukturirana sveska svjedoči o ozbiljnosti posla kojem je Kujačić pristupio.
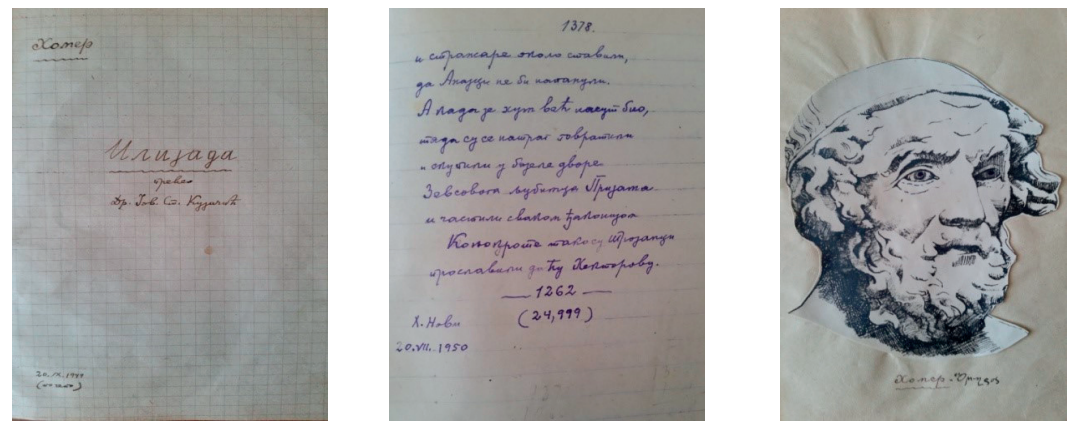

Iako nedovoljno značajan za analitčki pristup rukopisu, svakako je interesantan i pronalazak jedne slike, koju je po svemu sudeći, Kujačić iśekao iz određenoga štiva, ali je, iz nama nepoznatih razloga, ona ostala u svesci. Riječ je o slici srpskog pripovjedača, Paja Markovića-Adamova, prvoga vlasnika i urednika književnoga časopisa Brankovo kolo, koji je počeo izlaziti u Sremskim Karlovcima 1895. godine. Razloge njenog postojanja u Kujačićevu prijevodu ne možemo znati, ali vjerujemo da je za autora rukopisa imala posebno značenje.

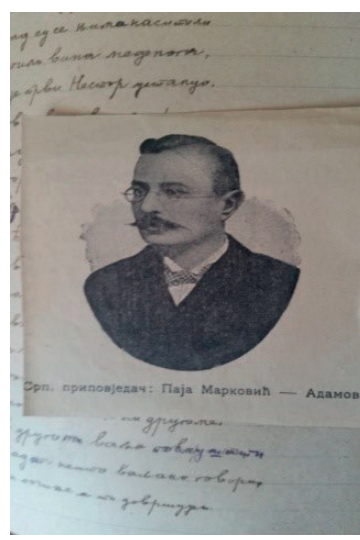


Sitno pisanim, čitkim ćiriličnim pismom, Kujačić ređa stihove epa vodeći računa o interpunkcijskim znacima i redosljedu riječi u stihu, pri čemu se s lakoćom prati svima nama dobro poznata priča o padu Troje. Ono što odmah uočavamo u tekstu koji čitamo, a što nam ipak ostaje nejasno, jesu podvučene pojedine vlastite imenice u prvih nekoliko pjevanja (Zevs, Atrej, Apolon, Ahil, Hera, Prijam, Agamemnon...). Da je Kujačić predano radio na svom prijevodu Ilijade, govore i korigovani djelovi rukopisa, ispisani različitim mastilom. Brojne stihove, naročito u posljednjim pjevanjima epa, prate ispravke različitoga tipa. $\mathrm{Na}$ određenim mjestima autor je pojedine riječi obilježavao brojevima (slika 2), dajući im tako drugačiji redosljed. Jednu boju mastila zamjenjuje drugom (slika 1), a takođe se uočava da je na prethodno brisani stih ispisan drugi (slika 3).

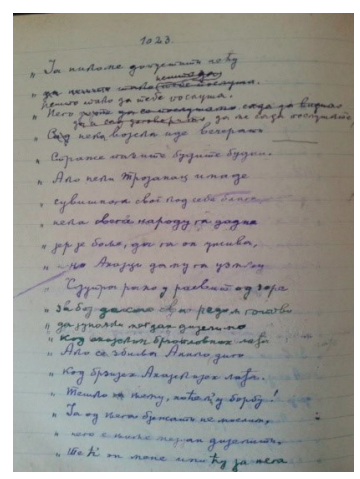

Slika 1

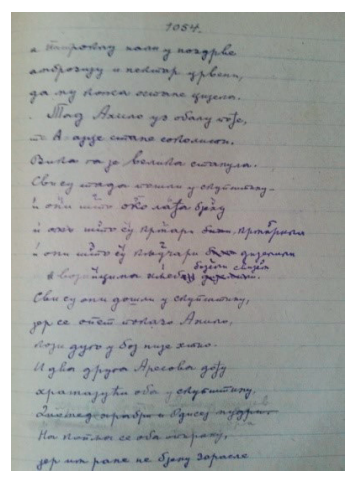

Slika 2

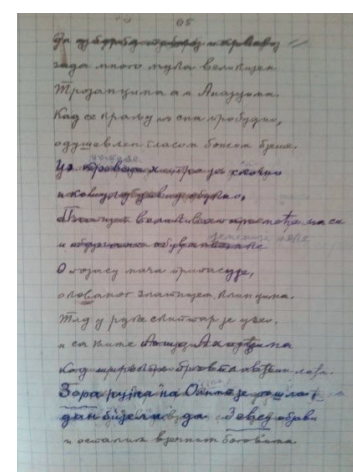

Slika 3

Navedeno potvrđuje činjenicu da se Kujačić iznova vraćao osnovnome prijevodu, mijenjajući brojne stihove, pažljivo vodeći računa o smisaonosti teksta koji ostavlja na stranicama rukopisa. Brojnost njegovih korekcija te umiješanost različitih boja mastila (crna, plava, zelena, pa čak i grafitna olovka), kao i razlivenost mastila na nekim stranicama, najbolji su svjedok uloženog napora dr Jovana Kujačića da što kvalitetnije finalizuje svoj prevodilački poduhvat. Poput najznačajnijih autora svjetske književnosti (na primjer Flobera), prepoznatljivih po veoma predanom i pažljivom pristupu pisanju svojih umjetničkih djela, tako se i kod Kujačića, kao veoma posvećena „radnika svoga posla“, uočava prekrajanje pojedinih djelova svoga prijevoda, brižljivo kraćenje stihova, ali i selekcija određenoga leksičkog materijala: 

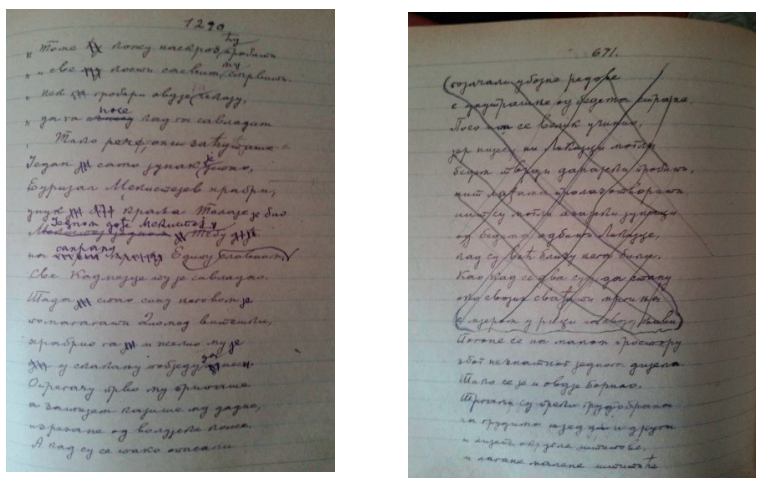

Imajući u vidu koncepciju rukopisa iz 1950. godine, za koji vjerujemo da je u to vrijeme predstavljao završeno autorsko djelo u potpunosti pripremljeno za štampu, odlučili smo uporediti ga s izdanjem Ilijade iz 2003. godine (DANU, Podgorica). Komparativnom analizom dvaju prijevoda, primijetili smo određena odstupanja, na koja želimo ukazati u cilju osvjetljavanja načina izrade prevodilačkoga zadatka. Da se Kujačić suočavao sa teškoćama oko prijevoda uvodnih stihova Ilijade, otkriva početak tih stihova, koji su, kako se jasno vidi u svesci, promijenjeni i ispisani drugačijom bojom mastila u odnosu na tekst koji slijedi. U tome smislu pratimo tekst iz rukopisa i objavljene knjige, koji karakterišu određene izmjene:

\section{RUKOPIS:}

„Pjevaj ljutnju zlokobnu boginjo Ahileja Pelejeva sina Ona jade zada Ahajcima. Moćne duše mnogijeh junaka proganjala je u mračni pakao, a njih sama, kao plijen, dade gladnim psima , a gozbu pticama."
KNJIGA:

„Pjevaj ljutnju zlokobnu, boginjo, Ahileja Pelejeva sina. Ona zada jada Ahajcima, mnoge duše hrabrijeh junaka bacila je u mračni pakao, a njih same ko plijen ostavi gladnim psima i divljim ticama."

Poput navedenih, brojni su primjeri u kojima su riječi iz Kujačićeva rukopisa promijenjene u druge, vjerovatno stilski prijemčivije tematici djela. Tako, umjesto Kujačićevih stihova: „, vi drugi Ahajevi junaci“, dobijamo „,i vi drugi ahajski vojvode“; ,,a ucjenu sjajnu prihvatiti“ - ,a cijenu sjajnu prihvatiti“; ,,il' ja isti il’ Ahajac drugi“ - ,ja il’ drugi Ahajac pokori“; „Gle ti njega!“ - ,Viđ ti njega!““; „krenuo na lađi iz Lakademona“ - ,pošo lađom iz Lakademona“; „,Velji jadi Trojance čekaju“ - „Teške muke Trojance čekaju“; 
„, iz kreveta hitro je skočio“ - „,iz ložnika hitro je ustao“; „moja vjerna i čestita žena“ - „moja vjerna i čestita ljuba“; , ,a prsi je bio upalijeh“ - ,a prsi je uleknutih bio"i sl.

Dakle, kao što su se urednici objavljenoga izdanja Ilijade trudili da svojim intervencijama utiču na kvalitetniji stih, tako se i sam Kujačić „borio“ sa sopstvenim prijevodom, izmještajući redosljed riječi u stihu, ispisujući novi na prethodno nepotpuno obrisani stih. Na nekim mjestima otkrivamo da se upravo taj nepotpuno obrisani stih, koji se nazire ispod onoga koji ga prekriva djelimično, našao u Ilijadi iz 2003. godine.

Posebnu pažnju prilikom komparativnoga sagledavanja Kujačićeva rukopisa i objavljenje knjige privukle su nam riječi koje su, za razliku od izvorne verzije, u štampanome tekstu jotovane:

„za Hristovu lijepu djevojku“ (rukopis)

„za Hristovu lijepu đevojku“ (knjiga, I pjevanje, stih 191, str. 25)

„našo ga je tu gdje mirno spava“ (rukopis)

„našo ga je tu đe mirno spava“ (knjiga, II pjevanje, stih 29, str. 37)

„pa kada su Jelenu vidjeli““ (rukopis)

„pa kada su Jelenu viđeli““ (knjiga, III pjevanje stih 270, str. 58)

„sjedi ovdje pored mene starca“ (rukopis)

„sjedi ovđe pored mene starca“ (knjiga, III pjevanje, stih 286, str. 58)

„Djece joj je dvanaest umrlo“ (rukopis)

„Đece joj je dvanaest umrlo“ (knjiga, XXIV pjevanje, stih 965, str. 367)

Međutim, bez jotacije ostale su riječi sjesti, sjekira, sjutra:

„dotjerao da u njega sjedne“(rukopis)

„doćerao da u njega sjedne“ (knjiga, XI pjevanje, stih 712, str. 173)

„ono ti je nalik na sjekiru“ (rukopis)

„ono ti je nalik na sjekiru“ (knjiga, III pjevanje, stih 105, str. 56)

„Sjutra ćemo u zoru misliti“ (rukopis)

„Sjutra ćemo u zoru misliti“ (knjiga, IX pjevanje, stih 990, str. 146) 
Za razliku od prve verzije Kujačićeva rukopisa u kojoj je autor ostao dosljedan izboru odgovarajućih riječi, štampano izdanje Ilijade karakteriše neujednačenost prijevoda, kao u ovim stihovima:

„Andromaha Hektorova žena“ (rukopis)

„Andromaha Hektorova ljuba“" (knjiga, XXII pjevanje, stih 820, str. 334)

„Ali ženu Andromahu divnu“ (knjiga, VI pjevanje, stih 590, str. 105)

„Etramila Pitejeva ćerka“ (rukopis)

„Etramila Pitejeva šćerka“ (knjiga, III pjevanje, stih 254, str. 58)

„Dođi amo, moja mila ćerko“ (knjiga, III pjevanje, stih 285, str. 58)

„,baš zbog tebe, kćeri moja mila“ (knjiga, III pjevanje, stih 354, str. 59)

Interesantno je pomenuti i upotrebu imenica ptica i huka, koje su različito upotrijebljene u tekstu. Tako, umjesto Kujačićeva prijevoda:

„Testarović, prvi lovac ptica“ ,Uka stoji, daleko se čuje...“

u štamanom izdanju nalazimo:

„Testarović, prvi lovac tica“ Huka stoji, daleko se čuje...“

(I pj., stih 120, str. 24) (II pj., stih 237, str. 39)

Nestandardna upotreba imenice sveštenik ostala je sastavni dio kako rukopisne tako i štampane verzije starogrčkoga djela:

„Tad je bio među Trojancima

neki Dares, svještenik Hefestov..." (V pjevanje, stih 14, 15, str. 79)

„Ko pravog je njega svještenika

poštovao narod kao boga." (V pjevanje, stih 127, 128, str. 80)

Komparativnim sagledavanjem pomenutih prijevoda željeli smo ukazati na stvaralački proces nastajanja književnoumjetničkih djela, u ovom slučaju prijevoda Ilijade na crnogorski jezik. Imajući u vidu da je publikovano izda- 
nje Ilijade nastalo na osnovu Kujačićeva rukopisa iz 1951. godine, a rukopis do kojega smo došli datira iz 1950. zaključujemo da je riječ o dva autorska rukopisa odnosno redakcijama nastalim u različitom periodu. Iz toga razloga napravili smo komparativni pregled prvoga rukopisnog i objavljenoga djela, a potom pokušali utvrditi stepen sličnosti ili različitosti u njihovom koncipiranju. Na koji način je Kujačić određene prevodilačke nedoumice riješio u prijevodu iz 1951. godine te kako su pojedine riječi strukturirane ostaje izvan naših saznanja. Međutim, brojnost stilskih korekcija u prvome rukopisu, ćera nas na pomisao da je Kujačić pristupio izradi drugoga kako bi ponudio što pregledniji tekst, prijevod oslobođen umetnutih ispravki.

Zadržavajući se na koncipiranju i izradi autografa iz 1950. godine, smatramo da je Kujačić iskazao zavidnu kreativnu energiju, lucidno snalaženje u oblikovanju teksta, kao i sposobnost selekcije leksičkih jedinica kojima želi najbolje predočiti imaginativne zamisli starogrčkoga djela. Ukazujući na značaj stvaralačkoga procesa, u kome se neko djelo rađa, Radovan Vučković naglašava da se pojam kreativnosti procjenjuje upravo „po količini radne energije i talenta piščevog uloženog u napor da se u delu rasporede elementi koji ga tvore na najbolji način koji će privući čitaoce, pa tako dokazati svoju vrednost". ${ }^{\text {? }}$

Godinu dana, koliko je trajao Kujačićev prevodilački projekat, dovoljno govori o serioznosti završena posla, čiji detalji poput nalijepljene slike Homera, kao i umetnute slike pripovjedača Paja Markovića, svakako, utiču i na specifičnost opisanoga rukopisa. Pišući o značaju Kujačićeva stvaralačkoga rada, crnogorskoga prijevoda Ilijade, Novak Kilibarda, u predgovoru objavljenoga izdanja, ističe da je dr Jovan Kujačić „,metodom suptilne selekcije, izabrao lekseme, stileme i žanrovska poetološka sredstva iz klasičnog deseterca za stih kojim je preveo Homerov heksametar". ${ }^{8}$ Osim toga, primjećuje i „osjetan uticaj Njegoševe specifikacije klasičnog usmenog deseterca“. ${ }^{9}$

Uzimajući o obzir navedeno, želimo još jednom skrenuti pažnju na ukupnu sliku stvaranja crnogorskoga prijevoda, pokazujući čitalačkoj javnosti postojanje još jedne verzije Kujačićeva rukopisa, kojom pratimo razvoj teksta od prvobitne zamisli autorove pa sve do danas publikovanoga djela.

Radovan Vučković, Pisac, delo, čitalac, Službeni glasnik, Beograd, 2008, str. 256.

8 Novak Kilibarda, „O Homeru i njegovoj Ilijadi“ (Uz prijevod Ilijade dr Jovana Kujačića), u: Homer, Ilijada, DANU, Podgorica, 2003, str. 15.

9 Isto. 

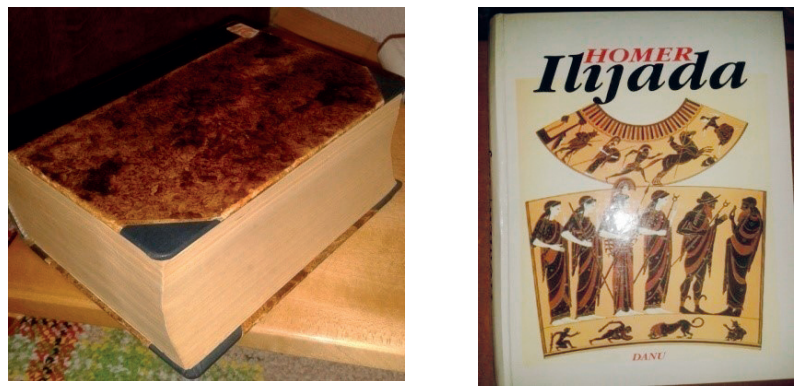

Na kraju istraživačkoga rada nadamo se da smo analitičkim sagledavanjem značajnijih elemenata tekstualne strukture prijevoda pokušali ukazati na vrijednost sačuvane rukopisne tvorevine.

\section{Literatura}

- Brković, Balša: „O prvom crnogorskom prijevodu kapitalnog starohelenskog epa o padu Troje, Homerove Ilijade“. U: Homer, Ilijada, DANU, Podgorica, 2003.

- Kilibarda, Novak: „O Homeru i njegovoj Ilijadi“ (Uz prijevod Ilijade dr Jovana Kujačića). U: Homer, Ilijada, DANU, Podgorica, 2003.

- Vučković, Radovan: Pisac, delo, čitalac, Službeni glasnik, Beograd, 2008.

- „U ateljeju Mirka Kujačića“ (četvrtak, 20. mart 2008), Dostupno na: $<$ http://www.divninitekstovi.blogspot.com>, Preuzeto: 28. 10. 2014. godine.

- <http://www. medicinabar.com>, Preuzeto: 24. 10. 2014. godine.

\section{Marijana TERIĆ}

\section{JOVAN KUJAČIĆ'S MANUSCRIPT OF 1950}

In this paper, the author reflects on the manuscript of Dr. Jovan Kujačić of 1950, which is kept in the Homeland Museum in Nikšić. Through analytical review of the manuscript, the author describes the process of creating the translation of the Iliad into Montenegrin. In this regard, the manuscript is compared with the release of the Iliad from 2003 (DANU, Podgorica), with similarities and differences in their conception discussed. Finally, the author draws attention to the remarkable creative energy of Jovan Kujačić, as well as the specificity of his manuscripts.

Key words: Jovan Kujačić, manuscript, Iliad (2003), translation activity, comparative approach 

Vukota BABOVIĆ (Beograd)

UDK 821.163.4.09-31Lalić M.

Pregledni rad

bvukot@sezampro.rs

\section{BEŚEDE O LELEJSKOJ GORI*}

Ove zabilješke su nastale kao potreba da iznesem svoja čitalačka uvjerenja o Mihailu Laliću, crnogorskom piscu. Prvi sud koji mi je odavno u pameti glasio je: evo čestitog siročeta iz Trepče koje je obogatilo našu kulturu - pa neka tako i ostane.

Pročitao sam njegove romane, a još jednom Lelejsku goru, i svjedočim o piščevoj nadarenosti, modernosti, pismenosti i obrazovanju. Skromnost ovog svjedočenja, a ona postoji kao izraz poštovanja piščevog lika, ne može osporiti ove epitete, možda može dijelom zamagliti njihova stvarna protezanja.

Djelo Mihaila Lalića uspješno se shvata u kontekstu tema evropske kulture dvadesetog vijeka. Samim tim ovo djelo se locira univerzalnim koordinatama literarnih vrijednosnih sudova.

Stvaralačka i etička pozicija Mihaila Lalića neugrožena je.

Ključne riječi: Mihailo Lalić, Lelejska Gora, beśede

\section{Čiji su pisci crnogorski književnici?}

Čitam Lelejsku goru štampanu 1962. Ličnosti komuniciraju crnogorskim govorom. On nije samo dijalekatska osobenost. To su emancipovani zvuci koji se talasaju u rezervoaru crnogorske istorije, precizne metafore koje čuvaju vrijednosti predačke elokvencije. Sram bilo svakoga ko ovo poriče (bolje sa rastavnicom: po-riče). Nalazim na strani 163: Je li rana od prebola? $\mathrm{Na}$ drugom mjestu pisac upotrebljava odličan naš glagol ispametiti. Naišao sam u romanu na crnogorsko žensko ime Sokola. Za jednog gospodina pisac veli da je teškośen. Drugome su počađale oči. Zašto ne ići u susret ovom govoru? Nije riječ o arhaizmima već o vitalnim jezičkim čvorovima koji imaju svoje mjesto u modernom komuniciranju današnjih naraštaja u Crnoj Gori.

* Predavanje održano 28.11. 2014. godine na Fakultetu za crnogorski jezik i književnost na Cetinju. 
Dosta ih je koji ne misle tako. Svi ih vidimo s obravnicama na leđima. U obravnicama su krupni dragulji crnogorske kulture. Malo oštrijim tonom reklo bi se da opažamo pokušaje šverca.

Pa u obravnice su strpani Mihailo Lalić, Stefan Mitrov Ljubiša, Marko Miljanov Popović, Njegoš... Kome nijesu ispale, nazire tamo i gusle Starca Milije. Nedavno smo čuli kroz odškrinuta vrata SANU da je Starac Milija iz Kragujevca!

Kad se Lelejska gora pojavi u prestižnom izboru srbijanskih romana, mi se ne ljutimo. Kad jedan aforističar promoviše novo izdanje Primjera čojstva i junaštva, on Miljanovoa sina kuje u zvijezde srbijanskog neba. Pa neka, opet nema tu ništa za zlu volju; naročito ne za profilatičke i dezinfekcione mjere. U čemu je palanačko lukavstvo aforističkog tipa? Kad se formira hodočasnička odabrana družina koja će tabanati od Lelejske gore do Zidanog mosta, kvislinškim stazama „slobode“, u koloni nedostojnih popova će biti i promoter aforističar kome ćemo dati kodno ime Nećković. Onaj isti koji je veličao sadržaj Markovih priča, pa prema tome i nezaobilazne rečenice o Crnogorcu Đulji Jovanovom, paradigmi slobodarstva u Crnoj Gori.

Kako sad? Glatko odbijanje Đulje Jovanova da bude predatorska perjanica, neugasivo je svijetlo u srpskoj kulturi, a predatorske perjanice iz Drugog svjetskog rata su mučenici u srpskoj tradiciji, je li to? Ovakvi paradoksi nas inspirišu da problem svojatanja crnogorskih autora i elemenata njihovog stvaralaštva shvatimo kao lako rješiv. Ako nosiš - nosi sve! Ako uzimaš selektivno, ovo hoću a ovo neću od Lalića i Miljanova, potpisuješ projekte sramnih manipulacija kukavičkim rukopisom spahije Pifagora Pifagoroviča Četokuckog iz Gogoljeve priče Kočije. Transakcija je ovako projektovana: objavićemo na sva zvona da Lalić pominje Nemanju u Lelejskoj gori (str. 562), kako da ne, ali ćemo predati zaboravu da je hodočašće predatorskim bogazama Lalić opisao umjetnički snažno u romanu Pramen tame. Reklamiraćemo načelnu moralnost vojvode Marka, ali ćemo nastojati da se stopi piščev vrhunski primjer crnogorske slobodarske etike. Tako funkcioniše „lukavstvo palanke“ (Z. Paković). Pitam: Kako bi se u Drugom svjetskom ratu ponio Đulja Jovanov? Kako Vuk Mićunović? Pa, nesreće jedne, bili bi u partizanima. Ako ne možeš da podneseš tu prostu istinu, a ti diži ruke od literature Marka Miljanova i Mihaila Todorova; izričemo ti najtežu kaznu - da zanijemiš.

Markomiljanovska i njegoševska etika jeste trajno živa zato što ima svojstvo društvenog transpondera, koji prima pozitivne signale iz prošlosti i, dekodirajući ih u sadašnjosti, već priprema njihovu emisiju za budućnost.

Naglasimo, prisvojiti djelo s namjerom da se prikrije i vremenom utuli bitno u njemu - jeste akt „hapšenja“ djela procedurom smještanja u edicije i enciklopedije. Ko tvrdo ukoriči u crvenu kožu i zlatotiskom opervazi knji- 
gu, on računa na vlasništvo intelektualne svojine. Svojina će se distribuirati parcijalno - kako pośednik, koji je „ovlašćeni“ tumač, odredi.

Isto, pojedinim lalićolozima i njegošolozima udjeljuju se doktorske titule, naučne diplome s prevashodnim ciljem da postanu akademski objašnjivači baštine: ovo ćemo da prenaglasimo, ono šiljemo u zaborav. I da se marginalizuje kritička riječ laičkih čitalaca.

Perspektiva nije tako mračna. Mrčenje ugaonika iz temelja crnogorske kulture, paradoksalno, ruši se sam od sebe, iznutra: zbog kukavičluka da se pozajmljeno autentično upotrijebi.

\section{Lalić je prevodljiv}

Krajem aprila 1940. raspisala se Isidora Sekulić o Njegošu. Papir jedva izdržava stogove ushićenja! Prvo da citiram nešto na planu generalnog prećerivanja: „Venac je grmen veliki izrastao iz maloga naroda, veličanstveno i svečano delo“. Onda slijedi dekonstrukcija pjesnikove ličnosti: „Rade je prvo bio visok i besmrtan duh, pa tek zatim umetnik“. Na kraju ovaj pamtljivi detalj iz povorke raščlanjenih elemenata: „Umetnost uvek tako hodi za duhom“.

Isidora čita stih „Krv je ljudska rana naopaka“ $\mathrm{i}$ jada se: „Taj stih propade u svim prevodima koje sam gledala“. I onda kad se ide tim putem po spjevu, naravno štikla zapne za iščevrljenu deseteračku tarabu: „Neka bude borba neprestana! / Neka bude što biti ne može!“"

„Ovaj poslednji stih, klasičnu našu komandu ponosa i prkosa, ni u jednom od razgledanih prevoda nisam našla reprodukovan sa mišićnom zanetošću koju joj Vladika dade.“ (Ne kaže Pjesnik no Vladika - jer pjesnik uvek tako hodi za vladikom.)

Odbijaju me ove ideje začaranosti maternjeg jezika. Pisao sam negđe prije deset godina, povodom prevoda Besudne zemlje Milovana Đilasa: Ako svaki prevod zvuči banalno, to jest pokazuje manjak „mišićne zanetosti“, biće da je i izvornik od prośečne mišićne vrste. Književnica Isidora ne objavljuje pokušaj svog prevoda, na bilo kom od šest ili sedam konsultovanih jezika. Pročitani tuđi prevodi joj se ne sviđaju. Na granici ozlojeđenosti veli:

„I uvukoše se u prevode slabomoćni pomoćni glagoli uz glagol; i uvukoše se uslovni konjunktivi da razmekšaju tvrdi indikativ.“

Naučna i književna djela treba prevoditi, u oba smjera. (Ona nemaju srećnu osobinu slikarstva, vajarstva i muzike: prijemčivost nevezanu za maternji jezik homo sapiensa.) Time se stvaraju preduslovi da se kulture susrijeću. Posle toga se mogu formirati univerzalni vrijednosni sudovi i time rangirati autorski doprinosi. Odličnu je misao imao pjesnik Stevan Raičković pošto je preveo Šekspirove sonete; rekao je, otprilike, da je time Šekspir po- 
stao i ovdašnji pisac. Kad sam nedavno učestvovao u prevođenju Galilejevih Dijaloga i Ajnštajnovih radova, śetio sam se ove anegdote: ako su rečena djela prevedena, i eno ih na policama naših biblioteka, Galilej i Ajnštajn postaju domaći stvaraoci.

Na nedavnoj manifestaciji povodom sto godina od piščeva rođenja, viđeli smo u Spomen-domu u Trepči na desetine prijevoda Lalićevih romana na vodeće evropske jezike. Lalić je prevodljiv pisac. Istina je da se u prevodima proze ponešto od izvornog zvuka zagubi, ali generalno manje nego u prevodima poezije (koja uvijek računa na muziku rečenice i ritam slogova). Ali da „rahitičavi pomoćni glagoli“ mogu sve da upropaste - to ne. Jer, tako nešto liči na nagovještaj misaone pustoši djela. Teza o suštinskoj neprevodljivosti beletristike je opasna. Opasna je stoga što nas uvodi u izolacionizam palanačkog tvorčestva.

Poznat je i ubjedljiv primjer da se Edgar Alan Po može kod nas čarobno prevesti... Zbilja, ona njegova zloslutna ptičurina vrijedi alan ipo i na našem jezičkom kantaru. Pasternak tek kako je prevodljiv; zato, gospodo, što je mučenje malih bogalja jednako monstruozno svuda na zemaljskom šaru. Jer su virovi uzburkane ljudske duše svuda isti. Jer je nespokojstvo bilo kojeg čovjeka uvijek i naš, hemingvejevski nemir. Prevodljiv je i slovenački pjesnik Tomaž Šalamun, dobitnik Njegoševe nagrade 2013.

Mi treba stalno da se pribojavamo one oštre riječi koja se odnosi i na oblasti šire od pravnih sudova; mislim na upozorenje sasvim prevodljivo na sve jezike: Što se grbo rodi, vrijeme ne ispravi. I još nešto: neka nam skromnost uvijek dopusti da shvatimo kako se ne može svaka istina ukalupiti u deseterac.

Hoću da kažem: crnogorski jezik nije samo idiomski i dijalektički konstrukt. To se ośeća i kroz prevodljivu rečenicu Mihaila Lalića koja je harmonična veza napisanog i kazanog.

\section{Laureati, ovakvi i onakvi}

Njegoševa nagrada je naša kulturna institucija. Ustanovljena je kao prestižno priznanje u oblasti književnosti jugoslovenskih naroda. Prvi lauerat Njegoševe nagrade bio je Mihailo Lalić. Tako je ta tradicija dobro počela. Lalićeve teme jesu prvorazredne njegoševske preokupacije. Poželjno je da je dobitnikovo djelo koherentno sa duhom nagrade.

Već je akt nagrađivanja Dobrice Ćosića narušio tu koherenciju. Rođen u Drenovi, došao je sa velikim drenovakom u ruci po insignije s Cetinja. Zlovoljan, pokušava da adaptira Isidorin egzaltirani, idiomatski obojen pristup Njegoševoj deseteračkoj misli. Zato je već pred mikrofonom u paučini ideje 
„neka bude što biti ne može“. Naći će se kasnije u njegovim knjigama popalančenje ovog sadržaja u vidu groteske - „mi možemo i ono što ne možemo“. U skladu sa ovom besmislicom tekla je i njegova politikantska diverzija na Cetinju, kad je upriličena svečanost u domaćinovoj kući. Vidio je sebe kao nacionalističkog kokota koji tom prilikom i na tom mjestu može da čeprlja po crnogorskoj istoriji i kulturi. Da je bila riječ o neopreznosti u izboru slavljenika, viđelo se i kasnije, ne jednom. Navodimo nekoliko primjera:

„Zapadni se čovek dehristijanizovao, kao što se Crnogorac rasrbio (U tuđem veku, str. 34).“ Ustanak 1941. partizan Ćosić je naveo kao primer „herojskih podviga“ protiv sebe (Isto, str. 37)! „Crna Gora: strahovito primitivna zemlja i neradan narod“ (Isto, str.105). „U Drugom svetskom ratu bili smo oruđe Kominterne i Engleza“" (Isto, str. 301).

Takav zatrovani stil je nezamisliv kod Lalića. Mi „strahovito primitivni“ dopustićemo sebi da uočimo: Ćosićeva rečenica da je „početak novog veka 1. januara 2000.“ obična je petparačka glupost neobrazovanog pudara. Oče naš srpske nacije, tekući milenijum je počeo 1. januara 2001. Sram te bilo, mislioče s drenovakom!

Postoje dva pola percepcije Njegoša. Ćosićevo kokoćenje (arhetipiziranje crnogorstva; Njegoš je iskazao taj arhetip; van zadatog arhetipa, Crnogorac se rascrnogorčuje) i Nikolaidisov stid (od navodnog antimuslimanstva). Za nas, i jedno i drugo izgleda kao nepotrebna i štetna misija. Zato sam i govorio u Beranama ovako:

„Petrifikaciji riječi poturica doprinijelo je površno a nerijetko jetko tumačenje Gorskog vijenca u ključu dnevne politike. 'U racionalnoj raspravi nemoguće je osporiti da centralno Njegoševo djelo, Gorski vijenac, govori o istrazi poturica, čišćenju Crne Gore od muslimana.' Ovo je stav savremenog crnogorskog književnika A. Nikolaidisa... Ovđe afirmišem upotrebu alternativnog pojma, predatorstvo; ima jedan slučajni smisaoni rukavac koji baš zgodno zvuči. Suština Njegoševog diskursa je slobodarstvo koje je antiteza predatorstvu; nije riječ o sukobu dva civilizacijska modela (od kojih je svaki po sebi legitiman). Tako i Lalić. Zasluga je ova dva autora što su na našim prostorima poetski snažno afirmisali moralno živu temu predatorstva. Predatorstvo je krupna književna tema, vjerujem razumljiva i mnogim drugim narodima..."

A pogledajmo kako piše kod samog Lalića, da dokumentujemo. Rečenica na strani 26 glasi: „Ne daju im ni soli da kupe, a zbog soli su se i prije ljudi turčili. “Na strani 198. imamo direktan stav: ,ako su Turke otjerali, zulume nijesu. Sad su drugi Turci i drukčije poturice - nema mira“. 
Zanimljivo je ovđe pominjanje soli. Nijesam bio lijen, pa sam u Lelejskoj gori detektovao ove stranice na kojima se pominje ucjenjivački kapacitet soli u okupatorovoj strategiji: $26,55,61,74,84,111$. Inat kao motiv pomenut je samo jedanput (str. 518), so evo pet-šest puta. Porobljeni čovjek ne odlučuje ni o čemu na imanju, moglo je da se izgubi i pravo na navodnjavanje (str. 55). $\mathrm{Da}$, postojala je i dozvola za zelje (str. 80).

Ne možemo, glupo je da otpišemo Njegoša zarad „mira u kući“. Između ostalog to bi posljedično značilo da je Lalić bio nekritičan kad je pristao da njegovo ime uđe u spisak dobitnika Njegoševe nagrade, i to pod rednim brojem jedan. Pa eno u Lelejskoj gori dva poglavlja imaju moto s Njegoševim stihovima. Izbor tih stihova govori o autentičnom shvatanju smisla Gorskog vijenca. Lekcija koju drži Mihailo Lalić onima koji vrše dekonstrukciju fenomena Njegoš sredstvima unosnog nacionalizma/antinacionalizma je ova: $\mathrm{Na}$ početku se moraju razdvojiti državnik, pjesnik i vladika; ne može pjesnik da hodi za vladikom, a državnik za pjesnikom, ili obrnuto. Inače imamo papazjaniju i memorandume s nemogućim zahtjevima. Moderni književnik koji se upušta u tumačenje književnog djela na način političara u jeku izborne kampanje - neka sebe zamisli sa dnevnikom u učionici na času maternjeg jezika. Književnost se ne čita bukvalno, moralo bi se đeci još s vrata poslati upozorenje. Lalić jeste književnik od nivoa.

\section{Lado kao Sizif}

Često se Lalićev lik Lado Tajović penje iz rizičnih seoskih punktova uz livade, pa šumarcima i kroz omare, iz pitomine gore do kamenih visova, da bi prije ili kasnije spuštao se niz strmeni, klizavim bogazama, kroz klekovišta, opet do šljivnjaka u selu. Pisac ima strpljenja da detaljno priča o ovim usponima i spuštanjima, ali te slike u ponavljanju i kod inteligentnog, ali nervoznog čitaoca hoće da izazovu dosadu. No utisak je da pisac pokušava da indukuje u čitaočevoj svijesti mit o Sizifu. To je tema koju ne treba preskočiti.

Lelejska gora je na mnogim stranicama stanište svijesti o besmislu i lokalitet „,sizifovskih rabota“. U momentima kad je najviše Sizif, Lado prevrće u mislima i do granica „filozofije samoubistva“ (Kami). Tu se opstaje takođe kamijevski: „izdržati uprkos apsurdu“. Svakog trena može sve vrijedno ovog života (ljubav prema Nedi, vizija pravične države...) propasti, ali čovjek ide od smrče do smrče, od pećine do pećine, njegujući nadu. Lalić tako komponuje radnju da se pouzdano zaobilazi stupica učenja koje se zove kvietizam. Mogli bismo, dakle, Lelejsku goru nazivati i Sizifovo Brdo.

Lalićev Sizif, međutim, nije onaj koji je prikazan na čuvenoj Ticijanovoj slici. Prije bismo ga mogli povezati s instalacijom u gradu Vroclavu. 
Umjetnik Tomaš Moček prikazuje ogromnu kamenu kuglu koju sprijeda gura jedan patuljak, dok sa suprotne strane, u pozi pomagača, opstruira zajednički posao jedan drugi patuljak. Ili sam bar tako razumio dinamiku njihovog odnosa, jer se savršeno uklapa u simboliku života učesnika u vihoru ratnih okupacionih dana u brdima Crne Gore.

$\mathrm{Na}$ više mjesta književnik skreće pažnju čitaocu na sunčev disk koji je najprije na istočnoj strani neba, nalazimo ga potom iznad vrhova četinara; pri kraju dana, kad se zatvori luk dnevnog hoda, rumeni krug je na zapadnoj strani neba. Nije to lekcija iz astronomije, kako bi se dalo banalizovati, već asocijacija opet na Sizifa. Naime, jedna je od interpretacija tog mita upravo repetitivna nebeska igra: teret sunčeve kugle neko tegli sa istočnog horizonta do zenita, ali se užarena lopta tu ne zadržava no se istog trena strmoglavljuje prema zapadnom horizontu: śutradan - isto. Tako kad Lado prati iz dana u dan sunčev hod, čitalac doživljava tu opservaciju kao nešto dublje od dnevne monotonije života, on je učesnik u poslu uzaludnosti i apsurda. Čitalac docrtava piščevom literarnom opisu opominjuću antičku mitsku sliku.

Lalić računa na smislena oživljavanja probranih asocijacija vezanih za kulturu uticajnih civilizacija; one jesu interakcije u viziji koje mogu da oplemene čitaočevu maštu. Možda ovaj domet jeste i nedovoljno istražen teorijski aspekt književnikova umijeća.

Još da ilustrujemo: recimo da je nesporna i asocijacija na donkihotovsko ponašanje glavnih junaka pripovijesti. Dok pratimo postupke pravičnog lutalice koji u selu štiti samohrane i ugrožene dame, pisac vaskrsava u čitaočevoj mašti i španske spisateljske tradicije, u tom broju posebno anamunovske. S druge strane, nije li Lado u dva ili tri svoja energična postupka inkarnacija onoga pravičnika koji je obitavao u Šervudskoj šumi pored grada Notingema, a zvao se Robin Hud? Naposljetku kad se Lado kupa u hladnom i modrom Limu, scena ima ritualni šmek, ona je jedna neočekivana ali prijatna asocijacija na biblijske motive.

\section{Ratište i stratište}

Tokom Drugog svjetskog rata proživio je Mihailo Lalić teške dane. Mjesecima je bio utamničen u beogradskim zatvorima Glavnjača i Ada Ciganlija. Potom sužanj u andrijevičkoj apsani, a ubrzo je ostavio svaku nadu, u danteovskom smislu riječi, pred četničkim krugom kolašinskog pakla. A kao njemački zarobljenik robijao je u Solunu. Proveo je, dakle, duge mjesece i godine, mnogo sekundi neizrecive neizvjesnosti, kad je u praskozorje svakog od tih mučnih dana mogao očekivati izvođenje na egzekuciju. 
Očito mu nijesu nedostajala ona granična životna iskustva kad se ličnost suočava s ništavilom, kad se vrijednosni sudovi i životne norme mjere na kantaru neumoljive dame Justicije (nije čudo da se od zla ljudskog sklonila na Nebo i eno je i dan-danas đe nas gleda iz sazvežđa Virgo). U tom pogledu imao je Lalić životnu avanturu koja se može uporediti s avanturom jednog Dostojevskog, koji se gledao oči u oči s carskim streljačkim strojem. Ko preživi stratište ne postaje po automatizmu istaknuti intelektualac i književnik, ali ko upisuje u svoju biografiju i takvu egzistencijalnu bizarnist, on je ne može sakriti u lavirintima svog stvaralaštva.

Ne mislim da je u poslijeratnom periodu prošao ijedan Lalićev dan, a da nije pišući pomišljao u čudu slučajno preživjele jedinke, da se egzistencija rimuje sa esencija, i to ne samo na polju jezika. Dobili smo jednog ćutljivog, suzdržanog, smirenog, čestitog i radnog pisca.

Romani Mihaila Lalića su strukturirani kao „skup događaja“. Ne vidimo u njima povorku spoljašnjih istina koje su došle, odnekud sa strane, da se ovaplote u čitaočevoj imaginaciji. Roman ima radnju, nešto se čini i tek potom se inkubira životna filozofija. Promišljanje o boljem svijetu istinski počinje na poligonu crnogorskih planina, te su visoravni istorijski poligoni; tu na terenu se gomila životno iskustvo konkretnog čovjeka. Ima Lalićevih čitalaca koji za radni sto sijedaju s predrasudom da saznaju „kako se kalio čelik“. Onda se neugodno vrpolje kad otkriju manjak ideologiziranog štiva. Kako sad? Zar na Lelejsku goru ne stižu direktive iz hotela Luks u Moskvi? Ne stižu. Lalićevi junaci su obični ljudi sa sopstvenim uvjerenjima koja se formiraju poslije onoga što im se dnevno događa. Oni dakako nijesu pustinjaci, pojavljuju se tu i prvaci partijskih ćelija; koji imaju svoje manje ili više apstraktne političke stavove i životne vizije, ali su nerijetko i izloženi ironiziranju baš sa platforme raskoraka, sa zahtjevima dnevne egzistencije pojedinca. Autentično je ponajprije ono što je aktuelno od svitanja do zalaska, i još više od zalaska do svanuća. Kao po receptu Serena Kjerkjegora, gerilac Tajović se trudi da živi strasno i iskreno - tu je ključ njegove jedinosti.

\section{Užasna snaga očiglednosti}

Naše je da napravimo napor da zamislimo prve dane poslije monstruozne klanice u Drugom svjetskom ratu. Sart je tada pisao: „Egzistencijalizam je pokušaj da se izvuku sve posljedice s pozicije dosljednog ateizma“. Egzistencija prethodi esenciji. Ovo mora da se dopalo još mladom Laliću! On je početkom pedesetih godina u Francuskoj, na izvoru nove ljevičarske filozofije. Pojedinac nema pravo ni mogućnost da se uspavljuje i uljuljkuje; on je do guše u realnom svijetu, u lokalnom prostor-vremenu, i ostaje mu lična akcija 
kao stvarna alternativa. Ladovo bivstvovanje na Lelejskoj gori živa je ilustracija ovih piščevih utisaka. Lado ima svoju egzistenciju, o kojoj promišlja odgovorno (sopstveno), on ima porodično zgarište u selu, snahu koja antičkom snagom podiže dijete, ljubljenu ženu u katunu; a potom, jeste i to, on je dijelom ,ideologizirana čestica“ jednog pokreta. Svi mi imamo stvarni život, iznutra; drugi vide naš život, spolja.

Podvižnici na Lelejskoj gori imaju svoju egzistenciju. Čitalac tek poslije nje vidi filozofiju bivstvovanja... Pa, u romanu se više pominje nesnosna šuga glavnog lika (već na str. 8) nego doktrina Lenjinovog komunizma.

Tajovića, svakako, prvo vidimo da djeluje. Iz njegovih radnji, akcija, prepoznajemo njegov ljevičarski impuls. Taj stav nije ad hoc deklarativan. Ličnost je odgovorna za svoje postupke, iz te individualne odluke izvire etika življenja. Kad je Tajović surov, pisac taj akt ne vidi kao jednoznačan ishod jednog posebnog genetskog sklopa. Realnost Ladove egzistencije diktira ponašanje, a ne predodređenosti ljudske prirode. Junak profiliše samog sebe potrebom egzistencijalne akcije, i odgovornim izborom mogućnosti. Kad se sveti, kad ubija, kad preuzima sud u svoje ruke, Tajović je u ishodu lišen kajanja, stida ili krivice pred partijom - jer motivi nijesu a priori ideološki. On suštinski nije ni loš ni zao, već su ti atributi a posteriorni sudovi o onome što je on izabrao da je nužna akcija.

Lalić onoliko puta uvodi svoje junake u životni apsurd. Svojom desnom nogom Tajović pokušava da ne upadne u moralnu kljusu koja se najčešće šablonizuje kroz stav da se „rđave stvari ne događaju dobrim ljudima“. Svojom lijevom nogom on pokušava da zaobiđe i drugu etičku stupicu vidljivu u lakonskoj izjavi da je „svijet nefer“. On razrješava te dileme uglavnom sartrovski: odlučujem da živim apsurdni život, ali ne nasumce kao tetrijeb već kao svjesno biće koje odgovorno izabira.

U borbi za oslobođenje od okupatora gerilci su se ratne 1942. godine odlučili da lokalno djeluju u crnogorskim brdima, da pomognu nadanja stanovništa, kroz opasnost svog prisustva i dnevni pogibelj. Jer, Sartrov prijatelj Kami kaže na jednom mjestu u romanu Kuga (str. 150): „Očiglednost ima u sebi užasnu snagu koja najzad sve pobjeđuje“. Tamo ćemo naći i ovaj uzvik (str.195): „Braćo moja, treba biti onaj koji ostaje.“ Kod nas, kao i u Francuskoj.

Sa svojim slikama strahova i jeza, sa epidemijama dešperantnosti, sa krizama rezonovanja, sa cunamijima nadanja - da, možda je Lalić blizu titule vasojevićki Sart. 


\section{Umjetnost faktografije}

Kod Kamija može se naći i ovakva programska rečenica (Kuga, str. 157): „Pripovjedač nije htio skoro ništa da mijenja radi umjetničkih efekata, izuzev kad je u pitanju bila osnovna potreba da pričanje bude donekle povezano.“

Moglo bi se, sa neznatnim prećerivanjem, reći da je ovaj stvaralački kredo preuzeo i Mihailo Lalić. On je smjesta spreman da žrtvuje makar i izazovnu maštu dobroj faktografiji. Ali, koncentrisan je i vješt u umjetničkom povezivanju, u sekvenciranju istinitih događaja. $U$ ovoj vrsti proze, i u onom vremenu, mnogi su pisci upadali u zamku insistiranja. Moj je utisak da kod Lalića postoji prava mjera insistiranja. Kao što se zna, tada je riječ o dobrom ukusu. Na primjer:

Kad u Pramenu tame pratimo kloparanje voza duž tek oslobođene Zemlje, kloparanje voza sa ljudskim škartom iz ratnih meteža, u jednom momentu konvoj klizi pored groblja bačenog, oštećenog, polomljenog, zarđalog okupatorovog ofanzivnog oružja. Prva činjenica transportujuće gomile poraženih dvonožaca, i druga činjenica gromade rashodovane gvožđurije koja je koliko juče sijala smrt na bojištima i na stratištima, u suočavanju i mimohodu, povezuje pisac vješto, umjetnički suvislo, kroz atmosferu iznenadnog susreta dva otpada - krvavih ruku i osramoćenog baruta u oružju.

Opise prirode daje Lalić izdašno, kao važan elemenat faktografije. Čovjek je tamo čovjek svog okruženja, i pisac nam počesto olakšava da simbolikom zeca u skoku, umornog preleta vrane, bjelasanja ribe u brzaku, nepomične stijene na vjetru, zagonetne pećine, magle preko brda, kiše u klancu, nagorelog panja, pośečene bukve - lakše prodremo u dušu i emocije homo sapijensa. Opisi krša, niskog oblaka i nagle susnježice na „orkanskim visovima“" Lelejske gore ne ustupaju pred klasičnim opisima iz pera jedne Emilije Bronte. Posebno su dojmljivi detalji:

Mazge u Crnoj Gori. Uspješna parabola! Nije da su u našim brdima one nepoznata specija, ali ne u koloni, i u tolikom broju, i u konteksu s puškama „talijankama“ i lakim brdskim topovima. Dakle, evo na stranicama Lalićeve proze mazge kao ratna faktografija. Simbol odurnih uljeza, inkarnacija nepozvanog gosta. Ne talijanski soldat, već talijanska mazga, koja svojom snagom, vučnom silom, izdržljivošću, i uz sve to beslovesnošću, bolje svjedoči o apsurdu okupacionog egzorcizma.

Te mazge su bile natovarene; nosile su, uz oružje, džakove namirnica: makarone, brašno, so, šećer - sve ono što je bilo i ucjenjivački potencijal fašističke tajne policije (OVRA). Tako, da se postavi solidna SOVRA, omogućavala je OVRA. Ova baš napadna, i fina u svojoj informativnosti, rima, nameće se čitaocu, ali je oprezni pisac eksplicitno ne pominje. 
A iz porodičnih faktografija znamo o raskalašnosti talijanskih okupatora; o poćerama za kokoškama koje rakolje, o hajkama na neoprezne i zabezeknute mačke, o istrebljivanju odomaćenih žaba kreketuša, pa i zmija - kao o mentalnoj slici fašističkih intrudera. U mojim śećanjima postoji detalj roditeljske priče: Imali smo u strani iznad kuće u Budimlji rasnu krušku kaličanku, koja sazrijeva već u avgustu. Talijanska patrola, sa svojom kokošarskom vizijom okupatorske uloge, u prolazu trese drvo i odnosi plodove ispred golotrbe đece tih gladnih dana četrdeset druge.

\section{Ljevičar u đetetu}

Vrijeme Prvog svjetskog rata su Lalićeve predškolske godine. Majka Stana Bajić ga je podizala „u zlo doba i godine gladne“. (Te naše crnogorske majke, izmučene golemom nemaštinom, jele su ono što od oskudnog obroka ispred gladne đece i čeljadi preostane.) Pala je Stana u postelju, sa groznicom, pogledala u plafonsku čakmu, kroz prozor niz trepačku luku, pogledala u svog sina, zanjihala se u nesvijest i oprostila se od svijeta. Otac Todor ubrzo je umro, od Kamijeve bolesti - tuberkuloze. Tako se pojavilo još jedno siroče u Crnoj Gori. Ovo je ipak bilo naročito Siroče, koje će ubrzo obogatiti crnogorsku kulturu. Podigla ga je maćeha Jaglika. Sad molim da budete uviđavni povodom sljedeće digresije:

Jaglika (primula officinalis) je radosni cvijet ranog proljeća na prisojnim stranama naših pobrđa. Postoji sasvim prirodno izvedeno crnogorsko žensko ime Jaglika. Danas je ono izgleda rijetko. Htjeli smo Mirjana i ja da kćerku nazovemo Jaglika i tako poboljšamo ovu ugroženu statistiku. Tome se suprostavila Mirjanina majka Milica, iznoseći neoboriv argument: znala je jednu Jagliku kojoj se desila strašna tragedija u porodici, tako i tako je bilo. Danas, dakle, imamo kćerku Milenu, farmaceuta, kojom se jednako ponosimo kao da je Jaglika. Jednom sam prehladio grlo, jedva sam govorio; kćerka je poručila: treba da piješ čaj od jaglike!

Kad se ovome dodaju književnikova rana i kasnija gladovanja, robovanja i bolovanja, dobija se slika jednog životnog okruženja sa egzistencijalnim patnjama koja je naginjala ka lijevoj dispoziciji. Ali kao što obično biva, jedan sitan detalj može ponekad da govori više nego krupni načelni uvidi. U staračkim zapisima Epistole seniles, na strani 55, ima nešto upečatljivo. Pisac se śeća sa kojom je averzijom gledao veterinarske intervencije na domaćim životinjama. To moramo da opišemo:

Brkati seoski konzilijum bi uhvatio svinjče, dok se ono svom snagom opiralo i kvičalo da se čulo do na dno sela. Glava konzilijuma sad radi nešto monstruozno: stavlja brnjušku; rilicu nesrećne životinju probode parčetom 
žice, iglom u stvari, i žicu na kriju savije u krug, napravi kao neku zakučaljku. I to je sve. Ako bi svinja pokušala da rilja oko kuće, brnjuška bi ju povređivala. Svorenje je zanavijek ośećalo apsurd svog života: stvoreno je da rilja, a riljati ne može.

Ta bezobzirna eksploatacija drugog „božjeg stvora“ frapirala je dječaka koji je iz prikrajka, iza koša, posmatrao rad Konzilijuma. Utisak je bio tako snažan da ga se on gnuša u danima sunovrata svog života. I sam se śećam sličnih događaja iz Budimlje. Naš nadriveterinar koji je stavljao brnjuške i vršio kastracije (škopljenje) krmadi zvao se Madžgalj.

Kao i sve drugo, i instinkt socijalne pravde ima izgleda svoje veće $i$ manje, i značajnije i minornije, i vidljive i nevidljive podsticaje.

\section{Pas kao emancipovani vuk}

Kod zabrinutih intelektualaca danas je u fokusu pažnje razorno bujanje etnonacionalizma. Tu pojavu uočavamo u svakoj samodefinisanoj grupi u kojoj članovi grupe veličaju do nebesa navodno izuzetne, skoro svetačke osobine svoje grupe. (Jedan pjeva u Lelejskoj gori, str. 150: „Vasov rod je jedrog zdravlja, lijepijeh crta lica, on je ponos raške zemlje, i kitna joj perjanica“.) U takvom kolektivu, naravno, svaki pojedinac ima oreol izuzetnosti. Takva skupina ima svoje granice, međe. To nijesu obične granice, već moraju biti demarkacione linije između dobra i zla: zlo je uvijek spolja. Da se ne otkrije unutrašnja laž, granica mora da isijava mržnju prema Izvanjcu.

U grupi (čoporu) neophodno je njegovanje straha. Uz ośećanje straha, naime, mišljenje je iracionalno, a jedino iracionalnost može biti podloga za njegovanje lažnog samopoštovanja u palanačkom izolacionizmu. Zbog toga je Lalićeva literatura relevantna za razumijevanje plemenskih mehanizama etnonacionalizma. Pogledajmo ovaj primjer (Lelejska Gora, str. 164): „Ljudi s bradama pominju Marka Kraljevića - jer i on je, kao oni, bio turska pridvorica, ali to mu nije smetalo da postanje srpska perjanica. Ni njima, dakle, neće smetati. Je li neko lanuo da će smetati?... Nije niko. ... I bolje da nije. Nek se ni u buduće ne usudi, jer bi ga to glave stalo, jer i knjez Miloš je vodio politiku i prodavao vojvode pašama i glavu Crnog Đorđa poslao sultanu, a baš to mu je pomoglo da uredi Srbiju..."

Etnonacionalisti imaju dva magistralna pravca postupanja sa Lalićem. Prvi je: uvesti koliko god je moguće više elemenata njegovog djela u etnonacionalistički zabran. Drugi: sve što nije moguće konfinirati treba sistematski predavati zaboravu. Evo šta kaže istoričar Todor Kulić: „Za sjećanje je najvažnije ovo što se prećutkuje. U regionu skoro i da nema negativnog pamćenja vlastitih dželata. Zaboravljaju se. Pamte se uglavnom vla- 
stite žrtve. Pravo sjećanje još uvek je u nas stranputica na kojoj ne srećete nikoga. Iako negativno pamćenje svedoči o dobrom ukusu kulture sećanja, ono jeste i sila koja odbija da se svidi. Dopadljivo sjećanje je ono drugo koje je prenaseljeno vlastitim žrtvama. To je iskrivljena optika, razroko gledanje, ali je i privlačno jezgro svakog etnonacionalizma jer moralistički pravda odštetu i osvetu“.

Mnoge teme koje su naše novine tobož otkrivale devedesetih, i do današnjeg dana, nalaze se jasno ispričane kod Lalića (komitske epizode, nasilja nad crnogorstvom, masakri rodoljubivih partizanskih ustanika, most na Foči, nasilje nad crnogorskom kapom i sl.). Pisac nije imao višak iluzija; znao je da je teško iskorijeniti spregu etnonacionalizma i etnofiletizma. Ali riječ je o nastojanju da se od vuka napravi pas - makar to i makar toliko (metafora T. Kuljića).

\section{Kletva po crnogorski}

Ne možemo beśediti o crnogorskom govoru a da prešutimo kletve. To Lalić zna i evo da citiramo po književnikovom izboru:

„Dabogda vam nesrećan bio taj rat što ste ga započeli u zao čas za vaše glave! Mora da vam bude nesrećan kad ne znate ni šta ste započeli. Rat i pljačka idu zajedno, a vi bi htjeli da ih rastavite - dabogda vam se meso s kostima rastavljalo! Ostadoše mi kljusad bosa, ne date čovjeku ni potkov da uzme - daće jaki bog da vas bose tjeraju po snijegu i da vas vrelim olovom potkivaju!..." (str. 37).

\section{Šopenhauerov uvid, još jednom}

U Beranama sam rekao: Lalićev običaj da misli i piše u brdima, na katunima, među borovima, na visovima, osamljen i u tišini, uz bruj vjetra, dublje sam pojmio tek kasnije kad sam kod mladog Šopenhauera pročitao: „Smatram da pogled koji se pruža sa visoke planine neverovatno doprinosi širenju ideja... svi mali objekti iščezavaju, a samo ono veliko zadržava oblik“.

Sad bih ovom dodao i citat iz Lelejske gore, sa strane 363:

„Pa i ovi naši rusvaji s urnebesima i mržnjama - pomanji bi izgledali kad bi se pogledali s nekog većeg brda ili iz nekog drugog vremena.“

\section{Brđanski bluz}

U svijetu je poznat, rado slušan bluz, muzička forma s kraja XIX vijeka na jugu Amerike. Te pjesme, ti songovi, pričaju nam o mukama potlačenih ljudi bez posla i obeznađenih u poslu, o nevoljama u prostom puku, prostim 
pričaju stihovima s potresnom muzičkom podlogom. Imamo taj snažni socijalni momenat u bluzu, ali i više od toga, tu su prateće divne slike iz prirode i duboka duševna stanja siromašnih i skrajnutih pojedinaca. Da navedem primjer uzet iz "St. Louis Blues":

I hate to see the evening sun go down,

Yes, I hate to see that evening sun go down

'Cause it makes me think I'm on my last go 'round

Ovoga sam se śetio kad sam kod Lalića čitao pasus: „Tužna misao navede ga da zapjeva tužnu pjesmu: Nema zore, nema dana, nema pisma od dragana" (str. 508). Ne znam šta nas je spriječilo da ne stignemo i mi da šire afirmišemo žanr brđanski bluz, jer evo evidentno trebalo je još samo ponoviti, jeste, nema zore, nema dana, nema pisma od dragana i da se približimo $i$ formom klasičnom bluzu; elegija je već tu, ona natapa crnogorsku momačku i đevojačku pjesmu inače. Postoje livadske biljke u katunu, kao kaćun. Postoje elegični zvukovi po livadi, evo citata od našeg pisca:

„Izgubljeni odjek pjesme Oj živote... to je neko neznan pjeva davno, tamno, u daljini s one strane, glasom što ga više nema - Oj živote, oj livado, oj livado puna meda, puna meda i čemera... što si mene, oj livado, oj livado čemerikom, čemerikom zadojila i pelimom othranila?..."

Ovome treba dodati jesenju pjesma u dvoglasu: „Brzo l' moja mladost minu, kao magla uz planinu“. A već smo pomenuli: „Je li rana od prebola, Lado, Lado“.

Nikad nije kasno, možda se večeras u nekoj Trepči rodilo dijete koje će u nepoznatom modernom ritmu, instrumentima i glasom, od ovih stihova napraviti brđanski bluz crnogorske kulture.

\section{Obnavljanje lekcije}

Kad sam u stranstvovanju počinjao da zaboravljam neke crnogorske riječi, idiome i sintagme, kod Lalića sam mogao da osvježim memoriju. Evo nekih odlomaka pogodnih za takvu edukaciju:

„Sto hiljada lira dobije ko ga ubije, a predeset ko ga prosoči.“ On progovori. „Glas mu je nejednak, na precmiljke i preskamuke.“ Iznenada „grunu puška“.

Śede na busen trave. Othuknu: „počađale mu oči“. Čuje zvonki zvuk metala, „neki od njih otkiva kosu“. „Iz torbe je izvukao trijesku luča.“

U planini se lako zaluta. Ovđe šiklja jelar, na koju treba stranu? Najzad „prepoznadosmo prodo“. Biramo prostrto, „,ne poznaju se tragovi po šuškoru“. Pored staze vidimo „pseće grožđe od kojeg smo nekada pravili mastilo.“

Umoran i zabrinut čovjek „vuče se preko izbrežina“, kroz „smrekove grane“, dolje mu je „starevina“. Nije dolazio odavno, ni „lani ni predlani“. 
Savremene tehnologije u građevinarstvu su takve da kad prelazimo rijeku slabo uočavamo da smo na mostu. To nije tako kad se hoda Ćuprijom na Drini. U Crnoj Gori znali smo za improvizovane mostove preko divljih brzaka. Nekad je most bilo jedno jedino stablo postavljeno s obale na obalu. Trebalo je kuraži i vještine da se ide tim mostom kad su proljećne i jesenje povodnje. Lalić piše: „Mostim po njenom vitkom stablu“.

Malo poslije zalaska sunca idu goveda i ovce sa ispaše, idu dviske i junice, lagano, puteljkom preko pristranka s rijetkim drvećem, kroz hrastovu šumu s listosjecima, najzad kroz šljivnjake; gazdarica čeka „da prijavi stoku“.

Kod Andrića, najbolje, možemo naći potresno lijepe opise naglog izrastanja đevojčica u prvoklasne ljepotice kasabe, i još strmoglavije rano propadanje udatih žena. Kod Lalića čitamo: ,žena šljune čim se uda“.

Planinareći nagledali smo se veličanstvenih vidika Crne Gore. Postoje izuzetna mjesta sa kojih je pogled baš neponovljiv, to se mjesto zove pomolak. Na primjer: ,pomolak s kojeg se vidi razgranat Lim“. Može se reći i vidikovac, ali je suviše plitko, turistički nebrižljivo; može se reći osmatračnica, ali je termin nesnosno militarizovan. Kako je krenulo, ako ne rehabilitujemo pomolak, uskoro će svi pričati - idemo na vju.

Sirotinji je i flaša nekad bivala skupa i teško dostupna; flaša od stakla, plastike nije onda bilo. A zapušač je prosto morao da bude proizvod domaće radinosti. Otuda „zapušač od oklasine“. Oklasina je u mojoj Budimlji još i tala.

\section{Lijepe slike u cigloj rečenici}

Onaj nedostojni nosilac Njegoševe nagrade često piše rogobatno. To su davno uočili mnogi, pomenimo samo dva kompetentna analizatora - S. Slapšak i M. Kovač. Evo jednog nasumičnog primjera: Ćosić ostavlja u knjigama i ovakav lingvistički čičak: „ovog proleća budućnost imaju samo drveće i biljke“. Laliću zacijelo ne može da se desi da „budućnost imaju drveće“. Mrzitelj Crne Gore, koja je davalac nagrade, piše i ovako: „Sada, posle napada na Ameriku Osame bin Ladena..." Ko napada Ameriku? I je li Amerika Osamina? Takvog jezičkog hramanja nema kod Lalića. Onda još i ovako piše Ćosić: „Ali, ne postoji ni jedan dokaz da bi čovek bio srećniji da nije ugrizao jabuku u Edemskom vrtu.“ Lalić bi se prije vratio u četnički zatvor nego što bi napisao ,ugristi jabuku“ u ovom kontekstu. Lalićeva rečenica je po pravilu bremenita ljepotom i isijava istinske umjetničke iskre. Moramo to da dokumentujemo.

Naslov poglavlja na strani 16 glasi: Katun jablan s česmom i đevojkom. I katun, i jablan, i česma, i đevojka u jednom sjajnom prizoru. Sama divota u grudima čitaoca, ali i potajna slutnja i nespokoj - predośećaj koji će se obistiniti. U domenu likovnom dostojno kičice Van Goga. 
Na drugom mjestu čitamo: „Mora da se ide i kad se ne zna kud“. Vaistinu takvu dinamiku ośećamo na svim raskrsnicama, a nije im mali broj. Posebno, ako igrate šah, ovaj sud ćete zapamtiti, poželite da se pozicija okameni, ali se potez mora odigrati.

Evo jedne rečenice koja može da opstane kao zaokružena pjesma: „Naokolo / muklo / i sporo / talasanje / planina / i vječnosti/.“" Priložimo bez komentara nekoliko sličnih rečenica:

- „Hvali se pećinama kao da ih je sam napravio.“

- „Pustara liči na trbuh gole žene kako ga crtaju francuski slikari.“

- „U daljini ispred mene stoji visoka Lelejska gora: prije su bila samo dva vrha, kao dva leleka skamenjena, sad je odnekud i treći izrastao.“

- „Crn je, sam je, možda je on minotaur u prodolima Lelejske gore.“

- „Ima jabuka petrovača što miriše na dječaštvo.“

- "Ostavili staru Anđu da od žalosti sama svisne.“"

- „Nema nikog da mi kaže jesam li lud i koliko.“

- „To je ona sitna pakost što i najmirnije može da razdraži.“

- „Skojevski osvetnici s pištoljima protrče ulicom Zmaja od Noćaja.“

A jednu bolnu, sažetu i sažeženu sliku ću izdvojiti: „Spustio bih se noću do Međe - da pogledam duvarinu stare kuće Tajovića; da pogledam je li trava izrasla na ognjištu đe je Džana spremala priganice za praznike..."

\section{Ne plavetno, i ne crveno}

Nije kratak spisak onoga što se Crnogorcima branilo kroz vremena. Te ne slobodu, te ne nezavisnost, te ne mauzolej, te ne televiziju, te ne dnevne novine, te ne univerzitet, te ne azbuku, te ne fonem, te ne grafem... Dotle je došlo da se stiglo: ne plavetna boja! I ne crvena boja! Kad neko nešto neće, neće on to na sto načina.

A plavetno je boja vedrog neba. Đe? Povrh Koma i nad Lovćenom. A crveno je boja krvi prolivene za slobodu. Kad i đe? Vazda, od Vučjeg Dola do Jasikovca.

U hajci, jednoj od hajki, na Lada u Lelejskoj gori, ori se četnička pjesma „Nema više i ne smije, crven barjak da se vije“.

Poslije crnogorskih izbora u prvoj deceniji trećeg milenijuma shvatili smo da ova ostrašćenost protiv crvenila u našoj postojbini nije samo antikomunistička. 


\section{Metal orikalk}

Izdvajamo poglavlje koje počinje na strani 190: Atlantida nije potonula.

Atlantida je mitsko ostrvo iza Heraklovih stubova (Gibraltar, Atlantski okean). Bogovi su se jednom sporili čije je što na Zemlji. Posejdonu je prilikom diobe pripala Atlantida. Ostrvo božanske ljepote, đe su ubirane dvije žetve godišnje. No zbog rastuće moralne izopačenosti, Zevs je kaznio obijesne žitelje; Atlantida je potonula u kataklizmi.

Lalić koristi ovu legendu da u njoj prepozna cikluse vlasti i talase sile koje s vremena na vrijeme potapaju poražene narode i predjele, do istrebljenja. Donosim dio dijaloga Lada Tajovića sa inžinjerom Dragom Nečekićem:

- Da nijesi otkrio nešto krupno?

- Mislim da jesam: Atlantida nije potonula.

- Pa gdje je, kad nije?

- Razorili su je susjedi - opljačkali, sve potukli i rasćerali.

- To je nova pretpostavka, odgovara vremenu.

- Odgovara prirodi ljudskoj, zato vjerujem da je tačna...

Ovo crnogorski pisac Lalić piše pedeset i neke. Tridesetak godina kasnije imaće za temu Atlantide golem interes jedan drugi crnogorski pisac (Pekić). Simbolika Atlantide kao da je posebno privučena istorijskim magnetizmom Crne Gore?

Kao fizičara liječak me interesuje detalj da su srećni i imućni Posejdonovi potomci, na Atlantidi, imali, pored namirnica, nebrojenog blaga i rudnog bogatstva - jednu rijetkost: metal ORIKALK. On se isticao osobinom da je sijao kao vatra. Ne znam, ali lijepo zvuči, da je asocijativni Lalić viđao majdane orikalka na obroncima Vasojevića, u planinskim sutonima pred Prvi maj?

\section{Izjava o čestitosti}

Ove zabilješke su nastale kao potreba da iznesem svoja čitalačka uvjerenja o Mihailu Laliću, crnogorskom piscu. Prvi sud koji mi je odavno u pameti glasio je: evo čestitog siročeta iz Trepče koje je obogatilo našu kulturu - pa neka tako i ostane.

Pročitao sam njegove romane, a još jednom Lelejsku goru, i svjedočim o piščevoj nadarenosti, modernosti, pismenosti i obrazovanju. Skromnost ovog svjedočenja, a ona postoji kao izraz poštovanja piščevog lika, ne može osporiti ove epitete, možda može dijelom zamagliti njihova stvarna protezanja. 
Djelo Mihaila Lalića uspješno se shvata u kontekstu tema evropske kulture XX vijeka. Samim tim ovo djelo se locira univerzalnim koordinatama literarnih vrijednosnih sudova - i dobro mu je zbog toga.

Stvaralačka i etička pozicija Mihaila Lalića neugrožena je.

\section{Vukota BABOVIĆ}

\section{DISCUSSIONS OF LELEJSKA GORA (THE WAILING MOUNTAIN)}

In the present paper, the author discusses some aspects of work of Mihailo Lalić, a twentieth century Montenegrin writer and an orphan from Trepča who enriched Montenegrin culture significantly. The work of Mihailo Lalić can successfully be placed and understood in the context of European culture of the twentieth century. Therefore, Lelejska gora can, as one of his best novels, be located on the basis of universal coordinates of literary value positions.

Key words: Mihailo Lalić, Lelejska gora, Montenegrin literature 


\section{Danilo RADOJEVIĆ (Podgorica)}

UDK 821.163.4(497.16).09

Petrović Njegoš P. II

Pregledni rad

Dukljanska akademija nauka i umjetnosti

\section{SAVIĆ MARKOVIĆ ŠTEDIMLIJA O NJEGOŠU I CRNOJ GORI NJEGOVA VREMENA}

Proučavanje Njegoševa državničkog i pjesničkog puta vršio je Savić Marković Štedimlija u međuratnome periodu, od 1931. do 1940. godine, a zatim poslije izlaska iz ruskih i jugoslovenskih zatvora, od 1960. do 1969. godine. U člancima koji su nastajali prije Drugoga svjetskog rata preovlađuje publicistički metod koji sadrži i polemičke elemente. Ti su članci i obimom kraći. U drugoj fazi svoga rada, kad je mogao, zbog sudske zabrane, da objavljuje samo pod pseudonimom, nastajale su radnje koje su rezultat arhivskoga i drugoga istraživanja. U njima je Savić Marković donosio do tada nepoznate činjenice iz Njegoševa života. Ove radnje, svojim bogatstvom novih viđenja činjenica, kao i naučnom obradom predstavljaju nezaobilaznu dopunu odabrane literature o Petru II Petroviću Njegošu.

Ključne riječi: Savić Marković Štedimlija, Petar II Petrović Njegoš, crnogorska književnost

Od malo godina svoga slobodnog življenja Savić Marković Štedimlija posvećivao je veliki dio izučavanju i rasvjetljavanju činjenica iz života i pjesničkoga djela Petra II Petrovića Njegoša. Desetogodišnjim tamnovanjem u sovjetskim gulazima, a zatim na Golom Otoku, bio je prekinut njegov stvaralački rad. ${ }^{1}$ O svojim stradanjima u gulazima Savić Marković

1 Savić Marković Štedimlija (Stijena, Piperi, Podgorica, 12. I 1906 - Zagreb, 25. I 1971), publicista i književnik. Pošto je završio osnovnu školu u rodnome mjestu, učio je gimnaziju u Podgorici, Peći, Nišu, Aleksincu, Jagodini i Leskovcu. Bio je isključivan iz škola zbog komunističkoga djelovanja. Prava i filozofiju studirao je na Sveučilištu u Zagrebu. Na početku svoje knjige Crna Gora u Jugoslaviji (1936), donio je kratke bibliografske podatke o sebi: „Pisao je pjesme, novele, kritike i članke u raznim listovima i posebno. Dosad je objavio knjigu stihova Rub jave (1929), političku brošuru Gorštačka krv - Crna Gora 1918-1928 (1928), knjigu članaka i polemika o umjetničkom i kulturnom životu Crne Gore Skidanje maske (1932); iz oblasti književne kritike, brošure: Simulanti u socijalnoj literaturi (1932), Mistifikatori likvidiraju umjetnost (1934) i Antikrležijanci (1933), zatim 
napisao je dvotomno djelo. ${ }^{2}$

Prvi članak o Njegošu objavio je 1931. godine. ${ }^{3}$ U tome tekstu on piše o razlikama između Gorskoga vijenca i Mažuranićeva spjeva Smrt Smail-age Čengića, na osnovu primjene crkvenog obreda pričešća. ${ }^{4}$ On zapaža da se u Njegoševu djelu pričešćivanje ratnika događa nakon njihova povratka iz okršaja u koji su pošli „bez ispovijesti i priprave“, a u Mažuranićevu spjevu

zbirku eseja o jedanaestorici hrvatskih pjesnika $O$ nama govore pjesnici (1932) i brošuru Školovanje crnogorske omladine (1935)“. Nakon navedenih knjiga i brošura, Sav. Marković je do Drugoga svjetskog rata objavio i djela: Osnovi crnogorskog nacionalizma (1937), Crnogorske štamparije (1938), Božidar Vuković i mletački štampari u XVI vijeku (1939) i Tragom Popa Dukljanina (1941). Ośećajući obavezu da djeluje u interesu Crne Gore, u aprilu 1941. god. u Zagrebu je osnovao Crnogorski nacionalni komitet, a zatim Crnogorski ured, preko kojih je radio na spašavanju od ustaškog terora Crnogoraca, Jevreja i pripadnika pravoslavne konfesije koji su mu se obraćali za pomoć. Period od 1945. do 1955. godine proveo je u gulazima u Sovjetskom Savezu. Pošto je predat jugoslovenskim vlastima, pod optužbom da je sarađivao s režimom NDH osuđen je na osam godina strogog zatvora, od čega je izdržao četiri, u Staroj Gradiški i na Golom Otoku. Nakon izlaska iz zatvora sudski mu je bilo zabranjeno da javno djeluje pa je svoje članke, da bi bili objavljivani, potpisivao pseudonimima, koristeći ime svoje žene Ljubice Klančić i rođaka Tomaša Markovića, učitelja. Tokom toga, zrelog perioda svoga naučnog rada, napisao je i posebno značajne radnje o Njegošu. Pod imenom Tomaša Markovića objavljen je prvi tom Savićeva djela Istorija školstva i prosvjete u Crnoj Gori, uz recenziju akad. dr Đorđa Sp. Radojičića (Zavod za izdavanje udžbenika Socijalističke Republike Srbije, Beograd, 1969). Da je uporedo koristio pomenute pseudonime, potvrđuje i podatak da je članak „Njegoševo zanimanje za Lipsku pećinu“ objavio pod imenom Ljubice Klančić (Naše planine, 3-4, 1961), a dopunu pod imenom Tomaša Markovića (Stvaranje, 9-10, 1961, str. 776-777). Iz srpskih nacionalističkih krugova Sav. Marković uporno je označavan kao „separatista“ i ,crnogorski ustaša“ (vidi: R. V. Petrović, Crnogorske ustaše, Beograd, 1997). Na prijedlog Blaža Kilibarde, Vlada Republike Hrvatske posmrtno je rehabilitovala Savića Markovića Štedimliju, dodijelivši mu status „bivšeg političkog zatvorenika“.

2 Deset godina u gulagu I i II knj., Podgorica 2004. Ovo izuzetno vrijedno svjedočanstvo Savić Marković napisao je u zatvoru, po nalogu UDB-e. Rukopis toga djela priredio je Blažo Kilibarda, a izdavač je Matica crnogorska. U vrijeme priprema za izgradnju Njegoševa mauzoleja na Lovćenu, Kilibarda je bio sekretar Odbora SR Hrvatske za podizanja ovoga spomenika. Građu o radu pomenutoga Odbora prikupio je i priredio za štampu (uz predgovor „Dug prema Njegošu“) B. Kilibarda (Lovćen, Njegoš, Meštrović, Zagreb, 2004).

3 Savić Marković Štedimlija, „Neslaganje Njegoša i Mažuranića“, Letopis Matice srpske, sv. 1-2, jul - avgust 1931, str. 86-93.

4 Tekst „Neslaganje Njegoša i Mažuranića“ Savić Marković prvo je objavio u LMS, a zatim unio u knjigu Skidanje maske (Zagreb, 1932, str. 91-96), uklopivši ga u širu radnju pod naslovom „Tajna jedne “tajne”“. U tekst je dodao i sljedeću bilješku: „Neki istoričari sporili su da je ikada postojala istraga poturica, barem ne onako kako je to u Gorskom vijencu predstavljeno, ali njihove tvrdnje nijesu mogle da se održe na suprot populariziranoj legendi o ovome događaju u Njegoševom spjevu, ma da do sada ničim nijesu njihove tvrdnje opovrgnute. Njegoš je ovaj događaj prosto mogao iskonstruisati da bi dao 'kostur' svome djelu po njemu“ (Skidanje maske, str. 94). 
pričešćivanje boraca učinjeno je prije bitke na Mljetičku: ispovjednik borce pita za grijehe, dajući im oproštaj pošto ih je pozvao na kajanje. Mažuranić se pridržavao redosljeda hrišćanskoga obreda, a Njegoš, piše Savić Marković, „ne priznaje kajanje kao put za očišćenje od grijehova“. Kod Mažuranića borci idu u osvetu, a kod Njegoša oni odlaze u „napadnu borbu“.

Temi osvete kod pomenuta dva velika pjesnika, Marković je posvetio posebnu radnju, pod naslovom Osveta kao kršćanska dužnost. ${ }^{5} \mathrm{U}$ toj raspravi izvršio je komparativnu analizu stava I. Mažuranića u spjevu Smrt Smail-age Čengića, preko lika Novice Cerovića, i Njegoševe motivacije da napiše Gorski vijenac. On osnovnu Njegoševu misao oko razrješenja, konflikata u prirodi i ljudskim zajednicama analizira u radnji Njegoševa formula sile. ${ }^{6}$ Marković ističe uslovljenost: da je sila ,izvor slobode“, da se sloboda „održava silom“, a čim iščezne sila ,iščezava i pravo“. Sloboda se „ne stiče bez sile“. Sila se mora koristiti samo do određene mjere, da ne ugrozi slobodu i pravo drugih, jer onda prelazi u tirjanstvo: „To prekoračenje je neke vrste zloupotreba prava, i to Crnogorci, zajedno sa Njegošem, nazivaju 'tirjanstvom'“.7 Savić Marković utvrđuje da crnogorskom misliocu, za utvrđivanje granice upotrebe sile služi: „crnogorska etika - čojstvo“. On dolazi do pretpostavke da postoji sličnost između navedene Njegoševe misli i, pola stoljeća docnije, podjele koju je izvršio filozof F. Niče: na jako i slabo ispoljavanje. Njegoš ne traži od božanstva pomoć pred početak velikog pregnuća jer, po njegovom mišljenju, u čovjeku se sažima „kosmičko jedinstvo svijeta“, a u Gorskom vijencu dao je borbu suprotnosti.

S. Marković je zapisao da je smisao Gorskoga vijenca - „u buđenju i jačanju sile u Crnogorcima“; međutim, crnogorski narod stalno je bio u vrtlogu borbe za očuvanje slobodne egzistencije, pa bi bila suvišna tako usmjerena poruka Njegoševa djela. Drugo je pitanje - njegova neumoljiva poruka izdajnicima crnogorske slobode. Međutim, Njegoš je u svojoj obuzetosti problemom neslobodnih slavenskih naroda, njima upućivao crnogorski primjer borbene etike. Zato je i posvetio Gorski vijenac prahu srpskoga ustaničkog vođe, Karađorđu, kao podsticaj njegovom sinu knezu Aleksandru koji je od

Savić Marković Štedimlija, „Osveta kao kršćanska dužnost“, Mladost, god. XII, br. 9, Zagreb, 1933, str. 207-210.

6 Savić Marković Štedimlija, „Njegoševa formula sile“, Nova Evropa, knj. XXVI, br. 12, Zagreb, 1933, str. 413-424. Njegoš je bio protivu nasrtanja na slobodu drugih; svoje pjesničko djelo posvetio je borbi za slobodu, kao i borbi u „granicama odbrane“.

Op. cit., 415. 
očevog ubice (Miloša Obrenovića) ${ }^{8}$ preuzeo vazalni status kneževine. ${ }^{9}$ Marković nalazi da su Crnogorci svojom silom stvarali vlastitu slobodu, ali ih je etika čojstva priječila da je zloupotrijebe, a turski osvajač nije poznavao to mjerilo, jer mu je bio primarni cilj pribiranje bogatstva od podređenih naroda, pa je zato postajao tiranin. Njegoš osuđuje imperijalnu strast osvajača i stalno korišćenje nadmoći, jer u ljudskom društvu treba da „umna sila toržestvuje, na suprot zakonu jačega koji vlada u prirodi“, đe vlada „divlja pamet“. Marković u navedenom tumačenju kaže da se likovi koji predstavljaju crnogorsku stranu u Njegoševu djelu tome suprotstavljaju; pjesnik čini napor da se očuva sklad i ravnoteža.

Savić Marković je bio podstaknut nekim tumačenjima Jevta Milovića, u knjizi Veliki uticaj Geteov na Njegoša, da napiše kritički osvrt. ${ }^{10}$ Milović je tvrdio da se „svuda osjeća uticaj“ Getea na Njegošev Gorski vijenac i Šćepana Maloga, kao i da je naš pjesnik čitao u originalu spjev Faust. Upoređujući ta djela, Marković je došao do zaključka da Milović za te teze nije imao ,jasnih i određenih dokaza“, jer on, između ostaloga, kaže da je Njegoš za lik vještice u Gorskom vijencu našao inspiraciju u Faustu. Međutim, primjeri koje je Milović uzeo iz Gorskoga vijenca i Fausta, nijesu dovoljan dokaz da je Njegoš poznavao to Geteovo djelo. Zato je Savić Marković zaključio da je Milovićeva radnja neutemeljena, jer pitanje „srodnosti između Getea i Njegoša ovim radom nije ni dotaknuto". ${ }^{11}$

O pokušaju Stanka Perunovića da dramatizuje Gorski vijenac, Marković veli da to Njegoševo djelo nije napisano za pozornicu, pa i ne odgovara po sadržini i načinu obrade za scenu. Zato on misli da dramatizacija Gorskoga vijenca treba da bude „posve samostalno i novo djelo“. ${ }^{12}$ Perunovićevu tvrdnju da je Njegošu bio cilj da ,što ljepše i živopisnije opiše narodne običaje i vjerovanja“, on ne prihvata, dovodeći to u vezu sa onim autorima koji Njegoševo pjesničko djelo pokušavaju da predstave kao da je to ,istoriska i naučna istina“. Perunović je takav odnos zasnivao na knjizi književnoga kritičara Pavla Popovića, O Gorskom vijencu. U svom kritičkom osvrtu na Perunovićevu dramatizaciju, Marković je objašnjavao scenu u kojoj se javlja sestra Batrićeva

8 Kao što je poznato, po nalogu kneza Miloša, Vujica Vulićević je ubio Karađorđa (1817), čiju je glavu odro papudžija Peja, u Beogradu, ispunio je slamom, pa je Miloš tu obrazinu uputio na Portu, što je bio dokaz pokornosti.

9 Vidi: Danilo Radojević, „Njegoš, njegovo vrijeme i djelo“, predgovor Gorskom vijencu, Školska knjiga, Zagreb, 1981, str. 8.

10 Savić Marković Štedimlija, „Gete i Njegoš“, Zeta, br. 39, s. 4-5; br. 40, Podgorica, 1934, str. 3-4

11 Ibidem.

12 Savić Marković Štedimlija, „Dramatizacija Gorskog vijenca od Stanka Perunovića“, Zeta, br. 52, 53, 54, 1934; br. 3, 4, 1935. 
kao pokazatelj da je bilo došlo do gašenja slobode, do ,procesa propadanja crnogorske sile i nestajanja slobode“, pa da je zato ta scena prijelomni momenat u donošenju odluke o ustanku. Savić Marković misli da bi scena sa sestrom Batrićevom mogla poslužiti kao osnov za dramatizaciju Gorskoga vijenca. On ne prihvata preradu koju je učinio Stanko Perunović jer je ostao na govornom iskazu kao bitnom, iako se pozorište, kako Marković misli, „više oslanja na oko nego na uho“. I u eseju „Djelo sestre Batrićeve“, Marković je, upućujući na kompozicionu strukturu Gorskoga vijenca, dokazivao da je uloga toga lika bitni dramski elemenat spjeva, jer je bilo došlo do stagnacije volje na skupštini glavara, da se spriječi „opasnost od raspadanja crnogorske državne zajednice" ${ }^{13}$ Njegoš je prekinuo to stanje - glasom tužilice, sestre Batrićeve, koja je sa žalbenicama prilazila skupštini. Svojom tužbalicom sestra Batrićeva kaže da će glava njenoga brata biti istaknuta na bedem Travnika, đe su već dospjele mnoge glave njegove braće, što znači da je Batrić žrtva neprijateljskog okruženja, ne od „domaćih Turaka“; ali je njihova bliskost nesumnjiva, i to je pokazano u sceni kad Vuk Mandušić pita Arslan-agu, koji je došao na pregovore, đe je kupio tako lijepi saruk: ${ }^{14} \mathrm{u}$ odgovoru Arslan-aga veli da mu ga je poklonio vezir kad je išao u Travnik, na kome će biti istaknuta glava Batrićeva. Kulminacija dramske napetosti u toj sceni nastaje kad bezimena sestra (njoj Njegoš nije dao ime, da bi postigao opštost borbenoga stava, kad su u pitanju Crnogorke) uzima nož iza pojasa đeda Bajka i ubija se. Da bi taj prijelomni momenat dobio i racionalnu odlučnost, javlja se na sceni iguman Stefan, koji obrazlaže pravo Crnogoraca na slobodu i samostalnost.

Pomenuti esej Savić Marković je završio izvođenjem komparacije dva različita lika, đe je istaknut društveni značaj čina sestre Batrićeve, u odnosu na Majku Jugovića iz pjesme usmenog stvaraoca. ${ }^{15}$ Tragika Majke Jugovića je

13 Savić Marković Štedimlija, „Djelo sestre Batrićeve“, Nova Evropa, br. 11, Zagreb, 26. XI 1935, str. 357-367.

14 Saruk, tur., tkanina kojom Turci obmotavaju kape, čalma (Rječnik Njegoševa jezika, knj. II, s. 255).

15 Savić Marković Štedimlija u knjizi Skidanje maske, u poglavlju „Tajna jedne 'tajne'“, kritički se osvrnuo na neke stavove srpskoga književnika Dušana S. Nikolajevića o Njegošu i Gorskome vijencu, koje je iskazao u članku „Revizija vrednosti Gorskog vijenca“ (Pravda, 30. XI, 1. XII i 13. XII 1928). D. S. Nikolajević (1885-1961) slične teze je iznio u brošuri Njegošev Gorski vijenac (Beograd, 1923). On, između ostaloga, veli: „Ni umetnik, ni mislilac, ni rodoljub u višem smislu, Njegoš je varvarin jake trezvene pameti“; dalje on kaže da civilizacije nema u Gorskom vijencu pa, u očima onoga koji shvata umjetnost i misao, to djelo „ne može biti prava veličina, umetnička i misaona“. Nasuprot Gorskoga vijenca Nikolajević ističe epsku pjesmu o majci Jugovića, da je to ,jedna od najvećih tvorevina umetnosti vaskolikog čovečanstva“. Posebno treba naglasiti da D. S. Nikolajević tvrdi da Njegoš „nije dostizao one usamljene visine“" narodnih pjesama, već je bio ,jedan duh, ali pod lokalnošću“. Te tvrdnje D. S. Nikolajevića podstakle su Savića 
pasivna, dok je sestra Batrićeva „najosjetljiviji instrument za mjerenje slobode“ cijeloga naroda, pa njeno samoubistvo daje podsticaj za otpor. Njegoš je taj lik unio u dramski spjev da bi pokazao spremnost i žena na najvišu žrtvu kad je zemlja u takvoj opasnosti, a ne samo da „nariču“.

Savić Marković Štedimlija osuđivao je zloupotrebu Njegoševa pjesničkog djela u političke ciljeve, koji su okrenuti protivu crnogorskoga naroda. Tako on piše o Tomu Oraovcu, o njegovoj upotrebi Njegoša za opravdanje svoga političkog djelovanja. On upoznaje čitaoce o metodama rada Oraovca koji je tada (1935) bio predśednik Društva za proučavanje istorije Crne Gore u Beogradu, pa kaže da „nikad u svojim napisima ne navodi izvore, pomoću kojih bi se moglo kontrolisati da li je istina što on govori. A ako sami potražimo te izvore, vidimo redovno da on piše netačno, kako mu se kad svidi“ ${ }^{16}{ }^{1} \mathrm{Za}$ ovo skretanje pažnje na (negativni) primjer dovođenja Njegoša u kontekst koji odudara od pjesnikove misli, Marković je bio podstaknut člankom T. Oraovca koji je objavljen u Pravdi (1935), u kome se on ,javlja kao vatreni branilac vladike Rada“, osuđujući pisanje Vladimira Plamenca, iako je sām više decenija djelovao protivu opstanka crnogorske države i dinastije Petrović Njegoš. U novoj državi (Jugoslaviji), Oraovac i drugi sudionici uništenja svoje države, ośetili su se zapostavljenim, pa su počeli isticati vrijednosti crnogorske prošlosti i značajne ličnosti. Zato Marković podśeća Oraovca na njegovu brošuru, koju je objavio u Njujorku za vrijeme Prvoga svjetskog rata (1917), u kojoj je propagirao falsifikate o crnogorskoj povijesti, pa i da je Njegoš bio protivnik mudrih i pametnih glavara, koje je ,preko kupljenih najamnika“ ubijao (,,vladici se takvi ljudi nijesu dopadali jer je tražio plemensku svađu, da bi tako mogao držati dizgine u ruke"). ${ }^{17}$

Markovića da napiše esej o sestri Batrićevoj iz Gorskoga vijenca, u kome je taj lik komparirao s likom majke Jugovića.

16 S. Marković Štedimlija, „Ko kleveta Njegoša?“ - Zeta, br. 46, 15. XI 1935, str. 3.

17 Ibidem. U radnji „Epske kontradikcije Mićuna Pavićevića“, u knjizi Skidanje maske, str. 109-152, Savić Marković je analizirao karakter i metode djelovanja M. Pavićevića koji je želio da postigne književni uspjeh zavaravajući neke uticajne ljude da o njemu pohvalno pišu, da je u anegdotama „dao više Crne Gore od vladike Rada, koji je gledao sa prijestola i oltara“. Osnovni podsticaj Štedimlijin da napiše pomenuti tekst, bio je da pokaže namjere Mićuna Pavićevića da preko upornoga izmišljanja anegdota tendencioznog sadržaja, velikim dijelom okrenutih protivu kralja Nikole i Njegoša, ruši njihov ugled kao vladara i književnika. Pavićević je početkom 1916. godine došao na Krf kod izbjegličke srpske vlade, koja ga je uputila u SAD i Kanadu da radi na prikupljanju dobrovoljaca za srpsku vojsku među crnogorskim iseljenicima. Od tada je M. Pavićević radio na realizaciji srpskoga političkog plana o prisajedinjenju Crne Gore Srbiji. Štedimlija zaključuje da je M. Pavićević smatrao da je kralja Nikolu moralno uklonio ,prikazujući ga u svim negativnostima u raznim pričama, anegdotama i posebno člancima i publikacijama. A vladiku Rada je prvo kao čovjeka unizio jednom anegdotom 'Kosijerom po vladici' (...), a da ga sruši kao pjesnika 
Knjiga Psihologija u Gorskom vijencu od dr Dragoljuba Brankovića ${ }^{18}$ izazvala je Štedimliju da napiše kritički osvrt, u kome konstatuje da je ta knjiga nastala kao nastavak nerazumijevanja Njegoševe misli, koje nalazimo kod Branislava Petronijevića, u čijoj raspravi je Njegoševa filozofija svođena „na obično rezonovanje jednog trezvenog gorštaka“. ${ }^{19}$ I za episkopa Nikolaja Velimirovića Marković utvrđuje da je pokušao da Njegoša „pohrišćani, podmećući mu da je bio dualista“. Dalje Marković navodi da je književni kritičar Pavle Popović htio da „naučno objasni“ Gorski vijenac i da ga dovede do razumijevanja onima kojima „nije u prirodi niti u karakteru da shvate ovog crnogorskog mislioca“. Marković misli da se pokazuje težnja da se Njegoš ,skine sa svoje lovćenske visine, da bi se mogao učiniti rođakom, nacionalnim bratom onih čiji duh nije bio niti će u dogledno vrijeme biti kadar da se uspne do Njegoševog mislilačkog prijestola“. Primjera negativnog korišćenja nekog od sadržaja iz djela velikih stvaralaca ima i u drugim sredinama, pa Marković navodi slučaj njemačkoga filozofa F. Ničea, koji je kult „prave, žive sile digao na najveću visinu“, i u vrijeme Prvoga svjetskog rata Njemačka ga je „uznosila i slavila“, a djela toga filozofa dijeljena su vojnicima u rovovima, da njima „krijepe svoj ratnički duh“. Savić Marković zaokružuje taj primjer činjenicom da Ničea „slavi Hitlerova Njemačka“, iako taj ,,veliki pjesnik i filozof nije nikad bio, niti htio biti ono čim ga hoće (učiniti) najdrskiji ugnjetači i ubojice slobode i jakog duha u čovjeku“" ${ }^{20}$ Značajno je ovaj stav istaći da bi se dobila punija slika o duhovnim opredjeljenjima samoga Savića Markovića Štedimlije, jer je predstava o njemu, iz političkih pobuda, od njegove pojave na publicističkoj sceni smućivana ili falsifikovana. U navedenome tekstu Marković je zaključio da je ista sudbina, kao i Ničea, zadesila i Njegoša, u nekim tendencioznim tumačenjima.

Veoma važnu distinkciju naglasio je Marković kada je napisao da je Njegoš bio patriota, ali da nije bio nacionalista, jer se strasno borio (što se vidi iz njegove obimne prepiske) za slobodu svih ugnjetenih - „bez obzira kojoj su naciji pripadali. On se borio protivu 'turske vjere', ali ne iz drugih razloga,

najavio je preko časopisa Naša knjiga publikaciju 'Plagijati narodne poezije u Gorskom vijencu'" (str. 119).

18 Izdanje knjižare Geca Kon a. d., Beograd, 1936.

19 S. Marković Štedimlija, „Degradiranje Njegoša. Psihologija u Gorskom vijencu od Dragoljuba Brankovića“" Zeta, br. 10, 8. III 1936, str. 3. Kritičke osvrte na Brankovićevu knjigu napisali su Trifun Đukić (Glasnik Jugoslovenskog profesorskog društva, knj. XVI, Beograd, 1936, str. 766-767), Marko Marković (Slobodna misao, Nikšić, 2. VIII 1936) i Janko Tufegdžić ( $S K G$, knj. XLVII, 1936, str. 404-405). Prof. Dragoljub Branković autor je i knjige Psihologija u Luči mikrokozmi (1936); bio je inspektor Ministarstva prosvjete. Ibidem. 
nego zato što je za njeno širenje i održavanje bilo tijesno vezano tlačenje i porobljavanje naroda i što je ona dopuštala vršenje tih nečovječnih čina“". ${ }^{21}$

Nepravilna tumačenja Njegoševa shvatanja pojma genija podstakla su Štedimliju da tome pitanju posveti posebnu radnju, pod naslovom „Njegoševa teorija genija“. ${ }^{22}$ On primjećuje da su tumači Njegoševe misli ,sveli njegovu teoriju genija na jednu običnu, banalnu misao“, i otklonio je kao „netačnu i nenaučnu“. On komentariše tumačenje B. Petronijevića koji je napisao da ne vjeruje u Njegoševu teoriju genija, koju je on izveo iz poznatih stihova („Iz grmena velikoga lafu izać trudno nie, / u velikim narodima geniju se gnijezdo vie"). ${ }^{23}$ Marković polazi od objektivne činjenice da Njegoš nije bio naučnik i teorijski filozof, već pjesnik-mislilac, „u glavnom praktični filozof"; misao je iskazivao u slikama, metaforično, „konstatacijama čovjeka iz svakidašnjeg života“. Njegoš naziva genijem nosioca sile koja je u stanju da probudi zamrzle snage u narodu, što znači da je pjesnikovo mjerilo genijalnosti ,sila, njena moć i intezitet". Marković dalje veli da narod nasljeđuje učinak onih sila koje su bile upotrijebljene u prošlim vremenima. Ali kad u jednom narodu nema takve tradicije, kad su „staze neutrvene“ - onda je put genija u takvoj sredini teži. Na kraju Marković zaključuje da je netačna tvrdnja da je Njegoš odricao mogućnost pojave genija u malome narodu, već da je geniju teže da se odnjivi u takvoj sredini, ali da „nije i nemoguće“.

Zanimljivo je istraživanje Savića Markovića o uzrocima negativnoga odnosa prema Njegošu i Crnoj Gori talijanskog književnika i političara N. Tomazea. On utvrđuje da neraspoloženje Tomazea dolazi godinu dana poslije poznate bune iz 1848. godine, jer od tada često iskazuje svoje negativno mišljenje o Njegošu, što je nastavio i poslije smrti našega pjesnika (1851). Tomazeo veli da je Njegoš ,jak pisac“, ali da je „episkop razbojnik, magnetizovan od petrogradskog Dvora i bečkih bordela, čovjek na kome je bila i barbarska rđa i pakosnica civilizacije“. I pri kraju svoga života Tomazeo je osuđivao Njegoša, da je kupovao „ruskim zlatom francusko vino da loče među golim svojim klisurama“. ${ }^{24}$

Promjenu ranije prisnoga odnosa Tomazeova, vjerovatno je S. Marković trebao tražiti i u Njegoševu odnosu prema revolucionarnim događajima iz 1848. godine, kad je on nudio pomoć banu Jelačiću. Kao što je poznato, tada je došlo do obnavljanja Mletačke Republike (1848-1849), u čijoj je vladi

$21 \quad$ Ibidem.

22 Savić Marković Štedimlija, „Njegoševa teorija genija“, Zeta, br.1, 2, 3, 4, od 7, 14, 24, 31. januara 1937.

23 Dr Pero Šoć, Posveta 'Gorskom vijencu', Beograd, 1951, faksimil prijepisa Posvete, na osnovu koga je cenzura dala odobrenje za štampu.

24 Savić Marković Štedimlija, „Njegoš i Tomazeo“, Obzor, br. 186, Zagreb, 1937, str. 1-2. 
Tomazeo postao ministar kulture. Poslije ponovne austrijske okupacije Venecije, Tomazeo je prognan na Krf (1849), pa je od tada ponavljao napade na Njegoša. Osim toga, poznato je da je Tomazeo čitao Gorski vijenac; vjerovatno nije mogao prihvatiti izrazito negativnu sliku Mletačke Republike koju je Njegoš dao, jer se Tomazeo borio za njenu obnovu i zato stradao.

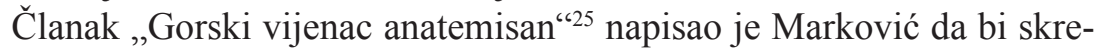
nuo pažnju na etičku osudu Gorskoga vijenca, koja se pojavila u zagrebačkom listu Hrvatska straža: „Neka dakle ko hoće hvali Gorski vijenac sa estetičke strane, etika ga mora osuditi! Zato bi trebalo ovo djelo ostraniti od školske lektire". Autor navedenoga poziva na proskripciju toga Njegoševa djela, zapisao je da to čini „, ime vjerske tolerancije“. Marković valjano kvalifikuje orijentaciju pomenutoga lista, klerikalce oko njega koji su bili poznati po svojoj netoleranciji, odbacujući taj napad na pjesnika Njegoša. On daje podatak da $\mathrm{u}$ to vrijeme Gorski vijenac ,nijesu osudili ni Muslimani ' $u$ ime vjerske tolerancije "“. ${ }^{26}$

S. Marković Štedimlija je pokazivao osobitu energiju pri izučavanju literature o Njegošu i o crnogorskoj prošlosti, pa su zato značajna njegova zapažanja o falsifikatima, nedovoljno potkrijepljenim ocjenama o povijesnim činjenicama i ličnostima. Između dva svjetska rata na te probleme rijetko je skretana pažnja jer je nametan stav da su svi crnogorski problemi postali prošlost, da su riješeni, a rijetki pojedinci koji su pokušavali da se crnogorski narod, njegova prošlost i kultura, ne poništi zaboravom, izazivali su sumnju da nijesu odani novoj državi. Istaknuti pripadnik te grupe intelektualaca bio je i Savić Marković, autor, između ostalog, značajne knjige Osnovi crnogorskog nacionalizma (1937). ${ }^{27}$ On se kritički osvrnuo na način predstavljanja crnogorske prošlosti poljskog naučnika Henrika Batovskoga koji je prikazivao publikacije o Crnoj Gori. Batovski je te svoje članke objavljivao u poljskim časopisima, a autor je i jedinice o Crnoj Gori u velikoj Enciklopediji političkih nauka. Marković je u kritičkom osvrtu konstatovao da je Batovski izostavio značajni period crnogorske najstarije povijesti: Dukljansko Kraljevstvo. Ocje-

25 Savić Marković Štedimlija, „Gorski vijenac anatemisan“, Zeta, god. 8, Podgorica, 21. marta 1937. Tekst iz klerikalne Hrvatske straže tada je komentarisan u listovima: Jugoslovenska pošta (Sarajevo) i Javnost (Beograd).

26 Ibidem. Tokom proslave 200-godišnjice Njegoševa rođenja (2013), javile su se oštrije ocjene od navedene anateme pomenutih klerikalaca: Njegoš je od nekih Bošnjaka nazvan „genocidnim pjesnikom“ koga treba odstraniti iz školskih programa. Osudu da je Njegoš „genocidni pjesnik“ valjano je osporio dr Adnan Čirgić, u radnji „Je li Njegoš genocidni pjesnik?“ (Matica, časopis za društvena pitanja, nauku i kulturu, god. 55, jesen 2013, str. 547-556).

27 Vidi: Dr Danilo Radojević, Tri zabranjene knjige Savića Markovića Štedimlije, izd. DANU, Podgorica, 2008. 
njujući taj propust Batovskoga, on kaže da to nije slučajno, jer se pri izradi pomenutog teksta služio Narodnom enciklopedijom Stanoja Stanojevića, koja je „krcata tendencioznih pamfleta protivu Crne Gore“..$^{28}$ Marković se bavio pitanjem da li je ep Osman Ivana Gundulića ${ }^{29}$ uticao na Njegoša, i da li ga je čitao u rukopisu koji je pośedovao. ${ }^{30} \mathrm{Kad}$ je došao u Crnu Goru Antun Mažuranić, Njegoš mu je poklonio primjerak rukopisa Osmana koji se u nauci pominje kao „crnogorski rukopis“. Marković misli da se uticaj Gundulićeva Osmana može utvrditi u Gorskome vijencu jer je Njegoš u crnogorskoj povijesti i literaturi prvi ,popularizirao srpsko ime, a nijedno djelo ne bi ga na to moglo podstaći kao Osman“ u kojem se opširno govori „o propasti srpske despotovine".

Emfatični naslov članka „Vatronosne riječi. Njegoš pjesnik slobode“"31, upućuje na mogući odgovor - zašto je Sav. Marković odlučio da podśeti na Njegoševe stihove koje izgovaraju u dva dramatična trenutka vladika Danilo i iguman Stefan. To se događe pred donošenje odluke o udaru na potuđeni dio Crnogoraca, i kad stižu u Cetinjski manastir prvi sudionici ustaničke borbe. Stihovi koje komentariše Štedimlija u navedenome članku, uzimajući ih kao reprezentativne iskaze duševnoga stanja i životnog iskustva tih likova, ne nose u sebi nejasnoće ili dvoslojna značenja, pa se može zaključiti da ih je autor odabrao s ciljem da preko njih asocira na konflikte koji se konstantno zbivaju u povijesnom trajanju. Po tumačenju Sav. Markovića, slijepi iguman Stefan predstavlja glavnoga pokretača borbe, jer on donosi odlučne sudove na osnovu dubljih saznanja o vječnome trajanju suprotnosti, u prirodi i samome čovjeku. Vladika Danilo je lik koji je u fazi sticanja (temeljnih) iskustava. Utvrdivši tu razliku, autor zaključuje da je Njegoš-pjesnik podijelio sebe na dva lika: na vladiku Danila i igumana Stefana. Članak „Vatronosne riječi“ izdvaja se od ostalih tekstova u ovome izboru, po namjeri autora da otkriva pjesnikove poruke koje imaju trajno značenje. Tekst je pisan u mutnom istoriskom trenutku, na početku Drugoga svjetskog rata (1939), pa se nazire intencija autora da pokaže punu aktuelnost Njegoševih pjesničkih rasuđivanja, da se mora biti „naredan“ za sve istorijske izazove.

28 Savić Marković Štedimlija, „Dr Henrik Batovski o Crnoj Gori“, Zeta, br. 7, Podgorica, 1938, 3. Henrik Batovski je preveo Gorski vijenac na poljski jezik (1932).

29 Savić Marković Štedimlija, „Gundulić i Njegoš“, Obzor, br. 42, Zagreb, 1938, s. 1-2. Tekst je objavio i u: Jadranski dnevnik, god. V, br. 177, 1938, str. 9.

30 Ep Osman nije štampan dvjesta godina, jer je Malo vijeće Dubrovačke Republike priječilo, da ne bi njegov sadržaj izazvao Turke; prvi put je objavljen 1826. godine; do tada je širen i čitan u prijepisima, od kojih je do danas sačuvano blizu 80 primjeraka.

31 Savić Marković Štedimlija, „Vatronosne riječi. Njegoš pjesnik slobode“, Naša zemlja, god III, br. 2, Beograd, 1939, str. 5-6. 
Godine provedene u zatvorima nijesu pogasile Štedimlijin stvaralački duh. Izlaskom iz zatvora nije ukinuto njegovo intelektualno zatočeništvo: priječila ga je sudska presuda da publikuje tekstove pod svojim imenom pa ih je potpisivao imenom svoje supruge Ljubice Klančić. Međutim, svestrano poznavanje crnogorske prošlosti, jezika, kulture, otkrivanje arhivske građe, rijetka istraživačka strast, izraziti kritički um - što su sadržavale radnje koje su nastajale u tome periodu, budile su znatiželju uredništava časopisa i listova kojima su upućivane, da otkriju pravoga autora jer je ime Ljubice Klančić bilo novo i nepoznato u kulturnom životu jugoslovenskih naroda. Tada je počinjala potraga za ličnošću koja stoji iza toga imena, i, nakon otkrivanja, najčešće bi bila spriječena njegova dalja saradnja, a ima i slučaj da je, zbog vrijednih (novih) podataka, tekst objavljen, ali bez navedenoga Štedimlijinog pseudonima ${ }^{32}$ Pod svojim imenom objavio je neke radnje u splitskom časopisu Crkva u svijetu, kao što je studija „Zagonetka Popa Dukljanina“. Uz ovu studiju, što je posebno značajno pomenuti, on je objavio crtež lica i naličja pečata dukljanskog vladara arhonta Petra, što je prvi put učinjeno „u našoj povijesnoj literaturi““.33

Vrijedno je navesti slučaj koji se dogodio samo pola godine prije smrt S. Markovića Štedimlije. U vrijeme širokog otpora podizanju Njegoševa mauzoleja na Lovćenu, objavio je Savić Marković pismo podrške Odboru koji je radio na realizaciji toga velikog kulturnog poduhvata. ${ }^{34} \mathrm{U}$ tome pismu pomenuo je zločine koje su činile nad crnogorskim narodom srpske okupacione vlasti pri ugušivanju ustanka za odbranu crnogorske države (1919), pa da je kralj Aleksandar riješio da podigne kapelu, da bi time odobrovoljio Crnogorce

32 Takav slučaj je objavljivanje članka „Drugi Njegošev pogreb“ (Istorijski zapisi, knj. XIX, s. 2, Titograd, 1962, str. 291-302), koji nije potpisan ni pseudonimom. Članak je potvrda, iz drugih izvora, istraživanja Rista J. Dragićevića u članku „Prenos Njegoševih kosti na Lovćen“ (Članci o Njegošu, Cetinje, 1949, str. 213-217), u kome je utvrdio da je prijenos bio 8. septembra 1855. Tada je glavni urednik Istorijskih zapisa bio Mirčeta Đurović. U bibliografiji Istorijskih zapisa, čiji je autor bibliograf Vaso Jovović, unijet je pseudonim Ljubica Klančić (Istorijski zapisi, knj. XXIV, Titograd, 1977, str. 495), jer je vjerovatno Jovović našao sačuvani rukopis.

33 Savić Marković Štedimlija, „Zagonetka Popa Dukljanina“, Crkva u svijetu, br. 1, Split, 1969, str. 67-85. Uz snimak pečata vladara (arhonta) Petra napisao je Marković sljedeće podatke: „Francuski bizantolog Gustave Schlumberger objavio je 1884, u svojoj knjizi Sigillographie de l'Emprire Bisantine ovaj pečat dukljanskog vladara Petra (Petrislava), koji se tada čuvao u Kabinetu medalja u Berlinu, ali je uslijed raspadanja olovne legure vjerovatno odavna propao. Petar ili Petrislav bio je savremenik makedonskog cara Samuila, a vladao je Dukljom potkraj X ili početkom XI stoljeća. Naslijedio ga je na prijestolju sv. Vladimir, čiji životopis donosi Pop Dukljanin. Ovo je najstarije domaće vrelo za povijest Duklje, iako je na stranom jeziku. Sada se ovdje objavljuje prvi put u našoj povijesnoj literaturi“.

34 Savić Marković Štedimlija, „Znamo tko vodi kampanju protiv Njegoševa mauzoleja“, Vjesnik, Zagreb, 26. aprila 1970. Tekst je objavljen i u: Umetnost, br. 27-28, Beograd, 1971, str. 141-142. 
da „obustave otpor njegovu režimu“. S. Marković je na kraju konstatovao da je ta kapela trag ,jednog sramotnog vremena" koji treba ukloniti, a da je borba protivu Mauzoleja rezultat organizovane velikosrpske kampanje. Na njegovo pismo odmah je, u listu Pravoslavlje, reagovao episkop žički Vasilije. ${ }^{35} \mathrm{~S}$. Marković je uputio pismo (odgovor) glavnom uredniku Pravoslavlja, Milisavu A. Protiću, 8. juna 1970, ali on nije htio da ga objavi. ${ }^{36}$

Povodom 110 godina od Njegoševe smrti pojavio se Markovićev tekst o drami Śćepan Mali, pod imenom Ljubice Klančić. ${ }^{37}$ On zapaža da je malo pisano o drami Śćepan Mali, da je to djelo palo u zaśenak ranije objavljenih Njegoševih djela, ili što je to ometala cenzura Bahova apsolutizma. On je otkrio kritiku anonimnoga autora, pod naslovom Lažni car Šćepan Mali, koja je objavljena u četiri nastavka, u podlistku bečkog dnevnika Wiener Lloyd, od februara 1853, na njemačkom jeziku. Pomenuta kritika do tada u radovima o Njegošu nije pominjana, niti je zabilježena u bibliografijama, pa se može tvrditi da je bila nepoznata. S. Marković je taj članak, nepoznat „književnoj i naučnoj javnosti“, preveo na crnogorski jezik, uz svoje komentare, skrećući pažnju da je anonimni autor koristio Poviesnicu Crne Gore Milorada Medakovića, za podatke o životu Šćepana Maloga, kao i o Njegoševu odnosu prema tome samozvancu. Iste godine pojavila se u crnogorskome časopisu Istorijski zapisi njegova studija „Njegoševa misija u Beču 1850“, pod djelimično izmijenjenim pseudonimom - Ljeposava Klančić. Marković je u toj opširnoj radnji dokazao koji je bio glavni motiv Njegošev, da u hladnim danima, novembra i decembra 1850, iako je bio bolestan, putuje u Beč, osporavajući mišljenje onih autora koji su tvrdili da je cilj njegova putovanja bio da izmiri patrijarha Rajačića i budimskoga vladiku Platona Atanackovića. Austrija je bila spriječila da preko njene teritorije (iz Kotora) uvezu Crnogorci oružje koje je Njegoš bio kupio. Njegoš je bivao sve uvjereniji da će Omer-paša Latas, pošto u Bosni poništi otpor begova centralnoj vlasti (Porti), napasti Crnu Goru, što se i dogodilo dvije godine docnije. Austrija je bila zauzela neprijateljski stav prema Crnoj Gori, jer je tada bila u sporu s Pruskom, pa nije šćela dopuštiti Crnogorcima uvoz oružja da se ne bi zamjerila Turskoj, koja bi, u slučaju austro-pruskog rata, mogla biti saveznica Pruske. Njegoš je, uz posredovanje bana Jelačića, uspio da predśednik vlade Švarcenberg ukloni zabranu prono-

35 E(piskop) ž(ički) V(asilije), „Nekvalifikovani reporter“, Pravoslavlje, br. 75, Beograd, 14. maja 1970, str. 4. Vasilije tvrdi da Marković „izmišlja stvari koje je svakako nekad sanjao ili sanja pa mu se one sada čine kao prava realnost".

36 O tome pismu vidi: D. Radojević, Tri zabranjene knjige Savića Markovića Štedimlije, Podgorica 2008, str. 16-17.

37 Ljubica Klančić, „Kritika Šćepana Malog od jednog Njegoševog savremenika“, Stvaranje, br. 9-10, Cetinje, 1961, str. 735-751. 
šenja oružja preko Kotora. Ta odluka došla je pošto je uz posredovanje ruskog cara postigut sporazum između Austrije i Pruske.

U radnji „Šest priloga o Njegošu“38 obradio je Marković šest tema, dokumentovano i sažeto. Kad su u pitanju rezultati arhivskih istraživanja Rista J. Dragićevića, oko različitog datiranja Njegoševa rođenja, ${ }^{39}$ Marković je, odajući priznanje njegovu istraživačkom naporu, našao nove podatke koji potvrđuju Dragićevićev zaključak. Književnik Stanko Vraz, koji je visoko cijenio Njegoševo pjesničko djelo, kad je odlučio da piše o Gorskom vijencu i Luči mikrokozma, zatražio je od Milorada Medakovića da mu uputi Njegoševe biografske podatke. Medaković, koji je tada bio Njegošev sekretar, uputio je Stanku Vrazu, u februaru 1848. godine, tražene biografske podatke, koje je vjerovatno dobio od samoga Njegoša. U toj biografiji stoji da je rođen 1. novembra 1813. godine. Original te biografije čuva se u Nacionalnoj biblioteci u Zagrebu, odakle je S. Marković prepisao i prvi put publikovao. U prilogu pod naslovom „Da li je Njegoš posjećivao amerikanski brod u Napulju?“ - otklonio je S. Marković mistifikaciju Ljubomira Nenadovića koji je opisao navodnu Njegoševu, i njegovu, pośetu tome vojnom brodu. Njegošev sestrić Stefan Perović Cuca, na osnovu pisama koje mu je upućivao Njegošev pratilac Đuko Sredanović, objavio je podatak da je Njegoš, prije nego je Nenadović došao u Napulj, pośetio francuski ratni brod koji se bio ukotvio u napuljskoj luci. ${ }^{40} \mathrm{Da}$ bi provjerio Nenadovićevo kazivanje, Bogdan Lj. Popović pregledao je arhiv američke mornarice iz 1851. godine i nije našao pomen Njegoševe pośete američkom brodu „Nezavisnost““ ${ }^{41}$ Ta Popovićeva istraživanja podstakla su Savića Markovića da pokaže da Nenadovićeva Pisma iz Italije nijesu pouzdana kao istorijski izvor, ,iako su dragocjen dokumenat o Njegošu kao ličnosti““. Potrebno je skrenuti pažnju i na Markovićev zapis „O jednoj namjeri da se ubije Njegoš“, u kome je sugerisao da bi, provjerom arhivske građe, bilo potrebno utvrditi da li je Austrija imala saučesništva u toj zamisli.

U velikoj studiji „Spolia opima““42 Savić Marković je tragao za porijeklom kod Crnogoraca ratnoga običaja śečenja glava neprijateljskim vojnicima u boju, i odnošenja kao ratnoga trofeja. Taj običaj je postojao u vojsci Rimske Imperije. Izraz spolia opima najprije je označavao materijalni ratni plijen, a

38 Savić Marković Štedimlija, „Šest priloga o Njegošu“, Književnost, Beograd, 1963, str. 160-180. Časopis Književnost, čiji je urednik bio Eli Finci, a sekretar redakcije Svetlana Velmar-Janković. I ta radnja bila je potpisana istim pseudonimom (Ljubica Klančić).

39 R. J. Dragićević, „Godina Njegoševog rođenja“ u: Članci o Njegošu, Cetinje, 1949, str. $27-35$.

$40 \quad$ Serbske novine, br. 21, 22. feb. 1851.

41 Prilozi za književnost, istoriju, jezezik i folklor, 1-2, 1959.

42 (Ljubica Klančić), „Spolia opima“, Glasnik Etnografskog muzeja na Cetinju, knj. III, Cetinje, 1963, str. 219-276. 
u taj plijen spadala je i glava vođe neprijatelja. Śečenje glava protivniku bio je i turski običaj, koji su Crnogorci prihvatili od njih, da bi im vraćali, za počinjeno zlo, na isti način. Tokom viševjekovnog otpora agresorima, kod Crnogoraca je običaj śečenja glava dobijao „naročit smisao, različit od smisla što ga ima kod drugijeh naroda“. Njegoš je tvrdio da Crnogorci sijeku glave samo u sudarima s Turcima, a da to ne čine neprijateljima koji su hrišćani. Duh ratnoga natjecanja podstakao je Njegoš podizanjem Tablje (kule) na platou iznad Cetinjskoga manastira, 1835. godine ${ }^{43}$ Tablja je podignuta da bi u njoj bio smješten odred straže, 24 stražara i jedan serdar. Marković misli da su na Tablji isticane turske glave od 1836. godine, jer je za to bio jak motiv: pogibija 52 Crnogorca na Grahovu. Prilikom pośete Crnoj Gori (1844), engleski egiptolog J. G. Vilkinson, ${ }^{44}$ govorio je Njegošu da treba odustati od toga varvarskog običaja. Njegoš mu je odgovorio, da bi Crnogorci odustali, ali kad bi to prvo učinili Turci, jer kad bi bilo prvo crnogorsko odustajanje, onda bi se to kod Turaka shvatilo kao crnogorska slabost. Tada je Vilkinson pošao u Mostar, kod hercegovačkoga Ali-paše Rizvanbegovića, da posreduje, da bi Turci prvi odustali od śečenja glava. To posredovanje opisao je sam Vilkinson. Marković smatra da je isticanje turskih glava na Tablju trajalo do septembra 1850. godine. Turci su mnogo ranije metali pośečene crnogorske glave na više tvrđava: Skadar, Podgorica, Spuž, Nikšić, Mostar, Trebinje, Travnik, i dr. Studija „Spolia opima“ rezultat je širokoga istraživanja u izvorima i literaturi, što S. Markovića Štedimliju izdvaja među rijetke, uzorne istraživače crnogorskoga stanja duha Njegoševa vremena.

Poznato je da je Njegoš pokušavao da se prilagodi odnosima koji su vladali u aristokratskim društvima tadašnje Evrope, da bi smanjio prepreke u komunikaciji crnogorskih predstavnika s institucijama tih zatvorenih krugova. Marković je otkrio u bečkome arhivu tri diplome koje je Njegoš izdao Stefanu Peroviću Cuci, Andriji Peroviću i Ivanu Aleksiću, da su pripadnici „drevne visokoblagorodne crnogorske familije“, odnosno „starinske kneževske porodice“. Stefan je, uz tu diplomu, predao molbu u Beču da bi se mogao potpisivati titulom „knez“, ali ta molba nije bila prihvaćena. ${ }^{45} \mathrm{Te}$ činjenice dopunjavaju sliku Njegoševa vremena, u kome se ostvarivao kao pjesnik, državnik i diplomata.

43 Sto godina docnije, 1935, Tablju je porušila inžinjerska jedinica Zetske divizijske oblasti, zbog pripreme terena za podizanje katedrale koja je trebala biti posvećena Savi Nemanjiću (D. Radojević, „Još jedan atak na Cetinjski manastir“, u: Opet crnogorske teme, izd. DANU, Podgorica, 2009, 91-96.)

44 John Gardner Wilkinson autor je knjige Dalmatien und Montenegro (London, 1848).

45 (Ljubica Klančić), „Njegoševe diplome“, Književne novine, br. 299, Beograd, 15. aprila 1967, str. 9. 
U svojoj knjizi Petar Petrović Njegoš (Moskva, 1887), P. A. Lavrov naveo je ocjenu situacije u Crnoj Gori nakon Njegoševe smrti, iz časopisa Ruskij arhiv, za godinu 1867, kao izvještaj anonimnoga ruskog diplomate. Više je istraživača tragalo za tim tekstom, ali ga nijesu uspijevali naći, jer ga u toj godini izlaženja Ruskog arhiva nije bilo. Istoričar Risto J. Dragićević, u radnji „Crna Gora krajem 1851. godine“ ${ }^{46}$ piše da „, našoj zemlji niko nema traženi Ruski arhiv"za 1867. godinu. Međutim, S. Marković Štedimlija otkrio je da je u pomenutoj knjizi P. A. Lavrova pogrešno navedena godina kad je tekst anonimnog ruskog diplomate objavljen, jer je publikovan 1876. godine, tj. deset godina docnije. Marković je dalje utvrdio da se tu ne radi o jednome anonimnom članku, ,nego o nizu povjerljivih političkih izvještaja nekog diplomatskog činovnika, koji je, po svoj prilici, bio na radu u ruskom poslanstvu u Beču“. Ti izvještaji su objavljeni pod naslovom Crnogorski poslovi, i oni otkrivaju odnos Rusije prema Crnoj Gori, o prilikama poslije Njegoševe smrti, do početka 1852. godine. Videći značajne podatke u tim izvještajima, Marković ih je preveo na crnogorski jezik, i uz svoje vrijedne komentare, učinio dostupnim naučnoj javnosti. ${ }^{47}$

Kad govorimo o Saviću Markoviću Štedimliji kao tumaču Njegoševa uticaja na crnogorsku nacionalnu svijest, nužno je pomenuti njegovu studiju Osnovi crnogorskog nacionalizma ${ }^{48}$ đe je valjano ocijenio dugotrajni udio Njegoševe misli koja je zbog pjesničkog uobličenja bila sugestivnija. Marković kaže da je Njegoš ,udario sve temeljne kamenove crnogorskom nacionalizmu, ali ne pod pravim imenom, te ostavio vrata na sve strane (otvorena) za njegovo dalje formiranje“. On je na toj konstataciji zastao, nije pomenuo uticaj S. M. Sarajlije na mladoga Njegoša ${ }^{49}$

Proučavanje Njegoševa državničkog i pjesničkog puta vršio je Savić Marković Štedimlija u međuratnome periodu, od 1931. do 1940. godine, a zatim poslije izlaska iz ruskih i jugoslovenskih zatvora, od 1960. do 1969. godine. U člancima koji su nastajali prije Drugoga svjetskog rata preovlađuje publicistički metod koji sadrži i polemičke elemente. Ti su članci i obimom kraći. U drugoj fazi svoga rada, kad je mogao, zbog sudske zabrane, da objavljuje samo pod pseudonimom, nastajale su radnje koje su rezultat arhivskoga i drugoga istraživanja. U njima je Savić Marković donosio do tada nepoznate činjenice iz Njegoševa života. Ove radnje, svojim bogatstvom novih viđenja

46 Risto J. Dragićević, „Crna Gora krajem 1851. godine“, Istorijski zapisi, sv. 1, 1953.

47 Savić Marković Štedimlija, Borbe i intrige oko nasljedstva Petra II Petrovića Njegoša, Zagreb, 1969.

48 Savić Marković Štedimlija, Osnovi crnogorskog nacionalizma, Zagreb, 1937, str. 109. Isto u: Tri zabranjene knjige Savića Markovića Štedimlije, izd. DANU, Podgorica 2008.

49 Vidi o tome: D. Radojević, CXIV godina i ličnosti, izd. DANU, Podgorica 2011. 
činjenica, kao i naučnom obradom - predstavljaju nezaobilaznu dopunu odabrane literature o Petru II Petroviću Njegošu.

\section{Bibliografija}

- Črrgić, Adnan: „Je li Njegoš genocidni pjesnik“, Matica, br. 55, 2013.

- Dragićević, Risto J.: „Crna Gora krajem 1851. godine“, Istorijski zapisi, Sv. $1,1953$.

- Dragićević, Risto J.: „Godina Njegoševog rođenja“, u: Članci o Njegošu, Cetinje, 1949.

- Nikolajević, Dušan S.: „Revizija vrednosti Gorskog vijenca“, Pravda, 1928.

- Radojević Danilo: CXIV godina i ličnosti, Dukljanska akademija nauka i umjetnosti, Podgorica, 2011.

- Radojević, Danilo: „Njegoš, njegovo vrijeme i djelo“, predgovor Gorskome vijencu, Školska knjiga, Zagreb, 1981.

- Radojević, Danilo: Opet crnogorske teme, Dukljanska akademija nauka i umjetnosti, Podgorica, 2009.

- Radojević, Danilo: Tri zabranjene knjige Savića Markovića Štedimlije, Dukljanska akademija nauka i umjetnosti, Podgorica, 2008.

- Rječnik Njegoševa jezika, knj. II, Beograd - Titograd - Cetinje, 1983.

- Štedimlija Savić Marković (Ljubica Klančić): „Njegoševe diplome“, Književne novine, br. 299, Beograd, 1967.

- Štedimlija Savić Marković, Borbe i intrige oko nasljedstva Petra II Petrovića Njegoša, Zagreb, 1969.

- Štedimlija, Savić Marković (Klančić, Ljubica): „Kritika Šćepana Malog od jednog Njegoševog savremenika“, Stvaranje, br. 9-10, Cetinje, 1961.

- Štedimlija, Savić Marković (Marković, Tomaš): „Njegoševo zanimanje za Lipsku pećinu“, Stvaranje, 9-10, 1961.

- Štedimlija, Savić Marković (Marković, Tomaš): Istorija prosvjete i školstva u Crnoj Gori, Zavod za izdavanje udžbenika Socijalističke republike Srbije, Beograd, 1969.

- Štedimlija, Savić Marković (Ljubica Klančić): „Spolia opima“, Glasnik Etnografskog muzeja na Cetinju, knj. III, 1963.

- Štedimlija, Savić Marković: „Degradiranje Njegoša. Psihologija u Gorskom vijencu od Dragoljuba Brankovića“, Zeta, br. 10, 1936.

- Štedimlija, Savić Marković: „Djelo sestre Batrićeve“, Nova Evropa, br. 11, Zagreb, 1935.

- Štedimlija, Savić Marković: „Dr Henrik Batovski o Crnoj Gori“, Zeta, br. 7, Podgorica, 1938. 
- Štedimlija, Savić Marković: „Dramatizacija Gorskog vijenca od Stanka Perunovića, Zeta, 1934.

- Štedimlija, Savić Marković: „Gete i Njegoš“, Zeta, br. 39, sv. 4-5, br. 40, Podgorica, 1934.

- Štedimlija, Savić Marković: „Gorski vijenac anatemisan“, Zeta, god. 8, Podgorica, 1937.

- Štedimlija, Savić Marković: „Gundulić i Njegoš“, Obzor, br. 42, Zagreb, 1938.

- Štedimlija, Savić Marković: „Ko kleveta Njegoša“, Zeta, br. 46, 1935.

- Štedimlija, Savić Marković: „Neslaganje Njegoša i Mažuranića, Letopis matice srpske, sv. 1-2, jul - avgust, 1931.

- Štedimlija, Savić Marković: „Njegoš i Tomazeo“, Obzor, br. 186, Zagreb, 1937.

- Štedimlija, Savić Marković: „Njegoševa formula sile“, Nova Evropa, knj. XXVI, br. 12, Zagreb, 1933.

- Štedimlija, Savić Marković: „Njegoševa teorija genija“, Zeta, 1937.

- Štedimlija, Savić Marković: „Osveta kao kršćanska dužnost“, Mladost, god. XII, br. 9, Zagreb, 1933.

- Štedimlija, Savić Marković: „Šest priloga o Njegošu“, Književnost, Beograd, 1963.

- Štedimlija, Savić Marković: „Vatronosne riječi. Njegoš pjesnik slobode“, Naša zemlja, god. III, br. 2, Beograd, 1939.

- Štedimlija, Savić Marković: „Zagonetka Popa Dukljanina“, Crkva u svijetu, br. 1, Split, 1969.

- Štedimlija, Savić Marković: „Znamo tko vodi kampanju protiv Njegoševa mauzoleja“, Vjesnik, Zagreb, 1970.

- Štedimlija, Savić Marković: Crna Gora u Jugoslaviji, 1936.

- Štedimlija, Savić Marković: Deset godina u gulagu, knjiga I i II, Matica crnogorska, Podgorica, 2004.

- Štedimlija, Savić Marković: Osnovi crnogorskog nacionalizma, Zagreb 1937.

- Štedimlija, Savić Marković: Skidanje maske, Zagreb, 1932.

- Vasilije, episkop žički: „Nekvalifikovani reporter“, Pravoslavlje, br. 75, 1970.

- Wilkinson, John Gardner: Dalmatien und Montenegro, London, 1848. 


\section{Danilo RADOJEVIĆ}

\section{SAVIĆ MARKOVIĆ ŠTEDIMLIJA ON NJEGOŠ AND MONTENEGRO OF HIS TIME}

The present paper discusses the study of Njegoš statesmanship and poetic works, conducted by Savić Marković Štedimlija in the interwar period, from 1931 to 1940, as well as after leaving the Russian and Yugoslav prisons, from 1960 to 1969. The articles created before World War II are characterized by a journalistic method comprising polemical elements. These articles are shorter as well. In the second phase of his work, when he could, because of an injunction, publish his work only under a pseudonym, Štedimlija created works on the basis of archives and other research, bringing previously unknown facts from Njegoš's life to light. In their wealth of new perceptions of facts and scientific analysis - these studies must supplement the selected literature about Petar II Petrović Njegoš.

Key words: Njegoš, Savić Marković Štedimlija, Montenegrin literature 


\section{Sofija KALEZIĆ-ĐURIČKOVIĆ (Podgorica)}

Fakultet za crnogorski jezik i književnost - Cetinje sofija.kalezic@fcjk.me

\section{CRNOGORSKA KNJIŽEVNOST ZA DJECU I OMLADINU ODLIKE I PREDSTAVNICI}

U vremenu nakon Drugog svjetskog rata, koje je u književnoj istoriji označeno pod kumulativnim nazivom neorealizma, dolazi do ekspanzivnijeg razvoja književnosti za djecu i omladinu, nego što je to bio slučaj u minulim epohama.

Savremena crnogorska književnost naznačene epohe posvećene mladima i njihovim uzrasnim preokupacijama, nije se mogla razvijati nezavisno od korijena koje je nosila. Sa današnjeg aspekta svakako može biti zanimljivo koliko su ovi stvaraoci vješto uspijevali da u tkivo savremenog svijeta djetinjstva upliću niti tradicionalnog epskog etničkog duha, te osjećanje crnogorskog čovjeka i njegovog podneblja. Njihova proza govori u prilog onome što je tada bilo savremeno, ali se kroz takav spoljašnji plašt lako može prepoznati biće prošlosti. Takva vrsta literature djelovala je u pozitivnom smislu vlastitim pedagoškim efektom jer je mladom čovjeku pomagala da razumije puteve koji su drugi prelazili do njenih ideala, a koji su se, pored svih stradanja i patnji, morali nastavljati da bi i dalje bilo života. I pored toga što u Crnoj Gori nijesu postojali uslovi pogodni za razvoj književnosti za djecu, kakvi su i prije romantizma postojali u drugim područjima Balkana, već od pojave prvog romana ovakve vrste - Svemoćnog oka Čeda Vukovića 1953. godine, preko ostvarenja Dušana Kostića, Mihaila Ražnatovića, Mihaila Gazivode, Ante Staničića, Mirka Vujačića, Milenka Ratkovića, Dušana Đurišića, Dragana Radulovića i ostalih autora, crnogorska književnost za djecu i omladinu uvedena je u tokove moderne južnoslovenske i evropske literature ovakve profilacije.

Ključne riječi: tradicija, književnost, rat, Crna Gora, stvaralaštvo, djeca, omladina

Djelo samo ne može da ostvari svoje potencijalne funkcije, već o njihovom ostvarivanju odlučuje odnos djelo - čitalac.

Manfred Nauman 
Tradicija epske pjesme, a samim tim i kulture pripovijedanja u Crnoj Gori bila je veoma razvijena, pa je vrijeme nakon Drugog svjetskog rata iznjedrilo cio niz kvalitetnih autora za djecu (Čedo Vuković, Dušan Kostić, Mihailo Ražnatović, Stevan Bulajić, Mihailo Gazivoda, Ante Staničić, Mirko Vujačić, Ivan Ceković, Milenko Ratković i drugi), od kojih su se mnogi od njih primarno afirmisali kao pisci za odrasle, koji su se u kraćim ili dužim vremenskim intervalima, vraćali tzv. dječjem stvaralaštvu. Karakter ovih djela vrlo je raznovrstan, od Tima 'Lavlje srce' (1956) Čeda Vukovića i njemu srodnih ostvarenja modelovanih pretežno humorističkim manirom, sa motivom antropomorfizacije životinjskog svijeta, do pričalačke linije koju njeguje u Stevan Bulajić u romanu o divljim guskama Krilati karavan (1955), u kojoj se kroz dramu ptičje seobe i sticanja životne škole naziru prva „rasterećenja“ životinjskih junaka od ljudskih karakteristika.

„I dok je srpska književnost, kao i druge nacionalne literature kontaktnih naroda", o osobenostima crnogorske dječje književnosti pisao je Milorad Nikčević, ,imala svoju genealogiju, kontinuitet razvoja i afirmisane predstavnike književnosti za djecu još u periodu romantizma i svoju istaknutu dječju periodiku, dotle se u crnogorskoj književnosti takav književni žanr nije zadugo mogao javiti. Iako je bilo pokušaja da se stvori neki oblik književnosti za djecu, rezultati su na estetskom planu i sadržaju bili mršavi ili skoro zanemarljivi, što je razumljivo kad se u obzir uzmu specifičnosti razvoja crnogorske literature. Crnogorska književnost je nosila u svojoj sredini prvenstveno predznak tradicionalne književnosti epskoga sadržaja. Nije se, dakle, ni mogla roditi takva inspirativna klima koja bi podsticala stvaraoce epske sredine da progovore intimno, emotivno o svojim ljubavnim, lascivnim, satiričnim, a kamoli dječjim emocijama i osjećajima“" (Nikčević 2011: 153).

U tekstu Naznake crnogorske poezije za djecu krajem XIX i početkom $X X$ vijeka Nikčević nabraja niz danas gotovo potpuno anonimnih autora, koji su se sa više ili manje uspjeha oprobali u domenu poetskog dječjeg stvaralaštva, od Krsta R. Jovanovića (1855-?), Rista M. Popovića-Čupića (1870-1922) do Krsta V. Markovića (1882-1902), Nikole D. Vučetića (1884-1918) i ostalih autora. Ovaj proučavalac jezika i književnosti ističe da su stvaraoci crnogorske literature dugo bili istinski čuvari epskih zbivanja, pa su se čak ustručavali da vlastite emocije, ljubavne porive i najsuptilnija osjećanja javno izliju u literarna djela. Moguće da je sklonost crnogorskog naroda ka priči i pričanju, poštovanju tradicije i epskog duha predaka, doprinijela da dominantan žanr u domenu stvaralaštva za djecu i omladinu postane roman, nerijetko u kritičkoj i teorijskoj literaturi nazvan kraljem literarnih vrsta, koji na najuspjeliji način sublimira lirske, epske i dramske elemente.

Od autora rođenih početkom XX vijeka koji su se na uspio način opro- 
Crnogorska književnost za djecu i omladinu: odlike i predstavnici

bali u domenu dječje poezije izdvaja se ime Radovana Stevovića (Kobilji Do, Cetinje, 1910 - Meljine, Herceg Novi, 1989), koji je svojom poetskom zbirkom Pjesme za djecu (Ruski Krstur, 1982) unio ne samo inovacije u strukturu dotadašnje rime, nego i savremen način tretiranja djeteta, njegovih interesovanja, potreba i mjesta u okviru porodičnog života. Stevovićeve Pjesme za djecu predstavljaju neobičnu tvorevinu, poetski prvijenac autora koji je ušao u osmu deceniju života. „Posle uspješnog rada na epskoj poeziji, pisac se 'pod bjelinom inja' prihvatio dečje lire da, kao podmlađena jesenja trava, okupi decu oko sebe i da im po kosi prospe zvučne akorde", u pogovoru ovom djelu pisao je Milorad Radunović. „U ovoj knjizi istinski nežni deda peva svojim unucima. Iskrena i elementarna roditeljska ljubav prema deci struji u ovim pesmama kao topli fluid u predele dečjih snova i osećanja“ (Radunović 1982: 32).

Ako zanemarimo ponekad nedopjevano poetsko tkivo u nekoliko pjesama ove zbirke, bićemo nagrađeni toplom prirodom gorštaka koji pjeva potomstvu. Autor zaviruje u mnoge uglove dječjeg života i za svoje pjesme pronalazi žive i privlačne detalje. Prostrano je područje njegove misaonosti i osjećajnosti - od razigranih predmeta, do pravog kamiona ili autobusa, od sniježnih planina do vojvođanske ravnice. „Veseli i dinamični ritam, detalj u pokretu, živa slika - sve je to blisko Stevoviću - čiji stihovi često odišu naglašenom muzikalnošću (Bački ovčar, Snješko, Opasna kuca). Pored ovog, Radovan Stevović ume da okupi decu oko priče, oko svog doživljaja, da bi ih na svoj način zasmejao (Lov na medvjeda). Raznorodne životinje u Pećini u ruju mogao je da okupi zajednički stan ili samo autorov san... Zaista, Stevovićev duh u ovim pesmama deluje kao podmlađena jesenja trava“, Radunović nastavlja vlastitu impresiju o Stevovićevoj poeziji za djecu (Radunović 1982: 33).

Životinje i biljke dominiraju u ovoj knjizi, ali u njoj ima i urbanog života koji često junake dovodi u smiješne situacije (Baka i djed, Maleri u kući). Od slike razigrane mladosti (Berba), do statičnog portretisanja dvorišta (Djedovo dvorište), pjesnik lako pronalazi poetske motive u detaljima iz svakodnevnog života. U Stevovićevim pjesmama ima duboke senzibilnosti kada su u pitanju oni koji se žrtvuju za druge (Pozdrav majci) i tihe roditeljske čežnje za djecom koja su daleko od njega, pa im po macama sa razglednica šalje pozdrav (Razglednica).

Pripovjedačka ostvarenja Mihaila Gazivode (Drušići, Rijeka Crnojevića, 1908 - Vršac, 1971) zauzimaju značajno mjesto u crnogorskoj literaturi za mlade. Njegove poznate knjige priča i pripovjedaka za djecu nose nazive: Trojka (1956), Da vam povjerim (1964), Ogrebotine (1970) i Razgovor uz oganj (1971). Roman za djecu Lanac ovaj stvaralac je publikovao u Sarajevu, 1965. godine. Cjelokupno njegovo stvaralaštvo oslanja se na dva važna elementa - na ljepotu pejzaža i svježinu zavičajnog podneblja i istovreme- 
no škrtost prirode i nedostatak osnovnih uslova koji bi njenim stanovnicima omogućili pravo na podnošljiv i dostojanstven život. Gazivodine priče iz zbirke Razgovor uz oganj ispripovijedane su u prvom licu jednine, što njegovoj prozi daje notu iskrenosti i neposrednosti. U svim ostvarenjima glavni junak je dječak Mirko Otašević, čiji umjetnički lik sadrži upečatljivu dimenziju autobiografskog, po čemu je ovaj pisac sličan Kostiću.

Mirkov životni krug čini porodica u kojoj se osjeća da je značajno okrnjena za njenog najvažnijeg člana - majku. On majku nije uspio ni da zapamti i ova velika praznina koju dječak nosi u sebi izrasta u lajtmotiv ove zbirke pripovijedaka. I pored toga što se o majci i uspomenama vezanim za nju ne govori nikada na otvoren način, Mirko utoliko intenzivnije osjeća da njegovo djetinjstvo nije ni nalik djetinjstvima njegovih drugova koji rastu okruženi materinskom ljubavlju i brigom. Očeva majka, njegova baka, Mirkovu bol ublažava nekada sa više, a nekada sa manje uspjeha. U porodičnoj trojci koju čine dječak, otac i baka, ona je umjetnički ostvarena sa puno pozitivnih osobina, od strpljenja, tolerancije i sposobnosti opraštanja do požrtvovanosti, nesebičnosti i snage koja joj pomaže da se bori sa životnim nedaćama.

Gazivodin narativni stil krasi dinamičnost kazivanja i pročišćenost izraza, a njegov rječnik je obogaćen raznovrsnim arhaizmima, starinskim, već zaboravljenim riječima - turcizmima, tuđicama i provincijalizmima. Svi ovi elementi čine da njegov način vođenja priče djeluje nenametljivo, prirodno i originalno. U romanu Lanac autor primjereno omladinskom uzrastu tretira društvenu, porodičnu i ljubavnu tematiku. Oslikavajući osjetljivo doba adolescencije, pisac je ponudio sliku prvih treptaja srca i duše, kroz emotivni odnos glavnog junaka Peka prema nekoliko djevojaka - Vesni, koja predstavlja predmet njegovih želja i maštanja, a potom Ljilji i Nadi, drugaricama koje gaje očigledne simpatije prema njemu.

Posebno treba istaći zanimljivo strukturiranje romana koje sprovodi Mihailo Gazivoda - poigravajući se vremenskim planovima pripovijedanja, on interpolira u osnovnu narativnu nit junakova sjećanja, koja su u vezi s konkretnim događajima. U tom smislu motivacija uvođenja raznih reminiscencija, gotovo uvijek je opravdana. Kada se na samom početku romana govori o Pekovom polasku i gimnaziju i o tome da u novoj školskoj sredini ima dosta njemu poznatih lica, spominje se i Vesna. Odmah nakon toga slijedi odlomak koji govori o njihovom upoznavanju, koji narator smješta u sadašnji trenutak. Završavajući datu priču, slijedi vraćanje na osnovnu nit - pripovjedač prelazi na nabrajanje novih drugova, što predstavlja okvir da se navede po neka upečatljiva epizoda iz prošlosti u vezi sa svakim od njih.

Razvijen motivacioni okvir ovog romana, sa kojim se konstantno prepliće zanimljiva organizacija vremena pripovijedanja, javlja se kao osnovni 
kvalitet ove Gazivodine proze. Navedeni djelovi štiva djeluju kao da pripadaju istom narativnom kontekstu; riječ je o mnoštvu događaja među kojima se pripovijeda o periodu adolescencije, kroz koji duvaju vjetrovi dva sasvim suprotna svijeta - djetinjstva i odraslih. U osnovi ovog romana, o čemu govori i njegov naslov, jeste priča o odrastanju i potrebi pojedinca da bude prihvaćeni dio društvenog konteksta, još jedna karika u lancu ljudi koji se međusobno grupišu prijateljskim i generacijskim vezama.

Ante Staničić (Tivat, 1909 - Beograd, 1991) predstavnik je pustolovno-realistične proze za djecu i mlade. Takvu poetiku on razvija već od prvoga romana Mali pirat (1956), sve do posljednjega pod nazivom Nemirna (1991). Smatra se autorom koji je uspio da izgradi jedan od najkvalitetnijih obrazaca crnogorske literature za djecu i omladinu. Staničić je objavio i tri zbirke priča: Binga (1974), Minuš (1977) i Đerdan priča za decu (1979), koje zajedno sa njegovim romanima, od kojih je Mali pirat uvršten u nastavne programe obavezne lektire, čine korpus pustolovno-realističke proze namijenjene mladima. Piščev zavičaj - primorje i more predstavlja osnovni prostor na kojem se realizuje radnja većeg segmenta njegovih ostvarenja. U Staničićevom djelu umjetnički su dočarani Budva, Tivat, Bokokotorski zaliv, a veći dio asocijacija vezan je za piščevo djetinjstvo, putovanja i plovidbe. Zbivanja u njegovim ostvarenjima su veoma dinamična, a doživljaji junaka neobični, dok je fabula po pravilu istorijski zasnovana $i$ ispričana uvjerljivim realističkim modelom.

Živo vođenim dijalozima, uz dokumentanost i motive pronađenog zapisa, autor na literarno ubjedljiv način stvara elemente romanesknog svijeta. U umjetničkoj predstavi djela fabulativna zanimljivost ima važnu ulogu, otkrivajući izuzetnost junaka putem cijelog spektra pozitivnih i negativnih emocija, opise prirode i ostale strukturne elemente, koji su nosioci sadržajne interesantnosti i sugestivnosti. Avanturističkim prosedeom ili sudbinskim čekanjem, autor zaustavlja akciju, što potencira stvaranje različitih moralnih i etičkih stavova likova. Stoga je Staničić nazivan romanesknim hroničarem Boke Kotorske, koji u svojim ostvarenjima oživljava jedan minuli svijet i njegove kulturne obrasce.

Djeca u ostvarenjima Anta Staničića locirana su po pravilu u primorski ambijent, u čijim okvirima osjećaju čari stvarne sreće. Ovaj autor je osjetio elementarnu snagu prirode, a iz prirode je upio zvuke i pokrete, tajanstva iskonske ljepote i mnoge specifične oblike života. Priroda je u njegovim djelima nepredvidljiva i ponekad surova, u njoj je mnogo uvala, vrtača i visova. On, kao i djeca u njegovim pripovijetkama i romanima, voli tu i takvu prirodu bez obzira što su uslovi za egzistenciju teški, opori i često sputavajući. Međutim, u njegovom djelu ne osjeća se okovanost i skučenost, ono zrači ljubavlju, nadom i toplinom i vjerom u moć prijateljstva i solidarnosti. 
Zajedno sa Gazivodom i Staničićem, Dušan Kostić (Peć, 1917 - Meljine, Herceg Novi, 1997) jedan je od najizrazitijih crnogorskih autora literature namijenjene djeci i omladini. Neposredno nakon rođenja u Peći, on iste godine ostaje bez oca i prelazi s majkom u Crnu Goru, te najupečatljiviji dio djetinjstva provodi na obalama Plavskog jezera i rijeke Lima, između planina Prokletija i Visitora. Za dječju je čitalačku publiku napisao poemu Gradić Jelengaj (1954) i romane Gluva pećina (1956), Sutjeska (1958), Modro blago (1963) i Gora Koštanova (1967). U crnogorskoj književnosti za djecu Dušan Kostić se javlja na samom početku njenog konstituisanja, te se eksponira svega tri godine nakon pojave romana Svemoćno oko Čeda Vukovića, 1953. godine, koji se smatra prelomnicom u domenu dječjeg stvaralaštva na navedenom prostoru.

Svojom Gluvom pećinom (1956) on promoviše žanr dječjeg ratnog romana, u crnogorsku literaturu za najmlađe unoseći obilježja sovjetske književnosti, koja je poslijeratnih godina vršila intenzivan uticaj na domaću kulturnu scenu u gotovo svim njenim domenima. U Gluvoj pećini autor opisuje dizanje ustanka u Crnoj Gori i pogibiju grupe komunista. I pored toga što je predmetno vezan za početak Drugog svjetskog rata, ovaj istorijski događaj prisutan je samo kao narativna podloga, a glavni sukob u djelu izveden je na dva osnovna plana: partizani-četnici i domaće stanovništvo-okupator. U pripovjednom nukleusu tretiran je fenomen dvoumljenja i previranja stanovništva, koje od ove dvije strane ne zna kojoj treba da se prikloni. Kao idejnu okosnicu svog romanesknog prvijenca, autor je koristio čitav spektar različitih etičkih dilema.

Svejedno da li je riječ o radnji, stanju ili raspoloženju, ritam prikazivanja i umjetničke slike koje se smjenjuju, nizovi motiva, njihove veze i uzajamnosti u ovom djelu brze su i dinamične. Izraz i rečenički sklop pojednostavljen je, što je uslovljeno potrebom stvaraoca da literarne predstave budu komunikativne s uzrastom kojem je djelo namijenjeno. Duh naivizma, koji je prisutan u romanu, predstavlja početni impuls u Kostićevom stvaralaštvu. Budući da djeca preuzimaju glavne uloge u romanu, ovo ostvarenje je prožeto njihovim inventivnim i nesmirenim duhom. Istorijski događaj odigravanja bitke na Sutjesci prikazan je u pozadini, a primarno umjetničko mjesto zauzelo je spisateljevo oslikavanje unutrašnjih sukoba i njegovo psihološko poniranje u svijest likova. Formiranje pripovijednog sižea na motivima Narodnooslobodilačke borbe i revolucije predstavljalo je osnovni literarni kreativni model nakon Drugog svjetskog rata u domenu romana za djecu i omladinu. Kostić u ovom ostvarenju pravi važan zaokret jer je jedan od prvih autora koji mališane ne prikazuje kao svemoguće junake, već kao individue nemoćne da se ratnoj stihiji odupru, ali koje opstaju zahvaljujući iskonskom nagonu samoodržanja. 
„Kad se opšti juriš na ratnu temu stišao i uglavnom poražena armija dječjih romansijera okrenula u drugom smjeru, jedan broj pisaca, pretežno onih koji su se već oglasili u periodu između dva rata, vratio se, ne bez nostalgičnog naboja. Istina, on je bio među piscima koji su možda imali najmanje razloga za to", o daljem razvoju ratnog dječjeg romana i vrijednosnom aspektu Kostićevih djela pisao je Novo Vuković. „Njegova dva ratna romana, Gluva pećina i Sutjeska, spadaju u red djela koja pred čitaocem ubjedljivo demonstriraju tragičnu poziciju djeteta u ratu; Sutjeska je čak vrlo dobar i nestandardan romaneskni tekst, u kom se uspjelo ukrštaju, razdvajaju i stapaju različiti tokovi radnje i u kom se fokus, neočekivano ali suptilno, pomjera sa opšte drame - drame bitke u kojoj se hiljade ljudi bori na život i smrt - na ličnu, psihološki bojenu dramu jednog djeteta, pred kojim se ruši njegov idilični svijet"“ (Vuković 2001: 134).

Izbjegavanje do tada obilato korišćene tzv. crno-bijele tehnike upadljivo je i u narednom autorovom romanu namijenjenom djeci - Modro blago (1967). I pored toga što je u središtu naracije već mnogo puta korišćen motiv zakopanog blaga, može se reći da se ovo ostvarenje sa izrazito akcionom podlogom da svrstati u kategoriju dječjeg romana sa poslijeratnom tematikom. U njemu je očigledna autorska tendencija za osavremenjivanjem i inovisanjem stvaralačkog postupka, dok je kompletan pristup tekstu uključivao dozu imaginativnosti i radoznalosti svojstvenoj dječjoj vizuri stvarnosti, koja je u prva dva romana djelimično izostala. Osim neprikrivene autobiografičnosti, ovo ostvarenje sadrži živ princip fabulativne angažovanosti, u najvećoj mjeri oličen u etičnosti junaka, model pripovijedanja blizak jednostavnosti narodnog kazivanja, svježinu zavičajnog jezika, izrazitu vaspitnu komponentu i druge.

Junaci u romanu Modro blago formirani su na osnovama kontrapunkta, kako psihičkih, tako i fizičkih obilježja. Svijet djece izražen je kroz suprotnost svijetu odraslih, sa tim što je u njemu nešto naglašenija lirska dimenzija međusobnih simpatija i prvih ljubavi nego u spominjanim ostvarenjima. Osim što su junaci pažljivo izvajani sa svim čistim odlikama koje djeca u realnosti posjeduju (ljubav prema igri, pripadnost kolektivu, poštovanje prijateljstva, sposobnost praštanja, iskrenost u odnosima, neiskvarenost i čednost), oni se javljaju kao sublimacija izrazite etičnosti, ispoljene u raznovrsnim situacijama, odnosno pripovjednim kontekstima. Insistiranje na ovakvom portretisanju junaka ispoljavao je i sam autor: „Osim forsiranja zanimljivosti fabule $\mathrm{i}$ istinitosti događaja, opšte atmosfere i opisa ambijenta, etičnost je okosnica sva četiri romana“, Kostić je ispoljavao stanovišta vlastite eksplicitne poetike. „Želja mi je bila da nju neosjetno ugradim u dušu mladog čitaoca - nije to gola didaktika“"(Milović 1990: 97). 
Fabula posljednjeg Kostićevog djela namijenjenog djeci - Gora Koštanova (1983) odvija se u mirnom i zabačenom bezimenom gradiću uoči Drugog svjetskog rata. Simbol koštana, kako se u lokalnom govoru naziva kesten, oslikava divljinu i čistotu prirodnih ljepota. Glavni akteri radnje su dječak Vuk sa malom porodicom koju čine majka i ujak Miljan, kao i Vukovi drugovi - Esad, Šoćko, Laban, Draško, Draškova sestra Jelka i drugi. U romanu se takođe eksponiraju i uspješno ostvareni epizodni likovi, kao što su, na primjer, stari ribar Omer Čoča, hodža Aljuš, učitelj Rakuš ili Draškov otac - načelnik Lazar. Pojedine od osnovih dimenzija romana, prezentirane već u uvodnom njegovom dijelu, jesu socijalne i egzistencijalne. Vuk živi u oskudnom vremenu, u veoma siromašnoj porodici, ozbiljno uskraćen za jednog od njenih najvažnijih članova - oca. Iako se u romanu o Vukovom ocu na neposredan način ne govori gotovo nimalo, nije teško primijetiti da u samoj atmosferi djela, naročito na njegovim početnim stranicama, dominira osjećanje praznine i uskraćenosti.

Angažovani odnos ovoga pisca oličen je u njegovoj potrebi da na mladog čitaoca vaspitno djeluje, ukazujući na društvene deformitete njegovog i našeg vremena. Pritom Kostićeva proza sadrži anticipativan smjer, budući da nijedno državno uređenje nije izolovano od devijantnosti kakve predstavljaju vjerska i nacionalna polarizovanost. Kostić nas usmjerava ka čovjekoljublju, toleranciji i širini, značaju lijepe riječi i prijateljstva, neophodnosti uzajamne podrške i razumijevanja. Misao da je čovjek u svakom momentu odgovoran prema svojoj porodici, zajednici u kojoj se razvija i vremenu koje dolazi predstavlja jednu od značajih idejnih okosnica njegovih djela navedene profilacije.

Dok u poemi razvija legendu o nastanku čudesnog planinskog jezera u središtu bujne vegetacije, Dušan Kostić u romanima za djecu postiže zavidan nivo pripovijedanja. Njegova djela su moderna u smislu psiholoških poniranja u složene svjetove dječje imaginativnosti i osjećajnosti, ali i po unutrašnjim kompozicionim i strukturnim načelima. Osnovno raspoloženje u njegovoj poeziji za mlade je patriotsko - pjesnik se sjeća sumornih ratnih dana i izražava vjeru u slobodu. Kostić se svojim romanima navedene kategorije pokazao kao vanredan poznavalac zavičajnih predjela i ljudi; likovi djece u njegovim ostvarenjima izrazito su etično profilisani, ali ne i lišeni karakteristika koje odlikuju dječji način percipiranja svijeta.

Mirko Vujačić (Grahovo, Nikšić, 1919 - Beograd, 1998) stvorio je obimno djelo za djecu i omladinu, na čelu sa romanom Morski jastreb (1960), koji je dugo vremena takođe predstavljao obaveznu lektiru osnovnoškolskih programa. Morski jastreb je priča o dječaku Zdravku i partizanu Vučjaku, kao i njihovim podvizima u borbi sa italijanskim okupatorom. Pojedini prizori romana realizovani su uzbudljivo i sa dosta romantičarskog pretjerivanja. Vu- 
jačić je literarno najubjedljiviji kada po realističnom modelativnom obrascu slika psihološke i mentalne svjetove mladih ljudi, njihove želje, ambicije, prve zaljubljenosti, izvodeći ih na književnu pozornicu sa svim vrlinama i nedoumicama, strahovima i nesigurnostima. Odvažnim, jakim i plemenito strukturiranim junacima, ovaj stvaralac je obogatio misaone i imaginativne prostore najmlađe čitateljske populacije, često obrađujući motive herojstva i humanosti u surovim ratnim okolnostima.

Od ostalih Vujačićevih romana vrijedi spomenuti romane iz njegove početne i središnje stvaralačke faze - Tužni cirkuzanti (1960), Kad zvezde postanu igračke (1969) i Djed Štukina družina (1973). „Sve su to akcioni romani, sa mnogo dinamične radnje, sa puno dramatičnih akcenata, ali ni u jednom posebno, ni u svima skupa, Vujačić nije postigao onu romaneskno-literarnu ubjedljivost i prirodni razvoj radnje kao u romanu Tužni cirkuzanti", konstatovao je Dragoljub Jeknić. „Vujačić je nastojao da djetinjstvo prikaže u različitim situacijama u danima rata i okupacije, da pokaže što više relacija koje su razorno i tragično djelovale na svijet djetinjstva, ali i da pruži uvid u u takođe raznovrsne otpore svijeta djetinjstva razornim i tragičnim silama i okolnostima (Jeknić 1971: 89).

Jedan od najizrazitijih crnogorskih autora u domenu romana za djecu, Čedo Vuković (Đulići, Andrijevica, 1920 - Podgorica, 2014), početke svog literarnog angažmana u domenu stvaralaštva za djecu označio je poetskom formom, publikujući poemu Vitorog (1948), sa temom iz Narodnooslobodilačke borbe. Korpusu navedenog temata, koji je obilato koristio u svom obimnom pripovjednom djelu, Vuković se u okviru literature posvećenoj dječjem i omladinskom uzrastu, više nije vraćao. Romanima Svemoćno oko (1953), Tim 'Lavlje srce' (1956), Letilica profesora Bistrouma (1961) i Halo nebo (1963), autor se okrenuo žanrovima naučno-fantastičnog i pustolovnog, kao i romana u kojima su glavni junaci životinje. Glavni junak u sva četiri njegova romana je dječak Željko, koji predstavlja primjer djeteta iz realnog svijeta, sa interesovanjima tipičnim za njegov uzrast. U literarnoj kritici sa pravom je uočavano da je preko ovako koncipiranog junaka autor nastojao da modeluje tip dječaka kojeg će nadograđivati iz jednog u drugo ostvarenje. Željkov umjetnički lik ujedno predstavlja metaforu djetinjstva, odnosno njegovih najvažnijih svojstava - dinamičnosti, poetičnosti, radoznalosti i plemenitosti, te je ovakvim modelativnim postupkom pisac nastojao izgraditi bitnu strukturnu sponu među svojim ostvarenjima.

„Željko je kao književni lik“, o ovom je literarnom junaku pisao Jovan Ljuštanović u tekstu „Romani za decu Čeda Vukovića“, „podređen osobenoj fluktuaciji između stvarnog i irealnog. Ta fluktuacija je književni ekvivalent jedne opšte psihičke osobine dece na određenom uzrastu, literarni odgovor na 
dečju sklonost sanjarenju, na njihovo priželjkivanje čudesnih moći, na čežnju za avanturom. Može se slobodno reći, da je, u skladu sa tim i potreba za čudesnim imanentna psihizmu i kulturnoj sferi deteta. Dobar deo književnih dela za decu, pogotovu proznih, počiva upravo na sugestivnom stvaranju iluzije da se irealni dečji snovi i želje mogu lako i brzo ostvarivati. Romani Čeda Vukovića pripadaju upravo toj grani proze za decu. Otuda, Željko i nije lik u klasičnom smislu te reči, nije na realistički način zaokružena psihologija, on je osoben psihološki kroki deteta uopšte“ (Ljuštanović 1998: 42).

Vrijednosti naučne fantastike uslovljene su piščevom vještinom uspostavljanja odnosa između racionalnog i iracionalnog, kao i brojnim drugim stvaralačkim elementima: inventivnošću motiva, pitoresknošću pejzaža, čvrstom i zanimljivom fabulom, magijom naracije. Ovi romani predstavljaju neobičan spoj međusobno polarizovanih imaginativnih svjetova, pa se mogu tretirati i kao neka vrsta modernih bajki, u okviru kojih su oštro suprotstavljeni fenomeni dobra i zla. Sklonost ka nauci i njenim otkrićima Vukovića su uvrstili u korpus malobrojnih predstavnika savremene crnogorske naučno-fantastične proze namijenjene djeci. Budući izrazito „obojeno“ idejom da cjelokupno čovjekovo bivstvovanje treba da bude podređeno misiji dobra, djelo ovog književnika sadrži snažan humanistički angažman. Njegova fantastika nije izvan sfere realnosti, već je hipotetično-realistička, a romaneskna imaginativnost nadograđena je motivima klasičnih bajki.

U pogledu literarnog kvaliteta posebno se izdvaja ostvarenje Tim 'Lavlje srce', koji sadrži originalno koncipiranu fabulu o dva fenomena koja intenzivno okupiraju svijet mladih - ljubav prema fudbalu i ljubav prema životinjama. Antropomorfizujući životinjske junake, Vuković im pridaje ljudska svojstva, pa u portretisanju likova ovaj roman sadrži karakteristike basne. U fudbalskom timu sastavljenom od životinja - karakteri, strasti i reagovanja junaka su atipični i nepredvidljivi, pa životinje, i pored toga što zadržavaju pojedine osobine svojih vrsta, preuzimaju „ulogu“ čovjeka, što ovaj roman nadograđuje originalnom strukturom, sa kombinacijom motiva koji nijesu ustaljeni. Diskretno ismijavajući fudbal kao svojevrsnu mušku opsesiju, autor umeće brojne duhovite prizore i pasaže, što ovo ostvarenje čini humorističnim i svježim.

O upotrebi jezika kako u ovom, tako i ostalim ostvarenjima za djecu, bez neke specifične lingvostilističke analize koja bi govorila o njegovoj asocijativnosti i svježini, dovoljno govore nazivi samih aktera radnje: Željko je onaj koji želi, lav je Grivaš, ukrotitelj zvijeri - Munja, spiker - Brzorječko, noj - Trčko, dok su igrači u timu Startović, Šupljorukić, Brzodriblović, Makazić, Promašić, Faulović, Ofsajdović ili Kiksalo. I u drugim Vukovićevim ostvarenjima, kao u romanu Svemoćno oko, izrazito je prisutna simboličnost i vrcavost imena: sjeverna zemlja je Snježanija, grad - Ledenbreg, zemlja 
Crnogorska književnost za djecu i omladinu: odlike i predstavnici

sunca i pijeska - Ekvatorija, profesor se zove Bistroum, njegova tvrđava Mašinograd, pilot - Brzopletko, a zmaj - Nestižime.

Preostala tri Vukovićeva ostvarenja mogu se svrstati u kategoriju dječjeg naučno-fantastičnog romana, u okviru koje ovaj žanr pravi prve prodore u oblasti crnogorske književnosti za djecu i omladinu. Njihova fabulativna okosnica vezuje se za neobične tehničke izume, što omogućava upliv fantastičnog u naizgled realističnu podlogu zbivanja. Obilje sadržaja tipičnog za naučno-fantastičnu prozu vješto je kombinovano sa folklornim motivima, pa Vukovićevi romani navedene profilacije ne sadrže vizionarske ambicije tipične za ovaj žanr, već više posjeduju karakteristike kakve dječje fantazmagorične igre. Na takav način Čedo Vuković inoviše domaću dječju prozu uvođenjem razuđene predmetne $\mathrm{i}$ imaginativne rijeke, koja teče u pravcu modernizacije dotadašnjih oblikovnih postupaka.

Mihailo Ražnatović (Dujeva, Rijeka Crnojevića, 1922 - Beograd, 1992) još od vlastitih literarnih početaka njeguje ljubav prema ranim godinama mladosti. Njegov odnos prema zavičaju u najvećoj mjeri izražen je u zbirkama pripovjedaka Majka (1954) i Vrati me u dom moj, orle (1961). U drugim narativnim ostvarenjima, prisutan je ne samo opis djetinjstva i ljubavi prema zavičaju, nego i tema rata i mučnog življenja u njemu. Voja Marjanović je pisao da je „stil i jezik u Ražnatovićevoj prozi čine čast ovom piscu. Ražnatovićev jezik je lokalan, ali ne i provincijalan, a njegova misaona i emotivna fraza natopljena lakoćom izraza daje štivu boju i zvuk muzike“ (Marjanović 1973: 16). Motivi sunca, izvora, bosonogog djetinjstva, ali i oni socijalne i psihološke profilacije dominantni su u naraciji ovog autora. Kroz čvrstu vezu sa tradicionalnim duhovnim zaleđem ovaj pisac gradi osnovna fabulativno-motivska čvorišta svojih pripovjedaka. U narativna ostvarenja neorealističkog prosedea namijenjena dječjem uzrastu i interesovanjima, koja su kvalitetno napisana, a nedovoljno proučena, može se svrstati roman Voja Terića Abar.

U romanu Abar Voja Terića (Polja, Mojkovac, 1924), publikovanom 1957. godine, prepliću se elementi pustolovnog romana, ispunjenog kako realističkim, tako i modernističkim sadržajem. Roman odlikuju naglašena vještina fabuliranja, kao i specifična organizacija prostora i vremena. U fabulativnom središtu djela nalazi se arhetipski motiv potrage za blagom, „Sižejni obrasci o inicijaciji i zakopanom blagu u Abaru“, o narativnom postupku u ovom ostvarenju pisao je Jovan Ljuštanović, „međusobno su palimpsestirani, lanac prepreka istovremeno igra simboličku funkciju unutar jedne i unutar druge priče. Potraga za blagom znači istovremeno i inicijaciju Filipa Popa, što je sasvim prihvatljivo i unutar arhetipskog resursa iz kojega Vojo Terić crpi glavne sižejne linije svog romana“" (Ljuštanović 2004: 59). 
Roman Abar obiluje mnoštvom raznovrsnih elemenata koji ga čine složenijim u odnosu na tipično ostvarenje predviđeno za dječju čitalačku publiku. Glavni junak u velikoj mjeri odstupa od koncepta svemoćnog junaka, s obzirom na to da mu nijesu nepoznati strahovi, sumnje i nesigurnosti. Terićev Abar za razliku od nad-junaka iz avanturističkih proza Anta Staničića, koji je godinu dana ranije publikovao Mali pirat, u velikoj mjeri je umjetnički oslikan kao prototip čovjeka iz stvarnosnog konteksta. U okviru domaće literarne tradicije, Afrika je rijetko predstavljala mjesto u kojem bi bila locirana radnja romana. U predmetno-fabulativnoj osnovi djela leži lov na blago, što se može razumjeti kao uobičajeni motiv pustolovnih romana, ali autor narativnu strukturu svog teksta prožima detaljima kakve čine borba alžirskog naroda za slobodu i djelovanje Legije stranaca kao surovog instrumenta održanja vlasti, što ovu tvorevinu čini neobičnijom i bližom društveno-političkim aktuelnostima piščevog vremena.

U epilogu romana glavni junak umire, što takođe čini odstupanje od klasično modelovanog hepienda kakav po pravilu srijećemo u slučaju avanturističko-pustolovnog ostvarenja. Mlade čitaoce privlači egzotični afrički ambijent, u okviru kojeg se spominju Sahara, Alžir, Biskra i drugi lokaliteti. Imena junaka, kao što su Abar, Marsel, Trafik ili Ivon, takođe doprinose uvjerljivosti i privlačnosti ovog djela.

$\mathrm{Za}$ više od dvije decenije rada na djelima za djecu i omladinu Stevan Bulajić (Vilusi, Nikšić, 1926 - Sarajevo, 1997) je napisao pet romana i dvije knjige pripovjedaka - Izviđači Vidrinog jezera - 1953, Moj djed lovac-1954, Krilati karavan - 1955, Njih šezdeset - 1956, Zemlja bez batina - 1958, Nebeski mornar - 1960. i Šalalajko - 1974, koji spadaju u sami vrh crnogorskog stvaralaštva za najmlađe. Svako Bulajićevo djelo nastalo je u punom doživljaju svijeta djetinjstva, pa otuda posjeduje kompleksnu umjetničku cjelovitost. „Svaki od njih je jedna oaza događanja, jedan predio života“, o Bulajićevom stvaralaštvu za djecu i omladinu pisao je Dragoljub Jeknić, „svojim nenastavljanjem, nenaslanjanjem jednog na drugi u bilo kom smislu sem u onom umjetničkom, stvaralačkom, oni svjedoče o šarolikosti i raznobojnosti svijeta u kome živimo, promjene koje slijedimo, stvaralačka izvorišta koja se u pjesniku javljaju... Šalalajka njegovo sunce ne napušta, on ide za njim, on će pod toplim suncem života izrasti, formirati se u kompletno biće ljudskosti, uprkos svim nedaćama na koje nailazi i na koje će nailaziti u ovom svijetu punom ljepote, ali i tragičnih protivurječnosti“" (Jeknić 1971: 67).

Sva Bulajićeva ostvarenja na neki način su umjetnički modelovana i saopštena kroz evokaciju prošlosti. U prvom ostvarenju Izviđači Vidrinog jezera pisac traga za suštinom dječjeg bića. Najviše dara, po književnokritičkom sudu, on je ispoljio u ostvarenju Krilati karavan, u kojem je simbolički into- 
niranim prizorima u kojem je opisao let divljih gusaka, pripovijedao o ljepoti drugovanja, smislu žrtve i ljudskoj dobroti. U romanu Njih šezdeset, pisac je tretirao problem ostavljene djece, lišene roditeljske ljubavi, dok se u djelu Zemlja bez batina vratio opisu težnje mladih da žive na slobodi, sukobljavajući se sa institucijama koje brinu o njihovom vaspitanju. Nebeski mornar je priča o mladim jedriličarima i njihovim snovima o plavim prostranstvima. Roman Šalajko istražuje identitet odbačene individue, neprilagodljive djece koji se ne mire sa postojećim poretkom stvari. Nakon niza knjiga koje je posvetio životu savremene djece, Bulajić se vratio ratnoj tematici romanom Dom na divljoj travi. U opisu prirode njegov stil je originalan i maštovit, što na umjetnički uspio način demonstrira u pripovijeci Divljan i vuk.

Zanesenost čarima i ljepotom svijeta, pjesnik Žarko Đurović (Bogomilovići, Danilovgrad, 1928) umjetnički je na uspio način izrazio u svojim zbirkama poezije za djecu, među kojima se po kvalitetu i čistoti književnog izraza mogu izdvojiti Dječak i mjesečeve ruke (1970) i Cvrčak na klarinetu (1993). Osobina koja povezuje njegovu poeziju za odrasle i djecu je hermetičnost te naglašena asocijativnost i simboličnost. Đurovićeve lirske minijature po pravilu ne dobijaju konačni oblik dovršenosti, već ostaju u naznakama. U njima nema konačnih prizora i dovršenih slika, one se umjetnički realizuju kroz treptaj, nagovještaj, emociju. Većinu njegovih poetskih struktura moguće je doživjeti sinkretički, preko više čula, jer ih čitalac prima kroz specifičnu muzikalnost, dočaranu bojom i oživljenu ritmom. U ovom pjesmama sve je nedokučivo, one predstavljaju utisak, viziju i impresiju, nadograđenu dubokom i sadržajnom porukom.

Đurović nije tipičan dječji pjesnik jer su njegova ostvarenja lišena uobičajnih poetskih „rekvizita“ kakve predstavljaju lakoća, površnost, oslanjanje na nonsens i igru. Stoga njegove pjesme u najvećoj mjeri čine svojevrstan vid misaone fantazije, obogaćene duhovnom radoznalošću za otkrivanje pojava i fenomena iz neposrednog okruženja. Njegove pjesničke slike protkane su realijama i irealijama, dok se vizije stvarnosti i fantazije međusobno dopunjuju. Prožete prefinjenim smislom za humor i naglašenom refleksivnošću, pjesme Žarka Đurovića odlikuju se zavičajnim motivima, i pored toga što zavičaj nije konkretizovan pjesničkim slikama na način koji bi djetetu ponudio prepoznavanje lokaliteta. Njegov pristup predmetima je antropomorfan: u pjesmi sve na živ i dinamičan način komunicira jedno s drugim, dok djeca svim predmetima udahnjuju jedan novi život i smisao postojanja. Stoga se može reći da je Đurovićev univerzalni motiv dijete, ono što je njemu blisko i što mu obogaćuje život.

Ivan Ceković (Golubovci, Podgorica, 1930) jedan od najvažnijih predstavnika crnogorske poezije za mlade, zastupljen je u antologijama, zbornicima i školskoj lektiri. Bavio se novinarstvom i književnošću; bio je urednik 
Radio Titograda, Duge, Rada i Beogradske nedelje. Dobitnik je nagrade Mladog pokolenja (1964) za dječju književnost, nagrade Neven (1967), Trinaestojulske nagrade (1981) i drugih priznanja. Objavio je zbirke poezije: Oko što ne umire ćutke (1956), Ratu umjesto psovke (1958), Kakav je to način (1961), Ravnaj se po boru (1964), Kad bi mjesec bio balon (1964), Šetači laganije (1967), Hod i ruža (1970), Pozna zora (1972), Nek izvoli kako ko voli (1973), Otići dalje (1976), Zašto postoji sve (1976), Putovati svijetom makar trotinetom (1976), Ko se sa kim grli (priče za djecu, 1990), Zvjezdani vrt (1965), Sunce u tvojim očima (1979). Od ostalih Cekovićevih djela vrijedi spomenuti Poznanstva sa dečjim piscima (1970) i Čitao sam da čitate (1979), kao i izbor iz Cekovićeve poezije koji je priredio Milo Kralj pod nazivom Sunce u tvojim očima (1989).

„U knjizi Sunce u tvojim očima“, pisao je Kralj o ovom ostvarenju, „su pjesme i bajke u kojima su ispreplijetani jan i java, ljubav i vedrina, čarolija prirode i neizvjesnost igre, a sve je prepuno srca. Ceković najčešće piše o prirodi i ljubavi, o dječacima i djevojčicama i njihovom radoznalom duhu pred čarolijama i tajnama svijeta koji ih okružuje i onoga što se tek naslućuje. Priroda je zlatni okvir u kojemu se dešavaju san i java svakog dječaka $i$ djevojčice, ona je aktivni saučesnik njihove svakodnevne igre i razmišljanja u samoći. Priroda se u ovim pjesmama i bajkama pojavljuje u sto lica; čas je to sunce, čas oblak, morska pjena, gradski bulevar, buba, čas veliki slikar - mraz na prozorskim oknima. Viđena i obogaćena dječjom maštom, ona tu maštu obogaćuje novim slikama i razmišljanjima. Ceković nikada ne opisuje prirodu kao nešto izdvojeno od ljudi, već je uvijek oblikuje po njihovom liku i snu“ (Kralj 1989: 9). Sve Cekovićeve pjesme i bajke predstavljaju svojevrsne himne ljubavi prema roditeljima i domovini, kao i svemu što mlade okružuje. Sa tim svijetom on istinski živi, zapisujući njegove zgode i nezgode, javne i tajne snove.

Vojislav Vulanović (Zagorak, Danilovgrad, 1931) objavio je zbirke poezije za djecu: Gde da smestimo sunce (1972), U polju dom (1982), Ne dam tati ja u lovce (1987) i Sunce Trešnjeva (1991). Njegovu poeziju odlikuje predmetno-motivska zaokruženost, što produkuje time da je sa jednakim interesovanjem mogu čitati djeca i odrasli. Pjevajući o prirodi, ovaj poeta zapravo pjeva o čovjeku i njegovoj vezi sa prirodom. Kod njega je izraz zasnovan na emociji koja čini pokretačku snagu pjesme. Fenomen veze sa tradicijom, on je na uspio način izrazio u zbirci poezije Sunce Trešnjeva, u kojoj pjeva o bilju, zorama, pticama i kamenitim predjelima. U Vulanovićevoj poeziji za djecu, život se ne uči porukom, nego primjerima; on se djetetu ne obraća sa visine i distance, već ga tretira kao prijatelja po svemu jednakom sebi. Za njega je dijete budući čovjek i dostojan sagovornik, koji plijeni intelektom i imaginativnošću. 
„Vulanović ne daje djetetu igračku u ruke“, o karakteristikama Vulanovićeve poezije pisao je Žarko Đurović. „To ne znači da ga treba lišiti te potrebe. Ali, on je u prirodi našao sve što je potrebno dječjem oku i duši. U zamjenu za igračku dao mu je sunce, koje će svakog jutra svratiti na kamene prozore Trešnjeva. I ne samo Trešnjeva, nego svih prozora na kojima se pojavljuju dječje glave. Iz pjesnikovog oka svijet zavičaja prenijet je u san djeteta. I dijete je imalo što upiti i što darovati“ (Đurović 2009: 90). U Vulanovićevoj poeziji svjetlucaju vatre mašte, igre i radovanja; ona je nježna i puna čežnje ka nedosegnutim realnim i imaginarnim predjelima djetinjstva. Osnovna vrijednost njegovih pjesama počiva u njihovoj nepretencioznosti i jednostavnosti, koje čine da one na lak i neposredan način mogu zadobiti simpatije i naklonost najmlađe čitateljske i slušalačke publike.

Pisac zastupljen u osnovnoškolskim programima predviđenim za proučavanje školske i domaće lektire u Crnoj Gori je Milenko Ratković (Bar, 1931), čija je drama Pisak lokomotive (1969) nagrađena na konkursu televizije Zagreb. Važan dio Ratkovićevog literarnog angažmana čine romani za djecu i omladinu, od početnih Školjka iz zavičaja (1970) i Blago bijelog brda (1974), do onih iz završne stvaralačke faze - Tajna stare tvrđave (1988) i Pubertetska čežnja (1999). Njegov stvaralački luk u domenu dječje priče i pripovijetke takođe je obiman, još od prve zbirke Dioba Šunjine družine (1951). Ratkovićeva proza zrači toplinom i iskrenošću doživljaja; njega interesuje svijet djetinjstva u cjelosti, umjetnički uobličen kako na prostorima konkretnih doživljaja, tako i u beskrajnim svjetovima dječje imaginativnosti.

Dragoljub Jeknić je u tekstu „Pregled crnogorske književnosti za djecu“, publikovanom u časopisu Stvaranje 1971. godine, napisao da je u pitanju autor čija proza ne posjeduje neke specifične uglove posmatranja svijeta djetinjstva: „Zahvaljujući toj osobini da se svijet djetinjstva posmatra kontinuirano i sa svakog mjesta, kod njega imamo bogat spektar situacija djeteta. Njegovu priču ispunjavaće jednom usamljen dječak, dječak samac u igri ili na putu, drugi put priča će biti posvećena samo dvojici dječaka, onda dječaci u većoj ili manjoj grupi, u šumi ili na polju, pored rijeke ili na planini, kraj kuće ili u razredu, u školskom ili tuđem dvorištu, u porodici ili sa životinjama, u lovu ili jednostavnom traganju za ljekovitim biljima i plodovima, sa sebi ravnima, vršnjacima ili starijim i odraslim ljudima, u stvaralačkoj igri ili igri rata“ (Jeknić 1971: 132). Ipak, najznačajnije Ratkovićevo pripovjedno ostvarenje svakako predstavlja Pisak lokomotive, u kojem je na dubok i stvaralački sugestivan način uspio da izrazi ljepotu razumijevanja drugog čovjeka i važnost empatije. Ako se tematsko-motivska područja Ratkovićevog djela pažljivije rasloje, shvatićemo da je ratna i poslijeratna stvarnost njihov lajt-motiv. 
„Kao pisac koji se vaspitavao na poetici angažovanog realizma“, ističe Tihomir Petrović, „on u romanima Školjka iz zavičaja (1970), Dvoboj u gradu dječaka (1976), Ratne igre (1980) i drugde, slika otpor dečaka okupaciji i moralne dileme koje donosi rat, pri čemu, onde gde se na tok radnje reflektuje sam ratni eho i sudbina junaka, jače zadržava pažnju čitaoca... U trenutku plodonosne usredsređenosti on sastavlja pripovetke, romaneskne celine i lirski impregnirane pasaže individualnog pečata i snažnih poetskih slika: nudi čitaocu tekstove određene arome, boje i zvuka - iznad proseka klasične tehnike izražavanja modernog senzibiliteta. Kratka priča je dominantan žanr u kojem autor pokazuje veći uspeh. Proza Srna (1963), Vragolani (1966), Uzbuna u šumi (1970), u okviru kraće priče Dvorac iz bajke, Legenda o jarčevoj pećini, U medveđoj koži, koji se približavaju antologijskim vrednostima, prikazuje ga kao stvaraoca vrednog boljih umetnika (Petrović 2008: 56). I pored toga što ga privlači težnja za pedagogijom, ona je u Ratkovićevom djelu sprovedena na posredan i infuzan način, bez grubog didaktiziranja, te nadograđena idejom plemenitosti i finim stvaralačkim osjećajem za mjeru.

Dušan Đurišić (Gradinje, Dmitrovgrad, 1932) nekadašnji direktor podgoričke biblioteke „Radosav Ljumović“ i glavni i odgovorni urednik književnog lista za djecu Osmijeh, jedan je od najpoznatijih crnogorskih stvaralaca za mlade. Najpoznatija Đurišićeva ostvarenja su poetske zbirke Veliki kapetan (1964), Zelena Zeta (1970), Vrti se vrtuljak (1971), Bez pardona (1972), Baroni di Makaroni i knez de Majonez (1974), Radoznala staza (1982), Morska lula (1983), Morska ogrlica (1987), Vjetrovita kuća (1993), Ćiribu-Ćiriba (1996), Svijete zdravo (1997), Laku noć, maleni (1998), Sjena i sjaj (1999), zbirka priča za djecu Zlatna Anja i patuljci (2000) i roman Duga iz djetinjstva (2008). Đurišić je jedan od najpoznatijih crnogorskih antologičara poezije za djecu i odrasle, pa su poznati njegovi izbori - San u pidžami (antologija uspavanki - 1986), Sunce na jugu (jermenska poezija za djecu-1988), U istoj kući (antologija poljske poezije za djecu - 1990), Kolo prijatelja (izbor svjetske poezije za djecu - 1990), Mongolska poezija za djecu (1990), Šta pjeva vjetar (njemačka poezija za djecu - 1990) i Uvijek ljepota (antologija kratkih priča crnogorskih pisaca za djecu - 1993).

Uglavnom nema osnovnoškolske čitanke nižih razreda u kojima Đurišićeve pjesme nijesu zavrijedile svoje pravo mjesto i punu pažnju kako kod djece, tako i kod vaspitača. Njegova poezija zastupljena je u više zbornika i antologija, te prevedena na ruski, mađarski, češki, bugarski, makedonski i brojne druge evropske jezike. Očigledan dokaz metodološki postepenog i pažljivo građenog razvojnog puta ovog poete predstavlja njegova čitalačka publika, a to su prije svega djeca. Malo ima najmlađih, naročito sa crnogorskih prostora, da naizust ne znaju velik broj Đurišićevih pjesama, što ne treba da 
čudi imajući u vidu melodičnu pitkost i lakoću kojom njegova pjesma ulazi u sluh, što je jedna jedna od nepokolebljivih potvrda uspjelosti i prihvaćenosti jednog pjesnika. Đurišićeve pjesme nastavljaju da žive sopstveni umjetnički vijek u pamćenju i dušama čitalaca, probijajući se od djetinjstva do zrelih faza njihovog života, pretačući se u narednu generaciju. U njegovoj poeziji upadljivo je precizno ulaženje u psihologiju djeteta, kao i suptilno pronalaženje $i$ razvijanje literarnog interesovanja kod djece. Pjesničke slike su svježe, čime se njihov doživljaj ostvaruje spontano i neposredno, poređenja su inventivna, pronađena maštovito i originalno. Pjesme za djecu Dušana Đurišića predstavljaju nježnu poeziju lirski opisanih pejzaža i životnog optimizma punog bajkovitosti u cjelokupnoj svojoj idiličnosti. Većina njegovih pjesama se odlikuje naglašenom ritmikom i rimovnom lakoćom, u kojoj pjesnik ne zapada u opasnost da gradi rimu radi rime, već njegovo stihotvorstvo uvijek sadrži neko inventivno rješenje, koje čitaoce iznenadi neočekivanošću i ljupkošću.

Konkretno potkrepljenje ove teze predstavlja pjesma Ljubičice $u$ vazi, iz zbirke Zelena Zeta (1970), u kojoj je teško uočiti granicu između dječje poezije i poezije za odrasle. Pjesma sadrži neskriven podtekst koji asocijativno izaziva starijeg čitaoca poput Cesarićeve Voćke poslije kiše, a sa druge strane nailazimo na pažljivo sintetizovana čula, primarna za psihu djeteta čulo mirisa i opažaja: „Sa stola, iz vaze, ko bi / povratio ih životu? / Prosuše miris po sobi- / posljednju svoju dobrotu“" (Đurišić 1970: 12). Pjesma je ljupka minijatura, pejzažna lirika data je sa blagom refleksivnom notom i izvjesnom dozom meditativnosti. Glavni junaci Đurišićevih pjesama su godišnja doba, mjene u prirodi; njegovu poeziju preplavljuju pulsirajući ritmovi života, dok je elementarni seoski ambijent opjevan u panteističkom zanosu. Zato možemo reći da je Đurišić pjesnik svjetlosti i poleta; njegova poezija je puna zvukova, slike su životvorne i ubjedljive, pa se mogu lako zamisliti i doživjeti. Epilog je u skladu sa osnovnom intonacijom pjesme te pruža iskričavost vrhunca, predstavljajući pravi poetski vatromet.

Romanom Duga iz djetinjstva, Đurišić se motivski nadovezuje na fenomenologiju u raznovrsnim varijetetima izloženu i obrađenu u svojoj poeziji. „U zrelim stvaralačkim godinama“, u pogovoru ovom romanu pod nazivom Romansijersko umijeće Dušana Đurišića pisao je Žarko Đurović, „Đurišić je riješio da se ogleda u danas veoma popularnom književnom žanru, simbolično naslovljenom Duga iz djetinjstva. U pogledu tematike i motiva Đurišićev roman, veoma zanimljiv i privlačan za čitaoce, potvrđuje naše uvjerenje da je autor stvaralački zaokupljen svijetom djetinjstva, koji predstavlja neiscrpni izvor njegove umjetničke kreacije. Djetinjstvo je ostavilo toliko dubok trag, da književnik Đurišić od njega ne može pobjeći i kada bi htio. Radnja romana zahvata vrijeme Đurišićeva djetinjstva i prostor „rajskih predjela“ Gradinja i 
Caribroda, Ćurioca i Danilovgrada, mjesta koja će opsesivno, presudno i trajno djelovati na njegovo posmatranje, promatranje života i događaja, literarno formiranje i stvaralaštvo" (Đurović 2008: 109).

U ovom autobiografskom ostvarenju autentični piščevi doživljaji čine okosnicu literarne kreacije, dok intimni ton njegovog narativnog stila kod čitaoca izaziva širok emotivni spektar. Roman se sastoji iz tri narativne cjeline pod nazivima „Stazama zatravljeni“, „Dok Nišava teče“ i „Daleke zvijezde nad ravnicom“, kroz koje autor izražava antiratno raspoloženje, realističkim scenama prikazujući prizore iz društvenog i porodičnog života. Zahvaljujući literarnom umijeću iskusnog književnika i pitkosti njegovog pripovjednog stila, pisac je zbirku ličnih ispovijesti vješto uklopio u romanesknu cjelinu, narativnom šetnjom kroz beskrajna prostranstva djetinjstva.

Bosiljka Pušić (Ćuprija, 1936) je u Jagodini završila gimnaziju, a u Beogradu na Filozofskom fakultetu odsjek za jugoslovensku i svjetsku književnost. Udajom se vezuje za Boku Kotorsku (Kumbor i Herceg Novi). Radila je u hercegnovskoj srednjoj školi kao profesor srpskohrvatskog jezika. Odlaskom u penziju počinje da slika (imala je petnaest samostalnih i tridesetak grupnih izložbi). Od 1970. godine, kada je publikovala prvu knjigu pjesama Krila iste ptice, objavila je preko trideset knjiga, ogledajući se u različitim književnim vrstama, a gotovo svaki njen roman nominovan je za neku od prestižnih nagrada. Njene knjige za djecu nose nazive: Hercegnovske čarolije (2000), Koga boli uvo kako ja rastem (2000), Ružičasti delfin (2001), Žabljada (2003), Doživljaji magarčića Magića (2004), Kobajagična putovanja (2006), Plavojko (2000), Ko te šiša (2010), Kralj koji je pojeo i sebe (2012) i Bašta od papira (2014).

Slikovnica Hercegnovske čarolije, objavljena u izdanju Osmeha iz Podgorice 2000. godine, prvo je djelo Bosiljke Pušić, nakon čega slijedi zbirka poezije publikovana iste godine pod nazivom Koga boli uvo kako ja rastem. „Zbirka pjesama Koga boli uvo kako ja rastem Bosiljke Pušićc“, o ovom ostvarenju kritički sud je izrekla Anđa Backović, ,je izazovna i interesantna upravo zbog takvog razumijevanja djetinjstva i mladosti. Riječ je o potrebi djeteta da ga razumiju i, na taj način, da razumiju poseban jezik kojim ono govori o sebi, svojim osjećanjima, očekivanjima, željama, dilemama. Da li je taj jezik za njegovu okolinu razumljiv? Sigurno ne sasvim, ponekad i potpuno. Zar nam i poruka Koga boli uvo kako ja rastem ne govori o tome da se ne razumijemo, da uvo (i oko) odraslog ne prima takve signale, kao da dolaze iz nekog nepoznatog svijeta. Ta dva jezika postaju dva svijeta, ponekad veoma udaljene psihološke vrijednosti, a što su dalje više izazivaju osjećanje nezadovoljstva, ljutnje, samoće, odbacivanja“ (Backović 2009: 118). 
U zbirci priča Ružičasti delfin autorka umjetnički realizuje niz zanimljivih priča sa realističnim, bajkovitim i poučnim sadržajem, kao što su $P a$ stir koji je postao kralj, Zlobne sestre i Divlja ruža. Knjiga je naslovljena po istoimenoj priči, u kojoj je glavni junak Def. Osnovna stilogena sredstva su personifikacija i simbolizacija, što na posebno uspio umjetnički način dolazi do izražaja pričama Krilata žabica i Crveni konj. Osnovna ideja njene poeme u stihovima Žabilijada je da se ne treba plašiti i mrzjeti nepoznate susjede, već da ih treba upoznati i uživati u razlikama.

Djelo Doživljaji magarčića Magića su sačinjeni od dvadeset i tri motivski povezane priče, tako da istovremeno djeluje i kao mini roman mozaičkog karaktera. U narativnom fokusu je simpatično ispripovijedana priča o magarčiću koji iz prirode bježi u grad, u kojem kroz različite avanture komunicira sa djecom. Naročito su uvjerljivo opisani prizori koji se odigravaju u cirkusu, u kojima je poput Kolodijevog Pinokija pouka data na nenametljiv i efektan način. Iako je namijenjen djeci najmlađeg uzrasta, ovaj roman se bavi ozbiljnim temama savremenog života i odrastanja u svijetu koji je fizički i mentalno zagađen. Ljupka i suptilna priča o magarencetu koje se otiskuje u svijet, tragajući za svojim snom, otvara niz važnih pitanja samog odrastanja, koje se više ne dešava u idiličnom kontekstu, već u surovom realitetu prljavih rijeka, deponija, medijske propagande i licemerja raznih kvazi-humanih organizacija. Kako odrasti, sačuvati san i spasiti svijet djetinjstva, neke su od tema koje ova knjiga otvara. Spisateljica se obraća djeci i odraslima, nudeći im priču o putovanju koje se završava duboko u svakom od nas, sa porukom da sačuvamo u sebi svijet djetinjstva iz kojega cijelog života možemo crpiti energiju, kako bi sebi život učinili vrijednim i smislenim. Ono što prevazilazi okvir ustaljenih problemskih područja u crnogorskoj književnosti za djecu je to što je Pušićeva u ovom ostvarenju obradila ekološku temu, odnos prema manjinama (Romima) i hendikepiranoj djeci.

Roman Kobajagičina putovanja oslikava zamišljena putovanja naratorke, koja pripovijeda o doživljajima iz egzotičnih kontinenata i zemalja, od Afrike i Indije do Mongolije i Australije, dok se prološki i epiloški segmenti djela odvijaju u Herceg Novom. Knjiga je istovremeno poučna jer djeca mogu mnogo da saznaju o kulturi, običajima i geografskim odlikama opisanih krajeva. Osim motiva putovanja, u ovom ostvarenju dominantan je motiv ljubavi prema unučadima i potrebe da se njihova saznanja izgrađuju kroz igru.

Posljednja ostvarenja Bosiljke Pušić Plavojko, Ko te šiša i Kralj koji je pojeo sebe takođe u visokoj mjeri oslikavaju spisateljičin suštinski osjećaj za izazove djetinjstva i mladosti, ispoljen putem svježeg i neposrednog jezika, približenog djetinjoj svijesti i načinu komunikacije. U zbirci poezije Ko te šiša kroz stihove je deci otkrila teret „magarećih godina“ i sve ljepote sazrijevanja 
i odrastanja, dok je u Kobajagičnim putovanjima pričama premrežila cijelu planetu imaginarnim putovanjem. Cjelokupno autorkino djelo emanira veliku ljubav i poštovanje prema djetetu, kao i stvaralačku potrebu da se istakne njegov smisao za kreativnost i poštuje djetinji individualitet.

Knjiga bajki Kralj koji je pojeo i sebe zbirka je savremenih i univerzalnih bajki u kojima ona ne nudi mladim čitaocima utopijsku viziju svijeta. Njeni junaci su najčešće mladi u običnim životnim situacijama kojima se objašnjava postojanje određene pojave, ali i analiziraju emocije i ljudski odnosi, dok je dimenzija vremena uglavnom relativizovana. U ovim bajkama se pojavljuju i personifikovani likovi - oživotvoreni oblak, vjetar, zvijezda, rosa, ali ipak čovjek, koji se čeliči kroz iskušavanje različitih tegoba, u centru je bajkovnog univerzuma Bosiljke Pušić. U ovoj zbirci mogu se zapaziti dvije osnovne vrste bajki: prve - nalik na tradicionalne, na čiju se strukturu i građenje sižea autorka oslanja (Dobar i zao vetar, Glog i Drena, Kralj koji je pojeo $i$ sebe, Kraljevo uvo, Pastir koji je postao kralj) i druge - u kojima se opisuju savremeni problemi mladih (Satenske cipelice, Šareni autobus, Tajna stare stolice, Zlatno srce, Prosjakov dar), riješeni uz dejstvo fantastike.

Važna predmetna područja njene nove pjesničke zbirke za djecu Bašta od papira predstavljaju radost življenja i učenje života putem sazrijevanja. Posmatrana sa strukturno-kompozicionog stanovišta, zbirka se sastoji iz tri cjeline: „Mravinjak u parku“, „Razne zgode i nezgode“ i „Šenuli s pameti skrenuli“. U pjesničkom segmentu nazvanom „Mravinjak u parku“, autorka je opisala podzemni i nadzemni mikrokosmos ovih insekata, stavljajući akcenat na njihovu egzistencijalnu organizaciju i život u okruženju. „Ima tu i ljubavne priče sa hepiendom, opisa svadbe i svatova, sa naglašenom ekološkom notom i svešću o okolini i pripadanju zajednici“, konstatovala je Žana Ognjenović. „Lakoćom pesničkoga kazivanja i bogatstvom imaginacije pesnikinja stvara jednostavan i čaroban svet, primamljiv i deci i odraslima. I kad piše o insektima i drugim životinjama, Bosiljka Pušić nam šalje poruku o ljudima $i$ ljudskim naravima, o opštem dobru. U poglavlju 'Razne zgode i nezgode' Bosiljka Pušić širi poetsku tematiku, mada su opet životinje i njihove (ne)zgode u centru pažnje (zašto se slonica ne o-sloni, rođenje pačića, jagnjeta, mačića, morskih kornjača), tu su i pesme o ugroženom životu pojedinih vrsta (biserna školjka, galeb), pa i samog mora. Najveći broj pesama ovog poglavlja su posvećeni mlađim školarcima, njihovim svakodnevnim brigama i preokupacijama, učenju i prvim simpatijama. Mnoge od ovih pesama su priče u stihovima“ (Ognjenović 2014: 16).

Posljednje poglavlje ove knjige nosi šarmantan naziv - „Šenuli s pameti skrenuli“. Na granici anegdotskog i humornog ove pjesme nam pružaju pogled na život iz jednog iščašenog ugla, s obzirom na to da se pjesnikinja 
Crnogorska književnost za djecu i omladinu: odlike i predstavnici

pita šta se dešava kada testera, kašika, stolnjak, ovca, tramvaj, šerpa, mačak ili tegla džema skrenu i sa pameti šenu. Pušićeva je pjesnikinja koja od malog pravi veliko, svakodnevne životne pojave i fenomene izdižući na viši poetski nivo, pokazujući čitaocima da ne postoji malo ili manje važno, već je sve što nas okružuje jednako zanimljivo i vrijedno divljenja i ushićenja.

Najnovije njeno ostvarenje, drama za dječji i omladinski uzrast - Mladi Njegoš, napisana u koautorstvu sa Marijom Čolpom, već se igra u beogradskim osnovnim školama i gimnazijama. Bosiljka Pušić je uspela da značajna pitanja svojih knjiga za djecu i odrasle uvije $\mathrm{u}$ formu inteligentnog humora, iza kojeg se kriju značajna egzistencijalna pitanja. Ona je pisac Boke Kotorske, i kao niko do sada opisala je Boku, njene ljude i znamenite događaje u poeziji i prozi za djecu, kao i pjesmama, pričama i romanima za odrasle.

Slobodan Vukanović (Podgorica, 1944) je objavio i osam knjiga za djecu: Tako hoćemo (pjesme i priče), Bal lutaka (drama), Alisa i Arkadije (drama), Milena od Kotora (tri drame), Devet ajkula u Montenegrogradu (priče, poezija, igrokazi), Škozorište (antologija dramskih tekstova za djecu), Leptirija voli nebo (dvije drame i šest minijatura) i roman Ana i sedam robota. Drame su mu izvođene u pozorištu i na radiju. Zastupljen je u preko 30 antologija, panorama i izbora. Njegova poezija zastupljena je u udžbenicima za osnovnu školu: Izbor iz savremene crnogorske poezije za djecu i Savremena crnogorska poezija, a sada je u čitankama Kako to može i Čarolija čitanja. Prevođen je na engleski, ruski, francuski, bjeloruski, italijanski, arapski, njemački, poljski, mađarski, rumunski, slovenački, makedonski, turski i bugarski jezik.

„Na prvi pogled Bal lutaka je vedri dramski igrokaz, koji u suštini počiva na tri iskazajne ravni, uobličen jedinstvenom unutrašnjom vezom", o stvaralaštvu ovog književnika pisao je Slobodan Bošković. „Najprije je to živi, razdragani prostor igre, iz kojega se, naoko, pojednostavljeni svijet preobraća u dramatičnu, da kažemo i haotičnu situaciju, odjednom poremećene svakodnevice stvarnog. Dakle, svijet običnog kulminiraće u žestoku dramu koja donosi nepoznato. Najprije, 'nepoznato' u naravima odraslih, koji nastoje da i dječji svijet vide samo 'svojim' očima, a u stvari, drže ih po strani, permanentno. Ova opasna igra, zahvaljujući djeci, pokazaće kako i najmlađi imaju svoje ozbiljne rezone. Bolje reći, pokazaće lakomislenost odraslih, već uštavljenih rezonima svog oguglalog duha i rasuđivanja. Time je i uzbuđenje pri čitanju ove drame za djecu još veće“ (Đuričković 2009: 142). Lakoća kojom je Vukanović svoje dramske tekstove približio uzrastu najmlađe čitalačke publike, dokaz je njegovog kompleksnog poznavanja dječje drame, kao i suštinskog razumijevanja značenja i značaja igre u životu svakog djeteta.

Poznati motiv o tragičnoj ljubavi Romea i Julije autor je obradio kao svoju scensku bajku o dramatičnoj, ali srećnoj ljubavi između Alise i Arkadi- 
ja. Drama počinje prologom - cvrkutom ptica u proljeće, u kojem Ivan Suncokretni i Ivan Ljubičasti sa zanosom razgovaraju o dalekom kraljevstvu u kojem svaki grad ima svoj jezik, grb i zastavu, a stanovnici se teško međusobno sporazumijevaju. Jasno je da je u pitanju aluzija na naše nekadašnje vjerske i nacionalne polarizovanosti i netrpeljivosti jer geslo obje države glasi - „Bolje je moje nego tvoje“. „Slobodan Vukanović ima pripovjedačkog dara i sluha za stvaranje atmosfere, ali mu nedostaje iskustvo da pomoću dijaloga dramaturški komponuje akciju, pa njegovi dijalozi, u kojima ima i ponavljanja, rijetko stvaraju dovoljan dramski napon i ne podstiču dovoljno dječje interesovanje iščekivanjem 'šta će dalje biti'. Tako, na primjer, umjesto što isuviše verbalno raspravlja o liječenju i bolesti Arkadija (zbog zabranjene ljubavi), bilo bi mnogo interesantnije razvijati postojeću i inventivnu ideju kako će Arkadijevo oboljenje u jednom kraljevstvu i bolest Alise - u drugom, zaraziti i uspavati kraljeve i njihove velikodostojnike, koje će poslije sto godina probuditi Sunčica i Vladimir", o problemima scenske bajke u ostvarenju Alisa i Arkadije pisala je Sanja Živanović (Živanović 2009: 145).

U ostvarenjima Škozorište - antologija dramskih tekstova za djecu i Leptirija voli nebo, koje se sastoji od dvije drame i šest minijatura, Vukanović se potvrdio ne samo kao pouzdan antologičar, izgrađenog književnog ukusa i kriterijuma, nego i kao pisac koji je napravio suštinski iskorak u do tada siromašnom fondu dramske literature za najmlađe na crnogorskim prostorima. Stvaraočev izraziti dar ne samo za temat naučnofantastičnog, već i za njegovo prilagođavanje zahtjevima modernog života, na literarno uspio način došao je do izraza u Vukanovićevom romanu Ana i sedam robota, punom inventivnih fabulativnih obrta i zanimljivo vajanih junaka.

Gordana Sarić (Nikšić, Konjic, 1945), profesorica francuskog jezika, pjesnikinja, spisateljica, aktivna članica brojnih društava, organizatorka i voditeljka kulturnih manifestacija, urednica poezije na Radio Nikšiću, dobitnica nagrade za kulturu svog grada „18 septembar“, život je posvetila kulturi, umjetnosti, ljepoti i humanosti. Ispisujući klasičnu poeziju, ona lako nalazi put do čitalaca koji u njenim stihovima često sebe pronalaze. Publikovala je devet knjiga poezije i dvije proze za šta je dobila brojna priznanja i nagrade. Objavila je i tri zbirke poezije za djecu i CD Pjesmoslov kao obavezno nastavno sredstvo u drugom razredu osnovne škole.

Pjesmoslov Gordane Sarić predstavlja novinu u učenju crnogorskog jezika, koja se prvog puta u takvom obliku pojavila u crnogorskim nastavnim programima za osnovno obrazovanje. Autorka je napisala trideset i dvije pjesme posvećene svakom slovu ponaosob, u sklopu kojih daje uputstva kako se ona pišu, kao i primjere riječi koje određenim slovima počinju. Muziku za ovaj neobični Pjesmoslov napisala je profesorica Olivera Dakić. Kada je 
napisala pjesme o slovima, Sarićeva je došla na ideju da napiše i pjesme o brojevima jer su u asocijativnom smislu za nju bili veoma slični ili istovjetni, pa tako ćirilično „3“ postaje broj 3 u zbirci Nestašni brojevi. Pjesme za djecu Gordane Sarić u svojoj igrivosti, poletnosti i muzikalnosti predstavljaju poeziju radosti i ljepote. One na raznovrstan način govore o brojnim životnim preokupacijama i fenomenima - radosti, ljubavi, ljepotama Crne Gore, kao i svakodnevnim zbivanjima bliskim djeci, s najbližim i najdražim, u kući, školi i na ulici.

Njena prva knjiga za djecu - Narandžasta pjesma (Montegraf, Nikšić, 1995) čini logičan izraz interesovanja za djecu u cjelokupnom spisateljičinom prosvjetno-pedagoškom radu. Kao dominantvo svojstvo ovog poetskog ostvarenja uočava se autorkino uspjelo poznavanje dječje psihologije, koje se manifestuje na raznovrsne načine i izvire kroz različita tematsko-motivska čvorišta njenih pjesama. Bilo da je u pitanju borba za roditeljsku naklonost, doživljaj mlađeg člana porodice kao konkurencije, polazak u školu, đačke obaveze koje se obično prihvataju kao teret, prve simpatije, ljubav prema djedu i baki, neiscrpni svijet sanjarenja i fantazijskih predstava - pjesnikinja ovaj šaroliki spektar izlaže sa iskrenom emotivnom proživljenošću i unutarnjom radošću.

Ova knjiga se sastoji se od četiri ciklusa različitih temata, ali slične organizacije - „Narandžasta pjesma“, „Rodiće se beba“, „Vrtić i Pametno unuče". Pjesnikinja se mjestimično oslanja na iskustvo J. J. Zmaja, u sklopu kojeg ne demonstrira osobitu zainteresovanost da izbjegne rimovanje po svaku cijenu, ali se zato u pjesmama Noć i dan, Prosidba, Novi član, Ljubomora, Dobro jutro, dječji svijete, Drugarstvo i drugim, prepoznaju traganje za kreativnom individualnošću i svježina poetskog izraza, koji čine izvjesnu vrstu oslonca na ršumovićevsko-antićevski model modernijeg stvaralačkog izraza.

U izvjesnim slučajevima njenu poeziju možemo shvatiti i kao pozitivno didaktičnu jer ona istovremeno potencira neophodnost sticanja korisnih đačkih navika, kao što su urednost, ljubav prema knjizi, sklonost ka higijeni, odnos saradnje prema drugovima i uklapanja u kolektiv i poštovanje osnovnih pravila bontona (Pravila, Vitamini). Sarićeva imenuje široki registar iskustvenog svijeta mališana, u rasponu od vrtića do škole, sa svim karakteristikama složnog procesa odrastanja, osamostaljivanja, sticanja lijepih navika, razvijanja drugarstva i iznad svega - dobrote. Na takav način prilazeći spomenutom tematu, autorka i ne piše novi poetski krug, nego nastavlja svoj rad mijenjajući samo čitateljsku publiku jer pojedinosti specifične za poeziju ove spisateljice namijenjenu odraslima, zapravo izrastaju iz primarnog svijeta predmetnosti ostvarenja namijenjenih djeci. Ovo istovremeno znači da pjesnikinja iznad svega potencira duhovnu slobodu i individualost svakog djeteta, potrebu da bude voljeno i da samo izražava ljubav. „Gordana Sarić je u najljepšem smislu 
žena koja zna vidjeti i osjetiti proljeće i mladost i tamo gdje ih naizgled nema. Čini se kao da nam je došla iz nekog izvanvremenog svijeta punog sunca, svjetlosti i muzike, iz svijeta u kome je naučila da voli i bude voljena“, u recenziji ovog ostvarenja napisala je sociolog Branka Tanasijević.

Druga zbirka pjesama za djecu Gordane Sarić, o kojoj je već bilo riječi i koju je u inspirativnom smislu iznjedrio njen Pjesmoslov, nosi naziv Nestašni brojevi (2006), dok je poetska zbirka Kraljevstvo Šigi Migi, koju je posvetila svojim unucima Mariji i Dušanu, proglašena za najbolju knjigu dječje poezije 2010. godine od strane stručnog žirija Udruženja književnika za djecu Crne Gore. U svojim ostvarenjima namijenjenim djeci, autorka zauzima poziciju u kojoj didaktičnost doživljava iz djetinje perspektive, te se prema njoj odnosi kao prema nečem što narušava lepršavost i neobaveznost življenja, uvodeći ga u kalupe svakidašnjih obaveza i formi ponašanja nametnutih od strane odraslih, koje mališani teško prihvataju. Poezija za djecu Gordane Sarić predstavlja uzneseno slavlje ljepoti, ushićenju, zanosima i osmijesima, jednom riječju - sreći.

U aktuelnom nastavnom programu Crne Gore za četvrti razred osmogodišnje škole, djelo crnogorskog književnika Vuka Cerovića (Bijelo Polje, 1946) Hrabri dječak Dronjo jedini je roman sa realističkim sadržajem. Cerović je predavao Književnost za djecu i omladinu na programu za Srpski jezik i književnost Filozofskog fakulteta u Nikšiću. Piše prozu za djecu i odrasle, književnu kritiku i radio drame. Objavio je za odrasle tri zbirke priča (Drhtaj na rubu - 1979, Priče sa periferije - 1986, Tuđi život - 1987) i trilogiju Krug (Zle godine - 1989, Jesen u proljeće, Ljeto u Durakovcu -1985). Za djecu je objavio dva romana iz trilogije Hrabri dječak Dronjo - 1991. i Dječak traži oca - 1995, kao i dvije zbirke priča - Blago ispod naše kruške - 1984. i Rođaci sa Lazina - 1987, po kojoj je snimljena TV serija. Roman Hrabri Dječak Dronjo dobio je nagradu Politikinog zabavnika kao najbolja knjiga na tadašnjem srpskohrvatskom jezičkom području za 1991. godinu.

Osjećajući otuđenost djeteta bez oca i majke, autor je pratio dječaka Duška u brojnim trenucima samoće i suza. Na većini stranica ove knjige, čitalac će osjetiti da se piščeve simpatije odnose na svu djecu koja pate, da njegova priča o ubogom i napuštenom sedmogodišnjem dječaku emanira stvaraočevu nježnost, upućenu svim mališanima svijeta. Predmetnost romana Hrabri dječak Dronjo odnosi se na potresno oslikano djetinjstvo glavnog junaka, sedmogodišnjeg Duška, koji zbog zapuštenog i neurednog izgleda nosi nadmak Dronjo. U početnim poglavljima romana mali Duško je prikazan kao posmatrač razvoda braka svojih roditelja. Živeći kao podstanar kod baba-Jovane, u lošem socijalnom i porodičnom ambijentu, dječakov boravak u prirodi i kontakt sa šumom autor prikazuje kao vid emotivnog pročišćenja i uspostav- 
Crnogorska književnost za djecu i omladinu: odlike i predstavnici

ljanja duhovne ravnoteže. Kratko vrijeme nakon razvoda otac se ženi, a majka se, i pored sinovljevog negodovanja, udaje za svog šefa Radeta.

Roman Hrabri dječak Dronjo je dijelom istinita priča o dječaku iz jednog gradića, koji je iz toplog roditeljskog gnijezda dopao na ulicu i ostao sam; koga su u kratkom vremenu napustila oba roditelja jer se otac oženio, a majka se nakon nekog vremena preudala. Dječaka nije prihvatio očuh, pa je morao da pobjegne iz njegove kuće. Iako se majka vratila, Duško nije prestao da sanja o ocu, o nekadašnjoj porodičnoj slozi, niti je ikada prestao da se nada da će se njegovi roditelji pomiriti i ponovo živjeti onako kao što su živjeli prije razvoda. Pisac kroz fabulu romana svog glavnog junaka dvostruko prati: kao posmatrača porodične drame i kao učesnika u njoj. Otac, kojeg je dječak neizmjerno volio i koji je za njega predstavljao uzor, biva zamijenjen uvijek namrgođenim i zločestim očuhom. Kao što su relacije između djece i odraslih u romanu plastično prikazane, isto tako je uvjerljivo oslikan odnos između same djece. Ona su prikazana kao bića koja su, poput odraslih, sklona manjim ili većim pakostima, ali njihova zloba je kratkog vijeka i brzo pokazuju svoje pravo, čisto lice. Više nego odrasli, spremni su jedni drugima da pomognu i da se solidarišu u tuđoj nesreći.

Prelaskom u očuhovu kuću, dramski zaplet u romanu dostiže kulminaciju. Radeva djeca iz prvog braka, Darko i Sandra, dječaka loše prihvataju i njihov zajednički život pun je trauma za obje strane. Njihove međusobne čarke bivaju prekidane velikim Radetovim kaišem, te novo porodično gnijezdo pisac sa pravom naziva „kućom mržnje“. I pored toga što se relacije između djece polako popravljaju, Duškov odnos sa očuhom iz dana u dan postaje sve gori, da bi se konačno završio dječakovim bjekstvom od kuće. Od tog momenta počinje novi dio romana, koji prikazuje potucanje glavnog junaka, prijateljstvo sa čika-Stojanom, prelazak kod baba-Jovane, početak prvog razreda, bakinu smrt i konačno, kad se i bukvalno našao bez ikog ko bi ga prihvatio - njegov boravak u Domu za nezbrinutu djecu.

U sklopu završne epizode posvećene Duškovom boravku u Domu, prikazane su scene nasilja koje nad njim vrše dječaci iz Doma za maloljetne delikvente. I pored toga što je nedorastao i napušten, Duško je u romanu eksponiran kao moralna i izgrađena osoba, koja odbija predlog njegovih novih poznanika da se upusti u krađu. Roman Vuka Cerovića Hrabri dječak Dronjo se, i pored toga što oslikava teško i tragično djetinjstvo glavnog junaka, ipak završava srećnim krajem - majka se vraća po Duška i on joj, ophrvan ogromnom ljubavlju koju osjeća prema njoj, oprašta. Ovakvim krajem autor je prikazao da su odnosi između djece i roditelja daleko kompleksniji nego što nam se to u prvi mah čini. Sa jedne strane, jedni drugima dopuštamo priliku da napravimo greške, čak i one koje se mogu smatrati neoprostivim. Sa dru- 
ge - nošeni pozitivnim osjećanjima i svjesni žrtve koju roditelji podnose na svom najčešće napornom i odgovornom putu, za gestove i postupke za koje bi svakog drugog osudili - roditeljima po pravilu opraštamo. Osim toga što govori o kompleksnim odnosima unutar porodične zajednice, ovo ostvarenje na poseban način je društveno angažovano. Ono pokreće veoma važna pitanja o odnosu društva prema napuštenoj djeci, njihovom tretmanu kako u socijalnom okruženju, tako i o egzistenciji unutar organizacije Doma, stručnosti i savjesnosti ljudi kojima su povjerena na čuvanje, zaštiti prava nezbrinutih mališana, pravilnog rada na njihovom usvajanju i inkorporiranju u novo porodično okrilje.

Romani o dječjem životu i stradanjima u njemu sve više zaokupljaju pažnju savremenih pisaca. U temama koje nameće moderno vrijeme pisac i čitalac se osjećaju bliži realnosti, a težnja ka istinama savremenog kontakta sa ljudima i svijetom, uklanja nekadašnju ratnu, istorijsku ili idilično-romantičnu predstavu o djetinjstvu i ljudima.

Dušan Govedarica (Gornje Čarađe, Nikšić, 1948) objavio je desetak zbirki poezije i jedan roman za odrasle, kao i knjige poezije za najmlađe: Svemoćni pastir (1982), Elektro pile (1988) i Djeca birala cara (1994). Pjesnički glas Dušana Govedarice je prepoznatljiv i osoben u kontekstu domaće poetske riječi namijenjene djeci, budući da se već svojim prvim ostvarenjima namijenjenim najmlađima okrenuo temama i intresovanjima savremenog djeteta. Dijete modenog vremena i njegov osobeni senzibilitet predstavlja najgovještaj novih tema i inovativnog gledanja na svijet poezije u domenu crnogorske literature za djecu. Univerzalni motiv Govedaričine poezije je bunt protiv stega i kalupa koji se nameću današnjem djetetu. Zalaganje za ravnopravne odnose u porodici i društvu, prožeto notom humorističnosti takođe spada u lajtmotiv njegove vrcave poezije. U prikazivanju otvorenog i ravnopravnog tretiranja djeteta, Govedaričini stihovi zrače neposrednošću i toplinom.

„Njegov humor je diskretan, a poetski delatan“, o osobenostima autorove poezije za djecu pisao je Živan Živković. ,pesničke slike su žive, impresivne, a intonacija stihova - koliko vezane za tradiciju, toliko i za današnji 'govor' poezije (bez obzira na to da li se radi o poeziji za decu ili poeziji za odrasle). Ova svojstva zbirke Djeca birala cara ilustrujemo sa svega dve strofe pesme Hajka, koje glase: „Na mene se diže hajka: gdje sam bio, što sam pao? / Ova dama, moja majka, ne zna da sam odrastao. // Stalno traži nemoguće: ne galami, jedi voće. // Onaj što je glava kuće, razviče se kad god hoće“ (Živković 2009: 154). Njegove knjige svoje čitatelje čine zrelijim i odgovornijim, a pedagoško-didaktička komponenta u njima data je na nenametljiv i simpatičan način. 
I pored toga što je možda neobična njegova profesionalna opredijeljenost za svijet brojeva i matematike, s obzirom na to da je diplomirao na Prirodno-matematičkom fakultetu u Beogradu, Jovo Knežević (Kovren, Bijelo Polje, 1948) se sa uspjehom oprobao i na polju literature za mlade. Ovaj stvaralac je objavio zbirke poezije za djecu: Djevojčice i dječaci (1989), Sni i staze (1988), Hajde ptico da pevamo (1997) i Čarobna knjiga sa tavana (2001). Kneževićeve zbirke priča i pripovjedaka za djecu nose nazive: Deda iz doline kukureka (1992), Kad porastem biću dete (1994) i Korpica sa snovima (1999), dok se njegov roman za djecu zove Bajkan (2000). Prateći literarnu liniju koja je potekla iz pera vrsnih stvaralaca kakve predstavljaju Dušan Radović, Miroslav Antić i Ljubivoje Ršumović, Knežević ispisuje svojevrstan panegirik svijetu djetinjstva i odrastanja, kao i zavičaja - djetinjeg trajnog utočišta.

Dijete, po mišljenju Kneževića, postaje ličnost ako s nesputano igra okruženo ljubavlju i ako je okruženo zdravim zavičajnim ambijentom. U romanu simboličnog naziva Bajkan, autor čitaocu približava poetsku viziju suštine odrastanja, nesputanoj igri koja pomjera granice slobode. Knežević na umjetnički uspio način slika dijete $u$ doba kad se u njemu javlja svijest o vlastitom identitetu, njegovo djelo plijeni trajnim estetskom vrijednošću i dubinom poruke.

Blagoje Rogač (Crkvice, Nikšić, 1949), sa svojim obimnim i kvalitetnim stvaralačkim opusom posvećenim djeci - Obećani pohod (1987), Ovo zbilja nije šala (1989), Seoba iz groba (1990), Sjaj meseci u vrtešci (1991), Stani malo, strašni svete (1993), Pesnička čitanka (1997), Pesničko ogledalo (1998), Ne dirajte sunce (1998), Pismo zmaju (1999), Nepoznato carstvo (2000) i Sreća magareća (2001) takođe spada u nezaobilazno ime kada je u pitanju crnogorska književnost za djecu. „Pesnik Blagoje Rogač stasavao je u vremenu postradovićevskog pesničkog modernizma“ o ovom književniku pisao je Vuk Milatović, ,ali mu nije mogao pripadati po svom stvaralačkom senzibilitetu i načinu organizacije pesme. Sa jedne strane, on se iznedrio iz jednog osebujnog, poetski nadahnutog i snažnog pesničkog prostora, prostora izražene pesničke samosvesti - verovanje u poeziju kao u čudo, kao u mitski zanos i paradigmu postojanja, što bi mogao biti njegov epski i lirski zavičaj, a sa druge strane, iz postvučovskog ili postdanojlićevskog pesničkog viđenja sveta. Te dve-tri 'postojbine' njegove pesme, ti stvaralački podsticaji i umetnička motivisanost uslovile su: bujan i razuđen jezik, potrebu za modernim izrazom, ali ne po svaku cenu i slikovito-figurativne i fantazijske predstave sveta (Milatović 2009: 162).

Lirski zanos i naglašena poetska imaginativnost pružaju pečat prepoznatljivosti Rogačevoj poeziji: on je dinamičan stvaralac koji pjeva o poznatom, tražeći u njemu neotkrivene vrijednosti. Važna crta njegove poetske ri- 
ječi je plemenitost, kroz koju se autor približava djetinjem doživljaju i vizuri stvarnosti. On pred mladog čitaoca postavlja zadatke u formama literarnih igara, pa njegova poezija predstavlja zanimljiv i neobičan duhovni eksperiment. Osjećanja su važan dio Rogačevog stvaralačkog identiteta i kreativne prepoznatljivosti, a životne istine u njegovom pjesništvu se primaju kroz raskošnu skalu emocionalnih poruka.

Dragan Radulović (Nikšić, 1951 - Podgorica, 2002) je jedan od najznačajnijih poslenika poetske riječi u domenu domaćeg stvaralaštva za djecu i omladinu. Radulović je bio urednik Studentske riječi i Nikšićkog pionira, nakon čega je radio kao urednik programa za djecu Televizije Crne Gore. Sarađivao je sa brojnim književnim listovima i časopisima, u okviru kojih mu je poezija prevođena na strane jezike. Bavio se ilustrovanjem i slikanjem, a ostvario je više dokumentarnih TV emisija za djecu. Zastupljen je u antologijama, čitankama i lektiri, bio je član Udruženja književnika Crne Gore. Od početnih poetskih zbirki Okrpljene cipelice (1973), Krilati dječaci (1975) i Titove ruke što se smiju (1977), preko onih iz središnje stvaralačke faze - Blesma (1981), Leptir na asfaltu (1982) i Pa to ti je (1982), do završnog segmenta njegovog kreativnog opusa posvećenog svijetu djece i dječjem doživljaju stvarnosti - Balavko prvi (1987), Srcolovka (1988), Nemoj ovo nikom reći (1995), Hoću kući (1998) i Kako rastu krila (2002), Radulović je održao kontinuitet kvaliteta svoje poezije. Poetskom riječju ovog značajnog crnogorskog stvaraoca književna kritika se nije bavila u mjeri u kojoj je njegovo djelo i cjelokupni Radulovićev kulturni angažman to zasluživao. Ovaj poeta je priznat u širim okvirima literature za djecu, što na najbolji način potvrđuje njegovo dobijanje Trinaestojulske i Zmajeve nagrade.

„Poezijom Dragana Radulovića kritička misao nije se bavila u dovoljnoj mjeri“, o problemu recepcije motivski širokog i obimom impozantnog stvaralačkog luka ovog poete pisala je Svetlana Kalezić. „Kada je to činila uglavnom su se mišljenja kretala između veoma oprečnih stavova - od onih koji su naglašavali da je ovaj stvaralac ' $u$ crnogorsku djeju literaturu nio neosporno nove tonove' (M. Kralj) do drugih koji su isto poricali, insistirajući na stereotipnosti pomenutog autora, na 'lirici nedovoljno svježoj, čak prepoznatljivoj' (V. Marjanović). O čemu se zapravo radi? Svakog velikog pjesnika, bez obzira na to kojoj se publici obraćao, djeci ili odraslima, karakteriše inovativnost - da o već poznatim temama progovori novim načinom i jezikom jer teme se ne mogu množiti u beskraj, ali načini njihove interpretacije treba i mogu“" (Kalezić-Radonjić 2006: 417).

Iako se Radulovićev poetski opus može podijeliti u nekoliko cjelina, te cjeline ne korespondiraju sa potencijalnim fazama njegovog stvaralaštva. Poznato je da je njegov talenat imao neobičnu sudbinu - pokazao se u punom 
sjaju već prvim stihovima ovog autora, te mu nijesu bile potrebne faze sazrijevanja. Prvim kreativnim koracima ovaj stvaralac je snažno obilježio svoj poetski teren i kroz dvadesetak zbirki, koliko ih je objavio, održavao liniju kvaliteta koju je na početku dosegao. U suizdavaštvu Unireksa i RTV Crne Gore nedavno su objavljena izabrana dela Dragana Radulovića u pet knjiga: Okrpljene cipelice, Leptir na asfaltu, Nemoj ovo nikom reći, Čuvaj nebo za pticu (ekološka čitanka) i Tata, ugasi mrak (1995). Prve tri knjige donose izbor iz dosadašnjih izdanja, a četvrta i peta su novi rukopisi. Ovim projektom Radulović je krunisao 25 godina intenzivnog pisanja za mlade, sām izvršivši izbor i idejno-tematsku klasifikaciju svojih poetskih ostvarenja.

„Već je svojom prvom knjigom“, zapazio je Milutin Đuričković, „Dragan Radulović najavio oslobađanje od tradicionalnih okvira i vidno izdvajanje iz pastoralno-idiličnog pevanja, kakvo je doskora vladalo u književnoj produkciji za decu u Crnoj Gori. On je, naime, na početku stvaranja nagovestio modernost i vitalnost tematike, koja se semantički i strukturalno razlikuje od njegovih savremenika. Radulović je relativno brzo osvojio pažnju čitalačke javnosti, mada se književna kritika njegovim delom bavila, uglavnom, uzgredno i sporadično... U pristupu literaturi za decu i omladinu, Dragan Radulović se okreće novim temama i pitanjima, koja su i te kako svojstvena i bliska mladima urbanog senzibiliteta. Njegovi stihovi kao da idu u korak sa vremenom i u saglasnosti su sa aktuelnim zbivanjima u okruženju. Iako su pojedini motivi odveć korišćeni i rabljeni, Radulović ih, ipak, znalački i vešto inovira, ispoljavajući tako i smisao za nonsens, neobičnost, humor“ (Đuričković 2014: 12).

Radulovićeva poetika temelji se na osobenom poimanju života i modernoj viziji djetinjstva. U pojedinim pjesmama prepoznaje se uticaj predstavnika beogradske škole (Lukić, Radović, Ršumović), mada je njegova poetska riječ specifična jer uspostavlja nov i simbolički poredak odnosa. Radulović je poeta koji se zalaže za mudrost igre, vedrinu i osmišljen odnos bivstvovanja u urbanim uslovima života. Njegova maštovita igra duha potvrđuje poznavanje teorijskih zakonitosti moderne dječje pjesme, naročito kada je riječ o poentiranju, refrenima i misaonim obrtima. Pjesnik se zalaže za autentičnost i prevazilaženje klasičnog modela pjevanja. Kombinujući pojavni i skriveni ambijent, on smisaonim vezama stvara alogičnost, burlesku i parodiju, što posebno pokazuju pjesme iz posljednje dvije knjige. S druge strane, ima dosta pjesma koje su muzički komponovane, zastupljene u lektiri, antologijama, čitankama, što svjedoči o njihovoj estetskoj vrijednosti i prihvaćenosti. Radulovićeva poetska atmosfera je prisna i protkana nesvakidašnjom maštovitošću, dok je poniranje u svijet djece iznjedrilo mnoštvo raznolikih značenja, veselost $\mathrm{i}$ životnost. 
Imam kuću nemoguću, / u njoj ložim led u peći.

Smrkne joj se pri svanuću, / nemoj ovo nikom reći.

Prozori su na njoj vrata, / možeš leći, al'stojeći.

Miševe nam pseto hvata, / nemoj ovo nikom reći (Radulović 1995: 30).

Jedno od najzanimljivijih Radulovićevih ostvarenja jeste poetska zbirka publikovana 1994. godine u Beogradu, stvorena u koautorstvu sa Duškom Trifunovićem, Ljubivojem Ršumovićem i Mošom Odalovićem, pod nazvom Lirski poker. Pjesme su duhovito, ponekad satirično obojene i posvećene spomenutim književnicima, reprezentantima u okvirima jugoslovenskih književnosti poezije za djecu i omladinu. Prva pjesma iz zbirke Lirski poker posvećena je Dušku Trifunoviću - Kud si krenuo svijete, a pretposljednja - Durmitorski pozdrav, Ljubivoju Ršumoviću. Jedna od uspjelijih pjesama iz ovog ostvarenja nosi naziv Podesi nišanske sprave i vlastitim epilogom dovoljno govori o pjesničkim idealima spomenutih autora:

Drhte ranjene šume / $i$ nebo je bez lica,

Jesi li čuo, Ršume, / da više nema ptica?

Blijedi, slični nesnu, / kroz prostor jeziv i tih,

Od čega ćemo pjesmu?! / Od čega ćemo stih?!

Mržnja lukavo vreba, / šta ćemo prazni potom,

U ovo doba treba / pucati, ali-dobrotom!

Podesi nišanske sprave / ko Duško, Mošo i ja,

Ako nam dođu glave / ostaće - poezija! (Radulović 1994: 20).

$\mathrm{U}$ ovom svojevrsnom lirskom imeniku nema ni traga od spomenarske banalnosti, frazerstva ili trivijalnosti koje bi bile preuzete u vidu klišea ili manira, već ona predstavlja svojevrsni lirski biljeg u vremenu najproduktivnijeg stvaralačkog trajanja četvorice prestižnih umjetnika riječi. Svaki lik druga ili prijatelja u pjesmama Radosti na zajam, Vremena su ko sante, Bogatstvo, Pazi stari, Djetinjasta, Kako si mi, Dramatična komedija i ostalima, realizovan je na nježan i poetičan, stvaralački promišljen način. Zbirka Lirski poker, ostvarena u duhu neprekinutog fluida prijateljstva i uzdizanja najhumanijih međuljudskih osjećanja, zajedno sa ostalim Radulovićevim poetskim ostvarenjima, prerasta u humanu književnu misiju dobrote, iskrenosti i odanosti.

Radulovićeve dokumentarne emisije za djecu - Velike nevolje malog Borisa, Ljubica ljubičica, Gorki slatkiši, Kolijevka i brojne druge storije o sudbinama djece iz ciklusa Mali-veliki, obišle su svijet, okićene značajnim domaćim i međunarodnim nagradama i priznanjima. Osim književnim i televizijskim radom, bavio se fotografijom i slikarstvom - samostalno je izlagao u Podgorici, Novom Sadu, Budvi, Kotoru, Kraljevu, Tivtu i drugim gradovima. Dragan Radulović je bio urednik nekoliko časopisa za najmlađe, inicijator i 
voditelj brojnih muzičkih i drugih festivala za djecu, a veliki broj njegovih pjesama je komponovan.

Djelo Dragiše Jovovića (Petrovići, Nikšić, 1951) namijenjeno najmlađoj čitateljskoj publici čine zbirke poezije Da se pitam (1993), Koncert na obali (1995), Zavrzlamke (1999), Ples sa vjetrom, izabrane i nove pjesme (2001), Sunčeve pregršti (2004), Jedra malog mornara (2008), te zbirke priča Kopač zlata (1998), Mali lovac (2006) i Pećina duhova (2011). Jovović je sekretar Udruženja crnogorskih pisaca za djecu i sekretar Udruženja književnih prevodilaca Crne Gore. Živi i radi u Podgorici. Njegova djela prevođena su na više stranih jezika, a knjiga priča Kopač zlata prevedena je na engleski, ruski, španski, turski, grčki, rumunski i bugarski jezik. Pjesme su mu zastupljene u više antologija i udžbenika. Osim poezije i proze, ovaj stvaralac piše drame, epigrame i aforizme.

„Zbirku pjesama Ples sa vjetrom autora Dragiše L. Jovovića pročitaće sa uživanjem i odrastao čovjek i dijete“, o Jovovićevom poetskom izboru pisao je Vuk Cerović. „Ovo je knjiga o odrastanju, pjevanje o životu djeteta od najranijih svjesnih dana, do mladosti, do puberteta, do početka srednje škole, do prve ljubavi i prvih najslađih i najgorčih poljubaca. Zbirka je pisana tematski, podijeljena na šest ciklusa, od kojih svaki obrađuje određeni period djetinjstva, odnosno dječijeg doba. Prvi ciklus 'Zavičajni vidici' sadrži pjesme ispjevane o najranijem djetinjstvu, sjećanja na blažene trenutke provedene u roditeljskoj kući, pred brižnim očima majke, vraćaju pjesnika u rajsko doba, među najdraže, među mile ljude, među drage stvari; pjesnik ponovo postiže ljubljenu harmoniju sa svijetom, ponovo proživljava sve one radosti koje je proživio jednom“ (Cerović 2009: 169). U ciklusu „Volio bih da sam rijeka“, ovaj poeta pjeva o prvom djetinjem susretu sa školom i raspustu provedenom na moru. Jovovićev poetski ciklus „Jezik u čvoru“ sadrži poetske strukture vezane za naredne etape odrastanja djeteta, prvim ljubavima i nedoumicama, dok „Poruka svijetu“ izlazi iz djetetove intime, sublimirajući antiratnu poruku. Posljednji segment poetskog izbora „Lijepa riječ“ usmjeren je na nešto stariji uzrast u kontekstu kojeg dijete postaje odgovorno za vlastite postupke, te počinje razmišljati o različitim životnim fenomenima.

Jovović se u literaturi za djecu ogleda i kao vrstan prozaik, što na uspio način svjedoče njegove zbirke priča Kopač zlata, Mali lovac i Pećina duhova. U navedenim djelima upadljiva je upotreba narodne leksike, obojene raskošnim govornim koloritima. Priče u zbirci Kopač zlata („Nafta u bunaru“, „U nemilosti“, „Kopač zlata“, „Gospodar i mazga“, „Razmišljanje jedne banane“, „Antonija Krnjo“, „Žal za Kolonijom“) su anegdotskog karaktera, po pravilu zasnovane na određenom doživljaju iz djetinjstva ili isječku iz seoskog života. Široka motivska lepeza ovog ostvarenja najčešće se odnosi na vragolije djetinjstva. U ostvarenju Mali lovac, od početnih „Noć i dan“ i „Razmišljanje jedne 
banane“ do završne priče „Antonija“, likovi su slojevito i plastično umjetnički dočarani, dok su obrti duhoviti, sa djeci primjerenim idejama i porukama. Jovovićevo prozno kazivanje namijenjeno mladima obojeno je lirskom toplinom, neposrednošću, duhovitošću i iskrenošću. Autor svoje kratke proze artikuliše na jednostavan način, vodeći računa o efektnom epiloškom raspletu.

Svedenost poruke djela koja je saopštena čistom narodnom frazom spada u najvrednije valere njegovog stvaralačkog izraza, što na uspio način dolazi do izraza u ostvarenju Pećina duhova, koje se sastoji iz četiri narativna segmenta: „Vila iz legende“, „Kazivanje starog Radovana“, „Muzika iz duboke doline“ i „Čudesna svjetlost“. „Scenografija ove zbirke“, u pogovoru ovom ostvarenju pod nazivom „Baciti kamen u more vremena“, pisao je Jovo Knežević, ,nosi u sebi svojevrstan paradoks; dok su realni životi junaka, i njihove pojedinačne sudbine, stiješnjeni u uskim međama zavičajnih gora, livada $i$ stijena, dotle je njihovo proživljavanje neograničeno u vremenu i kolektivnom trajanju. Njima neprekidno u život dolaze duhovi, vile i vještice, ali ne iz čarobnih dvoraca ili začaranih pećina, već iz vremena, sjećanja i pamćenja“ (Knežević 2011: 74). Pojedinačni i kolektivni narodni duh sublimiran je na prološkoj i epiloškoj granici Jovovićevog djela, čineći zatvoren krug u okviru kojeg ono funkcioiniše na čvrstoj etničkoj i etičkoj podlozi.

Drama kao književni rod literature za djecu i omladinu najslabije je razvijena u svijetu i kod nas. „Čak i neka čuvena djela“, pisao je Novo Vuković u svojoj knjizi Uvod u književnost za djecu i omladinu, „kao što su Berijev Petar Pan ili Meterlinkova Plava ptica, svoju slavu ne duguju formalnoj pripadnosti dramskom rodu, niti pozorišnom uspjehu, nego činjenici da su to u suštini priče sa bajkovitom i fantastičnom atmosferom, te da se u tom smislu i doživljavaju. Uzroke te pojave, po svemu sudeći, treba tražiti u onoj više puta isticanoj potrebi djece za pripovjedanom literaturom i naracijom uopšte. I u krugu dramskih tekstova i u njihovoj pozorišnoj realizaciji dijete ipak najradije traži neobičnu priču, posebno bajku. 'Susret djeteta sa pozorištem počinje od bajke', veli Lav Ustinov, dodajući da je ovaj žanr za njega najpristupačniji i prema tome najvažniji“ (Vuković 1996: 42).

Blaga Žurić (Bijelo Polje, 1953) prosvjetni je nadzornik za crnogorski, srpski, bosanski i hrvatski jezik u Zavodu za školstvo Crne Gore. Piše poeziju i prozu za djecu i odrasle. Objavila je zbirke poezije sa djecu Bajka na izvo$r u$ (1997), za koju je recenziju napisao Dragan Radulović, Gdje vjetar spava (2000), zbirku priča za djecu i mlade Hoću lutku koja govori (2005), slikovnicu Crna Gora moja domovina (2006) i Igra zidnog sata (2010). Njen roman $U$ kraljevstvu slova nalazi se u aktuelnom crnogorskom predmetnom programu sa četvrti razred u predloženim djelima za čitanje kod kuće, odnosno spisku ostvarenja predviđenih za domaću lektiru. Objavila je priručnik za nastavnike 
Crnogorska književnost za djecu i omladinu: odlike i predstavnici

Bajka i njena metodička interpretacija u školi u izdanju Zavoda za udžbenike i nastavna sredstva iz Podgorice, 2012. godine. Zbirka priča Hoću lutku koja govori proglašena je knjigom godine za djecu i omladinu u Crnoj Gori (2005), dok je roman U kraljevstvu slova nominovan za nagradu Mali princ, 2014. godine.

U zbirkama Bajka na izvoru i Gdje vjetar spava, autorka je isključila pedagogizirane pouke i opise, pri čemu je sa kolektivnog (istorijskog) prešla na individualno (psihološko), težeći korjenitom zaokretu prema modernijem senzibilitetu i izražajnim mogućnostima. Time se kvalitet ove literature uzdigao na znatno veći stepen, podrazumijevajući širok dijapazon tema i motiva, sa autonomijom dječjeg sveta i drugim konstitutivnim elementima koji ga čine. U početnim ostvarenjima Blage Žurić, sublimirana je poetska istina o čovjeku i njegovoj težnji da izađe iz tame u svjetlost i ukroti prirodne stihije. Poruka ovog djela izražava neugasive ljudske želje i snove, težnju da se pobijedi zlo u prirodi i u samom čovjeku, da se obogati i uljepša život.

Sadržavajući više od fantastičnog i čudesnog, narativna ostvarenja Hoću lutku koja govori i Igra zidnog sata posjeduju velik broj raznovrsnih značenja. „Žanr čudesnog najčešće vezujemo za žanr bajke“, pisao je Cvetan Todorov. „Zapravo, bajka je samo vrsta čudesnog i natprirodna zbivanja u njoj ne izazivaju nikakvo iznenađenje - ni stogodišnji san, ni vuk koji govori, ni čarobne moći vila. Ono što bajke razlikuje je određeni način pisanja, a ne isključivo pripadnost natprirodnom" (Todorov 2010: 54). Reklo bi se da u većoj mjeri način pisanja, odnosno neobičan narativni model, nego sami motivi, navedene tvorevine uvršćuju u korpus djela sa fantastičnim sadržajem.

Roman Blage Žurić U kraljevstvu slova, osim nesvakidašnjeg pripovijednog postupka, posjeduje i niz neobičnih junaka: pas Roki, Ružičasti delfin, Zeleni žabac, žabac Kraka, Limeni drvosječa, mačak Markiša, svitac Svitko, zec Pahuljko, vjeverica Ljutka, cvrčak Smješko, Draginj-vila i ostali. „Kada na kraju priče djeca uspiju da oslobode slova zarobljena u Zloduhovoj pećini, ona su shvatila kako je velika vrijednost učenja. Iz začarane pećine tada pred njih stupaju Pipi Duga Čarapa, Ježurka Ježić, Limenko i Strašilo, Hari Poter...", ističe Anita Radanović u pogovoru romanu $U$ kraljevstvu slova. „Hvataju se u kolo i igraju, radosni zbog ponovnog susreta. Šta bi se, zaista, dogodilo da svijet koji je opsjednut video-igricama, računarima, televizijom i sličnim medijskim sredstvima, zaboravi na knjigu? Zaboravlja li takav svijet biblioteke, škole, čitaonice? Uskraćuje li sebi na taj način priliku da bude mudar i maštovit? Baveći se ovim pitanjima $U$ kraljevstvu slova postavlja pred mladog čitaoca jedan ozbiljan problem savremenog svijeta - knjige tišti samoća“" (Radanović 2013: 85).

Posvećen znacima pisanim na kamenu, pergamentu i papiru, ovaj roman za djecu Blage Žurić nas poziva na druženje sa slovima, emanirajući 
svevremenu poruku posvećenu značaju knjiga. Njegovu neobičnost potencira, između ostalih činilaca, i tretiranje aktuelnih društvenih i psiholoških problema, kakve predstavljaju kriza čitanja te okrenutost djece svijetu kompjutera i vizuelnih animacija.

Ime Dragane Kršenković-Brković (Priština, 1956) crnogorskoj i nekadašnjoj jugoslovenskoj književnoj javnosti je poznato već dugi niz godina, koje je ova autorka ispunila vrijednim literarnim ostvarenjima. Iz njenog bogatog stvaralačkog opusa vrijedi izdvojiti knjige za djecu - Tajna plavog kristala (1996), Duh Manitog jezera (2010), Tajna jedne Tajne (2011), Muzičar s cilindrom i cvetom na reveru (2013) i Modra planina (2015). Dragana Kršenković-Brković je diplomirala je na Fakultetu političkih nauka Univerziteta u Beogradu i na Fakultetu dramskih umjetnosti, a magistrirala na Filozofskom fakultetu Univerziteta Crne Gore (smjer nauka o književnosti). Četiri njene bajke su uvrštene u čitanke za osnovne škole u Crnoj Gori i Makedoniji. Dobitnica je nagrade za najbolji dramski tekst za djecu u SFRJ 1990. godine za bajku Čudesna zvezda. Dvije njene pripovijetke - Momin kamen i Vatra u Aleksandriji, zastupljene su u silabusu Katedre za slovenske jezike i književnost na Kalifornijskom univerzitetu u Berkliju. Njena knjiga bajki Duh Manitog jezera odabrana je od strane Internationale Jugend Bibliothek iz Minhena za White Ravens 2011, godišnju selekciju najznačajnijih knjiga za djecu u svijetu koje se izdvajaju svojim inovativnim umjetničkim stilom.

Još od početnog ostvarenja Iza nevidljivog zida publikovanog 1997. godine, ova spisateljica otkriva dramu kao svoj omiljeni izražajni model, a u domenu stvaralaštva za djecu - dramu u bajkovnom vidu ili obliku kao krajnje moderan i neobičan umjetnički žanr na crnogorskim literarnim prostorima. Poznate bajke poput Peroovih, Grimovih ili narodnih, savremenim piscima su često služile kao pouzdan obrazac ili predložak na čijim su temeljima mogli formirati vlastite autohtone literarne prizore i motive, ali za bajke Kršenković-Brković se može primijetiti da su u visokoj mjeri umjetnički originalne, protkane posve unikatnim motivima i simbolima. Građu svojih bajki ova umjetnica osmišljava kroz zanimljiv i maštovit dijalog junaka, „oblačeći“ bajkovno u dramsko ruho. Na takav način rađa se nesvakidašnji spoj smjenjivanja replika junaka kroz humorističan sadržaj, ,presvučen“ intenzivnom dozom imaginativnosti i dramatičnosti. Lajtmotiv u ovim tvorevinama jeste potraga, realizovana kroz osvajanje životnog smisla i sklada, u koje njeni junaci žele da postave kako sebe, tako i sebe uz suodnos sa drugima. Djelo Tajna plavog kristala i druge bajke, sastoji se od pet dramskih bajki: „Tajna plavog kristala“, „Bajka o krilatom konju“, „Hozentaurus“, „Neobična priča ili nevolje jednog malog zareza“ i „Čudesna zvijezda“. 
U pogovoru ovom ostvarenju pod nazivom „U traganju za bajkom Tajna dramaturgije Dragane Kršenković-Brkovićc "Aleksandar Milosavljević ističe: „Osnovna dramska situacija od koje gotovo redovno u svojim tekstovima polazi spisateljica jeste potraga. Pred njenim junacima se po pravilu, kako to uvek i biva u bajkama, postavlja složen zadatak (iz nekoliko etapa) koji moraju da budu razrešeni da bi misija bila realizovana. Razume se da rešavanje zadataka na probu stavlja sve ključne osobine koje treba da poseduje heroj, da od pogleda na svet projektovanog u konkretnoj bajci i priželjkivanog modela junaka zavisi karakter zadataka i njihov redosled. A junaci ovih drama su, nema sumnje, nosioci vrlina koje krase heroje priča iz klasične starine“" (Milosavljević 2010: 154).

U neobičnim i krajnje modernim bajkama Dragane Kršenković-Brković pravda se dostiže uz pomoć čarobnih sredstava, ali na način kakav nije ustaljen u klasičnim tvorevinama ove vrste. Istovremeno, djeca mogu otkriti kakva svojstva posjeduje čarobni napitak, kako cvijeće pobjeđuje bolest i kakva su svojstva čudesnog kamena. Ono što predstavlja „standardni“ postupak ove spisateljice jeste da, kao po tradiciji magijskog ili magičnog realizma, ono što je u uobičajnom životu obično - prikazuje na izglobljen i neobičan način, dok ono što spada u sferu ustaljenog i neočekivanog - kod čitaoca izaziva čuđenje i nevjericu. Osim početne bajke, po kojoj je cjelokupna knjiga dobila naziv Duh Manitog jezera, ovo djelo posjeduje još tri veoma uspjela ostvarenja - „Dječak sa čarobnim prstima“, „Skriveno blago malog trola“ i „Legenda o Zorou“.

O samosvojnosti i motivskoj originalnosti ovakvog specifičnog vida bajkovnog svijeta pisala je Nađa Durković u pogovoru knjizi Duh Manitog jezera, pod nazivom „Čarobni prsti dramskih bajki Dragane Kršenković-Brković": „Svijet bajki Dragane Kršenković-Brković naseljen je realnim i fantastičnim likovima. U Duhu Manitog jezera upoznajemo Danila i Nikolu, ali i Starog vilenjaka - čuvara neba i zemlje, svijetla i vazdušnih struja, Gospodara podzemnih voda, vladara sjenki, podzemne tame, voda i snova, Planinsku vilu, Proljećnu vilu, Duha jezera, sluge gospodara podzemnih voda, Šumskog duha, sluge Planinske vile. Mjesto dešavanja radnje je planina Lukavica u središnjem dijelu Crne Gore (imenovano je realno mjesto dešavanja radnje, za razliku od neodređenosti klasičnih bajki 'iza sedam gora i sedam mora...'). Autorka u dramskoj bajci Dječak sa čarobnim prstima, u maniru Oskara Vajlda, sažeto i efektno otkriva bezimenog junaka koji može biti svaki rasijani dječak koji mnogo rasuđuje, a čija osjećajnost može da ga liši smisla za stvarnost (Durković 2010: 155). U fabulativno-predmetnom jezgru navedenih bajki postavljena je drama junakove borbe protiv moćnih sila, pa se stoga može reći da one, univerzalizujući usud čovjekove borbe za opstanak, čine most između prošlosti, sadašnjosti i budućnosti. 
Naredna ostvarenja Dragane Kršenković-Brković višeslojna su i mnogoznačna, kao što je slučaj i sa njenim prethodnim dramskim bajkama. Knjige Tajna jedne Tajne, Muzičar s cilindrom i cvetom na reveru i Modra planina predstavljaju segment spisateljičinog bajkovnog ciklusa formiranog u proteklih 25 godina. Ova knjiga je ušla u selekciju Međunarodnog bijenala ilustracije 2011. u Bratislavi i Međunarodnog bijenala ilustracije 2013. u Beogradu. Prateći glavnu heroinu po imenu Tajna, čitalac se upoznaje sa njenim dnevnim životom, navikama i čežnjama. Djelo Tajna jedne Tajne pred čitaoce dovodi novu heroinu - Tajnu, u inovantan književni kontekst nepoznat u drevnom žanru bajki, kao i originalan pristup staroj i često obrađivanoj temi, kakvu predstavlja prva ljubav. Osnovna ideja djela sa jedne strane ohrabruje djecu da otkriju skrivenu stranu života, a sa druge - stimuliše u njima želju da saznaju šta leži unutar različitih životnih pojava, odnosa i fenomena.

Heroina Tajna ima sposobnost da leti kroz prostor i kroz misli ljudi. Ta joj sposobnost daje moć da čuje šta djeca i odrasli žele, o čemu sanjaju, za čim čeznu ili sa kakvim problemima i teškoćama se suočavaju. Njena potreba da pomaže djeci i odraslima da ostvare snove ili da se suoče sa problemima, daje njenom karakteru osobine novog heroja. Tajna jedne Tajne je knjiga posvećena prvim osjećanjima privlačnosti i ljubavi; ona pomaže djeci da savladaju nepoznate emocije i zbunjujuća osjećanja. Kao moderna bajka ona posjeduje emotivno, simboličko i pedagoško značenje, budući da su u fabulativnom sloju djela tretirani dječji strahovi od seksualnosti, stida, brige i sumnji, što najmlađima pomaže da se suoče sa teškoćama i nepoznatim pojavama u životu. Poruka ovog ostvarenja potencira optimizam i nadu u bolju budućnost, nudeći mogućnost mladim čitateljima da prevaziđu teškoće odrastanja i strah od nepoznatog. Napisano u popularnom stilu ovo ostvarenje zrači spokojstvom i vedrinom.

Muzičar sa cvetom i cilindrom na reveru je bajka data kroz formu slikovnice, namijenjena kako za najmlađi, tako i za nešto stariji uzrast. U oktobru 2014. ovo djelo je u Beogradu nagrađeno nagradom Neven za ilustraciju. Ova knjiga poziva najmlađe čitaoce da se pridruže radoznaloj i vragolastoj Sanji da zavire i u nevidljivi i čudesni svijet knjiga i života književnih junaka. U pitanju je moderna bajka, koja drevnu temu otkrivanja svijeta obrađuje na nov način. Poigravajući se sa stvarnim činjenicama i maštom, ova knjiga pomaže djeci da otkriju da je život mješavina svakodnevnih stvari i začuđujućih pojava, kao i magije svakodnevnog života i vizije nestvarnog. Uzbudljiva i inovativna, ova knjiga stimuliše čitaoce da krenu na jedinstveno putovanje otkrivanje misterioznog života junaka jedne nepročitane knjige.

„Bajka je kao književna vrsta s kojom se djeca najranije susreću, koja ih prati prilično dugo i ostavlja najjače tragove“, o značaju bajki, čija fabulativna 
okosnica, ideje i poruke prate mladog čitaoca još dugo nakon što izađe iz djetinjstva pisao je Milan Crnković. „Dijete, doživljavajući bajke, u malom prolazi sve ono što su narodi tisućama godina mislili o svijetu, kako su u svojoj mašti predstavljali sile koje vladaju u svijetu i odnose u društvu, što su željeli i za čim su težili. Danas ima u svijetu više tisuća tiskanih zbirki koje sadrže bajke pojedinih naroda i pokrajina. U sudaru sa civilizacijom bajka nestaje, a nekad stvoreno golemo blago izučava se i nekako se uvriježilo mišljenje da mlade generacije, ulazeći u život imaju najbolje predispozicije za čitanje i razumijevanje bajki“" (Crnković 1986: 21).

Dramska bajka Modra planina posljednje je ostvarenje namijenjeno dječjem uzrastu i recepciji svijeta ove književnice, a krase ga maštovitost, inventivnost i situaciona komika. Riječ je o zbirci koju čine devet originalnih bajki napisanih u dramskom obliku: „Kormilo drveno novo prodajem“, „Plavo drvo“, „Zmaj od Hridi“, „Kreni desno, tri koraka levo“, „U izlogu“, „Mrgud Strašni“, „Ljubavni jadi jedne busole“, „Hvatač snova“ i „Modra planina“. Neobične bajke Dragane Kršenković-Brković krasi orginalan i savremen pristup žanru bajke, pojava velikog broja novih junaka, obrada starih književnih tema, kao što su ljubav i strah, na nov način, vjera da djeca mogu lako da prihvate nerealističke likove - jednu Tajnu, Kormilo, Zarez, Slova, Busolu, muzičke oznake (Četvrtinu, Osminu, Šesnaestinu) ili likove iz stripova kao svoje idole. Kroz njih isijava vjera u moć bajke da izrazi unutrašnju, dublju stranu života, nesvakidašnji način da se djeca pozovu da se pridruže igri i povjerenje u moć priče.

Autor proza i dramskih tekstova za djecu Nenad Vujadinović (Kotor, 1964) u književnoj kritici je predstavljen kao makedonski pisac i lingvista koji se rodio i odrastao u Crnoj Gori i kao crnogorski pisac i teoretičar jezika koji je u intelektualnom pogledu stasao u Makedoniji. Vujadinović je publikovao pet knjiga proza za djecu: Priča o kornjačinom licu (Приказна за лицето на Желката - 1987), Zovem se Vil (Се викам Вил-1990), Želim da budem kоšarkaš (Сакам да бидам комаркар - 1995), Roni (Ronny - 2004), Prinсеza roda (Принцезата на штрковите - 2008), zbirku dramskih tekstova Nećete mi vjerovati šta se desilo večeras (Нема да верувате што ми се случи вечерва - 2005), kao i više kratkih priča, filmskih i televizijskih scenarija. Tokom 2007. i 2008. godine njegova knjiga za djecu Ronny u izdanju ISSA (International Step By Step Association, Amsterdam, 2004) prevedena je i objavljena na srpski, engleski, francuski, španski, ruski, ukrajinski, češki, slovački, jermenski, rumunski, mađarski i poljski jezik.

U književnosti za djecu Vujadinović primjenjuje tematsko-stilski postupak modernog prosedea, dajući joj prepoznatljive karakteristike visokog umjetničkog dometa. Očigledno je da su autorovo dramsko iskustvo i rad na 
filmu na direktan način uticali na njegov književni izraz. „Njegova djela imaju čvrstu strukturu, a racionalnost u konstruisanju priče u gotovo nevjerovatnoj mjeri postaje funkcionalna i ekonomična u narativnom smislu“, o svojstvima Vukovićeve proze za djecu pisao je Grigorij Markoski. „Nenadu Vujadinoviću neprestano uspijeva da vješto sakrije i potom plasira informacije, golicajući tako radoznalost čitaoca kojem se direktno obraća. On je najčešće njegov direktni sagovornik, onaj koji nenametljivo prenosi priču slikama, iskomponovanim kao da su montirane na filmskom montažnom stolu. Ovom utisku doprinosi i česta upotreba prezenta u narativnoj strukturi priče, u slučajevima u kojima se uobičajeno upotrebljava neko od prošlih gramatičkih vremena, što tekstovima daje dinamičniji izraz. Ovakav stilski postupak naročito je konsekventno sproveden u najnovijem romanu za djecu Princeza roda, ali se jasno prepoznaje i u njegovim najkraćim pričama“" (Markoski 2009: 188).

Na posebno uspio način ovaj pisac za mlade obrađuje probleme djece u urbanim sredinama, što nije čest slučaj u domaćoj književnosti navedene profilacije. Putem savremenog izraza, Vujadinović stvara neobične i upečatljive karaktere koji čitaocima otkrivaju tajne i iskušenja ljubavi, učeći ih strpljivosti i mudrosti.

I pored toga što je gluma njegova primarna profesionalna orijentacija, Dejan Đonović (1965) se sa jednakim uspjehom oprobao i u umjetnosti riječi. Kad je u pitanju stvaralaštvo za najmlađe, Đonović je sačuvao živo sjećanje na vlastito djetinjstvo, koje je uspješno pretočio u svoju prvu poetsku zbirku Rasprodaja snova (2002). Na stranicama svog literarnog prvijenca ovaj autor pjeva, šali se i raduje, demonstrirajući iskreni polet u trenutku kada se na crnogorskoj književnoj sceni za djecu osjeća izvjesno strukturno ponavljanje i zamor. Promociju svojih knjiga on je osmislio putem kostimiranog pjevanja i igranja, čime je pokazao višestruk smisao za kreativnost i lakoću u povezivanju i međusobnoj kompatibilnosti različitih grana umjetnosti. U izdanju Kreativnog centra 2004. godine publikovano je drugo Đonovićevo ostvarenje - Odlična ideja, koje je ušlo u najužu konkurenciju za nagradu Politikinog Zabavnika navedene godine.

Kao najuspjelije njegove pjesme mogu se izdvojiti one koje oslikavaju tzv. nonsensnu poeziju, kao što je, primjera radi pjesma Uspavanka, čiji završni stihovi glase: „bigu-ligu, čiča-miča / uspava me ova priča, / didu-lidu, njonja-njanja / došlo doba da se sanja“ (Đonović 2002: 12). Od ostalih poetskih stuktura mogu se izdvojiti one koje se odnose na stvari i pojmove iz neposrednog dječjeg okruženja (Cmok, Pupak, Društvena pjesma, Štikle, Patike), umjetničko oslikavanje situacija na duhovit način i karakterističnih za djetinjstvo (Babica, Tatamama, Probudalka, Tata kupa zvijezdu), te davanje savjeta za snalaženje (Evo šipak Babarogi, Lipa). Humoristično opisana 
razlikovnost između dječje mašte i stvarnosti prikazana je u pjesmama Strašni gusar i Rok an fol, dok je situaciona komika na uspio način došla do izraza u pjesmi Iz Engleske došla patka.

„Ako bi trebalo sumirati osnovne karakteristike ove pjesničke zbirke moglo bi se reći da Đonović u svojoj drugoj knjizi Odlična ideja uspjelo kombinuje tradicionalni prikazivačko-deskriptivni model pjevanja sa 'sagovaračkim' modelom radovićevskog tipa“, o umjetničkim odlikama druge Đonovićeve poetske zbirke pisala je Svetlana Kalezić-Radonjić. „Prilagođavanje dječjoj tački gledišta, a na drugoj strani iznevjereno očekivanje kroz pomjeranje perspektive u sagledavanju stvarnosti - dvije su strane između kojih se kreće Đonovićevo poetsko klatno, što ovu zbirku čini naglašeno dinamičnom. Na kraju, iščitavanjem ove zbirke jasno se otjelotvoruje jedan od stavova Dušana Radovića - pravi pjesnik je onaj koji zna da 'proceni vrednost sadržine' i podari joj 'odgovarajući oblik i dužinu'. Kada se tome doda i izuzetna emocija kojom ova knjiga isijava, sasvim je jasno čime je popločan najkraći i najdirektniji put do zahtjevne dječje čitalačke publike - kvalitetom“ (Kalezić-Radonjić 2009: 196). Dejan Đonović je ostvario značajan pomak u odnosu na dotadašnju crnogorsku književnu scenu u domenu poezije za najmlađe, ispunivši je i nadogradivši toplim i lirski intoniranim umjetničkim prizorima, te svježim i neobičnim jezičkim kombinacijama.

Autor koji je takođe privukao pažnju čitalačke publike navedene profilacije je Velimir Ralević (Berane, 1970), sa svojim kvantitativno i kvalitativno zapaženim stvaralaštvom, koje u prvom redu čine zbirke poezije za djecu: Mravinjak u žitnom polju (1995), Svitac u grlu (1997), Mirišem na ljubav (2000), Zlatni prozor (2002), Tanjini prsti zvone (2004), Brod u žitu (2006), Zaljubljeni vitez (2009), Mjesečarenje na suncu (2011), Bečkerečka mečka (2013) i Kroz život jurišaj (2014). Ralevićeve pjesme zastupljene su u brojnim zbornicima i časopisima te u preko trideset antologija u zemlji i susjednim zemljama. Ovaj pjesnik za djecu dobitnik je mnogih nagrada i priznanja, od Vidovdanske povelje i nagrade Udruženja književnika Crne Gore za dječju knjigu godine, do međunarodnih nagrada za ukupno književno stvaralaštvo Stara maslina i Zlatno Gašino pero.

Ralević u svojim zbirkama poezije - od kojih je književna kritika u najvećoj mjeri zapazila Mravinjak u žitnom polju, Svitac u grlu i Mirišem na ljubav - pjeva o ljubavi kao najvažnijem uslovu odrastanja i sazrijevanja. Njegova poetska zbirka Zlatni prozor (2002) može se doživjeti kao ljubavna balada dječaka koji stoji na pragu mladićkog doba. Ovaj poeta se pokazuje kao poštovalac dječje potrebe za muzički čistom poezijom, sa naglašenom ritmičnošću i simboličnošću. Posljednja pjesma u zbirci Zlatni prozor pod nazivom Odlazak, doživljava se kao svojevrsna pozivnica na prva životna iskušenja i radosti. Kroz njegovu poeziju otvara se čudesan pogled na jedan 
drugi svijet - svijet neslućene ljepote dječjeg doživljaja stvarnosti i naglašene imaginativnosti. Pojedine Ralevićeve pjesme prevedene su na engleski, ruski, rusinski, bugarski, makedonski i lužičkosrpski jezik, dok su druge izvođene i nagrađivane na dječjim muzičkim festivalima.

Crnogorska književnost posvećena najmlađima prerasta u vid stvaralaštva kojem je nužno pokloniti i kritičku pažnju, pa se velik broj priznatih imena iz oblasti kritičke misli orijentisao ka ovakvoj vrsti stvaralaštva (Novo Vuković, Voja Marjanović, Muris Idrizović, Dragutin Ognjanović, Slobodan Ž. Marković, Dragoljub Jeknić i drugi), u okviru kojih posebnu pažnju poklanjaju i crnogorskim dječjim književnicima. Mada ograničena brojem autora, ova se vrsta literature parametrima vlastitog literarnog kvaliteta može mjeriti sa ostalim književnim grupacijama. U XXI vijeku uveliko je prevaziđena zabluda o dječjoj književnosti kao o sporednom vidu umjetničkog izražavanja, pružajući joj se ravnopravno mjesto na panorami nacionalne literature.

U kontekstu savremene scene crnogorskog stvaralaštva za djecu, potrebno je spomenuti imena Cvijete Todorović (Dabovići, Danilovgrad, 1939) koja je objavila poeme i pjesme za djecu Pod šumskim svodom (1987) i Šta ko sanja (1989), Otvoreno nebo (1993), Latice oka (1995) i Dječja prava (2000), Dobrašina Jelića (Slatina, Andrijevica, 1946) u čijem se književnom opusu namijenjenom djeci kvalitetom izdvajaju zapisi Viči polako (1995), Jasne Vuković (Beograd, 1950) sa zbirkom poezije za djecu Ružindan (1989), Milosave Mijović (Gračanica, Andrijevica, 1954) u sklopu čijeg se književnog opusa posvećenog djeci izdvaja poetska zbirka Da me bube ne izgube (1997), Slavke Klikovac (Mojanovići, Golubovci, 1958), sa knjigama poezije za djecu - Proljeće u kosi (1993) i Pred vratima škole (1994) i zbirkom scenskih tekstova za djecu Sunčeva razgovorijada (2009), Ljubinke Vešović (Pljevlja, 1958) - O svemu što volim (2002), Ime na klupi (2003) i Srce mi je puno tebe (2004), Ljiljane Dašić-Cvetković (Berane, 1959) koja je objavila: Maslačci u letu (1989), Sačuvano djetinjstvo (1990), Nek se tata ljuti (1990), Otvori prozor, Saša (1991) i roman Zan iz sna (1995), dok je veoma moderni i inventivni Goran Bjelanović (Velika, Berane, 1961) napisao neobičnu zbirku poezije za djecu pod nazivom Kućica za ptice (2001), koju je posvetio ćerki Jovani i sinu Bogdanu. Uspjele konstituitivne komponente u djelima ovih književnika čini naglašena liričnost, živi dramatski prizori i univerzalnost poruke.

O problemu književnosti za djecu Crne Gore, koja nije u dovoljnoj mjeri proučena i sistematizovana sa književno-istorijskog i književno-teorijskog stanovišta pisao je Milutin Đuričković: „Ova literatura, koja se nejednakim intenzitetom i izvesnim prekidima stvara vek i po, ima svoje korene i čvrsto poetičko uporište u narodnoj tradiciji i folkloru, u mitologiji i kratkim umotvorinama, prenošenim sa generacije na generaciju. Slično drugim litera- 
turama i kulturama, a naročito južnoslovenskim, prvo su nastajali kraći lirski oblici (pesme, uspavanke, tašunaljke, zagonetke), da bi se potom razvili i širi epski oblici, kao što su: bajke, priče, pripovetke, legende. Usmeno stvaralaštvo bilo je, dakle, nepresušni izvor nadahnuća i prvi oblik vaspitno-saznajnog delovanja kod dece i mladih, čime se uticalo na njihovu svest i porodično odgajanje. Kao plemenska i drevna patrijarhalna sredina, Crna Gora je imala nešto drugačije etičko-estetičke norme i odnos prema nacionalnoj prošlosti, na koju se gledalo sa mnogo pijeteta i odvažnosti. Time se kod dece budilo saznanje o etničkoj pripadnosti, junačkim borbama za slobodu i osećanje za pravdu, istinu i čovečnost" (Đuričković 2012: 16).

Književna kritika literature namijenjene djeci i omladini u svom najčešće subjektivno intoniranom pristupu nije se u dovoljnoj mjeri bavila samim djelima, odnosno problemima materije i forme, specifičnostima kompozicionih načela, načinima pripovijedanja i umjetničkim oblikovanjem junaka. Bavljenje tipologijom crnogorskog romana za djecu i omladinu uslovilo bi i poređenje ostvarenja iz ove grupacije sa onima iz susjednih književnosti, čime bi se stekao kompletan uvid u razvoj ovog žanra na crnogorskim prostorima. Tako se dolazi do neobičnih podataka koji se uglavnom odnose na pojavu, genezu i specifičnosti romanesknih djela - prvi crnogorski roman za djecu Svemoćno oko Čeda Vukovića pojavljuje se 1953. godine, nezavisno od drugih literarnih kretanja tog doba na širem području nekadašnje Jugoslavije, u kojoj je u naznačenom periodu uglavnom dominirao socrealistički kreativni model.

Budući da nije imala kontinuiran razvoj, ova literatura nije mogla posjedovati odgovarajuću kritičku podršku. Više godina književna kritika u ovoj oblasti bila je oskudna i nedovoljno stvaralački prisutna. O knjigama za djecu i mlade pisalo se sporadično, pa se književnokritička misao o ovoj literaturi konstituiše nesistematizovano. Razni novinski i časopisni prikazi, zapisi i osvrti, predgovori i pogovori, svodili su se, uglavnom, na prigodničarski karakter i uopštene stavove, bez dubljeg analitičkog zalaženja u osnove poetike. Kontinuirano praćenje i izučavanje književnosti u Crnoj Gori za decu i mlade dobija ozbiljan i ravnopravan status tek u kritikama Voje Marjanovića, Nova Vukovića i Dragoljuba Jeknića, a u novije vrijeme u studijama i prilozima Slavoljuba Obradovića, Vuka Cerovića, Milutina Đuričkovića, Jova Kneževića, Svetlane Kalezić-Radonjić i drugih. 


\section{Literatura}

- Crnković, Milan: Dječja književnost (Priručnik za studente i nastavnike), Školska knjiga, Zagreb, 1986.

- Durković, Nađa: „C̆arobni prsti dramskih bajki Dragane Kršenković-Brković“, pogovor knjizi Dragane Kršenković-Brković: Duh Manitog jezera $i$ druge bajke, Zavod za udžbenike i nastavna sredstva, Podgorica, 2010.

- Đuričković, Milutin: Pisci i detinjstvo (Prilozi iz književnosti za decu i mlade), Legenda, Čačak, 2012.

- Đuričković, Milutin: Sunce u prozoru (Kritika o književnosti u Crnoj Gori za decu i mlade), Gligorje Dijak, Podgorica, 2009.

- Đurović, Žarko: „Romansijersko umijeće Dušana Đurišića“, pogovor romanu Dušana Đurišića Duga iz djetinjstva, Pobjeda, Podgorica, 2008.

- Jeknić, Dragoljub: „Pregled savremene crnogorske književnosti za djecu“, Stvaranje, Titograd, 1971, br. 1.

- Kalezić, Sofija: „Pjesnik u zavičaju (Poezija Dušana Đurišića)“, u hrestomatiji Milutina Đuričkovića: Poetika djetinjstva (Književna kritika o djelu Dušana Đurišića), Kulturno-informativni centar „Bijeli Pavle“, Danilovgrad, 2007.

- Kalezić, Svetlana: „Pjesništvo Dragana Radulovića“, u zborniku radova: Savremena crnogorska književnost (zbornik radova sa međunarodnog naučnog skupa održanog na Filozofskom fakultetu u Nikšiću 29-30. IX i 1. X 2005), Univerzitet Crne Gore, Podgorica, Filozofski fakultet, Nikšić, 2006.

- Kalezić-Đuričković, Sofija: „Nastavno proučavanje romana Vuka Cerovića 'Hrabri dječak Dronjo'“, u knjizi: Kalezić-Đuričković Sofija: Nastavno proučavanje romana u osnovnoj školi, Zavod za udžbenike i nastavna sredstva, Podgorica, 2006.

- Kalezić-Đuričković, Sofija: Pogovor zbirci poezije za djecu Gordane Sarić Narandžasta pjesma, Montegraf, Nikšić, 2005.

- Knežević, Jovo: „Baciti kamen u more vremena“, pogovor zbirci priča Dragiše Jovovića: Pećina duhova, Udruženje crnogorskih pisaca za djecu i mlade, Podgorica, 2011.

- Ljuštanović, Jovan: „Romani za decu Čeda Vukovića“, Mostovi, br. 153-4-5, Pljevlja, 1998.

- Ljuštanović, Jovan: Crvenkapa gricka vuka. Studije i eseji o književnosti za decu, Dnevnik, Zmajeve dečje igre, Novi Sad, 2004.

- Marjanović, Vojislav: „Likovi mladih u Kostićevim romanima“, Stvaranje, Titograd, 1973.

- Marković, Slobodan: Zapisi o književnosti za decu III (pojave, žanrovi, recepcija), Beogradska knjiga, Beograd, 2003. 
- Milosavljević, Aleksandar: „U traganju za bajkom (Tajna dramaturgije Dragane Kršenković-Brković)“, pogovor knjizi Dragane Kršenković Brković: Tajna plavog kristala i druge bajke, Zavod za udžbenike i nastavna sredstva, Podgorica, 1010.

- Milović, Jevto: „Razgovor sa Dušanom Kostićem“, u knjizi: Milović, Jevto: Umjetnička radionica, Budva, 1990.

- Nikčević, Milorad: „Naznake crnogorske poezije za đecu krajem XX i početkom XXI vijeka“, u: Lingua Montenegrina, god. IV/1, br. 7, Institut za crnogorski jezik i književnost, Podgorica, 2011.

- Ognjenović, Žana: Objavljena knjiga za djecu Bosiljke Pušić „Bašta od papira ", Pobjeda, Podgorica, pon. 17. mart 2014.

- Racković, Nikola: Leksikon crnogoske kulture, Društvo za očuvanje crnogorske kulturne baštine, Podgorica, 2009.

- Radanović, Anita: „U kraljevstvu dobrih slova“, pogovor romanu Blage Žurić: U kraljevstvu slova, Narodna knjiga, Podgorica, 2013.

- Radulović, Dragan: Izabrana djela, Unireks, RTV Crne Gore, Podgorica, 1995.

- Radunović, Miodrag: Pogovor, pogovor zbirci Radovana Stevovića Pjesme za djecu, „Rusko slovo“, Ruski Krstur, 1982.

- Todorov, Cvetan: Uvod u fantastičnu književnost, Službeni glasnik, Beograd, 2010.

- Vuković, Novo: Uvod u književnost za djecu i omladinu, ITP Unireks, Podgorica, 1996. 


\section{Sofija KALEZIĆ-ĐURIČKOVIĆ}

\section{MONTENEGRIN LITERATURE FOR CHILDREN AND YOUTH (FEATURES AND REPRESENTATIVES)}

In the time after the Second World War - cumulatively referred to as neo-realism in literary history, the literature for children and youth develops more expansively compared to the previous periods. The literature itself did not wait for parallel critical interest in it; instead it was expansive, especially in the second half of the twentieth century, both in qualitative and quantitative terms. Under the influence of the growing literary production, its first hermeneutical views have begun to appear, as well as scientific treatment of some of its problem areas.

Contemporary Montenegrin literature dedicated to young people and their preoccupations could not be developed independently of the roots it had. Speaking from today's point of view, it is interesting how these creators managed to skilfully weave into the fabric of the modern childhood world the traditional epic ethnic spirit and the feeling of the Montenegrin people and their region. Despite the fact that in Montenegro there were no conditions favourable for the development of literature for children, such as the ones that existed before Romanticism in other areas of the Balkans, ever since the appearance of the first novel of this kind - Svemoćno oko (The Almighty Eye) by Čedo Vuković in 1953, through the works of Dušan Kostić, Mihailo Ražnatović, Mihailo Gazivoda, Anto Staničić, Mirko Vujačić, Milenko Ratković, Dušan Đurišić, Dragan Radulović and others, Montenegrin literature for children and young people has been introduced in the subject mainstream modern South Slavic and European literature.

Key words: tradition, literature, war, Montenegro, creation, children, youth 


\title{
Anka VUČINIĆ-GUJIĆ (Podgorica)
}

UDK 821.163.4.09-1Lompar M.

Izvorni naučni rad

Zavod za školstvo Crne Gore

anka.gujic@zzs.gov.me

\section{POETIČKE DOMINANTE TRIPTIHONA IZ NACIONALNE BIBLIOTEKE MLADENA LOMPARA}

\begin{abstract}
Pjesnička zbirka Triptihon iz nacionalne biblioteke predstavlja sintezu stvaralaštva Mladena Lompara i ukazuje da je antitradicionalist kad su u pitanju motivi, pjesnička forma i metrički konstrukti. Izrazite tekovine postmoderne - umetanje imaginarnih diskurzivnih zapisa, mitske stileme, kombinacija fikcije i fakcije i fragmentarnost iskaza sastavni su dio Lomparovih poetskih tekstova. U postmodernom maniru spaja istorizam, intertekstualnost i fikciju, ne izričući tom prilikom nikakve vrijednosne sudove. Heterometričnost strofa, izbjegavanje stroge segmentacije poetskog reda i rime u poetskim tekstovima Triptihona uslovili su da Lomparova poezija poprima karakter pjesama u prozi. Postmodernistička tehnika navodno pronađenog dokumenta, binarne opozicije i kontrastiranje svjetlosti i tame, učestalost omiljenih lirskih denotata, Lomparu su prateći elementi za semantizaciju grijeha. U Triptihonu iz nacionalne biblioteke uočljivo je aktivno promišljanje smislenosti umjetničkog stvaranja, a varijacije od pozitivne do negativne konotacije riječi omogućila je višestrukost gledišta u poetici postmodernizma. Na ovaj način Triptihon pokreće brojna aksiološka pitanja i traži emotivno angažovanog čitaoca.

Kjučne riječi: poetika postmoderne, intertekstualnost, kombinacija fikcije i fakcije, binarne opozicije
\end{abstract}

Triptihon iz nacionalne biblioteke tvore tri ciklusa (Kraljica Jakvinta, Opat Dolči $i$ vrijeme stida, Tri pisma Darinki i narod jedinstvenog kraja i Boca lude princeze) i ova zbirka bogato korespondira s Lomparovim prethodnim tekstovima.

Broj tri je izraz intelektualnog i duhovnog reda, božanskog i u kosmosu i u čovjeku i on kao temeljni broj sintetizuje trojedinstvo živog bića jer čovjek predstavlja sjedinjenje neba i zemlje. Triptihon je prvobitno bio oblik knjige 
koja se sastojala od tri povoštene spojene tablice na kojima se pisao tekst, i zato triptihon i u likovnim umjetnostima predstavlja sliku od tri krila (dijela) koji čine tematsku i idejnu cjelinu. Biblioteke kao raspoložive riznice znanja i simbol spoznaje u punom smislu te riječi, korespondiraju s istoriografskim diskursom zbirke.

Istorijski događaji i istorijske ličnosti jesu tematsko-motivsko uokvirenje Lomparovih poetskih tekstova, ali je njegovo interesovanje usmjereno na individualne sudbine i na njihove unutrašnje lomove. Kao podtekst za svoju literaturu uzima nacionalnu istoriju u atipičnom postupku jer su ga interesovale ličnosti iz napomena pisanih istorija Crne Gore, „koje su u dosadašnjoj naučnoj obradi statistički podatak, a u svom vremenu su bile značajne i ostajale su mogućnosti za ljepotu pjesničke osvete" "1. Fakti u Triptihonu iz nacionalne biblioteke jesu polazna osnova, ali je nivo esteteske informacije pojačan osobenom rekonstrukcijom povijesti. Posebne vrijednosti u literaturi ostvaruju se kada diskursi subverzivno djeluju jedan na drugi, kao što je u postmodernoj strategija fiction i faction. Pošto ,poezija leži u žiži književnog doživljaja, jer je to forma koja najjasnije potvrđuje osobenost književnog, njegovu različitost od svakodnevnog diskursa jedne empirijske jedinke o svijetu“2 odlična je nadopuna narativima, koji su u duhu novog istoricizma gdje se napušta stanovište da je istorija stabilni, linearni fenomen, već se na nju gleda sa skepsom.

I ako ima sposobnost da objedini više diskursa, kod Lompara ta raznolikost nije hijerarhizovana jer svaki može dati informacije vrijedne za razumijevanje određenog problema i pojave. U Triptihonu je artefakt postignut dihotomijom fikcija-stvarnost, a lajtmotiv - nedozvoljena, grešna ljubav predstavlja poetičku koordinatu istorijskih reminiscencija. Visoka provokativnost Lomparovih poetskih tekstova upravo se ogleda u prikazu postupaka i osjećanja istorijskih ličnosti koji su narušili strogi moralni kodeks, pa je i njihova incidentna ljubav u strogom doticaju sa smrću ${ }^{3}$.

Postmodernistička fasciniranost ekstremnim situacijama upućuje da je Lomparovo interesovanje za istorijske teme strogo selektovano, ali diferencijalni temporaliteti omogućavaju širi kontekst. U narativu Triptihona je autorova napomena da je svaki grijeh istorije dobra pjesnička podloga, ,jer prava događanja samo se slute a pepelište nije jalovo za pjesničko traganje ", ${ }^{4}$ tako da je u recepciji djela bitno poznavanje njegove sociološke i kulturološke tematske podloge. Lompar je nepovjerljiv prema konceptu sveznanja i zato lirskim op-

Vijesti, 5. jun, 2010.

Džonatan Kaler, Strukturalistička poetika, Beograd, SKZ, 1990, str. 242.

O tome vidjeti u: Tatjana Bečanović, „Triptihon Mladena Lompara“, predgovor knjizi poezije Triptihon iz nacionalne biblioteke Mladena Lompara, Cetinje, Dignitas, 2006.

4 Mladen Lompar, Triptihon iz nacionalne biblioteke, Cetinje, Dignitas, 2006, str. 71. 
servacijama stvara fikcionalni konstrukt i aktivira pitanje reference. Intertekstualne intencije, kao tipičan postmodernistički postupak, omogućavaju sinhronijsko i dijahronijsko sagledavanje istorijskih fragmenata, čime hronotop pokazuje veći stepen varijabilnosti, a Lompar citiranjem sekundarnih sistema iz svog repertoara znanja o kulturi crpi motiv za otkrivanje aporija u poetskom tekstu. Inicijalni poetski impuls je ukrašeni pergament kupljen u Kairu, ili tri pisma pronađena u Državnom muzeju namijenjena Nikoli ili obilazak Muzeja morske boce, što upućuje na postmodernističku tehniku navodno pronađenog dokumenta, tako da autor nastanak poetskih ciklusa objašnjava diktatom proviđenja.

Lomparov semantički sistem raslojava se na binarne opozicije (bog-grijeh, svjetlost-tama). Svjetlost i tama zajedno simbolizuju komplementarne ili naizmjenične vrijednosti jednog razvojnog ciklusa. Tenzija se ostvaruje tezom i antitezom u pojedinačnom, da bi iz toga proizišla sinteza na području opšteg, ali napetost ne mora postojati samo između idejnih struktura, nego i između ritmičkih, tematskih i sintaksičkih struktura.

Grijeh je arhisema Triptihona iz nacionalne biblioteke, jer predstavlja semantičko jezgro zbirke. Arhisema uključuje sve zajedničke elemente leksičko-semantičkih opozicija, ali u isto vrijeme izdvaja diferencijalne elemente svakog od njih. Grijeh nastaje kao konstrukt pojmova koji obrazuju sklopove semantičkih opozicija (zemaljsko-nebesko, čovjek-bog, svjetlost-tama). Ovakva strukturna poetska opozicija doživljava se kao smisaona, jer su binarno uravnoteženi sasvim suprotni impulsi.

Osim toga, za utvrđivanje odnosa između uzusa pjesnikove upotrebe interpunkcije i njene uobičajene upotrebe indikativan je i grafički znak (kurziv, verzal). U većini pjesama Triptihona početno slovo inicijalne lekseme tipografski je istaknuto, a namjerno je izostavljena upotreba očekivanog interpunkcijskog znaka - velikog slova (verzala) i tim metatetičkim postupkom ostvarena je funkcija naglašavanja, a pošto govorni niz ima inerciju progresivnog kretanja, početak stiha ima potencijalnu ritmičku moć i Lompar je vješto koristio ritmičke zalihe koje se nalaze na prednjoj granici stiha. Odsustvo stihovnog izometrizma, ne narušava sam sistem, već se shvata kao odstupanje od određenog principa, minus prisustvo, nastalo zbog prezumpcije poetskog teksta na stihove.

Početak ciklusa Kraljica Jakvinta, opat Dolči $i$ vrijeme stida ima određenu modelativnu funkciju, jer nije samo svjedočanstvo o postojanju grijeha, već i zamjena kasnije kategorije uzročnosti. Dukljanska obala postaje umjetnički prostor i organizacioni elemenat likova, a unutarnja sintagmatika elemenata u tekstu postaje jezik prostornog modelovanja. Postmodernističkom tehnikom pronađenog dokumenta, pergamenta sa slikom opata u klečećem 
položaju i Jakvinte u rajskom pejzažu Lompar biblijskim asocijacijama na Adama i Evu otvara novo semantičko polje - grijeh. Shvatanje sudbinske određenosti dato je iz dvije tačke glediša - Arhiriza - ljepota je tvoj udes i Jakvinte - hrlila sam svom udesu. Leksička ponavljanja na kraju konstruktivnih granica stiha doprinose semantičko-emocionalnoj obojenosti i povećavaju redundancu teksta. Međutim, imenica ljepota ovdje gubi samostalnost koju ima jer uspostavlja korelativni odnos sa sudbinskom propašću u poetskom tekstu, tako da Lomparovo djelo postaje znak jedinstvenog sadržaja.

Kratak stih i glasovno podudaranje doprinose da zvučni sloj presudno utiče na formiranje semantičkih struktura.

stolovala $\mathrm{si}$

i u samostanskoj čamotinji

daleko od razvijenih zastava Bodinovih

i svoje grabljivosti

Ponavljanjem i isticanjem istih fonemskih realizacija one se prividno semantizuju na osnovu stepena uređenosti u različitim leksemama. Fonološka unifikacija postignuta fonetskom sekvencom $s t$, različito pozicioniranom (stolovala, samostanskoj, zastave, grabljivosti) uspostavlja vezu između izraza i sadržaja, što doprinosi izuzetnosti Jakvintine sudbinske određenosti (fatuma).

Veličanstvenost Jakvintine ljepote date ikoničkim znakom (graciozna, crnokosa, senzualnih usana) uslovljava presjek tri semantička polja ciklusa - grijeh, oprost, stid, nagoviještenih već u prološkoj sintagmi. Fakat kombinacije grijeh-kazna određuje prezumpciju prisustva zajedničke semantike, jer je opat bio usitnjen pred svojim grijehom, a poniženje povodom Jakvintinog naknadnog odbijanja shvata kao zasluženu kaznu. Lompar se u duhu postmodernizma poigrava tačkama gledišta, pa je opat Dolči iz autorovog ugla tvorac izuzetnosti zbog ljepote grijeha, a pjesniku je sudbina namijenila da ostavi pisani trag o tome. Semantička diferencijalnost sintagme - ljepota grijeha - proistekla iz hrišćanskog morala, u smisaonoj strukturi prvog ciklusa Triptihona javlja se kao semantička ekvivalentnost.

Anaforskim sintagmama - dok sam klečao pred prividom tvog obličja, dok sam tražio drhtaj u sjenovitosti očiju, dok sam u svetačkom zanosu čekao grč da skrutne tu prelest, koje predstavljaju sintaksičko-gramatičke paralelizme, prikazana je opatova spremnost na žrtvu, dok je Jakvinti oduzeta semantička samostalnost, lirsko $j a$. Stilskom simetrijom glagola u negaciji Lompar potencira Jakvintinu odlučnost da se povuče (nijesi odabrala pravi grijeh za vječnost, način da gledaš u crveni cvijet šipka i da mu se raduješ, nijesi vidjela kako sunce uživa dok opasuje tvoje nago tijelo koje se pomalja iz mora, nijesi 
znala da se osvrneš okolo da te usreći jedan teški pogled). Nar je simbol plodnosti, a hrišćanska mistika prenosi simbolizam plodnosti na duhovni nivo, na simbol božanskih savršenstava u njihovim nebrojenim pojavama. Nar tako predstavlja najuzvišenije tajne boga, njegove najdublje misli i najnedohvatnije veličine. Međutim, Lompar se fokusira na cvijet šipka, jer u grčkoj mitologiji koštica nara, koja osuđuje na podzemni svijet, simbol je kobnih slasti, a i crvena boja je simbolički kodirana. I glagol gledati je semantički ulančan jer bi prolazni užitak kušanja nara bio potisnut ustaljenim zakonom podzemnog svijeta. Temporalni konstrukti opata Dolčina (dok sam klečao, dok sam tražio, dok sam čekao) su u semantičkoj korelaciji sa opatovim doživljajem Jakvintinog odbijanja (nijesi odabrala, nijesi vidjela, nijesi znala). Anafore koje učestvuju u konstrukciji veće tekstovne cjeline doprinose ritmičkom raščlanjivanju i stvaraju cijelu hijerarhiju nadjezičkih ekvivalentnosti. Upotreba glagola biti u opozitnosti afirmacija - negacija upućuje da gramatičke kategorije u poeziji iskazuju relaciona značenja i da u znatnoj mjeri stvaraju model poetskog viđenja svijeta. Stih da te usreći jedan teški pogled upućuje da su lekseme usreći i teški ritmički ekvivalentne, ali doprinose semantički kontrastnim polustihovima, koji su suprotni na osnovu opštejezičkog značenja.

Lompar je Opatovo obraćanje Gospi (Jakvinti) uvijek propratio upotrebom velikog slova, a apostrofa je naglašena strogom segmentacijom poetskog retka i redukovanjem stiha na jednu riječ. Iz Opatovog aksiološkog aspekta Jakvinta nije zaslužila njegovo posrnuće, već su njeni postupci paradigma sebičnošću suženih granica grešnosti.

Zmija, kao biblijski motiv, simboliše pad opata Dolčina i definiše prostor njegove nemoći. Lompar u Pjesmi opata Dolčija boga markira kao tvorca grijeha, čime uključuje njegovu rasprostranjenost u cijelom univerzumu, ali socio-kulturni model kao naknadni društveni konstrukt nameće potrebu ljudima da sakralnim načinom života ugode bogu. I u stihovima molio sam da te ne poželim / duhom pocijepanim sugestivnom metaforom iskazuje vječitu raspolućenost ljudskog bića između dva pola iste stvarnosti - profanosti i svetosti. „Ako metafora u isti mah priziva i učvršćuje univokno, doslovno značenje, kao i što ga potiskuje, kako bi sebe razlikovala od njega i njemu prepustila primat u okviru logocentričnog svijeta“, 5 onda Lompar alogičnom i začudnom metaforom ostvaruje mikrosemantičku tenziju zbog heterogenosti članova sintagme. Grijeh kao konstanta ljudskog postojanja implicira i suprotnost, što je iskazano parentezom (kako bi drugačije nastajali sveci), ali je za djelovanje svetaca potrebno zlo sjeme i zlo vrijeme (Mitropolit).

5 Novica Milić, A, B ,C, Dekonstrukcije, Beograd, Narodna knjiga, 1997, str. 102. 
Naslućeni odgovor dat je strogom segmentacijom poetskog retka i svođenjem stiha na jednu leksemu

- suzom

kletvom

i mušketom -

\section{/Mitropolit/}

Eliptičnost iskaza i sintaksičko redukovanje doprinosi zgusnutosti i snazi izraza. Suza kao kapljica koja umire isparavajući, nakon što je svjedočila, simbol je bola i zalaganja i značenjski je premrežena sa kletvom kao negativnim denotatom, dok mušketa, stara vojnička puška iz XVI i XVII vijeka predstavlja simbol odlučnosti i hrabrosti da se odbrani svetost. Ritmička ekvivalentnost postignuta instrumentalnim sufiksom -om, objedinjuje semantički diferencijalne pojmove.

Provocirana antiteza stvara leksičku disonancu i oksimoron podesan da iskaže komplikovana duševna stanja. Autorova napomena za opata Dolčija - ušao je u vrijeme crne idile - pokazuje da je postignut napon između semantičke strukture umjetničkog jezika i prirodnog jezika, jer ako idila odiše skladom i duhovnom čistotom, lišenom napetosti i sukoba, povezivanje sa crnom bojom koja simboliše haos, ništavilo i tjeskobu, tugu i smrt, pojačava semantičku napregnutost.

Transfiguracija podrazumijeva premještanje sadržaja iz jednog u drugi kontekst, najčešće iz jednog prostorno-vremenskog okvira u drugi, pa Lompar opata Dolčina premješta iz vremena Bodina u vrijeme Petra I. Postmoderna je dvoglasna u svojim pokušajima da istorizuje i kontekstualizuje situaciju, pa stavljajući opata Dolčina/Dolčija u različite istorijske kontekste, Lompar putem kritičke ironije ispituje i prošlost i sadašnjost.

Dopisane pjesme opata Dolčija su u duhu postmodernističkog nadograđivanja istorije fikcijom i njegovim prikazom Crne Gore postiže se djelimično otuđena tačka gledišta, jer je data iz ugla jednog izvanjca, a otežana forma zbog prikaza Crne Gore iz neobičnog ugla ukida automatizam percepcije: 


\title{
Montenegro
}

\author{
ovo će biti Crna Gora \\ još mnogo vjekova \\ - u tamnicu zatvorenje \\ i okovi \\ i uvijek će tu biti \\ sveci i pjesnici \\ žrtve i krvnici \\ lutaće još dugo \\ učiti strane mitove \\ izgovarati tude molitve \\ bolovati rane drugih \\ i skapavati
}

Pošto opatu Dolčiju izmiče stabilna i uravnotežena slika Crne Gore, Lompar daje jedan kolebljiv opis, što se reflektuje na sintaksu.

U pretežno jednostavnim rečeničnim konstrukcijama nadjačava parataksa s izraženim asindentonom u trećoj strukturnoj cjelini. U strofama se primjećuje posebna vrsta agramatičnosti u iskazima, jer su sastavljene od klauza, i ostavljene van cjeline u koju bi se prema očekivanju uklopile. Sinonimske stileme - tamnica, okovi i zatvorenje, usmjerene na prostorno i vremensko modelovanje Crne Gore, izraz su sumorne poetske perspektive. Glagolska imenica zatvorenje, neobična $\mathrm{i}$ arhaična istog je semantičkog sadržaja kao tamnica i okovi i upućuje na ljudsku i moralnu podvojenost.

U drugoj strofi uočljiva su nagla prebacivanja po kontrastu iz jednog u drugi disparatni niz (sveci i pjesnici, žrtve i krvnici). Ako se semantička konfrotiranost drugog antinomičkog para primijeni na prvi, pjesnicima je na taj način oduzet oreol sveca i u toj vječitoj antitetičnosti često su ovjenčani grijehom, koji ih čini posebnim.

Nedostatak svijesti Crnogoraca o značaju vlastitog identiteta sadržan je u svakom stihu završne strukturne cjeline, a okrenutost drugim, stranim kulturama i empatičnost sa tuđim bolovima, biće uzrok njihovog dugog lutanja i traganja (još mnogo vjekova), sa tragičnim ishodom, što je istaknuto leksemom - skapavati, koja je graforitmički osamostaljena poenta.

Grijeh u Lomparovim poetskim tekstovima gubi negativnu konotaciju jer likovi koji su prema Lotmanovoj tipologiji dinamični, dejstvaoci, prelaze granice, stupaju u semantičko antipolje i zato o svijetu sude na osnovu spolj- 
nih znakova religije i morala. Do prevrednovanja grijeha dolazi usljed postmodernog stava da nema poretka koji bi osigurao pravila ponašanja, čime su narušeni čvrsti identiteti. Astigmatičan način viđenja stvari doprinosi da se sve završava u estetskoj igri, bez mogućnosti univerzalnog znanja i opšteprihvaćene istine. Pošto se umjetnički lik izgrađuje ne samo na principu realizacije, već i odstupanja od tradicionalne kulturne sheme, semantizovan je Lomparov odnos prema oprostu. Autorova napomena sadrži semantičku opoziciju - nije (Jakvinta) tražila oprost, svi su se o nju ogriješili i opata Dolčina - ti si za sve imala oprost i trajaćeš mojom žrtvom.

Lompar vremensku dimenziju hronotopa pomjera niz vjekova unaprijed, smještajući opata Dolčija u vrijeme Petra I, ali ponovo sa Erosom i Tanatosom u međuodnosu, jer su ljubav i smrt semantički premrežene. Tako dva vjerska poglavara zakleti Bogu da će žensku put gledati samo kao ljudski grijeh postaju žrtve ljubavnih spletki. Tu uočavamo Lotmanov princip sa-protiv postavljanja značenja - Petar I je zbog mučeničkog života proglašen svecem. Opat Dolči nije zbog mučeničke smrti. Akt paralelizma ovdje ima različit smisao, jer nakon ponavljanja riječi mučenički, koja stvara semantičku napregnutost, slijedi antonimični par život-smrt. Ali, u tom vječitom polaritetu Opat je lišen blagonaklonosti sudbine, što neminovno uslovljava njegovo povlačenje i poraz, nagoviješten u pjesmi Pogled kroz prozor (o Sveti / prijatelju / napuštam te zbog onih/koji su mi sudbina - kažeš / stežući svoj štap kao simbol iščezle snage / treba ti moja krv / moj Bog / i moj oprost).

U sklopu Nezapisanih pjesama opata Dolčija je poetski tekst Da pjesma ne bude koji pravi otklon od uobičajene tematike grijeha, oprosta i stida, već je semantizovan Lomparov odnos prema riječima, pa se može govoriti o autoreferencijalnosti, tj. o književnom i jezičkom diskursu kojim se iskazuje stvaralačka samosvijest.

gospode

plaše se moje nenapisane pjesme

pa stradam

na vječito njegovo u tamnicu zatvorenje

rekli su

i bi im malo

pa mi dodadoše

okove po nogama i rukama

da pjesma ne bude

nikad više

da se utre 
da se pjesnicima

jednom zauvijek

objavi cijena riječi u ovoj zemlji

mre li misao

Gospode

/Da pjesma ne bude/

Semantička ekvivalentnost prvog i završnog stiha ove pjesme i apostrofsko obraćanje /gospodel, upućuje da je gospod jedno kojem teže sve pojave, ali u postmodernom maniru varijacija je samo u pisanju malog slova na početku i velikog - na kraju. Poetska konstrukcija stvara osobit svijet značenjskih analogija i suprotnosti, ali umjetnički efekt nastaje upravo u borbi. Pjesnikovo stradanje izazvano strahom njegovih nenapisanih pjesama, završilo je u odsustvu misli i obesmišljavanju egzistencije /mre li misao gospode/.

Izbjegavanjem glagola u prvom licu singulara pjesnik postiže objektivnu tačku gledišta jer lirsko ja nije semantički stožer teksta. Sociološka i kulturološka situacija ne pružaju povoljnu klimu za pjesničko stvaranje, što je istaknuto okazionalno poetskim sinonimima - da ne bude (pjesma), da se utre - udruženih s adverbijalnom oznakom nikad. Odrične zamjenice i adverbi idu među riječi koje su najjače natopljene koncentrisanom afektivnošću i zbog toga su lirski izvanredno izražajne. Semantostruktura je dopunjena brojnim denotatima (tamnica, okovane noge i ruke, teški prsti, stihovi razbijeni kao krčazi) i iniciraju smisaoni centar pjesme da se pjesnicima / jednom zauvijek / objavi cijena riječi u ovoj zemlji. Ako su riječi najčistiji simbol iskazivanja bića koje sebe misli i sebe izražava ili bića koje je drugi spoznao, onda Lomparov iskaz da pjesnici zaćute predstavlja detronizaciju umjetnosti. Fonološki paralelizam (ponavljanje samoglasnika $i$ ) navodi da se ove riječi poimaju kao semantički međusobno korelativne. Fonema $i$ je u ovim riječima strukturno različito pozicionirana, jer se u prva dva stiha nalazi u medijalnoj poziciji, za razliku od trećeg stiha gdje je u sufiksu i gdje se ironizatorskim težnjama akcenat stavlja na leksemu - riječ i prostornu stranu hronotopa. Semantička opterećenost foneme $e$ doprinosi intonacionalnom saobražavanju i kadencama na kraju strofe.

Gramatičke kategorije izražavaju relaciona značenja, pa je modelovanje umjetničkog prostora istaknuto sintagmama - u ovoj zemlji i moje more, što asocira na prostornu blizinu, nasuprot tom bezimenom, duhovno dalekom svijetu koji ne omogućava stvaralačko ispoljavanje.

Vrijeme stida počinje Iskazom koji se sastoji iz tri cjeline. Filozofema iskaz (izraz) je znak Lomparovih poetskih tekstova, a pjesnički iskaz počiva na umjetničkoj uvjerljivosti i izražajnoj strani poetske artikulacije. U običnoj 
upotrebi jezika sadržaj se ostvaruje u konkretnoj, pojedinačnoj vezi sa stvarnošću, dok pjesnički iskaz može biti prožet simboličnošću, budi asocijacije na šira iskustva čitalaca i pokreće njihov cjelokupni intelektualni i osjećajni potencijal.

\section{ISKAZ}

1.

u svjetlost ciljajte

da ne znaju umrijeti -

čuli smo naredbu

i nije nas bilo

odjednom

sa svjetlosti je pao svlak

i mi smo ostali u njenoj crnoj suštini

oči nam više nijesu trebale

niti lik

bio je dodir

glas

i duh

sjećam se da smo i čuli -

pamtim pisak ptica nad morem

i muk praznine

(kao u crkvi što je Bog izbjegava)

i riječi :

usmrtili su nam svjetlost

nije bilo munja

ali se nijesmo ni spaljivali

(iako odavno ovdje nije bilo velike smrti)

u strahu od onoga

što će plamen odnijeti 
Čitav Lomparov Iskaz je u svjetlosnoj simbolici i zato se nizovi okazionalno-poetskih antonima (svjetlost - crna suština) percipiraju s obzirom na semantička polja koja su aktivna u komunikacionom sistemu. Paradoks kao figura misli, na početku - u svjetlost ciljajte da ne znaju umrijeti - ostvaruje semantički naboj nelogičnošću i neskladom. Oko je simbol intelektualnog opažanja i metaforički može obuhvatiti i pojmove ljepote, svijetla, svijeta, kosmosa, života, pa ironijskim iskazom - oči nam više nijesu trebale / niti lik - dolazi do gubitka identiteta i obezličavanja, čime se negira humanost življenja. Distanciranost od osjetilnog svijeta omogućava umjetniku da na osobit način otkrije i objelodani stvarnost, tamu i izopačenost svijeta i egzistenciju ispunjenu bolom. Lompar neprestano rekonstruiše skup jezičkih komponenata s obzirom na estetsko dejstvo cijele manifestacije i zato izbjegava značenjski oštro ograničene riječi i bira izraze bogate asocijacijama. Sociokulturne okolnosti do kojih recipijent može doći samo asocijativnim putem, predstavljaju Lomparovo polazište za promišljanje čovjekove sudbine. Diskurs vlasti i moći sveden je isključivo na svoju konotativnu ulogu, jer posjeduje neki asocijativni ili emotivni „višak“ u odnosu na denotaciju.

Ptica kao simbol viših stanja bića i momenata duhovnosti ponovo aktuelizuje riječi i njihovu nesposobnost da iskažu složenost čovjekove unutrašnjosti, pa otud muk praznine i riječi - usmrtili su nam svjetlost. Munja označava iskru života i plodovitu moć, a na duhovnom nivou proizvodi unutrašnji bljesak. Dominacija negativnih oblika glagola (ne znaju umrijeti, nije nas bilo, oči nam više nijesu trebale, nije bilo munja, nijesmo spaljivali, nije bilo velike smrti) semantički korespondira s prevlašću tame u svjetlosnoj antinomičnosti. Preuzimanjem arhetipskih i drugih istorijski utemeljenih književnih simbola i njihovim nadograđivanjem u novom kontekstu novim značenjima, Lompar kreativno ispoljava filozofske $\mathrm{i}$ intelektualne intencije. Lomparovo višestruko kodiranje poetskog teksta ogleda se u tome što ne polazi samo od jezičkog znaka (munja, plamen), već i od semiotike i znakovnog događaja, odnosno procesa u kojima čulima dostupna jedinica upućuje na nešto izvan sebe, na autentičan hronotop, pod uslovom da je čitalac u stanju da ta dva momenta poveže.

Lomparov negatorski odnos prema normativnoj sintaksi i insistiranje na ukidanju interpunkcije ne znači odstupanje od logičkog slijeda. Običan jezički materijal javlja se u neobičnim značenjima, jer rečenice teku jedna za drugom bez vidljivih sintaksičkih i značenjskih granica, stapajući se u sintaksički neodređene formacije. Zato se u Iskazu intonacija i ekspiracija (intenzitet izdisaja) uzajamno uravnotežavaju, jer nekada tendenciju ka brisanju granica između riječi, djelova rečenica, smjenjuju težnje da se granice naglase i podijeli struja disanja na odsjeke. 
ISKAZ

2.

doći će

neka neshvatljiva jasnoća

i prije nego što stignete

do hridina nad morem

borićete se

biće to stravično

prvo će vam ukinuti kalendare

i rječnike

zabraniti pečatanje

i crkvu

uzeti pravo

i dostojanstvo

(biće još uvijek mrak)

kad bude svjetlost

(ona mora doći)

progoniće vas

trpati u kazamate

prebijati

vući po blatu

i čekati na nišanu vaša čela

(ona se moraju podići)

vaše domove

gore i obale

i nebo

a onda će podići vaše zastave ...

više ne vidim ništa

nema kraja-

uzdahnu...

Kao kosmička objava ili kao unutrašnje prosvjetljenje, svjetlost je uvijek poslije tame, a u širem smislu svjetlost i tama su izraz sveopšteg dvojstva, što upućuje na nerazdvojnost ta dva korelata. Međutim, mrak i svjetlost $u$ 
Lomparovim poetskim tekstovima su specifične metonimije stvarnosti, a istovremeno i invarijantne jedinice Lomparove poetike. Mrak, koji obesmišljava čovjekovu egzistenciju i gdje je dostojanstvo življenja ukinuto narušavanjem nacionalnih, vjerskih i u krajnjem smislu ljudskih obilježja, zamijeniće svjetlost, ali protivrječnost misli i suprotnost opšteprihvaćenom mišljenju i logici usloviće paradoksalni obrt. Neizbježnost svjetlosti poslije tame ne nudi ljepše trenutke bivstvovanja, pa se paradoks javlja u vidu protivrječnog zaključka koji upućuje na dublji smisao.

Futurističkim oksimoronskim prikazom („,doći će neka neshvatljiva jasnoća") sintaksički su povezane dvije jezičke jedinice (imenica i pridjev) suprotnog značenja, koje u okazionalnom odnosu stvaraju nelogičnost i nesklad. $\mathrm{Na}$ taj način stvoren je inicijalni naboj i povećava se informativnost poetskog teksta.

Negativna konotacija svjetlosti modelovana je specifičnim oscilacijama prikaza poetskog prostora - od kazamata, blata do nišana usmjerenog na domove, gore, obale i nebo. Ako se blato po etičkom simbolizmu poistovjećuje sa talogom, dnom i nižim nivoima bića, onda je u duhu kosmičkog i moralnog simbolizma ljudska egzistencija ukaljana. Efekat izjednačavanja krajnjih tačaka prostora (obale i nebo) ukazuje na semantiku zla i model svijeta koji ne pruža drugu mogućnost postojanja. Zato je disparatnost bliskih i udaljenih poetskih prostora objedinjena zajedničkom oznakom - nišanom, a pored njegove očekivane usmjerenosti na domove, gore i obale, semantičku tenziju stvara njegova orijentisanost na nebo. Zbog nišana usmjerenog na nebo semioza Iskaza se usložnjava, jer je nebo složeni simbol svetog reda univerzuma, regulator kosmičkih principa, tako da spajanjem dva konfrotirajuća znaka, referenca poprima obrise groteske kao posljedica remećenja opšteg poretka u svijetu. Izrazita lirska sugestivnost parenteza - ona (svjetlost) mora doći i ona (čela) se moraju podići - upućuje na ljudski poriv da borbom postanu sudionici svog vremena i izbore se za dostojanstven život.

Nakon svjetlosne antinomičnosti, Lompar stihom - a onda će se podići vaše zastave - koji je izdvojen i kao strofa, artikuliše bojni poklič, a u okviru civilizacijskih i sociokulturnih sistema i pobjedu. Interpunkcijski znak, tri tačke, na kraju ovog i završnog stiha korelira sa stavom da nema kraja, što je indikativno za nezaokruženost egzistencije.

Lomparov Iskaz pokazuje da je ,poetski diskurs višeznačan i ironičan, u njemu se osjeća tenzija, posebno u načinu karakterisanja, a pažljivo čitanje, zajedno sa poznavanjem konotacije, omogućiće nam da otkrijemo tenziju i paradoks svih uspjelih pjesama“. 6

Džonatan Kaler, Strukturalistička poetika, Beograd, SKZ, 1990, str. 243. 
ISKAZ

3.

kažem ljubavi

ali gluvo doba nije čulo misao

kazao sam i nešto obično

kao:

cijelog dana si bila pred pjesmom

i tražila se

ali to nijesu riječi za tišinu

i njeno strogo vrednovanje

a onda sam misao vratio praznini

i čekao

(nikakav poduhvat

više nije bio dostojan beznađa)

Težina poetske artikulacije posebno je ispoljena u trećoj cjelini Iskaza i izrazito naglašena sintaksičkim sječenjem prvog stiha (kažem ljubavi) i stavljanjem akcenta na povratni glagol ( $i$ tražila se).

Uobičajeni lajtmotivski nizovi (ljubav, poezija, stvaralaštvo) u Lomparovom diskursu mijenjaju značenjsku struju, jer nije pjesnik taj koji se traži pred pjesmom, već ljubav. Potisnutost subjekta - agensa, čija svijest treba da bude aktivna, predmetom - pacijensom, koji gubi pasivni princip, omogućava fleksibilna postmoderna paradigma, gdje se značenjsko raščlanjivanje rečenice ne poklapa uvijek sa formalnim sintaksičkim raščlanjivanjem. Iako ljubav prozilazi iz jedinstva suprotnosti, nelagoda poetskog imenovanja je sušastvena odrednica umjetničkog kreiranja.

Tišina i ćutanje imaju diferencijalna obilježja, jer je tišina uvod u otkrovenje, otvara prolaz, obavija velike događaje, označava napredak, dok je ćutanje nazadovanje i ono je zatvaranje, tako da je odabir riječi za tišinu strogo selektovan. Ako se pjesnik prazninom oslobađa vrtloga slika želja i osjećanja, znači da izbjegava tačku prolaznih egzistencija kako bi svoju pažnju usmjerio ka apsolutnom. Praznina kao čin ukinuća svakog čina i odsutnost poimanja, semantički je usklađena sa parentezom na kraju poetskog teksta (nikakav poduhvat više nije bio dostojan beznađa). Tako se semantičko polje Iskaza formira na osnovu složene interakcije partikularnih i kontekstualnih značenja i među njima se uspostavlja metatekstualni dijalog.

Korelativnost glagola - tražila se, vratio, čekao upućuje da se Lomparovi iskazi ne zaokružuju, jer postmoderni liričar nameće jedan pa- 
radoksalni zadatak - da smisao istovremeno iskaže i prikrije. Osim toga, ni metrički obrasci nijesu očigledni, a i specifičan tipografski raspored pobuđuje drugačiju vrstu čitanja.

Lomparov Iskaz, pokazuje ,kako neka sintagma ili fraza postaje potencijalno pjesnička u času kad gubi denotativnu određenost arbitražne i provjerljive obavijesti zadobijajući istovremeno začudnost i nadređenost više mogućih konotacija. Gubiti osnovno značenje, a stjecati začudna suznačenja uistinu je nužnost na putu svake sintagme do novog, obuhvatnijeg, poetski paradigmatiziranog značenja“"?

Prvi ciklus Triptihona završava se lirskom minijaturom Vrijeme stida.

prije nego što je pao jarbol

kao crta ispod sabiraka

čekasmo neka zelena ostrva

i zlatno žalo

dolazilo je vrijeme stida

Spušteni jarbol postaje stožer pjesme i objektivni korelativ snažne emocije ili lokus trenutka otkrovenja. Kraj poetskog ciklusa bi trebalo da aktivira obilježje cilja, ako je početak teksta povezan sa modelovanjem uzroka, međutim, Lompar završnim stihom - dolazilo je vrijeme stida, kraj stavlja u ulogu antipočetka i preosmišljava sav sistem kodiranja teksta. Ako grijeh Jakvintu i opata Dolčina čini veličanstvenim, zašto dolazi vrijeme stida. Time se postiže dezautomatizacija primjenjivanih kodova i umanjuje redudanca teksta.

Pjesnik presijeca dva poetska plana - prošlost i budućnost, a dinamički dualizam ostvaren je naponom između očekivanog (zelena ostrva i zlatno žalo) i date realnosti. I jarbol je sinegdoha (metonimijsko svođenje cjeline, broda, na detalj) i njegov pad u predmetnost pjesme simboliše potonulu lađu i egzistencijalni krah, nakon svođenja životnih računa. Ostrva kao simbol iskonskog duhovnog centra i paradigma utočišta u sintagmi su povezana sa zelenom bojom koja označava vitalni princip, dok je žalo (pješčana morska obala) semantički ukomponovana sa zlatnom bojom koja je sunčev simbol i središte topline. Otud jarbol u horizontalnom položaju i zlatno žalo i zelena ostrva podvučeni crtom u sabiranju kao matematičkoj operaciji, nagovještavaju dolazak stida, tako da je snažnim konotacijama aktivirana referencijalnost poetskog teksta i dat autorov verbalni mikrosnimak.

$7 \quad$ Vlatko Pavletić, Ključ za modernu poeziju, Zagreb, Globus, 1986, str. 19. 
Pored uobičajenog samoglasnika - $a$, u fonostrukturi lirske minijature je vokalska dominanta - $o$, a još od Platona je inicirano, a pjesnici moderne su taj stav prihvatili da se glasovima može distingvirati značenje, tako da je slovo $o$ - uklopnica u značenje veliko, krupno, i - sitno, pa opozitnost mikro-makro doprinosi stvaranju verbalno-slikovnih začudnosti.

Drugi poetski ciklus Tri pisma Darinki i narod jedinstvenog kraja upućuje da poetsko istraživanje Mladena Lompara nije samo usmjereno ka dešifrovanju istorije, već njegovi likovi ulazeći u različite istorijske kontekste dobijaju semantičko-emocionalnu obojenost i postaju indeksni ili indeksno-ikonički znakovi. Partikularni svjetovi likova Triptihona odnose se na semantičnost nedozvoljene ljubavi i tako prezentuju sebe umrežene sa drugima. Za razliku od muških likova koji su indeksno-ikonički znakovi, ženski likovi se pojavljuju u različitim konstruktima prirode i istorije, ali nijesu lirski subjekti, jer su lišeni ispoljavanja misli i osjećanja, a tim i semantičke autonomnosti. Tako je rodna problematika izražena na nivou sižea i u metaforici jer su ženski likovi prikazani kao objekti i predmeti nečije žudnje.

Lompar izgrađuje autohton odnos prema biografskim konvencijama tako što istorijsku situaciju rasprši i ponovo afirmiše na postmoderan način. U poetskom ciklusu Tri pisma Darinki i narod jedinstvenog kraja gdje je prikazana Darinkina unaprijed grešna ljubav prema knjazu Nikoli, prološke sintagme proznih fragmenata imaju simboličko značenje. U duhu postmoderne Lompar koristi mitski kodirane i bajkovito stilizovane strukture i stileme. Naziv prvog proznog fragmenta Bajka o princezi $i$ vukovima ističe ustaljen sukob između dobra i zla, a sintaksička konstrukcija „Bijeli konj ponio je princezu u sniježna brda, ali vukova ima i u bajci“ pojačava antitetičnost i disonantnost između bajkolikog idealiteta i crnogorskog realiteta. U sljedećem proznom fragmentu, već leksemom izgon iz prološke sintagme Izgon iz bajke naglašava se da epilog bajke gubi stereotipnost zasnovanu na srećnom završetku i tako pojačava modelativnu funkciju kraja teksta kao protest protiv osnovne ideje. Semantička opozitnost dobra i zla, i pobjeda dobra kao vrhovnog principa sadržana u kodu bajke, narušena je prelazom likova u različito semantičko polje i ova odstupanja obrazuju „rasejavanje u junakovom ponašanju oko srednje norme“. 8

Sljedećim proznim fragmentom Samo poezija obilježenog upitanošću u prološkoj sintagmi pjesnik balansira između faktičkog i imaginarnog, ali postmoderni pristup slobodnog kombinovanja daje mogućnost višeznačnosti poetskom tekstu.

Uočljiv je ikonički znak u prikazu knjaginje Darinke - podsjećala je na antički kip od crvenkastog mramora utopljen u raskošni enterijer. Ali bljesak

8 Lotman, J. M., n.d., str. 326. 
sa neba je svakog trenutka preobraćao sliku, izvlačio oštre konture i pretvarao mramor u fluidni komad dragocjenosti. Sintaksički paralelizmi iz dva narativa - biću knjaz i neću zbog ljubavi krvoliptanje iz grudi. To je uostalom i nezapisana želja onog koji mi ostavlja tron (knjaz Danilo)/ i /Biću ispunjenje onog života koji je za njega ostao nepojmljiv. I neću zbog ljubavi krvoliptanje iz grudi, uvaži riječi sa početka bajke. On je tako jednostavno znao biti u pravu (knjaginja Darinka)/, Darinki daju određeni stepen semantičke samostalnosti, ali ona ne želi ispovijest kao božji dar. Zašto obezvrijediti grijeh čiji sam bila vinovnik. Sve te zabranjene ljubavi koje su mogle biti da sam htjela samo meni su oslonac. Ko bi uostalom bio u stanju shvatiti dobrotu jednog surovog naro$d a$, dječačku zanesenost njegovih vođa, bezbožnost njegovih svetaca. ${ }^{9}$ Knjaginja Darinka kao strankinja uočava dihotomiju karaktera crnogorskog naroda i svjesna je grijeha zbog narušavanja strogog moralnog kodeksa crnogorske patrijarhalne sredine.

Citatatnošću kao tipičnom postmodernističkom tehnikom, i fotografijom, Lompar nas vraća faktografskom modelu. U autorovom tekstu pojavljuju se elementi tuđeg teksta (iz kraljeve autobiografije), ali navodnici predstavljaju dovoljno specifično sredstvo za izražavanje granica navedenih riječi u poetskom tekstu. Funkcionalna izmjena pjesničke pozicije ogleda se u izmjeni načina obraćanja Nikole Darinki, prvo - knjaginjo, pa Gospo, i na kraju ponovo knjaginjo, kao i u upotrebi upravnog govora, tako da se preklapaju spoljna i unutrašnja tačka gledišta. Međutim, Lompar je istorijskim konstruktima utisnuo sopstveni pečat i modelovao njihov tok, tako da fiktivno postaje indikativnije i tako se Crna Gora oslobodila svoje knjaginje, a ona svoje djetinje bajke. Unutarnja i spoljna vidna pozicija stupaju u izvjesni konflikt, a glagol osloboditi koji bi trebalo da ima pozitivne konotacije, ovdje dobija ironijski kontekst.

Liotar u duhu postmodernih promišljanja osporava moć legitimizacije naracije kao totalizujuće sheme objašnjenja. Lompar uvodi fotografiju u pojedine poetske tekstove Triptihona iz nacionalne biblioteke čime omogućava recipijentima raznovrsnost uvida u predmetni sloj. „Tumačenje koristi fotografije da nas, kao čitaoce, učini svjesnim naših očekivanja vezanih za narativnu i slikovnu interpretaciju, kao i naše naivne, ali opšte vjere u predstavljačku tačnost fotografije. " 10

Disonantnost postmoderne lirike ogleda se u odvajanju forme od sadržaja, čime se tematski sklop čini minornim u odnosu na ritmički i zvukovni.

9 Lompar, n.d., str. 126.

10 Hačion, n.d., str. 28. 


\section{PRVO PISMO (FRAGMENTI)}

to je bilo stvarno daleko

samo pomisao

ponekad

do odluke u tjeskobi

poslije su se

izmakli svi oslonci

i ostao sam da lebdim

u zgusnutom osjećanju

ali prije pada

iz nagovještaja u sjećanje

bljesak mi je ostavio crni ožiljak

Poetska modulacija početka je u duhu inicijalne paradigmatike bajke i očekivanja narativne strukture. Ali, višeznačnost sintaksičkih sklopova koju nameće stih doprinosi njegovoj dinamizaciji. Lompar upotrebom slobodnog stiha i grafičkim razdvajenjem govornog niza programira i način čitanja pisma, a poliritmija koja je ugrađena u strofični oblik narušava izofunkcionalno raščlanjivanje govornog niza.

Druga segmentovana cjelina, u kojoj je u sklopu sintaksičkih članova rečenice izostavljen prirok (glagolski oblik), implicira eliptičnu konstrukciju koja izrazu daje pereceptibilnost, sažetost, energiju. Imenica odluka sugeriše na glagol o dlu čiti, tako da rečenični članovi sa aktuelnom polupredikacijom postaju potencijalno cijele rečenične jedinice (klauze).

Semantički napon epifanijskog karaktera ljubavi između Nikole i Darinke i spoznaja nemogućnosti njenog ostvarenja stvara jak energetski momenat. Svijest o narušavanju krutog crnogorskog sociokulturnog koda, koje je u Autobiografiji knjaza Nikole dato samo kao nagovještaj (najžalije mi je ako sam veoma grešan), ekvivalentna je semantemi pad i arhisemom grijeh - pad intertekstualno je povezana sa sudbinom opata Dolčija. Antinomičnost epiloškog poetskog retka - bljesak mi je ostavio crni ožiljak - je antitetičan jer bljesak zabranjene, incidentne ljubavi, ostavlja doživotnu patnju (crni ožiljak). Tako ,istoriografska metafikcija ponovo uspostavlja označeno putem svoje 
metafikcionalne samorefleksivnosti o funkciji i procesu proizvodnje značenja, iako istovremeno ne dozvoljava da referent nestane“. ${ }^{11}$

U drugom pismu psihotenzija je primarna i dominira strukturom poetskog teksta.

\section{DRUGO PISMO (FRAGMENTI)}

ludimo

odlukom neprepoznatljivog izvršioca

(zašto smo sami sebi

posljednje saznanje)

slutim tvoj strah

od prepoznavanja

ali

kazao sam

(i dobro je što

osjećanje ima pravo na svoju azbuku)

Nemogućnost potpunog stapanja sa životnošću drugog bića dovodi do psihičke raspolućenosti subjekta pjesme, mladog crnogorskog knjaza Nikole i njegove strine. Iako znamo da kruti crnogorski moralni kodeks sprečava ostvarenje te ljubavi, knjaz Nikola navodi da je razlog njihovog rastrojastva u sferi onostranog i da je to odluka neprepoznatljivog izvršioca. Fenomen drugosti izvornog ja, odnosno sposobnost potpune identifikacije subjekta sa drugim subjektom, ostvarena je gramatičkom množinom. Upitni oblik parenteze (zašto smo sami sebi poslednje saznanje) upućuje da je najteže spoznati sopstvo i korelat je sa završnom parentezom gdje nam kao utjeha ostaje mogućnost da verbalizujemo svoja osjećanja.

U drugoj strofi dolazi do asintaksičkog sječenja teksta, gdje zbog odjelitog izgovora dolazi do intonacijskog raščlanjivanja, a u skladu je sa psihološkom strukturom rečenice. Osim toga, Lompar dinamičnu strukturu i složen emotivni registar lirskog subjekta gradi upotrebom glagola unutrašnjih stanja ili verba sentiendi (ludimo, slutimo). Treće segmentovana cjelina ima zatamnjenu semantiku, jer ostaje nepoznat sadržaj knjaževih riječi, tako da asocijativnim svrstavanjima pjesnik omogućava recipijentima da dograde sloj shematizovanih aspekata.

11 Hačion, n.d., str. 250. 
U drugom pismu navodi da je biser rano upao u školjku smrti, i ako je biser simbol sublimacije instinkata, oduhovljenje materije, onda se uloga mističnog centra bisera pomjera i školjka za njega nije toplo utočište, već negativni denotat.

Postmodernističko progresivno miješanje žanrova kao rezultat igre stvaralačkog duha nastoji da sučeljavanjem fiktivnog i fakcije formira univerzalno značenje i dospije do umjetničke istine.

Motivsko polazište fragmenta Narod jedinstvenog kraja je progon pisaca i stav da „niko kao prognani pisac ne poznaje svoj narod i svoje progonitelje (krst opata Dolčija i kralja Nikole primio je i Jevrem Brković) ${ }^{126}$. Gušenje slobode umjetničkog stvaranja povezano je sa prostornom stranom hronotopa (u ovoj zemlji), dok vremenska odrednica hronotopa nije iziferencirana, ali ako se ima u vidu da je krst opata Dolčija i kralja Nikole primio Lomparov savremenik, pjesnik Jevrem Brković, onda se različitim narativnim vremenima čitav problem uzdiže na univerzalni nivo.

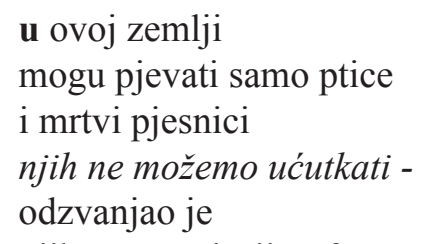

Ptice simbolizuju duhovna stanja bića i imaju ulogu posrednika između neba i zemlje. U jasno izdiferenciranom poetskom prostoru (u ovoj zem1ji) semantička ekvivalentnost ptica i mrtvih pjesnika inicira paradoks, kojim se izražava misao, suprotna opšteprihvaćenom mišljenju i logici. Paradoks je uočljiv i na kraju segmentovane cjeline (odzvanjao je / njihov prazni trijumf), a izbjegavanje emfatične (upitne i usklične) konstrukcije pjesnik zamjenjuje asintaksičkim sječenjem teksta.

Lompar uočava psihološku i fizičku degradaciju pjesnika putem straha, oduzetosti misli i izgona i zato se pita:

ako ikada više posegnu za riječima

hoće li svjedočiti

o svom posrnuću u čovjekolikost /Putanja konačnosti/

12 Lompar, n. d., str. 149. 
U pogodbenoj konstrukciji uočljiva je protaza kao sintaksički postupak, a modifikovana apodaza data je u upitnoj formi.

Antitetičnost leksema u sintagmi u - posrnuću u čovjekolikost - upućuje da su značenja riječi funkcionalno zavisna od mogućnosti njihovog međusobnog kombinovanja. Nepredvidljivost ishoda pjesnikovih stvaralačkih napora upućuje ne samo na referencu (označeno), nego i na pjesničku poziciju, tačku gledišta sa koje nešto izriče, a samim tim i vrednuje. Važan element teorije dekonstrukcije tiče se znaka i njegove iterabilnosti (ponavljanja). Tako riječi u Lomparovoj poeziji postaju iterabilni znak ali iako je svjestan neophodnosti stvaralačkog ispoljavanja, riječi su i izvor ljudske patnje. Prema tome, ponavljanje znaka (riječi) upućuje da ne postoji neko idealno svojstvo koje bi znaku garantovalo pouzdanost i nepromjenljivost, jer je sve podložno sistemima konteksta. Jezik postmodernog pjesništva opire se svakoj jednoznačnosti, a dekonstrukcija se kreće u okviru nerješivih suprotnosti (aporija).

Mračnost egzistencije, posebno poetske, Lompar iskazuje stavom da će ludilo pjesnika trajati i oksimoronom da će ubrzo postati srećni leševi, što je svojevrstan vid groteske. Organizacija prostornog modela svijeta počiva na opoziciji koja se uspostavlja između prostornih struktura - u ovoj zemlji i tamo, na drugim obalama. U Lomparovoj poeziji se stih kao redak u pjesmi hijerarhijski nadređuje metričkoj cjelini.

sjetite se

tih slijepih i bijesnih bića mračnih prostora

na svjetlosti

/Putanja konačnosti/

Semantička opozitnost svjetlost - mrak, posebno istaknuta opkoračenjem upućuje na vječitu borbu suprotstavljenih sila. Osim toga, opkoračenje, kao jedno od mnogobrojnih formalnih pjesničkih sredstava, u ulozi je usporavanja ritma nužnog za recepciju složenog misaonog sadržaja. Ovakvim segmentovanjem preraspoređuje se i semantički sadržaj pjesme i uvećava semantički naboj i djelova ispred i iza pauze u opkoračenju. U epiloškom dijelu navodi:

nigdje misao nije uzaludna

kao u ovoj zemlji

iako za naš jezik

postoji precizna azbuka /Putanja konačnosti/ 
Autentičnost Lomparove poetike je u prikazu raslojavanja lirske svijesti, što je najbolje dočarano opozitnošću - mogućnost misli-uzaludnost misli. Stalna napregnutost između dvije semantički suprotstavljene konstrukcije stvara energetski momenat.

Treći poetski ciklus Boca lude princeze kao semantičko jezgro ima prikaz zabranjene ljubavi između crnogorskog princa Mirka Petrovića u trenutku njegovog rastrojstva i bolničarke Marije, svršene pitomice Đevojačkog instituta na Cetinju, kao i sudbine kćerke Jelene, koja je i rođena kao plod tog zanosa. Postmoderna polazi od stava da je naše znanje o prošlosti semiotički posredovano i „tvrdi da su istorija i fikcija diskursi, označavajući sistemi i da izvode glavni zahtjev za istinom iz tog identiteta". ${ }^{13}$

Grijeh, kao ključna semantička kategorija, na istovjetan način je artikulisan iz ugla knjaza Mirka (mislili su (znam i misliće) / da sam van traga predaka / a dosanjao sam njihove grijehe / iz svetačkog mira - i lude princeze Jelene - Zavjet, donijet u božanskom nadahnuću još više je gonio na razmišljanje o čovjeku kojemu se ispostavlja račun za grijehe cijele dinastije. Međutim, u postmodernističkom duhu Lompar uspostavlja autentičan aksiološki sistem i razbijanjem rigidnih sociokulturnih normi crnogorske sredine $u$ svom poetskom modelu ukida negativno određenje grijeha.

Lekseme iz proloških sintagmi ciklusa Boca lude princeze - o s veta, ostavština, predaja, zamori - semantizuju Marijinu duhovnu klonulost i upotpunjuju odnos između lika - dejstvovaoca i semantičkog polja koje ga okružuje. Marija stupa u semantičko antipolje jer Mirko potiče iz vladarske porodice i ima zakonitu suprugu, što uslovljava patnju lika dejstvavoca, a to je invarijantna jedinica Lomparove poetike. Estetika sa-protiv postavljanja ogleda se u binarnoj opoziciji između Marije i patrijarhalnog svijeta u kojoj je Marija „preživljavala iskeženu masu“. Estetika istovjetnosti Marijine i Jelenine sudbine uočava se $u$ iščekivanju pronalaska boce, ali ne zbog poruke, već zbog samog čina čekanja koji osmišljava njihove egzistencije (meni više ne treba poruka. Čekanje je bila moja svjetlost), ali su sjedinjene ogromnom tugom (Jelena je ipak patila zbog majčinog života. I majka zbog njenog.).

U proznom fragmentu ciklusa je obavještenje da je na brodu nastao prinčev zapis adresiran na Marijino ime i u boci bačen talasima. Boca simbolizuje spasonosno znanje koje donosi mir, a „moreplovac koji baca u more bocu u času kad njegov brod tone se smiješi misleći kako će to krhko staklo nositi njegovu misao i ime do luke, da bog može dopustiti bezumnim vodama da pogubljuju lađe, ali ne i misli i da je jednom bocom pobijedio smrt ${ }^{144}$.

13 Hačion, n. d., str. 163.

14 Gerbran, Ševalije, n. d., str. 72. 
Razdvajanje tijesno povezanih sintaksičkih djelova u zasebne stihove iz kojih se izdvajaju pojedine riječi ili akcenatske cjeline stvara opkoračenje, gdje razilaženje metričko-ritmičke od sintaksičko-semantičke strukture izaziva kod čitaoca umjetnički valentno - prevareno očekivanje.

\section{Jednom je Jelena rekla majci da je sva ta igra} besmislena.

\section{|Predajal}

Preneseni izraz postaje centar pažnje, jer važno sredstvo za informaciono aktiviranje nije samo realizacija strukturnih normi, nego i njihovo narušavanje. Igra dopušta da pored poštovanja pravila izbije najdublja spontanost $i$ ako je ona u osnovi simbol borbe protiv smrti, protiv neprijateljskih sila, leksemom besmislena koja je pripojena igri, i koja je ujedno cijeli stih, uništava se njen karakter i obesmišljava cjelokupnost egzistencije. Inicijalna pričalačka uzrečica - jednom doprinosi narativnosti poezije i ima moć da nas prevede iz realnog u imaginativni svijet.

Lompar na kraju svakog stiha naglo mijenja princip fonološke organizacije, tako da se na kraju svake strukturne jedinice (stiha ili strofe) uvijek mijenja konstruktivni princip, u trenutku kad se mogućnost predvidljivosti povećava:

\section{ponekad bi}

stala na vrh hridi

razvučena horizontom

\section{/Trenuci jednake dragocjenosti/}

U trenutku kad postoji težnja ka vokalskoj unifikaciji na kraju poetskog retka ispoljenoj u prva dva stiha, naglo se ispoljava tendencija ka raznolikosti. Međutim, diferencijalna obilježja fonema na kraju Lomparovih stihova, uslovljavaju i naknadnu semantizaciju. Semantički napon postignut je spajanjem opozitnih denotata, jer hrid, stijena - simbol nepomičnosti i postojanosti, korelira sa horizontom i mnoštvom mogućnosti, a posebno je intenzivirana sintagmom razvučena horizontom, koja je ujedno i trop - metafora. Zato naizgled i neznatne glasovne razlike mijenjaju tkivo smisaonih spojeva, a narušavanje fonološke ekvivalentnosti upućuje na stalan konflikt automatizacije i dezautomatizacije poetskih konstituenti.

Za razliku od prethodnog primjera gdje postoji usklađenost fonoloških i semantičkih promjena na sintagmatskoj osi, u sljedećem primjeru fonološki diferencijalizam ne osporava semantičko prožimanje. Djevojčica Jelena kao vidljiv znak grešne ljubavi semantički je povezana s Marijinom zakletvom na šutnju i nadu (iščekivanje boce), jer sve su to trenuci jednake dragocjenosti. 
bili su to trenuci

uvijek jednake dragocjenosti

poslije kojih je

dugo grlila djevojčicu

(kao pronađenu bocu)

\section{/Trenuci jednake dragocjenosti/}

Fabulativni aspekt porijekla fantomske boce dopunjen je indeksnim znakom - pješčanikom koji ističe - i nagovještava smrt knjaza Nikole i parentezom - I njegova zemlja je bolovala, zasužnjena i neizlječiva, da bi pojedinačno i totalitarno uz semantostrukturi bilo objedinjeno zajedničkom leksemom - konačnost (sve se vuklo bliskim tragom konačnosti).

Estetske prirode je ponavljanje parenteze jer trenutke Marijine osame u pokušaju osmišljavanja egzistencije Lompar semantički premrežava ikoničkim znakom - slikom kćerke Jelene koja je ležala u pijesku kao nepronađena boca, da bi je potom Marija dugo grlila kao pronađenu bocu. U poetskom kontekstu boca (pronađena - nepronađena) poprima karakter indeksnog znaka, jer Jelenino postojanje implikuje produžetak nedozvoljene ljubavi. Jelenin doživljaj Marije - gledala je njenu neproslovljivu razgovjetnost i Marijin doživljaj Jelene - zagledana u njeno nečitljivo pjegavo lice - obrazuju kontrastne konstrukcije i u skladu je sa semantičkom aktivnošću diferencijalnih elemenata (mladost-zrelost, čednost-iskustvo).

Lompar nekada izdvaja riječ kao posebnu semantičku jedinicu, mada je ona u poetskom jeziku samo funktiv složene semantičke funkcije. U pjesmi Zamori lude princeze odjelitost poetske riječi u stihovima (ipak / nije to bilo najgore što su znali) upućuje da ritmička segmentacija stiha ne dovodi do potiranja granice riječi, nego do izoštravanja osjećaja za nju. Zamori, samoća i neizvjesnost uslovljavaju složenost unutrašnjeg svijeta princeze Jelene, a odjelitost rječce ipak upućuje da patrijarhalna sredina raspolaže brojnim saznanjima, ali se to ostavlja recipijentu da dogradi u svojoj svijesti.

Interesantna su zapažanja J. N. Tinjanova o slikovno-ritmičkoj upotrebi nesamostalnih riječi u stihovnom jeziku: „Ako je stih sveden na jednu riječ, onda sama okolnost što je riječ jednaka samostalnom stihu, što ona stoji na prelomu - u znatnoj mjeri povećava njenu snagu, izdvaja je, podstičući oživljavanje osnovnih obilježja“" ${ }^{15}$

Metrička pauza u pjesmi Vjetar $\boldsymbol{u}$ čempresima ukazuje da odjelitost adverbijalne oznake za mjesto (tu) od sintagme - u mediteranskom gradiću - utiče na prostorno modelovanje umjetničkog svijeta i Lompar tako naglašava da princeza Jelena potiče iz nama bliskog životnog miljea. Deiktike

15 Vinogradov, V. V., Stilistika i poetika, Sarajevo, Zavod za izdavanje udžbenika, 1971, str. 220. 
upućuju na prostorno-vremensko okruženje u trenutku komunikacije i nagovještavaju da duhovna skučenost mediteranskog gradića uslovljava Jeleninu psihološku klonulost:

tu

u mediteranskom gradiću

čekajući

sagorjela je u strastima

ne znajući

ni lik

ni tijelo

koje bi željela sresti

/Vjetar u čempresima/

Deridin stav da jezik i značenje nemaju svoj početak i kraj je indicija da svako čitanje Lomparovih poetskih tekstova generiše novo, suplementarno čitanje i da uvijek postoji mnoštvo različitih značenja koja se mijenjaju zavisno od konteksta i učinka iznevjerenog očekivanja. Afrodita, boginja čarobne ljepote, rođena iz morske pjene, oplemenjuje divnu ljubav, pa artikuliše mitemu koja nas vraća iskonskom. U poetskom tekstu Afrodita se vraća talasima data je vremenska strana hronotopa (jesen godine 1946) kao i prostorna (riva, morski ambijent), a ikonički znak (vitka, princeza u dugoj bijeloj haljini) premrežen ja sa indeksnim (boca u moru). Međutim, taj indeksni znak je uzrok Jelenine unutrašnje raspolućenosti, ali i njene osvete malograđanskoj sredini željnoj skandala i incidentnih situacija. Voda je arhetipski simbol i iskazuje se kao šifra pjesničkog jezika i u ulozi je kodifikovanja Jeleninog odnosa sa svijetom. Nadmoć princezinih pokreta u trenutku ulaska u more i odvajanja od izbezumljene mase iskazana je stihom „zamahnula je rukama kao leptir“, što u hrišćanskoj simbolici upućuje na dušu lišenu svog tjelesnog omotača i simbol je preporoda.

Naslovna sintagma poetskog teksta Zvuci mrtve partiture je oksimoron, koji je kao figura misli posebna vrsta antiteze odnosno paradoksa u kojem se spajanjem logički protivrječnih pojmova stvara novi pojam. U Lomparovoj interpretaciji oksimoron gubi antitetičnost jer patnja je pratilac ljubavi knjaza Mirka i zato se njegov život ne uklapa u paradigmu bajke (ali / ja sam gostovao u toj bajci / i stradao).

Eufonijska organizacija redosljeda glasova najčešće teče tako da se određeni glas višestruko ponavlja. 
ništa mi ljudski nije nedostajalo

da (zapisujući pastorale)

stignem do ove sumnje /Zvuci mrtve partiture/

Uključivanjem elemenata nižeg nivoa u proces obrazovanja smisla nastaju okazionalne semantičke opozicije, pa otud sumnja kao polazište za demistifikovanje tragova predaka. Naime, pastorala je iskazivala težnju za pastirskim, idiličnim svijetom, koji se suprotstavlja životu na dvoru, a prerušeni pastiri i pastirice treba da budu simbol istinskih vrijednosti suprotstavljeni lažnom redu mondenskog života. Iako je u pastoralama ljubav univerzalna pokretačka snaga koja vlada svijetom, okazionalna arhisema sumnja - grijeh predaka povezana je sa crnogorskim kulturnim modelom patrijarhalne sredine i nemoguće je tumačiti izvan date tekstovne strukture izraza. Rigidnost etičkih normi uslovila je istorijske fakte na veličanstvenost prikaza dinastije Petrović, ali je postmoderna semioza narušila istinitost istorije i pokazala krhkost $\mathrm{i}$ ranjivost empirijskih stanovišta. Lirska minijatura nalazi se na epiloškoj granici ciklusa.

(smiri se more

pokloniću ti ovи pjesmu)

ako se tamo bilo što nastavlja

ne želim da se vratim

izvini Marija

ovdje je sve previše življeno

Ključne semanteme - more i pjesma su u binarnoj opoziciji (pjesma je ta koja treba da smiri nemirno more i buru u pjesniku) i data joj je iscjeliteljska moć. Ozbiljno-meditativnim tonom Lompar odbacuje mogućnost produbljivanja odnosa između mora i pjesnika, što uslovljava negativan odnos knjaza Mirka prema izvorištu (ne želim da se vratim). Prema kosmičkoj shemi povratak je načelo zatvaranja, ali knjaz Mirko pravi otklon od kružnog oblika ljudske egzistencije gdje suviše izražen intenzitet emocija uslovljava njegovo povlačenje.

Naziv epiloške sintagme Triptihona - I dalje - pokazuje da pjesničko djelo predstavlja samo trenutnu umjetničku konačnost u širokom izboru životnih i imaginarnih varijacija. U završnom proznom fragmentu dat je topos smrti i groblja u koje biće tone u prolazne ali neizbježne tmine.

Da bi čitalac percipirao tekst mora u svojoj svijesti aktivirati tipizirane postmoderne kodove, jer kraj bi trebalo da svjedoči o konstrukciji svijeta 
kao cjelini. Međutim, postmodrnizam zbog pluralizma gledišta omogućava da formalni završetak djela bude početna tačka njegove buduće semantičke nadogradnje. Modelujući bezgraničnu stvarnost sredstvima konačnog teksta, pjesnik dolazi do saznanja - da je smisao ipak u nekim papirima, ali ipak, ne želi dalje istraživanje.

Mladen Lompar je u Triptihonu pokazao da postoje dvostruke naslage istorijske rekonstrukcije, od kojih je svaka prikazana metafikcionalnom samosvješću. Odlomci tekstova učitani u novo umjetničko ostvarenje predstavljaju svojevrsnu citatnost i omogućavaju intertekstualnost, svojstvenu poetici postmodernizma. Triptihon je autohtono djelo crnogorske postmoderne lirike, jer istorizam Lomparovih poetskih tekstova nije opterećen nostalgijom, a i konstruktivni principi poetskih tekstova čine otklon od tradicionalnih pjesničkih modela.

\section{Literatura}

- Lompar, M.: Triptihon iz nacionalne biblioteke, Dignitas, Cetinje, 2006.

- Bečanović, T.: „Triptihon Mladena Lompara“, predgovor knjizi poezije Triptihon iz nacionalne biblioteke Mladena Lompara, Dignitas, Cetinje, 2006.

- Cerović, R.: Crnogorsko književno iskustvo, DANU, Podgorica, 2003.

- Aristotel: O pesničkoj umetnosti, Zavod za udžbenike i nastavna sredstva, Beograd, 1988.

- Bart, R.: Književnost, mitologija, semiologija, Nolit, Beograd, 1971.

- Bataj, Ž.: Književnost i zlo, BIGZ, Beograd, 1977.

- Gerbran, A., Ševalije, Ž.: Rečnik simbola, Izdavačka kuća KIŠA, Novi Sad, 2004.

- Grevs, R.: Grčki mitovi, Familet, Beograd, 1999.

- Eko, U.: Svakodnevna semiotika, Narodna knjiga/Alfa, Beograd, 1997.

- Epštejn, M.: Postmodernizam, Zepter Book Word, Beograd, 1998.

- Flaker, A.: Period, stil, žanr, Službeni glasnik, Beograd, 2011.

- Fridrih, H.: Struktura moderne lirike, Svetovi, Novi Sad, 2003.

- Hačion, L.: Poetika postmodernizma, Svetovi, Novi Sad, 1996.

- Hristić, J.: Oblici moderne književnosti, Nolit, Beograd, 1968.

- Igliton, T.: Iluzije postmodernizma, Svetovi, Novi Sad, 1997.

- Ingarden, R.: Doživljaj, umetničko delo i vrednost, Nolit, Beograd, 1975.

- Istorijski leksikon Crne Gore, (Per - Ž), Podgorica, Vijesti, 2006.

- Jerkov, A.: Nova tekstualnost, Unireks, Prosveta, Oktoih; Podgorica, Beograd, Nikšić, 1992.

- Kajzer, V.: Jezičko umetničko delo, SKZ, Beograd, 1973.

- Kaler, Dž.: Strukturalistička poetika, SKZ, Beograd, 1990. 
- Kojen, L.: Studije o srpskom stihu, Izdavačka knjižarnica Zorana Stojanovića, Sremski Karlovci - Novi Sad, 1996.

- Kompanjon, A.: Pet paradoksa modernosti, Institut za crnogorski jezik i književnost, Podgorica, 2012.

- Kosidovski, Z.: Biblijske legende, SKZ, Beograd, 1993.

- Liotar, Ž. F.: Postmoderno stanje, Bratstvo-jedinstvo, Novi Sad, 1988.

- Lotman, J. M.: Struktura umetničkog teksta, Nolit, Beograd, 1976.

- Markjevič, H.: Nauka o književnosti, Nolit, Beograd, 1974.

- Metafora, figure i značenje, Zbornik teorijskih radova (izabrao i priredio Leon Kojen), Beograd, 1986.

- Milić, N.: A, B, C, Dekonstrukcije, Narodna knjiga, Beograd, 1997.

- Milosavljević, P.: Metodologija proučavanja književnosti, Trebnik, Beograd, 2000.

- Milosavljević, P.: Logos i paradigma, Trebnik, Beograd, 2000.

- Mukaržovski, J.: Struktura pesničkog jezika, Zavod za udžbenike i nastavna sredstva, Beograd, 1986.

- Oraić-Tolić, D.: Muška moderna i ženska postmoderna, Naklada Ljevak d.o.o., Zagreb, 2005.

- Pavletić, V.: Ključ za modernu poeziju, Globus, Zagreb, 1986.

- Petković, N.: Lirske epifanije Miloša Crnjanskog, Srpska književna zadruga, Beograd, 1996.

- Petković, N.: Ogledi iz srpske poetike, Zavod za udžbenike i nastavna sredstva, Beograd, 1990.

- Petković, N.: Ogledi o srpskim pesnicima, Društvo za srpski jezik i književnost Srbije, Beograd, 2004.

- Petković, N.: Od formalizma ka semiotici, BIGZ, Beograd, 1984.

- Popović, T.: Rečnik književnih termina, Logos Art, Beograd, 2010.

- Rajić, Lj.: Tekst u vremenu, Geopoetika, Beograd, 2008.

- Solar, M.: Edipova braća i sinovi, eseji, Golden marketing/Tehnička knjiga, Zagreb, 2008.

- Solar, M.: Povijest svjetske književnosti, Institut za crnogorski jezik i književnost, Podgorica, 2012.

- Solar, M.: Suvremena svjetska književnost, Školska knjiga, Zagreb, 1982.

- Strukturalni prilaz književnosti, (R. Bart, C. Todorov, Ž. Ženet, J. M. Lotman, K. Bremon, S. Lasić, A. Ž. Gremas, A. K. Žolkovski, N. Milošević), Nolit, Beograd, 1978.

- Škreb, Z./Stamać, A.: Uvod u književnost, Grafički zavod Hrvatske, Zagreb, 1983.

- Vinogradov, V. V.: Stilistika i poetika, Zavod za izdavanje udžbenika, Sarajevo, 1971. 


\section{Anka VUČINIĆ-GUJIĆ}

POETIC CHARACTERISTICS OF MLADEN LOMPAR'S TRIPTYCH FROM THE NATIONAL LIBRARY

Collection of poems Triptych from the National Library is a synthesis of Mladen Lompar's creativity, indicating his anti-traditionalist approach to motifs, poetic form and metric constructs. Postmodern features - the insertion of imaginary discursive records, mythical stylemes, combination of fiction and faction and fragmentation are an integral part of Lompar's poetic texts, while postmodernist techniques of allegedly found documents, binary oppositions and contrasts of light and darkness are among his favourite elements for depicting sin. The Triptych from the National Library is an evidently active reflection on the meaningfulness of artistic creation, which is how it raises a number of axiological questions and asks for an emotionally engaged reader.

Key words: post-modern poetics, inter-textuality, combination of fiction and faction, binary opposition 

UDK 821.163.4(497.16).09-31

Pregledni rad

\title{
Lejla VESKOVIĆ (Bijelo Polje)
}

lejlagene@yahoo.com

\section{NOVA CRNOGORSKA KNJIŽEVNOST KAO HRONIKA POSLJEDNJIH BALKANSKIH RATOVA}

\begin{abstract}
Rad razmatra odnos nove crnogorske književnosti prema ratnoj prošlosti s početka devedesetih. Na osnovu romana Dragana Radulovića Auschwitz cafe, Mimezis Andreja Nikolaidisa i Život i smrt Milana Junaka Vojislava Pejovića analiziraju se osobenosti novog crnogorskog romana. Prepoznaju se zajedničke crte kao što su: društveno angažovani tekst, autobiografičnost, brojne reference na popularnu kulturu, antiheroji i superheroji kao protagonisti, otklon od tradicionalnog epskog rezonovanja ali i nastavljanje prethodnih literarnih obrazaca.

Ključne riječi: nova crnogorska književnost, novi crnogorski roman, Auschwitz café, Mimezis, Život i smrt Milana Junaka
\end{abstract}

Početak razvoja nove crnogorske književnosti vezuje se za vremenski okvir balkanskih ratova s početka devedesetih kao protest rijetkih glasova koji su odbili da daju doprinos crnogorskom učešću na dubrovačkom i bosanskom ratištu. Važnost postojanja takvih mišljenja primjećuje se tek danas, sa vremenske distance, u drugačijem društvenom kontekstu, kada Crna Gora nastoji da relativizuje svoju ulogu i zauzme poziciju neutralnog posmatrača. Kompletan identitet Crne Gore kao zasebne teritorijalne, jezičke, kulturološke pa i religijske zajednice zasniva se na postojanju tih par rijetkih glasova koji su se još u ratnim godinama zapitali „ko je kriv“ i ,šta da se radi“. Književnost je postala jedina institucija koja je već devedesetih procesuirala zločince, izricala presude, čuvala crnogorski jezik i identitet, ,,branila druge od sebe i sebe od drugih".

U knjizi Najnoviji glasovi crnogorske proze: izbor iz djela crnogorske dvanaestorice Milorad Nikčević navodi stvaralački korpus ,starijih“ pisaca na čijim narativnim tradicijama izrastaju pisci ,mlađe“ generacije, a kojima su se ovi priključili na anarhističkim barikadama odbrane vječito izromantiziranog crnogorskog koncepta „čojstva i junaštva“. U taj stvaralački korpus ,starijih“ ubrajaju se djela: Jevrema Brkovića (Monigreni), Sretena Asanovića (Putnik), 
Zuvdije Hodžića (Davidova zvijezda), Novaka Kilibarde (Crnogorska hroni$k a$ ), Radoslava Rotkovića (Šuma Svetog Leonarda), Čeda Vulevića (Ogrtač boje mirte), pentalogija Huseina Bašića (Tuđe gnijezdo, Pusto tursko, Kapije bez ključa, Bijeli Azijati, Kosti i vrane), Jovana Nikolaidisa (Valdinos 33), Miraša Martinovića (Putevi Prevalise), Miodraga Vukovića (Mlaka voda) i svih drugih koji čine stvaralačku poveznicu s najmlađom crnogorskom prozom. ${ }^{1}$

„Mlađu“ generaciju koju nazivaju „djecom cvijeća“ crnogorske literature kao najprepoznatljiviji čine: Igor Đonović, Momčilo Zeković, Željko Stanjević, Dragan Radulović, Ognjen Radulović, Aleksandar Bečanović, Milovan Radojević, Predrag Sekulić, Ognjen Spahić, Andrej Nikolaidis, Balša Brković, Vladimir Vojinović i dr. ${ }^{2}$ Sličnost u književnom radu ovih pisaca doprinosi nastanku određene paradigme koja ovu književnost izdvaja, ali i stavlja u zajednički kontekst onoga što se danas naziva savremenom južnoslovenskom književnošću. Božena Jelušić, kada govori o tipičnoj proznoj književnoj produkciji crnogorskih pisaca, predlaže upotrebu termina moderni crnogorski roman, ako se ima u vidu da moderni roman označavamo sredstvima kao što su: napuštanje tradicionalne motivacije postupaka i zbivanja, izmijenjene kategorije prostora i vremena, simultanizam, montaža i kolaž, te mješavinu različitih vrsta pripovjedača uz mješavinu stilova i pastiš. Autorica navodi da je termin crnogorski postmodernistički roman jednako valjana odrednica s obzirom na to da postmodernizam ne znači napuštanje strategija modernosti već samo njihovo izoštravanje. ${ }^{3}$

Osobenosti novog crnogorskog romana ovdje se ekstrahuju na osnovu tri takva primjerka: romana Dragana Radulovića Auschwitz cafe, Mimezis Andreja Nikolaidisa i Život i smrt Milana Junaka Vojislava Pejovića. Zanimljivo je da je autor posljednjeg romana američkog prebivališta, pa je u dogledno vrijeme moguće očekivati brojnije glasove crnogorske dijaspore i pojavu crnogorske emigrantske književnosti. Zajednička osobina sva tri romana je da predstavljaju traumatske ispovijesti o raspadu zajedničke zemlje, kao i da su snažno svjedočanstvo vremena koje je oblikovalo romaneskne sižejne linije, odabir tema i idejno-ideološku pozadinu. Stvarnost devetesetih čine dobrovoljne vojne i paravojne jedinice, ali i nasilna regrutacija, specifična muzič-

1 M. Nikčević, „Nadvremenski glasovi: stoljetni hrvatski i crnogorski književno-kulturni identiteti“", u: Najnoviji glasovi crnogorske proze (književnoteorijski i izborni pregled), uredili: Milorad Nikčević i Jakov Sabljić, HCDP „Croatica - Montenegrina“ RH / CKD „M - M“, Osijek 2007, str. 21.

2 Ibidem, str. 21.

3 Božena Jelušić, „Moderni crnogorski roman između Mihaila Lalića i Danila Kiša (Dragan Radulović, Balša Brković, Ognjen Spahić i Andrej Nikolaidis)“, u: Najnoviji glasovi crnogorske proze (književnoteorijski i izborni pregled), uredili: Milorad Nikčević i Jakov Sabljić, HCDP „Croatica - Montenegrina“ RH / CKD „M - M“, Osijek 2007, str. 31. 
ka pozadina koja veliča ratnu pljačku i bratoubilačke instinkte, siromaštvo, redove za hranu, preprodavače deviza i benzina, žestoke momke, izbjeglice, otpuštene radnike, kupljene glasače prvih višestranačkih izbora ali i svih narednih, ulične proteste, politički i vojno angažovano sveštenstvo, ućutkanu „inteligenciju“, i sve ono što čini dekorum bilo kojeg rata.

Stvarnost u crnogorskoj književnosti često biva izmještena iz ove sredine i prebačena ili u raniji istorijski kontekst, kao u romanu Sretena Asanovića Putnik u pokušaju da se odgonetne prapočetak crnogorskog zastranjena, ili na teritoriju udaljenu od balkanskog žarišta, kao u romanu Andreja Nikolaidisa Oni, čija je radnja smještena na američko tlo, ili u romanu Hansenova djeca Ognjena Spahića, koji radnju izmješta na rumunski jugoistok. Udaljeni kontekst neće čitatelja odvojiti od crnogorske zbilje, već će je multiplicirati univerzijalizacijom prostora i vremena. Lutanja Crnogoraca po Argentini i Parizu između dva svjetska rata, mistifikacija američkog provincijskog života, cipele Imelde Markos, kao i odbljesci rumunske revolucije, katarzički utiču na estetski senzibilitet ali i na političku svijest crnogorskog čitatelja i glasno progovaraju na pitanje ,„sta da se radi“, za koje je krajnje vrijeme da prestane da bude predmet književnog interesovanja.

U tri romana koji su ovdje uzeti kao primjerski, radnja je smještena na pozornici crnogorskih malih sredina u vrijeme posljednjih balkanskih ratova, kada su te sredine metamorfozirale $\mathrm{u}$ distopijske vizije zajedno sa pozorišnim rekvizitima i učesnicima drame. Crnogorske sredine poput Budve (Aushwitz café), tadašnjeg Titograda (Život i smrt Milana Junaka) ili Ulcinja (Mimezis) postaju ukleti gradovi, a njihovi stanovnici žedni krvi i uništenja, evociraju sličnosti sa junacima horora i naučne fantastike. Protagonosti sva tri romana, poput junaka iz romana Dostojevskog, pritisnuti prostorom i vremenom sklanjaju se u mansarde, trošne kuće i zapuštene stanove, svedeni na egzistencijalni minimum. Zanimljivo je da su ovi antiheroji na kraju uzdignuti na visine junaka Šekspirovih tragedija ili superheroja naučne fantastike, a da im piščeve izrazite parodije, ironija i cinizam ne umanjuju visine onih koji su iznad svog vremena. Prelomni trenutak u romanu Mimezis nastaje u jutarnjem susretu junaka samoizgnanika sa komšijom nalik na „duha pokojnog kralja“ u kojem ovaj paranoično prepoznaje potencijalnog povampirenog gubitnika prošlog rata, a koji ga pozdravlja raščerečen između dva limunova drveta krilaticom „u zdravom tijelu zdrav duh“, pripisanoj Njegoševom autorstvu. Antijunak tada razrješava hamletovsku dilemu i svoju pasivnost zamjenjuje pacifističkim novinarskim angažmanom koji je u ovom slučaju autobiografski element, inače svojstven za novi crnogorski roman. Nova crnogorska književnost je aktuelna pojava u punom razvoju koja još uvijek čeka potvrdu vremena i kritičko promišljanje, pa su stoga svi oblici vrijednosne ocjene jednako relevantni. 
U internetskom prostoru moguće je pročitati da čitaoci Nikolaidisu pripisuju „ideološku tendecioznost“ koja postaje sama sebi svrha i opterećuje roman. Također mu se pripisuje i dobijanje poena na „kontroverznost“, koja se uglavnom svodi na politički stav „svi ste vi zločinci i odgovorni ste za Srebrenicu i Dubrovnik". ${ }^{4}$ Roman Nikolaidisa jeste između ostalog vjerodostojan prikaz „enciklopedije jednog društva i vremena“, što ga čini politički angažovanim, a to je opet zajednička osobina novog crnogorskog romana. U istoriji književnosti nije ni rijedak slučaj da su pisci postajali sekularni duhovnici i nosioci društvenih promjena, obično onda „kad narod zaćuti“.

Herojstvo protagoniste drugog primjerskog romana, koje je značenjski ubilježeno u njegovo prezime Junak, očituje se u njegovoj magbetovskoj odlučnosti da uprkos balkanskoj stvarnosti nalik na istoimenu Šekspirovu dramu, slijedi svoj unutrašnji glas pisca, a ne ratnika, koji će ga uputiti na nepoznata i neizvjesna lutanja, da bi završio u rukama doktora u Americi, odlučnog da realizuje književne ambicije svog preminulog pacijenta na osnovu njegove posmrtne zaostavštine $u$ formi nečitkog dnevnika i nezavršenog rukopisa. Pozadina i ovog romana je ratnička paranoja trećeg svijeta iz kojeg Junak herojski dezertira.

U romanu Auschwitz café protagonista najprije svjedoči otmici i ubistvu saputnika u vozu na stanici Štrpci, a potom i kolektivnoj zločinačkoj orgiji koja postaje hronotop romana. Simbolična promjena imena, samoizgnanstvo i nihilistička zloupotreba alkohola i droga ne uspijevaju da umanje krivicu prećutkivanja zločina. Postavši ,živi mrtvac“, mučen snom i javom, i ovaj junak smiraj ipak pronalazi u smrti, ali ne prije nego što je iskupio „svoj zločin ćutanja i nemoći“ i raskrinkao vlastodržačke generatore zla. Korumpirana i totalitarna vlast i degenerisano društvo kao posljedica te vlasti opet je česta tema mnogih romana novije crnogorske književnosti, kao što su roman Balše Brkovića Paranoja u Podgorici koji se neposredno bavi crnogorskim društvom ili roman Hansenova djeca Ognjena Spahića u kome je slikovna pozadina diktatura Čaušeskua.

Ako je u prethodnom periodu „Lim tekao kroz crnogorsku književnost“ i sjever čuvao njen kontinuitet, u savremenom kontekstu jug preuzima primat književnog stvaralaštva, a Podgorica postaje ne samo ustaljeni toponim romanesknog pripovijedanja nego i protagonist sam za sebe, poput Petrograda ruskog fantastičnog realizma ili Džojsovog Dablina. Podgorica postaje ne samo pozornica ratnih i tranzicijskih previranja, nego živi i univerzalni simbol vremena kome crnogorsko društvo još uvijek dorasta. Centralizaciji crnogorske

$4 \quad$ Nova crnogorska književnost - mitomanija ili stvarnost?, http://www.znaksagite.com/diskusije/index.php?topic=5198.0, (11.05.2014). 
književnosti na glavni grad doprinosi i pojava zbirke pripovijetki Podgoričke noći koja je rezultat udruženog rada šire postjugoslovenske scene u kojima su junaci radnji Podgoričani ili je radnja smještena u Podgorici. Negatori postojanja crnogorskog jezika ili odvojenosti crnogorske književnosti od srpske literalizaciju Podgorice pripisuju provincijalizaciji crnogorske kulture i pokušaju da se smjesti na mapu balkanskih književnih centara.

Crnogorski pisci se i ideološki udaljavaju od balkanskog miljea pa svoje sižejne linije popunjavaju referencama na zapadnu popularnu kulturu i filozofsku kritičku misao, ispitujući primjenjivost određenih književnih teorija i smještajući crnogorsku književnu riječ u književnoistorijski okvir širi čak i od evropskog. Osporivači crnogorske književnosti u ovome i vide njenu neodrživost pa sadržajnu i formalnu razuđenost savremenog crnogorskog književnog korpusa tumače kao posljedicu inferiornosti i kompleksaško hvatanje za prihvaćene kvalitete, ne bi li tako potvrdili svoju vrijednost. Na pomenutoj internet stranici moguće je iščitati mišljenja kako „mlađi crnogorski književnici imaju problem čoveka koji se najednom načitao knjiga, otkrio Džojsa, Ničea, Hajdegera, Bernharda, Beketa, i sad ima potrebu da nam otkriva toplu vodu, da najbanalniju svakodnevicu i trivijalne dileme svojih književnih junaka uzdigne na nivo nečeg ozbiljnog time što će ubaciti nekakvo deridijansko tumačenje u celu tu zavrzlamu“ ili kako ti isti pisci izražavaju stav, ,svi ste vi glupaci jer slušate Miroslava Ilića, a ja sam pametan jer slušam Joy Division“. 5

Roman Mimezis je organizovan u poglavlja koja su naslovljena po indie hitovima tako da grafički podsjeća na muzički album. Sličan postupak koristi i Aleksandar Bečanović koji na kraju svojih djela nudi prigodnu muzičku pozadinu kao preporučenu muzičku listu. U romanu Život i smrt Milana Junaka sadržani su dnevnički zapisi o pogledanim filmovima, kupljenim albumima ali i postmodernistički omaž najdražim piscima kao i "roman unutar romana“ u maniru Agate Kristi. Auchwitz cafe može da posluži kao scenarijum za holivudsko-crnogorski naučnofantastični film. Neosporno je da crnogorska nova književnost otvoreno elitistički pršti od rokenrola, džeza, francuskog novog talasa i poetičkog realizma, novog njemačkog kina, klasičnog Holivuda, italijanskog neorealizma; neosporno je i da se radnja motiviše, a književni likovi otkrivaju kroz njihove kolekcije muzičkih ploča, omiljene lektire i filmove. Bilo bi brzopleto i nepravedno optužiti crnogorske kulturne stvaraoce i konzumente za šovinizam i kulturni fašizam. Nije potrebno studiozno sociološko istraživanje da se shvati da konzumacija kulture zapravo jeste društvena stvarnost onog dijela crnogorske populacije koja je izabrala apstinenciju (i još

5 Nova crnogorska književnost - mitomanija ili stvarnost?, http://www.znaksagite.com/diskusije/index.php?topic=5198.0, (11.05.2014). 
uvijek bira) od uobičajenog društvenog angažmana, kada je to društvo preplavila ikonografija ratnohuškačkog i tranzicijskog kiča, a sfera interesovanja se eskapistički izmjestila u ljepše svjetove. Proizvođači i konzumenti crnogorske kulture, iako gurnuti na istorijske margine, nijesu kukavice koji zatvaraju oči pred stvarnošću, već oni upravo tu stvarnost mimetički reprodukuju, ali kroz filmske kadrove i indie soundtrack. Kada i progovore direktno o balkanskom boju, tu nema jednostranog politikanskog optuživanja, već ogoljene životne tragedije ljudi svedenih na arhetipske simbole dobra i zla sa obje zaraćene strane.

Crna Gora devedesetih, kao i tranzicijska Crna Gora novog milenijuma, mada pjesnički inspirativna, nije u pomenutim romanima predstavljena kao poželjna adresa. Iako ,junaci našeg doba“ razmatraju emigraciju, oni ipak dovode u pitanje i postavljene vrijednosti „razvijenijih“ društava. Milan Junak u obećanoj zemlji, HIV pozitivan, iz nerazjašnjenih okolnosti završava u plastičnoj vreći. Seamus iz Auchwitz café-a ne raskrinkava samo domaću mafijašku vlastelu nego i implicira da je njen opstanak potpomognut interesom kapitala bjelosvjetskih korporacija. Konstantin iz Mimezisa ne razrješava ličnu dilemu da li da prihvati ultimatum na ženidbu svoje višegodišnje djevojke, napusti zemlju i nastani se u Holandiji, moguće zbog svog platonovskog filozofskog ubjeđenja koje zagovara sjedelački način života ili zbog nakaznosti svijeta kojeg kreira moć novca na čiju nas nepravednost od Filipina do Kanade podsjeća ludistička avantura njegove djevojke.

Borislav Jovanović ovakvu globalizovanu naraciju, odvojenu od balkanskih rustikalnih pejzaža, a vezanu sa svijet i savremenost, tumači kao uspostavljanje diskontinuiteta u odnosu na tradiciju. Autor navodi da je nova crnogorska književnost isto tako sva u znaku dekonstrukcije, kojoj su izložene tematske zadanosti, tradicionalni obrasci, kao i stereotipno ruralno rezonovanje. ${ }^{6}$

Iako nova crnogorska književnost definitivno označava konačan raskid sa dominantno herojsko-epskim diskursom prethodnih perioda, ona ipak predstavlja kontinuitet one književne tradicije utemeljene između Lalića i Kiša.

U svojoj suštini crnogorska književnost zapravo predstavlja idejnog čuvara onog pod čime se idealistički podrazumijeva autentičnost crnogorskog bića, a tematski se vezuje za preispitivanje odgovornosti Crnogoraca za žrtve jugoslovenskog raspada, kako na svojoj tako i na komšijskim teritorijama, hroničarski bilježeći ratno i poratno izgubljeno međuvrijeme dok „očekujemo što će iz svega proizaći”.

6 B. Jovanović, „Najnoviji crnogorski roman (dekonstrukcija, autopoetika, diskontinuitet)“, u: Najnoviji glasovi crnogorske proze (književnoteorijski i izborni pregled), uredili: Milorad Nikčević i Jakov Sabljić, HCDP „Croatica - Montenegrina“ RH / CKD „M - M“, Osijek 2007, str. 28. 


\section{Literatura i izvori}

- Jelušić, Božena, „Moderni crnogorski roman između Mihaila Lalića i Danila Kiša (Dragan Radulović, Balša Brković, Ognjen Spahić i Andrej Nikolaidis)“. U: Najnoviji glasovi crnogorske proze (književnoteorijski $i$ izborni pregled), uredili: Milorad Nikčević i Jakov Sabljić, HCDP „Croatica - Montenegrina“ RH / CKD „M - M“, Osijek 2007, str. 31-38.

- Jovanović, Borislav, „Najnoviji crnogorski roman (dekonstrukcija, autopoetika, diskontinuitet)“. U: Najnoviji glasovi crnogorske proze (književnoteorijski i izborni pregled), uredili: Milorad Nikčević i Jakov Sabljić, HCDP „Croatica - Montenegrina“ RH / CKD „M - M“, Osijek 2007, str. 23-29.

- Nikčević, Milorad, „Nadvremenski glasovi: stoljetni hrvatski i crnogorski književno-kulturni identiteti“. U: Najnoviji glasovi crnogorske proze (književnoteorijski i izborni pregled), uredili: Milorad Nikčević i Jakov Sabljić, HCDP „Croatica - Montenegrina“ RH / CKD „M - M“, Osijek 2007, str. 13-21.

- Nikolaidis, Andrej, Mimezis, Durieux, Zagreb / Otvoreni kulturni forum, Cetinje, 2003.

- Pejović, Vojislav, Život i smrt Milana Junaka, Daily Press, Podgorica, 2008.

- Radulović, Dragan, Aushwitz Café. Dystopia, Drakar, Budva, 2003.

- Nova crnogorska književnost - mitomanija ili stvarnost? http://www.znaksagite.com/diskusije/index.php?topic=5198.0, (11.05.2014).

\section{Lejla VESKOVIĆ}

\section{NEW MONTENEGRIN LITERATURE AS A CHRONICLE OF RECENT BALKAN WARS}

The paper discusses the relationship of new Montenegrin literature to the wartime past of the early nineties. Features of the new Montenegrin novel are analysed based on the novels Auschwitz Cafe by Dragan Radulović, Mimesis by Andrej Nikolaidis and The Life and Death of Milan Junak by Vojislav Pejović. The readers may notice the common features such as socially engaged text, autobiography, numerous popular culture references, anti-heroes and superheroes as protagonists, a deviation from the traditional epic reasoning, as well as the continuation of previous literary forms.

Key words: new Montenegrin literature, new Montenegrin novel, Auschwitz Café, Mimesis, The Life and Death of Milan Junakž 

UDK 821.163.4-1:398(497.16)

Pregledni rad

\title{
Vladimir VOJINOVIĆ (Podgorica)
}

Fakultet za crnogorski jezik i književnost - Cetinje

vladimir.vojinovic@fcjk.me

\section{NOVO ČITANJE CRNOGORSKE USMENE PROZE}

\begin{abstract}
Autor je u radu iznio aspekte prevrednovanja crnogorskih usmenih proznih formi. Polazeći od rezultata ranijih sondaža crnogorske usmene proze, koje su obavljali Radoje Radojević, Danilo Radojević, Radosav Medenica i Niko S. Martinović, autor rada akcentovao je značaj daljega izučavanja produkata usmenoga stvaralaštva i značaj njihova rasvjetljavanja u duhu savremene teorijske vizure i savremenih književnokritičkih metoda. U radu je izvedena teza o marginalizaciji dostignuća prethodnih istraživača u oblasti afirmisanja i interpretiranja formi crnogorskih usmenih proznih formi kao posljedice procesa opstruiranja uspostave crnogorskoga nacionalnog identiteta.

Ključne riječi: crnogorska usmena književnost, usmena proza, klasifikacija, jednostavni oblici, antologije
\end{abstract}

\section{Konstituisanje nacije kao uslov opstanka}

Čini se u najmanju ruku anahronim govoriti o nacionalnome osvješćivanju u trećemu milenijumu. U eri kada već kreću teze o novome stadijumu planete, tj. u vrijeme kad je globalna mreža uspjela da poveže naše centralne nervne sisteme na bezbroj načina. U dokumentarcima nazvanim po imenu britanskoga kosmologa Hokinga saopšteno je da će se naša civilizacija jednoga dana pitati kako su se to i kada tačno pojedinačni centralni nervni sistemi prvi put uvezali u jedan veliki, globalni mozak. Ko zna, možda je čovjek uistinu tek nekakav molekul primitivnoga organizma koji će se tek za desetak milenijuma razviti u punoj mjeri i zavladati međugalaktičkim prostorima? No, dok to s galaksijama ne riješimo, valja nam izmisliti par tisuća ljekova i vakcina, spasiti ozon, pogasiti ratna Žarišta, očistiti planetu od oružja za masovna uništenja, etc, etc. Riječju - opstati.

Priča o nastanku nacija prilično je povezana s pričama o opstanku. Zato se nacija doima kao sinhronijsko-dijahronijska kategorija, puna tvar i mjerna jedinica globalnoga vremena, onoga koje se ne tiče samo jedne epohe ili jedne 
vremenske zone, nego cijeloga razvoja čovječanstva i svih tačaka na planeti. Formiranjem nacija čovječanstvo je okrenulo veliki kosmički sat za još jedan krug. Tada, otprilike u 12. vijeku naše ere, ljudska rasa uspjela je da se otrgne od okova jednoga vida života i stvori okolnosti za razvitak nauka koje su nas dovele tu đe smo danas.

Dakako, svemu tome prethodio je veliki proces udaljavanja od jezičke konvencije. Od pisama nerazumljivih nepismenome puku, a koja su imala konkretni cilj - jačati i učvršćivati uticaj religija. Zbog toga se srednji vijek i doima kao vrijeme suspenzije mašte i ukidanja mogućnosti slobodnoga mišljenja. Sve to je, čini nam se, najbolje razumio vladar srednjovjekovnoga carstva pod kojim je Evropa, makar na kratko, bila jedna cjelina. Hoteći da se oslobodi crkvenih uticaja, Karlo Veliki pokrenuo je inicijativu izrade pravopisa njemačkoga jezika koji bi se približio narodnim govorima, izrade rječnika, gramatike, osnivanja naučne akademije, i to upravo uz pomoć pučkih, narodnih formi. Vrijeme je to kada se po teritorijama današnje Evropske unije, u zemljama koje su počele da skiciraju nacije, javljaju prvi zapisi velikih nacionalnih epova, negđe vijek prije, negđe vijek kasnije. Narodi, vjesnici nacija, maštali su o boljim svjetovima i tkali Beovulfa, Ep o Nibelunzima, Kalevalu, Pjesmu o Rolandu, Pjesmu o Sidu, Pjesmu o pohodu Igorevu. Nerijetko, pojava tih epova značila je istovremeno i pojavu prvih iskri nacionalnih jezika, označila je početni stadijum formiranja nacija. Zato su ta ostvarenja uvijek na udaru onda kad se želi problematizovati bilo koje od pitanja iz oblasti nacionalnih jezika ili nacionalnih kultura. Śetimo se samo s koliko je energije Roman Jakobson polemisao i dokazivao da je Pjesma o pohodu Igorevu jeste nastala oko XII vijeka, pobijajući time tezu po tezu svih onih koji su tvrdili da je taj spjev falsifikat Aleksandra Ivanoviča Musina Puškina, koga su optuživali da je iz čisto političkih razloga posegnuo za falsifikovanjem. Čini se, takođe, da niko ovim i sličnim temama nije bio inficiran kao evropski romantičari, koji su, razumije se, bili rukovođeni i političkim tendencijama a ne samo estetskim kriterijumima pri čitanju i obradi folklorističke građe. I upravo su romantičarske inicijative bile te koje su napijale balkanske intelektualce idejama o značaju jačanja nacionalne svijesti i ulozi usmene književnosti u tome procesu. Ali, za razliku od sredina u kojima su u eri romantizma te ideje dožiljavale prevrednovanje, ili „ponovno čitanje“, na prostorima Balkana procesi sistemskoga oslobađanja jezika uz pomoć formi usmene i pisane književnosti i prijevode biblijskih tekstova sa staroslovenskoga na narodni jezik, stali su se javljati tek u prvoj polovini 19. vijeka. 


\section{O ulozi folklorista u formiranju nacije}

Vuk Stefanović Karadžić je, dakako, ponajviše doprinio svim tim procesima. Balkanski folklorist i reformator jezika znao je da su i južnoslovenski narodi sve vrijeme, pa i mnogo prije XII vijeka, ośećali što i komšije iz središta evropskoga kontinenta i da su te svoje ośećaje takođe čuvali u pjesmama i pričama, i kako-tako dočekali XIX vijek i trenutak da u njihove zemunice zađe neko koga sve to zanima. Vuk je, kao što znamo, štampao knjige koje nijesu bile ispunjene mrtvim slovima. Njegove knjige su zbirke živih riječi naroda što su bili na nišanu i jedne i druge i treće sile, naroda koji su pokušavali da se uvežu u veći sistem i iskorače iz okova srednjega vijeka. Otud ne treba da čude ni posljedice interpretacija Vukovih uradaka, sadržane u ovim stavovima: a) Vuk je nametao austrijske želje srpskoj kulturi i odvajao je od ruskih uticaja i b) Srbi (su) svi i svuda. Zapravo, za tu dijalektiku misli o Vukovu doprinosu jezičkoj reformi zaslužni su pravoslavni oci, koji su, nakon neuspjelih anatemijskih napada na folkloristu, došli do zaključka da je jezik koji je Vuk stvorio (osluškujući narodne govore) svrsishodnije proglasiti svetim. Tim aktom je jezik ponovo istrgnut iz ruku naroda, ,autorizovan“ $i$, bar za kratko, izmaknut od naučnoga fokusa. Istovremeno, to je značilo da je smanjen rizik od artukulacije različitih nacionalnih ośećanja i standardizovanja različitih nacionalnih jezika. Crkva je, dakle, mnogo prije slavistike razumjela da jezici nipošto nijesu mogli nastati kao narodni i nacionalni jezici izvanj država, naroda i nacija kao njihovijeh tvoraca i predstavnika. ${ }^{1}$

Karadžić je više puta dolazio u Crnu Goru. Teško bi bilo reći jesu li Vukovi česti dolasci u Crnu Goru više bili motivisani usmenom književnosti ili politikom kojoj je služio, ${ }^{2}$ ali nije teško zaključiti da je radom na sakupljanju i afirmaciji crnogorskih usmenih pjesama i pripovjedaka doprinio, makar posredno, i definisanju crnogorske nacije. Upravo je Vuk u Crnoj Gori pokrenuo proces koji je prepoznat kao put do pronalaska odgovora na pitanje o nacionalnome jeziku i naciji. A nije novina da je upravo Vuk prvi upotrijebio sintagmem crnogorski jezik. ${ }^{3}$

No, za nas je za ovu priliku od posebne važnosti podatak da se taj balkanski folklorist zanimao i za crnogorsku usmenu prozu. U knjizi Srpske

Vojislav P. Nikčević, „Vukov model standardnog jezika u teoriji i praksi“, u: Vuk Karadžić i Crnogorci (zbornik radova), Institut za crnogorski jezik i jezikoslovlje, Cetinje, 2005, str. 25.

2 Novak Kilibarda, „O današnjim pristupima Vuku Karadžiću“, u: Vuk Karadžić i Crnogorci (zbornik radova), Institut za crnogorski jezik i jezikoslovlje, Cetinje, 2005, str. 54.

3 Vojislav Nikčević, Crnogorski jezik II, Matica crnogorska, Cetinje, 1997, str. 375. (Viđeti i: Vuk Stef. Karadžić, Etnografski spisi o Crnoj Gori, Prosveta - Nolit, Beograd, 1985, str. 273.) 
narodne pripovijetke objavio je po jednu bajku i basnu koje mu je saopštio Tešan Podrugović, četiri pripovijetke koje mu je poslao Vuk Popović i petnaest pripovjedaka koje mu je poslao Vuk Vrčević. To je pokrenulo lavinu interesovanja za crnogorsku usmenu prozu ondašnjih i kasnijih folklorista i antologičara. Brojni književnici i naučnici u periodima vladavina Petra II, Danila I i Nikole I Petrovića Njegoša (među kojima i izvanjci Simo Milutinović Sarajlija i Pavle Apolonovič Rovinski) dali su doprinos sakupljanju i čuvanju crnogorske usmene proze. Mnogi od njih su od naroda prikupljenu proznu građu objavljivali u crnogorskoj periodici, kao obavezni prilog listova, u posebnim rubrikama, jer je jedno glasilo u tim vremenima bilo nezamislivo bez sličnoga sadržaja. S praksom prikupljanja i objavljivanja crnogorske usmene proze nastavilo se i nakon propasti dinastije Petrović, u periodu između dva svjetska rata. U to vrijeme najaktivniji folkloristi bili su Mićun Pavićević i Stojan Cerović, koji su objavili i brojne knjige s crnogorskom usmenom prozom. Nakon Drugoga svjetskog rata doprinos u očuvanju crnogorske usmene prozne baštine dali su Joksim Radović, Radosav Medenica, Niko S. Martinović, Radoje Radojević, Danilo Radojević, Obrad Višnjić, Vukale Đerković, Jovan Čađenović, Nikola P. Rajković, Boro Vujačić, Janko Vujisić i Pavle Đonović.

Prva ozbiljnija sistematizacija foklorističke građe i odabir reprezentativnih uzoraka pojedinih crnogorskih proznih vrsta, u skladu s izvjesnim estetskim načelima i onovremenim književnokritičkim metodama, obavljeni su šezdesetih i sedamdesetih godina prošloga vijeka. To je vrijeme kada (1962) u Antverpenu s radom počinje i Internacionalno društvo za proučavanje narodnih pripovjedaka, i kada jugoslovenska predstavnica u tome tijelu, Maja Bošković-Stulli, zagovara tezu da narodne pripovijetke, bez obzira na svoje međunarodne sižee i motive, nose na sebi pečat nacije koja ih pripovijeda. ${ }^{4}$ Te prve ozbiljnije sistematizacije i antologijski pristupi pojedinim vrstama crnogorske usmene proze rezultirali su uspostavljanjem manje ili više održive nomenklature, uočavanjem nekih posebnosti vrsta crnogorske usmene proze i detektovanjem sličnosti pojedinih crnogorskih usmenih proza s usmenim prozama drugih nacionalnih književnosti. U tome smislu najveći doprinos naučnome tretmanu usmene prozne građe dala su dva crnogorska naučnika, braća Radoje i Danilo Radojević, koji su, sarađujući s titografskim Grafičkim zavodom i NIO Pobjeda uspjeli da izopšte crnogorsku usmenu proznu građu iz korpusa drugih nacionalnih književnosti. Odbacujući pozitivističke modele obrade teksta i oslanjajući se na formalističke premise i filološke kriterijume,

4 Maja Bošković-Stulli, „Regionalne razlike među narodnim pripovijetkama“, u: Narodna umjetnost (Zagreb), 7/1970, str. 1, 3. 
Radojevići su trasirali temelje budućim, strukturalističkim ili poststrukturalističkim pristupima a u njihovoj nomenklaturi i interpretativnoj, književnokritičkoj obradi, crnogorska usmena proza prvi put dobila je mjesto koje joj po svemu pripada. Zahvaljujući tome što su Radojevići uspjeli da svaki pojedinačni umjetnički uspio usmeni uradak otrgnu od „priređivačkih“ postupaka kojim su ih prethodni antologičari gurali u tuđe književne korpuse, prije svega intervenišući nad jezikom i stilom „originala“, bajke, basne, legende i priče postale su stubovi-temelji budućega procesa standardizacije crnogorskoga jezika.

Od tih aktivnosti braće Radojević do danas prošlo je skoro pola vijeka a za to vrijeme crnogorske usmene proze uglavnom su samo preštampavane. Svijet se u međuvremenu upoznavao s brojnim teorijskim tezama o naraciji. Prije svih sa strukturalističkim, naratološkim, odnosno poststrukturalističkim, koje su prihvatane ili odbacivane. Uporedo s tim, u južnoslovenskim naučnim i stručnim krugovima odvijao se i proces prihvatanja teorije iznikle iz rješavanja i rješenja homerskoga pitanja, odnosno razumijevanja pojedinačnih usmenih pjesama i kao autorskih produkata a ne samo zaostavštine cijeloga kolektiva. To je, između ostaloga, rezultiralo zastarijevanjem pojedinih nomenklatura usmene poezije i udaljavanjem od principa svrstavanja pjesama $\mathrm{u}$ motivsko-tematske cjeline, ili cikluse, jer postalo je jasno da je nemoguće svrstati dvije pjesme $u$ istu podvrstu ili ciklus ukoliko se one dotiču tek iste teme ili jednoga sličnog motiva a da pritom ne raspolažu i većim brojem istovjetnih ili sličnih elemenata struktura zahvaljujući kojima bi se moglo govoriti o ujednačenosti estetskih kvaliteta. Izolovano posmatranje pojedinačnih proizvoda usmene književnosti kao autohtonih proizvoda rezultiralo je i uočavanjem poetičkih karakteristika pojedinih pjesnika-pjevača. Zato je savremena montenegristika, na primjer, taj proces indukovala kroz pristup pjesnicima-pjevačima kao autorima, o čemu najbolje govori i objavljivanje pjesama Starca Milije ${ }^{5}$ i Tešana Podrugovića ${ }^{6}$ u zasebnim monografskim publikacijama i s njihovim imenima kao imenima autora.

Tako je s usmenom poezijom. Ostalo je, međutim, da se vidi da li je slične metode moguće primijeniti pri obradi crnogorske usmene proze. Zbog toga nam valja preispitati ranije pristupe toj građi.

Starac Milija, Pjesme, Institut za crnogorski jezik i književnost, Podgorica, 2012.

6 Tešan Podrugović, Pjesme, Institut za crnogorski jezik i književnost, Podgorica, 2012. 


\section{O legendama}

Sve aktivnosti na sakupljanju, odabiru i klasifikaciji crnogorskih legendi, bajki, basni i priča, Radoje Radojević utemeljio je tezom da su nastanak i geneza tih usmenih proznih formi u crnogorskoj književnosti proizvod preplitanja praslovenskih, paganskih, antičkih grčkih i antičkih rimskih s kasnijim hrišćanskim i otomanskim kulturnim tekovinama. Jasno je onda zašto crnogorska fantastika ima mnogo specifičnih crta, izraženih u posebnim mitskim predstavama ili u osobenim karakteristika opštepoznatih predstava $i$ vjerovanja. ${ }^{7}$ Naime, Radojević podśeća na istraživanja Rista Kovijanića i M. S. Drinova koji su govorili o tome da su na crnogorskome primorju postojale stare grčke naseobine, u kojima su nastajale legende o postanku gradova (Kotora, Budve i Ulcinja) te da su te i druge legende njegovali i romanizovani Iliri a potom i doseljenička slovenska plemena, i tome korpusu pridodavali legende o Teuti, o caru Dioklecijanu, tj. Dukljanu i druge. Zato je danas, usljed spajanja mitoloških elemenata, kultova, vjerovanja, običaja i tradicija, teško govoriti o tome koliko u crnogorskim legendama, bajkama, vjerovanjima, u narodnoj fantastici uopšte, ima elemenata prvobitno slovenskih, a koliko ilirskih, odnosno romanskih ili drugih. ${ }^{8}$

To je bila istorijska osnova Radojevićeva proučavanja legende. Za teorijsku osnovu on je pronašao uporište u stavu da je riječ o jednome od najstarijih oblika usmene književnosti, po fantastičnim sadržajima vrlo sličnome bajci, a tijesno povezanome s mitom. Upravo Radojević koristi termin fantastika kao zajednički imenitelj ili sinonim za legendu i bajku. On takođe tvrdi da $u z$ legende idu i tvorevine koje ne spadaju u fantastiku, ali se njihovi sadržaji ne zasnivaju na istorijskim činjenicama, ili su te činjenice izmijenjene i pomjerene u tolikom obimu, da su dobile karakter legende. Odsustvo natprirodnih sila u njima čini da djeluju realnije. (...) Često su vezane za poznate junake $i$ druge znamenite ličnosti, za tradicije o postanku bratstava, plemena, naselja $i$ gradova, za nastanak toponima i prezimena, za porijeklo pravnih $i$ drugih načela i običaja itd. ${ }^{9}$

Prema jednoj teorijskoj tezi (pa i prema međunarodnoj klasifikaciji narodnih proznih vrsta) koja je bila aktuelna u periodu nakon Drugoga svjetskog rata, legendarna priča, ili legendarna pripovijetka, posmatrana je kao foklorizovani oblik apokrifa i srednjovjekovnih žitija. Dakle, posmatrana je kao oblik koji je prije svega bio usmjeren na uspostavu kulta jedne svetačke

\footnotetext{
7 Vilina gora: antologija crnogorskih legendi (priredio Radoje Radojević), Grafički zavod, Titograd, 1971, str. 21

Ibid, str. 16.

9 Ibid, str. 31-32.
} 
ličnosti u narodu, koji je u tu svrhu crpio argumentaciju iz domena fantastičnoga, čudesnog. Čudo je tretirano kao jedno od ključnih „oružja“ glavnih likova legendi i kao narativni dokaz da su ti likovi zasluživali status svetaca. Prema toj teorijskoj pretpostavci, forma legende sazdana je tako da pretpostavlja vjerodostojnost kazivanja, s tendencijom da se u nju vjeruje, dok se njena sličnost $\mathrm{s}$ bajkom ogleda ne toliko u fantastičnim motivima koliko $\mathrm{u}$ višeepizodičnosti. ${ }^{10} \mathrm{No}$, bitnije od svega vezanoga za tu teorijsku pretpostavku je izvor legende - pisani dokument, kao i stav da je sadržina toga dokumenta postala narodna, odnosno da je folklorizovana.

Da li je ova teza do kraja precizna i što onda podrazumijevati pod crnogorskom legendom?

Savo Vukmanović je, analizirajući predanja i legende durmitorskoga kraja, konstatovao da je upravo durmitorsko područje bogato narodnim pričama kojih ima raznovrsnih, sa već poznatim motivima, samo sa nešto izmijenjenim i prerađenim sadržajem, i novih, najvjerovatnije lokalnog postanka. ${ }^{11}$ On dodaje da među tim narodnim pričama i narodna predanja i legende ima mnogo onih u kojima se govori o postanku izvjesnih mjesta i njihovih naziva, a u vezi s događajima i ličnostima po kojima su i dobili ime, kao i o izvjesnim čudesnim zbivanjima, o svecima i nekim čudesnim pojavama po kojima su nastali mnogi nazivi, te da ima i onih u kojima ima pomena i o duhovima, đavolima, vilama i krilatim konjima koji se pojavljuju i žive u visokim planinama i dubokim jezerima.

Nasvježiji teorijski opis crnogorske legende dao je Novak Kilibarda. On smatra da su legende nastale iz potrebe da se objasni neka pojava u prirodi, u ljudskome životu i u istoriji. To je po pravilu kratka priča jednostavne kompozicije. Kako je istakao Vido Latković, objašnjenja u legendi su naivno fantastična, a kad raspolažu realističkijem pojedinostima legende su uglavnom izmišljene. Čak i kad se veže za istorijsko predanje dokazi su prepušteni fantastici zato što su motivi legende pretežno internacionalnog smjera. Mogu se razlikovati dva vida legendi: jedne koje govore o mjestima i druge koje govore o licima, iako je vrlo česta pojava da su u istoj legendi spojena ta dva njezina vida. ${ }^{12}$

Radojević je prikupio i za antologiju izabrao 130 legendi koje su zapisane u Crnoj Gori a objavljene u knjigama Vuka Karadžića, P. A. Rovinskog, Ilije Jelića, Milana Majznera, Ilije Zlatičanina, Maksima Šobajića, Tvrtka Ču-

10 Rečnik književnih termina, Nolit, Beograd, 1986, str. 391.

11 Dr Savo Vukmanović, „Predanja i legende oblasti Durmitora“, u: Rad XXII-og kongresa Saveza udruženja folklorista Jugoslavije na Žabljaku 1975. godine, Cetinje, 1985, str. 24.

12 Novak Kilibarda, Istorija crnogorske književnosti I: usmena književnost, Institut za crnogorski jezik i književnost, Podgorica, 2012, str. 199. 
belića, Rista Kovijanića i drugim, te u glasilima Prosvjeta, Nova Zeta, Književni list, Bosanska vila, Srpski etnografski zbornik, Glasnik Etnografskoga muzeja na Cetinju, Nikšićke novine, Slobodna misao, Zapisi, Crnogorac, Južnoslovenski filolog... Neke od legendi direktno su mu saopštili i pojedini kazivači.

Sljedeći njegov korak bila je klasifikacija legendi. Radojević se obavljajući taj posao susreo s izvjesnim poteškoćama, pa je posegnuo za preispitivanjem modela klasifikacije ranijih tumača usmene književnosti - Vuka Karadžića, Vuka Vrčevića, Novice Šaulića, Veselina Čajkanovića, Jaše Prodanovića, Vida Latkovića i Tvrtka Čubelića. U pogovoru antologije naglasio je da nijedan od tih modela klasifikacije nije do kraja precizan, pa ni oni koji su se oslanjali na Aarne-Thompsonov međunarodni indeks tipova, budući da $\mathrm{u}$ indeksu nema ni legendi ni skaski. U legendama vlada takva isprepletenost motiva, strukturalno ugrađenih u razne teme i misaone izraze, da je vrlo teško izvršiti podjelu na cikluse ili krugove koja bi zadovoljavala i motivski i strukturalistički princip. Ne prihvatajući ni grubu formalnu podjelu na 'legende o mjestima' $i$ 'legende o ličnostima', u knjizi sam izvršio šire grupisanje legendi po srodnosti motiva, pri čemu sam vodio računa o strukturalnoj bliskosti. ${ }^{13}$ Taj princip rezultirao je grupisanjem legendi u 16 kategorija, i to - u kategoriju o caru Dukljanu, o gradovima, o feudalnim vladarima, o svetiteljima i crkvama, o postanku stvari (životinja, prirodnih pojava i natprirodnih bića), o snazi i junaštvu, o ljubavi i ženidbi s vilama, o dobrim i zlim vilama, o lovcima, o kumstvu i kletvi, o čudesnim vodenim bićima i duhovima, o natprirodnim svojstvima ljudi, o đavolima, o skrivenom blagu, o raju i paklu i u kategoriju humorističkih legendi.

S obzirom na to da su teorijski dometi jugoslovenskih naučnika vremena u kome se pojavila Radojevićeva antologija bili projektovani ondašnjom teorijskom literaturom i priličnim kašnjenjem prijevoda dominantnih teorijskih tekstova iz razvijenih evropskih naučnih centara i kružoka, ne može se smatrati Radojevićevom omaškom diferenciranje motiva i strukture kao posebitih i nespojivih elemenata interpretacije. Ipak, pribjegavanje pomenutome principu klasifikacije rezultiralo je kategorizacijom koja je prvenstveno tematska, budući da je grupisala one legende koje su se bavile istim ili sličnim temama. Iz toga polazišta Radojević je stigao do zaključnoga stava o osobenostima crnogorske legende, ali uočene specifičnosti više se tiču odabira građe za umjetničku obradu nego samoga načina obrade. Radojević, recimo, zaključuje da crnogorske legende karakteriše pojava pojedinih likova koji se rijetko javljaju u legendama drugih nacionalnih književnosti, poput: lika cara

13 Vilina gora, str. 255. 
Dukljana (čije ime je sinonim za Sotonu), likova zduvača ili vjedogonja (koji nijesu zli duhovi, već oni koji noću napuštaju ljudska obličja pa brane kuću, porodicu, bratstvo ili pleme od neprijateljskih duhova; otud se i kanonizovani crnogorski vladika, Petar I, u narodu posmatra kao zduvač), likova ungreva (ljudi natrpirodne fizičke snage)... Ne znači to i da je Radojević zanemario način pripovijedanja ${ }^{14} \mathrm{u}$ legendama, ali se teško možemo oteti utisku da on nije bio i dominantni faktor pri klasifikaciji legendi.

Radojević je, međutim, ne samo na osnovu intuicije no ipak usputno, ukazao na to da su ljepota i sve posebnosti crnogorske legende sadržane u osobenome jeziku i stilu. Priređujući antologiju za štampu, uložio je veliki napor da se crnogorske legende vrate svome izvornom obličju, tj. da se očiste od intervencija 'izvanjaca' i nekih Crnogoraca koji su htjeli da jezik legendi učine što više 'književnim'. Primijetio je Radojević kako ima više primjera da zapisivač, ili onaj koji prepričava legendu, potpuno ili djelimično zadržava izvorni oblik upravnoga govora, a u indirektnom govoru služi se 'svojim jezikom', iako je poznato da u usmenoj književnosti nema razlike između upravnog $i$ indirektnog govora. ${ }^{15}$ Zato je: a) mijenjao pojedine savremene lekseme autohtonim crnogorskim izrazima, b) prevodio s ruskoga jezika legende koje je zapisao Rovinski u duhu i obliku narodnoga pripovijedanja i c) zadržao jezik kazivača u legendama koje je sam zapisivao. Sve to, uprkos neostvarljivosti uspješnoga vraćanja na izvorne oblike legendi koje su objavljene, učinio je na tako temeljit način da je objavljene legende sasvim moguće podvrgnuti postrstrukturalističkim metodama obrade proznih tekstova.

\section{O bajkama}

Kad je 1976. godine Radoje Radojević objavio knjigu Vatra samotvora: antologija crnogorskih narodnih bajki ${ }^{16}$ postalo je jasno da je crnogorska usmena proza toliko rasprostranjena i prisutna u serijskim i monografskim publikacijama nastalim u periodu od druge polovine XIX vijeka do početka Drugoga svjetskog rata, da je pri prvom pogledu na pojedina ostvarenja vrlo teško razlučiti da li su one zaista proizvod usmenosti, ili svojevrsni književničko-podražavajući uradak. Radojević u predgovoru Antologije navodi da je njegov osnovni kriterijum odabira bajki bio književna vrijednost te proze, te

14 Radojević u predgovoru antologije uzgredno saopštava da legende afirmišu domišljatost, mudrost, duhovito pripovijedanje, te da je u njima fabula tako koncipirana, radnja dramatizovana, ideja zgusnuta, da istakne ljudski um, hrabrost, domišljatost (Vilina gora, str. 27).

15 Vilina gora, str. 256.

16 Vatra samotvora: antologija crnogorskih narodnih bajki (priredio Radoje Radojević), Grafički zavod, Titograd, 1976. 
da je u skladu s tim načelom vodio računa, koliko (...) je to bilo moguće, ${ }^{17} \mathrm{o}$ motivsko-tematskoj raznovrsnosti i zastupljenosti bajki raznih krajeva Crne Gore. Da bi taj izbor sačinio, pregledao je svu crnogorsku i drugu periodiku, od pojave Njegoševe Grlice do prvih decenija XX vijeka (Prosvjeta, Luča, Nova Zeta, Književni list) te veliki broj zbirki i drugih publikacija u kojima je objavljivana bajka (koju su zapisivali: Vuk Vrčević, Novica Šaulić, Ilija Zlatičanin, Luka Jovović, Jošo Ivanišević, Đuro Špadijer, Đoko Dragović, Stevan Dučić, Risto Popović, Miraš Đukić, Simo Mijović i drugi). U knjigu je uvrstio 57 bajki.

Pogledajmo najprije iz kojih je filozofskih teza i teorijskih premisa Radojević crpio snagu za formiranje svoga osnovnog načela za odabir bajki. U svome radu on je pošao od Marksove teze o mitovima kao prauzoru umjetnosti i od Hegelova stanovišta da je umjetničko posmatranje poniklo iz čuđenja. Otud se kao nužni nametnuo stav o bajkama (pa i crnogorskim) kao formama u kojima je izražen klasni karakter umjetnosti te koje istorično pružaju sliku klasnih društvenih odnosa i nepravdi koje iz njih slijede. ${ }^{18}$ Slikanje tih odnosa, koji korijen imaju u feudalnom društvu (što počiva na privatnoj svojini), dovodi do formiranja razlika među karakterima likova (predstavnicima klasa), ali i do projektovanja određenih situacija u koje junaci upadaju i zahvaljujući kojima prelaze granice svjetova (klasa). Te karakteristike bajke Radojević posmatra kao opšte karakteristike forme zastupljene u svim nacionalnim književnostima, ali on jasno podvlači da i crnogorska bajka, kao i bajke drugih nacionalnih književnosti, ima svoju posebnost, jer ako je motiv ili siže možda i preuzet iz neke druge usmene književnosti, bajka opet ima specifičan umjetnički jezik duhovne nadgradnje naroda u kojem je nastala, koji se - pored ostalog - izražava i u drukčijim razrješenjima pojedinih tema i različitim tokovima sižea. U stvari, ovaj se problem javlja u dva vida: postojanje takozvanih varijanti u sklopu crnogorske usmene književnosti, i neke sličnosti sa bajkama drugih naroda. U oba slučaja bi bilo veoma teško i nesigurno etiološki utvrđivati primat nastanka 'prototipa' $i$ određivati red ponavljanja 'varijanti'. ${ }^{19}$

Evo što je Radojević primijetio i definisao kao specifičnost crnogorske bajke. Najprije, on je iznio stav da su na crnogorsku bajku najviše uticali antički grčki mitovi (preko antičkih grčkih kolonija koje su bile nastanjene na crnogorskome tlu). Zatim, u crnogorskim bajkama istovjetan je odnos prema „gornjem“ i „donjem svijetu“. U njima su, takođe, dominantni motivi izbavljenja i spašavanja od domaćega zla (lakomstvo, zavist zle žene, zle maćehe

\footnotetext{
Ibid, str. 394.

18 Ibid, str. 10.

19 Ibid, 13.
} 
i sl.). Crnogorska bajka usmjerena je i na slikanje likova i predmeta iz života naroda a ne iz života viših slojeva (što je posljedica društvenoga uređenja Crne Gore kroz vjekove). Radojević navodi i to da je jedna od specifičnosti crnogorske bajke razvijeni scenski postupak, tj. uvođenje scene. I na koncu, u crnogorskim bajkama nerijetko se putem naratorskih komentara glorifikuju junaštvo i moral likova. Ovom spisku osobenosti uvijek $i$ isključivo fantastične, čudesne priče, ${ }^{20}$ valja dodati i jednu osobenost o kojoj je slovio Novak Kilibarda: Kod junaka u bajkama, koji raspolažu natprirodnom snagom, nekih puta je vidljiva izrazita humoristička tendencija koja može da glavnog junaka pretvori u komičnu osobu. ${ }^{21}$

Kad je konstatovao i pobrojao specifičnosti crnogorske bajke, Radojević je pristupio selekciji reprezentativnih bajki i njihovu grupisanju, i to na sljedeći način. On je pošao od stava da struktura bajke, njena sadržina i forma, pruža otpor motivskoj (i svakoj drugoj - ako bi imala svrhe) klasifikaciji. ${ }^{22}$ Iznoseći teze i nedoumice Vladimira Propa, koji se opredjeljuje za klasifikaciju 'sa stanovišta strukture', $i$ to prema funkciji junaka, Radojević navodi da je i ovaj teoretičar uviđao da taj princip ne odgovara na sva žanrovska pitanja. Zato je, razmatrajući mogućnost klasifikacije crnogorskih bajki, Radojević uspostavio nekoliko idejno-motivskih cjelina, uslovno uzetih, prema idejno-estetskim i etičko-socijalnim sadržajima koji poenti bajke daju osnovi motivski pečat. Gledajući na problem motiva u bajci kategorijalno (a tako bi valjalo gledati), morali bismo prihvatiti činjenicu da je i bajka stvarana po zakonima poetike, da su i u njoj umjetnički izražene moralne i socijalne ideje, ovaploćeni empirijsko-filozofski pogledi. (...) Dakle, gledajući na bajku kao na svaki drugi literarni čin (i pisani, razumije se), bez obzira na ove njene specifičiosti $u$ etiologiji $i$ morfologiji, u strukturi i u sredstvima umjetničkog izraza, smatram da ona - kad je stvarno to - u sebi nosi osnovnu ideju koja se umjetnički ovaploćuje kroz neki osnovni motiv. Zato sam i nastojao da rasporedom bajki u antologiji bar malo istaknem nekoliko motivskih cjelina, šire uzetih, bez određivanja ikakvih granica među njima. Ukoliko bi sam čitalac zapazio prelijevanje idejno-motivskih tokova u knjizi, onda bi to značilo da je od takvog pastupka bilo makar neke koristi. ${ }^{23}$

\footnotetext{
20 Na ovaj način Maša Bošković-Stulli objašnjava termin bajka (Maja Bošković-Stulli, „O terminologiji hrvatskosrpske narodne pripovijetke“, u: Treći kongres folklorista Jugoslavije (zbornik radova), Cetinje, 1958).

21 Novak Kilibarda, Istorija crnogorske književnosti I: usmena književnost, Institut za crnogorski jezik i književnost, Podgorica, 2012, str. 199.

22 Vatra samotvora, str. 395.

23 Ibid, str. 396-397.
} 
To su uglavnom i razlozi zbog kojih se u antologiji Vatra samotvora rame uz rame nalaze bajke neujednačene estetske vrijednosti, odnosno više i manje umjetnički uspjele bajke. ${ }^{24}$ Od svega što je Radojević naveo kao argumentaciju za razvrstavanje crnogorske usmene bajke nama se čini najznačajnijom zapravo ona pomalo uzgredna Radojevićeva konstatacija da je i bajka stvarana po zakonima poetike. Samo ostaje da se vidi je li to poetika usmene književnosti u cjelini posmatrana, ili poetika individue, koja je nosilac i afirmator moralnih i socijalnih ideja. Čini se, na osnovu sprovedenoga grupisanja bajki prema sličnim motivima (i njihovim prelivanjima), da je Radojević na pola puta između individualnoga poetičkog i poetike kolektiva, ali da ipak krči put onome načelu da se sistematizacija bajke ne može precizno izvoditi iz fabule (na osnovu Propovih funkcija junaka, ili aktanata iz modela Alžirdasa Žilijena Grejmasa), već iz komunikacije, odnosno pripovjedačke konkretizacije. Kazivači su, kao što su pokazala terenska istraživanja u zonama gdje se bajke još i danas živo pričaju (npr. Mađarska), u svom dnevnom radu iznimno osjetljivi na izvedbene okolnosti (...). Naslov jednoga novog zbornika (Görög-Karady 1990) koji ističe u prvi plan varijabilnost usmene književnosti - D'un conte... à l'autre. (Od jedne do druge priče) - upozorava na donedavna zaboravljenu činjenicu da nijedna bajka zapravo nema jednu, konačnu, valjanu inačicu te da u skladu s Lyotardovim analizama narativne pragmatike, u svakome okružju pričanja mora nanovo distribuirati prava na statuse kazivača, junaka i slušatelja. ${ }^{25}$

Ovoj tezi idu u prilog terenska iskustva Maje Bošković-Stulli, koja je među crnogorskim iseljeničkim familijama u hrvatskome selu Peroj zabilježila crnogorsku varijantu usmene bajke koju je kazivač u izvornoj varijanti čuo na italijanskome jeziku.

Svaka buduća sistematizacija crnogorske usmene bajke zato mora poći od pripovjedačke konkretizacije, mora pri odabiru najuspjelijih primjeraka te forme usmene proze kao jedan od ključnih parametara obuhvatiti i identitet kazivača ili zapisivača iste, od čijih narativnih sklonosti i pripovjedačkih bravura nesumnjivo zavisi i njen umjetnički kvalitet. Ośećao je to i Radojević. Zato je, kao i u slučaju priređivanja legendi, pročišćavao bajke od kasnijih redaktorskih i uredničkih natruha i činio napor da intervencijama u sferi jezika i stila bajkama vrati prvotno obličje, tj. da ih štampa u onoj jezičkoj i stilskoj formi kakvom su se bajke ukazale prvim zapisivačima.

24 Primjer su bajke Zlatokosići i I zlo se može okrenuti na dobro, sa sličnim motivima, ali različitih estetskih vrijednosti.

25 Vladimir Biti, Pojmovnik suvremene književne i kulturne teorije, Matica hrvatska, Zageb, 2000, str. 31. 


\section{O basnama}

Birajući proze za antologiju crnogorske basne, ${ }^{26}$ Radoje Radojević je argumentima pojačao raniju tvrdnju o grčkim kolonijama na prostorima Crne Gore i ostacima antičke grčke rasprostrtim po kolektivnome crnogorskom nasljeđu. O tome saznajemo iz predgovora knjige, čiji je autor Danilo Radojević (koji je nastavio bratovljev posao u trenutku kad je Radoje Radojević tragično preminuo). Danilo Radojević je prelistao bratoljeve rukopise i pronašao zapis iz koga se jasno vidi da je Radoje Radojević izveo zaključak o nesumnjivome kulturološkom uticaju antičke Grčke na Crnu Goru. Glavni afirmator i eksponent toga uticaja je, prema Radoju Radojeviću, razvijena crnogorska usmena basna, jedna od ključnih osobenosti crnogorske usmene književnosti, po kojoj se naša književnost razlikovala od drugih književnosti naroda Jugoslavije, i po kojoj je slična albanskoj narodnoj književnosti.

Treba, međutim, viđeti šta je Radojević podrazumijevao pod pojmom basna, budući da u odgovaranju na to pitanje ni savremeni tumači usmene književnosti i teoretičari književnosti nijesu saglasni. Prema teorijskim tezama koje su bile aktuelne u vrijeme kad je Radojević pripremao antologiju crnogorske basne, riječ je o usmenoj proznoj formi koja pretpostavlja animistički i animalistički pogled na svijet te u kojoj dolazi do postovjećivanja čovjeka s životinjom. ${ }^{27}$ Tako i Novak Kilibarda za crnogorsku basnu tvrdi da ima dva smjera. U jednim basnama preovlađuje realističko-humoristički pristup radnji, a u drugim, u kojima su takođe junaci životinje kao nosioci ljudskih osobina, akteri radnje su dati u suženoj, alegorijskoj funkciji. Kako izgleda, basne se već od davnih vremena nijesu bitnije mijenjale. Ostajale su jednolike po formi, a krug tema koje određuju je uzak i očevidno je da se on od davnina nije mijenjao. Poneki istraživači usmene proze razlikuju „, basnu“ od „priče o životinjama" po tome što se u stvaranju basne pošlo od priče o životinjama, ali je naglašavanjem alegorijskoga smisla istaknuta uočljiva izmjena. Ističe se $i$ to da je basna po pravilu kraća od priče o životinjama koja sadrži više epizoda nego basna. Međutim, kad se uzme u obzir prihvaćeno mišljenje da je ta razlika izvršena u pisanoj književnosti a ne u usmenom predanju, treba za sve priče u kojima su akteri radnje životinje nazvati jednim imenom - basne. ${ }^{28}$

Sakupljajući građu za antologiju, Radoje Radojević je odabrao 95 basni iz ostavštine Vuka Vrčevića, Novice Šaulića, P. A. Rovinskog (koje je sam preveo s ruskoga jezika), Stevana Dučića, Ilije Zlatičanina, Rista Popovića,

26 Kad je sve zborilo: crnogorske narodne basne (izbor Radoje Radojević), NIO Pobjeda, Titograd, 1979.

27 Rječnik književnih termina, str. 70.

28 Kad je sve zborilo, str. 198. 
Steva Zimonjića, Andrije Jovićevića, Vuka Karadžića i Sima Terića. Iako ga je smrt spriječila da kompletira studiju o odabranim basnama, na osnovu sadržine antologije i njegovih zapisa i ispisa kojima se služio njegov brat Danilo može se zaključiti da je i Radoje Radojević basnama smatrao sve priče u kojima su akteri radnje životinje. Pritom se mora naglasiti da je pravio razliku između basni i fantastičnih priča, odnosno bajki u kojima se javljaju životinje koje govore. Diferencijacija tih formi proizvod je analize strukture. Pri izboru basana Radoje Radojević se držao estetskog kriterijuma. Tragao je za onim basnama, u kojima je anonimni stvaralac uspio da ostvari najduhovitiju situaciju, snažnu sliku i najprirodniji dijalog. ${ }^{29}$ Otuda, kao posljedica brižljivih sondaža, i stav o autohtonosti crnogorske usmene basne kao plodu karakterističnih nijansiranja u govoru i jeziku kod personificiranja ljudskih osobina $i$ društvenih odnosa..$^{30}$ Osim toga, sve eventualne sličnosti crnogorske usmene basne s basnama drugih nacija, kao i obilje internacionalnih motiva, Radojević je posmatrao kao uticaje koji su daleko manji nego što su neki autori formalistički tvrdili. U crnogorskim basnama, tvrdio je Radojević, odražen je način mišljenja i sistem moralnih vrijednosti Crnogoraca, saopšten pripovjedačkom tehnikom sveukupne crnogorske usmene proze. ${ }^{31}$

U posljednjem stavu Radoja Radojevića krije se ključ autohtonosti ukupnoga crnogorskog usmenoga nasljeđa. Dakle, forme crnogorske usmene proze razlikuju se od formi i obličja usmenih proza drugih nacionalnih književnosti i po jeziku, ali, bitnije, po tehnikama pripovijedanja.

Kad je konkretno riječ o crnogorskoj basni, autohtonost se, prema Radojeviću, ogleda u različitosti sadržaja, poenti koja je suprotna od očekivane i uobičajene, u drugačijim razrješenjima narativnih situacija od onih koja se srijeću u sličnim basnama, i u, na koncu, izostanku moralne pouke na epiloškoj granici teksta. Radojević je pokazao i to da je onim basnama koje su sadržale moralnu pouku (a štampane su u glasilima ili monografskim publikacijama) naravoučenije naknadno dodato, jer izvorna varijanta crnogorske basne pouku krije u unutrašnjosti svoga organizma. Način pripovijedanja u crnogorskoj basni, bolje reći, je takav da je ukupan pripovjedački instrumentarij orijentisan prema pouci što se upravo zato eksplicitno ne izriče.

\footnotetext{
29 Ibid, str. 231.

$30 \quad$ Ibid, str. 47.

31 Ibid.
} 


\section{O pričama}

Ne može se kazati da je prilikom sačinjavanja izbora crnogorske usmene priče Potopno vrijeme $e^{32}$ napušten koncept klasifikacije usmene proze prema temama i motivima. I u toj se knjizi, kao i u prethodna tri izbora (antologijama legendi, bajki i basni) očituje nekoherentnost klasifikacijskoga koncepta koja je posljedica teorijskih neusaglašenosti vremena u kome su izbori sačinjeni. Sabirajući usmene humorističke, moralističke, istorijske priče (odnosno predanja), zabilježene u periodu od sredine XIX do prvih decenija XX vijeka - a objavljene u knjigama Vuka Karadžića, Vuka Vrčevića, P. A. Rovinskog, Novice Šaulića, Stevana Dučića i u glasilima Luča, Bosanska vila, Prosvjeta, Glas Crnogorca, Nova Zeta i Zbornik za narodni život i običaje Južnih Slove$n a-$ i odabirajući 77 najuspjelijih za knjigu, Danilo Radojevićs ${ }^{33}$ ih je, nastavljajući rad Radoja Radojevića, takođe razvrstao prema sličnosti zastupljenih i obrađenih motiva. Tako je sadržaj knjige Potopno vrijeme podijeljen u 11 tematsko-motivskih cjelina.

To, međutim, ne znači da se Radojević apsolutno oglušio o signale koji ukazuju na osobenu strukturu. O samim razlikama priče u odnosu na druge usmene prozne vrste on je proslovio u predgovoru knjige, naglašavajući da je put prikupljanja i odabira usmenih priča unekoliko komplikovaniji od puteva obrade bajki, basni i legendi, koje su se lakše održavale u sjećanjima. Osim toga, Radojević je akcentovao i crnogorski kult oratorstva, zahvaljujući kome je sačuvan izvjestan broj onih priča koje svjedoče o razvitku te forme usmene književnosti. U njima ima, primjećuje Radojević, elemenata drugih proznih vrsta, ali se po svojim motivima $i$ sredstvima umjetničkoga izraza ${ }^{34}$ od njih odvajaju. Narodni stvaralac obrađivao je neobične situacije, koje imaju moralnu snagu, dramatičnost ili neku osobitu boju, što fabulu čuva od zaborava. (...) U jednom broju naših narodnih priča za fabulu su uzimani izvjesni psihološki trenuci, u kojima se plastično mogao pokazati detalj iz svakodnevnog života. ${ }^{35}$

Ipak, analiziranje motiva u pojedinim usmenim pričama nije povelo ka decidnom odgovoru na pitanja o posebnosti crnogorske usmene priče. Jedan od razloga za to iznio je i Radojević na samom početku studije (predgovora), primijetivši da je veliki broj motiva pozajmljen iz drugih nacionalnih književ-

32 Potopno vrijeme: crnogorske narodne priče (izbor Radoje Radojević i Danilo Radojević), NIO Pobjeda, Titograd 1982.

33 Radoje Radojević je započeo a Danilo Radojević nastavio sakupljanje i odabir najuspjelijih crnogorskih usmenih pripovjedaka.

34 Ibid, str. 11.

35 Ibid, str. 27-28. 
nosti. O sredstvima umjetničkoga izraza, odnosno o načinima pripovijedanja, malo je rečeno. Međutim, bitna novina koju je Danilo Radojević donio, a koja se tiče našega nastojanja da sagledamo mogućnosti novoga čitanja cjelokupne crnogorske usmene proze, sadržana je u prilogu Registar zapisivača narodnih priča. Na kraju knjige Radojević je dao informacije o tome ko je koju priču zapisao. Smatrao je da je to vrijedno za izučavanje razlika u umjetničkom domašaju. ${ }^{36}$ Mi taj postupak posmatramo kao kamen temeljac procesa novoga čitanja crnogorske usmene proze.

\section{VII. $\mathrm{O}$ anegdotama}

Sakupljačkim i priređivačkim aktivnostima braće Radojević prethodio je rad Radosava Medenice, koji je uočio posebnosti najfrekventnijih usmenih proznih formi u crnogorskome kolektivu. U predgovoru antologije crnogorskih anegdota ${ }^{37}$ Medenica je pretresao sociološku i književnoteorijsku argumentaciju koja govori o značaju usmene književnosti. Najprije je, posmatrajući anegdotu, uspio da izvede teze o toj formi usmene književnosti kao smjerokazu za pronalazak odgovora na pitanja o psihologiji kolektiva i mentalitetu Crnogoraca. Potom je naglasio da je za lakši hod prosječnoga čitaoca kroz kompleks izvjesnih osobenosti karaktera i mentaliteta Crnogoraca neophodno poznavanje podataka o socijalnim i političkim uslovima njihova života, tj. podataka o životnoj filozofiji i narodnim idealima. Medenica je pritom imao na umu udaljenost svoga vremena od onih epoha čiji život anegdote opisuju. No, time je ipak pokazao da je krajem šezdesetih prilično bio uticajan pozitivistički tretman umjetničke literature, te da se nijesu bile stekle povoljne okolnosti za posmatranje jedne usmene prozne forme kao narativa koji jeste svijet za sebe.

I Medenica je, međutim, posvetio pažnju crnogorskome kultu oratorstva i primijetio kako su u pričanju Crnogorci veoma vješti, odnosno da njihov razgovor teče polako, tečno, da pričalac smišlja i bira izraze, ubacujući ponekad i uzrečice, očigledno dok nađe pogodan izraz da odjene svoju misao. ${ }^{38} \mathrm{On}$ je zbog toga smatrao da tako zbijena, zgusnuta, kratka priča, odnosno anegdota više liči na dokument, no ako se u njenom profilu jasno i plastično osjenči jedna ličnost i njen izraziti karakter, onda je sigurno po srijedi anegdota kao izvjestan umjetnički doživljaj, iako je ova vrsta narodnog stvaralaštva svakako primitivan književni rod. ${ }^{39} \mathrm{~S}$ ovim posljednjim Medeničinim stavom još bi

\footnotetext{
Ibid, str. 271-272.

37 Crnogorske anegdote: antologija, priredio Radosav Medenica, Grafički zavod, Titograd, 1967.

38 Ibid, str. 35.

39 Ibid, str. 47.
} 
se dalo polemisati, jer anegdota apsolutno nije ni književni rod niti primitivan oblik, ali polemika s tim stavom je suvišna budući da ga je i sam Medenica opovrgao dalje u tekstu. Evo kako on dalje piše: kratka priča, odnosno anegdota, ne zaodijeva, dakle, nikakav događaj kao takav, ona ga samo projicira u što kraćoj ali što oštrijoj i reljefnijoj slici; zahvata malo, ali duboko; često jednom crtom, jednom iskrom osvjetljava čovjeka i baca svjetlo na njegov ambijent. ${ }^{40}$ Iz ovih redova upravo se da naslutiti moć jedne usmene prozne forme i njena sposobnost da u haiku maniru s malo reljefnih, znakovitih riječi kaže mnogo.

Medenica navodi da anegdota nije imala tu sreću da bude proučavana onda kad je i krenulo interesovanje za narodno stvaralaštvo Južnih Slovena, te da je pravu ekspanziju interesovanja ta usmena prozna forma doživjela tek u prvoj polovini XX vijeka. Do momenta objavljivanja antologije Medenica je u monografskim i serijskim publikacijama crnogorske bibliografije detektovao prisustvo od 5.000 do 6.000 zabilježenih anegdota, od kojih je za antologiju probrao oko 350. Obavljajući taj veoma složeni posao, Medenica je zaključio da su anegdote skinule izvjesnu maglovitu romantičarsku koprenu sa Crne Gore i Crnogoraca, da su romantične gudure ispunile realnim životom i riješile ozbiljni nesporazum o takozvanom apsolutizmu i stezi vladavine posljednja tri Petrovića dinasta. Ovim je Medenica ukazao i na suštinu anegdote kao $z a$ nimljive priče o nekoj istorijskoj ličnosti ${ }^{41}$ kratke priče neobičnoga doživlja$j a, \mathrm{~s}$ duhovitom poentom i podvučenim osnovnim odlikama junakovoga lika. Međutim, govoreći o odrazu stvarnosti u jednoj usmenoj proznoj formi, Medenica je ukazao i na dvije vrlo bitne činjenice koje su se ticale razvitka forme anegdote - na veliku popularnost anegdote između dva svjetska rata i na čin falsifikovanja, podmetanja književnih autorskih uradaka kao usmenih anegdota. Medenica o tome piše vrlo opsežno na nekolike stranice svoga predgovora. To su redovi puni ogorčenosti prema međuratnome folklorogu Mićunu Pavićeviću, koji je, nakon uspjeha u objavljivanju prve tri knjige crnogorskih anegdota, pristupio hiperproduciranju oponašajućih formi putem kojih je pokušavao da ostvari i neke skrivene političke ciljeve. Tu vrstu intencionalnoga ośetio je svojevremeno i Pero Slijepčević. Čim naiđu na Petroviće, zapisao je Slijepčević, i naročito na kralja Nikolu, osetite u njima onu 'omladinsku' antipatiju. To je vrlo deplasirano u jednom materijalu kojega se tiče samo čista čovečnost iznad političke mode. Skoro svuda nadmudren, a najčešće sitan, kralj Nikola bi po ovim zbirkama izgledao manji od prosečnog Crnogorca.

40 Ibid, str. 48 .

41 Rečnik književnih termina, str. 25. 
On to sigurno nije bio. ${ }^{42}$ Medenica je u ocjeni takvih uradaka bio precizniji a prema Pavićeviću oštriji. Primijećeno je, naime, da u knjigama Pavićevića, pored znatnog dijela veoma uspjelih anegdota $i$ priča u pogledu sažetosti, reljefnosti lika i istorijske izvornosti, postoji i dosta veliki broj rđavih, koje ne kazuju gotovo ništa, a naročito dobar dio onih koje pokazuju očiglednu tendenciju $i$ nose na sebi pečat hotimičnih prerađivanja, dotjerivanja, čak $i$ falsifikovanja onoga što te priče i anegdote iznose. ${ }^{43}$

Dakle, i ovaj slučaj je pokazao da su forme usmene književnosti ne samo indikator postojanja nacije, već i veoma snažno sredstvo za ostvarenje društveno-političkih ciljeva. Upravo zato su i Slijepčević i Medenica ukazali na proces obespredmećivanja crnogorske anegdote i zloupotrebe te usmene forme od strane „napredne jugoslovenske omladine“, koja je između dva svjetska rata pokušala da ukine i narodno pamćenje, odnosno śećanje na slavnu prošlost posrnule crnogorske države. Kolika je, međutim, bila moć tih falsifikata svjedoči i Medeničina antologija. Ni Medenica, naime, antologiju nije potpuno pročistio od sličnih uradaka. U pojedinim anegdotama koje su objavljene u antologiji upravo je ośetna ona intencija da se Petrovići silu na sramotu prikažu kao nedostojni vladarskih titula. Osim toga, prve stranice antologije donose i dugačke proze, koje dakako ne spadaju u anegdote, već im je mjesto u monografskim publikacijama koje objedinjavaju humorističke pripovijetke.

Pogledajmo onda što je to rukovodilo Medenicu da na ovaj način klasifikuje anegdote. Prilikom obrade građe Medenica se rukovodio dijahronijskim principom - da pruži što potpuniju sliku kroz jedan dosta dug istorijski period, da bi se stvari dale sagledati u najkrupnijim koracima izvjesnoga istorijskog toka, od najstarijeg doba ka savremenom. Potom, Medenica se trudio da odabere one anegdote koje ukazuju na crnogorski mentalitet i da kroz anegdotu budu zastupljeni svi krajevi Crne Gore. I na koncu, svu je građu rasporedio prema ključnim temama koje anegdote obrađuju, dok je u samim tekstovima intervenisao sažimanjem razvučenih segmenata strukture, trijebljenjim knjiških izraza, sređivanjem sintakse rečenice, stilizovanjem iskaza...

Medenica je u pogovoru antologije, navodeći stepen i količinu korekcija nad tekstovima, pobrojao imena zapisivača i priređivača zbirki anegdota (Ljubiša, Matavulj, Vrčević, Marko Miljanov, Pavićević, Stojan Cerović, Tunguz-Perović, J. Ivanišević, Lj. Nenadović, Šobajić, T. Đukić, M. Vujačić, D. Boričić, M. Vukićević, I. Zlatičanin, B. Marjanović i I. Peličić). Kad se tome doda podatak da je u predgovoru oštro napao Pavićevića za falsifiko-

42 Pero Slijepčević, „Anegdota kao umetničko delo“, u: Narodna književnost, Nolit, Beograd, 1972, str. 533.

43 Crnogorske anegdote, str. 58. 
vanje, onda je jasno da je pružio nove argumente onoj tezi o individualnome poetičkom, na kojoj počiva naš pokušaj da se pokrene proces novoga čitanja crnogorske usmene proze.

\section{O sitnim proznim vrstama}

Nepune dvije godine nakon pojavljivanja Medeničine antologije, titogradski Grafički zavod objavio je antologiju crnogorskih poslovica i izreka. ${ }^{44}$ Priređivač Niko Simov Martinović načinio je izbor iz ogromnoga korpusa crnogorskih poslovica, izreka, blagoslova, kletvi i zakletvi kako bi pokazao po kojim su nepisanim zakonima živjela crnogorska plemena. Ovim stavom Martinović je ukazao na etičke, odnosno ideološke dimenzije i status ovih kratkih proznih formi među crnogorskim plemenima. Sublimacija višemilenijumskoga iskustva i napregnut jezički potencijal rezultirali su pojavom proznih oblika koji su, osim nepisanih pravila po kojemu su se sistemi upravljali, predstavljali ujedno i definicije brojnih prirodnih pojava, pojava u društvu i tipova ljudskih karaktera.

To je i razlog da je Martinović sistematizovao ove sitne prozne vrste koristeći metod dva eminentna znalca Crne Gore, Valtazara Bogišića, jugoslovenskog naučnika, i Pavla Apolonoviča Rovinskog, ruskog naučnika, ${ }^{45}$ razvrstao po problemima na relaciji čovjek - zajednica - država, dobivši veliki broj motivsko-tematskih cjelina u koje je svrstavao pojedine prozne vrste. Mana ovoga modela je u tome što su pri takvoj klasifikaciji potpuno zanemareni strukturalni obrasci tih usmenih proznih vrsta, zbog čega je izostalo razlikovanje elementarnih, teorijski uspostavljenih kategorija. Naime, iako je u podnaslovu knjige koristio pojmove poslovica i izreka, sadržaj antologije raspoređen je prema pojedinim tematskim i motivskim krugovima, u okviru kojih se javljaju poslovice, blagoslovi, kletve i zakletve. Izreke su izostale, bar u podnaslovima motivsko-tematskih cjelina, pa je ostalo nejasno da li je Martinović pojmove poslovica i izreka tretirao kao sinonime, odnosno kao izraze koje označavaju istu vrstu usmene proze, i ako jeste, zašto su se oba pojma našla u podnaslovu antologije. Moguće da ih i nije tako tretirao, ali ono što je evidentno je da su se u odjeljcima namijenjenim poslovicama našle i brojne izreke. A razlika među strukturama poslovica i izreka je više nego očigledna: prve su uglavnom konstruktivno složenije, oslanjaju se na pozicije dva ili više sintagmema, sačinjene su od prostoproširenih ili složenih rečenica, tj. od međuzavisnih segmenata koji funkcionišu po principu paralelizma, katkad s

44 Evanđelje po narodu: antologija crnogorskih poslovica i izreka (priredio Niko $S$. Martinović), Grafički zavod, Titograd, str. 1969.

45 Ibid, str. 18. 
kondicionalnim, uslovnim ustrojstvom (ako, kad...) i kao takve predstavljaju definicije problema i pojava u društvu i među ljudima; druge su, pak jednostavniji oblici, najčešće su to dvočlani ili tročlani sintagmemi, i kao takve su konkretni opisi stanja definisanih poslovicama, one su svojevrsni pečati na pojedinačne karaktere ili okolnosti, kojima se i okolnosti i karakteri podvode pod jednu od poslovičnih vrijednosti a njihova je uloga supstitucijalna, nerijetko i eufemizacijska - u krajnjem, izreka je svedena poslovica, i potvrda istine koja je obuhvaćena iskazom poslovice.

Utisak je ipak da Martinović nije razlikovao poslovice od izreka, kao i da nije bio posebno zaokupljen njihovom formom koliko sadržajem, kontekstualnim refleksima, znakovima i simbolima koji iz njih isijavaju. Njegovo angažovanje izostalo je i u pogledu usaglašavanja jezika i stila pojedinačnih poslovica i izreka, pa čak i onih koje bi se našle na istim stranicama knjige. Otud se u istome iskazu javljaju leksemi s grafemima koji su posljedica jotovanja i leksemi s glasovnim sklopovima koji nijesu podvrgnuti jotovanju. $\mathrm{Na}$ taj način objavljene ove prozne forme nijesu zadovoljile ni u to vrijeme važeći srpskohrvatski jezički standard.

Moramo da zaključimo da sve navedeno jeste važna argumentacija za pokretanje procesa novoga čitanja crnogorskih sitnih usmenih proznih formi. Nije da nam od Martinovića u tome smislu nije bilo pomoći. Martinović je precizno popisao izvore kojima se služio, a tu spadaju: Hiljferdingov zbornik iz 1868, te knjige Vuka Karadžića, Valtazara Bogišića, P. A. Rovinskoga, S.M. Ljubiše i Joksima Radovića. Stalo nam je, pisao je Martinović, da ovom knjigom, podstreknemo istoričare književnosti, filologe i istoričare prava da daljim proučavanjima tog problema bolje osvijetle našu prošlost $i$ iz nje izdvoje, kao pozitivnu, težnju čovjeka da se oslobodi animalizma i klasnih ograničenosti. ${ }^{46}$ Taj pošteni odnos Martinovića prema prošlosti i budućnosti, rukovođen samospoznajom, upravo i obavezuje na preciznija osvjetljavanja i usmenih proznih formi i procesa koji se odvijaju pod krovom nacije koja ih je odnjegovala.

\section{Zaključak}

Kao što smo viđeli, prve ozbiljnije sistematizacije i antologijski pristupi pojedinim vrstama crnogorske usmene proze rezultirali su uspostavom, negđe manje negđe više održive nomenklature. Braća Radojević, Medenica i Martinović, sarađujući s rukovodiocima Grafičkoga zavoda i NIO Pobjeda, koje su izvodile projekat neponovljive vrijednosti - biblioteku „Luča“, odnosno

46 Ibid, str. 25. 
ediciju posvećenju istoriji crnogorske književnosti - uspjeli su da od zaborava otrgnu ono čemu je prijetio definitivni nestanak. Doprinosi tih znalaca, s aspekta savremenih književnih teorija i nijesu mogli biti od epohalnoga značaja, ali njihovome radu pripadaju velike zasluge koje se jasno vide kad se taj rad posmatra sa socioloških, politikoloških, folklorističkih, književnoistorijskih i lingvističkih tačaka gledišta. Ova četvorica naučnika sačuvali su od nestajanja legende, bajke, basne, priče, poslovice, izreke, kletve, zakletve i blagoslove. Sačuvali su duh vremena u kome su te usmene prozne vrste nastajale, sačuvali su argumente koji idu u prilog tezi o bogatstvu i razuđenosti umjetničkih formi u crnogorskoj usmenoj književnosti - i najbitnije - sačuvali su crnogorski jezik. A nije nepoznanica novijoj crnogorskoj istoriografiji da su neki od njih bili izloženi i oštrim osudama zbog saopštavanja stručnih i naučnih stavova o postojanju falsifikata kojima se udaralo po crnogorskoj prošlosti (poput falsifikata Mićuna Pavićevića ili Erdeljanovićeva ubacivanja legendi o srpskome princu Savi Nemanjiću u zbirku narodnih umotvorina jednoga crnogorskog plemena), kao i zbog saopštavanja otvorenih i nedvosmislenih stavova o postojanju crnogorske nacije i crnogorskoga jezika.

Budući da je i formalno utemeljen crnogorski jezički standard i da na raspolaganju imamo precizni teorijski instrumentarij za analizu narativa, smatramo da su se stekli svi neophodni uslovi da se pristupi novome čitanju crnogorske usmene proze.

\section{Literatura}

- Biti, Vladimir. Pojmovnik suvremene književne i kulturne teorije. Zagreb: Matica hrvatska. 2000.

- Bošković-Stulli, Maja. „O terminologiji hrvatskosrpske narodne pripovijetke“, u: Treći kongres folklorista Jugoslavije (zbornik radova). Cetinje, 1958.

- Bošković-Stulli, Maja. „Regionalne razlike među narodnim pripovijetkama“, u: Narodna umjetnost (Zagreb), 7/1970, 1.

- Crnogorske anegdote: antologija (priredio Radosav Medenica). Titograd: Grafički zavod. 1967.

- Evanđelje po narodu: antologija crnogorskih poslovica i izreka (priredio Niko S. Martinović). Titograd: Grafički zavod. 1969.

- Kad je sve zborilo: crnogorske narodne basne (izbor Radoje Radojević). Titograd: NIO Pobjeda. 1979.

- Karadžić, Vuk. Etnografski spisi o Crnoj Gori. Beograd: Prosveta - Nolit. 1985. 
- Kilibarda, Novak. „O današnjim pristupima Vuku Karadžiću“, u: Vuk Karadžić i Crnogorci (zbornik radova). Cetinje: Institut za crnogorski jezik i jezikoslovlje. 2005.

- Kilibarda, Novak. Istorija crnogorske književnosti I: usmena književnost. Podgorica: Institut za crnogorski jezik i književnost. 2012.

- Nikčević, Vojislav. „Vukov model standardnog jezika u teoriji i praksi“, u: Vuk Karadžić i Crnogorci (zbornik radova). Cetinje: Institut za crnogorski jezik i jezikoslovlje. 2005.

- Nikčević, Vojislav. Crnogorski jezik II. Cetinje: Matica crnogorska. 1997.

- Podrugović, Tešan. Pjesme. Podgorica: Institut za crnogorski jezik i književnost. 2012.

- Potopno vrijeme: crnogorske narodne priče (izbor Radoje Radojević i Danilo Radojević). Titograd: NIO Pobjeda. 1982.

- Rečnik književnih termina. Beograd: Nolit. 1986.

- Slijepčević, Pero. „Anegdota kao umetničko delo“, u: Narodna književnost. Beograd: Nolit. 1972.

- Starac Milija. Pjesme. Podgorica: Institut za crnogorski jezik i književnost. 2012.

- Vatra samotvora: antologija crnogorskih narodnih bajki (priredio Radoje Radojević). Titograd: Grafički zavod. 1976.

- Vilina gora: antologija crnogorskih legendi (priredio Radoje Radojević). Titograd: Grafički zavod. 1971.

- Vukmanović, Dr Savo. „Predanja i legende oblasti Durmitora“, u: Rad XXII-og kongresa Saveza udruženja folklorista Jugoslavije na Žabljaku 1975. godine. Cetinje, 1985. 
Vladimir VOJINOVIĆ

\section{NEW READING OF MONTENEGRIN ORAL PROSE}

The author of this paper presents revaluation aspects of Montenegrin prose forms. Starting from the results of previous analyses of Montenegrin oral prose, performed by Radoje Radojević, Danilo Radojević, Radosav Medenica and Niko S. Martinović, the author stresses the importance of further study of the products of oral expression and their clarification in the spirit of contemporary theoretical viewpoint and modern literary and theoretical methods. The paper brings a thesis on the marginalization of the achievements of previous researchers in the field of affirmation and interpreting the forms of Montenegrin oral prose forms as a result of the process of obstructing the establishment of the Montenegrin national identity.

Key words: Montenegrin oral literacy, oral prose, genre, classification, anthology 



\section{Tijana RAKOČEVIĆ (Podgorica)}

UDK 821.163.4.09-6:17

Petrović Njegoš P. I

Pregledni rad

tijanarakocevic23@gmail.com

\section{POSLANICE PETRA I KAO ESTETSKI PROIZVOD}

U radu se kroz književno-etičke opservacije odabranih segmenata istražuju osobenosti jezičkoga izraza Petra I Petrovića, preispituju literarni potencijali Poslanica i otkrivaju estetske dimenzije datoga književoumjetničkog teksta u kontekstu epohe u koju se svrstava.

Ključne riječi: racionalizam, estetski proizvod, literarnost, metod red-po-red, crnogorska etika

Žalosno materijalno stanje najbolje se vidi po tom, što Vladika nema ni hartije, on kopije - a možda i pisma - piše na tuđim kuvertama, a često $i$ na poleđini pojedinih pisama! ${ }^{1}$ Braneći svoj narod svetošću svoje arhipastirske odore, usrdijem i bogougodnim preporukama čuvajući duhovno jezgro Crne Gore i plemensku svijest odviše samovoljnih i na saradnju nepristajućih Crnogoraca, prosvijećeni vladika stvara djela neprolazne, ali i dvostruke vrijednosti: na prvom mjestu istoriografske, za nas mnogo bitnije - književne. U tom se smislu Poslanice, kao kakva antologija međusobno korespondentnih tekstova, mogu često, čitalački naivno, posmatrati kao mikrostrukturne komponente romanesknoga svijeta: njih karakteriše tematska usaglašenost tipična za štivo toga tipa, likovi koje nam predstavljaju najčešće su istureni dio kopna koji je za nas cijeli kontinent, one ilustruju životni tragizam gorštaka osuđenih na borbu sa neprijateljem koji se nalazi unutar njih samih, i na kraju - one su udahnule život junaku koji zaboravlja da je Petar I i postaje fiktivna tvorevina sputana svojom funkcijom i etičkim načelima. Dakle, nužno je posmatrati $P o-$ slanice kao estetski, a samim tim i umjetnički proizvod s osobenim smisaonim poretkom, ali i neraskidivom vezom $\mathrm{s}$ istorodnim tekstovima.

Prosvjetiteljski nanosi, kao neka vrsta vezivnog tkiva u ovome književnom tkanju, najprije se očituju u moralnim, religijskim, filosofskim i političkim refleksijama samoga autora, koji u ovome slučaju na sebe preuzima ulogu aktivnoga sudionika u aktuelnim dešavanjima. Lava kulturnoga preporoda, po

1 Dušan Vuksan, Petar I Petrović Njegoš, Narodna knjiga, Cetinje, 1951, str. 333. 
ugledu na evropsku politiku pomirenja i ponovnog razbistravanja svijesti zamračene vjerskim pogromima, neizostavno se preliva na svaku od poslanica, pri čemu se ističe činjenica da su one igrale značajnu ulogu kada je trebalo osvijetliti umne puteve geomorfološki izolovanih i posve konzervativnih sagovornika. Zato u „Poslanici Drobnjacima“ nailazimo na izrazito napredne ideje: ... a ja ne bih rad ni Turčinu, koji je dobar i pošten čojek, nikakva zla koliko ni dobrome i poštenome Hrisćaninu, zašto znam što mi Bog zapovijeda. ${ }^{2}$ Petar I razlikuje dva tipa ličnosti, samim tim i dva nivoa svijesti koja su međusobno zavisna i u svakom se trenutku mogu pretvoriti u svoju suprotnost; ${ }^{3}$ protivurječje principa dobra i principa zla poima se kao arhitektonski sklad svega što postoji, samim tim nema mjesta za sredinu koja bi idealni dualizam mogla samo pokvariti: I teško onomu čelovjeku, koji govori, da je svjetlost tmina, a tmina da je svjetlost. ${ }^{4}$ Da je autor na strani razuma, logike i savršenoga uređenja (iako je religijska potka teksta determinisala način na koji će se, u retorskom maniru, uticati na recipijenta ${ }^{5}$ ), svjedoči i jedan, ne toliko detaljan, ali sasvim neobičan opis stanja apsolutne pravde, sloge i poslušanija, koji u nekim djelovima podśeća na strukturalističke modele idealnog sistema:

Ja želim da vazda naša braća iz našega naroda budu u našu zemlju sudci i da oni, koji budu na to mjesto iz dogovora obštega postavljeni, vladaju narodom i upravljaju po načinu razumno $i$ sveđer više slava, čest $i$ sloboda $i$ blagopolučije vaše obćeno $v$ mir $i$ slogu vašu srećno $i$ čestito raste, $i$ da ovo đeci vašoj nakon sebe ostavite, neka ona imena vaša u vijeki hvale i prevoznose i neka mogu radostnim glasom govoriti: (...) Vi ste ugasili meždusobni rat $i$ krvoprolice, vi ste ukrijepili slogu i jedinstvo među narodom $i$ vi ste nam dohranili i ostavili dražajšu voljnost $i$ slobodu, a mi ćemo predrago ime vaše u pameti i u srcima našim s najvećim blagodarenijem do groba nositi i sinovom našim ot roda u rod ostavljati, neka ime i slava vaša bude bezsmrtna! ${ }^{6}$

Vjera u opipljivo, empirijsko, provjerljivo odbacivanje fatuma kao sile koja upravlja čovječjim odlukama i nepokolebljivo povjerenje u isplativost hrišćanskoga života na srednjem stupnju zemaljske ljestvice čini zanimljiv konglomerat tradicionalizma i racionalističkih strujanja:

Ja bih želio, da mi kogođ kaže koju sreću, koje li blago može soldat steći, a osobito soldat crnogorski, koji ostavlja svoj dom, a mnozina i svoje

\footnotetext{
Petar I Petrović Njegoš, Poslanice, Obod, Cetinje, 1951, str. 83-84.

Crnogorska književnost u književnoj kritici III, Univerzitetska riječ, Nikšić, 1990, str. 26.

Poslanice, str. 198.

5 Vidi: Nela Savković-Vukčević, ,Retorika i stilistika u pismima i poslanicama crnogorskih vladika Danila, Save, Vasilija i Petra I Petrovića Njegoša“, Lingua Montenegrina, god. IV, sv. 2, br. 8, Institut za crnogorski jezik i književnost, Podgorica, 2011.

6 Poslanice, str. 40.
} 
žene i đecu i ne misli za vazda, nego za kratko vrijeme služiti. Ja se ne mogu domislit otkuda će ta sreća doći, nako se nadaju da će blago gotovo naći, samo da pođu i da ga prihvate. ${ }^{7}$ Osnovna programska načela epohe prosvjetiteljstva ogledaju se u demokratizaciji kulture i filosofskoj kritici stvarnosti ${ }^{8}$, a ti slojevi se najbolje mogu sagledati iz lingvostilističkoga aspekta. Jezički izraz kojim se autor služio Čedo Vuković karakteriše kao tvorevine klesane u strogo jednostavnim obrisima, bez kitnjaste glagoljivosti, bez nastojanja da se ljudska prostota zasjeni učenošću čovjeka koji poznaje nekoliko stranih jezika, koji ima dosta bogatu i raznovrsnu biblioteku, koji je obišao nešto svijeta... ${ }^{9}$ Filosofske, tačnije logičke premise kojima se služi Petar I imaju za cilj dezintegraciju mitomanskog modela bitisanja, on uvjerava Crmničane kao što slovesna mati uvjerava plašljivo dijete u nepostojanje zlih stvorenja, te se u ideološkom smislu nanovo vraća razumu kao jedinome istočniku božanske milosti:

Kako li može koja žena koga zaklati, kad ga ni su čim ne takne i kad mu ništa otrovno ne dade jesti ili popiti. Kako li ga iźesti može, kad mu tijelo javno u grob polaže cijelo. Vi govorite, da vještice po noći lete, a kako mogu lećeti, kad njihovo tijelo u odar leži. Vi odgovarate da njihov duh leti, no ja vam govorim i Bogom se zaklinjam, da to biti ne može, da duh iz čeljadeta po noći ili po dnevi iz tijela izide, niti da se opet u tijelo povrati, jer tijelo bez duha ostaje mrtvo, a mrtve niko voskresiti ne može, nako sam Tvorac neba $i$ zemlji, Bog, njegovom silom i blagovoljenjem. ${ }^{10}$

Nakon svega navedenog, postavlja se pitanje: kako se ovaj književni tekst odnosi prema ostalim tekstovima u južnoslovenskim književnostima inspirisanim promjenama koje donosi evropska prosvjetiteljska stvaralačka energija? Interesantnu podudarnost, koja se može pripisati i racionalističkome duhu stvaranja, primjećujemo već u predgovoru djela Život i priključenija Dositeja Obradovića u kome autor govori da nema literarnih pretenzija, već da je njegov jedini zadatak da predstavi istinu. Moralna pouka čini tematsku okosnicu oba djela, ali se Dositejev opus znatno razlikuje po količini i kvalitetu usvojenih parametara, zato svoje stavove artikuliše neobuzdano i smjelo; ne zaobilazeći nijednu društvenu pošast, odbacuje balast dogmatizma i sa sebe gotovo skida kaluđersko ruho. S druge strane, epistolarna forma (opet, ako izuzmemo činjenicu da Petar I nije računao na detekciju ovoga djela kao

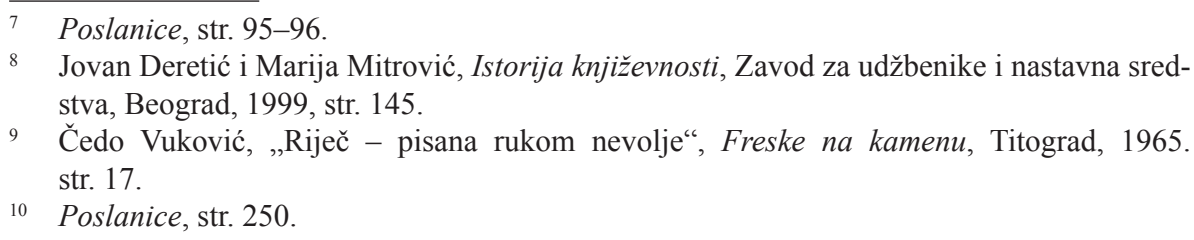


literarnog) još jedna je u nizu sličnosti koje možemo uočiti tokom uporednih čitanja dvaju tekstova.

Ipak, mogućnosti interpretacije opusa Petra I Petrovića u kontekstu duhovnoga pokreta koji svojim bićem zahvata dobar dio estetski oplemenjenih segmenata moraju se najprije dovesti u pitanje, budući da konstelacija odnosa između komunikatora (u ovom slučaju vladike i pripadnika različitih plemena) nalaže upravo upotrebu moralne pouke koja bi mogla funkcionisati i izvan društvenih koncepcija datoga doba; no ono što remeti valjanost takvih zaključaka jeste postojanje pojedinačnosti u opštem, odnosno kriterijuma po kojem se ove poslanice razlikuju od uobičajenih proglasa koji su vladari slali svojim podanicima. Prije svega visok stepen intimizacije s kolektivom koji ustrajava u moralnom posrtanju, prisustvo stilogenih faktora koji utiču na sugestivnost, kao i izgrađivanje lika naroda s posebnim nacionalnim karakteristikama čine formalni obrazac kojim se autor služio labavim i prezasićenim estetskom informacijom.

Prolazeći kroz gustu mrežu izvantekstovnih odnosa (poglavito odnosa prema stvarnosti, mitologiji, religiji) dolazimo i do pitanja umjetničke vrijednosti poslanica, tj. do načinā na koje se može izvršiti praktično ispitivanje njihove literarnosti koja se shvata kao nepromenljiva osobina svakog teksta, nezavisna od bilo kakvog društvenog ugovora. ${ }^{11} \mathrm{~S}$ druge strane: Književnost ne poseduje nikakvu trajnu i nepromenljivu suštinu, kaže Derida, jer svakom tekstu možemo pripisati literarnost zavisno od konteksta u koji ga stavimo. ${ }^{12}$ Isuviše fleksibilna mjerila, po svemu sudeći, ne dopuštaju slobodnije zaključke, pa ipak sa sigurnošću možemo tvrditi da se svaka devijacija od uobičajene upotrebe jezika može smatrati znakom literarnosti, ${ }^{13}$ te se zato sve češće naglašava značaj dominacije estetske funkcije na kojoj insistira i Rene Velek, a na kojoj ćemo se i mi zadržati, koristeći praktična znanja iz oblasti teorije književnosti.

„Poslanica Katunjanima“, iako načeta zubom vremena, u sebi nosi mnoštvo emocionalnih žarišta koja doprinose ljepoti i harmoničnosti izraza: No evo junaci, što je od najviše potrebe i dužnosti vaše, da vi s običnim duhom viteške hrabrosti budete spravni na obranu svojijeh granicah i svojega roda i otečestva, neka vide Hercegovački Turci, da se nijesu oni vitezovi izrodili, koji su njihove otce i đedove poražali i u ropstvo toliko putah odvodili, i neka poznadu, da ste vi dostojni sinovi istijeh vitezova, koji želite onu slavu, što su vam roditelji i praroditelji ostavili, da se vazda spominje $i$ u pjesme pjeva,

\footnotetext{
11 Anna Burzyńska Michał Paweł Markowski, Književne teorije XX veka, Službeni glasnik, Beograd, 2009, str. 532.

Isto, str. 399.

13 Zdenko Lešić, Teorija književnosti, Službeni glasnik, Beograd, 2008, str. 61.
} 
kako što $i$ danas pjevaju $i$ vječno će pjevati... stojati viteška djela prvijeh $i$ sadašnjijeh Crnogoracah, koji su s Turcima ratovali. ${ }^{14}$

Kao što se može primijetiti, riječ je o jedinoj rečenici u kojoj je sadržan vapaj duše u ekstatičnom zanosu, strukturi toliko moćnoj i raskošnoj pred kojom bi, čini se, sām neprijatelj pao ničice i položio oružje pozivajući na primirje. Petar I i ovoga puta provocira čula čitalaca kreativnošću, ośećajnošću i viteškim poletom, želeći da izazove efekat - da osokoli, uznese do bezmalo sulude hrabrosti na bojnom polju i tako izvojuje pobjedu za svoje nemašne $i$ divlje sapatnike. Spisateljska strategija kojom se Petar I takođe služi u ovome fragmentu jeste veoma učestalo spominjanje predaka; Crnogorac koji odlazi u borbu s neizvjesnim ishodom mora biti očeličen sopstvenim uvjerenjem da je spiritualna veza s junačkim korijenom dovoljno jaka da mu pruži dodatni oslonac u odsudnim trenucima, iako na smrt gleda kao na nešto obavezno $i$ neizbježno: jednom se mre. ${ }^{15}$ Parcelacija sintaksičkog niza, gotovo poetska nepogrešivost $\mathrm{u}$ izboru leksike, jasna izdvojenost tzv. jakih pozicija u rečeničnome sklopu - čine navedenu konstrukciju mnogo složenijom i čitalački atraktivnijom, naročito ako uzmemo u obzir da je ovo jedina poslanica u kojoj nema ni traga svim onim kompozicionim kalupima u koje je Petar I smještao postulate zdravorazumske logike (vodeći se, razumije se, mišlju da će se ljudi mnogo brže śetiti onoga što im je toliko puta ponovljeno). To ukazuje na nesumnjivo postojanje $\mathrm{i}$ onih drugih, kristalizovanih misaonih oblika, koji se najbolje otkrivaju u neprekidnoj čitalačkoj aktivnosti, te zato, prateći hronološku liniju nastajanja poslanica, nailazimo na estetski izrazito obojene cjeline koji postaju žrtvama česte upotrebe i gotovo se neizmijenjene prenose iz poslanice u poslanicu: ...da ga svaki mrzi i počituje za narod varvarski, bezbožni, bezakoni i bezdušni, koji niti ima poštenja, ni čelovječestva, nego sama sramotna, hajdučka i razbojničeska djela. ${ }^{16}$

Novak Kilibarda je u predgovoru Antologiji usmene poezije Crne Gore naglasio: Jeste, cvijeće je svojom sveukupnošću ljepota za svakoga, ali, ipak, oblik i miris konkretnog cvijeća pretpostavlja ljudske aperceptivne prijemnike, što dovodi u sumnju uobičajenu tvrdnju da o estetičkoj naklonosti konkretnog lica ne treba raspravljati. ${ }^{17}$ Koristeći se zatim, možda ne uistinu dosljedno, metodom reda-po-red, ${ }^{18}$ mogli bismo doći i do egzaktnih dokaza zbog kojih posmatrani odlomak smatramo osobito skladnim i u estetskome smislu uspje-

\footnotetext{
Poslanice, str. 107.

15 Pavel Apolonovič Rovinski, Etnografija Crne Gore, tom I, CID, Podgorica, 1998, str. 263.

16 Poslanice, str. 111.

17 Novak Kilibarda, Viša je gora od gore, CID, Podgorica, 2010, str. 9

18 Bogdan Popović, „Teorija 'reda-po-red'“, u: Teorijska misao o književnosti, priredio Petar Milosavljević, Svetovi, Novi Sad, 1991, str. 430.
} 
lim. Nagomilavaju se, dakle, epiteti s posebnom afektivnom vrijednošću, semantički povezani i gradirani po intenzitetu: varvarski, bezbožni, bezakoni $i$ bezdušni. Ako svoju osobitu pažnju usmjerimo na one s jednakim prefiksom, viđećemo da melodičnost $\mathrm{u}$ istome trenu upućuje na poetski karakter poslanica (nekima od njih bi se mogao i oduzeti prozni lik i tako složiti u stihove ${ }^{19}$ ). Interpunkcija je najčešće jedan od najvažnijih indikatora pulsa jednoga umjetničkog teksta: ...koji niti ima poštenja, ni čelovječestva, nego sama sramotna, hajdučka i razbojničeska djela... Riječ je o jednoj organizaciji višeg reda koja suvišnosti ne odbacuje, već ih pretvara u goli ritam duše, krik koji se prenosi, shvata i oblikuje ćutanjem.

Uobičajena formula (idilično stanje koje bješe prije, i ono buduće, u kojem vidi samo nevolju i razočaranje) u jednoj poslanici Bjelopavlićima naročito dolazi do izražaja. U njoj Petar Prvi, pored eksplicitnih izraza nezadovoljstva i ljutnje zbog neposluha preko kojega se ovoga puta samo prećutno prelazi, neuobičajeno minucioznim potezima ilustruje apsolutnu slobodu koja smeta čovjeku zaljubljenom u vječni nemir i propadanje: Nijesu vi propali perčini proz habene kapice, ni laktovi kroz neoptočene gunjine, nego eto danas toke i dolame, džamadani sa širitima i gajtanima od srebra i zlata. Eto male puške i noževi srebrom okovani, dževerdari srmom navezeni, puške šarajlije i ćese s kitama, eto kule ograđene i agalaci turski od Spuža u vašijem rukama...

Posebno mjesto u poslanicama zauzimaju odlomci koji se odlikuju gnomskom kompaktnošću, ironijskim razmahom, kao i kratke, melanholične završnice koje bi se govorom tijela zacijelo morale prikazati slijeganjem ramenima ili dubokim uzdahom: Šta hoće ta prazna sila, kad ne može deset danah živjeti bez onoga, kome prijeti! ${ }^{20} \mathrm{U}$ „Poslanici Bjelopavlićima“ Petar I unosi rezignirane note u svoj način pisanja: Ja vas silom na poslušanije nagnati ne mogu... ${ }^{21}$, dok je emocionalno pražnjenje najvidljivije u poslanici opštega tipa, namijenjenoj Crnogorcima i Brđanima: Ja se od svega zla i dobra ličim i po danas niti me u vaše posle prizivajte, niti ću se u njih miješati, nego... ostajem jošt zaludu vaš dobroželatelj nesrećni... ${ }^{22}$

Neophodno je ovom prilikom ukazati i na specifikume kad je riječ o segmentima koji ovome djelu daju književne obrise, a u pojedinim momentima izazivaju oneobičeni pogled na njegovu žanrovsku pripadnost, stvarajući pritom ambijent napetosti, nedorečenosti i zapletenosti karakteristične

19 Vidi: Radoslav Rotković, Crnogorska književnost od početaka pismenosti do 1852, ICJK, Podgorica, 2012, str. 443.

20 Poslanice, str. 81.

21 Poslanice, str. 155.

22 Poslanice, str. 88. 
za književnoumjetničke tekstove koji su stvarani sa namjerama da to budu. „Poslanica Piperima“ je od svih sa kojima smo imali prilike da se susretnemo u istraživačkoj fazi rada jedina koja počinje bez dosljednoga titulisanja i pozdrava, te se ovakva pojava, čak i u najstrožijoj interpretaciji, može porediti $\mathrm{s}$ iznevjerenim horizontom očekivanja. Osim u formalnom pogledu, odstupanja se primjećuju i u izvjesnim narativnim pukotinama (svedenost u količini informativnosti) koje bismo, proučavajući drukčiji tekst, mogli nazvati i tamnim mjestima, mjestima neodređenosti. Krvave scene stradanja, sukoba i vjerolomstava u životima ljudi koji idu trčke na svoju pogibelj, naizgled usputno sočne i poput svjedočanstva uvjerljive, doprinose razvoju narativnosti kao posljednjoj odbrani od antiliterarnog, faktografskog: ...pak Burazerović iz Podgorice momak premami na vjeru i posiječe svojega kuma Boška Piletića iz... kojemu je srdce izvadio i na nož kroz Podgoricu nosio, a glavu u Skadar ponio i darove za nju primio. ${ }^{23}$

Dva velika etička sistema, hrišćanski i crnogorski, upravljaju duhovnim zakonitostima koje pronalazimo u Poslanicama. Hrišćanska etika, čije proplamsaje prepoznajemo kroz razlikovanje nagrade (blagoslov) i kazne (kletva) kao temeljnog principa na kojem počiva vjera u Svemogućega, čvrsto nakalemljena na autorske perspektive daljega postojanja svijeta u sveprožimajućem ekvilibrijumu, svoja učenja umnogome zasniva na samozaboravu i sposobnosti praštanja. S druge strane, crnogorska etika funkcioniše u samo u okrilju naroda koji ju je stvorio, njena načela počivaju na čitavoj mreži ograničenja čijim se poštovanjem dostiže uzvišeni ideal č o e k a - niz kanonski utvrđenih pravila i propisa na osnovu kojih jednom takvom čovjeku njegova društvena zajednica u Crnoj Gori odaje priznanje i počasti... ${ }^{24}$ No, da li religija priznaje autonomnost unutrašnjih zakona? ${ }^{25}$

U Primjerima čojstva i junaštva Marko Miljanov kaže: Ja ne želim zlo kaluđeru, ni da Bog, no mi se čini da je miliji Bogu koji na muke mre za njegovu pravdu, no da nosi lanac. ${ }^{26}$ Prikazani odnos je, razumljivo, donekle suprotstavljen idealu kojem u poslanicama teži Petar I: njegovo ośećanje pravde, istine i razuma magnetski je povezano s ośećanjem Boga svedržitelja koji haotičnu stvarnost čuva u savršenom poretku: Može bit, da se vi na nekoga nadate i kako čujem prijetite, govoreći, da će vaše biti... no, ne znate, hoće li Bog dopuštiti da bude tako. ${ }^{27}$ Međutim, činjenica je da stvarnosna podloga na kojoj

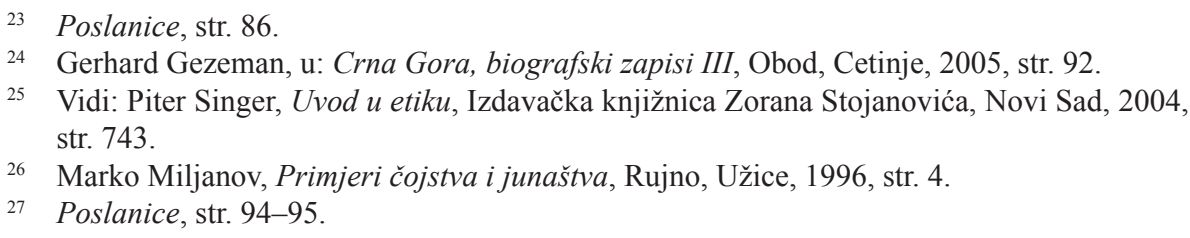


se gradi svijet djela proističe iz moralnog profila čovjeka s kojim se vodi imaginarni dijalog: Iako ima pamet koja se prema svemu odnosi kritički, koja sve mjeri i računa, Crnogorac često podliježe svojim strastima i vlastitom zanosu zbog svog nervno-sangviničnog temperamenta. Kod ovoga, u njegovom osjećanju višse je snage nego nježnosti. (...) Crnogorac se lako zanosi svojim sjajnim sposobnostima i smjelim ili, tačnije, drskim poduhvatima, pri čemu gubi osjećaj odvratnosti prema ličnostima koje se bave nemoralnim poslovima $i$ istovremeno prenebregava poštene trudbenike, a posebno zanatlije i ostale koji se bave nekim skromnim zanimanjem. ${ }^{28}$ Prema tome, interferencije hrišćanskog i crnogorskog koda najočitije su u ironijskim prikazima diskrepance između onoga što treba činiti i onoga što se uistinu čini, pa se istovremeno formira svojevrstan okvir u kome su čojstvo i junaštvo dva kvaliteta koja se nužno ne podrazumijevaju: Razumio sam za vaše junaštvo, koje ste učinili kod Vezirova Mosta... ${ }^{29}$ Isto tako, jednakost, kao suštinski kohezioni agens u plemenski uređenom crnogorskom društvu, poprima dimenzije opštehrišćanskog pristupa ustrojstvu zajedničkog života, zbog čega nalazimo dvije gotovo identične poslanice upućene zavađenim Piperima i Bjelopavlićima. Odnos prema ženi je nešto složeniji, iako se najčešće iščitava jedino iz pokušaja ženske osobe da dezavuiše sveti bračni ugovor i da dekomponuje tradicionalni šablon ispisan shvatanjima o muškarcu kao jedinki koja ima pravo izbora. Uprkos tome, u poslanicama nerijetko nailazimo na rješenja koja nijesu plod biblijske mizogine politike (što je, u neku ruku, očekivano od jednog mitropolita), već upravo suprotno - ona služe sterilnom birokratskom uzusu uzrok $i$ posljedi$c a$, koristeći stigmu i socijalnu izopštenost kao najsuroviji oblik kažnjavanja. Zato se u „Poslanici Crnogorcima“ navodi ime, prezime i porijeklo đevojke koja se ne želi udati za mladića koji traži njenu ruku (Dobrica, kćer pokojnoga igumna Petronija Damjanovića ${ }^{30}$ ) i na taj način, proklinjući svakoga ko se kani oženiti njome, osigurava barem privremenu pobjedu nad ženskom osionošću i samovoljom, jer individualna sudbina postaje kolektivna onoga trena kada opominje primjerom. Obrnuta situacija pak služi da se đevojačka čast, istaknuta uzvišenim zavjetom čednosti i poštenja koji predstavlja proizvod ukrštanja dviju etičkih postavki, sačuva vrlinom i plemenskom solidarnošću: neka lica na jednu sirotu đevojku familije Obradovića iznijeli jesu nevaljale $i$ nepristojne riječi za izgubit sreću i poštenje ovoj đevojki... ${ }^{31} \mathrm{U}$ ovim segmentima, najzad, ne nalazimo traga svim onim iscrpnim, na biblijski tekst oslonjenim predavanjima o ženinoj prirodnoj sklonosti ka zlomisli i grijehu, što se

28 Etnografija Crne Gore, str. 258-259.

29 Poslanice, str. 137.

30 Poslanice, str. 84.

31 Poslanice, Kamenarima XXVIII. 
svakako može tumačiti kao premoć racionalističkih aspiracija nad okoštalim zabludama serviranim od strane dogmatski orijentisane obrazovne elite.

Gledano iz aspekta svevremenosti, istinska književnost u poslanicama javlja se upravo na onim mjestima u kojima neobuzdana ljudska priroda sklona biblijskom padu, baš kao i u Luči mikrokozma, vodi neprekidnu borbu sa silama tame u istoj mjeri kao i sa silama dobra, nerazlučivim jednih od drugih. Zato zaključujemo da je kategorija moralnosti, izuzimajući nekoliko navedenih uzoraka, u crnogorskoj svijesti bila tek organski nastavak religijskih uvjerenja bez kojih bi njena egzistencija zasigurno bila dovedena u pitanje.

\section{Literatura}

- Apolonovič Rovinski, Pavel: Etnografija Crne Gore, tom I, CID, Podgorica, 1998.

- Crnogorska književnost u književnoj kritici III, Univerzitetska riječ, Nikšić, 1990.

- Deretić, Jovan i Mitrović, Marija: Istorija književnosti, Zavod za udžbenike i nastavna sredstva, Beograd, 1999.

- Gezeman, Gerhard u: Crna Gora, biografski zapisi III, Obod, Cetinje, 2005.

- Kilibarda, Novak: Viša je gora od gore, CID, Podgorica, 2010.

- Lešić, Zdenko: Teorija književnosti, Službeni glasnik, Beograd, 2008.

- Markowski Burzyńska Anna, Paweł Michał: Književne teorije XX veka, Službeni glasnik, Beograd, 2009.

- Miljanov, Marko: Primjeri čojstva i junaštva, Rujno, Užice, 1996.

- Njegoš, Petar I Petrović: Poslanice, Obod, Cetinje, 1951.

- Rotković, Radoslav: Crnogorska književnost od početaka pismenosti do 1852, ICJK Podgorica, 2012.

- Savković-Vukčević, Nela: „Retorika i stilistika u pismima i poslanicama crnogorskih vladika Danila, Save, Vasilija i Petra I Petrovića Njegoša“, Lingua Montenegrina, god. IV, sv. 2, br. 8, Institut za crnogorski jezik i književnost, Podgorica, 2011.

- Singer, Piter: Uvod u etiku, Izdavačka knjižnica Zorana Stojanovića, Novi Sad, 2004.

- Teorijska misao o književnosti, priredio Petar Milosavljević, Svetovi, Novi Sad, 1991.

- Vuković, Čedo: „Riječ - pisana rukom nevolje“, u: Freske na kamenu, Titograd, 1965.

- Vuksan, Dušan: Petar I Petrović Njegoš, Narodna knjiga, Cetinje, 1951. 
Tijana RAKOČEVIĆ

\section{EPISTLES OF PETAR I AS AN AESTHETIC PRODUCT}

Through literary-ethical observations of selected segments, the paper explores the features of linguistic expression of Petar I Petrović, reviewing the literary potential of the Epistles and revealing the aesthetic dimensions of the given literary-artistic text in the context of the era in which it is placed.

Key words: rationalism, aesthetic product, literary method, Montenegrin ethics 
UDK 821.163.4.09Kovač M.

Pregledni rad

\section{Sanja VOJINOVIĆ (Podgorica)}

Sekretarijat za kulturu i sport Glavnog grada Podgorice

sanjamiskovic@t-com.me

\section{Marko DRAGIĆ (Split)}

Filozofski fakultet Sveučilišta u Splitu

mdragic@ffst.hr

\section{ZNAČAJ TRADICIJE U PROZI MIRKA KOVAČA}

Usmena književnost i tradicijska kultura imaju izniman značaj u opusu Mirka Kovača. U radu se navode motivi usmene književnosti i općenito tradicije u prozi Mirka Kovača. U prozi Mirka Kovača ogledaju se: religijska (pravoslavna/katolička tradicija - religijski rituali, crkve, praznici) kao lajtmotivi u njegovim romanima i pripovijetkama; istorijska tradicija - istinske i mitske predstave koje postoje o istorijskim zbivanjima $\mathrm{u}$ geografskim odredištima te zbivanja u njegovim proznim djelima (najvećim dijelom je to Hercegovina) i narodna (seoska tradicija) koja je različita ili razlikovna od mjesta do mjesta navedenog geografskog područja. Tradicija se ogleda i u postmodernističkom postupku te poetici Mirka Kovača.

Motivska struktura proze Mirka Kovača zasnovana je na elementima predanja, legendi, anegdota, običaja, obreda, ophoda, divinacija, vjerovanja i dr.

Ključne riječi: usmena književnost, tradicija, postmodernizam, motivi

\section{Uvod}

Romansijer, esejista, autor TV i filmskih drama, tretiran kao savremeni crnogorski, hrvatski i srpski književnik, Mirko Kovač spada u onu plejadu pisaca koji su zbog iskazivanja stavova oprečnih vladajućim režimima, bili na udaru različitih političkih struja i uticaja. Spisateljsku sudbinu progonjenih (i politički u to vrijeme ,nepodobnih“) autora dijelio je s Danilom Kišom i Borislavom Pekićem. Značaj ovih pisaca za epohu postmodernizma na pro- 
storima južnoslovenskih književnosti, nesumnjiv je. Skupina pisaca povezana sklonošću ka istim ili sličnim proznim modelima, uvela je literarne inovacije koje su ih svrstale u redove postmodernista. I u njihovim je djelima prisutno slikanje društvene sredine i psihološko portretiranje, ali javili su se intertekstualnost, citatnost, dijalog s tradicijom i očuđavanje kao postupci svojstveni postmodernističkoj literaturi.

Usmena književnost je najstarija i najdugotrajnija vrsta književnosti koja postoji odkako postoji i čovječanstvo. Usmena književnost je uvijek tradicija pisanoj književnosti. Usmena književnost, jezik, dijalekti, toponimija, folklorno stvaralaštvo u području običaja, obreda, ophoda, plesa, muzike te tradicijska umijeća i obrti čine nematerijalnu kulturnu baštinu koja ima najveći značaj za očuvanje identiteta naroda i čovječanstva. Klasici svjetske književnosti nadahnjivali su se usmenom književnošću.

Nadahnuće za stvaranje svojih djela Mirko Kovač nalazio je u usmenoj književnosti, tradicijskoj kulturi i Bibliji. U radu se pod pojmom tradicija podrazumijeva usmena književnost i tradicijska kultura.

\section{Proza Mirka Kovača}

Prozu Mirka Kovača karakteriše bijeg od totalitarnoga režima i borba protiv njega koja odjekuje u njegovim radovima: pripovjedačkim, esejističkim, dramskim, filmskim. Zato se proučavaocu njegova književnog djela nameće specifičan tretman totalitarizma, ali i odnos prema svim elementima koji se prepoznaju ili podvode pod kategoriju tradicijske kulture.

Budući da je integrisana s društvenim i individualnim životom, te da pojam kulture obuhvata značenja koja su se taložila vjekovima, kulturu je teško definisati i cjelovito obuhvatiti u svim svojim aspektima. Širokoj lepezi značenja doprinose i različiti konteksti u koje se smješta kultura: filozofski, naučni, društveni, istorijski... Usko je povezana, ispreplijetana s tradicijom te pod tradicijskom kulturom podrazumijevamo gotovo sve...

Za tumačenje djela jednoga pisca neophodno je identifikovanje istinske dominantne vrijednosti njegove (nacionalne) kulture. Preispitivanje tradicionalnih vrijednosti podrazumijeva sagledavanje prošloga u kulturi, kulturnome nasljeđu, predanju ${ }^{1}$, razumijevanju onoga što je bilo.

„Sociološkim jezikom rečeno, čovek kao socijalno biće ukorenjen je u tradiciji. Ona pomaže očuvanju identiteta jednog naroda i istovremeno dopri-

\footnotetext{
1 Termin predanje može označavati tradicijsku kulturu, ali se najčešće pod tim pojmom podrazumijeva „vrsta priče koja se temelji na vjerovanju u istinitost njezina sadržaja“. Marko Dragić, Hrvatska usmena književnost Bosne i Hercegovine - proza, drama i mikrostrukture, Matica hrvatska, Sarajevo, 2005, str. 28.
} 
nosi formiranju jasne slike življenja tog naroda u budućnosti. Tradicija jeste sadašnjost prošlog (...) Pravo znanje o značaju tradicije i njenoj društvenoj relevanciji može se formirati u odgovoru na pitanje da li ona (ne) ugrožava svest o potrebi društvenih promena, odnosno da li su kulturne vrednosti dotične tradicije podsticajne za savremeno stvalaštvo. "2

Tradicija je „osnovni element" svake kulture jer sadrži stvaralačku dimenziju. Iz tradicije se crpi, na njenim osnovama se gradi, nadograđuje, ona se inkorporira u književno djelo. Jezik, religija i narodna predanja sačuvani u tradiciji jednoga naroda omogućavaju da se na njihovim osnovama izgradi novo djelo. Bez tradicije nema kulture, jer se sadašnjost vrednuje onim iz prošlosti, ma koliko prošlost i tradicija bili osporavani i negirani.

„Pisac je prožet kulturom iz koje potječe, vremenom, događajima, jezikom i historijom, ali on mora svaku tu posebnost približiti univerzalnom inače će ostati regionalist. Pisac gradi ljudske sudbine i saopćava priču iz svog kraja, jer je želi učiniti poznatom i vječnom. On svijetu mora uspješno predočiti vlastiti svijet. (...) tradicija ograničava, ali i daje. Obaveza je modernog pisca da je pametno i trezveno uzima, da se kritički odnosi prema njoj, te da je vazda spreman održati lekciju onima koji je pogrešno uzimaju ili zlorabe. ${ }^{\text {“3 }}$

Kroz djelo Mirka Kovača u odnosu prema tradiciji mogu se prepoznati sljedeći elementi tradicije, koje ćemo označiti:

1. religijska (pravoslavna/katolička tradicija - religijski rituali, crkve, praznici) kao lajtmotivi u njegovim romanima i pripovijetkama;

2. istorijska tradicija - istinske i mitske predstave koje postoje o istorijskim zbivanjima u geografskim odredištima te zbivanja u njegovim proznim djelima (najvećim dijelom je to Hercegovina) $i$

3. narodna (seoska tradicija) koja je različita ili razlikovna od mjesta do mjesta navedenog geografskog područja.

Kovač je iz tradicije kao kolektivnog pamćenja uzimao one vrijednosti koje su kompatibilne savremenom stanovištu ili savremenosti. Kovačevo djelo nalazi se razapeto između koncepata retradicionalizacije i modernizacije. Svojim djelom on oživljava stare, prevaziđene obrasce života. Može se reći da je opsjednut prošlošću (porodičnom prije svega), međutim kroz djelo su vidljivi njegovi pogledi, okrenutost ka modernizaciji koja je iskazana obradom motiva iz domena kulturne emancipacije.

Tumačeći djelo jednog pisca u okvirima tradicije, tragajući za elementima narodne, usmene književnosti, veoma je važno praviti distinkciju pojmova pri određenju onoga što je narodno. Razlikovno svojstvo pojmovima dao je i

2 Nikola Božilović, Tradicija i modernizacija (Evropske perspektive kulture na Balkanu), Sociologija, Vol. LII No 2, Beograd, 2010, str. 15.

3 Mirko Kovač, Evropska trulež, Fraktura, Zagreb, 2009, str. 86-87. 
prof. dr Marko Dragić u knjizi Poetika i povijest hrvatske usmene književno$s t i$, đe je naveo da ,pučku i usmenu književnost treba razlikovati. U uporabi je bio i naziv tradicionalna književnost. (...) U Hrvatskoj se naziv narodna književnost u službenoj uporabi zadržao do devedesetih godina dvadesetoga stoljeća“. 4

Prof. dr Novak Kilibarda je u svojim studijama pisao o razlikama termina narodska, narodna i usmena književnost. Pod pojmom narodske književnost prof. dr Novak Kilibarda podrazumijeva tekstove „koje stvaraju pismeni ljudi oslanjajući se na narodnu književnost kao na svoj jedini izvor. Dok narodni stvaralac i ne pomišlja da se svojim činom stvaranja može izdvojiti iz kolektiva kome socijalno i ideološko-politički pripada, dotle narodski književnik ima svijest o književnome stvaranju kao društveno-afirmativnome činu. (...) Narodski pisac, najminorniji kao i najznačajniji, ima određeni cilj kad se prihvati pera". ${ }^{5}$

Takođe, važno je pomenuti da je veliki broj studija od šezdesetih godina prošloga vijeka do danas posvećen interpolacijama usmene i pisane riječi. Ispitivanje odnosa usmene i pisane književnosti zahtijeva posebne metode, o čemu je u studiji Usmena književnost $i$ savremena crnogorska pripovijetka pisao i dr Vladimir Vojinović, đe navodi da „,svako nastojanje da se detaljnije sagleda i analizira odnos usmene i pisane riječi nosi veliki procenat rizika od gubljenja unutrašnjih vezivnih svojstava jednog teksta, u trenutku podvrgavanja umjetničkih oblika dekonstruktivističkim tretmanima. Čineći takvu vrstu reza po umjetničkoj strukturi, kako bismo pronašli ostatke procesa interpolacije, mi zapravo ulazimo u zonu dekontekstualizacije pojedinih segmenata strukture, te u svojevrsnu sudnicu autorima i poetikama..."6

Ovo je za nas važno stanovište jer se i u proznom djelu Mirka Kovača prepoznaju neposredni zapisi usmenih priča i predanja koji su svojevrstan dokaz motivskog, poetskog, strukturalnog bogatstva usmene tradicije. Pored ovih elemenata, u prozi Kovača prepoznaju se i određeni „razvijeniji oblici predanja“. U osnovi, prozna djela Mirka Kovača sadrže motive naslijeđene iz tradicijskih okvira, kao što su: motiv zmije, motiv vještice, motiv krvavog noža, motiv smrti itd.

Zajednički tematsko-motivski i jezičko-stilski elementi koji su prepoznatljivi u Kovačevim proznim djelima (Gubilište, Grad u zrcalu, Rane Luke

4 Marko Dragić, Poetika i povijest hrvatske usmene književnosti, Filozofski fakultet Sveučilišta u Splitu, Split, 2008, str. 12.

5 Novak Kilibarda, Studije i ogledi o crnogorskoj usmenoj književnosti, Institut za crnogorski jezik i književnost, Podgorica, 2012, str. 101-104.

6 Vladimir Vojinović, Usmena književnost i savremena crnogorska pripovijetka, Fakultet za crnogorski jezik i književnost, Cetinje, 2014, str. 231. 
Meštrevića, Nebeski zaručnici, Vrata od utrobe, Malvina, Kristalne rešetke) otvaraju prostor da se njegovo djelo sagleda u kontekstu tradicijske kulture. Kovač je tradicionalne elemente rekonstruisao unutar proznog teksta, smještajući ih u narativni okvir. Čitalac uočava da Kovačeva umjetnička arhitektonika počiva na književnoj tradiciji, reinterpretacijama koje su promjenljive i zavise od konteksta u kojem nastaju i primjenjuju se. Postmodernističkim postupcima, metaproznim okvirom pripovijedanja, koji ogoljuje postupak, Kovač ukazuje i na načine konstruisanja teksta.

Tragovi, zapravo elementi usmene književnosti u djelu Mirka Kovača ogledaju se prije svega u ekspresivnosti dijalekatskog jezika, struktuiranju i formi rečenice, zatim u predanjima i to onim „narodskim“. Pod ovim određenjima podrazumijevamo da je Kovač, s izuzecima, za paradigmu uzimao iz narodne predaje, one su mu bile osnov i za geografska pozicioniranja i smještanja radnji djela koja su uglavnom ograničena na prostor Hercegovine. Kao posljedicu jednoga ovakvog odabira tematskoga, motivskoga, hronotopskoga kreiranja djela jeste „mozaički izgled Kovačeve proze, koji, zapravo, ne nastaje disperzijom priče, nego pre slaganjem elemenata jedne strukture“.? Nastajanje svakog Kovačevog djela prate isti ili slični motivi koji su zapravo dio glasina, kako ih Radoman Kordić naziva, koje se reprodukuju uvijek iz druge tačke gledišta. Ne može nezapaženo proći i konstatacija da je Kovač uzimao od velikih pisaca ono što je pogodovalo njegovom sentimentu i njegovoj poetici pa s pravom njegov književni postupak nazivamo konstruktivnim. „Kovač bez mnogo obzira posuđuje ono što ga kod drugih pisaca opsenjuje: od Gogolja - kupovinu mrtvih duša (kod Kovača, kupovina leševa), od Poa - sliku pada kuće Ašer (kod Kovača, kuća Biriša), od Foknera - čitavog jednog junaka, idiota iz 'Buke i besa', kome će Kovač i u 'Mojoj sestri Elidi' i u 'Ruganju s dušom' dati, praktično, središno mesto, i to, verovatno, pod uticajem slike božjeg čoveka iz ruske književnosti, ili, pre, nejasno formulisane hrišćanske tajne. “8

Jasno je da djela Mirka Kovača pripadaju postmodernizmu, njegovim zakonitostima i kanonima, ali je očito da se Kovač oslanjao na domete usmene književnosti; na epitete usmene književnosti; paralelizme; na crnobijelu tehniku slikanja likova; na diferencijaciju pobjednika i poraženih, dobra i zla. U postupku karakterizacije, Kovač je izrazito odlučan kad iznosi vrijednosne sudove o likovima. I to je nešto što je naslijeđeno od usmene književnosti.

Radoman Kordić, Tumačenje književnog dela, Dečje novine, Gornji Milanovac, 1988, str. 180. Isto, str. 181. 


\section{Tradicija u postmodernističkom postupku Mirka Kovača}

Mirko Kovač je kao i pisci njegove generacije u svom književnom opusu povezivao modernističke koncepcije epohe koja se s početkom njegova književnog rada završavala i poetiku postmoderne koja je postala dominanta pripovjedačka strategija. Prozu Mirka Kovača karakteriše defabulacija, demitologizacija, intertekstualnost, citatnost, međužanrovi, ukidanje granice između stvarnosti i fikcije. „Poetički preokret koji je usvajao modernističko iskustvo i oblikovao nove odgovore na modernističke paradokse odigrao se u prozi Danila Kiša, Borislava Pekića i Mirka Kovača. Početkom šezdesetih godina nagovještaji ovih promena ogledali su se u dva kratka romana, 'Mansardi’ Danila Kiša i ‘Gubilištu' Mirka Kovača. (...) Prelomni trenutak, posle koga se u srpskoj književnosti moraju pokrenuti pitanja postmodernizma, odnosno - kako se ovde predlaže - postmoderne, označen je 1965. godine objavljivanjem tri značajna romana nove generacije pisaca: 'Bašte, pepela' Danila Kiša, 'Vremena čuda' Borislava Pekića i 'Moje sestre Elide' Mirka Kovača."

Oduvijek je književna tradicija nudila piscima obilje tema i motiva. Tradicija je zapravo tekst na čijim osnovama nastaje novi tekst - književno, umjetničko djelo. Zato i ne čudi što postmodernizam u književnosti obilježava pojava intertekstualnosti i citatnosti. „Intertekstualnost je pojava koja karakteriše umetnost reči od prvog dana njenog stvaranja i u različitim epohama samo je manje ili više, u ovom ili onom obliku, dolazila do izražaja." ${ }^{\text {"10 }}$

Svi proučavaoci Kovačeva stvaralaštva zapazili su motivsku preokupaciju u njegovim djelima koja se najčešće svodi na: sudbinsko određenje likova/junaka; promišljanja nad ideologijom; zlo kao neizbježnu kategoriju života; opis gradskoga trga u nekom bezimenome mediteranskom podneblju koje asocira na hercegovačko zaleđe i podnevno sunce kao simbol djela Mirka Kovača. „Poetika pripovedanja u kojoj je određena postmoderna druga refleksija nije samo pripovedačevo teorijsko i kritičko znanje o onome što čini kada pripoveda, ona je u postmodernizmu pre svega jedno od sredstava oblikovanja. Pripovedač više ne može uzeti reč slučajno, zato što mu se nešto dogodilo, ili je nešto čuo pa to želi da saopšti. On mora da bude poetički spreman da pronađe priču zaturenu u mnoštvu okolnih dokumenata, života i sudbina. Zato je on 'poetički pripovedač' " "11 To znači da se tradicionalne forme pripovijedanja

\footnotetext{
9 Aleksandar Jerkov, Nova tekstualnost, Unireks - Prosveta - Oktoih, Nikšić - Beograd Podgorica, 1992, str. 14-17.

10 Milena Stojanović, Pogled na piščev radni sto (okviri novog čitanja), Biblioteka Hrestomatija, Mali Nemo, Pančevo, 2006, str. 29-30.

11 Aleksandar Jerkov, n. d., str. 30.
} 
zamjenjuju poetičkim pripovijedanjem, koje je često svedeno pod intertekstualnost, u čijim okvirima svi upotrijebljeni tekstovi upućuju jedni na druge.

Kao konstanta pripovjedačke poetike Mirka Kovača izdvaja se metamorfoza pisma kao jedna od odlika postmodernističkih pisaca kojima i sām Kovač pripada. Njegova potreba da mu je djelo drugačije od prethodnoga, čini ga posebnim i rijetkim među savremenim piscima prostora nekadašnje Jugoslavije. Iz te različitosti ipak do izražaja dolaze one konstante koje se prelivaju iz jednog djela u drugo. Tako je zlo motivski uobličeno snagom piščevog jezika, ali ovom motivu ni sām pisac nije do kraja posvećen. Zlo je drugačije postavljeno od recimo motiva smrti ili zaborava koji dolazi nakon smrti. Kovačevi junaci izloženi su iskušenju samoga đavola. Otuda se i zlo pojavljuje kao nužnost jednoga takvog životnoga usmjerenja, a to zlo je simbolično dato u samom djelu.

Kao postmodernistički pisac Kovač rekonstruiše istoriju, uzimajući samo segmente istorije, često one tragične prizore, simbolične činjenice koje su dopunjene imaginacijom i tako prikazane. „Hoću reći: dokumentarnost je postupak, a ne književni pravac. " ${ }^{2}$

Bilo da je motiv Kovačeva djela predskazanje, san, čudo, parabola, fragment iz Biblije, svakodnevni svijet njegova djela, junaka, očuđen je, izglobljen, a perspektiva pripovijedanja pomjerena i izmještena u prostor fantastike. Tako biva da se priča samom čitaocu otkriva na neočekivan način a u tome i jeste suština Kovačeva pripovjednog postupka. Jer u postmodernizmu na snazi je pravilo da se „oblikovanje fikcionalnog sveta neposredno izlaže poetičkom umu pa saznanja o priči i pripovedanju ne slede ono što se ima ispripovedati, već se priča i pripovedanje upravljaju prema poetičkim pravilima pronađenim u istraživanju književnih tekstova, rukopisa i tuđih tekstova uopšte. Svet zamenjen tekstom, tekst viđen kao tekst od tekstova, pripovedanje protumačeno kao književni diskurs, sve su to teme koje prodiru u srpsku književnost da označe kako ona pronalazi jedan nov period, svoje postmoderno doba". ${ }^{13}$

Kovačevu prozu teško je tumačiti čvrstim i uskim okvirima teorije književnosti. Tome doprinosi njena strukturiranost koja je zapravo metastruktura jer se iza svake strukture nalazi još jedna struktura. Kovačeva pripovjedačka struktura u suprotnosti je sa do tada važećim kanonima pripovijedanja i strukturiranja književnog djela. Odsustvo bilo kakve centralne čvrste priče oko koje bi se razvila fabula karakteriše većinu proznih djela Mirka Kovača. Jedna od odlika Kovačeve proze je neprekidno upozoravanje na „status priče i

12 Mirko Kovač, n. d., str. 35.

13 Aleksandar Jerkov, n. d., str. 22-23. 
pripovedača, ali nigde i nikada na retoriku usmene književnosti i njena strukturna načela koja su, u osnovi, i strukturna načela njegove proze, temelj na kojem je bilo moguće ovo radikalno razgrađivanje“. ${ }^{14}$

Prvi roman Mirka Kovača Gubilište u maniru pripovjedača-hroničara „priziva“ Hercegovinu, jezikom, pričom, lokalnim govorom i dijalektizmima. Takvim pripovjedačkim postupcima Kovač „uvodi lokalno i folklorno“ i „Započinje relativizaciju modernističke poetike, ali apokalitični svet i modernistička pripovedna sintaksa, igra pripovedačke svesti, iskaza i identifikacija pripovedača sa različitim likovima i gledištima, teško se mogu pomiriti sa 'lokalnom bojom' koja je predstavljena kao jednako važna za sudbinu priče“. ${ }^{15}$

Kompozicija romana Gubilište je razuđena a takvom je upravo čine različite pozicije pripovjedača. U uvodu se predstavljaju pisac i priređivač rukopisa, a zatim se pripovjedna pozicija ustupa junacima priča koje slijede, a koje su u romanu pisane u prvom licu jednine u vidu pisama, zabilješki, ispovijesti ili nekih drugih rukopisa. Utisak koji se stiče čitanjem romana, čija tematika je usmjerena na prikazivanje propadanja porodice Biriš, jesu tamne, užasne, ružne, odbojne slike nestajanja jedne genealogije.

Značajno je navesti još jednu kategoriju pripovijedanja koja je prisutna u djelu Mirka Kovača, a to je parodiranje tuđeg teksta. To znači da je Kovač poziciju pripovjedača preoblikovao u poziciju pripovjedača-priređivača rukopisa, a uvodno dio romana je okvirna priča unutar koje su preostale priče razvrstane oko ,različitih centara interesa“.

Kovačevu prozu odlikuje i načelo paralelnoga pripovijedanja, kao i česta upotreba sintagmi priča se, pričalo se. Elementi Kovačeva literarnog postupka prevazilaze ograničenja koja su tim postupcima postavljena. Kovač razara dokumentarizam kao stvaralački postupak, značenjski tekst se izobličava, pozicija čitaoca je pomjerena. Ovakvim postupcima slabi se struktura pripovijedanja, kompozicija djela uopšte. Po homogenosti strukture, koja je samo prividna, izdvajaju se roman Vrata od utrobe i zbirka pripovjedaka $\mathrm{Ne}$ beski zaručnici. Epski prikaz rata u romanu Vrata od utrobe u funkciji je prividne homogenitosti strukture romana Vrata od utrobe.

Zbirku pripovjedaka Nebeski zaručnici odlikuje homogeno prikazivanje priče i njeno tumačenje.

Mit o razbludnom sinu itekako je prisutan u djelu, a Kovač ga u zavisnosti od konteksta u koji ga svrstava, poetički modelira. Važno je na početku tumačenja proze Mirka Kovača analizirati ulogu Biblije u njegovom obimnom proznom opusu. U romanu Vrata od utrobe, prepoznaju se navodi iz Staroga i

14 Radoman Kordić, Tumačenje književnog dela, Dečje novine, Gornji Milanovac, 1988, str.180.

15 Aleksandar Jerkov, n. d., str. 15. 
Novoga zavjeta koji su dati paradigmatski, a u kontekstu ukupne priče romana prepoznaju se parafraze iz Biblije.

Jedan od biblijskih motiva koje Kovač inkorporira u svojim djelima je priča o Kainu i Avelju (odnos Dimitrija i njegovog brata), priča o Judi (lik Đurice), priča o Isusu Hristu koja se pojavljuje u nekoliko varijacija, zavisno od konteksta u koji je Kovač smješta.

$\mathrm{Na}$ osnovu paralelizma s tekstom Biblije, Kovač gradi svoje tekstove, koji dobijaju značenje vječne priče, biblijske i priče iz života. Primjer takvoga građenja teksta jeste glava pod naslovom „Radosna pogača“ iz romana Vrata od utrobe. „Svi ovi oblici pozivanja na biblijsku besedu mogu proizlaziti iz svesnog opredeljenja, iz Kovačevog mišljenja da biblijski tekst sadrži kanonske predstave života i, pogotovu, kanon apokaliptične vizije. Ovakvom mišljenju ne bi protivurečilo ni to što Kovač, pokatkad, pozitivne predznake biblijskog teksta preokreće u negativne. Tako će on poglavlje 'Ne bilo dana u koji se rodih' (Vrata od utrobe), posvećeno Paolu Menzeu, napraviti kao varijantu 'Knjige o Jovu'; naravno, negativnu varijantu. Kovačev junak je hulja, te njegovo stradanje mora biti parodija stradanja pravednika Jova." ${ }^{\text {"16 }}$

\section{Poetika Mirka Kovača}

Prvo što čitaocu pada u oči kad pokušava da sagleda obiman opus Mirka Kovača je svojevrsno odstupanje od dotadašnjih narativnih obrazaca. Kovač ruši i pripovjedačku i romanesknu strukturu djela. U njegovoj prozi zapaža se odsustvo priče, ali i načelo građenja koje je zasnovano na razgrađivanju klasične književne forme. Međutim, ukoliko sagledamo dublje slojeve njegove proze, uočićemo da je konstruktivni princip jednoga djela usmene književnosti zapravo u osnovi njegove proze, temelj na osnovu kojih su njegova djela nastala. To se dā zapaziti na osnovu elemenata usmene književnosti koje su inkorporirane u Kovačevo djelo: jezik, struktura rečenice, govorne formule, predaja, predanje koje zauzima posebno mjesto u njegovoj prozi. U okviru tradicionalne usmene književnosti, predanje je kanon koje ujedno postaje i osnov, pokretački motiv, činilac iz kojeg se gradi i nastaje novo djelo.

U književnostima južnoslovenskih prostora godina 1978. je prelomna, jer se te godine objavljuju dva književna djela koja označavaju pobunu protiv svih oblika ustaljene književno-teorijske prakse, protiv totalitarizma, protiv šematizma u književnosti. Naime, 1978. godine objavljen je Čas anatomije Danila Kiša i Poslanica o evropskoj truleži Mirka Kovača.

16 Radoman Kordić, n. d., str. 192. 
„Kiš u ‘Času anatomije' i Kovač u 'Poslanici' domahuju svim ovim književnim kanonicima definitivni zbogom, u ime svoje ali i u ime literature, a čine to tako intelektualno nadmoćno i teorijski fundirano, da bi to doista mogao biti predznak nove klime u našoj književnosti. “17 „Kovač primjenjuje, virtuozno i stvaralački konzekventno, prastaru spoznaju: motivi koji su sami od sebe mučni, prokleti, tragičnim konfliknostima nabijeni, umjetnički rječitu transpoziciju mogu doživjeti samo prividnim oduzimanjem viška intenziteta. To je, u stvari, jedan vid oneobičavanja, ugrađan u cjeloviti romansijerski postupak. Time se postiže način 'subjektivne objektivnosti': roman je impostiran biografsko-kroničarski i sve je saopćeno iz izrazito individualnog rakursa (koji se neuhvatljivo fleksibilno stalno pomiče - čas 'govori' dječak M., čas pripovjedač, čas se identificiraju kao jedan subjekt, čas, opet, svjedoči klasični neutralni kroničar), a, istovremeno, sve je predočeno s pomno izgrađenom distancom. Uostalom, autor na jednom mjestu i eksplicitno aktualizira gotovo flaubertovski shvaćen impresonalizam: 'Ovde i pripovedač ima svoj stav o tome, ali on iznosio a ne sudi' ."18

Apstrakcije, mitologemi, istoriografski apokrifi postaju duhovni habitus Kovačeva književnog djela. Postupci kojima se koristi prilikom stvaranja djela su dokumentarnost i hronika-uspomena. Oba postupka prožimaju Kovačevo cjelokupno djelo, a karakteriše ih estetska forma da se sve može reći na nov i drugačiji način.

Postmoderne po vremenu u kojem su nastajale, fundamentalne po životnim pitanjima koja obrađuju (tretiraju), otvaraju, snažno obilježene autorovom individualnošću i osobenošću, Kovačeve knjige otkrivaju jedan novi smisao književnosti i vlastite poetike.

Iako su tri pisca (Kovač, Pekić, Kiš) svoja načela na početku svog književnog rada zasnivala na, ako ne istim, ono makar sličnim poetskim programima, svaki od njih ponaosob u daljem stvaralaštvu povlačio je svoja načela i viđenja književnog djelovanja koja su za to vrijeme bila izrazito politički obojena. Naime, etički imperativ koji su sva tri pisca postavila u svojim književnim djelima na početku svoga rada zasnivao se na negiranju, zapravo nećutanju pred političkim izazovima epohe kojoj su sva trojica pripadala. No, izuzev Mirka Kovača, Pekić i Kiš nijesu ostali do kraja dosljedni postavljenim ciljevima.

Skupa s Filipom Davidom, Kovač je uspostavio izvjesna poetička načela antitotalitarističke jugoslovenske književnosti koje su mogu podvesti pod jednu rečenicu: ,pisac mora na vješt i pametan način, duhovito i inteligentno,

17 Ivan Lovrenović, Mirko Kovač Vrata od utrobe, Beograd, 1978, (25. 08. 2013) http://ivanlovrenovic.com/2013/08/drugi-zivot-mirka-kovaca (pristup 18. 04. 2015.)

18 Isto. 
pisati o ovim našim propadanjima i lažima“.${ }^{19}$ Da se zaključiti da je Kovačeva poetika zasnovana na činjenici da svaki roman, svaka pripovijetka, svako djelo moraju biti napisani drugačijim postupkom, drugačijim načinom pripovijedanja, stoga se stiče utisak da ih nije pisao isti pisac jer osim pojedinih likova koji su junaci jednoga romana, pripovijetke, drame ili scenarija za film, teško se uočavaju ostali elementi sličnosti.

Uočava se da se u Kovačevu opusu, od prvih stvaralačkih djela, pa sve do posljednjega, romana-memoara, provlači pripovjedačko ja kao konstanta u njegovom pripovijedanju. Ona je zastupljena u zbirci pripovjedaka Ruže za Nives Koen, romanima Uvod u drugi život, Kristalne rešetke, Grad u zrcalu. Kovačevo pripovjedačko ja razbija monotoniju pripovijedanja javljajući se i u digresijama. Sām pisac je obrazložio svoj način pripovijedanja u intervjuu koji je s njim vodio Srećko Horvat, a koji je objavljen u časopisu Plima: „Ja ne znam da li bih uopće umio pisati u trećem licu, istina, pisao sam mnoga poglavlja u trećem licu, ali da li bih umio one intimne partije bez toga autobiografskog ja, to stvarno ne znam. Naprosto, divno se skrivati iza toga $J a$, čini mi se da ono mnogo toga dopušta, a ipak je nečim uvjetovano i ograničeno. Uza sve, meni pisanje u prvom licu pričinjava veliko zadovoljstvo, osobna iskustva lakše uklapam nego da to činim onim objektivnim načinom pisca 'kao svevidećeg"“.

Da je riječ o jednom posve osobenom piscu, navodi i Vida Ognjenović: „Mirko Kovač je bio i ostao svoj, samo sebi svojstven, i u vlasti samo svoga eruptivnog talenta za dubinsko raščitavanje, nimalo za to podatnog, svečoveka, svoga književnog junaka. Neustrašivo je zalazio u sve njegove pojavnosti, tražio ga u javnom i skrivenom, u uzletima i slabostima, u pravcima i krivinama, u zagonetkama i lucidnim otkrićima i u svim tim bojama i dimenzijama ga prikazivao u svojoj visoko naponskoj prozi.“'20 Romaneskne fikcije Mirka Kovača slične su od pojave prvijenca Gubilište, pa sve do romana Grad u zrcalu, koji se pojavio nakon pola vijeka od objavljivanja prvoga romana.

Kovačev pripovjedački postupak zasnovan je na grotesci, i to grotesci kao umjetničkoj strukturi koja je u suodnosu s apsurdnim, no koja mu se ne potčinjava. Značenjski, groteska obuhvata niz kategorija poput kategorije fantastičnog, tragičnog, smiješnog, natprirodnog. Sve navedene kategorije pronalaze svoje mjesto u prozi Mirka Kovača.

Sām Kovač u esejima anticipira svoju poetiku. On piše da za jednog pisca stvaranje poeme, romana, zbirke novela ili eseja, „nije dovoljno biti ob-

19 Mirko Kovač, Uvijek ćemo imati mitova za razaranje, razgovarali: Edin Salčinović, Mirnes Sokolović, Osman Zukić (21. 06. 2010.) http://www.sic.ba/rubrike/intervju/mirko-kovacuvijek-cemo-imati-mitova-za-razaranje (pristup 18. 04. 2015.)

20 Vida Ognjenović, „Mirko Kovač, svoj pisac“, Politika, 31.VII 2013. godine. 
daren i redati niz opažanja, već se moraš pobrinuti da sve opravdaš nekim dokazom, moraš praviti bilješke, moraš sređivati pročitane stvari, raspolagati priručnicima i enciklopedijama, prelistavati rječnike, a Bibliju držati stalno otvorenu kako bi te mamila da je čitaš, jer pisanje iz maloga mozga na određenu temu ili fabulicu stvar je diletanta u našoj sredini uvijek cijenjenih, dok se romanu ili poemi i drugom književnom rodu mora prići egzaktno, doduše i oprezno, sasvim pripremljen duhovno i tjelesno zdrav, u domu ili u izgnanstvu. U svakom slučaju negdje blizu drage osobe." ${ }^{21}$

Junaci Kovačeva proznog opusa odlaze ili dolaze svojim kućama, nedužni i krivi idu svojim životnim putanjama. Opis njihovih životnih kretanja, doživljaja, ukrštanja, razdvajanja i nestajanja sa lica svijeta snažno evociraju život sela, radničkih predgrađa, grada, s upornim i teškim siromaštvom koje pritiska dostojanstvo čovjeka. Tu su i tmasti, vulgarni i šareni životi pojedinih koji vrijednosti života sagledavaju kroz prizmu svojih nedaća i nevolja, predaka koji su im u nasljeđe ostavili psihoze ili teže oblike umne poremećenosti.

Kovač je svim tim znakovima protkao svoj opus iz koga, kao iz kakvoga manifesta epohe postmodernizma, izviru iskazi koji pozivaju teoretičare $\mathrm{i}$ kritičare na pozornost. A svi oni skupa upućuju na činjenicu da je riječ o prozi koja nastaje tako što kanon razgrađuje. ${ }^{22}$

„Eto, tako počinju priče i romani Mirka Kovača, ali ne nužno na stranicama knjiga, nego u imaginaciji njegova čitatelja. (...) U Konavlima, na trasi stare pruge, s koje su davno počupane tračnice, ali se kameni podzidi još uvijek dobro drže, $\mathrm{u}$ Trebinju, oko tržnice $\mathrm{i}$ ispred hotela, u Beogradu, naročito u mračnim i zapuštenim dorćolskim uličicama i dvorištima, u gluha doba noći i dana, u Zagrebu, na Zrinjevcu i oko hotela Palace, pred zatvorenim antikvarijatima i na uglu Mesničke i Ilice, upisana ja atmosfera Kovačeve proze, pojedinih pasaža iz njegovih priča i romana, ili kao u beogradskom slučaju, cijeli romani. Nijedan naš suvremeni pisac, još od Ranka Marinkovića u Kiklopu, nije se tako intenzivno ubilježio u ambijent ili u kulise svoga pripovijedanja." ${ }^{23}$

Kovač u svojim djelima teži neprestanim promjenama posmatranja i uključivanja u svoje djelo onih opštih, univerzalnih i vječnih tema. Svaka njegova knjiga je drugačija od prethodne, što potvrđuje da je pisac u sukobu sa samim sobom u neprestanoj promjeni. Stoga je važno pitanje forme u Kovačevu djelu. Ta izrazita lutanja u pogledu pripovjedne forme nijesu ništa drugo do Kovačev vlastiti literarni izraz kojega odlikuje odsustvo čvrste pozicije pripovijedanja. „'Gubilište’ - u više navrata dograđivan prvi Kovačev roman

21 Mirko Kovač, n. d., str. 26.

22 Radoman Kordić, n. d., str.179.

23 Miljenko Jergović: „Mirko Kovač - privatni pisac“, Ars, časopis za književnost, kulturu i društvena pitanja, 5-6, 2014, str. 111-112. 
- jeste tekst sljubljenih i alegorijsko-simboličkih značenja. 'Ruganje s dušom' i 'Vrata od utrobe' su zgusnute, apartne, pomalo hermetične knjige, pune biblijskih referenci koje čine da svaki čitalac postane egzeget. 'Uvod u drugi život' je fikcionalizovana autobiografija u kojoj se ne zaboravlja da 'je sprdnja velika umetnost', kako kaže jedan Kovačev lik. 'Životopis Malvine Trifković' je dokumentaristička povest, a priče iz 'Rane Luke Meštrevića' i 'Nebeskih zaručnika', ponavljajući pobrojane postupke i značenjske karakteristike, bliže se naročitoj, usložnjenoj varijanti realizma, pod kojim ovde valja podrazumevati 'trajno problematičan pojam'. “24

Postupak citatnosti je još jedna od odlika Kovačevih djela koji zapravo „nije samo jedan književni postupak, već je to proces povezivanja svih tekstova u jedan megatekst književnosti kojim se identifikuje svet““. ${ }^{25}$

\section{Zaključak}

Sliku Kovačeva opusa teško je svesti na jednu ravan. Kao i njegovi, po epohi, srodni pisci i Kovač demitologizuje, razara osnovnu priču, razgrađuje da bi na osnovama gradio novu priču, parafrazira postojeća književna i teološka djela, poigrava se sa svim djelima, postojećim likovima i citatima. Kao i Pekiću i Kišu, i Kovaču literatura postaje intertekstualna igra. Kovačevi tekstovi počivaju na paralelizmu sa svjetskom književnošću, Biblijom, mitovima, aluzijama, izmišljenim izvorima, Borhesom kao uzorom epohe u kojoj su nastajala Kovačeva djela.

Status priče i pripovjedača kod postmodernističkih pisaca različitim postupcima doveden je u pitanje. I Kovač se povinovao ovakvom književnom postupku, pa je u tom pogledu Gubilište zasnovano na parodiji „klasične književne besjede“. Nasuprot takvom postupku, u romanu Moja sestra Elida priča je osnov radnje, glavni lik romana, ona je sredstvo oneobičavanja. Funkcija priče o priči karakteriše roman Životopis Malvine Trifković, a roman Vrata od utrobe zasnovan je na arhaizovanoj priči i pripovjedaču koji čitaoca vodi kroz roman. Međutim, priču razaraju primjedbe izdavača i pisca koje su u funkciji derealizacije i relativizacije postojećeg. U Uvodu u drugi život, Kovač iznosi čitavu jednu poetiku koja je dosljedna dekonstrukciji pozicije i priče i pripovjedača. Ostajući na liniji tradicionalnog statusa pripovjedača i priče u uvođenju arhetipskih likova, Kovač ispisuje mit zasnovan na biblijskom motivu - životu i stradanju Isusa Hrista.

24 Mihajlo Pantić, Aleksandrijski sindrom 2, Srpska književna zadruga, Beograd, 1994, str. 52.

25 Isto, str. 37. 
Tumačiti djela Mirka Kovača podrazumijeva njihovo sagledavanje s aspekta mita, filozofskih sentenci, istorijskih dokumenata, djela svjetske književnosti, Biblije, koja kod Kovača zauzima posebno mjesto. Kovač postupkom „demitologizacije hrišćanstva, tj. mita o Hristu kao o jednoj od varijanti mita o proroku“". ${ }^{26}$

Čitajući Kovačevo obimno književno i esejističko djelo, stiče se utisak da ih nije pisao jedan pisac, a motivska struktura zasnovana na elementima narodne, usmene književnosti, a pritom mislimo na predanja, legende, običaje, anegdote, mitove (priča o vješticama, legenda o krvavom nožu, običaji obredi sahrane, smrti, funkcija sunca podnevnog, odlasci muške glave) često su povezani sa propašću te porodice...

Književni, dramski, filmski, publicistički, esejistički opus Mirka Kovača je prije svega obiman, zatim istančan, promišljen, nijansiran različitim temama, zavičajnim, beogradskim pasažima, ratnim vihorima, promišljanjima o književnosti, književnim poetikama pisaca, političkim prilikama, totalitarnom režimu, esejima o pisanju, dramskom radu i radu na scenarijima. Njegovo književno djelo je veličanstveno, sublimacija prošlosti i sadašnjosti...

\section{Literatura}

- Božilović, Nikola: „Tradicija i modernizacija (Evropske perspektive kulture na Balkanu)“, Sociologija, Vol. LII No 2, 2010.

- Dragić, Marko: Hrvatska usmena književnost Bosne i Hercegovine proza, drama i mikrostrukture, Matica hrvatska, Sarajevo, 2005.

- Dragić, Marko: Poetika i povijest hrvatske usmene književnosti, Filozofski fakultet Sveučilišta u Splitu, Split, 2008.

- Jergović, Miljenko: „Mirko Kovač - privatni pisac“, Ars, časopis za književnost, kulturu i društvena pitanja, 5-6, 2014.

- Jerkov, Aleksandar: Nova tekstualnost, Unireks - Prosveta - Oktoih, Nikšić - Beograd - Podgorica, 1992.

- Kilibarda, Novak: Studije i ogledi o crnogorskoj usmenoj književnosti, Institut za crnogorski jezik i književnost, Podgorica, 2012.

- Kordić, Radoman: Tumačenje književnog dela, Dečje novine, Gornji Milanovac, 1988.

26 Milena Stojanović, Pogled na pišćev radni sto (okviri novog čitanja), Biblioteka Hrestomatija, Mali Nemo, Pančevo, 2006, str. 81. 
- Kovač, Mirko: „Uvijek ćemo imati mitova za razaranje“, razgovarali: Edin Salčinović, Mirnes Sokolović, Osman Zukić (21. 06. 2010.)

http://www.sic.ba/rubrike/intervju/mirko-kovac-uvijek-cemo-imatimitova-za-razaranje (pristup 18. 04. 2015.)

- Kovač, Mirko: Evropska trulež, Fraktura, Zagreb, 2009.

- Lovrenović, Ivan: Mirko Kovač Vrata od utrobe, Beograd, 1978, (25. 08. 2013) http://ivanlovrenovic.com/2013/08/drugi-zivot-mirka-kovaca (pristup 18. 04. 2015.)

- Ognjenović, Vida: „Mirko Kovač, svoj pisac“, Politika, 31.VII 2013. godine.

- Pantić, Mihajlo: Aleksandrijski sindrom 2, Srpska književna zadruga, Beograd, 1994.

- Stojanović, Milena: Pogled na piščev radni sto (okviri novog čitanja), (Biblioteka Hrestomatija), Mali Nemo, Pančevo, 2006.

- Vojinović, Vladimir: Usmena književnost $i$ savremena crnogorska pripovijetka, Fakultet za crnogorski jezik i književnost, Cetinje, 2014.

\section{Sanja VOJINOVIĆ \& Marko DRAGIĆ}

\section{IMPORTANCE OF TRADITION IN MIRKO KOVAČ'S PROSE}

Oral literature and traditional culture are of paramount importance in the oeuvre of Mirko Kovač. In this paper, the motifs of oral literature and tradition in Mirko Kovač's prose are discussed. The prose of Mirko Kovač reflects religious (Orthodox / Catholic tradition - religious rituals, church, holidays) as leitmotifs in his novels and short stories; historical tradition true and mythical notions that exist about historical events in the geographic destinations and events in his prose works (mostly in Herzegovina) and folk (rural traditions), which are different or distinctive from one place to another in the specified geographical area. The tradition is reflected in the postmodern procedure and poetics of Mirko Kovač. On the other hand, the motif structure of Mirko Kovač's prose is based on elements of traditions, legends, anecdotes, customs, rituals, processions, divination and beliefs.

Key words: oral literature, tradition, Post-Modernism, motifs 



\section{Milorad NIKČEVIĆ (Osijek)}

UDK 821.163.4(497.16:497.5).09

Pregledni rad

Fakultet za crnogorski jezik i književnost - Cetinje

mnikcevi@ffos.hr

\section{TEORIJSKO-METODOLOŠKE REFLEKSIJE O KNJIŽEVNOJ TRADICIJI I TEORIJI LITERARNIH / KULTUROLOŠKIH UTICAJA, VEZA I ODNOSA}

U ovome radu autor donosi filološka razmišljanja, teorijsko-metodološke refleksije kako bi određene savremene književne pojave bile sagledane, određene i odmjerene ,prema tradiciji“, su/odnosno prema drugim književnostima, u kontaktnim (južnoslovenskim) i ostalim istočno i zapadnoevropskim književnim tradicijama.

Ključne riječi: komparatistika, literarni uticaji, metodologija, književna tradicija, crnogorska književnost, hrvatska književnost

U novije vrijeme na filološkim i slavističkim skupovima sve se više, kao prve i značajne teme, nameću problemi jezičkih, književnih i kulturoloških veza.

Još je poodavno ruski slavista В. М. Жирмуновски u studiji Проблемы сравнительно-исторического изучения литературы/ Bзаимосвазы и взаимодействые национальных литератур ${ }^{1}$ izrekao dalekosežnu komparativnu misao:

Nijedna velika nacionalna književnost nije se razvijala izvan žive i stvaralačke saradnje s književnostima drugih naroda, pa zato oni koji misle da uzvise svoju vlastitu (nacionalnu - prim. M. N.) književnost tvrdeći za nju da je uzrasla isključivo na mjesnom lokalnom tlu, ne osuđuju je samo tim činom na 'sjajnu izolovanost', nego na provincionalnu ograničenost i učaurenost ${ }^{2}$.

\footnotetext{
1 Akademija nauk SSSR, Moskva 1961. Up. i knjigu A. С. БУШМИНА, Методологические вопросы литературоведеческих исследований (posebno VII. poglavlje knjige „Преемственость“, Lenjingrad, 1969).

2 Prijevod teksta s ruskoga jezika je naš.
} 
U stvari, i sām sam u nekoliko svojih poredbenih knjiga o tom problemu prozborio. Tako sam u knjizi Komparativna filološka odmjeravanja, ${ }^{3}$ upoređujući različite literarne i jezičke modele spoznao:

Sve nacionalne književnosti, i po jeziku i po tipologiji kao takve, opstoje samo kroz jedinstvo općeg (zajedničkog) i posebnog (vlastitog), $u$ vidu koegzistencije i uzajamnosti nacionalnih, interkulturalnih, multinacionalnih i drugih sadržaja, koje čine dijalektičko jedinstvo mozaičke raznolikosti kao uvjet geneologije nastanka i razvitka. To predstavlja osnovnu dinamičku, pokretačku snagu, napretka svake literature i kulture. Riječju, bez suodnosa posebnog $i$ općeg, induktivnog $i$ deduktivnog, kontaktne kulture (...) bile bi amorfne, mrtve i nepokretne! Međusobno uzajamno interkulturalno djelovanje u dvjema (pa i više!) literaturama odvija se, to jest interferira se (razvija se) kroz dva svoja evidentna vida: a) primanja i b) davanja, to jest u oblicima (recepcije), $i$ emisije (referencije) raznih sadržaja (stimulansa): tematsko-motivskih, jezičnih, historijskih, arhetipskih, geografskih, filozofskih, religijskih, folklornih, etnoloških, etnografskih, regionalnih, socio-psiholoških, pedagoških, privrednih... i slično (...). ${ }^{4}$

I u mojoj nešto ranije objavljenoj knjizi Na civilizacijskim ishodištima (književni suodnosi i interferencije) $)^{5}$ našlo se u tematu dvanaest studija koje po svojoj metodološkoj fizionomiji spadaju takođe u oblast poredbenih proučavanja, kako to i podnaslov kaže, suodnosa i interferencija hrvatske i jednim dijelom onih kulturnih i civilizacijskih tekovina koje su uzrijevale na mediteranskom prostoru Boke Kotorske i dalmatinskom arealu. I u tim tematskim sadržajima usredsredio sam se na komparatističko, međusobno književnoistorijsko i književnoteorijsko komuniciranje književnosti s književnim modelima kontaktnih naroda, arhetipskim mediteranskim prostorom, pa i šire s evropskom literaturom. ${ }^{6}$ Tada sam u „Predgovoru“ istoimene knjige eksplicite

Osijek - Cetinje, 2006,

4 Milorad Nikčević, Komparativna filološka odmjeravanja, Cetinje - Osijek, 2006, str. 148.

5 Milorad Nikčević, Na civilizacijskim ishodištima (književni suodnosi i interferencije), CKD „M-M“, Osijek, 1999, $280+2$ str.

6 U terminima komparativan/komparatistički postoji određena distinkcija. Rječnik stranih riječi dr. Bratoljuba Klaića (Zora, Zagreb 1958, str. 658) donosi tumačenje samo za termin komparativan $=$ usporedan, poredbeni, uspoređujući, sravnjavajući. Za isti termin Leksikon Jugoslavenskog leksikografskog zavoda, Zagreb 1974, str. 364. nudi se obrazloženje: poredben, usporediv s drugim sličnim pojavama ili pojavama drugih područja. Simeonov višejezični Enciklopedijski rječnik lingvističkih naziva, Zagreb 1969. ove pojmove ne razrješava. On termin komparatistički uopšte ne spominje, mada uz upotrebu termina kompa- 
istakao da se jedino kroz takvu analitičko-književnu i kritičku optiku komparatističkog izučavanja određenih književnih modela mogu razotkriti i izučiti određeni književni relikti; mogu se razotkriti fenomeni nacionalnih literatura, dakle u slojevitoj komparatističkoj strukturi koja je uvijek integralna. ${ }^{7}$ Otuda mi se čini i važnost takvog metodološkog pristupa jezicima i literaturama.

$\mathrm{Na}$ istoj vertikali odnosa i interferencija utemeljio sam poodavno i institucionalni projekat pod prvobitnim naslovom Jezici $i$ kulture $u$ doticaju $u^{8}$ koji je započet prije dvije decenije (još 1994. godine), a koji se potom nadodao u široj naslovnoj varijaciji Kulture u doticaju: stoljetne hrvatske i crnogorske veze (komparativni kontekst) ${ }^{9}$ te u sadašnjem trenutku pod naslovom Stoljetni hrvatski i crnogorski književno-kulturni identiteti (interdisciplinarni komparativni kontekst $i$ status). Obrazlažući projekat u njemu sam još konstatovao: ni jedna nacionalna kultura ne nastaje u izolaciji, duhovnom vakumu, već se razvija $u$ susretima, interferencijama, suodnosima i prožimanjima, kako narodā tako $i$ njihovih interkulturalnih jezičnih $i$ književnih veza $i$ modaliteta. ${ }^{10}$ Plodotvorni kulturni stvaralački kontakti i poticaji su intenzivni naročito kad nastaju u

rativan daje brojne naznake iz drugih naučnih oblasti poput: komparativna akcentuacija, komparativna čestica, komparativni instrumental, komparativna fonetika, komparativna tvorevina itd. Stručnjak koji komparira jeste komparatist, a nauka koja se bavi poređenjem jeste komparativistika. Prema tome, termini komparatistika/komparatistički, koji su sve više u opticaju književne i jezične prakse, s gledišta nauke o jeziku su donekle ilegalni. Najpotpuniji prikaz komparativne književnosti pruža ipak Rječnik književnih termina Instituta za književnost i umetnosti u Beogradu, Nolit, Beograd, 1985, str. 366. U njemu se, između ostalog, navodi da je komparatistika „književnoistorijska i književnokritička disciplina koja se bavi izučavanjem književnosti pomoću poređenja jednog djela, autora ili književnog pokreta sa drugim, ponajprije izvan granica jedne nacionalne kulture, kao i poređenjem književnosti sa dugim sferama ljudskog izražavanja (sa likovnim umjetnostima, muzikom, istorijom, filozofijom i drugim)“". U svojim radovima termine komparativan/ komparatistički upotrebljavam ponajprije, kao i mnogi drugi komparatisti, onako kako ih je obrazložio Ivan Slamnig u studiji „Nacionalna literatura i komparatistika“ u knjizi Disciplina mašte (Zagreb, 1965), u kojoj on strogo distingvira komparatistički postupak „kao bitni postupak ispitivanja odnosa između posebnih, različitih, nacionalnih književnosti od postupaka literarne komparacije (paralele) koja je u funkciju uspoređivanja u okviru iste nacionalne književnosti“.

7 Up. Milorad Nikčević, Na civilizacijskim ishodištima (književni suodnosi i interferencije), str. 10.

8 U okviru tog projekta bilježe se sljedeći rezultati: Pola milenija Crnojevića štamparije, Zagreb 1994. (knjiga sažetaka); Pola milenija Crnojevića štamparije, Zagreb 1996 (zbornik radova); „Peroj / Istra - u prošlosti i sadašnjosti (zbornik radova)“, Tabula, br. 2, Filozofski fakultet, Pula, 2000. i drugi.

9 Finansira ga Ministarstvo znanosti Republike Hrvatske s određenim saradnicima i konsultantima iz RH i RCG, a glavni istraživač i redaktor je prof. dr. sc. Milorad Nikčević.

10 Up. Milorad Nikčević, „Predgovor“: u Odsjaji kultura (Hrvatska i crnogorska kultura stoljećima), CKD „M-M“ \& HCDP „C-M“, Zagreb, MMII (2002), str. 9-10. 
sličnim istorijskim i arhetipskim okolnostima, kulturnim uslovima i etnički i teritorijalno bliskim narodima. Oni su uvijek interaktivni i u onim literaturama koje su, manje ili više jedna od druge prostorno udaljene, ali imaju slične prirodne istorijske razvojne sudbine i uslove istovjetnog života i duhovnog razvoja. ${ }^{11}$ Pobliže kazano, u novije vrijeme brojni kulturolozi, književni povjesničari, književni teoretičari i jezikoslovci smatraju da je od svih književnih i filoloških sistema poredbeni problemski sistem (metod - prim. M. N.) najbliži prirodi kulturnih pojava ${ }^{12}$. Zapravo, u želji da se razotkrije djelo, to jest slojevitost književnog teksta, bar dio značajnih komponenti i pojedinosti, potrebno je tekst djela postaviti u svjetlost teorije uticaja i komparacija, bolje reći u svjetlosti teorije interferencija, susreta i suodnosa s književnim djelom ili pojavom nekoga drugog kanonskog stvaraoca, ${ }^{13}$ ili same pojave u određenoj stilskoj formaciji. Ovo ponajprije što reprezentativna književna djela, bez obzira na to jesu li nastala u prošlosti i (ili) u savremenosti (sadašnjosti) ${ }^{14}$, sintetizuju ne samo

11 Isto.

12 Jovan Deretić, Poetika Dositeja Obradovića, Vuk Karadžić, Beograd, 1974, str. 10. Misli se ovđe na sljedeće sisteme: dogmatsko-reproduktivni, pozitivistički, sociološki, psihološki, marksistički, teoriju interpretacije, fenomenološki, komunikaciono-informativni, heremeneutički, strukturalistički, eksplikacijski, psihoanalitički, estetsko-recepcijski, formalističku rusku školu, novu kritiku, semiotički, postmodernistički i slično.

13 Poredbeni je metod moguć, kao što smo istakli, i u okviru iste nacionalne literature posebno kad se porede kanonski pisci. To smo uostalom dokazali u poredbenoj knjizi Transformacije i strukture (Književne i metodičke studije), NIRO Školske novine, knj. 3, Zagreb 1984. Pratili smo poredbeno književno djelo dvaju pisaca, kroz dva korpusa: I. Ljubiša i Njegoš: književnoistorijske paralele, uzori i nadahnuća i II. Njegoševo djelo - izvor Ljubišinih tema, motiva i inspiracija. U ovoj smo knjizi studiozno analitički, komparativno i sintetički iscrpili odnos Ljubiše i Njegoša, detaljno proučili njihovu književnu tradiciju, odnos prema usmenoj književnosti, odnose dvojice pisaca kroz imanetne postupke i pokrenute probleme: „Uvodna metodološka razmatranja; Ljubišina prva saznanja o Njegošu“; „Stefan Mitrov Ljubiša u svijetu 'Gorskog vijenca'“ (I. dio); „Transformacijski tragovi epskog pjesništva i Njegoševih strukturalnih elemenata u poetsko-narativnom opusu Stefana M. Ljubiše“; „Ljubišina originalnost usprkos uticajima (Tematološki i motivski susreti, dodiri i prožimanja Njegoševa i Ljubišina djela Lažni car Šćepan Mali)“; „, Transformacijski nivoi usmene i pisane književnosti u djelima Petra II. Petrovića Njegoša i Stefana M. Ljubiše“ te na koncu: „Koherentnosti, susreti, dodiri i prožimanja tematsko-motivskih svjetova Stefana M. Ljubiše i Petra II. Petrovića Njegoša“" (II. dio). Sve je to popraćeno naučnom aparaturom, brojnim izvorima i bilješkama te korišćenom literaturom.

14 Termini „savremenost“, „savremena književnost“ u značenju sa terminom „svjetska književnost" često se koriste u svakodnevnom žargonu, ali daleko više u nauci o književnosti. Njihovo semantičko značenje nije nejasno: „savremena književnost“ shvata se najčešće kao književnost istorijskog razdoblja u kojem živimo, pobliže kao razdoblja književnosti nakon Drugoga svjetskog rata. „Svjetska književnost“, i pored mnogih pluralnih određenja, najčešće se smatra književnošću cijeloga svijeta za razliku od književnosti pojedinih književnosti nekih zemalja i naroda. Kad kažemo 'suvremena književnost'zacrtali smo, dakle, neke osnovne okvire književnosti u vremenu i prostoru; tim bi se nazivom mogla 
beletrističku i poetsku pisanu i usmenu tradiciju, jezičku tradiciju, a povezanost pisca s književnom (i jezičkom - prim. M. N.) tradicijom je moment koji se ne sme zaobići u književnim istraživanjima. ${ }^{15}$ Takvi pisci i djela anticipiraju, dakle, zavičajno (lokalno), univerzalno (nacionalno), klasično (tradicijsko) i moderno (avangardno), a naposljetku tradiciju sveukupne savremene književne i jezičke estetike. U takvom modelu proučavanja obrasci nacionalne književnosti ne smiju biti zatvoreni u nacionalne okvire, ali isto tako oni ne mogu postojati izvan nacionalnih granica. Prof. Aleksandar Flaker, jedan od istaknutih komparativista slovenskih jezika i književnosti, kaže da je ,uspoređivanje temelj svake znanosti“, a komparatistiku definiše kao zbir postupaka kojima se upoređuju dvije ili više nacionalnih književnosti, no nužno je i legitimno pri tome ne napustiti „krug nacionalne književnosti““. ${ }^{16}$ Svakako da tu Flakerovu zgusnutu definiciju komparativne književnosti možemo prihvatiti, ali moramo još jednom naglasiti $i$ to da se u takvom modelu nipošto ne brišu identiteti nacionalnih književnosti (narodnosno, nacionalno i jezičko) ${ }^{17}$, nego naprotiv: oni su (identiteti - prim. M. N.) osnova za poredbeno proučavanje književnosti u doticajima! Književnosti se upravo mogu upoređivati po određenim modelima, tipološkim i jezikoslovnim vrstama jer postoje različite tradicije i različite nacionalne književnosti i jezici. Razlike su jednako važne kao i sličnosti. Tek kad se djelo razmotri svestrano - komparativno, u odnosu prema književnoj i jezičnoj tradiciji i drugim oblicima i temama usmenog i pisanog stvaralaštva te cjelokupne tradicije i kulture, doći će se do pouzdanih sinteza i zaključaka o određenoj pojavi, o razdoblju, poetici, školi i tendenciji, o stvaraocima pisane riječi, o genezi, nacionalnoj pripadnosti pisaca, ${ }^{18}$ prirodi i tipologiji njihove umjetnosti riječi.

naznačiti književnost čitavog svijeta nakon drugog svjetskog rata. [...] 'Suvremena svjetska književnost' upućuje tako na brojne probleme, s kojima se susreće proučavanje suvremene književnosti shvaćene šire od jedne ili tek nekoliko nacionalnih književnih tradicija. Viđeti: Milivoje Solar, „Proučavanje suvremene književnosti“ u: Suvremena svjetska književnost, Školska knjiga, Zagreb, 1982, str. 7-8.

15 Jovan Deretić, Poetika Dositeja Obradovića, Vuk Karadžić, Beograd, 1974, str. 10.

16 Up. „Diskusija“, Gesta, br. 29, 30 i 31, Varaždin, 1998, str. 232.

17 Up. uvodni referat Vojislava P. Nikčevića, Narodnosna, nacionalna i jezička identifikacija crnogorske književnosti, Knjižica sažetaka, Nikšić, 2005, str. 5-6.

18 U sklopu tih složenih proučavanja nametnulo se i pitanje utvrđivanja nacionalne pripadnosti pojedinih istaknutih i kanonskih pisaca: Petra II Petrovića Njegoša, Vladana Desnice, Meše Selimovića, A. B. Šimića, Iva Ćipika, Sima Matavulja i dr. Na površini tih pitanja ponajčešće se reflektovao duh ekskluzivnog nacionalizma i nacionalističkog ,perspektivizma“. Nešto mirnije tonove u cijelom tom sporu pokušala je unijeti redakcija Enciklopedije Jugoslavije koja je nastojala utvrditi hijerarhijski kriterijum za određivanje pripadnosti pojedinih pisaca određenoj nacionalnoj tradiciji. Utvrdili su pet elemenata: 1) djelovanje pisca u krug određene nacionalne kulture, 2) jezički kriterijum (upotreba jezičke varijante i jezičkog idioma), 3) nacionalno porijeklo pisca, 4) izjava pisca o pripadnosti određenim književnim korpusima, 5) tematika i vezanost pisca za određenu teritoriju. U pojedinim 
I na koncu da zaključim: danas je aktuelan trenutak usredsređivanja filološke nauke na interkulturalne veze, odnose s literaturama, jezičkim i kulturnim modelima naroda u okruženju. Na taj se način uspostavlja zajednički interkulturalni kontekst i međusobno komuniciranje i interferiranje različitih pojava. Stoga je u ovom času potrebno detaljnije prozboriti s teorijsko-metodološkog aspekta upravo o književnoj tradiciji i o teoriji literarnih/jezikoslovnih i kulturoloških uticaja, veza i odnosa. Dakle, evropski književni kontekst postaje poprište za recepciju pobuda koje dolaze iz duhovnih sredina istočnoevropskoga i zapadnoevropskoga književnog kruga. Ograničenja na kulturama u kontaknosti, na jugo-istočni-evropski mikro rejon, naučno je opravdan samo zbog kulturološke (tipološke - prim. M. N.) sličnosti, zasebnosti i specifičnosti kontinuiteta, ali književni istraživači trebaju imati na pameti da je potpuni i sveopšti uvid u stvari moguć isključivo sa uspostavljanjem cjelokupnog (i svjetskog) makro-kontakta - 'europski i svjetski aspekt', kako kaže prof dr. sc. Joža Pogačnik. ${ }^{19}$

slučajevima (Ivo Andrić, Meša Selimović) takav koncept kriterijuma nije bio dovoljan. Složenost takvog modela ponajviše se odnosio na Njegoša. Stoga je redakcija ponudila „dvojnu pripadnost“ pisca. Međutim, mišljenja smo da se problem time samo dublje radikalizovao. Možemo li tako npr. zamisliti da rumunska književnost prisvoji E. Joneska koji je porijeklom Rumun, koji je čak počeo pisati svojim maternjim jezikom, ali je cijelo svoje djelo ostvario na drugom (engleskom i francuskom) jeziku. Slično je i s engleskim romanopiscem Dž. Konradom, ukrajinskim Poljakom - Todorom Jozefom Korzenijovskim, čije „književno izručenje“ zasigurno ne traže Poljaci. Iako ovaj problem zaslužuje posebnu teorijsku i praktičnu studiju, čini mi se da je najbolji koncept u tom trenutku ponudio književni komparatist Aleksandar Flaker u knjizi Poetika osporavanja, Zagreb, 1982, kad je utvrdio da je trenutak da se konstituisanje nacionalne literature mora vezati za tradicijsku vertikalu „u kojoj se mora naći sve što je s aspekta toga trenutka za konstituiranje relevantno“. Njegošev Gorski vijenac (1847), ako ga iščitavamo neopterećeno „objektivno je temeljni tekst o koherenciji crnogorskoga naroda i crnogorske kulture, pa se zbog toga opravdano našao u središtu suvremene pažnje Crnogoraca“. Isti autor citata Jože Pogačnik (Teme $i$ dileme, str. 128) dodaje da je zbog takvoga saznanja i sam J. Vidmar mislio upravo na takvu homolognost kad je prilikom primanja Njegoševe nagrade rekao: Njegoš je Crna Gora, a Crna Gora je Njegoš!, pa nastavio: Ako priznajemo činjenicu o postojanju crnogorske književnosti, onda je slijedeći korak da toj istoj književnosti priznamo i pravo na integralnu obradu svoje kulturne tradicije. Pitanje Njegoša i srpske književnosti na taj se način nameće na posve drugoj razini. Njegoša ima, očito, i u srpskoj književnosti ulogu određene epohalne inicijative o čemu srpska književna historiografija mora raspravljati, ali kod toga se ne smije zaboraviti da je jednaku, i još veću, inicijativu vremenski usporedo s Njegošem dao srpskoj kulturi i J. Kopitar koji svejedno i dalje ostaje - Slovenac - zaključio je Pogačnik.

19 Up. Jiža Pogačnik, „O usporednoj jugoslavistici“ u: Teme $i$ dileme, Mala teorijska biblioteka 20, IC, Revija, Osijek, 1986, str. 118. 
II.

Opredjeljujući se u ovom teorijskom radu za komparativnu i metodološku prezentaciju stvaralačkih dosega i postupka u kontaktnim literaturama, nužno je na ovom mjestu ukazati i na to da ovakav pristup u sebi nosi i brojne opasnosti. Nameću ih takva složena komparativna proučavanja i istraživanja, to jest teorije interferencija, odnosa, uticaja, odraza jednog pisca na drugog. Naime, problem prisutnosti određenih elemenata (književnih i jezičkih), dakle struktura jednog autora u književnom djelu drugog pisca (ili same tradicije) povlači sa sobom neizostavno i pitanje originalnosti, samosvojnosti, autentičnosti, preispitivanje estetičkih i svih drugih stvaralačkih vrijednosti opusa tog drugog pisca. Ili da budem jasniji: postavlja se komparativno-teorijsko pitanje. Je li onaj pisac koji „preuzima“, asimilira određene jezičke, stilske ili neke druge tematsko-motivske i sadržajne elemente, manje nadaren, umjetnički neoriginalan u tolikoj mjeri da se nije mogao vinuti u prostranstva svoje stvaralačke kreacije i imaginacije bez antejske veze s književnim nasljeđem (tradicijom) i piscem u čijem se prostoru i duhovnom horizontu i okruženju razvijao i stvaralački izrastao i uzrijevao?

Mnogi književni proučavaoci, ponajviše komparativisti, u svojim su se teorijskim studijama, diskurzivnim oblicima i teorijskim poredbenim člancima pozabavili tim gorućim problemom. O interferencijama, uticajima i odrazima govorili su mnogo više kao o uticajima i vezama koje prelaze granice nacionalnih jezikâ i nacionalnih književnosti ${ }^{20}$. Međutim, mnogo se manje govorilo i pisalo o uticaju jednog pisca na drugog, pogotovo se malo poredbeno pisalo o onim stvaraocima koji pripadaju istoj nacionalnoj književnosti i istom književno-jezičkom izrazu. A i takva su komparativna proučavanja sasvim danas moguća, kao što smo to pokazali na modelu Njegoš - Ljubiša ${ }^{21}$, i ona su veoma dragocjena i uspješna!

20 O teoriji uticaja, paralela i djelovanja raspravljalo se ponajviše u kontekstu rasprava o komparativnoj književnosti, tj. kao o temi uticaja i djelovanja koja prelaze granice jezika i nacionalnih književnosti. O tome osnovnu informaciju daju djela koja smo velikim dijelom navodili u fusnotama, popisanim izvorima i literaturi ovoga rada. Na ovom mjestu dodao bih još poneku značajniju komparativnu studiju: C. Pichos, A. M. Rousseau, Komparativna književnost, Zagreb, 1973; Z. Konstantinović, „O savremenim teorijama o uporednom proučavanju književnosti“", Uporedna istraživanja, br. 1, Beograd, 1975; „Teorije uticaja, delovanja i recepcije“, Polja, br. 335, Novi Sad, 1987. s uvodnom studijom Miodraga Radovića „Strah od uticaja“, str. 2-3. U vezi s problemom uticajâ uopšte, izvan konteksta uporedne književnosti, pored ostalih književnoteorijskih priručnika, može poslužiti: A. Žid. O uticaju u literaturi, Granice umetnosti, Beograd, 1967, str. 47-64; T. S. Eliot, „Tradicija i individualni talenat" u zbirci njegovih eseja u seriji Književni pogledi, Prosveta, Beograd, 1963.

21 Up. Milorad Nikčević, Transformacije i strukture (književne i metodičke studije), Školske novine, Zagreb, 1982. 
Treba reći da su pojedini komparativisti stali na stanovište da uticaji i odrazi mogu trajno da se reflektuju samo na one nedarovite i nesamostalne stvaraoce koji se najčešće ne mogu „odbraniti od mita tuđe veličine“, od njihove mistifikacije; na one stvaraoce koji nemaju u sebi dovoljno imaginativne snage i talenta da progovore svojim stvaralačkim jezikom i izvornim književnim prosédéom.

Povijest poredbene književnosti pruža više primjera koji mogu ilustrativno pokazati da su se čak i pojedini veliki pisci, izuzetne stvaralačke ličnosti na svom putu sazrijevanja, ugledali na druge, isto tako snažne, genijalne pisce, ali nijesu ostali zarobljeni njihovom stvaralačkom kreacijom; nijesu ostali u sjenci njihove zarobljene poetike, jezika i stila, stvaralačke veličine, već su im oni (stvaraoci) služili samo kao poticaji i(li) uzori kako bi lakše pronašli svoj stvaralački credo, stilsko-jezični put i stvaralački prosédé. ${ }^{22}$ Poznato je, naime, da je ruski romantičarski pjesnik Aleksandar Sergejevič Puškin, prema vlastitom zapisu i priznanju, na „oba uha saslušao učiteljsku riječ Shakespearevu“, ali nije ostao zarobljen njegovim genijalnim duhom, već ga je „njegov snažni talenat rano uputio na svoj vlastiti put" ${ }^{23}$ Isto tako se u svim pregledima istorije ruske književnosti navodi da je taj isti A. S. Puškin davao svojem mlađem savremeniku - romanopiscu Nikolaju Vasiljeviču Gogolju skoro gotove fabule za njegovo izuzetno romaneskno ostvarenje Mrtvih duša (1845), pa ipak je Gogolj, snagom svoga izvornog talenta, upotrebom stvaralačkog jezika, brzo i sigurno zakoračio svojim, sasvim novim, ,gogoljevskim putem“. ${ }^{24}$

I pjesništvo Branka Radičevića, jedno od najliričnijih, najsenzibilnijih i najznačajnijih poetskih ostvarenja srpske romantike, pojedini književni kritičari i povjesničari književnosti vezivali su za „pozajmice“ i stilske formacije

22 Književni istoričar Josip Badalić, autor mnogih studija iz područja uporedne književnosti, koji se najčešće bavio ruskom literaturom prema ostalim slovenskim književnostima, u knjizi Rusko-hrvatske književne studije, Liber, Zagreb, str. 6, piše: Tako je uostalom s cijelim književnostima: njih reprezentiraju i unapređuju samo talenti, bez obzira u čijoj su učiteljskoj atmosferi nikli i uzrasli: ranije ili kasnije oni progovore svojim glasom. Svojim talentom. I zato proučavanje učiteljskog doprinosa, razlučivanje - sine ira et studio - izvornoga od povremenoga ili slučajnom koincidencijom natrunjenoga sa strane valja smatrati, po mome mišljenju, korisnim doprinosom za što tečnije utvrđivanje geneze i zakonitosti razvitka ovog ili onoga književnoga stvaraoca ili čak ukupne nacionalne književnosti.

23 Isto, str. 6.

24 N. V. Gogolj u svojim Autorskim ispovjestima navodi da ga je Puškin nagovorio da napiše roman Mrtve duše. On doslovno kaže: „On me je (Puškin - prim. M. N.) davno nagovorio da se prihvatim nekog opsežnijeg djela (...) i, u zaključku svega, dao mi je sopstveni siže iz kojeg je on (Puškin - prim. M. N.) sâm namjeravao da napravi nešto u obliku poeme, i kojeg, po njegovim riječima, ne bi dao nikome drugom. To je bio siže Mrtvih duša". Viđeti S. M. Florinskoj, Russkaja literatura, UČPEDGIZ, Moskva, 1956, str. 261. Prijevod teksta je naš. 
zapadnoevropske književnosti, prije svega za njemačku i englesku romantiku. Naznačavani su uticaji i odrazi pojedinih francuskih, pa čak ruskih, slovačkih i čeških pjesnika. ${ }^{25}$ No, sve to nije škodilo da i do danas B. Radičevića, zajedno s P. P. Njegošem i drugim, slavimo kao izuzetno talentovanog pjesnika romantike; kao stvaraoca izuzetne jezičko-stilske lakoće, evokativne i umjetničko-suptilne lirske snage, kao krupnu figuru srpske književnosti, neovisnu od „blede i blage zvezde svojih uzora i učitelja“. ${ }^{26}$

Spisak imena pisaca koji su se razvijali u živom stvaralačkom dodiru i spisateljskoj „saradnji“ sa svojim prethodnicima, iz čije su se neposredne tradicije i blizine mogli napajati najraznovrsnijim idejama, gotovo da je neiscrpan. Uz već navedene, mogli bismo istaći i spomenutog Šekspira koji se koristio sižeima što ih je nalazio u pročitanoj literaturi, počevši od antičkih pisaca (recimo Plutarha!), pa sve do svojih savremenika. Aleksandar Dima preuzimao je naprosto motive, ideje i elemente od Valtera Skota i Šilera, a za naturalistu Emila Zolu su pojedini književni istraživači isticali da je opise porođaja u jednom svom romanu doslovno prepisao iz stručnih udžbenika za medicinu. Molijera, V. Skota i mnoge druge osvjedočene klasike su optuživali za „plagijate“, poricali im ponekad i stvaralačko-umjetničke vrijednosti njihovih ranih djela.

O problemu uticaja, teorije djelovanja, odraza, interferencija i pozajmica u književnosti progovorili su mnogi stvaraoci - pisci. Braneći stvaralačku originalnost svojih brojnih djela i naravno svoj odnos prema književnoj tradiciji i savremenicima, najsvestraniji njemački književnik Johan Volfgang Gete govorio je o tome iskreno:

Uvijek se govori o originalnosti, ali što ono znači? Čim se rodimo, počinje svijet na nas utjecati, i tako to ide do kraja. I to svagdje! Pa što i možemo osim energije, snage i volje nazvati svojim! - Kad bih mogao reći, što sve dugujem velikim prethodnicima i suvremenicima, ne bi mi mnogo ostalo.

I tako pjesnik Gete, podstaknut svojim sagovornikom, teoretikom i takođe piscem - Ekermanom, iskreno i jasno nastavlja:

25 Viđeti: Milorad Nikčević, „Paralele i dodiri jedne pjesme Branka Radičevića i Milvoa u svjetlosti dosadašnjih proučavanja“, Književnost i jezik, br. 4, Beograd, 1980, str. 427-436. Isti: „Branko Radičević i Charles Hubert Millevoye“ u: Ideje i paralele (Književni ogledi $i$ studije), Izdavački centar Revija, Osijek, 1984, str. 54-67.

26 Bogdan Popović, „Jedna paralela“, Letopis Matice srpske, knj. 350, sv. za jul, avgust, septembar, Novi Sad, 1935, str. 16. 
Ali ako hoćemo da govorimo iskreno, što je od toga bilo zapravo moje, osim sposobnosti $i$ želje, da vidim $i$ da čujem? Ja svoja djela nipošto ne zahvaljujem samo svojoj mudrosti, nego tisućama stvari i ljudi izvan sebe, koji su mi dali građu za to. Dolazili su mi ludu i mudraci, bistre glave i ograničeni, djeca i mladež, a isto tako i zreli ljudi; svi su mi govorili, kako im je pri duši, što misle, kako žive i rade i kakva su iskustva stekli, a ja nisam trebao ništa drugo učiniti nego samo zagrabiti $i$ požeti, što su drugi za mene posijali (...). ${ }^{27}$

U nastojanju da dokučim bar djelimično teoriju uticaja, susreta, komparacija, odraza i djelovanja, upravo da pokažem kako tuđa misao, jezička iskra, ideja, reminiscencija može da bude podsticaj, bljesak i začetak, stvaralačka klica neke druge misli, pasaža ili epizode drugog pisca, citiraću savremenog hrvatskog pjesnika moderne Vladimira Nazora. Njegove su se teorijske premise probile u stihovnu formulaciju pjesme Plagijati:

Ja ne gazim sjeme što ga vjetar nosi

u moj usjev; ja ga puštam neka zrene

u plamenu moga srca i u rosi

moga znoja. Rast će, kao da je od mene. ${ }^{28}$

Prema tome, veoma su rijetki i osamljeni u literaturi oni stvaraoci koji ne duguju nešto svojim prethodnicima, svojim omiljenim stvaraocima, svojoj duhovnoj i jezičkoj tradiciji, bez obzira na to jesu li ti stvaraoci djelovali i pisali u prošlosti ili sadašnjosti, to jest - savremenosti. Stoga je o savršenoj umjetničkoj čistoći i potpunoj autentičnoj samosvojnosti i originalnosti nemoguće govoriti, čak i u slučaju onih pisaca koji su svojom estetskom snagom i izrazom jezika označili najveće književne vrhove, stožere književnosti, koji su „bilježili raskršća književnih i stilskih epoha“, razdoblja, škola, pravaca ili tendencija.

Kad se sve ovo uopšteno sagleda i uporedi, bilo koje savremeno i značajno djelo, odmjereno u sklopu svih ovih teorijskih rasprava, koherentno-interferentnih dodirnosti, uticaja i paralela s književnim tvorevinama $u$ kontaknosti naroda, a naposljetku s djelima evropske književne tradicije, možemo sasvim sigurno zaključiti: nije važno tragati za onim strukturnim

27 Eckerman Johann Peter, Razgovor s Goetheom, Izbor, Zora, Zagreb, 1950, str. 37.

28 Vladimir Nazor, „Plagijati“, u: Na vrhu jezika i pera, Hrvatsko izdavački bibliografski zavod, Zagreb, 1942, str. 165. Nazor je prevodio italijanske savremenike i često mu je književna kritika „spočitavala da je pojedine prevodilačke segmente i poetske slike utkivao" u svoje pjesničko djelo. 
elementima određenog pisca koji je eventualno „uticao“ na svog poklonika i savremenika. Mnogo je važnije za literaturu utvrditi jesu li određeni elementi, koji su evidentni, možda prepoznatljivi kao strukture mikro i makro uticaji, stvaralački dovedeni u tipološko-funkcionalne i estetske skladnosti, stvaralačke odnose, to jest da li se oni javljaju u funkciji izgrađivanja umjetničkih vizija o svijetu i životu pisca. Zapravo, u prosuđivanju svijeta nekog zrelog djela i nevažno je ispitivati podśeća li nas nešto jedno na drugo i jesu li vidni idejni i tematski uticaji i sličnosti s ovim ili onim piscem i(li) pojavom; je li taj pisac preuzimao pojedine misli, slike, postupke u karakterizaciji likova, pasaže i digresije, jezičke obrte i reminiscencije od svojih prethodnika i književne tradicije ili nekog svog velikog i nezamjenjivog uzora. Za komparatistiku i nauku o književnosti je mnogo važnije ispitati i utvrditi, kako to ističu mnogi poredbeni proučavaoci, koliko se jedan pisac, koji se razvijao u snažnom i živom dodiru sa svojom književnom tradicijom, uzornim piscima svog vremena, a posebno $\mathrm{s}$ duhovnom tradicijom naroda $\mathrm{u}$ kontaktnosti, antičkom i evropskom tradicijom, ${ }^{29}$ uspio osloboditi tih veza i uzora. Riječju, utvrditi koliko mu je pošlo za rukom da snagom svoje tvoračke imaginacije svoj umjetnički izraz oslobodi i svijet svoje poetike natopi individualnim doživljajem i stvaralačkom kreacijom, da se unutrašnjim bogatstvom svoga stvaralačkog jezika i svojih sadržajnih djela, njihovih poruka, vine do opšteljudskih i svevremenskih - trajnih dosega i ljepota. Prisustvo naslijeđenog bogatstva tradicije ośećao je, kako smo to viđeli, gotovo svaki pisac, neki više a neki manje. Međutim, njen udio u djelu je, u zavisnosti od toga u kolikoj je mjeri pisac, snagom svoga talenta, uspijevao da taj uticaj i djelovanje tradicije prevlada, bolje reći da stvaralački transformiše u nov estetički kvalitet, da se uputi stazama svoje autohtone umjetnosti riječi.

Eto, u svim ovim misaonim relacijama prolegomene ove teme kretala su se moja filološka razmišljanja, teorijsko-metodološke refleksije kako bih određene savremene književne pojave sagledao, odredio i odmjerio ,prema tradiciji“, su/odnosno prema drugim književnostima, kako u kontaktnim (južnoslovenskim) i ostalim istočno i zapadnoevropskim književnim tradicijama.

29 Dr Jovan Deretić u knjizi Poetika Dositeja Obradovića, str. 18. izričito kaže: Proučavanje konkretnih izvora i uticaja samo je prvi korak u ispitivanju jednog šireg kompleksa pitanja koje obuhvataju piščev dug prema tradiciji (...). Ispitivanje te dublje, ne uvek lako odredive povezanosti dela sa književnom tradicijom, predstavlja, uz tumačenje samog dela, najvažniji zadatak književnosti. 


\section{Literatura}

- Badalić, Josip: Rusko-hrvatske književne studije, Liber, Zagreb 1972.

- Deretić, Jovan: Poetika Dositeja Obradovića, Vuk Karadžić, Beograd, 1974.

- Eckerman, Johann Peter: Razgovor s Goetheom, Izbor, Zora, Zagreb, 1950.

- Eliot, T. S.: „Tradicija i individualni talent“ u: Književni pogledi, Prosveta, Beograd 1963.

- Florinskoj, S. M.: Russkaja literatura, UČPEDGIZ, Moskva 1956.

- Grupa autora, Rječnik književnih termina Institut za književnost i umetnost u Beogradu, Nolit, Beograd, 1985.

- Konstantinović, Zoran: „O savremenim teorijama o uporednom proučavanju književnosti“, Uporedna istraživanja, br. 1, Beograd, 1975.

- Milorad Nikčević, Komparativna filološka odmjeravanja, CKD „M - M“, Osijek, 1999.

- Nazor, Vladimir: „Plagijati“ u: Na vrhu jezika i pera, Hrvatsko izdavački bibliografski zavod, Zagreb 1942.

- Nikčević Milorad: „Paralele i dodiri jedne pjesme Branka Radičevića i Milvoa u svjetlosti dosadašnjih proučavanja“, Književnost i jezik, br. 4, Beograd, 1980.

- Nikčević, Milorad, Transformacije i strukture, NIRO Školske novine, knj. 3, Zagreb, 1984.

- Nikčević, Milorad: „Branko Radičević i Charles Hubert Millevoye“ u: Ideje i paralele (književni ogledi i studije), Izdavački centar Revija, Osijek, 1984.

- Nikčević, Milorad: „Predgovor“ u: Odsjaji kultura (Hrvatska i crnogorska kultura stoljećima), CKD „M-M“ \& HCDP „C-M“, Zagreb, MMII (2002).

- Nikčević, Vojislav P.: „Narodnosna, nacionalna i jezička identifikacija crnogorske književnosti“" u: Knjižica sažetaka, Nikšić, 2005.

- Nikčević, Milorad: Komparativna filološka odmjeravanja, CKD „,M - M“, Osijek - Cetinje, 1999.

- Pogačnik, Jiža: „O usporednoj jugoslavistici“ u: Teme i dileme, Mala teorijska biblioteka 20, IC, Revija, Osijek, 1986.

- Popović, Bogdan: „Jedna paralela“, Letopis Matice srpske, knj. 350, sv. za jul, avgust, septembar, Novi Sad 1935.

- Radović, Miodrag: „Strah od uticaja“, Polja, br. 335, Novi Sad, 1987.

- Simeonov, Rikard: Enciklopedijski rječnik lingvističkih naziva, Zagreb 1969.

- Slamnig Ivan: „Nacionalna literatura i komparatistika“ u: Disciplina mašte, Zagreb, 1965.

- Solar, Milivoj: Suvremena svjetska književnost, Školska knjiga, Zagreb, 1982. 
- Žid, Andre: O uticaju u literaturi, Granice umetnosti, Beograd, 1967.

- БУШМИН А.С.: Методологические вопросы литературоведеческих исследований, Lenjingrad, 1969.

- Жирмуновски В. М: Проблемы сравнительно-исторического изучения литературы/ Взаимосвазы и взаимодействые национальных литератур Akademija nauk SSSR, Moskva 1961.

\section{Milorad NIKČEVIĆ}

\section{THEORETICAL-METHODOLOGICAL REFLECTIONS ON LITE- RARY TRADITION AND THEORY OF LITERARY / CULTUROLO- GICAL INFLUENCES, RELATIONS AND CORRELATIONS}

The author of the present paper compares different literary and language models, concluding, while referring to his book entitled Comparative Philological Studies, that all national literatures, defined as such on the basis of their language and typology, survive only through the unity of general (common) and special (own), in a coexistence and mutual cohabitation of national, intercultural, multinational and other contents, making up a dialectal unity out of diversity as a precondition for creation and development.

Key words: literary tradition, theory of literary / culturological influences, comparative studies, Montenegrin literature, Croatian literature 

UDK 821.163.4.09:1 Petrović Njegoš P. II

Pregledni rad

\title{
Sreten ZEKOVIĆ (Cetinje)
}

emplusctagmail.com

\section{JE LI NJEGOŠEVA MUDROST EKLEKTIKA, SINKRETIZAM, ZVANIČNO HRIŠĆANSTVO I U SLUŽBI KONZERVATIVNOG STAROG PORETKA?}

\begin{abstract}
U ovoj studiji se opovrgavaju noviji pokušaji svođenja Njegoševe poetske mudrosti na eklektiku i sinkretizam, na tvrdnju da je njegova religija hrišćanska poslušnost crkvi, ortodoksija hrišćanske teologije, njegov Bog „kršćanski Bog“, da je apologet carizma i u službi konzervativne „restauracije staroga poretka". U opovrgavanju navedenih tvrdnji ističe se jedinstveno ucjelovljena originalna Njegoševa poetska filozofija slobode da je njegova religija i teologija ne samo sasvim ,jeretična“, no i u gotovo svim bitnim elementima i protivna zvaničnom hrišćanstvu, učenju crkve, hrišanskom bogu i da je u službi afirmacije crnogorske „borbe neprestane“ za slobodu i međunarodnoga priznanja stvarne nezavisnosti Crne Gore.

Ključne riječi: Njegoševa originalnost, zloupotreba sinkretizma, Bog stvara „po zakonu prirode“, „,nevidljivi“"strukturalni odnosi elemenata u (o)kretanju
\end{abstract}

Više spisatelja s pravom su isticali jedinstvenost $i$ originalnost Njegoševog poetskog kosmosa, ${ }^{1}$ nasuprot onih koji ga olako, površno, istrgnuto iz cjeline njegova poezisa, ocjenjuju kao eklektika i sinkretizam u negativnom (zloupotrijebljenom) značenju ovoga termina i pojma. ${ }^{2}$ Među novijim (aktuelnim) je i neuspjeli pokušaj dr Željka Uvanovića u Izvorna religionzna poezija

1 Ovaj rad pretpostavlja tekst od istog autora ,Jedinstveno ucjelovljena originalna Njegoševa poetska filozofija slobode“, Matica, 2015, Podgorica - Cetinje.

2 Izraz (grč. syinkretizmos - ujedinjenje) koji su prvi koristili Pico de Mirandola, Bessarion i drugi, kad je iznova procvala klasika. Tada se naročito proučavao Platon kojeg su suprotstavljali dominantnom Aristotelu. Svoje nastojanje da sjedine ova dva filozofska sistema nazvali su sinkretizmom. Radi toga se svaki, često i nekritički, pokušaj da se različite filozofije, gledišta, mitovi sjedine u cjelinu naziva sinkretizmom, koji je gotovo sinonim za neoriginalnost $i$ eklekticizam. 
i prepjevi Petra II. Petrovića Njegoša i Ivana Mažuranića u kontekstu njemačke književnosti. ${ }^{3}$

Analizirajući Njegoševe „religiozne pjesme“ Ž. Uvanović kaže: „Radi se o duboko proživljenoj ekstazi susreta s kršćanskim Bogom“. Postavlja, kako sam kaže, „,barem glede Njegoša provokativnu hipotezu: on je crnogorski Helderlin, koji po pitanju motiva i gradiva za svoja djela u stihu na način klasičara koristi riznicu grčke i rimske antike, ali u svojem svjetonazoru u konačnosti zastupa romantizirano, gnostičko, heretičko, heterodoksno hrišćanstvo“. Uvanović dalje nastavlja da „to hrišćanstvo on poslušno zaodijeva u ruho ortodoksne teologije“, te se i u tom aspektu nadovezuje na „bidermajerski stil života i način reagiranja na političke i društvene probleme". ${ }^{4}$ Postavlja navodno provokativnu, a u stvari predodređujuću pretpostavku u formi pitanja kojom potvrđuje i sam njezin ishod i odgovor navodne upitnosti: „može li književnik u svojoj umjetnosti i javnom djelovanju zastupati sintezu klasicizma i romantizma, pa možda i bidermajera - bilo da kao predstavnici tzv. 'manjih' europskih književnosti koje kaskaju za vodećima svjedoče o eklekticizmu i sinkretizmu". Bez dosega do suštinske cjelovitosti i originalnosti Njegoševe pjesničke mudrosti, Uvanović je završno zaključio ono što je na početku ,postavio kao provokativnu hipotezu“: „Konačno, Njegoš kao da je protiv 'sotonske' ideje jednakih prava, protiv sotonine revolucije u nebu - 'da imamo svi jednaka prava', (4. pjevanje, stih 90). Napoleon, Cezar i Aleksandar Makedonski (u anagramskoj verziji svojih imena) definirani su kao otpadnici od božjeg poretka (4. pjevanje, stih 201-202). I u Luči mikrokozma Njegoš je, zapravo - kao pristaša bidermajerskog (baroknog) konzervativizma - za uspostavu staroga božjeg poretka, za restauraciju tradicije i 'svete', 'božanske' hijerarhije“. ${ }^{5}$

Navedeni rad Željka Uvanovića u cjelini ima intonaciju, podtekst i izričiti naum da u paraleli sa Ivanom Mažuranićem ublaži Njegoševu veličinu u odnosu na ovog hrvatskog ilirca, smještajući ih u kontekst „klasicizma, romantizma i bidermajera (u smislu književnosti konzervativne restauracije, bez komponente buntovne književnosti Mlade Njemačke!)“". ${ }^{6}$

Već u samom naslovu ovoga svog rada i citiranim pretpostavkama, Uvanović implicira šest bitnih apriornih (neupitnih) pretpostavki kao tvrde postulate, iako su temeljno problematični: 1. iz cjelokupne jedinstvene Njegoševe poetične mudrosti iščupava, istrgava i izoluje se njegova religiozna

U: Ivan Mažuranić (1814-1890), HCDP „Croatica - Montenegrina“, CKD MontenegroMontengrina u Osijeku \& Institut za crnogorski jezik i jezikoslovlje „Vojislav P. Nikčević“ - Cetinje, Cetinje - Osijek, 2011, str. 765-784.

Isto, str. 766.

Isto, $783 / 4$.

Isto. 
Je li Njegoševa mudrost eklektika...

poezija, kao da je tako imenovao sam Njegoš i teorija i kritika književnosti (nezavisno od toga što se u literaturi imenuje refleksivne/misaone/pjesme); 2. navodni Njegoševi „prepjevi“ - čime ukupnu njegovu poeziju klasifikuje ne samo u neoriginalni eklekticizam $i$ sinkretizam, nego i još ignorantnije u prepjeve; 3. da je Njegoš „mali“ književni epigon vodećih evropskih knjževnosti; 4. istrgavanje Njegoševe poetike iz glavnih evropskih tokova i neodgovarajuća njena apstraktna redukcija i identifikacija s njemačkom bidermajer knjiševnošću; 5. navodna Njegoševa poslušnost prema ortodoksnoj teologiji i 6. kompromis sa Svetom alijansom radi „restauracije staroga poretka“.

Dr Slobodan Tomović i drugi njegošolozi s pravom su isticali i obrazlagali da Njegoševe misaone pjesme (a ne religiozne) sadrže sve bitne elemente koji su se razvili u Luči mikrokozma, a i ona je po fabuli sekundarna, jer se ispod mitsko-alegorijskih slika i metafora kriju najdublji pojmovi njegove ucjelovljene i jedinstvene filozofije, njegova ontologija i metafizika. Fabula pjesama i Luče je u funkciji pjesnikova izrazitog zanimanja za filozofsko-metafizičke probleme do čijih rješenja dolazi sopstvenim posebnim pristupom i postupkom korišćenim i u ostalim djelima, pogotovo u Gorskome vijencu: književno-diplomatski metod kontrastiranja, konverzije, inverzije, anagrama, posrednoga alegorijsko-metaforičkog sabotiranja sopstvenog izloženog gledišta i opravdane fikcije ${ }^{7}$ kojim se skriva stvarna aktuelna društveno-istorijska i politička stvarnost Crne Gore i njezine „borbe neprestane“ za slobodu i nezavisnost. ${ }^{8} \mathrm{Ne}$ samo da nije sporan uticaj konkretne društveno-istorijske

Autor ovoga rada je takav metod imenovao u knjizi Etnička svijest dinasta Petrović Njegoš, Crnogorski PEN centar i CKK Cetinje, 2011. i u knjizi Simo Milutinovič, Petar I, Njegoš, CKK Cetinje, 2011. Opravdana fikcija se primjenjuje i u nauci i životu. Ako se pravilno shvati, ovakva fikcija je metodološko sredstvo da se u kontrastu s nestvarnim zamislima sama stvarnost potpunije ispita, osvijetli i shvati, i tako bolje savlada i teorijski i praktično. Fikcija je kao svojevrsni fantazijsko-misaoni eksperiment dobila u filozofiji (fikcionalizma) specifičan jezički izraz u vezniku „kao da“ (als ob), što će reći: zamišlja se neki nestvarni, odnosno nemogući slučaj kao da postoji i na njegovim konzekvecijama razmatra i posuđuje određena situacija, odnosno problem, bilo u nauci ili u životnoj praksi.

8 Takav metod primjenjivao sam da bi se u Njegoševoj prividnoj glorifikaciji srbinizma (srbinstva, srpstva), kao istočnoga tipa integralističke ideje svesrpskog južnoslovenstva (nasuprot ilirizma) uočilo njegovo veličanje crnogorcizma, crnogorskog narodnog kulturnog, odnosno nacionalnog preporoda i pijemontizma u borbi za zajedničko oslobođenje (baš nasuprot srpstvu). Naročito sam tim pristupom i metodskim postupkom nastojao da se u Gorskom vijencu umjesto uobičajene glavne ideje, istorijski nepostojeće tzv. istrage poturica, prepozna istorijski postojeća, Njegošu aktuelna, istraga priturica - izdajnika, „svjetovnih konvertita“, neislamiziranih Crnogoraca. Tu inverziju i subverziju Njegoš je činio iz diplomatskih razloga ugleda pred Evropom i velikim silama, a radi postizanja međunarodnog priznanja slobodne i nezavisne Crne Gore. Taj „diplomatski metod“ mogao je Njegoš isisati iz crnogorske narodne „diplomatije“, specifičnoga načina mišljenja, izraza, razgovora, dośetki, nadgornjavanja i sl. 
crnogorske prakse i okolnosti Crne Gore u borbi za slobodu i za formalno priznanje stvarne nezavisnosti, nego upravo se insistira da se to uoči, istakne i prepozna u Njegoševoj ukupnoj poetskoj mudrosti, podjednako u Gorskom vijencu, Śćepanu Malom kao i u Luči mikrokozma. Upravo je Njegoševa vladarska pozicija neposredno inspirisala njegovu jedinstvenu poetsku mudrost, ${ }^{9}$ što se ne može uočiti bez dubljeg prodiranja, posebno diplomatsko-književnom metodom skrivene alegorijske subverzije sopstvenoga gledišta, jer to u njoj nije prosti i neposredni ideološki i politički transparent koji Ž. Uvanović traži od Njegoša, maltene da se u duhu zapadno-evropskog prosvjetiteljstva i francuske revolucije deklarativno ispolji i opredijeli kao mehanički materijalista, ateista, jakobinac i otvoreni protivnik i razurnik aktuelnog carizma od kojega je tražio i očekivao i formalno priznanje slobodne i nezavisne Crne Gore. Međutim, Njegoš ne bi bio to što jeste, genijalni poetski mudrac, da je tako istupao. Ako ni zbog čega drugog, morao je taj svoj „diplomatsko-književni metod“ koristiti radi ukrivanja od ondašnje stroge cenzure koja je bila pod „budnim svemoćnim okom Meterniha“ i koja bi odbila objavljivanje svih njegovih djela.

Njegoš nema posebnu, izdvojenu religioznu poeziju ni prepjeve već jedinstvenu i ucjelovljenu poetsku mudrost, koja se ne da rastrzavati na iščupke, pa ni aspektomanskim i faktoromanskim iśečcima i ospoljenim, već ukrućenim naknadnim njihovim spajanjem u sabirnu cjelinu, niti apstraktnim i reduktivnim komparativnim seciranjem. Na takav način je Ž. Uvanović mogao „spakovati“ navodnu religioznu poeziju i prepjeve narodne mudrosti i u Gorskom vijencu, posebno u monolozima vladike Danila i slijepoga igumana Stefana, a takođe i uopšte kod svih onih starih mudraca, starogrčkih i poznijih filozofa koji su izlagali svoja filozofska shvatanja u pjesničkoj formi, kao npr. Parmenid u svojoj Kosmološkoj poemi, a to do sada nije niko radio. Takođe, takvim vještarenjem mogli bismo da svedemo na istrgnutu religioznu prozu gotovo sve filozofe koji su ne samo dolazili do imena i pojma Boga i upotrebljavali ga u skladu s tadašnjom opšteprihvaćenom terminologijom, no i ostavljali za njega onaj konačni nespoznajni „,bitni ostatak" (filozofski pojam boga i religioznosti), pa ih niko tako apstraktno istrgnuto ne smješta u posebnu religiju, niti samo u teozofiju ili teologiju. Može biti da bi Ž. Uvanović smjestio u bidermajerovski konzervativizam (suprotivan buntovnoj književnosti „Mlade Njemačke“!) i apsolutnu ideju G. Hegela (idealiste) i njegov temeljni stav: „Sve što je stvarno umno je, a

9 Razdvajanje Njegoševe državničke i državno-reformatorske mudrosti od njegove pjesničke mudrosti izričito kudi dr Čedomir Bogićević (Petar II Petrović Njegoš kao državnik $i$ državni reformator - Njegoševa filozofija pravde, Vrhovni sud Crne Gore - Podgorica, 2014). 
Je li Njegoševa mudrost eklektika...

sve što je umno je stvarno", kako su ga i shvatali starohegelijanci i uopšte ideologija „starog poretka“'?! Primjenom takve metode mogao je Uvanović primijetiti da je Martin Hajdeger preuzeo svoj temeljni stav ,zaborava bitka“ iz Njegoševe Luče: „Zaborave, san te obuzeo, / ti se prvo blaženo bitije / zaboravi nesrećnoj predala“.

Iz Njegoševe bio-bibliografije se zna da je bio najmanje ili nikako obaviješten o njemačkim književnicima s kojim ih Uvanović komparira. Nepoznato mi je da je Njegoš bio u dodiru sa tim njemačkim pjesnicima i da je bio pod njihovim uticajem. Ne samo da je Ž. Uvanović istrgao i izolovao Njegoševu tzv. religioznu poeziju, izvan njegove ucjelovljene poetske mudrosti, i nezavisno od toga da su mitske alegorijske i metaforičke slike bitno u funkciji njegove ontologije i metafizike, nego je koristio i totalni komparativizam sa njemačkim religioznim pjesmama bidermajerskog karaktera i kompromisa s kontrareformacijom, čiji preovlađjući način dovodi u pitanje Njegoševu samosvojnost i originalnost. Takav komparativizam zna da skriva nemoć da se pisac razumije iznutra, iz samih njegovih djela, njegove individualnosti, svoga vremena i njegovog konkretnog društveno-istorijskog bića. Totalni komparativizam, njegovo ,cjepidlačenje“, „seciranje“, iščupci i njihovo vanjsko, ospoljeno upoređenje, zbirno povezivanje, zapravo je totalni relativizam koji omogućava da se manipuliše i s gnosticizmm, agnosticizmom, skepticizmpm i drugo, što je i bio cilj Uvanovića da relativizuje Njegoševu genijalnost. Još je R. Dekart rekao da gotovo nema misli, pa ni gluposti, a da je nijesu već izrekli filozofi, umstvenici i poete, te zato i nema mjesta za punu originalnost. Zato bi Uvanovićev metod totalnog komparativizma mogao lako dovesti u pitanje originalnost i najvećih filozofskih i poetskih mudraca.

Navodnu Njegoševu poslušnost prema ortodoksnoj teologiji Uvanović „opravdava“ Njegoševim ustupkom „udvaranja“ Svetoj alijansi za restauraciju starog poretka zbog nužnosti teške situacije ondašnje vanjske i unutrašnje situacije u kojoj se nalazila Crna Gora. Navedeni razlozi su sami po sebi istinite istorijske činjenice, pojave i tendencije koji su značajni upravo za dublje razumijevanje Njegoševe suštinski svjetovne i ponarođene poetske filozofije antidogmatskog, slobodoumnog i slobodarskoga duha, naročito Gorskog vijenca. To Uvanović izopačuje, reducirano istrgava, iskazujući bitno nedovoljstvo svoga gledišta. ${ }^{10}$ Njegoš ih je duboko bio svjestan i nesporan

10 Navešćemo te razloge: „Naime, u konstelaciji odnosa velikih sila nakon odluka Bečkog kongresa 1815. g. i sveopće restauracije starog poretka iz vremena prije Francuske revolucije, Njegoš je morao očekivati neuspjeh i pri traženju potpore za crnogorsku državnu samostalnost kod Meterniha krajem 1836. i početkom 1837. (kada je nastala i pjesma-oda Knezu Meternihu), morao je trpjeti stalno miješanje ruske vlade u unutrašnje poslove Crne Gore, kao i to da mu krajem 1843. g. Turci iz Skadra okupiraju otoke Lesendro i Vranjinu u 
je njihov uticaj na njegovu ukupnu poetsku mudrost, ali ne na Uvanovićev rečeni način i u odnosu na bitni ustupak restauraciji starog poretka i njenoj teološkoj ortodoksiji, jer bi to bilo u temeljnoj koliziji i raskoraku, kako sa stvarnom crnogorskom „borbom neprestanom“ za slobodu i Crnom Gorom kao zbjegom slobode (crnogoski narodni kulturni-nacionalni preporod - crnogorcizam), tako i sa oslobodilačkom borbom koja čini zajednički predmet svih Njegoševih djela i njegove državotvorne mudrosti. Dobri poznavaoci Njegoševa života, rada i stvaranja ističu da on spada u najobrazovanije vladare i državnike svoga vremena.

Za razliku od ostalih narodnih (kulturnih) preporoda Južnih Slovena, Crnogorci su već od kraja XV i početkom XVI vijeka vršili dugovjeku nacionalno-oslobodilačku revoluciju u oružanoj i idejnoj (duhovnoj) „,borbi neprestanoj" koja je u osnovi bila novovjeka-antifeudalna, čiji je glavni subjekt i oslonac bilo slobodno-gorštačko seljaštvo. U strogom smislu, termin i pojam narodni preporod i ne odgovara odnositeljnom toku u Crnoj Gori, jer u njoj i nije bilo „nacionalnog preporoda“ $u$ smislu hatišerifskoga i naličnog osamostaljivanja, u ramu tuđinskih ustanova, uprava i zakonika (po načelu legaliteta), no se u njoj od početka samoniklo borbeno razvijao po principu narodno$s t i$, ponarođavanja, svjetovnosti (sekularnosti) duha. ${ }^{11}$ Toga radi se i ne piše i ne zbori o crnogorskom narodnom preporodu - vjekovni crnogoracizam ili crnogorcizam koji je bio u klinču i pritisnut između nametnutih preporoda

Skadarskom jezeru, dok je Osman-paša Skopljak podmićivanjem nastojao među Crnogorcima stvoriti izdajice i protivnike Njegoševe“" (kurziv je naš).

11 U prvom poznatom pisanom pomenu Crnogorskoga zbora, u mletačkom izvještaju iz 1500. (hroničara Marina Sanudoa) piše: „Crnogorci danas sazvaše zbor, da se okupe i posavjetuju što da čine" i donijeli odluku o nepriznavanja turske vlasti i stalnoj borbi za slobodu (Sazdanje Cetinja, 1984, 60). Od tada se izgrađuje, na nivou „opštestva crnogorskoga“ nacije ili kako stoji u Cetinjskom ljetopisu: „Crna Gora jest opšti zbor naroda“ (Crnogorski anali ili Cetinjski ljetopis, drugo prevedeno izdanje, preveo i obradio dr Božidar Šekularac, JP IIC Cetinje, Cetinje, ŠKP Štamparija Obod Cetinje, 1996, str. 52). Drugim riječima, Crna Gora je zbijeni, sjedinjeni, kompaktni, homogenizovani i samoorganizovani narod, odnosno nacija. Smatrana je od Porte prebivalištem rata (darubha rubom) $i$ vodila neprestanu gazu, odnosno rat za vjeru i narodnost. Martin Skadranin, kao savremenik i svjedok događaja, nazvao je u svojoj Povijesti o Skenderbegu ovaj uzburkani crnogorski prostor „nemirno pomorje“ (Crnogorski anali ili Cetinjski ljetopis, isto, str. 16; Martin Skadranin je Marin Barleti, koji je živio oko 1460-1513). Mlečani su Crnogorce nazivali podbadačima svijeh naroda, zbog neodstupnoga stamenoga otpora osvajačima. Crna Gora je smatrana centrom revolucije, a od početka je bila matica okupljanja razdrobljenih osvojenih krajeva Crne Gore, a jedanak i luča, kredo, nada i Pijemont oslobađanja na Balkanu. Tokom XVI i XVII v. Crna Gora je već imala atipične oblike novovjekovne (nacionalne) državnosti Principat i Vladikat ili paradoksalno dinastički vladičanski principat ili kako ga je nazivao vladika-gospodar Vasilije Petrović (1754): „Crnogorski slobodni principat“, „crnogorska slobodna Republika“, „slobodno knjaževstvo crnogorsko“. 
Je li Njegoševa mudrost eklektika...

većih južnoslovenskih naroda: ilirizma $i$ srbinizma (srbinstva, srpstva) pod austrougarskim i turskim carizmom. ${ }^{12}$

Za razliku od ilirca Ivana Mažuranića, koji se zbog političke situacije u austrougarskoj Hrvatskoj, ,povukao iz politike u matematiku, astronomiju i nipošto više književnost" ${ }^{13}$ Njegoš je je još upornije ustrajao na prtini ,borbe neprestane“", intenzivirao svoju državotvornu djelatnost, državno-političke reforme za konsolidaciju crnogorske države, formalno međunarodno priznanje njezine stvarne samostalnosti i slobode, specifičnu crnogorsku autohtonu sekularizaciju, političku i duhovnu (antidogmatsku). Nastavio je, sve do smrti, i svoje poetsko stvaraštvo kojim je internacionalizovao i ovjekovječio crnogorsku borbu za slobodu i samostalnost Crne Gore. Sve to baš u vremenu kada su mu vanjske sile (carizmi), izdajnici i unutrašnji protivnici, u zajedničkoj sprezi, pružali ne samo jake otpore, već i ozbiljno dovodili u pitanje opstanak Crne Gore i Crnogoraca.

Uvanovićev totalni komparativizam dovodi ga do neprimjerenog, odnosno neodgovornog etiketiranja Njegoševe Luče (koja podrazumijeva i njegove refleksivne pjesme) dogmatizovanim šablonskim klasifikacijama. Tako npr. Njegoševu metriku svijetla u Luči, odnosno Božije stvaranje kosmosa njegovim osvjetljavanjem iz tmine, tame ,po prirodnim zakonima“ upoređuje i nalazi da je nalik na Spinozin panteizam, ${ }^{14}$ ili uopšteno teopantizam. Ovo i pored toga što je to sasvim različito, prije svega i tim što kod Spinoze nema ni pomena o principu svjetlosti (pa ni tame), a zatim, Spinozina apsolutna supstancija ne korespondira uopšte s Njegoševim policentrizmom, odnosno pluralizmom galaktički uređenog kosmosa, a još manje s Njegoševim shvatanjem stvaranja kosmosa, prelaska mogućnosti u stvarnost, iz haosa u uređeni kosmos koji ima svoje granice i koji se sve više širi. Ovu komparativnu ekskurziju Uvanović čini samo da bi one najbitnije Njegoševe ontološke kategorije obezvrijedi tim što sugeriše da su, navodno, spinozističke. Ovo i pored toga što se Spinozin panteizam ocjenjuje kao „skriveni materijalizam“ i/li sveopšti naturalizam (Deus sive Natura) koji ozbiljno dovodi u pitanje ondašnji i današnji teizam zbog čega je Spinoza podjednako bio anatemisan i od jevrejske zajednice i od hrišćanske teologije. To je u koliziji s Uvanovićevim ocjenjivanjem Njegoša kao hrišćanskoga teiste, idealiste, spiritualiste, pa čak i subjektivnog idealiste, dualiste, što je ostao dužan da takvu kvalifikaciju obrazloži.

12 Taj klinč crnogorcizma između ova dva južnosloveska integralizma ośećaju se sve do danas $\mathrm{u}$ formi vjerskih fundametalizama i imperijalnih velikodržavnih i veljenacionalnih tendencija koje čereče jedinstvo crnogorskoga narod(nos)no/nacionalnog bića.

3 Ž. Uvanović, isto, 767.

14 Isto, 772. 
Neprimjereno je i svođenje Njegoševa shvatanja principa svjetlosti $i$ tame kao starinskog dualizma, jer kod njega ne samo da nije riječ o ,linearnom“ prodiranju svjetlosnh zraka i „crnokrakih mraka“, već o sfernom, „elipsastom“, policenetrirčnom, galaktičkom prostorno-vremenskom širenju u ,prstenove“, „kola“, ,nebesa kolovitnih“, nego što i svjetlost nije samostalni princip, već ima svoju supstancijalnost, svoj temelj u „blaženom žilištu“, „carstvu svjetovah“, „kosmičkom ognju“, „ognju besmrtnome“, ,vječnome ognjištu“, ,ognju svetome“, ,vječnoj zublji“, ,,plamenu božestvenom“, ,,elektrizmu plamom“, „,božijem elektrizmu“, ,plamu nebesa“, „ognju svijetlijem“, „božestvu ognja besmrtnoga“, „plamenoj buri“, „kosmičkoj oluji“, „usijanju“, ,plamenima“, ,vatri“, „ognju“. Iako Njegoševa vatra, oganj podśeća na Heraklitov „vječno živi oganj“ kao fizis logosa kosmosa, on nije supstancija svjetlosti, niti je kod njega bitan princip svjetlosti i tame. „Bog je car od svjetlosti“. Isto je i s mrakom, tminom (,tamnokrake mrake“) koja ima svoj osnov u haosu.

Njegoševa Luča i Bog u njoj, stvaranje svijeta i ostalo, u osnovnim elementima bitno se razlikuju (do jasnog i izričitog ne samo odstupanja, no i protivnosti) od oficijelnog hrišćanskog shvatanja, Biblije i od onih autora koji se uglavnom navode da je bio pod njihovim uticajem. Njegoš u bitnom ne pripada objavljenoj religiji (otkrivenju), koja počiva na vjeri i Svetom pismu, nego prirodnoj religiji koja izvore vjere nalazi u umu, kao najvišoj instanci u ljudskoj duši, duhu, po kojem je i nalik „besmrtnim duhovima“ i Bogu (,u čovjeku iskra bespredjelnog / uma tvoga ogleda se svjetlo“; „da čestica jesi ognja besmrtnoga / da imadeš svojstva sa ocem svijetah“; „Ovo čojka niže skota stavlja, / um ga opet s besmrtnima ravni“"). U svim bitnim polazištima i postulatima dolazi do izražaja neteološka zvanično-hršćanska priroda Njegoševa Boga. To se naročito ispoljava u poimanju Boga u odnosu obuhvatanosti antistavova, antipoda, antinomija, antisvijeta, antikosmosa, antimaterije, antiideje (duha): strogih pravila i nepravilnosti, svjetlosti i tame, haosa i kosmosa, osvijetljeno (organizovano) i nesvijetljeno (neorganizovano) svjetsko biće, predjeli đe dopire i đe ne dopire Božji zakon, Svemogući i Mogući (Bog), jedinstvenog univerzuma i beskonačno mnogo svjetova, simetrija osvijetljenog (Božjeg) i neosvijetljenog svijeta, tajnog slučaja i zakonitosti, slučaja i uzročnosti, duše i tijela, slobode i nužnosti i drugo. Za razlku od Biblije, ustanovljenog hrišćanskog shvatanja i Miltonova Izgubljenog raja, Njegošev Bog nije odjednom stvorio svijet, u stvari, nije ga ni stvorio, već ga trajno stvara i održava u vremenu i prostoru kao svoj amanet i zavjet, kao krajnji cilj, dok ne osvijetli i organizuje (kultiviše) cio univerzum (dok ne osvoji, proširi i oslobodi ,zatočenike tame“), dok „mračne točke kad nikđe ne bude“, „kad svi kraji zaplamte svjetlošću, tad će opšti tvorac počinuti / i svoj sveti zavjet ispuniti““. 
A ako je neograničen (,tamom obuzet", „vječna pomračina“), ni tada, jer je u njemu podjednako (simetrija) osvijetljenog i mračnog (neodređenog) svijeta. I ovđe se dolazi do antinomije: Božji cilj je da sve više smanji „tamni prostor" i „da se bezdne mračne osvijetle“, a na drugoj strani i „mračni prostor“ i „mračno vrijeme“" su vječni, pa se taj Božji konačni, ,sveti cilj i amanet" i ne može ostvariti. Uostalom, ,vječna zublja vječne pomračine“. „Da od svete odustanem dužnosti“ - kaže Bog - „mrake carstva bi ostalo vječno“, a to znači i stalnu opasnost od Haosa, remećenja Božijega kosmosa i njegova zakona, pravde i ljepote. Bog je ,jedan koji stvarat može“, „svemogućstvom vjenčan“, ,jednome je sve pokorno njemu“":

Ja sam - kaže - sam po sebi bio, bit po sebi već ništa ne može, jer je protiv zakona prirode, koja pečat moj na licu nosi.

Sotona je ,rob gluposti, vrag poretka opšteg“. Bog je svemogućstvom:

šar veliki neba blaženoga utvrdio na lakom vozduhu? kojino sam okean vozdušni nasijao sjajnim ostrvima

i vjenča ih svetim magnetizmom te pogledom jedan drugog drži?

Iako silu koja utvrđuje nebeska tijela naziva „svetim magnetizmom“, ovđe je riječ o privlačenju i odbijanju (atrakciji i repulziji) i zakonu gravitacije (to nije nikakav spiritualni i duhovni odnos). Održivost tijela ,na lakom vozduhu“" održava zakon gravitacije koji uslovljava da se tijela manja okreću oko većih tako što su okrenuta prema njima i oko njih se okreću jedan prema drugom, jer ih privlači njihova sila teže do određene mjere (granice): pogledom jedan drugog drži. ,Zakoni su opštega poretka / moj amanet a život prirode“. U pjesmi Misao Njegoš taj zakon naziva sveta simpatija (privlačenje): „U njim' sjaše sveta simpatija“. On ga još naziva lanac mirodržni. Sotona hoće da ,pravedne potire zakone“ (opšte zakone prirode), da prekroči svoje i naruši božanske (prirodne) granice, samu vječitu Božju pravdu, odnosno mjeru (granicu). Još je Heraklit dao sentencu da „ni sunce ne može preći svoju granicu (mjeru), jer će ga sustići Erinije, boginja pravde“. Sotona tim hoće „da prekine lanac mirodržni“, jer zaslijepljen glupošću, misli da je Božiji svijet „svezan za almaze nebrojne subove / te se vise u mojoj palati“, a ne zna da je on „svemoguće slovo stvoritelja“ (logos), „koje prostor punu mirovima, / a mirove sretnim angelima!" Sotona ne zna da Božje carstvo nema neki čvrsti, fiksni oslonac, držač, nepomično središte, ,,pupak svijeta“ (osu). Umjesto toga svijet drži ,lanac mirodržni“ koji ukazuje da se mirovi (svjetovi, nebeska tijela) održavaju u „lakom vozduhu“, bez nepo- 
kretnog oslonca, u međusobnoj (lančanoj) povezanosti na osnovu „zakona opštega poretka“ i ,života prirode“. Nema potrebe da se te poetične slike i izrazi objašnjavaju Božijom „duhovnošću“, spiritualnim moćima. Suština „utvrđenja“ nebeskih tijela i vremena i prostora u praznom prostoru (,lakom vozduhu“, „,vozdušnom okeanu“) je u njihovom međusobnom odnosu i zavisnosti u njihovom stvaranju, (o)kretanju po opštem zakonu prirode, a ne u njima samima, ni u prostoru i ni vremenu kao posebitim atributima jednog $i$ drugog, koji se pretpostavljaju u njihovoj vječnosti kao mogućnost, uslov i ishod samoga stvaranja, (o)kretanja; kao njihovo otrgavanje, oslobađanje iz žilišta slijepe tmine u uređeni kosmos, jednokupnoga prostorno-vremenskog uređivanja, organizovanja kosmosa. Bog stvara tako što utvrđuje kosmos u prostoru i vremenu po zakonima prirode, a suština stvaranja je „lanac mirodržni“, a u stvari (o)kretanje koje sve drži na okupu u međusobnim odnosima i rastojanjima bez kojih i ne bi bilo ni nebeskih tijela, ni prostora ni vremena, ni kosmosa, već bi se ustaljeni poredak poremetio, izazvao opšti poremećaj, kataklizmu, „mirogubni stresi“, vrnulo u haos mračni, u „mračne bezdne“, u zlo, g(o)rdost, u Ad. Zato je i borba na nebu oko vlasti (moći) borba za i protiv narušavanja Božije pravde ili ,zakona opštega poretka“ i ,života prirode“, borba svete pravde i nepravde, a pobjeda pravde neodstupna, nesuminuta i ,osvetnička“, prije svega u smislu teških posljedica koje je nepravda izazvala: „Svete pravde strogi su zakoni“, a potom i zaslužena kazna za nanešenu nepravdu, odnosno za narušavanje „Svete pravde“: „Gnjev pravedni oružje je pravde“.

Njegošev Bog je u procesu stvaranja vječite nebeske države vječiti ratnik, borac, junak koji u odlučnom tenutku lično učestvuje u borbi i zadaje spasonosni udarac, moćno djelo protiv „,nesmislenih masah“ koje su po pravilu uvijek poražene, ali ne i uništeni (jer su i oni vječni); protiv protivnika, pobunjenika i otpadnika (izdaje) stvaranja po prirodi uređenog kosmosa, vječite Božije pravde i ljepote. Trajno mu izmiče ostvarenje zavještanog punog cilja za čije ostvarenje je nepokolebljivo i neodstupno odlučan, bez dilema, a prema protivnicima nebeske pravde (a ujedno i utvrđenog prirodnog poretka), koji je narušavaju i hoće da je unište protivno „prirodnim zakonima“, sasvim nemilosrdan, osvetnički, do zatiranja:

Svete pravde strogi su zakoni,

Prestupnike moj bič nakazuje. sve je dužno njima sljedovati.

Njegošev Bog je i gord u svom jedinom samovlašću, samohvaljiv u svojoj moći, traži slavlje i priznanje, vjernost svojoj (jedinoj) svemoći, a primjerenu samilost za one koji mu se vrnu, pokaju, traže oprost za svoja zla djela. No, 
to sve radi kao zaštitnik kosmičkoga poretka po opštem zakonu prirode protiv narušavanja jedinstva čovjeka i prirode, prvo(bi)tnog stanja.

To je šira projekcija i refleksija borbe za vlast, moć realnog opšteg stanja u ,zemaljskim carstvima“ kao temeljnog ljudskog zla i prokletstva. Ujedno je i geodiceja, antropodiceja opravdanja Boga, božje pravde i zla u njegovom i ljudskom svijetu, određenija ,,po liku crnogorskoga slobodarskog čojskog junaštva“, „,borbe neprestane“ kojoj se ne vidi kraj (,borbi našoj kraja biti neće, do istrage turske al' naše“،, ,udri za krst i obraz junački / ko gođ paše svijetlo oružje, / ko gođ čuje srce u junaka“). Kao što nebeski rat pravde i nepravde predvodi Bog, tako i crnogorsku borbu za slobodu (pravdu protiv nepravde, tirjanstva) predvodi lično vladika-vladar. Njegoševo teološko razabiranje, u formi pjesničke alegorijske slike, prikladno je istorijskoj ratničkoj sudbini male Crne Gore „od svud stiješnjene“ (,,kakve sile put nje zijevaju“) ${ }^{15}$ predstavljene u Gorskom vijencu u kojem se zbori o užasnom kažnjavanju neprijatelja i domaće, nacionalne izdaje u ime pravde i prava na narodni opstanak, npr. istraga u Crmnici, razur grada Besca i ,po šestinu u grob sahranjuju“. Pravda je borba za slobodu po ,ljudskom pravu“, kao ,ljudske dužnosti najsvetije“, a nepravda je osvajanje i porobljavanje ljudi i naroda-nacija po ,svetom imperijalnom (carskom) pravu jačega“ koje pretpostavlja tirjanstvo, ropstvo i podložništvo.

Takođe, Njegoš ostavlja trajnu otvorenost antinomije smrtnosti i besmrtnosti, konačnosti i vječnosti, ali i konačnosti i beskonačnosti svijeta. I kad razura postojeći stvoreni (savršeni) svijet „,po prirodnim zakonima“ stvara novi takođe ,po prirodnim zakonima“. Četiri dana je trajala borba borba na Nebu, a tri dana je Bog stvarao (H)Ad, Pakao za Satanu i njegove legione (pobunjene arhanđele, otpadnike, izdajnike Boga, razurnike kosmosa po prirodnim zakonima), znači, za 7 dana je samo razurao svoj postojeći svijet. Nakon pobjede nad Satanom, Bog iznova stvara novi kosmos „,da namiri izgubljenu vojsku“ (,,izgub da namiri“, jer u kosmosu postoji opšta ravnoteža, sklad, harmonija koja ga i održava). Svako narušavanje prvobitnog jedinstva čovjeka i prirode (u užem i širem smislu) ima teške posljedice i za čovjeka i prirodu. Kao stvaralac Bog je svemoguć, a pošto stvara u vremenu u smislu procesa, toka, i ostvaruje novi prostor, on je mogući, jer pretvara moguće u stvarno, „bezdane tmine“ u nove kosmose, odnosno oslobađa nove svjetove. Samo u tom smislu može se shvatiti da se u Luči Bog imenuje svemogućim, a ponegđe mogući Bog („,mogući njegov štit“, „moguće njegovo slovo“) koji u procesu stvaranja sve više oslobađa i širi granice svoje svemirske (opširne) države. Bog se i sam usavršava, uzdizanjem nad sopstvenim bićem, postaje

15 Ne misli se samo na okolna i ostala carstva, nego i na tjeskobu i klinč crnogorcizma između ilirizma i srbinizma, nepriznatog crnogorskog pijemontizma u sukobu integralističkih ideja „uje(i)niteljskog oslobođenja“ južnoslovenstva. 
moćniji, djelatniji u ostvarenju svoje zamisli. Bog lično saopštava da se „sve više tvorenjem pruža“, da stvaranjem ne samo „otrgava vrijeme“ iz haotične (neodređene) ,nesmislene mase“ $\mathrm{i}$ oslobađa ga (da „slobodno leti“ $u$,nebeskoj državi“), no ujedno i njezinim uobličavanjem iz nje otrgava, oslobađa, produžava i tvori i sam prostor:

Što se više tvorenijem pružam, sve se njino carstvo umaljuje; vrijeme će i k toj cjeli doći da se bezdne mračne osvijetle.

I Bog je u svom tvorenju zavisan, vezan za vrijeme i prostor, koje ni on nije primordijalno stvorio, već su njemu savječni, kao i haos, neuobličena materija, koju Bog ne stvara, nego je zatiče i osvjetljava, uobličava, kultiviše u Kosmos (uređeni svijet). Tek u Božijoj tvorevini sjedinjuju se (nevidljivo) vrijeme i (vidljivi i opažljivi) prostor; Božija tvorevina je njihovo jedinstvo, neraspu(p)čiva veza $u$ i po prirodnom zakonu, ujedno „vozljubljeno slovo“ (logos), riječ, um, zakon i djelo. Bog ,i zbori i tvori“ (nalazi svoj odjek i u Gorskom vijecu: „Mićunović i zbori i tvori“, što se uopšteno odnosi i na crnogorski junački etos i etnos, apriornu opredijeljenost za borbu za slobodu, borbeno slobodarsko čojsko junaštvo, na vjeru i zadatu riječ). Poslije njegove pobjede nad Sotonom i pobunjenim anđelima, Bog je stvorio novi kosmos da „namiri grubitak“" novim legionima, svjetovima i njihovim sferama. Također, Bog ne stvara neposredno svjetove, nego, svojom umnom mudrošću, posredno koristi „plamene bure“ i/li „kosmičke oluje“ koje mu pomažu u procesu stvaranja koje je ujedno i (o)kretanje kosmosa.

Znači, vrijeme i prostor nijesu stvoreni od Boga, kako uči hrišćanska crkva; oni su prisutne latentne tamne mogućnosti iz kojih se plamenom svjetlošću stvaraju (osvjetljavaju) novi svjetovi. Sam Bog u prvom licu govori Arhađelu Mihailu, kad je otkrio tajnu zavjeru Sotonine pobune na nebu:

Koliko sam ja posla imao / dok sam vr'eme oteo mrakama,

iz njihovog lonca i tavnice / puštio ga da leti slobodno

po opširnoj državi vječnosti / i po carstvu svijetlog lica.

I Božje stvaranje, odnosno uređivanje svijeta zahtijeva red, poredak, opšte zakone, pa i u vremenu:

Sve nek krače svojijem vremenom, / koga vjenčah na besamrtje,

trenuć su mu v'jekah milioni.

U Gorskom vijencu ima korespondetnih stavova: „nove nužde rađu nove sile“. Iako nije tvorac vremena, koje je savječno tvorcu, vrijeme je božjim stvaranjem i (o)kretanjem kosmosa postalo vječno (besmrtno), a nezavisno od Boga, samo za sebe, neograničeno. 
I prostor se mjeri „božastvenim koracima“:

Koraci su moji božestveni, / no ja mogu to nazvat prostorom,

kaže lično Bog. I prostor je božjim stvaranjem i kretanjem kosmosa postao vječan, a nezavisno od njegove kosmičke artikulacije i uobličavanja, sam za sebe postojeći i beskonačan. Korak vječnog vremena je u skladu (sustopice) s korakom ovremenjenog i osvijetljenog (vječnog) prostora. „Rasprostranja svijetle granice“, oprostoravanjem i ovremenjavanjem ,raspostranja“, produžava, „širi“" granice kosmosa. Bog posebno i naročito ističe tajnu, tajanstvenost prostora (u upoređenju sa vremenom), koja je nedostupna i duhovnim nebeskim vječnim bićima, arhanđelima (arhanđelu Mihailu), a samo jednom, Božijem umu dostupna. On lično objašnjava teškoću shvatanja prostora: da se „prostor mrakah i prostor svjetlosti“ preobraze i sliju „u jedan svijet zrakah svijetlijeh“ i da se taj svijet ,pruži pravo u najtanju moguću žicu“ (pravu liniju) ${ }^{16}$ „,bi ti bio smo jedna točka“. „Među kola (svjetova) mećem rastojanje“ (međusobni razmak, udaljenost, razmjer između nebeskih tijela, održivu ravnotežu, sklad, harmoniju, opšte zakone prirodne), time

ja dopirem do granice mrakah, / mrakah mećem koliko svjetlosti;

ja ovako prostor razumijem.

Iz kosmičkog ognjišta zrači „,vječna zublja, vječne pomračine“. Kosmos „dopire do granice mraka“, što će reći, iz haosa nastali, uobličeni, uređeni postojeći kosmos, a sa njim ovremenjeni prostor i oprostoreno vrijeme, bez razilaženja, udvajanja, raspeća prostora i vremena, i zajedno kretanja, ${ }^{17}$ tj. $i$ vrijeme i prostor, zajedno i kosmos, su, ipak, konačni, ograničeni ${ }^{18}$,do granice mraka“ ili što je isto „,do granice zrakah svijetlijeh“, ali se „sve više tvorenjem pruža“ $i$ „rasprostranjaju svijetle granice“ ili ,šire“ osvjetljavanjem (stvaranjem) novih svjetova. Može se zaključiti da je Njegoš smatrao da je kosmos konačan, ali

16 Kvantitativna matematizacija i uprošćavanje, izopačenje vječnosti u beskonačnost $\infty$ odnosno svođenje loše beskonačnosti (kako je Hegel naziva) u lošu vječnost (viđeti o lošoj beskonačnosti i lošoj vječnosti: Sreten Zeković, „Iskustvena osnova septadno-oktadnog (o) kretanja, muzičke oktave, dijalektike i mita o Ananki“", Arhivski zapisi, Državni arhiv Crne Gore, br. 2,2012, str. 111-142).

17 Ovu terminologiju i neraspupčivost ovih pojmova, zbog njihovog opštenitog razilaženja, udvajanja, „oprostoravanja“ i „ovremenjavanja“ kao posebitih i zasebitih atributa (bilo Apstrakatne Materije ili Apsolutne Ideje), koristio sam nezavisno od Luče mikrokozma i njezinih tumača u svojim knjigama: Filozofija, muzika, mit, KOC, Cetinje; Muzika Anankinog vretena (poezija), Obod, Cetinje, 1991; Na raskršću bogočovjeka i čovjekoboga, CKK, Cetinje, 1994; Moj jezikovnik - rječnikovnik i pojmokovnik, CKK Cetinje, 2012, pod oznakama: Osmičenje, str. 34, Oprostoriti, str. 32, Oprostorenje, str. 33, Ovremenjavati, str. 36, Oprostorenje vremena i Ovremenjavanje prostora, str. 88 Oprostoriti, oprostorenje, ovremeniti, ovremenjavanje, oprostorenje vremena, ovremenjavanje prostora, osmičeje, osmica, spiralna osmica života, str. 184.

18 Slobodan Tomović, isto. 
neograničen, kao što smatra mnogo docnije savremena nauka. ${ }^{19}$ (očito prepoznata savremena teorija o sfernosti kosmosa (,zakrivljenog prostora / i širenju kosmosa").

Samo u ovom smislu i kontekstu, sa „prostorom mraka“ i „prostorom svjetlosti“, vremenom mraka i vremenom svjetlosti, možemo pojmiti češće pominjanje granice kosmosa (,četiri nebeske granice“, „da će mrake gonit za predjele / i granice osvijetlit bića“, „na granici neba“ i sl.) i objediniti, obuhvatiti: i konačnost i beskonačnost prostora i vremena, kosmosa, odnosno njegove konačnosti i vječnosti, i druge protivrječnosti, paradokse, racionalno i iracionalno itd. Kao da Njegoš ovim asocijativnim i alegorijskim slikama vrši apokrifnu subverziju njima odgovarajućih metafizičkih kategorija, do samog njihovog samoporicanja, samog tajanstva. I ovđe se kao bitno ukazuje na odnose koji održavaju (o)kretanje, a ono ih uslovljava i ishodi.

$\mathrm{Ne}$ samo da se nigđe ne pominje, kako naglašava $\mathrm{S}$. Tomović, da je kretanje odvojeno od materije (misli se na kretanje samo kao vrijeme), kao što su tvrdili mnogi religiozni autori, nego su kod Njegoša vrijeme i prostor jednokupnost, dvije neraspu(p)čive strane jedinstvenog stvaranja, zanago, samog stvarnog (o)kretanja (a ne apstraktne materije „same po sebi“), sam način razvoja, kretanja, a to znači, i opstojanja kosmosa. Ovim je Njegoševa Luča izuzetno originalna i do danas anticipatorska, tim prije što se često tumači sa uvriježenih starih nedovoljstvenih (prevaziđenih) filozofskih polazišta i pretpostavki. I prostor i vrijeme su vječni, i njih nije stvorio Bog, koji ih samo organizuje, osvjetljava, aktuelizuje (ostvaruje). Bog nije stvorio materiju; ona je njemu savječna, pa je i ne može uništiti, već samo uobličiti i/li razobličiti čime gubi određenost postojanja, a to znači i zatomljenost, zarobljenost prostora i vremena. Za razliku od crkvenog učenja, Bog ne stvara ex nihilo, već iz haotične materije, Haosa. Stvaranje je spojeno sa neumitnosti po prirodnm zakonima, što znači, suprotno crkvenom učenju, da Bog stvara po svojoj apsolutnoj slobo materije, iako to nijesu opravdavala opšta znanja njegovog vemena. ${ }^{20}$ To se ispoljava u Luči i cjelovitije u Bilježnici. Sotona dedukuje iz filozofske teorije o „tajnom slučaju“, slučajnom nastanku duhovnih bića, pa i Boga:

...tajni slučaj naš je otac bio, / avlaštito nas je satvorio

da pravilo biću sačinimo / i gordosti metnemo granicu...

Satanino plediranje na jednakost („da imamo svi jednaka prava“), koja je u osnovi prosvjetiteljskog materijalizma, u stvari se svodi na podjelu vlasti radi dovođenja u pitanje monarhističkog Božjeg vladanja, ograničenja Božjeg apsolutizma. Sotonino načelo jednakosti nije opštenito, ni jednakost u slo-

19 Robert K. G. Temple, Tajna zvijezde Sirijus, Stvarnost, Zagreb, str. 219: „Svemir je konačan, ali neograničen" (original London 1976).

20 Slobodan Tomović, isto, str. 474. 
bodi, i u svim uslovima, bezuslovno, jer i sam Bog priznaje: „Čovjek volje ostaje svobodne / ka svi drugi besmrtni duhovi“. Njega ne interesuje stvarna ravnopravnost. Osnovni motiv njegove pobune je vlastoljublje, težnja da $\mathrm{s}$ Bogom podijeli vlast nad svijetom vlasti, da ima vlast, moć, što je glavna karakteristika apsolutiste, autokrate, diktatora. Njegov izričiti zahtjev je: „Ištem vladu da podijelimo“, računajući da će to ostvariti lukavom, dvoličnom, demagoškom zloupotrebom mase, puka koja je i instiktivno naklonjena prirodnom pravu na jednakost.

Njegoš nam pruža mogućnost da prevaziđemo dijalektiku kao jedinstvo ili parnjenje parnosti (parnih suprotnosti koje su ustvari parne istosti) u dijalektiku kao jedinstvo ili parnjenje neparnosti - dvojenje neparnosti, dvojstvo trojstva i/li trojstvo dvojstva sa „ostatkom“ koji je „,bitni ostatak" ili promjenljivi „,višak“ ili „,nedostatak“ koji se naizmjenično izravnava (izjednačava, parni) u smjenjivanju, samom kretanju (npr. najočitiji smjena dana i noći, Sunca i meseca, svjetlosti i tame). Tim se otklanja ustaljeni, uvriježeni rascjep subjekta-objekta, čovjeka i prirode, racionalnog-iracionalnog, prostora i vremena, materije i ideje, ideje (boga) i prirode. Ž. Uvanović simplificirano i nametnuto u Negoševoj poetskoj mudrosti zamrznuto (van samog stvaralaačkog jedinstva) vidi samo ,jedinstvo nespojivosti“ da bi je okarakterisao kao eklektiku i sinkretizam u negativnom, zloupotrijebljenom značenju. Međutim, i ovđe se kao bitno ukazuje na odnosima koji održavaju (o)kretanje, a ono ih uslovljava i ishodi.

Luča pokazuje da je pjesnik bio upoznat sa filozofskim i naučnim kategorijama njegova vremena, naročito očito isticajnog policentrizma i neograničenog pluralizma svjetova, odnosno teorije galaksija, jer obilno zbori o beskrajnim svjetovima u kojima svaki svijet svoje sunce i sveru ima:

u beskrajni okean vozdušni, / đe su sunca samo kaplje sv'jetle, a mirovi jedva vidne iskre"... već trepetom sv'jet svjetovah gledah,.. sav nebesklon što mogah viđeti / mir mirova bješe napunio... milioni vobražavam da su / nasijata kola sa suncima; svako sunce predvodi mirove / koliko si kome odredio, / a mir svaki svoju sferu ima.

Pjesnik govori i o rastojanju svjetova:

Među kola mećem rastojanje,/ radi slave božeskoga vkusa:

kola dalja bliža obuzimlju, / ka šar veći što obuzme manji;

stoga kolo što je koje dalje / jeste više, su više šaarovah

ja dopirem do granice mrakah / mraka mećem koliko svjetlosti;

Pjesnik govori u filozofskim i naučnim kategorijama svojega vremena, docnijim i savremenijim: gravitacije (,sveti magnetizma“, „sveta simpatija“, „lanac mirodržni“), vremena, prostora, slučaja, uzroka, zakonitosti, slobode, 
nužnosti. Već sam naveo da pjesnik mitsko-alegorijski i simbolički anticipira docniju teoriju o ,„sirenju kosmosa“, „zakrivljenosti prostora“ (što je logična posljedica njegova sfernog, „kolnog“, „prstenastog“ prostora i vremena, navedenog rasporeda i odnosa svjetova i nebeskih tijela), kao i „kosmičkog praska“ (,plamene bure“, „plamene oluje“, „užasne grmljavine“, „mirogubni stresi“, „čas suđeni zazvoni svjetlosti“", „lomna jeka vojničke muzike“ i sl.).

Po bitnoj ontologizaciji Sunca, odnosno sunaca i svjetlosti u njihovoj supstancijalnoj svezanosti, Njegoš smatra da su i predhrišćanski i obogotvorno naturalistički ,poklonici sunca“ u većem osvjetljenju i razumijevanju ovih bitnih ontološko-metafizičkih pitanja, u smislu iskonskoga fizisa i logosa, odnosno Boga koji stvara po i na osnovu prirodnih zakona u prednosti u odnosu na hrišćansko učenje. Luču Njegoš privršava pravom odom Suncu i predhrišćanskim „poklonicima sunca“:

O nevini sinovi prirode, vi presretni poklonici sunca! o mudrosti prosta najsjajnija! Vi ste vjerni nebesni sinovi".

Do rođenja sv'jeta istinoga,

Svoje divljenje svjetlosti Sunca kao fizičkom, prirodnom biću Njegoš je ispoljio još ranije u pjesmi Oda Suncu, spjevana noću bez Mjeseca, a u Šćepanu Malom crnogorski borci se pred bitkom klanjaju Suncu, a ljube (svoju) zemlju da im da spokoj kad joj se vrnu. Njegoš je još 1837. u Beču izjavio: „Zaista bi bila velika glupost kad bi se i pravila razlika (između pravoslavaca i katolika u Crnoj Gori - prim. S. Z.), pošto mi svi pak tapkamo u mraku. Smatram da smo kudikamo udaljeniji od saznanja istine nego oni koji su se klanjali suncu" "21 Ova himna „poklonicima sunca“ ima kod Njegoša složenu osnovu, slojeve i značenje baš u odnosu na njegovo shvatanje prirode i njezino stalno prisustvo u uređenju Božijeg svijeta, kosmosa. „Nevini sinovi prirode“ su neotuđeni od nje i njoj nesuprotstavljeni, ,žive u skladu sa prirodom“, u jedinstvu sa njom, prvobitnom skladu s prirodom, te ne prelaze njene granice, ne ugrožavaju i ne narušavaju primordialno jedinstvo. U pjesmi Ko je ono na visokom brdu Njegoš i poetu naziva ,sin prirode“:

Ono ti je sin prirode - poet, tvorac mali najbliži božestvu on najbliže sa mogućim tvorcem od drugijeh sviju umnih stvari ima svojstva te ga sa njim zbližava.

A u Luči tvorevinu Boga poistovjećuje sa pjesnikom i poezijom:

21 Jevto Milović, „Njegošev boravak u Beču 1836 i 1837 i njegov pokušaj da pođe u Pariz“, Istorijski zapisi, God. VII, knj. X, 1, 1954, Cetinje, str. 88. Prvi izvještaj F. Oreškovića Lilienbergu, 3. 2. 1837. 
Je li Njegoševa mudrost eklektika...

„sve prelesti smrtne i besmrtne, što je skupa ovo svekoliko do opštega oca poezija?“
„Zvanije je svešteno poete, glas je njegov neba vlijanije, luča svjetla rukovoditelj mu, dijalekt mu veličanstvo tvorca“" „,i prelesna Božja poezija;““ samo duši plamena poete“.

U Luči Bog kažnjava otpadnike neba za pobunu i izdaju Adamovih nasljednika „su dvije duševne tablice“, odnosno „s dva sasvijem protivna zakona“. Jedan je „zakon pravde blage“, a drugi zla svakoga. Bog kaže da će čovjek moći ova dva zakona „,bez nikakve muke razlučiti“, tj. znati moralni zakon već i na osnovu prirodne svjetlosti uma ,nevinih sinova prirode“ čija je ,mudrosti prosta najsjajnija“ jer su ,vjerni nebesni sinovi“ ili, kako Bog kaže, koji „posvete misli mojoj pravdi““.

Prvobitno (ili preegzistenijalno) jedinstvo je izgubljeno sa gospodarenjem i vlašću nad prirodom, sa imperijalnom civilizacijom koja veliča i obogotvoruje imperatore, osvajače, samovlasnike u njihovoj vlasti i moći, antropokrate, autokrate koji hoće da budu „car zemlje, iako u ropstvu“ (u Gorskom vijencu imamo: „Zarobio sebe u tuđina“). Civilizatorski antropokrata i autokrata je trajno zarobljen u svojoj gordosti i nosi trajni njen teret:

„zbaci s sebe, oslobodi ga se, (okova) Zlo je njemu jedina utjeha“, (Satani)

pod tuđijem ne stenji bremenom“.

U Gorskom vijencu zbori: „Što se crnim zadoji đavolom / obešta se njime dovijeka".

U teologiji i znatnom dijelu filozofije svijet i priroda se misle i shvataju uglavnom po apolonsko-svjetlosnoj, plastificiziranoj vizuelizaciji, odnosno ejdetskom lik-ovnom principu (eidos-slika, lik, čista ideja) „duhovog gledanja“ (teorije, kontemplacije) u kojoj je priroda obezvređivana kao „drugo biće“, otuđenje u prirodi, kao „,res extenza“ (,protežna stvar“), prostor, kao apstraktha redukcija prirode samo na prostornost, odvojena od vremena (,res cogitans“'), duha, dijalektike, rezervisane samo za ljudsku povijest $u(o) d v o j e n u$ od Prirode, njoj suprotstavljenu, prema njoj osvajačku, gospodareću za Čovjeko-Boga, Antropokrate, koji je jedini tvorac smisla i svrhe života i svijeta, što se javlja i kao antropocentrizam i antropokratomorfizam. Najveće obezvređenje Priroda je dobila kod Platona (i njegovih sljedbenika, platonizma, neoplatonizma i u hrišćanstvu) koja je svedena samo na slab odsjaj, blijedu sjenku ,čiste ideje“" u „carstvu ideja“".

Iako neodvojiv od apolonsko-likovne vizuelizacije svjetlosti i sjenki, ali vatrene i sunčeve svjetlosti, kod Njegoša ovaj ejdetsko-umstveni (noumenalni) princip iskazuje svoje nedovoljstvo u ,bitnom ostatku“ (višku ili nedostatku), bilo kao tajanstvo, neizrecivost, nemoć spoznaje, agnostička ,stvar po sebi“", bilo kao iracionalni ostatak i dopuna racionalno-umstvene spoznaje 
i slično. To mu se javlja upravo kada ga takav umstveni princip dovede do same sopstvene granice na kojoj se gubi njezina slikovitost, postaje nevidljiva, nevizuelna, ali čulno-čujna opažljiva strana, sam fizis iskonske prirode kao dioniski princip izražen u muzici, u „nevidljivoj harmoniji koja je jača od vidljive harmonije" (Heraklit). U muzici, muzičkoj harmoniji suština nije u nevidljivim, ali čujnim tonovima (samim po sebi i za sebe, posebitim i zasebitim), već u njihovim čujnim odnosima, među sobom povezanim i zavisnim tonovima koji su u skladu, saglasni, čine njihovu harmoniju u kojoj sami tonovi tek postoje i dobijaju svoje mjesto, smisao i značenje u svojoj muzičkoj ucjelovljenosti. Stalno je prisutna i ona nevidljiva njezina strana - fizis kao dionisko-čulna muzika: hor; rashorena slatkoglasija; slavoglasno horenje muzike; himna vječite ljubavi; novi glasi besmrtne muzike; čujem glase besmrtne muzike; nebesne njene armonije; s grmljavinom nebeske muzike, a u fanfari nebeskog rata i lomnom jekom vojničke muzike.

Njegošu je u Luči primarno interesovanje, preokupacija i osnovna ideja ontološko-metafizičko, kosmološko i kosmogonijsko preobražavanje Haosa u Kosmos, uređenje postojećeg organizovanog kosmosa. Motiv i mit o pobunjenim anđelima, Sotonina zavjera, izdaja i pobuna na nebu je u funkciji Njegoševe osnovne ideje - ontološko-metafizičke u kojoj je već u preegzistenciji, prvobitnom jedinstvu riješen i problem teodicije: odakle i zašto zlo u božjem svijetu. Njegošev Bog je u biti i uglavnom obuzet mišlju kako da ukroti, kontroliše sve postojeće i da zavlada univerzumom. Sotonina pobuna je samo djelimična smetnja na putu ka tom postavljenom zavjetnom i obećanom cilju. To je i najoštrija razlika između Njegoša i Miltona kod kojega je Satanina pobuna i motiv čovjekovog grijeha u vezi sa Satanom glavna ideja i predmet Izgubljenog raja. Za razliku od zvaničnog hrišćanstva, Njegoš razlog grijeha i ljudskog pada na Zemlju smješta u preegzistencijalno stanje, već na Nebu, u samom ,nebeskom carstvu“, đe su i pobunjeni anđeli i Adamovi sljedbenici, prvotni ljudi, zadobili svoju kaznu zbog pobune i izdaje radi vlasti i nezaslužene moći.

Međutim, sasvim neočekivano i potpuno u neskladu i nedosljedno dosadašnjem pjevanju u Luči, njenoj strukturi i razvoju osnovne ideje, spjev se završava usklađivanjem s biblijskim učenjem o prvobitnom grijehu u Edenskom vrtu. Kao što je u Posveti u Luči s pravom i uspješno uočio neskladnost i da Posveta odmah razvija središnju ideju spjeva, koja je u neskladu sa $P o-$ svetom, ${ }^{22}$ tako i ovđe dr Slobodan Tomović konstatuje: „Ovo je jasna nedo-

22 Falsifikat Posvete u Luči učinio je Simo Milutinović i nadležni organ njenog izdavanja i štampanja. Viđeti o tome utančano i podrobno: Sreten Zeković, Simo Milutinović, Petar I, Njegoš, CKK Cetinje, 2014. Takođe i završni dio Luče kojim se „cenzorski“ izmiruje i upodobljava, odnosno preinačava, krivotvori Njegoševo u mnogo čemu i bitno odudaranje 
sljednost $u$ odnosu na cijelu konstrukciju spjeva“". ${ }^{23}$ U završetku komentara tzv. pete pjesme, nakon što je Njegoš utvrdio čovjekov grijeh već određen u pregzistenciju, kao metafizički grijeh, Tomović znalački zaključio: „Njegoš je radikalno previdio hrišćanski mit o Adamovij krivici na zemlji, vezujući čovjekov pad za preegzistenciju“. ${ }^{24}$ Isti autor to konstatuje i na kraju svog Komentara „Luče“ i još jednom izoštrava ovu protivrječnost, ali je elastično ublažava: „Zbog čega je Njegoš u svoj spjev unio biblijski grijeh, ako je već imao svoj koncept grijeha u preegzistenciji? Neki misle da je pjesnik to učinio iz opreza prema hrišćanskoj crkvi i kao pravoslavni vladika. Biblijski motivi koji se odnose na život prvih ljudi u raju, zatim pojmovi kao što su: narušavanje zavjeta, zabranjeni plod, prvo bratoubistvo, istjerivanje iz raja, idolopoklonstvo, odista nijesu u skladu s glavnom idejom spjeva po kojoj se odgovornost prvih ljudi desila u prethodnom, netjelesnom životu““. ${ }^{25}$ Nakon ovoga, Tomović nalazi vještačko izmirenje ove konstatovane protivrječnosti, ne samo u odnosu na glavnu ideju Luče, no i u Božjem opisu Zemlje određene za užasno ispaštanje grijeha zbog učestvovanja u pobuni za vlast, na jednoj, i samog opisa „,edemske krasote“, „divne soputnice“ (Eve), zemaljskom raju. odmah nakon što „Adam pređe nebesnu granicu“, „pred vrta vječnosti, na drugoj strani. Da je Njegoš htio da pravi ustupke sa zvaničnim učenjem crkve o ,zemaljskom raju“ i zabranjenom plodu sa drveta saznanja dobra i zla, ne bi, pored rečenog, Njegošev Bog još u preegezistenciji predestinirao pakao na Zemlji za Sotonovog sljedbenika Adama i u njegovoj duši u koju će:

njegova će duševna tablica

s obje strane biti načertana

s dva sasvijem protivna zakona:

na jednoj će zakon pravde blage bit' u svete načertan linije, na drugom će prevlasniku njina zla svakoga crnjet' se zakoni adski spomen sveze sa satanom.

$\mathrm{Na}$ osnovu „načertane dvije duševne tablice“ u čovjekovoj može lako da razlikuje dobro i zlo na osnovu ,zdravog razuma“ (,prirodne svjetlosti“ uma) bez velike, složene i zamršene učenosti. Ovim Njegoš radikalno previđa i zatura i ,zemaljski raj“ (edenski vrt) i smrtni grijeh zbog prekršenog zavjeta da

(jeretičnost) od oficijelnog hrišćanstva, crkvenog učenja i teologije, iako je i sam Tomović uočio i konstatovao taj nesklad. Iako često prepoznaje i u Luči i ostalim Njegoševim djelima refleksije i odzrcaje stvarnog crnogorskog društveno-istorijskog bića, pa i njegovog doba, S. Tomović ne prepoznaje u tzv. istrazi poturica ,istragu priturica“, izdaju „,svjetovnih konvertita“, neislamiziranih, hrišćanskiih Crnogoraca, izdajnika i otpadnika koji „, turskim barjacima predvode Turke" protiv svoje otadžbine Njegoševog vremena.

23 Slobodan Tomović, isto, str. 376.

24 Isto, 428.

25 Isto, 510. 
sa ne bere voće sa drveta saznanja dobra i zla koju je prekršila Eva, a s njom i Adam.

Kao što nije ni posumnjao da je tzv. Posvetu u Luči grubo falsifsikovao Simo Milutinović, S. Tomović nije ni pomislio da je i ova protivrječost rezultat istog falsifikatora u saradnji sa cenzorima ovog spjeva - srpske pravoslavne ortodoksije za koju je ovaj dodatak bio uslov za objavljivanje spjeva zajedno sa Posvetom.

I na vrhu, bez osnova je Uvanovićeva tvrdnja da je Njegoševa religija hrišćanska poslušnost crkvi, njegov Bog , kršćanski Bog“; a zašto ne ekumenski i/li masonski. ${ }^{26} \mathrm{U}$ svim bitnim polazištima i postulatima dolazi do izražaja karakter Boga koji bitno i odstupa i protivi se oficijelnom hrišćanskom shvatanju Boga i preegzistencije. Za ostale Uvanovićeve tvrdnje sljeduje njihovo opovrgavanje.

\section{Pokušaj da se Njegoš metne u službu konzervativne restauracije starog poretka}

Osim bečke policije i Meterniha i grof Lilienberg budno prati na Njegoševo kretanje po Beču: „U sporazumu s Meternihom Lilienberg se trudi svim silama da njegov ađutant kapetan Fridrih Orešković postane 'drug Vladičin' i to mu potpuno polazi za rukom. Orešković sad prati Njegoša ustopice, razagovara s njim, bilježi i dostavlja ih svome šefu Lilienbergu“27. Navešću ove Oreškovićeve izvještaje (sveske) koje je dostavljao svom šefu, jer u njima možemo naći vrlo važne podatke, stavove, tvrdnje i ideje kojima se može mnogo što objasniti u Njegoševoj ličnosti i njegovoj celovitoj mudroti, posebno za rasvjetljavanje Luče Mikrokozma, a i njegov odnos prema postojećoj diplomatiji koja je bila bitno crisstička. U prvom Oreškovićevom izvještaju od 3. 2. 1937. navodi se, između ostalog, i: „O religiji se vladika izjasnio: 'Crnogorci se doduše plaše Boga; samo ipak posjećuju rijetko crkvu, i to većina samo nekoliko puta u godini. U religiji vlada najveća sloboda; između pravoslavaca i ono malo katolika koji tu žive ne pravi se ni najmanja razlika. Zaista bi bila velika glupost kad bi se pravila razlika, pošto mi svi ipak tapkamo u mraku (s očevidnim izrazom slobodnog duha izjašnjavao se Vladika uopšte). Smatram da

26 Tvrdi se da je Njegoš bio i mason. U Luči Bog na svom tronu, prijestolu drži i čita plan građenja svijeta. Ponekad ga Njegoš imenuje i kao graditelja. Bog je arhitekta i ne stvara svijet odjednom, već po planu stvaranja kosmosa. „Sve nek krače svojijem vremenom“, „Koraci su moji božestveni, /no ja mogu to nazvat prostorom“. Sve u božjem carstvu je pravilno, „red svješteni na svemu caruje“, gotovo geometrijski poredak, sklad, harmonija. Uređeni (a to znači, Božji) kosmos je o zakonima prirode. Ukupni kosmos, beskrajni svjetovi grade se u srazmjeri, odnosima.

27 Jevto Milović, isto. 
smo kudikamo udaljeniji od saznanja istine nego oni koji su se klanjali suncu (s naročitim uživanjem priča on odmah poslije toga kako mu je jednom neki obični Turčin sa svojim jednostavnim razumom rekao: 'E vala, mi možemo da griješimo u svojoj vjeri, ali ipak ne vjerujemo u besmislenost da je žena rodila našega Boga')“'. ${ }^{28}$ Tvrdnja o religioznosti Crnogoraca zaista kratko izražava suštinu njihove religioznostit: prihvatanje Boga i strah od njega, ali odsustvo svake teološko-crkovne dogmatičnosti, što će se znatno izraziti i u osnovnoj ideji Luče mikrokozma. Izjava da tapkamo u mraku i da se nijesmo primakli istini dalje od predhrišćanstva već najavljuje Njegoševu jeretičku ideju Luče i nedogmatičnost duha, naravno, u vezi sa prethodnom tvrdnjom. Već i ovim potonjim citiranim stavom nekog običnog Turčina Njegoš je iskazao svoj ekumenizam i dosegao da umstvuje izvan okvira svoje religije, da je sposoban da se prema njoj kritički odnosi i da pokazuje interesovanje, uvažavanje i toleranciju prema ostalim postojećim vjerama.

Ovo tadašnje shvatanje „klanjanja suncu“ Njegoš je docnije u Luči veličao obožavanje Sunca i svjetlosti u smislu ,prirodne religije“ naspram „pozitivne religije" $u$ onom prosvjetiteljskom i Hegelovom smislu i značenju: „Narodna religija, koja proizvodi i podržava velika osjećanja, ide ruku pod ruku sa slobodom“ “. ${ }^{29}$ To je u skladu i s Njegoševim iskonskim shvatanjem prirode i crnogorskoga ,prirodnog zajedništva“ sa još dominantno nepostvarenom društvenom strukturom, odnosima među ljudima i njih prema prirodi i njegovim kuđenjem imperijalne (osvajačke) urbane civilizacije (u liku Mletaka i okolnijeh turskih gradova).

Isto, 88.

29 G.V.F. Hegel, 1, Rani spisi, Sarajevo, 1982, str. 41. Viđeti: Elementa montenegrina - hrestomatija br. 2/91 pod posebnim nazivom Crnogorska pravoslavna crkva?, izdavač Crnogorski (kon)federalistički pokret (glavni i odogovornri urednik i priređivač Sreten Zekovič), prilog Sreten Zeković, Slobodarska crkva i vjera Crnogoraca, str. 66. Tu se između ostalog navodi: „Ipak se bitno ne radi o nereligioznosti i ateizmu Crnogoraca. Riječ je o udaljavanju od oficijelnog hriščanstva. O jednoj 'prečišćenoj', konkretnim uslovima 'borbe neprestane' prilagođenoj religiji - onoj vrsti vjere koju su mnogi evropski mislioci nazivali: 'racionalna religija', 'prirodna religija', 'narodna religija', religija samoaktivnih naroda kao aktivnog kolektivnog subjekta. U crnogorskom slučaju, najbolji joj je naziv slobodarska religija Crnogoraca. Slobodan sam, prvi put, ističući tvrdnju da je religija Crnogoraca tradicionalnog doba veoma bliska onom idealu religiozne obnove čovječanstva, koji je postavio mladi Hegel svojim zahtjevom za vaskrsenje nepozitivne religije slobode nasuprot pozitivnim srednjovjekovnim i novovjekovnijem religijama. Ovo tijem prije što potonje (pozitivne) propovijedaju duh izmirenja sa stvarnošću, postojećim, prihvatajući sve kako jeste: zanoseći se sa sudbinski pasivnijem iščekivanjem u opštem despotizmu, potčinjenosti, imperijalnoj poslušnosti, nepružanja otpora osvajačima i protivljenje borbi za slobodu“". 
Ipak se bitno ne radi o nereligioznosti i ateizmu Crnogoraca. ${ }^{30}$ Riječ je o udaljavanju od oficijelnog hriščanstva. O jednoj „prečišćenoj“, konkretnim uslovima „borbe neprestane“ prilagođenoj religiji - onoj vrsti vjere koju su mnogi evropski mislioci nazivali: „racionalna religija“, „prirodna religija“, „narodna religija“, religija samoaktivnih naroda kao aktivnog kolektivnog subjekta. ${ }^{31} \mathrm{U}$ crnogorskom slučaju, najbolji joj je naziv slobodarska religija Crnogoraca. Slobodan sam, ističući tvrdnju da je religija Crnogoraca tradicionalnog doba veoma bliska onom idealu religiozne obnove čovječanstva, koji je postavio mladi Hegel svojim zahtjevom za vaskrsenje nepozitivne religije slobode nasuprot pozitivnim srednjovjekovnim i novovjekovnijem religijama, s tim što je u crnogorskom, odnosno Njegoševom slučaju u nerazdvojnom odnosu svijet-priroda-bog, haos (tama)-kosmos-svjetlost, fizis-Dionis-Apolon.

Ovo tim prije što „pozitivne religije“ propovijedaju duh izmirenja sa stvarnošću, postojećim, prihvatajući sve kako jeste: zanoseći se sa sudbinski pasivnijem iščekivanjem u opštem despotizmu, potčinjenosti, imperijalnoj poslušnosti, pasivnosti u odnosu na promjene, nepružanja otpora osvajačima i protivljenje borbi za slobodu. $U$ tom smislu, i pored nužne transcendencije i onostranosti (,drugom, višem svijetu“), „pozitivna religija“ je i „pozitivistička religija“, jer je čvrst čuvar srednjovjekovnog i feudalnog statusa quo (carizma i monarhizma) i kao takva ne nosi u sebi i ne razvija svijest o slobodi. Za nju je vlast, takva-kakva, data od boga, i po teokratskom načelu, po kojom se imperatori, kraljevi pozivaju da su po božjoj volji i proglašavaju se i svečevima.

Na drugoj strani, to ne znači da je ova, uslovno rečeno, ,prirodna (ili narodna) religija" Crnogoraca bila sasvim očišćena od prethodnog institucionalnog hrišćanstva - pravoslavlja. Crkva, sveštenstvo i pravoslavlje bili su najjači zaštitnik domaćeg feudalizma, srednjovjekovne carske ideologije, kulta svetih careva, kraljeva i dinasta (po jurisdikcijskom pripadanju srpskih) i opoziciona struja sekularizaciji, posebno crnogorskoj, sve dok nije bila prinuđena da se aktivno uključi u crnogorski oslobodilački pokret, da prihvata slobodno seljaštvo, izgubi svoju staru feudalnu osnovu i uobličava zajedno s njim crnogorski narodni etos i etnos, običajnost, obitavnost, ćudorednost, moralnost i državotvornost u cilju održavanja i napredovanja borbe za slobodu. Jednom riječju, bila je narodna, i kao sam narod, i slobodarska. Ta njezina

30 Vuk Karadžić navodi u svom djelu Crna Gora i Crnogorci, Beč, 1837 da su „uopšte Crnogorci manje sujevjerni nego Srbi, kao što su i manje religiozni nego ovi“".

Za Njegoša se zna da je, u pogledu religije, bio vrlo slobodouman čovjek. Mnogi stranci koji su s njim razgovarali nalazili su u njegovom karakteru „mnogo više od svjetovnog vladara nego od duhovnog vođe“.Oni su se divili ne samo njegovoj fizičkoj ljepoti i „velikoj inteligenciji“" nego i njegovim liberalnim pogledima.

31 Toga radi je i Mažuranovićevu slovinsku religiju u Čengiću primjerenije zvati prirodna religija nego religija prirode (Božidar Pejović). 
tendencija bila je preovlađujuća, posebno kroz svoj pristup narodnosti i svjetovnosti, sve do pred kraj XIX i početkom XX v. kada počinje institucionalizacija i etatizacija religije Crnogoraca, a sa njima „državna vjera“, njezina nerazdvojna dogmatizacija, kanonizacija i formalizacija.

No u dugotrajnom procesu crnogorske tradicionalne zajednice najbitnije je to da se sloboda stalno (re)produkovala kao sam način i odnos proizvodnje atipičnog oblika života i državnosti na osnovu sopstvenih sredstava za život slobodnog seljaštva-gorštaka u uslovima (i šire) jednog jedinstvenog fenomena: uglavnom srušenog domaćeg, a neprihvaćenog tuđinskog feudalizma i nekonsolidovanoga građanskog odnosa ,gospodstva i ropstva“. Stalna borba za slobodu i opstanak u njoj je osnovni i glavni konstituens crnogorskoga društvenog, narod(nos)nog, nacionalnog bića, njihovog ukupnog etosa i etnosa, proizvodnje vlastitog života $\mathrm{i}$ istorije. Njoj je prilagođen, u krajnjoj liniji, cjelokupni način života i sve njegove manifestacije, počev od društvene i vojno-političke organizacije (plemena, bratstava) preko pribavljanja sredstava za život, do stila ponašanja, odijevanja, shvatanja, morala, etike, pedagogije, psihologije, filozofije i religije. Dakle, sve do formiranja jednoga posebnog crnogorskoga pogleda na svijet. Po tom specifičnom jedinstvenom sistemu vrijednosti slobodarsko čojsko junaštvo su kruna ljudskih vrijednosti uopšte, osnova i krajnji smisao života, znači, u ontologiji slobode. Po njemu je najveća mudrost biti slobodan: živjeti u skladu sa slobodom (što podrazumijeva ) i život u skladu sa ljudskom prirodom ili u skladu sa nužnim ljudskim pravom na slobodu kao ljudskoj dužnosti najsvetijoj. Pošto istinska mudrost podrazumijeva i umstvovanje i u skladu s njim praktično djelovanje i ponašanje, onda: biti slobodan, znači, biti čovjek, misaoni atom, luča mikrokozma, čojski junak, jer se i povijesna i narodna i lična mogućnost ostvarenja slobode ostvaruje čojskijem junaštvom, junačkijem djelom. ${ }^{32}$.

Već i iz navedenih razloga religija Crnogoraca je poseban fenomen, kao što je i sam fenomen otrgnute crnogorske slobode, Crne Gore kao ,zbjega slobode“, „odsvud stiješnjenog“ okolnim carstvima i njihovom „dvoličnom diplomatijom“ (politikom) ${ }^{33}$. Ona je samosvojan izraz heroizma kao religije sa opštenitim kultom slobode. Poseban je susret i spoj crnogorske aksiologije slobodarstva, čojstva i junaštva i hrišćanstva. Pri tome naglašeniji su elementi stare, narodne religije, vjerovanja predaka, te narodne i nacionalne ideologije $\mathrm{i}$ kulta čojstva, nego hrišćanske dogmatike, teološke discipline, kanonskoga reda i hijerarhije nametnute „odozgo“. U njezinoj srži je junačka agonalnost, borbe-

32 Interesantno je da kod Crnogorca glagol biti(sati) znači i (iz)biti, tući, bitku voditi, (u)biti. Važi ontološka postavka: „Biti(sati), znači, bitku voditi, boriti“ (Viđeti: Sreten Zekovič, Rječnik starijeh Crnogoraca, CKK i Elementa montenegrina Cetinje, 1887, str. 41).

33 U navedenom agenturnom izvještaju, u razgovoru sa sagovornikom o diplomatiji, Negoš je zaključio: znači, diplomatija je dvoličnost. 
nost za paradigmu slobode, pri čemu se religija, narodnost, nacionalna svijest, običajnost, moralnost i državnost međusobno podstiču, miješaju, poistovjećuju, ali i dolaze u sukob saglasno osnovnoj, navedenoj svrsi, ontologiji slobode.

Suštinski je sukob između heroizma kao načina života (ili religije nacionalnog heroizma, odnosno heroizma kao religije i kulta) i Hristovih zapovijedi. Crnogorac je ubijeđen da Bog podržava njegovu pravednu borbu za slobodu, i da je on, baš takav-kakav je, ,po božjem liku“. U pomenutom spoju očito je i preovlađujuće zapostavljanje, zaturanje pravoslavne i uopšte hrišćanske dogmatike i kanona. Prihvataju se samo ukoliko se mogu prilagoditi i uobličiti u nacionalni i individualni heroizam, odnosno u crnogorsku borbu za opstanak u slobodi, u junačko čojstvo i/li čojsko junaštvo. Ljudsko pravo na slobodu je vrhovni zakon čovjeka i čojskoga junaka koji ne trpi ,regule“", nikakvu spoljnu silu koja mu sputava slobodu i njegovo ljudsko dostojanstvo - sopstveni izbor i odluku za ostvarenje svoje svrhe. Junak ne priznaje drugu hijerarhiju osim agonalnog prvijestva u junaštvu i čojstvu. Za crnogorskog tradicionalnog viteza važile su maksime: „Ove gore ne trepe regule“ i „,bez poretka najdublja nauka“. I pored toga, dolazi se do saznanja da „nad svom ovom grdnom mješavinom upet umna sila toržestvuje“. Ne samo da Crnogorci nijesu trpjeli regule, nego ih načela čojstva mijenjaju. upravo zato što ih sami stvaraju: heroj i čovjek im ne robuje, no ih stvara. ${ }^{34}$ To je u skladu i sa Njegoševim iskonskim shvatanjem prirode crnogorskoga ,prirodnog zajedništva“ sa još dominantno nepostvarenom društvenom strukturom, odnosima među ljudima i njih prema prirodi i njegovim kuđenjem imperijalne (osvajačke) urbane civilizacije (u liku Mletaka i okolnih turskih gradova).

Njegoš nije ni klasicista već i po svom izuzetno umjetničkom i originalnom narodno-epskom desetercu. Ne može se Njegoš ocjenjivati kao eklektik i sinkretista samo zato što je dobro poznavao staru mitiku i što je koristio u svojoj poetskoj mudrosti, jer je veliki broj značajnih filozofa i književnika to isto implementirao u svojim djelima, pa ih radi toga niko tako ne šablonizuje (Može li se tako, npr., čerečiti F. Niče zbog Zarataustre, korišćenja antičkih mitskih principa i vjera, npr. zbog insistiranja na jedinstvu dioniskog i apolonskog načela).

Njegoš je nesporni, ali kritički pristalica i privrženik nacionalnih revolucija Slovena i Južnih Slovena, novovjekovnog slobodoumlja i evropskog prosvjetiteljstva. Meternih ga je već 1837. u Beču okarakterisao da širi slovenstvo, da je prijemčiv za zapadni liberalazam, za vodeće ideje svoga vremena i da nema potrebnog poštovanja prema religiji $i$ monarhiji, zbog čega je bio

34 Elementa montenegrina - hrestomatija br. 2/91 pod posebnim nazivom Crnogorska pravoslavna crkva, izdavač Crnogorski (kon)federalistički pokret (glavni i odogovorni urednik Sreten Zekovič), prilog Sreten Zeković, Slobodarska crkva i vjera Crnogoraca, str. 67. 
pod stalnim i pojčanim policajskim i špijunskim nadzorom. ${ }^{35} \mathrm{I}$ bio je protivnik carstava, pa i Napoleona, Cezara i Aleksandra Makedonskog smatra Sotoninim, a ne Božjim nasljednikom, odnosno otpadnicima od božanske, prirodne i ljudske pravde, ljudske i narodne slobode, što zanago nije mogao reći za njemu aktuelne careve, ali ne, kako navodi Ž. Uvanović, iz poslušnosti prema crkvi i hrišćanstvu, nego prije svega i iz razloga cenzure za objavljivanje ovog, njemu najdražeg „djelca“.

Nakon Svete alijanse, Meternih je bio čuvar učvršćenja i restauracije evropskog monarhizma. Austrijsko i ostala carstva su zazirala od fenomena otrgnute crnogorske slobode i Crnu Goru smatrali žarištem revolucije za okolne potčinjene narode. Crnogorska oslobodilačka „borba neprestana“ bila je predmet svih Njegoševih djela, pa i Luče mikrokozma u kojoj se pjesničko-alegorijskim jezikom razmatraju osnovna ontološka i metafizička pitanja koja se sintetizuju u ontologiji slobode uopšte radi opravdanja i fenomena otrgnute crnogorske slobode. U metafizici Luče odzrcava se sve što se zbiva u ljudskom (zemaljskom) životu, društvu i odnosima među ljudima. Njegoš je napravio inverziju tako što je smisao odnosa među ljudima prenio u ravan mitologije i religiozne fantastike. ${ }^{36}$ Drugim riječima, napravio je projekciju ovozemaljskog života (uvijek spupčenu sa crnogorskim etosom i etnosom, borbom Crnogoraca za samoopstanak u slobodi), u nebeski život, što će reći, da se on može prepoznati antropomorfno, kosmopolitomorfno, istoriomorfno, antropokratomorfno. Znači, Njegoševa mitska slika višeg duhovnog svijeta (neba) prepoznatljivo je antaropologija. ${ }^{37}$ Zato nemaju osnove zaključci i tvrdnje Ž. Uvanovića, posebno ne ako se Njegoševa poetska murost shvata u njenom neraspu(p)čivom jedinstvu i ucjelovljenosti.

U liku pizmatičnog, gordog, sebičnog i iznad svega vlastoljubivog Satane (,samovlasca“) u pobuni protiv Boga, radi preuzimanja vlasti i stvaranja drugačijeg kosmosa protivnog prirodnim zakonima, Njegoš duboko i dalekovido prepoznaje da su njegove demokratske parole i navodna borba za jednakost $i$ jednake uslove samo propagandističko sredstvo, laža, obmana, prijevara, sofizam koji mu pomaže da se domogne vlasti. Iako daje vrlo impresivne i povodljive argumente Satani, Njegoš nije na njegovoj strani. To što istupa sa demokratskom idejom, da imamo svi jednaka prava, samo je umjetnički oblik kritičkog odnosa prema naivno prihvatanom, zanosno proklamovanom i gordo samovlasno ostvarivanom novovjekom idealu demokratije koji skriva svoju suštinu - opet zavjeru, prijevaru ugroženih i demagošku borbu za vlast koja je već iskazivana u tušte puta iskustvenoj logici života i činjenici

35 Jevto Milović, isto.

36 Slobodan Tomović, isto, str. 380 .

37 Isto. 
da se iza verbalnog privida humanizma najčešće skriva potencijalni diktator i totalitarna volja koja je i sve više surovija što je više demagoški iskazana propagandno kao bliža masi ili ima vću silu privlačnosti za nju. Njegošev Satana je budući diktator, samodržac, kojeg zanima bitno samo apsolutna vlast. Oni koji u kritičkoj literaturi, kao što je i Ž. Uvanović, o Satani zbore kao borcu „za jednaka prava“, smjelom suparniku neba koji želi da preuredi kastinsku strukturu u korist obespravljenih, da ograniči apsolutnu Božju moć, te iz toga izvode pogrešni zaključak da Satana nije posve negativna ličnost, već je on, iznad svega, revolucionar koji teži za ostvarenjem svjetske pravde, ne smiju da previde Satanin zahtjev za „krunom samodržavlja“ koji otkriva njegov demagoški karakter u službi osvajanja apsolutne vlasti. Taj zahtjev Satana više puta obrazlaže, a konačni smisao je u njegovim riječima:

Nek se svaki sa vrhovnom vlašću

na svom nebu gordi i veliča. ${ }^{38}$

Rečeni lažni (apstrakatni) humanizam mogao je Njegoš da prepoznaje i u zloupotrebi „teokoratskog principa“ po kojem je imperijalna (osvajačka) vlast i porobljavanje naroda u imperijama data od Boga, obogotvorena. Duhovni pratilac Njegoševe duše na putu u nebo kaže mu:

Šta te k ljudskoj vuče kolijevci,

đe kukanje i plač okrunjeno,

đe vjenčana glupost sa tirjanstvom,

đe se samo rad nesreće ljudske

bogotvori Cezar s Aleksandrom.

Njegoševa djelimična naklonost prema Satani samo je izraz umjetničkog uživljavanja u naivnom i megalomanski prihvaćanom epohalnom zanosu idejom razura starog poretka, ništenja Boga i lažno obećavanog novog svijeta na neprirodnim zakonima, ignorisanjem ljudske prirode i iskonske prirode. U takvom svijetu bitak čovjekovog bića, Luča mikrokozma se sasvim materijalizuje, svodi i izopačava u Čovjekoboga, Čovjekokratu, Antropokratu, Vlastodržca, u kojemu je sloboda i znanje osvajanje i gospodarenje nad prirodom, ljudskom pirodom (dušom), čovjeka nad čovjekom. U njemu sve jest vlast, koja život znači, a biti, znači, osvajati, vladati, a ne življeti u skladu sa vječnom ljudskom, prirodnom i Božjom pravdom, čovjekovom lučom kao „,iskrom vječitoga ognja“. To je ona zatamljena i zaboravljena luča mikrokoz$m a$ koju je pomračilo ono sotonsko vječno zlo u čovjeku koje umišlja da je on jedini stvaralac smisla i sopstvene sudbine. To je ono „sotonsko“ u Čovje-

38 Slobodan Tomović, isto, 471/2'. 
kobogu, Osvajaču, Imperatoru koji hoće da vlada svim, pa i Prirodom, Svijetom po sopstvenoj mjeri i da postane Bog. Da bi to postao mora da iznova gradi novi svetski poredak i stalno iznova da ga razgrađuje i vazda obnavlja na istoj osnovi, da zaludno gradi Vavilonsku kulu Vavilonskoga carstva. ${ }^{39}$

Njegoš je uvidio i nedovoljstvo te nove civilizacije, njezinu jednostranost, koja potpuno materijalizuje čovjekov bitak, pretvarajući ga u čovjekobo$g a$, novog osvajača prirode i ljudske prirode, ignoriše iskonsku prirodu i bogočovjeka. U tome je Njegoš anticipator savremenog kuđenja nedovoljstva te nove građansko-urbanističke civilizacije koja svoju „lošu beskonačnost“ (konačnog) vazda obećavano odlaganu i nedostižnu izopačava u „lošu vječnost““. Na drugoj strani, Ž. Uvanović na nekim mjestima dobro uočava aktuelne realne refleksije ondašnjeg doba u Njegoševim pjesmama i u Luči, što znači da je prepoznavao u njima svjetovne elemente i svjetovnu osnovu, uticaj i dešifrovanje, ali su to bili izuzeci. Da se to primjenjivalo načelno i dosljedno, sasvim bi bila druga slika o Njegošu, a da su se u „tajnoj svete porodice“ nalazila i otkrivala „tajna ovozemaljske porodice“, onda bi Uvanovićeva interpetacija autora bila takođe sasvim drugačija. Evo primjer za to: „Ali očito je da pravo objašnjenje za zlo i u sferi tada aktuelne politike, turske opasnosti i otpadnika u vlastitim redovima vidi u dubljoj sferi gnostičkog tumačenja svih ontoloških pitanja, u apokrifnom subverzivnom potisnutom tekstu.$^{40} \mathrm{Za}$ nas su ovđe bitne dvije stvari (koje sam kurzivom naveo): prva, da autor dobro uočava u Njegoševom vremenu otpadnike $u$ vlastitim redovima (izdajnike) i da ih dovodi u vezu sa objašnjenjem zla koje se reflektuje i u Luči (a ne samo u Gorskom vijencu u kojem je izvršena njihova istraga, a ne ,istraga poturica“); i drugo, Njegošev postupak apokrifnog subverzivnog potiskivanja teksta jer je taj oblik metode subverzije Njegoš koristio u Gorskom vijencu i ostalim djelima. Naime, Njegošev kompleksniji metod sam nazvao književno-diplomatski metod kontrastiranja, konverzije, inverzije, subverzije sopstvenog izloženog gledišta i opravdane fikcije. ${ }^{41}$

39 Viđeti o tome: Sreten Zeković, Na raskršću Bogočovjeka i Čovjekoboga-Sekularizacija, kosmopolitomorfizam, antropokratizam i oprirođeno-ljudski i oljuđeno-prirodni fideizam, CDNK Podgorica i Elementa montenegrina Cetinje, 1994. Takođe i S onu stranu moći i vlasti, CKK Cetinje, 2007.

40 Ž. Uvanović, str. 783.

${ }^{41}$ Autor ovog rada nazvao je tako ovaj Njegošev metod u knjizi Etnička svijest dinasta Petrović Njegoš, Crnogorski PEN centar i CKK Cetinje, 2011. i u knjizi Simo Milutinović, Petar I, Njegoš, CKK Cetinje, 2011. 


\section{Sreten ZEKOVIĆ}

\section{DOES NJEGOŠ'S WISDOM CONSTITUTE ECLECTICISM, SYN- CRETISM, AND OFFICIAL CHRISTIANITY, SUPPORTIVE OF CONSERVATIVE "OLD ORDER"?}

The present study refutes the recent attempts of reducing Njegoš's poetic wisdom to eclecticism and syncretism, as well as the claim that his religion implies Christian obedience to church and orthodoxy of Christian theology, that his God is "Christian God", that he is an apologist for the monarchy and that he supports conservative "restoration of the old order". In refuting the aforementioned claims, the author highlights the unique and original Njegoš's poetic philosophy of freedom, stressing that his religion and theology are not only entirely "heretical" but in almost all the important elements also contrary to official Christianity, church teachings and Christian God, as well as that it serves the affirmation of Montenegrin constant struggle for freedom and international recognition of the real independence of Montenegro.

Key words: Njegoš's originality, abuse of syncretism, religion, "invisible" structural relations 


\title{
Ethem MANDIĆ (Podgorica)
}

UDK 821.134.2(8).09-31

Izvorni naučni rad

Fakultet za crnogorski jezik i književnost - Cetinje

ethem.mandic@fcjk.me

\section{POJAM IGRE U ROMANU ŠKOLICE HULIJA KORTASARA}

\begin{abstract}
Autor u ovome radu tumači roman Školice autora Hulija Kortasara sa formalnog, stilskog i tematsko-sadržajnog aspekta. Takođe, u ovome se radu nastoji prikazati roman kroz četiri nivoa realizacije pojma igre, i to na fabularnom, pripovjedačkom, tematskom, stilsko-jezičkom i drugim planovima. Roman Školi$c e$, iako nastao na latinoameričkom tlu, dio je evropske romaneskne prakse i nastavak razvoja evropskoga romana i specifične njegove linije na latinoameričkom tlu.

Ključne riječi: Kortasar, Školice, Lotman, igra, roman, pripovjedač, jezik, Pariz, Moreli
\end{abstract}

...Igra daje čoveku mogućnost uslovne pobede nad nepobedivim (npr., nad smrću), ili veoma moćnim protivnikom.To određuje $i$ njeno magijsko značenje... Jurij Lotman

\section{IGRA FORME}

Školice (španski: Rayuela) je roman argentinskog pisca Hulija Kortasara. Napisan u Parizu i objavljen na španskom jeziku 1963. godine, i na engleskom jeziku 1966. u prijevodu Gregori Rabase, osvojio je 1967. US National Book Award.

Ovaj roman u prvom redu donosi novost na strukturalnom planu i zato je pitanje njegova žanrovskog određenja centralni problem. U književnoj kritici taj roman često je nazivan antiromanom, međutim sām Kortasar, u jednom intervjuu za emisiju $A$ fondo, kaže da je taj termin suviše negativan i otrovan i da otkriva želju za uništenjem romana kao žanra. U istom intervjuu kaže da su Školice, zapravo, potraga za novim značenjima i romanesknim mogućnostima, i da bi termin kontranovela bio više odgovarajuć, iz razloga što Školice predstavljaju drugačiji način kontakta između romana i čitaoca. Roman $\breve{S} k o-$ 
like nije avangardni pokušaj uništenja svih konvencija narativne proze, već modernistički pokušaj produbljivanja i eksperimentisanja s formom, koji je u romanu XX vijeka svoj vrhunac doživio sa romanom Uliks, irskog pisca Džemsa Džojsa, koji je prema riječima Danila Kiša „modernima otkrio dokle se može ići u eksperimentu, i koja je tome cena".

Školice su potraga s aktivnijim čitaocem koji napušta tipičnu pasivnu čitalačku poziciju. Roman nudi uslovnu mogućnost iluzornog ośećaja stvaralaštva ili učestvovanja u kreiranju sižejnog toka, on je potraga i igra, kako kaže sām Kortasar, za i sa čitaocem saučesnikom, pa je implicitni čitalac, ili drugo $j a$ stvarnog čitaoca, zaista „oblikovan u skladu sa vrednostima i kulturnim normama implicitnog autora". ${ }^{2}$ Ovđe treba razlikovati implicitnog čitaoca od stvarnog čitaoca, ali i od naratera (to jest čitaoca prisutnog u svijetu teksta).

U Kortasarovom djelu Školice čitalac nailazi na specifičnu strukturu romana. Na početku knjige nalazi se Putokaz, što u stvari znači da se poglavlja ovoga romana moraju čitati na određen način, s redosljedom koji preporučuje sām autor, redosljedom koji nije svojsten tradiciji realističkog romana čvrste fabularne motivacije i sukcesivnosti poglavlja. Dakle, ovaj roman daje neku novu, originalnu formu u svijetu narativne fikcije te predstavlja crtu moderne literature, a to je „neprestano preispitivanje ne samo forme, nego i celokupne literature pri pisanju svakog novog dela, svakog romana, svake priče“, 3 što je opet zapravo traganje za apsolutnom Formom.

Sām naslov Školice sugeriše da je roman igra. Pojam ,igre školica“ je u ovom romanu višeznačan, što će se ovim tekstom pokazati. Ovaj roman bi se mogao svrstati, prema Kunderinoj podjeli romana na četiri posebna zova unutar mogućih formi i spoznajnih oblika romana u Zov igre, u kojem bi on bio potomak romana Tristram Šendi i Fatalista Žak, romanima koji su, prema Kunderinim riječima, ,zamišljeni poput veličanstvene igre. To su dva vrhunca lakoće koja nijesu dosegnuta ni prije, ni poslije. Poslije je roman bio sputan imperativom vjerodostojnosti, realističkim dekorom, kronološkom strogošću. Napustio je mogućnosti sadržane u navedena dva remek djela, koja su mogla zasnovati evoluciju romana drukčiju od ove koju poznajemo (da, može se zamisliti i neka druga povijest europskog romana)“. ${ }^{4}$ Upravo roman $\breve{S k}$ kolice preuzima načela konstrukcije, odnosno organizacije fabule započetim ovim dvaju romanima i nastavlja evoluciju evropskog romana koju je mogao zamisliti Milan Kundera, napuštajući imperativ vjerodostojnosti i hronološku strogost $\mathrm{u}$ korist novog otkrivanja starog duha improvizacije na kojoj je roman

\footnotetext{
D. Kiš, Život, literature, Prosveta, Beograd, 2007, str. 163.

Dž. Prins, Naratološki rečnik, Službeni glasnik, Beograd, 2011, str 73.

J. Lotman, isto, str. 167

M.Kundera, Umjetnost romana, Meandar, Zagreb, 2002, str. 21.
} 
kao forma i izrastao. U ovome objašnjenju nastavka zaustavljene evolucije romana započete u XVIII vijeku, romanima čija je forma, prema Kunderi, veličanstvena igra, krije se objašnjenje zbog čega je danas Kortasar možda manje interpretiran i čitan od drugih latinoameričkih pisaca koji su pripadali pokretu latinoameričkog buma, kao što su Gabrijel Garsija Markes, Mario Vargas Ljosa, Horhe Luis Borhes. ${ }^{5}$ Hulio Kortasar pokušao je vratiti u roman veličanstvenu igru koja ga je $\mathrm{u}$ toku dva vijeka bila napustila.

Igra, prema riječima Lotmana, zauzima važno mjesto u čovjekovom životu. Igra se, u prvom planu, odnosi na spoljašnji pristup romanu, tačnije, odnosi se na podjelu poglavlja u romanu. Na početku autor kaže da prvih 56 poglavlja trebaju da se čitaju na „uobičajen način“. Nadalje kaže da čitanje druge knjige može da počne poglavljem 73 , a potom se treba pratiti redosljed koji je numerisao autor, ali čitalac može sām da bira poglavlja koja želi čitati. Dakle, mi kao čitaoci bi trebalo da preuzmemo na sebe čitalački prostor predložen u uputstvima. Roman postaje poput školice, bacamo kamen i pratimo njegovu putanju i na polje na koje kamenčić stane, to je poglavlje koje treba da sustignemo i pročitamo. U tako organizovanoj fabuli romana uvijek je prisutna hazardnost čitanja i ishoda priče.

Na nivou poglavlja, kojih ima ukupno 150, od kojih su 29 označeni kao Izostavljiva poglavlja, to znači da sama ta poglavlja stiču izvjesnu autonomnost, nezavisnost u odnosu prema drugim poglavljima i odnosu na samu

Up.: „Kao još jedan primjer za ilustraciju eksplozivnih i postupnih procesa navešećemo fenomen koji se desio u latinoameričkoj književnosti tokom šezdesetih godina. Naime, naziv tog 'pokreta' ima jako simbolično ime u kontekstu našega rada. Ta pojava poznatija je kao latinoamerički boom. Sām naziv asocira nas na eksplozivan proces koji je se desio u Latinskoj Americi, proces čija se detonacija desila na tlu Južne Amerike, koju je ośetio skoro čitav svijet. U tome periodu nastali su najbolji romani na tim prostorima. Stvarali su pisci poput Horhe Luisa Borhesa, koji se smatra jednim od začetnika samog pokreta, zatim Gabrijel Garsija Markes, Karlos Fuentes, Hulio Kortasar i drugi. Čitavom svijetu ta plejada pisaca prikazivana je kao jedan tim čija su se djela desila gotovo istovremeno. Ali, bližim pogledom viđećemo da taj naziv nije u svojoj suštini opravadan i da tu imamo slučaj, kako ga Lotman naziva, imitacije eksplozije. Svi ti romani i pisci koji čine latinomamerički boom nijesu stvarali istovremeno i, kako napominje Kortasar u jednom intervjuu za špansku televiziju, svi oni su stvarali svoja djela izvan svojih zavičaja, u samoći, i u raznim vremenima. Iako je pojava tih pisaca zaista donijela eksplozije na planu književne umjetnosti (Danilo Kiš kaže da je Borhes napravio revoluciju u pisanju pripovijetke i da se njena povijest gleda kao povijest pripovijetke prije i poslije Borhesa), taj proces nije bio eksplozivnoga karaktera. Naprotiv, proces je postepen i imao je izuzetnu progresivnu snagu. Kulturološki fenomen raznorodnih tekstova koji se slažu u jedan sloj i prave određenu kulturu unisonog karaktera, a ta kultura ima svoje mehanizme razvoja i povezivanja, u ovome slučaju postepenoga, dao je ono što mi danas posmatramo kao dio latinoameričkog nasljeđa. (Ethem Mandić, „Kultura i procesi kretanja u semiotičkim sistemima“, Lingua Montenegrina, Institut za crnogorski jezik i književnosti, Podgorica, 2013, str. 643.) 
fabulu, što će reći da je u samom djelu moguće pronaći više od jednog sižea. Siže dolazi od francuske riječi sujet - predmet. Odnosi se na događaje kako ih, odnosno kojim redom neko književno djelo donosi. Ukoliko prihvatimo ovu terminologiju koji su donijeli ruski formalisti početkom XX vijeka, onda roman Školice svojom formom i slijedom poglavlja daje nekoliko sižea. Koliko je mogućih čitanja, to jest kombinacija poglavlja tog djela, toliko je i mogućih sižea, a ova igra s otvaranjem više mogućih sižea predstavlja jednu vrstu formalističkog oneobičavanja (остранение) forme, ali i „postmodernističkog“ ogoljavanja samog postupka stvaranja sižea na osnovu zadate fabule, to jest književnog postupka koji su postmodernisti uzeli za jedno od svojih poetičkih načela komponovanja romana.

„Ostavljajući po strani ono što pripada fabuli, a kod njega ona je uvijek originalna, prevashodan elemenat njegovog pripovijedanja je ritam; on se nameće ostalim elementima od kojih je pripovijest izgrađena, često je čak i određuje stvara." ${ }^{\text {6 }}$ Poglavlja u Školicama su poetična, često lirsko nadahnuta, bogata stilskim figurama (Pariz je velika metafora), dok asocijativno pisanje, automatsko pisanje nadrealističkog karaktera, kompleksna sintaksa, dijalektički kolaži, sporedne bilješke, prepleti ekperimentalnoga, poetičnoga $i$ realističnoga daju autentičnost i samim tim mogućnost raznih čitanja djela. Raznovrsnost stilova i eksperimentalni karakter ovog djela govori o njegovoj pripadnosti onim modernističkim strujanjima kojima pripadaju romanopisci kraja prve i početka druge polovine XX vijeka. Ovaj roman predstavlja konglomerat, ali homogen konglomerat narativnih tehnika i tvori polipripovjedačku polifoniju.

Osim obimnoga poglavlja „S one strane“, koje govori o događajima glavnog junaka u Parizu, postoje ona koja su povezana glavnim tokom fabule i nastavljaju se jedno na drugo. Poglavlja od desetog do osamnaestog govore o jednom sastanku „Kluba zmije“ u Parizu i predstavljaju upliv esejističkog u narativni svijet romana, čineći ono što je Kundera povodom romana koji aktiviraju Zov misli nazvao pokušajem da roman bude vrhunska intelektualna sinteza. Na tim sastancima likovi romana, Gregorovius, Babs, Ronald, Wong, Maga, Etien, raspravaljaju o književnosti, slikarstvu, muzici, filozofiji. Poglavlja nijesu povezna motivacijski, radnjom, već jedinstvom mjesta i vremena. Postoje i poglavlja koja su povezana radnjom, recimo poglavlja koja govore o smrti Maginog sina Rocamadoura, ili poglavlja „S ove strane“, koja se odvijaju u ludnici koju je kupio upravitelj cirkusa.

6 H. O. Hrens, H.M Golobof, Istorija hispanoameričke književnosti, Matica srpska, Beograd, 1982. 
U prvom poglavlju romana („S one strane“) pripovjedačke situacije se često mijenjaju. Neka poglavlja su ispripovijedana u prvom licu, neka u trećem, često se koristi tehnika „toka svijesti“, unutrašnjeg monologa, kombinovanja raznih jezika i smjena citata, stihova iz džez pjesama, to jest intertekstualnog povezivanja pop kulturom i naratorovog govora u samo jednoj rečenici. Ovakav stil je semantički i stilski preopterećen i zahtijeva veću čitalačku pažnju i erudiciju. Školice napuštaju onu monolitnu tačku gledišta kojoj je robovao romantičarski i realistički roman. Kortasar je u ovom romanu vidno eksperimentisao sa svim elementima stila i forme. Takođe, sama struktura poglavlja kao zasebne homogene cjeline je razbijena. Na primjer u poglavlju 34 postoje grafički razdvojene dvije paralelne priče. Svaki neparni red je jedna priča, a svaki parni druga priča koje se dodiruju u određenim rečenicama upotrebom istih riječi. Tako dobijamo dva poglavlja u jednom. Jedna priča govori o Horacijevom stricu koji živi u Madridu, a druga je obraćanje Magi, koje se često sintaktički i semantički dodiruju upotrebom istih riječi na istim mjestima u poglavlju.

U 47. poglavlju Talita razgovara sama sa sobom snimajući se na magnetofonu. Pripovjedač nam prenosi taj govor uz tok misli same Talite. Na taj način imamo fokus percepcije u prvom licu, a da se ne napušta pripovjedačka situacija u trećem licu.

Tako stilski raznorodno ispripovijedano obimno poglavlje „S one strane" i na formalnom planu donosi sliku o raznolikosti i komplikovanosti života i različitosti kultura u Parizu, o mnoštvu likova iz raznih djelova svijeta, različitih po mentalitetu, razmišljanju. Ono stoji u opoziciji, to jest u kontrastu s Buenos Airesom i poglavljem „S ove strane“, koje je cijelo u trećem licu, ispripovijedano s pozicije sveznajućeg pripovjedača, koje opet sugeriše monotonost i ustaljenost života u Horacijevoj domovini, istovjetnost ili sličnost ljudi u okruženju u koje se Horacijo iz Pariza vratio. Takođe, naslovi poglavlja govore o jako bitnoj prostornoj odrednici samog pripovjedača, sastavljača poglavlja. Naime, ona govore o tome da se pripovjedač, ili pripovjedačka svijest, sve vrijeme nalazi „s ove strane“ u Buenos Airesu i odatle stvara, dok se Pariz daje kao ono što je bilo „s one strane“, u odsustvu, iako se nikad ne napušta vremenska pozicija prezenta. Osim toga, ovakva podjela aktivira granicu kao specifičan modelativni sistem s koje implicitni autor romana modeluje dva narativna svijeta, koji na taj način guta različite kulturne diskurse (evropske i latinoameričke) u jedan specifičan narativni svijet Kortasarova romana, u kojem su izmiješane kulturne, ali i kontrastno postavljene razlike Starog i Novog kontinenta. 


\section{IGRA SMISLA}

Iako su inovacije koje donosi roman uglavnom na planu forme, priča o Argentincu u Parizu i Buenos Airesu, Horaciju Oliveiri i njegovom traganju za kibucom želje, za otvorom i smislom je, takođe, izuzetno orginalna. Dakle, i na unutrašnjem planu, potraga se odvija u vidu igre, dostizanje neba sa zemlje, prolaz kroz otvor u središtu cirkuskog šatora, valjanje u piramidi balege; sve je igra jednog čovjeka u potrazi za smislom. „Igra je osobiti tip modela stvarnosti“", a Školice su, prema riječima Kortasara, pokušaj negacije svakodnevne stvarnosti i otvaranje, traganje za drugim mogućim stvarnostima, stvarnostima mogućeg svijeta, svijeta fikcije - „roman je napisan u znaku neumoljive potrage, koja se zbiva na svim zamislivim razinama“. Traga Oliveira, traga njegov prijatelj Traveler, tragaju članovi „Kluba zmije“, tragaju svi. Potraga je vrhunski smisao. Važan je put i potraga. Važniji od samog smisla, jer smisla nema, ili ga je nemoguće pronaći. „Ono traženo izražava se u mnoštvu figura, opsesivnih metafora, rasutih po cijelom romanu kao što su: most, prolaz, otvor, središte, ključ, kibuc želje. Po želji se može dodati: smisao, svrha, spas. Osnovna figura je, naravno, sama igra školice: „dopiranje od Neba do Zemlje, ali $u$ istoj ravni". Dakle, sama igra postaje smisao.

$\mathrm{U}$ tom smislu potrage, glavni junak prekida odnose s Magom, uprkos činjenici da ima ośećanja prema njoj, jer on želi biti „,svjesna lutalica“, odriče se konformizma ljubavi i svih prijatnih ośećanja. U biti njegove potrage je akcija (iako sam Horacio više puta naglašava da nije svjestan za čim traga, što o njemu misle i Maga kao i ostali članovi „Kluba“). Horacio misli da ne postoji neka povezanost među ljudima, a ako postoji ona ne traje dugo, kako se kaže na kraju poglavlja „S ove strane“: ,govoreći sebi da na kraju krajeva ipak ima nekog susreta, iako on ne može trajati dulje od toga užasno slatkog trenutka u kojemu bi bez ikakve sumnje bilo najbolje da se mrvicu nagnuo van i samo se spustio, paf, gotovo“8. Možda je samoubistvo jedini izlaz.

Uslovna prološka i epiloška granica poglavlja „S one strane“ i „S ove strane“ (ukoliko ih čitamo onako kako autor predlaže), govore o susretu. Na početku romana Oliveira se pita: „Hoću li sresti Magu?“ A na kraju zaključuje da je neki ,susret ipak mogućc“.

Maga je po Oliveirinom mišljenju već dostigla „Nebo“. Ona se intuitivno kreće „metafizičkim rijekama“, dok je on sav u kontemplaciji i zbog čega Maga kaže da je to njegov najveći problem: „Previše razmišljaš prije nego što bilo što učinišs“. To je razlog njihove različitosti. Oni su postavljeni kao

\footnotetext{
J. Lotman, Struktura umetničkog teksta, Nolit, Beograd, 1976, str. 102.

H. Kortasar, Školice, Pelago, Zagreb, 2009, str.377.
} 
dva suprotna pola, dva kontrasta, dva kontinenta, nebo i zemlja, čiji susret je moguć samo ako se izgradi most koji može spojiti te dvije različitosti, muški princip i ženski princip. A mogućnost njihovog „susreta“, nalazi se u vođenju ljubavi. U petom poglavlju kaže se: „Onda je jedina mogućnost susreta počivala u tome da je Horacio ubije u ljubavi gdje je ona uspjevala sresti se sa njime, na nebu hotelskih soba suočavali su se sa sobom jednaki i nagi, ondje je ptica feniks mogla uskrsnuti nakon što je on slasno zadavi, pusti da joj iz otvorenih usta potekne mlaz sline, zaneseno je promatrajući kao da je počinje promatrati, činiti je istinski svojom, dovoditi je na svoju stranu“".

Traganje ulicama Pariza, njihova potraga jedno za drugim bez prethodnog dogovora je želja, način da se pronađu izvan dogovora, izvan konformizma. Mostovi na kojima su se nalazili, između svih „Pont des arts“, je simbol susreta, spajanja ljudskih sudbina. Još važnije je pitanje koje postavljaju sebi, da li je njihov susret bio slučajnost, ili je to bio prst sudbine. Da li je susret ljubavnika i susret poglavlja slučajnost ili sudbina?

Simboličan je trougao koji se stvara između Horacija, Travelera i Talite. U pedeset $\mathrm{i}$ šestom poglavlju, njih troje prave most od dasaka, kako bi mogli Horaciju dodati mate (vrsta argentinskog čaja) i eksere. Taj most je simboličan jer predstavlja komplikovan odnos između Travelera i Horacija u čijoj se sredini nalazi sama Talita, čega je ona sama svjesna. Na kraju ona ne prelazi most, samo dobacuje stvari Oliveiri jer je preći most bilo i suviše opasno, kao što je granica na kojoj se susrijeću različitosti uvijek modelativno inspirativna jer predstavlja opasno polje susreta različitosti, o čemu na meastralan način govore romani Zuvdije Hodžića, Davidova zvijezda i Gusinjska godina.

Zanimljiv je odnos koji Oliveria ima sa Gregoroviusom. Taj odnos pomalo podśeća na odnos koji Oliveira ima sa Travelerom. Taj odnos je antagonistički, suparnički, jer se, kao i u slučaju s Travelerom, nalaze u trouglu sa još jednom ženom. Gregorovius ima ośećanja prema Magi. Iako antagonistički, njih dvojica su, kao i Traveler i Oliveira, u stvari slični. I Gregorovius, kao i Traveler želi biti prijatelj sa Oliveirom i kaže: „Zapravo bismo mogli biti prijatelji, da u tebi ima nečeg ljudskog“.

Igra školica je za glavnog lika vrhunski način spoznaje. Igra podrazumijeva akciju, pokret, ono što i sam glavni lik zagovara u romanu. „Igra nije suprotna spoznaji, naprotiv ona je jedno od najvažnijih sredstava za savlađivanje različitih životnih situacija, za učenje različitih tipova ponašanja“ ${ }^{9}, \mathrm{i}$ zato igra dopušta glavnom liku da kodira sopstveno ja, i pomaže mu da riješi jedan od najsuštastvenijih psiholoških zadataka - određenje svoje sopstvene suštine. „Igra, sa svojim dvoplanskim ponašanjem, sa mogućnošću uslovnog

9 J. Lotman, Struktura umetničkog teksta, Nolit, Beograd, 1976, str. 102. 
prenošenja u situacije koje su datom čoveku u stvarnosti nedostupne, omogućava mu da nađe svoju sopstvenu suštinu. ${ }^{~}{ }^{10}$

Horacio u svojoj igri poput đeteta ne napušta svijet igre, njene „uslovnosti“. On igra po pravilima, jer svaka igra ima svoja pravila. U romanu on često govori o tome šta se sve mora raditi da bi se našao smisao. Međutim, ostali likovi, pogotovo Maga i Traveler, kao karakteri, njegova su suprotnost i na taj način ističu dvoplanski karakter igre. U odnosu na njih čitalac vidi „tobošnjost“" igre, njenu dvojaku strukturu. Iz Horacijeve tačke gledišta igra dobija vrhunski smisao, ona je „ozbiljna“, ona se igra po pravilima i njegova uloga „svjesne lutalice“ mora biti vjerodostojna i orginalna, kao dijete kad igra astronauta, pliva na travi ili školicama nacrtanim na zemlji dostiže nebo.

„Suprotan slučaj narušavanja dvoplanskog ponašanja u igri jeste odbijanje da se igra prihvati ozbiljno, jednostrano isticanje njene uslovnosti i tobošnjosti."11 Tako članovi kluba često ističu Oliverino ponašanje kao nedolično i neobično i osuđuju njegovo ponašanje, posebno nakon smrti Maginog đeteta. „Čovjeku koji ne prihvata njena pravila, igra izgleda besmislena, bez ikakve veze sa ozbiljno realnošću. “12 Horacio Oliveira na kraju dvadesetog poglavlja kaže Magi: „Tko će ga znati, ja mislim da ni ti ni ja nismo suviše krivi. Nismo odrasli Lucia. To je zasluga, ali se skupo plaća. Djeca se poslije igre uvijek počupaju za kosu. Mora da je tako nešto. Trebalo bi razmisliti.“ Dakle, vidimo da Oliveira igru doživljava kao realnu i jedinu moguću.

Ponavljanja na kojima se bazira igra bilo kojeg tipa su sjedinjenje zakonitih i slučajnih procesa. Odstupanja koja se javljaju u toku igre su veoma značajna, i nositelj su visoke informativnosti, zahvaljujući zakonitosti ponavljanja situacija. „Početna pravila ne pružaju mogućnost da se predskažu svi potezi, koji se javljaju kao slučajni u odnosu na početna ponavljanja. ${ }^{\text {"13 }}$ Igra traganja po ulicama Pariza, koju igraju Horacio i Maga, odvija se uvijek po istim pravilima, međutim zbog „slučajnosti“ koje svaka igra nosi njihovi susreti su, iako slični, uvijek drugačiji, i neizvjesni. Na taj način svaki susret „dobija dvostruko značenje, budući da je na jednom nivou potvrda pravila, a na drugom - odstupanje od njega." ${ }^{14}$

U kontekstu igre „kibuc želje“, središte, otvor, prolaz, nekovencionalno ponašanje glavnog lika, ,znači dobiti uslovno, u igri dato razrešenje onih konflikata, koji se ne mogu razrešiti u praktičnom ponašanju uopšte ili u grani-

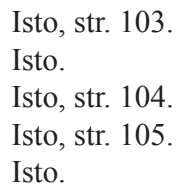


cama društvenog sistema." ${ }^{15}$ Otud je Horaciovo ponašanje traganje za drugim mogućim stvarnostima koji se ne uklapaju u norme svakodnevice. Otud Horacio kao lik prelazi granicu i stvara siže, zato je on onaj prijatelj koga mrze, kojeg se plaše, neposlušni brat, loš momak.

\section{IGRA JEZIKA}

Igra se odvija i na planu jezika te ,svjedočimo (i po mogućnosti sudjelujemo) u neprestanoj, s pozicije pisca samoubilačkoj borbi jezikom protiv samog jezika, kako bi se iznova krenulo od nule, od čiste točke sa onu stranu posvađanih polova“. Jezičkih igara u Školicama ima mnogo te je ovaj roman veličanstvena sloboda improvizacije. One jako podśećaju na đetinje igre s jezikom koje se pune zvučnih figura i premještanja, te aktiviraju kodove đečjeg jezika. Jedna od jezičkih igara je igra ,gliglijskog“ jezika koju igraju Maga i Horacio. Druga igra koju Horacio igra je igra „groblja“. Jezička igra koju igra sa Travelerom i Talitom u kojoj sklapaju rečenice od izumrlih riječi i anahronizama. Otkopavajući stare riječi unutar igre daje im nova značenja. Stavljajući ih u istu rečenicu, na sintaksičkom nivou ih sve povezuje s riječima koje nijesu napuštene u svakodnevnom govoru, daje im u ,procesu starenja metafora" novi život, dok zadržavaju śećanje na stari oblik dobijaju nova značenja. Uvijek se povezuju riječi s velikim fonološkim presijecanjima, tačnije sličnih po zvuku, s istim početnim slovom, aktivirajući često stilske figure kao što su aliteracija i asonanca. Evo jednog primjera igre groblja, iako prijevod ne daje sve anahronizme koje nudi original: „Siti klijenata i njegovog klikeraškog kliberenja, doveli su ga pred klisturu bez klinometra i natjerali ga da proguta klobučac. Potom su mu napravili klinički klistir u kloaki, iako je klecao te su mu izbile kloazme od naviranja vode pune klostridija, pa je posle lipsao kao kljast $^{66}$.

Igra jezika je preispitivanje jezika, razbijanje klišea i konvencija, otkrivanje novih smislova i sprega među riječima, dijalektika riječi. Igra jezika postaje metajezik i ima želju da sam sebe opiše.

Kortasar u već pominjanom intervjuu kaže da ritam njegovih riječi nije običan i nije lako prevodiv, jer se ne bazira na rimi, već je poput „swinga“ u džezu. Pun je improvizacija i teško uhvatljiv. Upotreba džeza kao žanra, tekstova iz džez standarda, iako dotad neliterarnog materijala, u Školicama, bivaju veliki generatori smislova i ritma, osim što predstavljaju intertekstualno ulančavanje s tekstovima pop kulture. Preplitanje tekstova iz džez pjesama i replika likova i pripovjedača, često na različitim jezicima, daje jezgrovitost,

15 Isto, str. 105. 
neku vrstu muzikalnosti riječima likova, pojačavaju subjektivnost i individualnu obojenost govora likova. Ovo je izuzetan primjer umjetničkog funkcionisanja neumjetnčkih tekstova, i otkrivanje metatekstualnih odnosa, te miješanja raznih vrsta umjetnosti i diskursa, i miješanje narativnog svijeta romana sa džez muzikom koja je vrhunski umjetnički izraz. „To je tako iz razloga što u umetničkom tekstu svaki detalj i svaki tekst u cjelini uključeni su u razne sisteme odnosa, pri čemu dobijaju u isto vreme više od jednog značenja“". ${ }^{16}$ Oni još jednom potvrđuju protejsku prirodu romana koji je sposoban da u svoj svijet uvlači različite tipove diskursa, na taj način šireći svoje žanrovsko polje uključivanjem muzike, umjetnosti i drugih oblika izražavanja.

\section{MORELIJEVA IGRA}

Da je „u umjetničkom tekstu svaki detalj i svaki tekst u cjelini uključen u razne sisteme odnosa, pri čemu dobijaju u isto vrijeme više od jednog značenja“" potvrđuje se jednom od morelijana iz romana $\breve{S} k$ olice. To je zapravo jedan citat koji nalazimo u samom djelu u sto četrdeset i petom poglavlju. Taj citat kaže: „To su, naime, principijelni, kapitalni i filozofski razlozi koji su me ponukali da izgradim djelo na temelju pojednih dijelova - shvaćajući djelo kao česticu djela - i odnoseći se prema čovjeku kao prema skupu dijelova dok čitavo čovječanstvo primam kao mješavinu dijelova i komadića“. U ovom citatu nalazimo načelo po kojem fiktivni pisac, alter-ego implicitnog autora, Moreli piše, po kojem je, dakako, moguće čitati i razumijevati sami roman Školice.

U morelijanama se nalaze umjetničke i spisateljske teorije, često u vidu citata i epigrafa, te se u u kritici fiktivni pisac Moreli često tumači kao Kortasarov alter-ego. Naravno, sa stanovišta formalističkih teorija taj pogled je isključen, međutim neke od morelijana možemo posmatrati kao teorijske eksplikacije o stvaranju romana Školice, ili poetički manifest romana unutar samog romana, roman o romanu, kao i ,program“ pobune koju zagovara glavni lik Horacio Oliveira. Takvu jednu eksplikaciju nalazimo u već pomenutom citatu iz sto četrdeset i petog poglavlja: „Ali kad bi mi netko zamjerio: da ta raskomadana koncepcija nije, po bogu ni po ljudima, nikakva koncepcija, nego samo glupost, poruga, nasamarivanje frajera, i da ja, umjesto da se priklonim strogim pravilima i kanonima umjetnosti, pokušavam da im se narugam tom porugom - odgovorio bih da se slažem, da je to upravo to, da su moje namjere baš takve i ne drukčije. I - vjere mi - usuđujem se priznati - ja, gospodo nastojim izmaći, koliko vašoj Umjetnosti, koju ne podnosim, toliko i

16 J. Lotman, Struktura umetničkog teksta, Nolit, Beograd, 1976, str. 107. 
vama samima... Budući da ne podnosim ni vas s vašim koncepcijama, s vašim umjetničkim stavom i s čitavim vašim umjetničkim krugovima“.

Dakle, vidimo da je u ovoj morelijani, kao i na drugim mjestima u romanu, prisutno objašnjenje modernističkih, nekonvencionalnih, možemo reći i anarhističkih teorija u odnosu prema umjetnosti i prema životu, na kojima je baziran i sam roman Školice. Odatle dolazi izražena sklonost pripovjedača ka svim eksperimentima, kako s formom, tako i s jezikom i slatke muke na koje stavlja sve svoje čitaoce, ali je i karakteristika romana kao forme koja se ne da kanonizovati, te roman stalnu redefiniciju vlastitih teorijskih okvira prihvata kao osnovnu konstantu svoje protejske prirode.

Još jedan primjer morelijane, koji je, takoreći, modernistički manifest fiktivnog pisca, nalazimo u sto šesnaestom poglavlju. To je, zapravo, po riječima autora bilješka zapisana olovkom: „Da povremeno se pati, ali to je jedini pristojan izlaz. Dosta je bilo hedonističkih, prežvakanih romana s psihologijama (kurziv Kortasarov). Treba se rastegnuti do krajnosti, biti voyant, kao što je želio Rimbaud. Hedonistički romanopisac nije drugo do voyer. S druge strane, dosta je s čisto opisnim tehnikama, s romanima 'o ponašanju', pukih filmskih scenarija bez utočišta u slikama“. U ovoj morelijani vidimo kako je roman XX vijeka raskinuo s „mimetčkom umjetnošću“, kako je čitava moderna umjetnost, kao i Školice, potraga za novim, za onim što je bio modernistički kredo, za onim što je Rembo imperativno tražio: „treba biti aposolutno moderan".

U Izostavljenim poglavljima, nailazimo na poglavlja u kojima se pojavljuju riječi pisca Morelija, naravno nikad u direktnom govoru, već u citatima i odlomcima, bilješkama, kao već gore pomenuta, koje nam autor Školica prenosi. U tom smislu, ta igra citata, inaugurisana u latinoameričkoj književnosti od strane Borhesa, pojavljuje sa na neki način kao komentar, kritika na sami roman u kojem se nalazi; ta igra na taj način postaje metaigra. Ona je parodija, jer se gradi na temeljima romana $u$ kojem se nalazi, i ima i istovremeno pozitivan i negativan odnos prema istom. Ona je $u$ konstatnom dijalogu s glavnom pričom, pogotovu kad poglavlja čitamo u izmiješanom redosljedu, koji nam predlaže sam autor. Tako se citatnost nalazi u paradoksalnoj situaciji da je izvan glavnog toka rijeke (fabule), ali je ipak sve vrijeme u njemu, kao njena unutarnja rijeka (digresivni materijal, teorijski prikaz, kritika i parodija), što ovaj roman čini par excellence primjerom romana kao najautoreferentnijeg žanra u književnosti, žanra koji guta različite diskurse.

Sve pomenute igre su igre vrhunske umjetnosti. U Školicama nalazimo izgubljeno zadovoljstvo igranja s umjetnošću, s formom, sa svim njenim bitnim svojstvima. Nalazimo intelektualno zadovoljstvo i emotivno, čulno uživanje. Što još drugo možemo i treba da tražimo od igre? 


\section{Literatura}

- Biti, Vladimir: Pojmovnik suvremene književne i kulturne teorije, Matica hrvatska, Zagreb, 2000.

- Cortasar, Julio: Školice, Pelago, Zagreb, 2009.

- Hrens H. O \& Golobof H. M: Istorija hispanoameričke književnosti, Matica srpska, Beograd, 1982.

- Kazaz, Enver: Bošnjački roman XX vijeka, Naklada Zoro, Zagreb - Sarajevo, 2004.

- Kiš, Danilo: Život, literatura, Prosveta, Beograd, 2007.

- Kundera, Milan: Umjetnost romana, Meandar, Zagreb, 2002.

- Lotman, Jurij: Struktura umetničkog teksta, Nolit, Beograd, 1976.

- Prins, Džerald: Naratološki rečnik, Službeni glasnik, Beograd, 2011.

- Solar, Milivoje: Moderna teorija romana, Nolit, Beograd, 1979.

- Žmegač, Viktor: Povijesna poetika romana, Matica hrvatska, Zagreb, 2004.

\section{Ethem MANDIĆ}

\section{NOTION OF GAME IN RAYUELA BY JULIO CORTAZAR}

The author of this paper interprets the novel Rayuela (Hopscotch) by Julio Cortázar, conducting the analysis from formal, stylistic and thematic perspective. The paper discusses the novel through the four levels of the realization of the notion of game on the plot, narrative, thematic, stylistic and linguistic and other plans. According to the author, novel Hopscotch, although written in Latin America, shares some features with European novelistic practice.

Key words: Cortázar, Rayuela, Lotman, game, novel, narrator, Paris, Morelli 
UDK 82.163.4.09(497.5).09-2

Izvorni naučni rad

\section{Lucijana ARMANDA (Split)}

Filozofski fakultet u Splitu

larmanda@ffst.hr

\section{KAKO VIDIMO DRUGE: AMERIKANCI U HRVATSKIM DRAMAMA}

Polazeći od imagoloških stajališta i pojmova kao što su image i mirage te od tvrdnje imagologa Manfreda S. Fischera da je naše stajalište o Americi više određeno našim slikama Amerike, a manje njenom stvarnošću, autorica pokušava otkriti kako su i zašto hrvatski dramatičari u likovima Amerikanaca projicirali svoje predodžbe o Americi. Nakon Kolumbova otkrića Amerike mnoge je dramatičare, romanopisce i pjesnike fascinirala ličnost Kristofora Kolumba te čudesna zemlja mogućnosti i utopije koju je on otkrio. Poslije te fascinacije u književnosti su svoje mjesto pronašli i likovi Amerikanaca. Pod pojmom Amerikanac autorica u skladu s rječničkim definicjama podrazumijeva i stanovnike američkog kontinenta $i$ to najčešće njegova sjevernog dijela, ali i Hrvate koji su iz svoje zemlje otišli u jednu od Amerika te na taj način postali Amerikancima. Autoricu posebno zanima funkcioniranje i značaj ovakvih likova u drami Milana Begovića znakovita naslova Amerikanska jahta u splitskoj luci, dramama Miroslava Krleže, drami Ivana Raosa i farsi Tomislava Bakarića.

Ključne riječi: američki san u hrvatskim dramama, likovi Amerikanaca, Milan Begović, Ivan Raos, Tomislav Bakarić

\section{Uvod}

U ovom radu analiziraju se likovi Amerikanaca i njihova funkcija u pet drama hrvatskih pisaca: u Amerikanskoj jahti u splitskoj luci Milana Begovića, dramama Vučjak i U logoru Miroslava Krleže, drami Kako je New York dočekao Krista: žalosna igra u tri čina Ivana Raosa i farsi Amerika, Amerika Tomislava Bakarića. U imagološkom smislu ti se likovi mogu podijeliti u nekoliko sasvim različitih kategorija; prvu čine domaći ljudi koji su otišli u Ameriku da bi se onda vratili u Hrvatsku, drugu čine pravi Amerikanci, 
a treću čine potomci naših ljudi u Americi koji su dijelom Hrvati i dijelom Amerikanci. S obzirom na to da se u radu težilo za ravnotežom, za analizu je uzet otprilike podjednak broj likova koji zastupaju prve dvije kategorije koje su najvažnije za ovaj rad. Također, potrebno je naglasiti kako je u hrvatskoj književnosti teško pronaći 'prave' Amerikance budući da je njihova funkcija najčešće upućivanje na domaće prilike uz pomoć bijega u strane geografske prostore. U zadnje dvije analizirane drame u kojima se javljaju likovi pravih Amerikanaca pojam Amerike odnosi se na konzumerizam i materijalizam koji se iz Amerike prenosi na domaće prostore. Analiza polazi od važnosti otkrića Amerike što je u stranoj i domaćoj književnosti dovelo prvo do veličanja, a onda do kritike ličnosti Kolumba. Nakon toga u književnosti se stvara mit o novoj zemlji koja bi trebala biti idealna pa zbog toga postaje utopija koja se kasnije ruši zbog materijalizma na kojem je zasnovana. Iz književnosti predodžba o Americi ulazi u druge medije i popularnu kulturu. Cilj rada nije utvrditi istinitost prikaza likova Amerikanaca, već ustanoviti koja je njihova funkcija u diskursu i strukturi drame i koliko imagološka odrednica doprinosi komparativnoj analizi književnih djela.

U metodološkom smislu rad se oslanja na najvažnije postavke koje su u svojim radovima iznijeli imagolozi kao što su Manfred Fischer, Hugo Dyserinck i Joep Leerssen. M. Fischer na književnim je primjerima upozorio na važne činjenice: kako nacionalni-imagotipski sustavi često potječu od drevnih mitova, što je za temu ovog rada jako važno te kako je slika strane zemlje u književnosti strukturni element estetskog konteksta (2009: 38). Ovo zadnje u svim svojim tekstovima naglašava i H. Dyserinck na čiju se tvrdnju, da su slike o stranoj zemlji dio intrinzične strukture teksta, ovaj rad uvelike naslanja jer upravo ta tvrdnja legitimira imagološka istraživanja. $U$ analizi se ističe i stajalište J. Leerssena koji književnosti i novijim medijima poput filma daje važno mjesto u širenju kulturnih stereotipa i upozorava kako nacionalne slike postaju opća mjesta i time upućuju na postojanje interteksta tj. na povezane tekstove koji ponavljaju takve predodžbe (2008a: 178). Ta razmišljanja do izražaja dolaze kada se usporede predodžbe o Amerikancima u raznim dramama. Osim toga, ovaj rad oslanja se i na zaključke hrvatskih teoretičara koji su analizirali spomenute drame, govorili o iseljeničkom pitanju i problemu Amerike u tekstovima hrvatskih pisaca.

\section{Kristofor Kolumbo i otkriće Amerike}

Poznati istraživač i moreplovac Kristofor Kolumbo rodio se u Genovi 1451. g., ali Ameriku nije otkrio ploveći pod talijanskom, već pod španjolskom zastavom Ferdinanda Aragonskog i Izabele Kastiljske koji su bili pokro- 
vitelji njegova putovanja. Za tako hrabar pothvat nije bilo lako naći financijska sredstva i potporu pa tako ni španjolski kraljevski par nije lako pristao na Kolumbovu ponudu. Prije španjolske ponude Kolumba su odbili Portugalci. U to vrijeme njegova ideja traženja zapadnog puta preko Atlantika do Indije bila je prehrabra i preskupa, ali se na kraju isplatila. Kolumbova znanja o globusu i zemljopisu nisu bila precizna, a nadahnjivao se i čudesnim opisima Marka Pola. Godina 1492. zauvijek će ostati zabilježena u povijesti jer je tada Kristofor Kolumbo prvi put kročio na američko tlo u pratnji tri broda: Niña, Pinta i Santa Maria. Bila je to njegova prva, ali ne i posljednja istraživačka plovidba i do kraja života bio je uvjeren da je došao u Indiju. Ipak, uz sve ostale časti koje je za života stjecao pa onda gubio, nije mu pripala čast da Novi kontinent nosi njegovo ime. Amerika je nazvana po talijanskom istraživaču Amerigu Vespucciju ${ }^{1}$ koji je istražujući ušće Amazone uspio dokazati da ta zemlja nije Indija, već sasvim novi kontinent. Kolumbo je prema Novom kontinentu zaplovio još tri puta te je usput otkrio mnoge otoke, ali njegova slava pomalo je počela blijediti pa je 1500. g. bio i uhapšen zbog tiranskog ponašanja prema podređenima, ali i zato što vlast više nije bila uvjerena u njegovu kompetenciju. Umro je 1506. g. u Valladolidu, a ostaci su mu premješteni u Sevillu pa nakon toga u Santo Domingo. Ni tu mu nisu dali mira pa su ga premjestili u Havanu te konačno 1899. g. vratili u Sevillu. Njegove kosti i njegova životna priča i danas su predmet brojnih rasprava pa tako nije sigurno jesu li kosti koje su prebačene iz Santa Dominga uopće njegove.

Život tog avanturista i moreplovca poslužio je kao nadahnuće brojnim umjetnicima i književnicima, a i Amerika mu je odala počast pa se njegovo ime nalazi u nazivu glavnog grada te države, glavnim gradovima još nekih američkih država (Južna Carolina, Ohio) te u nazivima rijeka, ulica i trgova. U ovom članku analiza se usmjerava na titaniziranje, a kasnije i ironizaciju njegova lika u književnosti, a onda i likova Amerikanaca jer bez njegova otkrića Amerike i kolonizacije ne bi bilo ni likova Amerikanaca u hrvatskim dramama. Za Kolumba su se zainteresirali književnci raznih nacionalnih književnosti uključujući i američku pa je tako 1828. g. američki pisac Washington Irving napisao Kolumbovu biografiju pod nazivom The Life and Voyages of Christopher Columbus. To je samo jedan od brojnih pisaca koji su za lik svojeg djela uzeli Kolumba, a mogu se izdvojiti još neki pisci kao što su Lope de Vega, Paul Claudel, Michel de Ghelderode, Dario Fo i Salman Rushdie.

Zanimljivo je da je upravo Amerigo Vespucci (1454-1512) osigurao zalihe mesa za jedno od Kolumbovih putovanja. Na poziv portugalskog kralja Manuela I. sudjelovao je kao promatrač u nekoliko putovanja koja su istraživala istočnu obalu južne Amerike između 1499. i 1502. g. Martin Waldseemüller proslavio je Ameriga tako što je na karti koju je izradio Novi kontinent nazvao prema njegovu imenu. 
Ovaj posljednji u časopisu New Yorker 1991. g. izdaje zanimljiv tekst pod naslovom Kako se ostvariše veze koje sjedinjavahu Izabelu Španjolsku i Kristofa Kolumba, Santa Fe, siječnja 1492. (Christopher Columbus and Queen Isabella of Spain Consumate Their Relationship, Santa Fe, January, 1492). Radi se o zanimljivom tekstu koji se poigrava idejom da su kraljica i Kolumbo ostvarili čak i fizički kontakt prije nego što mu je dala pristanak za plovidbu. Tekst je na hrvatski jezik prevela Višnja Machiedo prema francuskoj verziji, a moguće ga je naći u časopisu Treći program hrvtaskog radija iz 1993.g. ${ }^{2}$

Za Kolumbovu ličnost zainteresirali su se i hrvatski pisci pa je tako Junije Palmotić ${ }^{3}$ (1607-1657) napisao dijalogizirani kraći prizor o Kolumbu oko 1630.g. Ova verzija literarnog Kolumba sastoji se od 124 stiha i u njoj se Kolumbo titanizira, a govori se i o mogućnosti da su u službi na Kolumbovim brodovima bili i neki Dubrovčani. Taj motiv zaintrigirao je istraživače pa su se mnogi upustili u istraživanje dubrovačkog arhiva kako bi utvrdili je li to uistinu bilo tako. Ante Kadić uvjerenja je da su to samo legende koje su narodu potrebne, ali iz popisa osoblja na lađama jasno je da na njima nije bilo Hrvata (Kadić, 1992: 200). Osim Palmotića o Kolumbu je pisao i Brno Džamanjić (1735-1820) i to u svojem djelu Zračni brod tj. Navis aeria tiskanom 1768.g. u Beču i 1784.g. u Beču. Kao i Palmotić, i Džamanjić govori o bogatstvima koja se nalaze u novootkrivenim zemljama. Dalje, o Kolumbu je pisao i Miroslav Krleža ${ }^{4}$ koji mu je posvetio čitavu dramu 1918.g. Krležin Kolumbo pred-

2 U časopisu Treći program hrvatskog radija iz 1993.g. obilježena je petstota godišnjica otkrića Amerike. Radi se o pisanoj verziji u kojoj su tiskani najbolji tekstovi iz programa radija. Tako je u časopisu jedna od tema i Kolumbo i Novi svijet u prozi i poeziji, Kolumbo kao svjetska dramska tema, Kolumbovska tema u nas: od Palmotića do Fabrija. Neke od tekstova napisali su Višnja Machiedo, Dunja Fališevac i Nikola Batušić. U časopisu su tiskani ulomci nekih drama s kolumbovskom temom, ali i neke pjesme posvećene Kolumbu kao što su npr. one od Friedricha von Schillera i Pabla Nerude. Petstotu godišnjicu otkrića Amerike obilježio je i časopis Dubrovnik iz 1992.g. pa je cijelo jedno poglavlje nazvano Hrvatski pjesnici o Kolumbu i otkriću Amerike. Tu su tiskana pjesnička djela koja spominju Kolumba, a radi se o pjesnicima kao što su Mavro Vetranović, Junije Palmotić, Brno Džamanjić, Ivan Slamnig, Luko Paljetak itd. U časopisu su tiskani i zanimljivi tekstovi o iseljeničkom pitanju te o američkim motivima u hrvatskoj dramatici 20. stoljeća.

3 Junije Palmotić iza sebe ostavio je cijeli niz drama kao što su Atalanta izvedena 1629.g. i povijesna drama Pavlimir koja je izvedena 1632.g. i govori o povijesti Dubrovnika. Brojne Palmotićeve drame inspirirane su mitologijom, a u takve spadaju Ipsipile, Akile, Natjecanje Ajača i Ulisa za oružje Akilovo, Elena ugrabljena te Lavinija. Ima i drama koje su vezane uz talijansku modernu epiku, a vrlo bitan dio Palmotićeva dramskog opusa čine tragikomedije kao što su Danica, Captislava i Bisernica (Novak, 2000: 547-548).

4 Dramsko stvaralaštvo Miroslava Krleže Boris Senker podijelio je u pet ciklusa (Lukšić, 2000: 393), a ovdje se izdvajaju drame koje su bitne za analizu ove teme. Tako je posebno zanimljiva njegova druga faza u kojoj piše ekspresionističke scenske vizije u koje spada i drama Kristofor Kolumbo. Drama Vučjak pripada trećem ciklusu i to zajedno s Galicijom 
stavlja iskorak u odnosu na Palmotića i Džamanjića jer ga razapinje njegova posada. Ova verzija Kolumba ironična je jer govori o utopiji koju predstavlja nova zemlja koja će zapravo biti samo nastavak stare tradicije iskorištavanja slabijeg, a u tome zaista nema ničeg novog. Nedjeljko Fabrio ${ }^{5}$ u svojoj drami Admiral Kristof Kolumbo koja je prvotno objavljena u časopisu Kolo 1968.g., ide još korak dalje od Krleže. Naime, Fabrijev Kolumbo ne samo da ne vjeruje u novu zemlju, već namjerno ugrožava postizanje cilja te malo po malo ubija članove posade koji vide novo kopno. Tako Fabrijev Kolumbo uopće nije sretan što se njegov cilj ostvario (Fabrio, 2007). Slobodan Šnajder ${ }^{6}$ piše djelo pod nazivom Dijalektički Anticolumbus u kojem kao i kod Krleže Kolumbo razgovara s Nepoznatim. U časopisu Dubrovnik iz 1992. g. tiskane su pjesme koje su hrvatski književnici posvetili Kolumbu pa se među takvima nalaze i Ivan Slamnig, Dubravka Oraić, Luko Paljetak, Tonko Maroević i Slavko Mihalić.

Kolumbo je zanimljiv jer je otkrivanjem novog svijeta otvorio vrata brojnim utopijama u kojima se nova zemlja vidi kao raj u kojem teku med i mlijeko. Taj raj pretvorio se u nešto sasvim drugo kada je krenula kolonizacija $\mathrm{i}$ iskorištavanje zemlje i lokalnog stanovništva. U toj bici bilo je samo važno tko će ugrabiti što više. Amerika je bila obećana zemlja mogućnosti pa se pomalo stvorio mit $^{7}$ o američkom snu u kojem je svatko kovač svoje sreće i

i Golgotom, a u toj fazi miješaju se veristički, ekspersionistički pa čak i artistički postupci. U spomenutoj fazi Krleža se zanima za socijalna previranja. Drame $U$ agoniji, Gospoda Glembajevi, Leda i $U$ logoru čine četvrtu fazu. Kod drame $U$ logoru važno je napomenuti da u njoj pisac uvodi niz likova koji su predstavnici staleža koji imaju moć, a njima je suprotstavljen neurotični intelektualac.

5 Nedjeljko Fabrio (1937-) pažnju javnosti privukao je povijesnim romanima Vježbanje života iz 1985.g. i Berenikina kosa iz 1989.g., a 1994.g. napisao je i roman Smrt Vronskog naslanjajući se na Dostojevskog. Napisao je i drame Reformatori, Admiral Kristof Kolumbo, Čujete li svinje kako rokću u ljetnikovcima naših gospara?, Meštar, Kralj je pospan, Magnificant (Nemec, 2000: 211-212).

6 Slobodan Šnajder (1948-) objavio je niz drama kao što su Minigolf iz 1968.g., Histerična bajka iz 1969.g., Vrtuljak ljubavi iz 1974.g. te Metastaza iz iste godine. U ovoj zadnjoj kao lik se javlja August Cesarec pa tako Šnajder piše drame biografije kakve su i Kamov smrtopis iz 1977.g. te Držićev san iz 1979.g. Likovi u Šnajderovim dramama često su buntovni umjetnici i intelektualci, a njegovo je kazalište kompleksno i usko je vezanu uz njegovu lijevu političku opciju. Dijalektički anticolumbus može se naći u njegovim esejima Kaspariana iz 2005.g (Senker, 2000: 704-705).

7 Riječ mit u književnosti i kulturi ima brojna značenja i teorije što se može vidjeti i u Književnom leksikonu Milivoja Solara koji taj pojam objašnjava na dva načina; prvi je tradicionalno shvaćanje mita kao „svete priče uključene u mitologiju shvaćenu kao sustav u naracijama izloženog znanja kojemu se načelno vjeruje“, a drugi je način shvaćanje mita kao izmišljene priče i kao načina mišljenja koje se suprotstavlja znanstvenom mišljenju (Solar, 2012: 313). Pojmovnik suvremene književne i kulturne teorije Vladimira Bitija donosi još kompleksnija objašnjenja mita i to u četiri točke; u prvoj se govori o tradicionalnom pristupu tom pojmu, u drugoj o arhetipskoj kulturi koja mit vidi kao „elementarni 
svatko može uspjeti na novom tlu. O otkrivanju novog svijeta i pljački Slobodan Šnajder kaže: „Novi nam je Svijet Kolumbo poklonio nezavisno od volje Novoga Svijeta, to uzimamo kao sigurno. Kolumbo umro je vjerujući da je došao do Azije i bio je time zadovoljan. Jedino se stara predaja i ishodi prvih pljački nisu poklapali, plijen je ostao svejednako mršav“ (Šnajder, 2005: 144).

Godina 1492. promijenila je i povijest i geografiju, a sve te promjene odrazile su se i u književnosti koja je dugo u svojim utopijskim knjigama, pričama o neotkrivenim predjelima zemlje slutila Ameriku iako joj nije znala ime. Tako je slutnja imala razna imena, ali opisi su uvijek bili slični; to je zemlja okupana suncem i zlatom u kojoj je sve idilično i u kojoj je moguće uspostaviti drugačiji poredak stvari. No, kako taj poredak uspostavljaju ljudi sa starog kontinenta tako ni poredak ne može biti sasvim nov. U ovom dijelu rada piše se o otkriću Amerike, Kolumbu i utopijskim vizijama jer to ima veze s književnošću u kojoj postoji interes za lik Kolumba, a onda kasnije i za lik Amerikanca u književnosti.

\section{Američki san}

Od Kolumbova otkrića Amerike 1492.g. pa do konstituiranja američke države 1776.g. prošlo je dosta vremena, ali težnja i ideja o drugačijoj državi koja će primiti razne nacije bila je prisutna cijelo vrijeme. Definicija pojma američki san mijenjala se s godinama, ali taj je pojam uvijek bio vezan uz slobodu i uz mogućnost uspjeha. Tako su san, sloboda, uspjeh i novac pojmovi koji su se počeli vezati uz Sjedinjene američke države, a Kip slobode koji se nalazi na ulazu u New York podsjetnik je na sve navedene simbole. Taj kip čekao je sve one koji su iz svijeta dolazili u tu novu zemlju mogućnosti. Riječ san koristio je povjesničar James Truslow Adams 1931.g, ali i Martin Luther King 1963.g. u svojem čuvenom govoru kojim je želio potaknuti kraj diskriminaciji svake vrste.

U svijet su iz Amerike počele preko novina stizati neobične slike o svim čudima moderne tehnologije i priče o uspjehu malih ljudi koji su se obogatili uz rad i trud. To je ljude iz raznih krajeva svijeta navelo da sreću potraže upravo u Americi. Tamo su se uputili i mnogi Hrvati od kojih su neki ostvarili

zaplet ili siže koji ustraje kroz književnu povijest u obliku određenog fabularnog procesa, vrste i rasporeda likova te ambijenta što ih on podrazumijeva“, u trećoj točki govori se o strukturalističkom pristupu mitu u kojem je najzanimljiviji R. Barthes koji detektira mitsko mišljenje u svakodnevici zapadnog čovjeka u obliku naturalizacije određenih veza među znakovima i smatra da je zadatak semiotičkog čitatelja da razradi tokove privida, u četvrtoj se točki govori o marksističkoj kritici koja mit veže uz mehanizme svijesti kojima se pokušavaju kontrolirati niži društveni slojevi (Biti, 2000: 317-320). U ovom radu riječ mit najviše se približava strukturalističkom objašnenju tog pojma. 
američki san, a dobar dio ih je i propao pa je za njih san ostao samo to. Prema natuknici u Rječniku stranih riječi Bratoljuba Klaića Amerika je: 1. naziv za čitavo kopno, 2. često označava samo SAD, 3. u uličnom govoru uzvik Amerika! isto je što i divno, kolosalno, sjajno, 4. bogata zemlja, bogatstvo uopće, 5. otkriti Ameriku znači prikazati kao novo nešto što je već odavno poznato (Klaić, 2007a: 58). Također, pod natuknicom Amerikanac dvije su defincije: 1. stanovnik američkog kontinenta i to najčešće sjevernog dijela, ali i 2. u našeg svijeta to je naziv za pripadnika naše zemlje koji je kao iseljenik proživio određeno vrijeme u Americi (Isto). Rječničke natuknice navode se kako bi se što bolje objasnilo tko su to Amerikanci u hrvatskim dramama, a priča o Kolumbu i formiranju američke države i definiranju pojma američki san navodi se kako bi se što bolje analizirala i dočarala slika o Americi u hrvatskim dramama te kako bi se shvatilo zašto je ta slika upravo takva.

U hrvatskim dramama Amerikanci su često hrvatski emigranti koji su otišli iz Hrvatske zbog političkih i gospodarskih razloga. Iseljavanje velikih skupina ljudi iz Hrvatske i susjednih joj zemalja za Ameriku započelo je osamdesetih godina 19. stoljeća, a nastavilo se i između dva svjetska rata. Među tim emigrantima bio je velik broj Dalmatinaca, a listajući novine iz tog vremena kao što su Novo doba ili Pučki list može se vidjeti da je mnogo reklama za parobrode koji vode u obećanu zemlju. Na jednoj od reklama u Novom dobu piše da je odlazak putnika iz Splita tri puta mjesečno (Novo doba, broj 11/1928: 8). U spomenutim novinama iste se godine donosi podatak o broju milijunaša $u$ Americi, ali uz to stoji i upozorenje da se mnogi naši tamo razočaraju (Novo doba, broj 15/1928: 6). U Novom dobu postojala je i stalna rubrika pod nazivom Pisma iz Sjedinjenih Američkih Država u kojoj se moglo pročitati o životu ljudi s našeg područja u Americi. Tako su mediji donosili fascinantne podatke o zaradi u Americi, o zlatu i bogatašima, o životu naših ljudi tamo, ali prenosilo se i ono negativno. Hrvatski emigranti imali su upute o tome tko se može uputiti preko u Ameriku, a određene brodarske tvrtke nudile su tim ljudima i pomoć. U knjižici iz 1922.g. pod nazivom Tko se može otpremiti u Ameriku daju se detaljne informacije građanima o tome što im sve treba za put u Ameriku. U raznim domaćim i stranim novinama moguće je naići na podatke o našim emigrantima, a u emigrantskim bazama podataka nalaze se i njihova imena, opisi i detalje o tome kome putuju i koga su ostavili za sobom u domovini. Slika o Hrvatima u Americi, povratnicima iz Amerike te o samim Amerikancima prisutna je i u hrvatskoj književnosti koja je prikazivala izmaštanu Ameriku. Priče u medijima i povratnici iz Amerike bili su pravi izvor informacija o tome kakva je Amerika, a takve informacije formirale su sliku Hrvata o Amerikancima, ali i sliku ostalih naroda s ovih područja o Amerikancima. 
Posebna grana komparativne književnosti koja se bavi proučavanjem književnih predodžbi o stranim zemljama i narodima (heteropredodžbe), ali i o vlastitoj zemlji i narodu (autopredodžbe) naziva se imagologija (Dukić, 2009: 5). ${ }^{8}$ Takve predodžbe o narodima uglavnom su subjektivne pa znaju bili i poprilično iskrivljene. Često se predodžba koju ljudi imaju o određenoj zemlji i narodu ne poklapa sa stvarnošću. U ovom radu zanima nas slika koju hrvatski književnici imaju o Amerikancima - stanovnicima Amerike i domaćim ljudima koji su tamo emigrirali. Na tu sliku utječe izvanknjiževna stvarnost, a nas zanima kako se te predodžbe formiraju, koja je njihova funkcija i imaju li veze sa stvarnošću. Ovdje se postavlja i pitanje može li mehanizam utjecaja biti obrnut tj. može li slika o određenoj zemlji iz nekog književnog djela utjecati na sudove čitatelja. Zanimljivo bi bilo proučiti ulogu koju ,images i mirages imaju pri širenju nacionalnih književnosti izvan prostora njihova nastanka“. (Dyserinck, 2009b: 30)

Ovakve slike u književnosti zahtijevaju tekstnu analizu jer se u njima odražavaju društvena stajališta i one su ,poveznica između umjetničkog i empirijskog svijeta." (Syndram, 2009: 77) Za takvu analizu kao glavni korpus izabrano je pet drama: prva je Amerikanska jahta u splitskoj luci Milana Begovića iz 1930.g., drame Vučjak iz 1923.g. i U logoru iz 1934.g. Miroslava Krleže, drama Kako je New York dočekao Krista: žalosna igra u tri čina Ivana Raosa iz 1956.g. i farsa Amerika, Amerika Tomislava Bakarića iz 1969.g. U prvoj spomenutoj drami koja se analizira u ovom radu javljaju se pravi Amerikanci, hrvatski iseljenici koji se u svoju zemlju vraćaju kao turisti i kćer hrvatskog iseljenika koja je pola Hrvatica, a pola Amerikanka. U Krležinim dramama radi se o Hrvatima koji su neko vrijeme radili u Americi pa se onda vratili u Hrvatsku. Za razliku od toga, u Raosovoj drami i Bakarićevoj farsi mjesto radnje je New York i svi likovi su Amerikanci. Iako je u hrvatskoj književnosti dosta naglašeno iseljeničko pitanje, u ovom radu analiziraju se i drame koje za likove imaju originalne Amerikance kako bi se postigla ravnoteža jer se u imagološkom smislu radi o sasvim različitim likovima. Uz ove drame bit će spomenuta još neka djela u kojima ima sličnih likova. Bilo bi pomalo suvišno pokušati utvrditi jesu li ti likovi vjerni preslik iz stvarnosti jer to nije zadatak imagološkog istraživanja što potvrđuje i K. U. Syndram:

8 Davor Dukić 2009.g. piše predgovor knjizi Kako vidimo strane zemlje. Uvod u imagologi$j u$. Knjigu su priredili Davor Dukić, Zrinka Blažević, Lahorka Plejić Poje i Ivana Brković, a radi se o prijevodu bitnih tekstova iz područja imagologije. U knjizi su tekstovi Huga Dyserincka, Manfreda S. Fischera, Karla Ulricha Syndrama, Joepa Leerssena, Daniel-Henri Pageauxa i Jean-Marc Moura. 
„Te se predodžbe ne mogu smatrati istinitima ili lažnima ni po svojoj književnoj prirodi ni po izvanknjiževnoj referenciji. One odražavaju društvena stajališta i njihov odnos prema empirijskoj realnosti daleko je od pravocrtnoga. U okviru njihova fikcionalnog konteksta, referencija tih predodžbi je fikcionalna, no njihovo leksičko i semantičko punjenje sadrži odnos sa stvarnim svijetom i kao takve, one čine poveznicu između umjetničkog i empirijskog smisla.“ (Syndram, 2009: 77)9

Dakle, jasno je da predodžbe Amerikanaca u hrvatskim dramama ne mogu biti potpuno vjeran preslik stvarnosti jer književnost je mimesis, a predodžbe su subjektivne, ali nam zato mogu pomoći da shvatimo kako se umjetnici referiraju na izvanknjiževnu stvarnost i kakva je njihova uloga u širenju kulturnih stereotipa. Također, važno je utvrditi koliko su ti likovi važni za samu strukturu spomenutih drama i koliko se analiza drama mijenja kada joj se dodaju spoznaje o likovima Amerikanaca. ${ }^{10}$ Amerika je za ovakvu vrstu istraživanja zanimljiva jer se ne radi o zemlji s kojom Hrvatska ili njoj susjedne zemlje graniče i uz koju su bile povijesno vezane, ali zato se radi o zemlji koja je nepresušni izvor inspiracije za književnike raznih nacionalnih književnosti. Bilo bi zanimljivo usporediti sliku Amerikanaca u hrvatskoj književnosti sa slikama te zemlje u raznim drugim književnostima, no ovaj rad zaustavlja se na ovom prvom.

\section{Begovićevi Amerikanci}

Milan Begović (1876-1948) hrvatski je dramatičar, novelist, feljtonist, putopisac, romanopisac i pjesnik koji djeluje u razdoblju moderne. Njegov stvaralački vijek trajao je pedesetak godina pa je pisao razna djela od kojih su neka nastala prema narudžbi, ali najviše se istaknuo dramama. Najpoznatije su mu drame Božji čovjek, Pustolov pred vratima, Bez trećeg, komedija Amerikanska jahta u splitskoj luci te opsežni roman Giga Barićeva i povijesni roman Sablasti u dvorcu. Pjesme su mu objavljene u zbirci Boccadoro koja je naišla na oduševljenje mladih kritičara i pisaca i na negodovanje starih zbog

9 K. U. Syndram proučava odnos između predodžbi i izvanknjiževnih referencija na koje se te predodžbe odnose tj. upozorava na poveznicu umjetnosti i empirije. On smatra kako književni tekstovi odražavaju vrijednosti i značenja čije je razumijevanje usko vezano uz društvene, povijesne i političke čimbenike. Ipak, najvažniji zadatak imagološkog proučavanja književnosti sastoji se u analiziranju stupnja važnosti nacionalnih predodžbi u umjetničkoj, povijesnoj i društvenoj sferi.

10 Da su slike i predodžbe o određenoj naciji u književnim djelima zapravo svojstvo teksta potvrđuje i J.Leerssen koji smatra da su predodžbe intelektualni proizvod diskursa te da zadatak imagologa nikada nije bio da utvrdi kakav je neki nacionalni karakter (2009b: 87). 
izrazite putenosti u pjesmama. Begović je stvarao u sjeni velikog Krleže pa tako i Branko Hećimović u predgovoru Begovićevim djelima u ediciji Pet stoljeća hrvatske književnosti kaže kako u Begovićevim dramama nema pravog sukoba, već se radi o nizanju događaja u kojima se likovi stalno postavljaju u nove situacije (Hećimović, 1964: 13). Za razliku od toga, Krleža se u svojim dramama bavi unutarnjim previranjima pojedinaca koji se sukobljavaju s okolinom i društvom. Osim toga, Krleža je društveno angažiran, a Begovićeve drame lirski su intonirane i udaljene od stvarnosti (Isto: 13). Već u svojim prvim dramama Begović pokazuje interes za erotsko i za sukobe između muškarca i žene. On je svoje dramsko umijeće izučavao u Hamburgu i Beču gdje se u mladosti bavio redateljskim i dramaturškim poslovima.

Lepršava i pomalo ironična komedija Amerikanska jahta u splitskoj luci napisana je 1930.g. i djelomično se nastavlja na komediju Laka služba. U njoj pisac čitatelje uvjerljivo uvodi u atmosferu propadanja nekada bogate splitske obitelji. Glavni su likovi kontesa Kate de' Milesi, njezin sin Keko, Kekovi stričevi koji su prikazani gotovo kao karikature, krojačica Điđeta koja je zaljubljena u Keka, Filip J. Tudor koji je vlasnik jahte i njegova kćer Phoebe. Kate i Keko nalaze se pred bankrotom, a nekada su bili jako bogati pa je to za njih ponižavajuće. Mogući spas vide u prodaji slike koja je Tizianov falsifikat, a potencijalni kupci su Amerikanci koji su stigli u splitsku luku. Drama govori o slavnoj splitskoj obitelji koja je prisiljena na prijevaru kako bi opstala i kako ne bi završila na tavanu svoje kuće koja postaje preskupa za održavanje. B. Hećimović napominje kako je atmosfera propadanja krtičara Josipa Bognera podsjetila na Suton Iva Vojnovića (Isto: 17). Daljnja analiza pokazat će da to nije jedina dodirna točka između ova dva pisca jer su i jedan i drugi prikazali siromaštvo dalmatinske sredine u koju dolaze novci iz Amerike.

U spomenutoj drami pisac tumači kako se Keko upoznao s Amerikankom Phoebe i taj je susret za njega bio „kao neka fantazija o sreći i veličini koja ga je trenutačno obuzela iz potrebe da pobjegne iz skučenosti, mizerije i poniženja u koje ga je turilo postepeno duševno i materijalno propadanje njegove porodice“ (Begović, 1964: 156). Phoebe je zaručena, ali zanima ju i Keko pa želi da je on prati i pokazuje joj grad što Điđetu čini jako ljubomornom. Sam pisac u didaskalijama opisuje Phoebe kao modernu, elegantnu amerikansku djevojku koja je rođena u bogatstvu i navikla je da dobije sve što poželi. Drugim riječima, autor je opisuje kao pravu razmaženu bogatašicu koja je pomalo egoistična, ali je u duši ipak nepokvarena. Njeno je odijevanje moderno i pomalo prkosno, a kao prava osviještena Amerikanka ona puši cigarete. Za razliku od Điđete i naših djevojaka, ona je s muškarcima u razgovoru vrlo slobodna i ne srami im se obratiti i voditi razgovor što je vjerojatno povezano sa zamijenjenim odnosima spolova u ovoj drami o čemu govori B. 
Senker (1996: 33). Kada joj Keko kaže da ima originalnog Tiziana ona mu odvrati da bi ga htjela imati jer je novcem navikla sve kupovati. U takvim Phoebinim izjavama vidi se kako autor prikazuje tipičnu američku djevojku - ona je uvjerena da novcem može dobiti sliku slavnog Tiziana pa u polušali pita može li i Keka kupiti. U dvadesetim godinama prošlog stoljeća razvijao se novi tip samosvjesne djevojke koja je pomalo cinična i ponaša se poput muškarca. Čini se da Phoebe odgovara tom opisu koji se u nekim crtama slaže s opisom lika Jordan Baker iz djela Francisa Scotta Fitzgeralda Veliki Gatsby. ${ }^{11}$ Tako je moguće doći do zaključka kako je lik Phoebe u koji je pisac unio svoje predodžbe o slici samoosviještene Amerikanke dio šireg interteksta. Taj intertekst vrlo je složen i temelji se na antičkim mitovima o novom svijetu na koje se onda nastavljaju tekstovi o ostvarenju i rastakanju američkog sna. ${ }^{12}$

Phoebe se ponaša puno slobodnije od Điđete i rado ispija maraskino te se čudi Điđeti koja ne pije. Također joj kaže da bi joj se svidjelo u Americi jer tamo je svako piće zabranjeno i ljude se zbog toga stavlja u arrest, ali Phoebe ipak pije što će reći da je snalažljiva i da zna kada se treba, a kada se ne treba držati zakona. ${ }^{13}$ Ona Điđeti govori kako uz piće i pušenje ima još jedna djevojačka mana, a to je ljubav. Phoebe je naime sa svojim zaručnikom jer joj to odgovara, a ljubav je za nju sporedna. Ona pokušava Điđeti objasniti da biti zaručen nije isto što i biti zaljubljen. Zaljubljivanjem u Keka Phoebe ipak pokazuje osjećaje za koje se ponekad pravi i glumi da ih nema jer je u okvirima drame prikazana kao djevojka koja želi biti samostalna i neovisna. Značenje tog ženskog lika unutar drame jest da bude kontrast domaćoj djevojci Điđeti.

11 Francis Scott Fitzgerald (1896-1940) 1925.g. izdao je roman The Great Gatsby u kojem govori o američkom snu, uspjehu i varanju na kojem se uspjeh temelji te o rastakanju ideje američkog sna. Jedan od likova Daisy predstavlja američki san koji je Jay Gatsby želio ostvariti, a druga djevojka Jordan Baker tipična je samostalna Amerikanka koja se ponaša poput muškarca, cinična je i snalažljiva, ali je od Begovićeve Phoebe razlikuje to što do uspjeha dolazi varanjem. Djelo je doživjelo veliki uspjeh u SAD-u, ali i u svijetu. Fitzgeraldov roman u ovom se radu spominje zato što su njegove ekranizacije iz 1926., 1949., 1974. , 2000., 2002., 2013. i 2014. uvelike pridonijele širenju stereotipa o ponašanju Amerikanaca i Amerikanki u ludim dvadesetim godinama prošlog stoljeća, o odjeći koju su nosili, njihovim navikama i zabavama koje su priređivali. Roman Veliki Gatsby postao je fenomen popularne kulture pa je zato i mogao igrati veliku ulogu u širenju stereotipa.

12 O povezanosti imagotipskog sustava Amerike, utopijskih snova i antičkih mitova govori i M. S. Fischer koji također zapaža kako su čak i današnje slike o Americi vezane uz antičke mitove te kako je naše stajalište o Americi obilježeno našim slikama o toj zemlji, a ne stvarnošću (2009: 45).

13 Tu se aludira na zakon o prohibiciji koji u ludim dvadesetim godinama prošlog stoljeća u SAD-u zabranjuje proizvodnju i kupnju alkohola. Tako su lude dvadesete s jedne strane bile obilježene sve većom slobodom u ponašanju, odijevanju i seksualnom životu, a s druge strane ponovo se rađao puritanizam. To ne znači da se taj zakon uvijek poštivao jer su upravo u tom razdoblju profitirali krijumčari koji su nelegalno zarađivali na alkoholu. 
Begovićeva Phoebe još je u nečemu Amerikanka; ona ne priznaje aristokraciju kojoj se naizgled divi. Kada joj Điđeta kaže da je Keko aristokrat i da bi mu bila uvreda da mu plati za razgledavanje grada, Phoebe jako ironično kaže: „Ja nisam znala da se aristokratima ne mora plaćati za njihove usluge" (Begović, 1964: 172). Begović tek na površini oslikava naivnu i razmaženu Amerikanku, a onda pokazuje da je ona poštenija od splitskih aristokrata koji ju pokušavaju nadmudriti. Teško bi bilo tvrditi kako autor kritizira američki novac jer Phoebe nije pokvarena. Upravo suprotno, pokvareno se ponašaju konte Ruđe i konte Mome koji bi Phoebe rado prodali lažnog Tiziana i zamijenili njene dolare u mjenjačnici. I tu se ona pokazuje kao pamenija od njih jer cijelo vrijeme vodi igru, a da oni to ni ne znaju. Zadatak imagološkog istraživanja nije utvrditi je li Miss Phoebe vjerni preslik Amerikanke s obzirom na činjenicu da je slika subjektivna, što potvrđuje i D. H. Pageaux:

„Ali neosporivo je da je slika predodžba, mješavina osjećaja i ideja, čije je afektivne i ideološke odjeke važno shvatiti. Neposredna posljedica tih postavki je poništavanje lažnog problema u koji često zaglibi proučavanje slike: problema 'lažnosti' ili 'stupnja vjernosti' neke slike u odnosu na 'promatranu' zemlju, kao da je slika analogon stvarnosti (otkud proizlaze pogreške u 'percepciji')“"(Pageaux, 2009: 128).

Funkcija figure Miss Phoebe jest da bude suprotnost domaćoj djevojci Điđeti što znači da je njen stereotipni prikaz u drami prisutan kako bi autor bolje oslikao vlastitu kulturu i njene predstavnike, a ne stranu kulturu.

Stereotip Amerikanke kojem Phoebe naizgled pripada pojednostavljeni je kulturni izraz načina na koji je autor za potrebe drame oslikao Amerikance. U tu svrhu Phoebine izraze moguće je promatrati i s leksičke razine jer joj autor često u usta stavlja engleske izraze kao moj little konte, never, very nice, old boy i slično. Na leksičkoj razini Phoebe potvrđuje očekivanja publike i upravo ta razina vezuje ju uz stvarni svijet iz kojeg dolazi, ali njeni postupci krše očekivanja publike. To je zato što je status likova, kako to B. Senker tumači „redovito u proturječju s društvenom ulogom koju žele ili moraju igrati“ (1996: 32). Konačno, Phoebe i nije prava Amerikanka jer se ispostavlja da je njezin otac Filip Tudor kao dijete otišao iz Splita i to uz pomoć Kekove bake koja mu je dala nešto novca. Njegov je lik pojednostavljena verzija Amerikanca i autorova blaga ironična opaska. Važno je napomenuti i to kako Filip Tudor nije došao vrbovati Dalmatince i vabiti ih u Ameriku kako bi tamo radili kao roblje. Upravo suprotno, Filip je u Splitu u porodici splitskih aristokrata 
de' Milesi radio kao rob. On nije Niko Marinović iz Vojnovićeva Ekvinocija ${ }^{14}$ koji pohlepno zarađuje novac, hvali se i želi izrabljivati svoje zemljake. Njegova jahta Stella nema simbolični naboj Nikova broda Sloboda. Jedan od razloga koji se i u već spomenutom romanu Veliki Gatsby navodi kao uzrok što se američki san raspada jest pohlepa za novcem. Filip Tudor u tom smislu ne ispunjava očekivanja čitatelja koji bi možda očekivali čovjeka željnog osvete i još novca. U ovoj drami iseljeničko pitanje nije naglašeno kao u Vojnovićevu Ekvinociju. Umjesto osvete Filip pomaže porodici de' Milesi pa sve ostaje u lepršavom tonu drame koja za sobom ne povlači iseljeničko pitanje.

U Begovićevoj drami govori se o propadanju jedne aristokratske obitelji koju spašava američki novac. Kontesa Kate u jednom trenutku kaže da bi se i Bog veselio da dobije ček iz Amerike jer u to vrijeme svi su očekivali pisma i dolare iz Amerike od članova obitelji koji su tamo pošli raditi. Bila je to dalmatinska svakodnevica u kojoj je prevladavalo siromaštvo i čekanje dolara kao spasa s neba. Zato je znakovit intermezzo koji piše Begović i u kojem se kontesi Kati u snu javlja američka bajka u kojoj se vidi kako bi to izgledalo da je Keko oženio Phoebe, a ona primala pisma i dolare iz Amerike, a javlja joj se i konte Frančesko de' Milesi kojem se nimalo ne sviđa što ga žele prodati u Ameriku. Begovićeva drama odraz je šireg interteksta u kojem su se Amerikaci prikazivali kao oni koji imaju novce jer dolaze iz bogate zemlje što je autor povezao s temom propadanja aristokracije zbog nedostatka novaca. Ton u drami zbog toga nije ogorčen pa se Amerikanci ne prikazuju kao grabežljivci. Jedini pravi Amerkanac u drami jest Lee Prentice - zaručnik Miss Phoebe koji je vrlo rezerviran i poslušan i on i na leksičkoj razini odgovara učestaloj predodžbi Amerikanca jer na sve Phoebine upite odgovara sa: Yes, my darling! Njegov je lik pojednostavljena verzija Amerikanca i autorova komična opaska. Ipak, upravo Lee upozorava Phoebe da Tizianova slika nije original pa se ispostavlja kako ni on nije jednodimenzionalan lik. To je zato što ironijski odmak u književnim djelima može istodobno određenu pojavu ismijavati i legitimirati (Syndram, 2009: 72). Jedan od zadataka imagologije jest analizirati stupanj važnosti predodžbi u umjetničkoj, povijesnoj i društvenoj sferi (Isto: 81) pa se može zaključiti kako Begović u vedrom tonu obrađuje likove Amerikanca i Dalmatinaca koji očekuju novce iz Amerike. Tešku društvenu stvarnost on slika sa šaljive strane ne osuđujući previše Amerikance od kojih se ruga jedino Lee Prenticu, ali onda mu ipak daje ulogu onoga koji upućuje na prijevaru. Za razliku od Vojnovićeve Dubrovačke trilogije, Amerikanska jahta u splitskoj luci manje se uspješno bori s problemom prikazivanja propadanja aristokracije što je bila omiljena tema hrvatske moderne. Likovi Amerikanaca

14 Vidi više u Čale, F. (1992) 
u Begovićevoj drami imaju svrhu ukazati na kontrast između siromaštva splitskih obitelji i obilja koje predstavlja izmaštana Amerika. Čini se da obitelj de Milesi nema nikakav plan, već čekaju da ih spasi deus ex machina koji se u ovom slučaju materijaliziran u obliku hrvatskih Amerikanaca.

\section{Krležini Amerikanci}

Ni poznati hrvatski dramatičar Miroslav Krleža nije mogao, a da u svojim dramama ne spomene Ameriku i Kolumba. Kao što je već istaknuto, prvo je 1918.g. čitavu dramu posvetio Kolumbu u kojem se njegova ličnost titanizira te se ironizira utopija i mogućnost ostvarivanja novog poretka na novom kopnu (Krleža, 1981a). Nakon toga, 1923.g. piše dramu Vučjak u kojoj se javlja lik hrvatske Amerikanke Eve kojoj je mučna društvena situacija u zaostalom i korumpiranom Vučjaku i jedva čeka pobjeći u Ameriku gdje je već jednom bila. Godine 1934. Krleža piše dramu U logoru u kojoj se javlja lik Jože Podraveca koji je radio u Americi, a taj isti lik javlja se i ranije 1932.g. u Krležinu romanu Povratak Filipa Latinovicza. Krležini Amerikanci ustvari su Hrvati koji su neko vrijeme bili u Americi, a onda su se vratili u Hrvatsku pa Ameriku nostalgično dozivaju u svojim sjećanjima.

O Krležinim Amerikancima pisao je Darko Gašparović koji zaključuje kako je Krleža Novi svijet zahvatio s ironijske strane pa je za njega Amerika utopija i iluzija, a do tog zaključka dolazi jer Krležini Amerikanci sve ono što su prijeko vidjeli stavljaju u kontrast s neredom koji vlada kod nas u to vrijeme (Gašparović, 1992: 237). Joža Podravec Ameriku doziva dok se nalazi u strahotama prvog svjetskog rata u Galiciji, a Eva je sita neukog svijeta u zabitom i zaboravljenom Vučjaku pa želi pobjeći u toliko drugačiju Ameriku. I za Evu i za Jožu Amerika predstavlja san i utočište na koje pomisle kada se zasite svega što vide u svojoj zemlji. Naravno, Krleža je svjestan činjenice da je Amerika samo utopija, a to se lako može doznati ako se pročita njegov dramaturški opus u cjelini jer on je uvijek kritičan i kompleksan. Zato u analizi nema smisla izolirati Evine i Jožine rečenice, a bez da se u obzir uzme cjelokupno Krležino stvaralaštvo i stavovi.

Eva je nekada bila bistra učenica koja je pročitala sve knjige iz knjižnice u Vučjaku, a onda su je u osamnaestoj godini udali, no ona je za kratko vremena sve napustila. Otišla je u Ameriku gdje je bila vlasnica crnačkog bordela u Chicagu, a u Vučjak se vratila zbog smrti muža koji nije bio za Ameriku. Vučjak je obična zabit, ali jedan od likova imenom Horvat dolazi na ideju da ode na selo jer mu treba horizont, no upozoravaju ga da je naše selo centralna Azija i čista romantika. Da Vučjak ne širi horizonte zna i Eva koja je živjela u Americi, no u Vučjaku joj ne priznaju ništa i kada se Eva ponaša drsko onda je 
pitaju: ,Jesu li te tako u toj tvojoj Americi naučili psovati po majci?““(Krleža, 1981b: 205). Iz te rečenice moguće je izvući sljedeće zaključke; kao prvo postoji stvarna Amerika i ona Evina, kao drugo vidi se da se Stara koja izgovara ovu rečenicu želi narugati Evi i Americi općenito, a kao treće ako Stara i zna nešto o Americi onda je to da se tamo psuje i da je Eva iz te zemlje donijela loše manire. Ovo zvuči gotovo kao rečenica Shakespeareova Kalibana koji kaže da su ga kolonizatori i okupatori otoka na kojem on živi naučili psovati. ${ }^{15}$ Stara je prikazana kao lik koji je pun predrasuda o Americi, no pogrešno bi bilo iz toga izvesti zaključak kako je i Krleža kao autor pun predrasuda. U drami se implicira da je Amerika kojoj se nadaju likovi neostvariva iluzija koja je svedena na simbol i koja je u suprotnosti sa situacijom u Vučjaku.

Za Evu je Vučjak old kontri u kojoj sve smrdi, a zamjera i mužu što nije bio za Ameriku pa ga je Vučjak ubio. Kada joj situacija u Vučjaku postane nepodnošljiva ona bježi u fantaziju u kojoj vidi Ameriku kao utočište. Amerika joj se ukazuje kao rasvijetljene lađe, daleki gradovi u kojima se živi punim plućima i čuje se muzika. Evin san je uzeti tikete i gudbaj old kontri pa otputovati u Kaliforniju i saditi naranče ili možda otići na Floridu. Tako ona demonstrativno navija gramofon koji je u drami simbol tehnike i nove zemlje i na kraju izleti s Horvatom vani i viče: „Kuda? U Ameriku, beno jedna! Gudbaj, old kontri!““(Krleža, 1981b: 235) Gramofon se ističe kao predmet kojem nije mjesto u zabitom Vučjaku u kojem se Evi prigovara zbog njenih američkih navika. No, pisac u čitatelju izaziva sumnju da je Eva s Horvatom otišla u Ameriku jer njene su karte više bila nada nego stvarnost. Krležina Amerika pomalo je snovita i nestvarna što potvrđuje i Joža Podravec u drami U logoru (1973). Njemu su rekli da će na putu za Ameriku vidjeti divlje jelene koji plivaju po vodi, ali on je vidio samo bijele ptice koje su zamijenile naše

Misli se na lik Kalibana iz drame Oluja Williama Shakespearea (1564-1616). The Tempest ili Oluja napisana je oko 1610-1611., a tiskana je 1623.g. i pripada Shakespeareovim završnim djelima. Glavni lik je Prospero koji je nakon brodoloma koji mu je smjestio brat završio na nekom otoku zajedno sa svojom kćerkom Mirandom. Na otoku su zatekli lokalnog stanovnika Kalibana kojeg su podredili sebi. Prosperov brat Antonio uzurpirao je milansko prijestolje i riješio se brata, a onda je Prospero uzurpirao otok na kojem je nekad davno vladala vještica Sycorax koja je Kalibanova majka. Drama se može čitati s postkolonijalnog gledišta jer otvara mnoga pitanja, a pogotovo ona o kolonizaciji otoka i odnosu prema lokalnom stanovništvu. Jedan od citata iz drame opće je poznato mjesto. Prosperova kćerka Miranda izgovara rečenicu $O$ vrli novi svijete! jer je uzbuđena što na otoku vidi neke nove ljude i želi upoznati svijet koji nikada nije vidjela, iako je taj svijet sve samo ne divan. Rečenica je ironična, a tu ironiju iskorištava engleski pisac Aldous Huxley pa svoj roman iz 1932.g. naziva Vrli novi svijet. O vezi kolonijalnog i imagološkog pristupa govori i J. Leerssen koji napominje kako su postkolonijalne teorije Frantza Fanona i Edwarda Saida počele promatrati klišeje i stereotipe kao dio neravnoteže između kolonizatora i koloniziranih (2009a: 176). 
crne ptice. Priču o divljim jelenima Krleža koristi kako bi pokazao u kakve su sve priče o Americi vjerovali neuki ljudi, a Amerika nije raj kakvim su ga zamišljali naši ljudi puni nade. Eva je realnija od Jože i ona navija gramofon, a Joža vjeruje da su samo u Americi ptice bijele. I jedno i drugo Ameriku vide kao nadu u drugačiji svijet i to zato što se autor koristi ironijom koja ukazuje na to da se ni u Americi ne zarađuje lako. Autorova ironija odraz je nerealnih predodžbi koje njegovi likovi imaju o životu u Americi. Eva je jedan u nizu od Krležinih kompleksnih ženskih likova čija amerikanizacija ukazuje na ironiju i bunt, a Joža Podravec imenom i ponašanjem potvrđuje naivnost domaćih ljudi. U Krležinim dramama stvarna Amerika ne igra veliku ulogu jer je svedena na neostvarivi simbol.

\section{Raosovi Amerikanci}

Ivan Raos napisao je niz pjesama, novela, priča i romana pa je i najpoznatiji po romanu iz 1971.g. Prosjaci i sinovi u kojem slika Dalmatinsku zagoru. Njegovo stvaralaštvo obilježava zavičajnost, utjecaj usmenog stvaralaštva u pjesmama, autobiografizam, ali i kozmopolitizam koji je vidljiv posebno u njegovim dramama. Raosa odlikuje realističko pripovijedanje s elementima moderniteta pa je u tome blizak Begoviću (Muhoberac, 2000b: 612). Godine 1956. Raos piše žalosnu igru u tri čina Kako je New York dočekao Krista i $\mathrm{u}$ toj igri ironično govori o novcu i birokraciji koja vlada u gradu koji nema sluha za Kristov dolazak. Za razliku od prije spomenutih drama, mjesto radnje je New York, a glavni su likovi policijski inspektor Tom Dexter, prostitutka i doušnica Gipsy, sitni provalnik Krivonogi Bill, šef kontraobavještajne službe Slim i Krist. Za razliku od Begovića i Krleže, Raos za likove uzima prave Amerikance, a ne Hrvate koji su se odselili u Ameriku.

Čini se da je i Raosova Amerika puna ironije jer se svi likovi ponašaju kao dio sustava pa tako čak i lopov Bill tvrdi da se mora čuvati američka sloboda i demokracija, a porezni sustav mora biti jednak za sve građane (Raos, 1956: 10). Takav sustav ne prepoznaje Krista koji se kao i svi drugi građani mora pokoravati policiji. Navodeći kako u New York Krist ne može doći tek tako i zaustaviti promet jer bi to koštalo, autor aludira na poslovicu da je u Americi vrijeme novac. U takvoj obećanoj zemlji ljudi se pitaju koja im je zemlja ubacila Krista da ih špijunira jer ne vjeruju da im je došao pomoći samo zato što ih voli. U ovoj drami autor je likove prikazao kao dio američkog sistema zasnovanog na novcu i zaradi. Na nekoliko mjesta u drami pisac govori o američkoj slobodi i jednakosti na koju se najviše poziva lopov Bill. Na taj način autor kritizira sistem u kojem naizgled vlada ravnopravnost i sloboda, a zapravo su svi zaslijepljeni taštinom i novcem. Krist podsjeća Predsjednika 
da bi on morao služiti prostitutki i lopovu jer su upravo ti mali ljudi glasali za njega pa su i oni odgovorni što je tako socijalno neosjetljiv čovjek na vlasti. S jedne strane u takvom sistemu svi imaju pravo glasa, a s druge strane oni koji su na vlasti zaboravljaju čiijom su pomoću tamo dospjeli. U analizi se nameće pitanje kritizira li autor Ameriku i Amerikance ili kapitalistički sistem u cjelini i američku državu kao tipičnu predstavnicu tog sistema.

U strukturu te drame ugrađene su predodžbe o američkom identitetu koje nije stvorila samo naša država, već one postoje ,kao artikulirani diskurzivni konstrukti što kolaju društvima, tvore nacionalne identifikacijske uzorke“" (Leerssen, 2009a: 175). Te predodžbe temelje se prije svega na antičkim mitovima o Novom svijetu koji se trebao osnovati u Americi koju su istraživači u svojim tekstovima opisivali kao obećanu zemlju u kojoj svatko ima jednake šanse za uspjeh, a onda i na demitologijzaciji Amerike koja se pretvorila u zemlju koju pokreće i kvari upravo novac. U Raosovoj drami Amerika je zabrinuta za sigurnost i ne razumije Kristov dolazak. Pitanje je kako bi isti pisac prikazao svoju državu u koju dolazi Krist i bi li i autopredodžba bila jednako kritična. Da se radi o uvriježenom diskurzivnom konstruktu tog vremena potvrđuje i rečenica koju izgovara Slim, a kaže: „Ali nebo je još uvijek ničija zemlja, i đavolski prostrana. Ne bi nam smetala tamo jedna kolonijica" (Raos, 1956: 59). Na tom mjestu autor se referira na kolonijalnu politiku kojom je i stvorena američka država te anticipira misiju Apolla 11 na Mjesec 1969.g. Ta je rečenica ujedno kritika američke politike koja uvijek želi biti prva pa makar u kolonizaciji neba koje želi približiti raznim istraživanjima. Heteropredožbe o Americi uvijek se grade u odnosu na stajališta o vlastitoj kulturi i one su prisutne u promatrajućoj, a ne u promatranoj kulturi. Pisac svoju zemlju doživljava kao humaniju kada se radi o kolonizaciji u odnosu na zemlju koju promatra - Ameriku.

Pisac ove drame iznosi i predodžbe o američkim ženama pa se kao predstavnice javljaju prostitutka i doušnica Gipsy i Ann Sullivan - zvijezda Cosmos filma kojoj se nikad ne zna za dob. Gipsy je prikazana kao tipična prostitutka koja zavodi jednako svakog muškarca jer u ponašanju slijedi zadani uzorak. Takvim ponašanjem ona sebi osigurava dobit, ali potpuno gubi pojam o etici i moralu. Ona i Krista pokušava zavesti jer je on netko novi pa je samim time zanimljiv. Ona svakog muškarca naziva darling, a Kristu još dodaje i naziv Gospodin. Tom ženskom liku dana je funkcija upućivanja na američki konzumerizam jer ona Kristu kaže: „Ti si onaj mali Isusić, ona draŽesna lutkica pod božićnim borom“ (Raos, 1956: 28). Ovo je jedna od tipičnih predodžbi prisutnih u različitim diskurzima o Amerikancima koji su prikazani kao potrošačko društvo koje Krista vidi kao figuru ispod bora, a zaboravlja tko je on zapravo bio. Kritika je to ne samo Amerike, već svih društava koja se 
priklanjaju potrošačkim navikama i materijalističkim vrijednostima. I u liku Ann Sullivan autor je oštro kritizirao američke žene jer je ona još više opčinjena novcem, iako kaže da joj je draža slava, pljesak, cvijeće i autogrami. Ann je predstavnica američkih zvijezda koje žive za slavu, no u njenom liku autor upućuje na malu razliku između definicije američke i bilo koje druge filmske zvijezde. Takva reprezentacija proizvodi jednodimenzionalan model američke zvijezde za potrebe ove drame bez prikaza druge strane medalje. Ann je autoru poslužila i za izgovor najpoznatije američke rečenice da je vrijeme novac. Kako bi to i dokazala ona Kristu nudi brak i tako potvrđuje Gipsynu tvrdnju da su Amerikanke odlučne i pune krvi. Ovakva slika o Amerikankama može utjecati na stavove čitatelja koji će ih povezivati s ostalim opažanjima o Americi koja su rezultat gledanja filmova, čitanja časopisa i književnih djela i slušanja svjedočanstva onih koji su bili preko velike bare. Na taj način formirat će se u njihovoj svijesti pseudogeografski imaginarij koji ne mora imati puno veze sa stvarnim svijetom (Syndram, 2009: 79). Takav imaginarij dodatno se osnažuje postavljanjem drame u kazalištu i povezivanjem različitih medija koji zajedno imaju više utjecaja na publiku.

Na kraju Raosove drame Kristu nakon nepovjerljivosti i sumnjičavosti američkih građana ne preostaje ništa drugo nego vratiti se odakle je došao. Da nije otišao umro bi na prijedlog kardinala Foxmana u plinskoj komori za napredak kršćanstva i kako bi se dokazalo da su tamo svi jednaki. Krista je kardinal namjeravao otpremiti kao žrtveno janje u plinsku komoru. Tu se autor čak dotiče i vrlo ozbiljnog pitanja smrtne kazne pa tako zemlja koja promiče ljudske slobode u plinskim komorama ubija ljude. Iz svega navedenog može se zaključiti da je Raos kritičniji prema Amerikancima nego ostali dramatičari koji su predmet analize ovog rada. Dok se drugi dotiču pitanja emigracije, Raos generira predodžbe o američkom stilu života te kritizira materijalizam koji se uz taj stil redovito veže. Mogući razlog tako negativnog stava jest strah da će Drugi promijeniti i našu kulturu koja se sa subjektivnog stajališta možda još uvijek čini boljom. Također, postoji i druga mogućnost, a to je da je pisac zapravo želio uputiti kritiku svojoj državi pa bi Amerika bila samo alegorija za Hrvatsku i sve države koje se okreću materijalizmu i konzumerizmu.

\section{Bakarićevi Amerikanci}

Tomislav Bakarić (1940-2003) prije svega je dramski pisac, iako mu je prva tiskana knjiga roman (Kako je umro grad, 1966.g.) i pisao je kratke pripovijetke i prikaze knjiga. Osim toga, Bakarić je bio spiker na Radio Zagrebu od 1967.g. do 1990.g., a nakon toga bio je ravnatelj Hrvatskog radija da bi potkraj devedesetih godina bio urednik na HRT-u. Dramske tekstove piše za 
kazalište, televiziju i radio pa je tako u Poletu 1959.g. tiskao prvu dramsku sliku Anina odluka. Najpoznatije njegove drame za i radio i televiziju su: Davni miris ljubičica (1968.), Njezino veličanstvo ljubav (1969.), Bog i životinja (1969.) i druge u kojima je središnju temu čine egzistencijalni problemi hrvatskog intelektualca. Njegova farsa Amerika, Amerika pripada djelima pisanim za kazalište čime se počinje baviti 1969.g. Ipak, najpoznatiji je po dramama u kojima se javljaju povijesne ličnosti kao što je vrlo uspješna Smrt Stjepana Radića (1970.), Anno Domini 1573 u kojoj se tematizira seljačka buna i koja je 1974.g. na XV festivalu mladih i eksperimentalnih scena u Sarajevu proglašena najboljim dramskim djelom, prikazanju Malj koji ubija (izvedena 1976.) u kojoj razdoblje progona vještica služi kako bi se prikazale teške godine nakon sloma Hrvatskog proljeća 1971.g., drami Mora (1978.) u kojoj se kao ličnost javlja Frano Supilo. M. Muhoberac (2000a: 32) zaključila je kako je Bakarić blizak Bakmazu, Brešanu i, što je za ovaj rad još važnije, Fabriju jer pripadaju struji nove farse.

Farsa u tri čina Amerika, Amerika napisana je 1969.g., praizvedena je 1970.g. u kazalištu Gavella u režiji Vanče Kljakovića, a tiskana je 1994.g. u knjizi Malleus maleficarum. M. Muhoberac primijetila je kako u toj farsi ima odjeka engleske osobne drame Kesserlingova teksta Arsen $i$ stara čipka ${ }^{16}$ te kako se radi o crnom humoru i groteski jer „,navodni Amerikanci, New York, obitelj vlasnika pogrebnog poduzeća - otkrivaju se na kraju kao slika određenoga duhovnoga mentaliteta i anticipacija događanja početkom devedesetih godina“ (2000a: 31). To potvrđuje kako je u hrvatskim dramama teško naći likove pravih Amerikanaca jer, čak i onda kada su prisutni, njihova je funkcija aluzivno prizivanje domaćih prilika. Glavni likovi te farse jesu članovi obitelji Barcley koji su pogrebnici; John i njegova supruga Evelyn, njihov sin Marc Antonius koji ima psihičke probleme, psihijatar George March koji je u ljubavnoj vezi s gđom Barcley, pjesnik Zacharias Stewart koji je njihov stalni gost, milijunašica Helen Smith koja želi poslovati s obitelji Barcley i njen suprug Jonathan, odvjetnik Liberty Gunn te gangster Tom Murdock. Pogrebni poslovi obitelji Barcley ne idu najbolje za što je dijelom odgovoran i njihov suparnik Farley pa John odluči pozvati na razgovor gangstera koji bi trebao ubijati ljude koji bi prethodno sklopili ugovor s pogrebnim poduzećem

16 Radi se o komadu američkog dramatičara Josepha Kesselringa (1902-1967) iz 1939.g. koji je dodatno popularizirala filmska verzija u režiji slavnog Franka Capre. Radnja te crne komedije odvija se u dnevnom boravku obitelji Brewster u New Yorku, a gotovo svi članovi obitelji pokazuju znakove ekscentričnog i poremećenog ponašanja baš kao i članovi obitelji Barcley iz Bakarićeve farse. Kao jedan od simboličnih rekvizita i u jednoj i u drugoj drami javlja se mrtvački sanduk pa tako u Bakarićevim likovima i situacijama kao da odzvanja Kesselringov tekst. 
Barcley. Sreća se obitelji Barcley nasmiješi dolaskom milijunašice Helen koja želi s njima sklopiti ugovor da jednog dana i za nju obave pogrebne usluge, no onda im iznenada odluči ostaviti svoje nasljedstvo jer joj se svidi njihov poremećeni sin Marc i gđa Barcley koja Helen počne zvati majkom. Kako Evelyn vara supruga sa sinovim psihijatrom, tako se suprug zabrine da će ga njih dvoje otrovati kada Evelyn dobije nasljedstvo pa ih želi preduhitriti angažiranjem gangstera. Baš kao što je John i pretpostavio, Evelyn i George planiraju kako će ga se riješiti. Sve te planove sluša bolesni Marc koji bi se svih njih želi riješiti pa i on angažira gangstera. Nakon što se Evelyn i George ispričaju Johnu i nakon što on prizna kako je također pripremao ubojstvo, Helen ipak ostavi nasljedstvo Evelyn, a scena završava trovanjem Evelyn, Georgea i Johna. Marc je uvjeren kako je to napravio Tom prema njegovoj naredbi, iako su se oni sami potrovali.

U toj aluzivnoj i crnoj farsi mjesto radnje je dom obitelji Barcley u New Yorku, a sve prostorije u kući opisane su tmurnim bojama uz mnogo pogrebne draperije i mrtvačke sanduke koji služe kao stolice i kreveti pa se sve vrti oko smrti i zarade koju ona nosi za obitelj pogrebnika. Gangster Tom uvjerava Johna kako je njegov protivnik Farley uspješan zato što je angažirao jednog gangstera da za njega ubija ljude koji mu nakon smrti postaju mušterije pa onda John zaključuje da će imati milijune kada uništi Farleyja (Bakarić, 1994: 102). Svojoj ženi Evelyn naredio je da bude ljubazna prema milijunašici jer im treba njezin novac za što su se obadvoje spremni pretvarati da im je stalo do nje. U jednom trenutku psihijatar George ostaje sam s gangsterom i govori mu da John nikada ne bi naručio njegove usluge jer on zrači zločinom (Isto: 36), no ispostavlja se da je John spreman unajmiti gangstera da bi se riješio žene i njenog ljubavnika. U svim situacijama pokretač radnje je novac bilo da se radi o nedostatku sredstava ili o iznenadnom nasljedstvu koje je opet kamen spoticanja, a ne rješenje problema. Dok se obitelj Barcley na početku trudi da im Helen ostavi novac, kasnije pokušavaju postići suprotno, što se vidi u tome da se supružnici planiraju riješiti jedno drugoga nakon što Helen potpiše da je Evelyn njena nasljednica. Autor se izruguje lakoći s kojom supružnici planiraju ubojstvo jedno drugog što se potvrđuje u brojnim dijalozima. Čitatelj iz razgovora Evelyn i njenog ljubavnika Georgea saznaje kako je ona spremna glumiti veliku zabrinutost i strah kako bi ljubavnika navela na zločin: „Dok starci ne potpišu testament ništa mi se neće dogoditi, George. On zna da bi time prerezao granu na kojoj sjedi i zato će čekati. Moramo ga preduhitriti, razumiješ li? Moramo biti brži, u tome je stvar“ (Isto: 75). S druge strane John priznaje svojoj ženi da je i on nju planirao ubiti te da je čak zamišljao kako joj se tijelo raspada što ga je ispunjavalo srećom. Autor do apsurda dovodi situaciju u kojoj se Evelyn, George i John ispričavaju jedno drugome za ono što 
su namjeravali učiniti. Svrha crnog humora i ironije jest ismijavanje bračnih savjetovanja u kojima supružnici naizgled razlučuju greške u braku, a zapravo ne shvaćaju da su se udaljili.

Prvu opasku o Američanima, kako se u Bakarićevoj drami nazivaju Amerikanci, daje gangster Tom koji kaže: „Moj dosje u policiji veličanstvena je pohvala jednom uspješnom životu kakav je moguć samo u Americi.“ (Isto: 75) U toj rečenici vidi se da su svi tekstovi koji u hrvatskoj književnosti prikazuju Amerikance povezani i da se međusobno citiraju jer Bakarić pokazuje sličnosti s Raosom koji je u svojoj drami također navodio kako u Americi uspijevaju prostitutke i gangsteri. Osim toga, spomenuta izjava nosi snažnu implikaciju da takvo što nije moguće u drugim zemljama. To je ono što se iščitava iz površinske strukture rečenice, no ako se drama pogleda u cjelini onda je moguće doći do zaključka da se radi o aluziji na sve zemlje koje mogu pasti pod utjecaj smrti, novca, profita i materijalizma što uključuje i naše prostore. Osim sličnosti s Fabrijem i Raosom, vide se sličnosti i s Begovićem i to zato što Jonathan Smith citira rečenice Lee Prenticea iz drame Amerikanska jahta u splitskoj luci jer na sve upite svoje supruge odgovara sa: Da, Helen. Za razliku od Leeja, Jonathan se na kraju buni i prigovara supruzi da ga nikada ništa nije pitala te odlazi piti s pjesnikom Zachariasom. Ispostavlja se da su Jonathan i Helen otuđeni jer on pije i supruga mu ne znači puno, a ona njega omalovažava i njegovu potvrdu pokušava kupiti svojim novcem.

Na nekoliko mjesta u drami ističe se koliko je New York velik i kako su Američani najbolji ljudi. To potvrđuje i Njemica Margaret koja je zaposlena kako bi potaknula seksualno uzbuđenje u nezainteresiranog Marca koji tvrdi da se Njemice uvijek smiješe Američanima (Isto: 69). Gangster Tom tvrdi kako je on pravi Američanin jer su njegovi tamo došli 1780.g. čime se aludira na pitanje doseljenika u Ameriku, njihova (ne)uspjeha i amalgama različitih kultura koje se stapaju u američkom identitetu. Ironija se najviše osjeća kada John nakon što supruzi prizna da ju je želio ubiti, govori o Američanima pa kaže: „Postajem čovjek kakav sam oduvijek želio biti iskren, odan i snažan, kakvi su pravi Američani“ (Isto: 99). Kao i svi likovi u drami, John misli da zna što se podrazumijeva pod definicijom pravog Amerikanca. On smatra da je velik jer je priznao da je planirao zločin i odustao je od toga, ali još uvijek nije odustao od bogatstva i uništavanja protivnika. Njegova zabluda najbolje se vidi u sljedećem govoru koji je oda materijalizmu i kolonijalizmu:

„To je naše, a mi smo živi; možemo sjesti u bilo koju od tih fotelja i kad god to zaželimo osjetit ćemo naš život. Mi ispunjavamo ovu kuću našim tijelima: mi je činimo lijepom. Dovoljno je da prstima dotaknemo njene zidove pa da osjetimo tu čudesnu radost. Nije li tako? Sigurni 
smo, nitko nam ništa ne može; u tvrđavi smo, a oko nje iskopani su duboki jarci, duboki opkopi naše ljubavi. Izgradili smo veličanstvene mostove kojima dopiremo do srca svih ljudi ovoga svijeta i oni nam se dive. Naše bogatstvo njihovo je bogatstvo. Oni moraju biti sretni zbog naše sreće" (Isto: 99-100).

U tim rečenicama nalazi se ključ analize ove farse jer se u njima američki materijalizam, osjećaj moći i iluzija sreće ismijava do apsurda budući da je sasvim jasno da opkopi o kojima John govori zapravo označavaju krizu takvog sistema. Takvu analizu dodatno potvrđuje rečenica odvjetnika Gunna koji tvrdi da njegovim odvjetničkim radom upravlja „onaj pravedni duh dobra i ljubavi koji je naše pretke doveo na ovaj kontinent i koji ih je naveo da ovdje udare temelje svom novom domu“ (Isto:111-112). U toj rečenici moguće je iščitati sasvim jasnu aluziju na antičke mitove o Novom svijetu. Jonathanovu misiju uništenja protivnika na kraju želi nastaviti njegov poremećeni sin Marc koji želi pokopati cijeli New York, a ima dovoljno novaca da učini što želi. Time se materijalistička ideologija prenosi s generacije na generaciju. Kada je M. Muhoberac ustvrdila da je Bakarić anticipirao događaje devedesetih godina, vjerojatno je mislila na kraj drame u kojem Marc govori kako će svaki dan biti jedan lijepi sprovod od čega će on imati uspjeha i zarade. Marcova definicija Američanina jest seksualno osviješteni čovjek koji se ne boji i ne preza ni od čega ili barem onaj koji je uvjeren da je to tako. Bakarić je u svojoj farsi kritičan prema američkom materijalizmu te se uz ironiju koristi i crnim humorom. Također, autor se poigrava predodžbama o Amerikancima jer svaki od likova ima ponešto drugačiju verziju definicije pravog Amerikanca. Time $\mathrm{u}$ isto vrijeme dovodi u pitanje američki identitet, ali još više razne predodžbe i slike tog identiteta. Kao rezultat autorova poigravanja definicijom pravog Amerikanca nameće se kao moguć zaključak da u svakom društvu ima ponešto od američkog materijalizma i okrenutosti profitu. Bakarić zapravo cijelo vrijeme aludira na domaće prilike što potvrđuje i Nikola Batušić ${ }^{17}$ koji smatra da je autor samo promijenio zemljopisni okoliš kako bi čitatelje uvjerio u svoju projekciju amerikanizma koji označava suvremeni oblik postojanja u potrošačkom društvu (1970: 355).

17 N. Batušić zapravo piše kritiku praizvedbe Bakarićeve farse u režiji Vanče Kljakovića iz 1970.g. koja potvrđuje da se u farsi aludira na domaće prilike, tako što je redatelj odredio da se za vrijeme predstave na platnu projiciraju reklame domaćih prehrambenih i kozmetičkih proizvoda. 


\section{Zaključak}

Otkriće Amerike zauvijek je promijenilo globus i zemljopisne karte, a te promjene odrazile su se u politici, povijesti, kulturi i književnosti. Bila je to zemlja mogućnosti koju su prikazivali kao raj pa je tako krenula i masovna kolonizacija novootkrivenog područja. Geografski omeđena zemlja dobila je svoj naziv i mjesto na karti, a onda je dobila mjesto i u književnosti. Kolumbo, Amerika i Amerikanci ušli su razne nacionalne književnosti, a američka književnost postala je dio povijesti književnosti. U zemlji prosperiteta svoj komadić sreće potražili su i mnogi Hrvati i ostali narodi s našeg područja od kojih su neki uspjeli, a neki su propali. Hrvatski dramatičari raznih generacija u književnost su uveli likove Amerikanaca bilo da se radi o Hrvatima koji su odselili u Ameriku ili o pravim Amerikacima. Uz pomoć tih likova hrvatski su pisci projicirali svoje stavove i slike o Americi. Ponekad su to činili svjesno pa je kritika bila ciljana, a često je to bio rezultat kulturnog okruženja u kojem su publicistika, drugi književni tekstovi i noviji mediji poput filma stvarali predodžbe o Americi koje su postale tropi i dio jednog šireg interteksta. ${ }^{18}$

U hrvatskoj književnosti stvorila se slika o Americi koja je geografski gledano bila sasvim udaljena, ali ipak je utjecala na život naših ljudi. Geografija u analiziranim dramama često predstavlja prividan bijeg iz domaćih prilika kako bi se onda upravo upućivalo na prilike iz kojih se bježi. Prikaz Amerike u hrvatskoj književnosti ne podudara se uvijek sa stvarnom Amerikom jer se radi o predodžbi i reprezentaciji koja je stvorena za određenu priliku i dio je teksta. Pisci u svoje projekcije Amerike i njenih stanovnika kodiraju određene poruke u kojima je ono što je Drugo uvijek strano i može biti bolje ili gore od domaćeg. Površinska analiza većine drama pokazuje kako je pojam naizgled idealne, a zapravo zaradi podređene Amerike suprotstavljen domaćoj situaciji. Detaljna analiza pokazuje kako se te dvije situacije sve više približavaju i izjednačuju. Slika koju pisci stvaraju može utjecati na izvanknjiževne sudove o toj zemlji, a može podupirati i određene predrasude. Budući da se u ovom slučaju radi o dramama koje se prikazuju u kazalištu, onda je jasno da se utjecaj širi svakim postavljanjem na scenu.

Ivo Vojnović u Ekvinociju progovara o tada vrlo važnom iseljeničkom pitanju i govori o tome kako mnogi Hrvati u želji da što više zarade propadaju

18 Govoreći o doprinosu imagologije J. Leerssen (2009a: 178-182) naglašava kako predodžbe pomoću ponavljanja i međusobne sličnosti postaju tropi, a upravo to dogodilo se sa slikama o Americi. Također, ističe kako takve slike ne upućuju na stvarnost, već na intertekst ili rezonator drugih tekstnih pojava. Kao radna hipoteza navodi se mogućnost da književnost kao i noviji mediji poput filma i stripa utječu predstavljaju povlašten žanr za širenje stereotipa jer imaju utjecaja na publiku. 
radeći u američkim rudnicima. On u spomenutoj drami unosi lik hrvatskog iseljenika Nike Marinovića koji je bio i ostao pokvaren, a uspjeh u Americi samo je doprinio njegovu bahaćenju. Ako se Vojnovićevo stvaralaštvo analizira u cjelini, moguće je doći do zaključka da je kod njega često prisutna atmosfera propadanja, a po tome ga se može usporediti s Begovićem. Ipak, Begovićevi Amerikanci nisu bahati povratnici koji žele uništiti naše, već se žele odužiti i pomoći. Zanimljivo je da Begović splitske aristokrate pokazuje kao pomalo bahate i spremne na očajničke poteze, a povratnike iz Amerike prikazuje mudrijima. Iznimka je lik po imenu Lee Prentice koji je karikatura poslušnog poslovnjaka koji se pokorava mnogo osvještenijoj zaručnici. Begovićevi Amerikanci u cjelini drame Amerikanska jahta u splitskoj luci imaju zadatak ukazati na propadanje splitske aristokracije koja se služi raznim lukavštinama kako bi svoju sramotu sakrila. Upravo likovi Amerikanaca u funkciji su razotkrivanja i razgolićavanja te sramote na vrlo lepršav i vedar način, za razliku od tmurnih tonova i boja kojima Vojnović u Dubrovačkoj trilogiji prikazuje propadanje dubrovačke vlastele. Ovakva analiza potvrđuje pomirljivi stav H. Dyserincka da su images i mirages dio intrinzične strukture teksta (2009a, 2009b).

Kod Miroslava Krleže potrebno je poznavati njegov opus u cjelini jer jednu dramu posvećuje Kolumbu, u dvije drame uvodi likove Amerikanaca tj. Hrvata koji su bili u Americi, a jedan te isti lik takvog Amerikanca prisutan je i u drami i u romanu. Krležina Amerika iz drame Kristofor Kolumbo samo je utopija koju je nemoguće ostvariti jer nema te zemlje u kojoj je moguć novi poredak koji se temelji na starim idejama. U novom poretku opet bi do izražaja došla podjela na vladajuće i one koji im se moraju pokoriti. Krleža je uvijek politički angažiran pa ne treba čuditi što je ironičan i skeptičan prema ideji o idealnoj zemlji u kojoj bi se ispravile greške iz starih zemalja. Zato u dramama Vučjak i U logoru do izražaja dolazi njegov ironičan stav prema Americi koja ostaje samo san. O toj Americi drugi likovi imaju iskrivljenu sliku i to na temelju činjenice da je tamo uspjela jedna žena poput Eve, ali upravo ona dokaz je da u Americi svatko može uspjeti. Za Evu je simbol Amerike gramofonska ploča koju navija i koja je u kontrastu sa zaostalom sredinom u kojoj se nalazi. Autor je u prikazu slike o Americi ironičan jer upućuje na činjenicu da tamo nije lako uspjeti, ali isto tako implicira da je američka sredina pitomija od zabačenog Vučjaka. Analiza Krležinih Amerikanaca potvrdila je mišljenje K. U. Syndrama da ironijski odmak kojim se književni jezik koristi može biti u kontrastu s površinskim značenjem, a može stvoriti i neobičan amalgam koji u isto vrijeme nešto ismijava i legitimira (2009: 72). Krleža u svojim dramama često koristi ironiju kojom podriva prihvaćen način opisa stvari, prihvaćene norme i političke sustave, a na podrivanje ukazuju i likovi Amerikanaca u njegovim djelima. 
Čini se da je Ivan Raos najkritičnije prikazao Amerikance i materijalističko društvo u kojem žive, iako se nameće zaključak kako bi Raosova Amerika mogla biti alegorija za naše prostore i sve one zemlje koje se okreću materijalizmu. Takvo društvo nije bilo spremno prepoznati ni prihvatiti Krista jer nisu mogli shvatiti da im netko želi dobro iz čiste ljubavi. Najokrutniji je pisac bio prema Amerikankama koje su prikazane kao proračunate žene željne slave koje Krista vide samo kao figuru ispod bora. Iako se Raos obrušava na američko društvo, kritika se može odnositi na sva društva koja postaju kapitalistička i opsjednuta materijalnim što može uključivati i našu zemlju tj. kulturu iz koje pisac promatra i u kojoj Krist također postaje figura ispod bora. Njegova slika Amerike odgovara američkim reklamama za razne proizvode koje su iskorištavale sliku sretne obitelji koja se okuplja pored božićne jelke i otvara poklone. Takva je Amerika spremna potrošiti novce i kupiti proizvode koji se reklamiraju, ali nije spremna na Kristov pravi dolazak. U Raosovoj drami slika Amerike funkcionira kao intertekst stvoren od prethodnih književnih i publicističkih tekstova kao i tekstova i slika prisutnih u novim medijima kakav je film koji onda uključuje i televiziju te posebno reklame. Tomislav Bakarić također u prvi plan svoje farse stavlja američki materijalizam, ali se isto tako bavi različitim definicijama Amerikanca, upućuje na kolonijalnu praksu i preispituje vrijednosti kojima se diči američko društvo. Kod Raosa i Bakarića postoji mogućnost da se opisujući slike Amerike i rastakanja američkog sna zapravo upozorava na domaće prilike pa bi onda spomenuta slika o proračunatim Amerikankama bila odraz onoga u što se pretvaraju i domaće žene.

Hrvatski dramatičari koji generiraju predodžbe o Americi dolaze iz različitih generacija i povijesnih razdoblja, drugačijih su političkih i kulturnih pogleda, a ipak stvaraju intertekst u kojem se javlja mit o Americi i stereotipni likovi Amerikanaca koji ne ispunjavaju uvijek očekivanja čitatelja. Ti stereotipi ne predstavljaju nužno kritiku američkog društva, nego mnogo češće govore o aktualnim domaćim prilikama koje stereotipi osvjetljavaju. Ovim se imagološko istraživanje o likovima Amerikanaca u hrvatskim dramama ne iscrpljuje jer ima još pisaca koji ih spominju, a Amerikanaca ima i u drugim književnim vrstama. Osim toga, zanimljivo bi bilo vidjeti kako su Amerikanci prikazani u drugim nacionalnim književnostima posebno u našoj regiji pa bi tada istraživanje bilo potpunije, ali i opsežnije. Analiza navedenih drama pokazala je kako su slike o Amerikancima dio unutarnje strukture teksta i da se uz pomoć njih često upućuje na konotativna značenja teksta. 


\section{Literatura}

- Bakarić, T. (1994), Malleus maleficarum (Malj koji ubija): drame, Zagreb, AGM: Hrvatsko društvo kazališnih kritičara i teatrologa.

- Batušić, N.(1970), Tomislav Bakarić »Amerika, Amerika«, Republika, 7/8: 355-356.

- Begović, M. (1964), Amerikanska jahta u splitskoj luci. U: Augustin Stipčević (ur.), Pet stoljeća hrvatske književnosti, knjiga 75: Milan Begović I. Pjesme, drame, kritike i prikazi, Zagreb, Matica hrvtaska Zora, str. 151-232.

- Biti, V. (2000). Mit. U: Vladimir Biti. Pojmovnik suvremene književne i kulturne teorije, Zagreb, Matica hrvatska, str. 317-320.

- Čale, F. (1992), Iseljeničko pitanje u dramaturgiji »Ekvinocija«, Dubrovnik, 3 (5): 103-109.

- Dubrovnik - časopis za književnost i znanost, Nova serija, godište 3, 1992, broj 5 - Hrvati i Novi svijet (u povodu 500-te obljetnice otkrića Amerike)

- Dukić, D. (2009), Predgovor: O imagologiji. U: Davor Dukić, Zrinka Blažević, Lahorka Pleić Poje, Ivana Brković (ur.), Kako vidimo strane zemlje. Uvod u imagologiju, Zagreb, Srednja Europa, str. 5-22.

- Dyserinck, H. (2009a), Komparatistička imagologija onkraj »imanencije» $i$ »transcedencije« djela. U: Davor Dukić, Zrinka Blažević, Lahorka Pleić Poje, Ivana Brković (ur.), Kako vidimo strane zemlje. Uvod u imagologiju, Zagreb, Srednja Europa, str. 57-69.

- Dyserinck, H. (2009b), O problemu »images« $i$ »mirages« $i$ njihovu istraživanju u okviru komparativne književnosti. U: Davor Dukić, Zrinka Blažević, Lahorka Pleić Poje, Ivana Brković (ur.), Kako vidimo strane zemlje. Uvod u imagologiju, Zagreb, Srednja Europa, str. 23-35.

- Fabrio, N. (2007), Aluzivne drame, Zagreb, Profil international.

- Fischer, M. S. (2009), Komparatistička imagologija: za interdisciplinarno istraživanje nacionalno-imagotipskih sustava. U: Davor Dukić, Zrinka Blažević, Lahorka Pleić Poje, Ivana Brković (ur.), Kako vidimo strane zemlje. Uvod u imagologiju, Zagreb, Srednja Europa, str. 37-56.

- Gašparović, D. (1992), Američki motivi u hrvatskoj dramatici XX. stoljeća, Dubrovnik, 3 (5): 234-242.

- Hećimović, B. (1964), Milan Begović. U: Augustin Stipčević (ur.), Pet stoljeća hrvatske književnosti, knjiga 75: Milan Begović I. Pjesme, drame, kritike i prikazi, Zagreb, Matica hrvtaska Zora, str. 5-22.

- Kadić, A. (1992), Otkriće Amerike u hrvatskoj književnosti, Hrvatska revija, 42 (2): 200-210.

- Klaić, B. (2007), Amerika. U: Bratoljub Klaić (ur.), Rječnik stranih riječi, Zagreb, Školska knjiga, str. 57-58. 
- Klaić, B. (2007), Amerikanac. U: Bratoljub Klaić (ur.), Rječnik stranih riječi, Zagreb, Školska knjiga, str. 58.

- Krleža, M. (1973), Drame. U: Krsto Špoljar (ur.), Pet stoljeća hrvatske književnosti, knjiga 94: Miroslav Krleža. Drame IV, Zagreb, Matica hrvatska Zora.

- Krleža, M. (1981), Legende, Sarajevo, Nišro Oslobođenje i Ikro Mladost.

- Krleža, M. (1981), Tri drame, Sarajevo, Nišro Oslobođenje i Ikro Mladost.

- Leerssen, J. (2009a), Imagologija: povijest i metoda. U: Davor Dukić, Zrinka Blažević, Lahorka Pleić Poje, Ivana Brković (ur.), Kako vidimo strane zemlje. Uvod u imagologiju, Zagreb, Srednja Europa, str. 169-185.

- Leerssen, J. (2009b), Odjeci i slike: refleksije o stranom prostoru. U: Davor Dukić, Zrinka Blažević, Lahorka Pleić Poje, Ivana Brković (ur.), Kako vidimo strane zemlje. Uvod u imagologiju, Zagreb, Srednja Europa, str. 83-97.

- Lukšić, I. (2000), Krleža, Miroslav. U: Dunja Fališevac, Krešimir Nemec, Darko Novaković (ur.), Leksikon hrvatskih pisaca, Zagreb, Školska knjiga, str. 392-399.

- Muhoberac, M. (2000a), Bakarić, Tomislav. U: Dunja Fališevac, Krešimir Nemec, Darko Novaković (ur.), Leksikon hrvatskih pisaca, Zagreb, Školska knjiga, str. 31-32.

- Muhoberac, M. (2000b), Raos, Ivan. U: Dunja Fališevac, Krešimir Nemec, Darko Novaković (ur.), Leksikon hrvatskih pisaca, Zagreb, Školska knjiga, str. 611-612.

- Nemec, K. (2000), Fabrio, Nedjeljko. U: Dunja Fališevac, Krešimir Nemec, Darko Novaković (ur.), Leksikon hrvatskih pisaca, Zagreb, Školska knjiga, str. 211-212.

- Novak, S. P. (2000), Palmotić, Junije. U: Dunja Fališevac, Krešimir Nemec, Darko Novaković (ur.), Leksikon hrvatskih pisaca, Zagreb, Školska knjiga, str. 547-548.

- Novo doba, 10, 14. 01. 1928., br. 11, str. 8.

- Novo doba, 10, 19. 01. 1928., br. 15, str. 6 .

- Pageaux, D. H. (2009), Od kulturnog imaginarija do imaginarnog. U: Davor Dukić, Zrinka Blažević, Lahorka Pleić Poje, Ivana Brković (ur.), Kako vidimo strane zemlje. Uvod u imagologiju, Zagreb, Srednja Europa, str. 125-150.

- Raos, I. (1956), Kako je New York dočekao Krista, Koprivnica, Koprivnička tiskara.

- Senker, B. (1996), Predgovor. U: Vlatko Pavletić (ur.), Stoljeća hrvatske književnosti, Zagreb, Matica hrvatska, str. 11-34. 
- Senker, B. (2000), Šnajder, Slobodan. U: Dunja Fališevac, Krešimir Nemec, Darko Novaković (ur.), Leksikon hrvatskih pisaca, Zagreb, Školska knjiga, str. 704-705.

- Solar, M. (2011), Mit. U: Milivoj Solar, Književni leksikon, Zagreb, Matica hrvatska, str. 313.

- Syndram, K. U. (2009), Estetika alteriteta: književnost i imagološki pristup. U: Davor Dukić, Zrinka Blažević, Lahorka Pleić Poje, Ivana Brković (ur.), Kako vidimo strane zemlje. Uvod u imagologiju, Zagreb, Srednja Europa, str. 71-81.

- Šnajder, S. (2005), Kaspariana, Zagreb, Literarna biblioteka.

- Treći program hrvatskog radija, broj 39/1993.

- Tko se može otpremiti u Ameriku (1922?), Dubrovnik, Štamparija Giulli i dr.

- Vojnović, I. (2003), Ekvinocijo. U: Vlatko Pavletić (ur.), Stoljeća hrvatske književnosti, Ivo Vojnović, Izabrana djela I., Zagreb, Matica hrvatska, str. 265-331.

\section{Lucijana ARMANDA}

\section{HOW WE SEE OTHERS: AMERICANS IN CROATIAN PLAYS}

Stemming from an imagological point of view and notions such as image and mirage and the viewpoint of Manfred S. Fischer that our view of America is based on our images of America rather than on reality, the author of the paper attempts to reveal the way in which playwrights projected their own images of America in their characters of Americans. After Columbus had discovered America, a lot of playwrights, novelists and poets were fascinated by the character of Christopher Columbus and this miraculous land of opportunities and utopia he had discovered. After this initial fascination, writers became inspired by the character of Americans. When referring to Americans the author means inhabitants of the American continent, mostly its northern part, as well as Croatians who had gone to America and became Americans. The author is especially interested in the way these characters are portrayed and used in literature, particularly in the play of Milan Begović symbolically entitled An American Yacht in Split Harbour, as well as in the works of Miroslav Krleža, Ivan Raos and Tomislav Bakarić.

Key words: American dream in Croatian plays, characters of Americans, Milan Begović, Ivan Raos, Tomislav Bakarić 


\section{Marko EK (Osijek)}

UDK 811.163.4'28(497.5)

Izvorni naučni rad

Filozofski fakultet Sveučilišta J. J. Strossmayera u Osijeku

marko.ek@gmajl.com

\section{Tina VARGA-OSWALD (Osijek)}

Filozofski fakultet Sveučilišta J. J. Strossmayera u Osijeku

tvarga@ffos.hr

\section{NÁDASEV DOPRINOS „RETORICI POSTMODERNE“ U ROMANU DIVNA POVIJEST FOTOGRAFIJE}

Suvremeni mađarski pisac Péter Nádas (1942.) svojim književnim radom pripada generaciji „nove proze“ koja poetikom jezika ruši dotadašnje književne konvencije tradicionalnog pisanja. Roman Divna povijest fotografije (1995.) istodobno otvara prostor dvjema umjetnostima, književnosti i fotografiji, kojima uspijeva odgovoriti na suvremena postmodernistička pitanja, ali i uspostaviti inovativan postupak u mađarskoj književnosti. Poput Prousta, jer se roman nakon pada realizma okrenuo ironiji, Nádaseva zamisao o životu koji se ne može vratiti u sjećanje „vremenskim aparatom“ osim ako glavni likovi ne dožive svoj krah, a tada se ni ne mogu ničega sjećati, u romanu nije apsurdna, nego paradoksalna. Traganje za vlastitim identitetom načeto motivima Kunderinih Smiješnih priča dobiva svoj vrhunac u odnosu na Calvinov roman Ako jedne zimske noci neki putnik. Paradoksi koji pri tome nastaju, od komedija do tragedije u kontekstu lake i teške književnosti, sažeti su u značenju fotografije. U trenutku kada čitatelj napusti horizont očekivanja ,velikih priča“, kada gledatelj napusti horizont očekivanja studije o fotografiji, nastaje nova retorika.

Ključne riječi: Péter Nádas, mađarska književnost, postmodernizam, fotografija, Roland Barthes, 'laka i teška književnost', Italo Calvino, Milan Kundera, Jorge Luis Borges 
U mađarskoj književnoj povijesti ${ }^{1}$ Péter Nádas (1942.) uz Pétera Esterházyja (1950.) zauzima prostor „nove proze“ utemeljen već krajem sedamdesetih godina XX stoljeća novom poetikom jezika koja ruši dotadašnje konvencije tradicionalnog modernog pisanja. Linearno pripovijedanje zaokruženo cjelinom zamijenjeno je novom fragmentarnom tehnikom bez naglašenog uvoda ili završetka. Pri tome je svaki pojedinačni fragment jednako vrijedan upravo zbog svoje simultanosti čime se zapravo želi ukazati na novu književnu preokupaciju tekstom karakterističnu za razdoblje postmodernizma. Ugledajući se na njemačkog književnika i prevoditelja Arnoa Schmidta spoznaju o tome u svojim književnim djelima prema mađarskom povjesničaru i teoretičaru Szabóu Ernőu Kulcsáru u mađarsku književnost prvi donose upravo Nádas (Knjiga memoara, 1986.) i Esterházy (Uvod u lijepu književnost, 1986.).

Suvremeni mađarski pisac Péter Nádas svoje je književno stvaralaštvo započeo zbirkama priča Biblija (A Biblia, 1967.) i Traženje ključa (Kulcskereső játék, 1969.) u kojima se prisjetio svoga djetinjstva i iskustava koje je tada stekao. Njegov prvi roman Kraj obiteljskoga romana (Egy családregény vége, 1977.) u kojemu je riječ o sukobu generacija u staljinističkoj Mađarskoj dugo je bio zabranjivan od mađarske vlasti. Godine 1986. objavljuje monumentalni roman Knjiga sjećanja (Emlékiratok könyve), kojim je stekao međunarodni ugled. Riječ je o psihološkom romanu koji je nastao slijedeći tradiciju Marcela Prousta i Thomasa Manna. Nádas je Knjigu sjećanja pisao 11 godina, a namjera mu je bila opisati svijet kao sustav odnosa među ljudskim tijelima. Treba spomenuti i njegove poznate knjige eseja Igralište (Játéktér, 1988.) i Papirići i ostali napisi pronađeni i pomiješani (Talált cetli és más elegyes irások, 1992.), romane Godišnjak (Évkönyv: Ezerkilencszáznyolcvanhét, ezerkilencszáznyolcvannyolc, 1989.) i Divna povijest fotografije (A fotográfia szep tortenete, 1995.) te zbirku priča Minotaur (Minotaurus, 1997.).

Mnogi Nádasevi romani prevedeni su na brojne svjetske jezike, što potvrđuje njihovu uspješnost ${ }^{2}$ i priznatost u svijetu. Nádas je dobitnik brojnih nagrada, među kojima su najznačajnije Milán Füst, Nagrada za mađarsku umjetnost, Austrijska državna nagrada za europsku književnost, Nagrada Kossuth,

Szabó Ernő Kulcsár. A magyar irodalom története 1945-1991, Argumentum, Budapest, 1993.; radni prijevod Tina Varga-Oswald.

2 Primjerice, roman Kraj obiteljskoga romana preveden je na švedski jezik 1979. (Slutet på en familjeroman), na norveški 1980. (Slutten på en familieroman), na poljski 1983. (Koniec pewnej rodzinnej Sagi), na francuski 1991. i 1994. (La fin d'un rimski de Famille), na finski 2000. (Erään sukuromaanin loppu), na ruski jezik 2004. (Konyec szemejnovo Romana) itd. 
Leipziška nagrada, Nagrada Franz Kafka Republike Češke. Od 1993. godine član je mađarske Széchenyi Irodalmi és Mủvészeti Akadémia u Budimpešti, a visoki ugled uživa i u Njemačkoj, gdje često drži predavanja na Humboldtovu sveučilištu; u lipnju 2006. postao je članom i Akademie der Künste u Berlinu.

Roman Divna povijest fotografije, izvorno A fotográfia szep tortenete (1995.), objelodanjen je u prijevodu Kristine Peternai 2005. godine u izdanju nakladničke kuće Fraktura. Riječ je o romanu koji ne propituje povijest fotografije, kako bi se pomislilo slijedeći značenje naslova, nego o romanu u kojemu se traga za smislom života te pronalaženjem identiteta. Akteri romana Kornelija, Barun, Carlo van der Woeld, Henrijeta i Primarijus kreću se unutar svojih unaprijed zadanih konvencija i pokušavaju dosegnuti višu razinu svoga postojanja čime se ispostavlja da tragaju za drugim Ja, odnosno za mijenjanjem svoje početne osnove. Glavna junakinja plemkinja Kornelija koja nakon „putovanja“ zračnim balonom doživljava šok i biva smještena u sanatorij; likovi vezani uz nju, u ljubavnom trokutu, zaručnik koji ju i financira, ljubavnik Carlo kojemu je ipak stalo do nje pa i sami liječnici koji se kreću unutar temata njezina ozdravljenja, u ulozi su naglašavanja njezinih osobina te ostvarivanju identitetnih spoznaja o samima sebi pa i drugima.

Tragom tih tematskih okosnica u romanu Divna povijest fotografije nižu se fotografije, jedna za drugom, nalik albumu. To nizanje fotografija $\mathrm{i}$ njezina važnost upućuje se već (u hrvatskom izdanju) naslovnicom romana na kojoj je prikazana slika u bidermajerskom okviru Bele Csikosa Sesije Violinistica. Osim toga, zaključuje se da je fotografija prioritet, način tumačenja identiteta, života uopće, no ne samo to nego i fotografski način promatranja vremena koje nezaustavljivo prolazi, prostora koji je relativan, ljudi koji prolaze jedni pokraj drugih te odnosa jedne fotografije s drugom, njihovo uzajamno značenje. Tomu u prilog ide i bilješka iz životopisa iz koje se saznaje da je Nádas pohađao tečaj fotografije te dugi niz godina radio kao fotograf, što potvrđuje njegovo zanimanje za taj medij. Treba dodati i da je roman ispričana fotografija ili više njih, ${ }^{3}$ što uza se povlači određeni nivo nepravilnosti ljepote koja se kosi s naslovom romana Divna povijest fotografije, u kojem ipak nije riječ o divnoj ili možda lijepoj povijesti fotografije. Prema sposobnosti fotografskoga pisanja i preplitanja elemenata i motiva može se uočiti da je Nádas uistinu vješt fotograf koji umije povezati sve fotografije $u$ jedan album/ roman. Nizanjem fotografija kao u albumu prate se životi posve nepoznatih

Usp. Péter Balassa. Nádas Péter, Pozsony, Kalligram, 1997., str. 483. 
pojedinaca, osoba koje su prikazane kroz maglu i čije se sjene preseljavaju u tekst. Na taj način fotografija funkcionira kao identitetno polazište priče. U takvom obliku odnosa vanjski je svijet posve ništavan i nema direktan odnos s tim „unutarnjim“. Isto se tumačenje može poistovjetiti i s kompozicijskim ustrojstvom romana.

Roman je podijeljen na uglavnom kraća poglavlja kroz koja se prikazuju određene situacije, prepričavaju odnosi i prenose osjećaji, uspomene i misli. Upravo takvo kompozicijsko rješenje podsjeća na fotografije/ slike koje se izmjenjuju jedna za drugom i daju na uvid čitatelju, što opet svakako podsjeća na listanje albuma. Svako je poglavlje i naslovljeno: Vremenski aparat, Kraj romanse, Slika zemlje, Iznad svih oblaka, Izmjena slika, Poznajem ovog čovjeka, Nature morte, Grupna fotografija, Operacijsko uplitanje, Dvije slike iz prošlosti. Na taj način autor podsjeća na dinamičnu izmjenu slika/ fotografija, a dodatno dobiva na fragmentarnoj strukturi koja se prepoznaje i u samomu sadržaju romana, koji je rascjepkan i često nelogično povezan, ali i u navedenom kompozicijskome smislu. I to je još jedan razlog zbog kojega treba istaknuti kako je riječ o vrsnom primjeru postmodernističkoga ostvarenja. Postmodernizam odlikuje sažetost, autori ponajviše pribjegavaju kratkim književnim vrstama jer književni tekst može djelovati samo ako se čita brzo i okretno, ako se lista kao album. Postmodernističko književno razdoblje karakteriziraju obilježja poput skepticizma, relativizma i eklekticizma. Takva književna djela propituju spoznaju o pojedincu i svijetu putem okoline i društva, uopće sumnju u vlastito postojanje, razinu vjerovanja u općeprihvaćene vrijednosti i moralne kriterije te preuzimaju i povezuju različite teorije, sustave i stilove, znanstvena ili politička uvjerenja i njihovo ugrađivanje u oslikavanje istoga. Navedeno se potvrđuje i u Divnoj povijesti. Tekst je kratak, sažet, radnja teče vrlo brzo, ne postoji mnogo deskriptivnih trenutaka koji plijene pozornost i zaustavljaju čitatelja, ali se svakako nudi subjektovo propitivanje smisla i svrhe te vjerovanje u smislenost života.

Takvom postmodernističkom određenju romana treba pridružiti i motivsku strukturu romana na kojoj se temelji cjelokupni tekst. Motivacijska uloga u djelu zauzima najveći dio odgovornosti za izvrsnost teksta jer se preko nje uvedeni motivi uklapaju u zaokruženu cjelinu. Uvođenje svakoga motiva u tekst mora biti opravdano njegovom umjetničkom ulogom, ukoliko se motivi unose bez logična slijeda događa se raspad djela ${ }^{4}$. Tada je fabularnoj liniji osigurana čvrstoća prema kojoj se uključuju likovi i događaji. Najučestaliji prohodni motiv u romanu jest aparat. Riječ je o napravi uz koju je Kornelija

4 Usp. Boris Viktorovič Tomaševskij. Teorija književnosti: tematika, Matica hrvatska, Zagreb, 1998., str. 24. 
vezana i od koje se vrlo teško može rastati s obzirom na to da je fotografkinja. Aparatom roman započinje, i to naslovnom idejom poglavlja: Vremenski aparat, uz to se napominje njegova prisutnost u tekstu, ali i uz Korneliju. Nadalje se čita: Fotografski aparat također podignu u oblak. ${ }^{5}$ Kornelija ,„putovanje“ zračnim balonom također označuje kao sastavnicu koju treba zabilježiti. Trenutak je kratkotrajan, prolazan pa i podložan zaboravu, dok se slikom potvrđuje zamrzavanje trenutka i njegovo preseljenje u stalnost. Treba istaknuti i ulogu aparata u širem kontekstu koji funkcionira kao polazište Kornelijina identiteta. Treba napomenuti i to da periodizacijski gledano u književnoteorijskom smislu, za razliku od modernizma koji naglašava krizu identiteta, razdoblje postmodernizma identitet određuje sinkronijski, vrednujući i razmatrajući dijakronijski tradiciju i kulturu unutar književnosti. S obzirom na to da postmoderni teoretičari ne žele priznati postojanje korpusa koji bi to potvrđivao, njemu valja pristupiti na implicitnoj razini, barem kada je riječ o traganju/ definiranju identiteta u romanu Divna povijest. Traganje za identitetom u romanu projicirano je kroz glavne likove, implicitno, no treba dodati da je na taj način prikazano i traganje za identitetom kolektiva, sukladno postmodernističkom vremenu u kojemu je sve upitno i relativno. To se primjerice potvrđuje ostvarivanjem Kornelijina identiteta kroz fotografski aparat i fotografiju. Materijalizacija identiteta ostvarena je kroz plošno opisan aparat koji zaokružuje priču cijeloga romana. S druge strane, može se govoriti i o autorovu identitetu, dok je Kornelijina slika identiteta dana kroz fotografiju, autorova je dana kroz tekst, dakle pisanje. Tako se potvrđuje isprepletenost dvaju medija koji u ovu primjeru ne mogu jedan bez drugoga.

U takvu tumačenju treba istaknuti da je glavno polazište Nádaseva teksta upravo oblikovanje identiteta, uključujući djelovanje osobne prošlosti likova koja je u međusobnoj povezanosti sa sadašnjicom. Pitanje gubitka identiteta ravno je onom gubitku književnosti odnosno tradicije koje prethodi odgovoru Šeherazadine uloge. S druge strane, tradicionalna potraga za cjelovitošću romana odnosno uokvirene kratke novele, sinkronijom i dijakronijom, diskursom koji posjeduje unutarnje zakonitosti, u postmodernističkom svijetu sasvim je neopravdana. Tisuću i jedna noć, sada već univerzalna metafora postmodernizma, zamjena je izgubljenom pripovjedačkom instinktu. Analogija strukturom i zadovoljstvom pisanja/ pričanja/ fotografiranja odnosi se na književni tekst/ fotografiju kao objekt pripovjedačeve požude i tekst kao subjekt pripovjedačeva identiteta. Ljubav prema književnosti upisana je u strukturu romana $\mathrm{u}$ obliku fragmentiranih tekstova o fotografiji, koji se u određenim trenutcima približavanja i poistovjećivanja prekidaju, a napetost iščekivanja

Péter Nádas. Divna povijest fotografije, Fraktura, Zagreb, 2005., str. 15. 
moguće sinteze odnosno uporišta prelazi u potragu za paradoksom. Uokviravanjem novele/ romana zajedničkom metaforom ili njezinom samorefleksijom priča dobiva svoj kraj odnosno svoj početak. Tako određenje identiteta kao glavnoga motiva i pokretača priče ostvaruje poveznicu sa strukturnim i sadržajnim određenjem identiteta cjelokupne, ne samo mađarske, nego i srednjoeuropske književnosti, kojoj Péter Nádas i pripada.

Postmodernistički se identitet ne potvrđuje kao institucija ili motivska učestalost nego kao obilježje aktera koji se unutar takva postmodernističkiubrzana sustava ne snalazi pa i pomalo gubi u kontekstu lake i teške književnosti. ${ }^{6}$ Tako se svaki odnos u kojemu se dva subjekta nađu može opravdati ukalupljenim i već poznatim obrascima, točnije figurama. Francuski književni teoretičar Roland Barthes u svojoj knjizi Fragmenti ljubavnog diskursa upozorava na pojavu figura u književnim tekstovima: „Figure se jasno ocrtavaju kad u diskursu koji teče možemo prepoznati nešto što smo pročitali, čuli, doživjeli. Figura je omeđena (kao znak) i pamti se (kao slika ili priča). Figura je utemeljena ako barem netko može reći: 'Kako je to točno! Prepoznajem taj jezični prizor.' "'7 Barthes figure prikazuje na primjeru ljubavnoga odnosa i zaljubljenoga subjekta, ali one se mogu uklopiti i u svako drugo tumačenje. Također, Barthes ističe da se figure ,pojavljuju bez ikakvoga reda, jer uvijek ovise o slučaju (unutrašnjem ili vanjskom). ${ }^{\text {" }}$ To bi značilo da je njihovo pojavljivanje motivirano samim subjektovim stanjem, odnosno radnjom koja sama nameće razvoj figura. Tako se primjerice u poglavlju Najmirnije poslijepodne u godini prepoznaje figura Odsutan, prema Barthesovoj definiciji: „Svaka jezična epizoda koja iznosi na pozornicu odsutnost ljubljenog subjekta - kakvi god joj bili uzrok i trajanje (...).“9 U takvoj figuri napose se razilaze osjećaji, mišljenja i prisnost, što se u odnosu između Kornelije i Carla vidi u sljedećoj rečenici: I sad zaista nema više riječi, svatko završava svoj posao. ${ }^{10}$ Kada se između dviju osoba događa odsutnost nema više zajedništva, međutim, takva figura ne znači isključivost, što znači da se ponovna privlačnost ponovno može dogoditi. Malo kasnije Kornelija ipak privlači Carla i oni postaju prisni. U tome se trenutku prema Barthesovoj teoriji uključuje figura Potvrđi-

\footnotetext{
Usp. Milivoj Solar. Laka i teška književnost, Matica hrvatska, Zagreb, 2005.

Roland Barthes. Fragmenti ljubavnog diskursa, Pelago, Zagreb, 2007., str. 15.-19.

Isto.

Isto, str. 26.

Péter Nádas. Divna povijest fotografije, Fraktura, Zagreb, 2005., str. 135.
} 
vanje: „Unatoč i nasuprot svemu, subjekt potvrđuje ljubav kao vrijednost.“11 U takvom se svjetlu shvaća povezanost dvaju aktera koji ipak posjeduju osjećaje jedno prema drugome, stanje se mijenja: Bešćutnost je ostala u prošlosti, sada je sućutan. ${ }^{12}$

Između ljubavnika postoji tjelesna privlačnost. Tijelo kao simbol seksualnosti na takvome je tragu i u romanu, gdje se nailazi na položaj tijela u odnosu spram druge osobe: Pogleda Korneliju. Oboje kimnu glavama. Počinje se svlačiti. Nag se razvali po krevetu, laktom podboči glavu. Kroz leću gledaju jedno u drugo. Gledajući se čekaju pogodan trenutak. ${ }^{13} \mathrm{U}$ tome se može čitati figura Tijelo: „Svaka misao, svako uzbuđenje, svako zanimanje koje u zaljubljenom subjektu izaziva voljeno tijelo."14 Tijelo se u sličnome kontekstu pojavljuje na nekoliko mjesta u romanu, čime se figura dodatno potvrđuje. Također, jednakom se teorijskom razmatranju treba dodati i figura Slika. Riječ je o figuri koja svoje postojanje dijeli s motivskim nizom. Naime, slika je prohodni motiv cijelog romana, a u smislu figure okreće se samom njezinom smislu pa se pojavljuje i u naslovima poglavlja: I ovo je jedna slika, Slika zemlje, Dvije slike iz prošlosti... Tako je figura slike vezana uz ljubavnike i njihov odnos koji je umnogome zaokružen fotografskim aparatom, činom fotografiranja i slikom. Prema Barthesu: „Na ljubavnom polju najteže nam rane zadaje više ono što vidimo nego ono što znamo." ${ }^{\text {"15 }} \mathrm{U}$ navedenim figurama uočava se da je identitet aktera romana dan upravo kroz njihove međusobne odnose, osjećaje i uloge. Na taj se način romanom kreću likovi koji potvrđuju svoje mjesto u društvu i pronalazak nove pozicije postojanja u kontekstu lake i teške književnosti.

\section{4.}

Uz već spomenuti skepticizam, relativizam i novo shvaćanje tradicije, vjerojatno najznačajnija književna obilježja postmodernizma, ali i postmoderne kao kulturno-povijesnog fenomena, o kojima i o kojemu se raspravlja posljednjih četrdesetak godina, u književno-teorijskoj literaturi navodi se i niz drugih obilježja koja se uglavnom ne mogu obuhvatiti zajedničkim nazivnikom.

Jedna od takvih težnji sadržana je u knjizi književnog teoretičara i povjesničara Milivoja Solara Retorika postmoderne prema kojoj je i parafraziran naslov rada. U jednom od poglavlja navedene knjige Prvo predavanje:

\footnotetext{
Roland Barthes, n. d., str. 33.

Péter Nádas. Divna povijest fotografije, Fraktura, Zagreb, 2005., str. 136.

Isto, str. 135.

14 Roland Barthes. Fragmenti ljubavnog diskursa, Pelago, Zagreb, 2007., str. 72.

15 Isto, str. 121.
} 
paradoks Solar upozorava na pokušaj odgonetanja i opisivanja postmoderne na neki način ,iznutra“. Njemu se čini „kako se bit postmoderne ne može razabrati niti opisati drugačije nego jedino ako pretpostavimo da se ona može 'zrcaliti' čak i u samo jednoj rečenici.“"16 A ta njegova rečenica glasi: „Ova je rečenica lažna." Istaknutim paradoksom koji bitno određuje postmodernizam Solar raspravu o postmoderni prenosi s područja znanosti i filozofije na područje retorike. Pri tome napominje: „ako je obzor jezika jedini okvir i uvjet unutar kojih se možemo sporazumijevati, ako nema referencije ni ikakva uporišta u spoznaji, načelno je čitav jezični sustav autoreferencijalan, a tada je paradoks egzemplarni primjer." ${ }^{\text {"17 }}$

Različita priroda/ tehnika zapisivanja koju Nádas suprotstavlja u svome romanu Divna povijest fotografije nalaže različite uvjete strukturiranja umjetničke fotografije odnosno teksta. Ipak, temeljni problem odnosa fotografije i teksta svodi se na izbor ovih ili onih elemenata/prizora svijeta oko sebe, kao i na njihovu konačnu percepciju i interpretaciju. Stoga je književni tekst, a posebice postmodernistički o kojemu je ovdje riječ, prisiljen birati arbitrarnu interpretaciju, za razliku od fotografije - dokumenta - koja prema uvriježenom mišljenju vješto izmiče pred njom. Isto tako, valja naglasiti možda očito, ali ipak, da se utvrđena ograničenja sukcesivnog narativnog teksta u odnosu na Nádasev postmodernistički roman kompenziraju fotografijom koja podrazumijeva vlastitu simultanost prizora.

Vrlo sličan model pronalaska identiteta, uvođenja humora, odnosa među likovima i društvena stanja uvodi i češki pisac Milan Kundera. Iako je riječ o autoru koji je književno mnogo ranije djelovao, može se uočiti njegovo nasljedstvo prema određenim sadržajnim pa i kompozicijskim zakonitostima. Zbirka priča Smiješne ljubavi (1963.) izazvale su radikalan otpor od općeprihvaćenih i očekivanih normi društvene publike i zbog toga su se razlikovale od dotadašnjih tekstova. Kundera svoje Smiješne ljubavi određuje kao roman slobodne forme, ${ }^{18}$ iako je riječ o pričama, što se može primijeniti i na Nádasevu roman u kojemu također egzistiraju priče koje su odvojive, ali i povezane u cjelinu. Struktura romana Smiješne ljubavi sastoji se od sedam priča koje svojim jedinstvenim naslovom ukazuju na množinu raznolikih pojedinačnih iskustava i ljubavnih izraza temeljenih na motivu nesporazuma - paradoksa. Nesporazum nastaje zato što je ljudsko doživljavanje i promatranje istih situacija i zbivanja uvijek različito subjektivno. Suprotstavljanje dva različita svijeta izazvano nesporazumom, bilo na intelektualnoj, dobnoj, estetskoj, religioznoj, tjelesnoj ili emotivnoj razini, u

16 Milivoj Solar. Retorika postmoderne: ogledi i predavanja, Matica hrvatska, Zagreb, 2005. str. 11.-12.

17 Isto, str. 15.

18 Milan Kundera. Osamdeset devet riječi, Republika, 1987., br. 5-6, str. 502. 
pričama aludira i na različite vrste i naravi ljubavi. Opozicije koje pri tomu nastaju istina-laž (Nitko se neće smijati), mašta-stvarnost (Zlatna jabuka vječne čežnja), intimno-javno (Lažni autostop, Simpozij), prošlost-sadašnjost-budućnost (Neka stari ustupe mjesto mladim mrtvima), lijepo-ružno (Doktor Havel poslije deset godina), vjera-sumnja (Eduard $i$ Bog) najjasnije dolaze do izražaja upravo u erotskim/ ljubavnim aluzijama. Polazeći od iskonskog nagona za seksom (spolnosti) iz kojeg proizlaze navedene opozicije suvremenog društva, uloga zajedničkog odnosa u službi je razotkrivanja identiteta. „Kundera spolnost uzima kao jednakoodređujuću za ukupnost, jednako vrijednu za njegove likove kojima je često i energijski izvor, ponegdje prenaglašen, uvijek individualno modeliran, uvijek sudbinski vezan za pojedinu osobu, kratkorečeno evidentiran i priznat."19 Slično se događa i u Divnoj povijesti, priča je zasnovana na temeljnim motivima koji se provlače cijelim tekstom, motiv seksualnosti je također prisutan kao i jedan oblik suprotnosti i opozicije. Nadalje, smijeh kao dominantan motiv u Smiješnim ljubavima pojavljuje se i u Nádasevu romanu Divna povijest fotografije; riječ je o prikrivenom humoru, intelektualno obilježenom, koji se krije ispod površine priče. Taj oblik humora i smijeha može se tumačiti i u Kundere i u Nádasa kao lijek pomoću kojega se svakodnevica može liječiti. Njihov smijeh okrenut je akterima priče i kao takav ukazuje na nesavršenstvo individualne ljudske osobnosti koja se mijenja u svakom pojedincu. Čak i sam roman Divna povijest fotografije završava rečenicom Finita la commedia ${ }^{20}$, što može značiti da je sve prethodno napisano/ oslikano komično i samim time upitno.

Kada je riječ o postmodernističkim piscima, boljka narativnog teksta $u$ vidu simultanosti jezika i više je nego očita. Kao prototip tomu za primjer valja navesti Borgesov Aleph (1949.) koji će ujedno poslužiti i kao uvodna smjernica Nádasevoj ,retorici postmoderne“ u romanu Divna povijest fotografije:

Sklopio sam oči, otvorio sam ih. Tada sam ugledao Aleph.

Evo me sada u neizrecivu središtu svoje pripovijesti; ovdje počinje moj spisateljski očaj. (...) Kako da drugima prenesem beskonačni Aleph što ga moje bojažljivo sjećanje tek ovlaš zahvaća? (...) Osim svega ostaje nerješivo središnje pitanje: nabrajanje, makar i djelomično, beskonačnog skupa. U tom divovskom trenutku vidio sam milijune ugodnih i grozomornih čina: ni jedan me nije osupnuo više od činjenice da su svi okupljeni u istoj točki, da se ne preklapaju i ne stapaju. Ono što su mi oči ugledale bilo je istovremeno; ono što budem zapisao bit će susljedno, jer je takva narav jezika. ${ }^{21}$

\footnotetext{
19 Albert Goldstein. „Milan Kundera - Mudrost neizvjesnosti“, u Čuvari književnog nasljeđa 1, uredila Tea Benčić, Zagreb, 1999., str. 328

20 Péter Nádas. Divna povijest fotografije, Fraktura, Zagreb, 2005., str. 139.

21 Jorge Luis Borges. Aleph, preveo Milivoj Telećanin, Globus media: biblioteka Jutarnjeg lista XX. stoljeće, knj. 10, Zagreb, 2004., str. 118.
} 
Pozivajući se na književnog teoretičara Claudea Lévi-Straussa u Divljoj misli Milivoj Solar u svojoj knjizi Retorika postmoderne ističe kako „umanjeni model sam sobom izaziva estetski dojam jer omogućuje takav uvid u kojem cjelina prethodi dijelovima, pa se struktura razabire neometana slučajnostima onoga što je određenu predmetu zapravo nevažno." ${ }^{22}$ Uzimajući u obzir spornim ovdje iznositi sadržaj Alepha, u ovu svrhu ipak valja naglasiti kritiku pripovjedača: Daneri koji pokušava napisati spjev - visoko pozicioniran tradicionalni književni žanr - prisiljen je u opisu ići i do najsitnijih detalja koji vode do skladne cjeline. Takva cjelina zahtjeva zajednički temelj odnosno polazište sporazumijevanja, a pripovjedačeva je poruka upravo suprotna tomu:

Svaki jezik tvori spisak simbola; da bi se njima baratalo, sugovornici moraju imati zajedničku prošlost. ${ }^{23}$

Težnja za sveobuhvatom svijeta oko sebe, koja je u suprotnosti s težnjom za ograničavanjem svijeta oko sebe prikazanog u fragmentima brojnih podnaslova romana/ albuma, vodi paradoksu koji načelno može biti riješen jedino tako ako se u prostoru i vremenu uokviri promjer Alepha (koji bi) mogao iznositi dva-tri centimetra ${ }^{24}$ ili vremenski aparat ${ }^{25}$ kako slovi drugi u nizu podnaslova romana Divna povijest fotografije. Beskonačno vrijeme i beskonačni prostor sažeti su u objektivu fotografskog aparata i zaustavljeni fotografijom kao sredstvom svog izražavanja/ označavanja:

UHVAĆENI TRENUTAK

Nepomični krovovi, gluh sumrak, nijeme mačje oči. Malen škljocaj. Zatvori se iris fotografskog aparata. Mačka produži dalje. ${ }^{26}$

Ovako interpretiran paradoks omogućuje Nádasevom romanu/ albumu u svakoj fotografiji iščitavanje/ gledanje zapisa u kojemu se zrcali načelo cjeline. Međutim, konačna su rješenja uvijek varljiva i višeznačna pa valja ponovno imati u vidu i istaknuti sam kraj romana: Finita la commedia. ${ }^{27}$

Jezik odnosno fotografija tijekom Nádaseva romana, ne opisuje nikakvu zbilju niti objavljuje istinu, nego se kreće u navedenom paradoksu koji polazi od pretpostavke da je u sažetom svijetu fikcije sve moguće. Odnosi među likovima i događaji koji ih prate ukazuju na relativnost zbilje i fikcije, bilo da je riječ o fotografkinji Korneliji koja za vrijeme vožnje doživi šok i

22 Milivoj Solar. Retorika postmoderne, Matica hrvatska, Zagreb, 2005., str. 165.; navedeno iz Claude Lévi-Strauss, Divlja misao, prevela Jagoda Milinković, Golden marketing/ Kastmueller, Zagreb, 2001.

23 Jorge Luis Borges. Aleph, preveo Milivoj Telećanin, Globus media: biblioteka Jutarnjeg lista XX. stoljeće, knj. 10, Zagreb, 2004., str. 118.

24 Isto.

25 Péter Nádas. Divna povijest fotografije, Fraktura, Zagreb, 2005., str. 8.

26 Isto.

27 Isto, str. 139. 
završi u sanatoriju ili o njezinim intimnim odnosima s ljubavnikom, zaručnikom, liječnikom ili kuharom. Između ostalog u ovim se međuljudskim strastvenim odnosima, ovaj put Kornelije i Carla, daje naznačiti i moguće rješenje paradoksa:

Moja misao nije ništa doli: vidim jedno lice koje je u svim crtama identično licu muškarca kojeg volim, a ne mogu ga vidjeti. Osim toga, vaš glas. Mogu li čuti onoga koga ne mogu vidjeti? Ili imati povjerenja u to što vidim iako njegovo ponašanje ne daje povoda za takvu vrst sigurnosti. Što da radim?

(...)

Umirit ću vas. I vas sam zamislio. Nije vas bilo, nema vas, a kako će vas biti, ne znam reći. (...)

(...)

(...) Što imate od jedne slike? Ništa. Svijet objašnjavate kroz djelovanje jednog stvoritelja, ali priznajte da za stvoritelja ne nalazite objašnjenje. (...)

Ali, ja vam upravo o tome pričam, nesretniče jedan. Slika prethodi tumačenju. Ne daje ono što ne želite. Riječ dolazi tek poslije i zbog toga imate želje. ${ }^{28}$

Stoga trivijalna ljubavna priča, naravno prisutna i u Borgesovom Alephu, u Nádasevom romanu, istaknutim temeljnim postupkom paradoksa, više nije samo trivijalna, jer bilo koja njezina završna interpretacija može „uokviriti““ slučajnosti u prepoznatljive dijelove cjeline, bilo da se zaručnik Carl van der Woelde ubija u očaju svoje muškosti, a da se Kornelija povedena svjetlosti nebeskog svoda na tragu sanatorija izgubi u planinama i smrzne kao santa leda.

Ipak povezivanje se ovih fotografija/ fragmenata tekstova može opravdati tek navedenim trivijalnim očekivanjem unaprijed poznatog raspleta pa odgonetanje smisla cjeline valja tražiti, ovaj put ne u umjetnosti, povijesti, znanosti ili filozofiji, nego upravo u Nádasevom doprinosu retorici postmoderne. Ti su fragmenti tekstova povezani jednom okvirnom pričom - ljubavnom vezom Kornelije i Carla - ne tako novim književnim postupkom, kao što to nije ni isprekidana struktura fabule, a umjesto otkrivenja u Borgesovom Alephu Nádaseva Divna povijest fotografije odjekuje ironičnim tonom jer se u njoj ne očekuje pogled iz svih točaka univerzuma nego zamisao okvira fotografije cjelokupnog albuma: već spomenute Finita la comedia. ${ }^{29}$ Kornelijin fotografski aparat proizvodi niz fotografija koje nisu međusobno povezane unutarnjom logikom razvoja događaja jer ih se ni ne može ujediniti zajedničkim nazivnikom očekivanim možda i u naslovu romana. Divna povijest fotografije

28 Isto, str. 89.-90.

29 Isto, str. 139. 
naslov je koji govori o kronološkom slijedu razvoja događaja kroz povijest, koji prije svega, mogu biti baš kao što je to i sām jezik isključivo susljedni. Fotografije su samostalni, simultani izvori informacija, dokumenti, koje kao takve ne čine nikakvu strukturu. Nizovi tih fotografija slični su podnaslovima koje iznutra ništa ne povezuje osim iznovljenog tumačenja fotografije koji podrazumijeva razaranje postojećih konvencija pripovijedanja odnosno opreku lake i teške književnosti. Analogija koja se pri tome javlja u odnosu na roman Itala Calvina Ako jedne zimske noći neki putnik (1979.) govori o tekstovima/ fotografijama koji se neprestano prekidaju, a njihova se veza uspostavlja tek uokvirenom pričom Čitatelja i Čitateljice koji naposljetku u bračnom krevetu čitaju upravo pročitan roman. U Nádasevoj Divnoj povijesti fotografije takvu ulogu imaju ovdje imenovani likovi Kornelija i Carl:

Gotovo u istom trenutku spuštaju šalice, Kornelija se vraća svojim slikama, Carl van der Woelde papirima. Kornelija polako skuplja slike, Carl van der Woelde papire. ${ }^{30}$

Komedija ili tragedija - laka ili teška književnost prema istoimenoj knjizi Milivoja Solara - podrazumijevaju ironiju koja je prepuštena isključivo čitatelju u nadi za prolaznom krizom institucije književnosti u kojoj se mašta onoga koji piše i napor onoga koji čita smatraju suprotnostima.

I pored ovog zaključka Nádasev doprinos nije do kraja razjašnjen, ako se ne uzme u obzir uvodno razmatranje odnosa fotografije i teksta kao i konačnog paradoksa u odnosu na ironiju.

Poput Prousta, jer se roman nakon pada realizma okrenuo ironiji, Nádaseva zamisao o životu koji se ne može vratiti u sjećanje ,vremenskim aparatom" osim ako glavni likovi ne dožive svoj krah, a tada se ni ne mogu ničega sjećati, ovdje nije apsurdna, nego paradoksalna. Uloga jezika odnosno fotografije koja ga vješto zamjenjuje na tragu je novoga doprinosa jer se njime odnosno njome ukazuje na vlastitu referencijalnost.

Teoretizirajući o fotografiji unutar područja semiotike u svojoj kulturnoj studiji Svijetla komora: bilješka o fotografiji (1980.), kao semiotičar, pisac i književni teoretičar, Roland Barthes izvodi zaključke o fotografiji i njezinom položaju unutar suvremene kulture. Njegova jezična igra paradoksom/ oksimoronom (mračna komora) ${ }^{31}$ već u samome naslovu uspostavlja vezu između

$30 \quad$ Isto, str. 134.

31 Mračna komora osnova je za sve današnje kamere (foto aparate, kino, video, ili digaitalne kamere) štoviše, ona postoji u svim suvremenim kamerama, a predstavlja prostor između objektiva (otvora sa sustavom leća, kojim je zamijenjena rupica) i fotoosjetljive plohe na koju se snima. Plohe tog prostora suvremenih kamera ne smiju održavati svjetlosne zrake. 
teksta i fotografije. Nekoliko je obilježja prisutno u samom odnosu među kojima Barthes prednost daje fotografiji, bilo da je riječ o njezinoj simultanosti - ,ona smjesta pruža pojedinost odnosno „ovjeri onoga što se njome predstavlja“33 ili pak disperziji - koja omogućuje da se ,predmet (se) pruža u cijelosti. Ono što Barthesu predstavlja svjetlosnu zraku ravno je smrti odnosno prema književnom kritičaru Jošku Tomasoviću ,ako je svaki fotografski portret minijaturno iskustvo smrti (prelazak iz subjekta u objekt, središnji noem fotografije prema Barthesu jest upravo to je bilo), ako je fotografija poput primitivnoga teatra, snažno vezana uz kult mrtvih, Svijetla komora može se smatrati, kako to tvrdi glavni urednik Eric Marty u uvodu sabranih djela, ekstremno poetiziranim činom, silaskom Orfeja u carstvo sjena ili fikcija kojoj je theoria oslonac iskustva uskrsnuća."34 Takvomu razmatranju zasigurno prethodi i esej naslovljen Smrt autora (1968.) u kojemu je Barthes istaknuo značenje i ulogu čitatelja: ,rođenje čitatelja mora se dogoditi uz cijenu smrti Autora. “35

Ispreplitanjem intertekstualnih i intermedijalnih paradoksa Nádas uvodi inovativan postmodernistički književni postupak kojim se mađarska nacionalna književnost može smatrati bogatijom u odnosu na svjetsku. Barthesova opaska u intervjuu u povodu knjige iskreno je priznanje vlastite nemoći pred neprikazivom stvarnošću fotografije, baš kao što je i Nádaseva Divna povijest fotografije samo povijest. U trenutku kada čitatelj napusti horizont očekivanja „,velikih priča“, kada gledatelj napusti horizont očekivanja studije o fotografiji, nastaje nova retorika.

Treba li još samo dodati: „I onda, jedne večeri mjeseca studenog, malo nakon smrti moje majke, sređivao sam fotografije. Nisam se nadao da ću je 'naći', ništa nisam očekivao od 'tih fotografija jednog bića pred kojima ga se slabije sjećamo nego ako se zadovoljimo time da mislimo na nj (Proust, III, 886). ${ }^{\prime 636}$

32 Roland Barthes. Svijetla komora: bilješka o fotografiji, prijevod Željka Čorak, Izdanja Antibarbarus, Zagreb, 2003., str. 37.

33 Isto, str. 108.

34 http://www.matica.hr/Vijenac/vijenac441.nsf/AllWebDocs/Fotografija_kao_roman_svijeta

35 Roland Barthes. „Smrt autora“, u: Miroslav Beker (prir.), Suvremene književne teorije, Matica hrvatska, Zagreb, 1999., str. 201.

36 Roland Barthes, Svijetla komora: bilješka o fotografiji, prijevod Željka Čorak, Izdanja Antibarbarus, Zagreb, 2003., str. 81. 


\section{Literatura}

- Balassa, Peter. Nádas Péter, Pozsony, Kalligram, 1997.

- Barthes, Roland. „Smrt autora“, u: Miroslav Beker (prir.), Suvremene književne teorije, Matica hrvatska, Zagreb, 1999.

- Barthes, Roland. Svijetla komora: bilješka o fotografiji, Izdanja Antibarbarus, Zagreb, 2003.

- Barthes, Roland. Fragmenti ljubavnog diskursa, Pelago, Zagreb, 2007.

- Borges, Jorge Luis. Aleph, preveo Milivoj Telećanin, Globus media: biblioteka Jutarnjeg lista XX. stoljeće, knj. 10, Zagreb, 2004.

- Calvino, Italo. Ako jedne zimske noći neki putnik, Globus media, Zagreb, 2004.

- Goldstein, Albert. „Milan Kundera - Mudrost neizvjesnosti“, u: Čuvari književnog nasljeđa 1, uredila Tea Benčić, Zagreb, 1999.

- Kulcsár, Szabó Ernő. A magyar irodalom története 1945-1991, Argumentum, Budapest, 1993.

- Kundera, Milan. „Osamdeset devet riječi“, Republika, br. 5-6, 1987.

- Nádas, Péter. Divna povijest fotografije, prevela Kristina Peternai, Fraktura, Zagreb, 2005.

- Solar, Milivoj. Retorika postmoderne: ogledi i predavanja, Matica hrvatska, Zagreb, 2005.

- Solar, Milivoj. Laka i teška književnost, Matica hrvatska, Zagreb, 2005.

- Tomaševskij, Boris Viktorovič. Teorija književnosti: tematika, Matica hrvatska, Zagreb, 1998.

- 14.http://www.matica.hr/Vijenac/vijenac441.nsf/AllWebDocs/Fotografija_ kao_roman_svijeta 


\section{Marko EK \& Tina VARGA-OSWALD}

\section{NÁDAS'S CONTRIBUTION TO POSTMODERN RHETORICS IN THE NOVEL A LOVELY TALE OF PHOTOGRAPHY}

Through his literary work, the contemporary Hungarian writer Péter Nádas (1942) belongs to "new prose" generation, which uses poetics of language to part from former literary conventions of traditional writing. The novel entitled A Lovely Tale of Photography (1995) simultaneously creates space for two arts, literature and photography, managing to respond to contemporary postmodern issues, as well as to establish an innovative process in the Hungarian literature. Like Proust, because after the fall of realism the novel has turned to irony, Nádas's idea of life which cannot be restored in memory through a "time machine" unless the main characters experience a collapse, which is when they anyway cannot remember anything, is not absurd but paradoxical. It is at the moment when the reader leaves the horizon of expectations of a "great story", when the viewer leaves the horizon of expectations of studies of photography, that a new rhetoric is created.

Key words: Péter Nádas, Hungarian literature, Post-Modernism, photography, Roland Barthes, Italo Calvino, Milan Kundera, Jorge Luis Borges 

GRAĐA 

UDK 003.349.2:929 Dombaj P.

Izvorni naučni rad

\title{
Zlata ŠUNDALIĆ (Osijek)
}

Filozofski fakultet Sveučilišta J. J. Strossmayera u Osijeku

zsundalic@ffos.hr

\author{
Anela MATELJAK POPIĆ (Zagreb) \\ Hrvatski studiji Sveučilišta u Zagrebu \\ amateljak@hrstud.hr
}

\section{VJERSKA KNJIGA U SLAVONIJI 18. STOLJEĆA}

Tekstovi nastali od početka 18. stoljeća pa do 1855 . godine kada umire Ignjat Alojzije Brlić i kada prestaje izlaziti njegov Novouređeni ilirski kalendar iliti Svetodanik, čine korpus takozvane slavonske književnosti koja je, prostorno gledajući, nastajala na području koje je obuhvaćala Provincija sv. Ivana Kapistrana. Autori su bili, uglavnom, crkveni ljudi (isusovci, franjevci), rjeđe svjetovnjaci. Genološku sliku slavonske književnosti 18. stoljeća čine djela, uglavnom, prosvjetiteljskih orijentacija (M. A. Relković, Satir iliti divji čovik, 1762; Đ. Rapić, Satir obraćen, 1765; V. Došen, Jeka planine, 1767; A. T. Blagojević, Pjesnik-putnik, 1771; J. S. Relković, Kućnik, 1769; itd.), baroknih i rokokoovskih (A. Kanižlić, Sveta Rožalija, 1780; A. Ivanošić, Opivanje sličnorično groba Josipa Antuna Ćolnića od Ćolke, 1786), odnosno klasicističkih orijentacija (M. P. Katančić, Fructus auctumnales, 1791), čemu treba pridružiti i stihovane ratne kronike, ali i vjersku knjigu, čiji vrsni sastav N. Andrić metaforički određuje kao istine katoličanske (katekizmi), putove nebeske (molitvenici), zrcala istine (različita genera moralno-poučne proze), živote Božjih ugodnika (hagiografski spisi), a treba im pribrojati i: abecevice, pučku crkvenu pjesmu, lekcionare, prijevode pojedinih dijelova Svetoga pisma, prijevod $B i$ blije, prijevode iz crkvenih otaca, pučke knjige o raskolu između Istočne i Zapadne crkve, crkvenu dramu. Književnost u Slavoniji 18. stoljeća karakterizira stilski pluralizam, ali i isprelitanje vjerskog, poučnog i prigodnog zbog čega se u radu samo naznačuje njezina genološka slika, jer prije određenijih odgovora treba obaviti stanovite bio-bibliografske predradnje, što je na kraju 
teksta potvrđeno i konkretnim primjerom rukopisne propovijedi Petra Dombaja a Valcovarino iz 1754. godine.

Ključne riječi: slavonska dopreporodna književnost, stilski pluralizam, vjerska knjiga, genološka slika, Dombaj

Prije osnivanja Jugoslavenske akademije (danas Hrvatske) sredinom 19. stoljeća (1866.) i njezinih edicija: Rad (1867.), Starine (1869.) i Stari pisci hrvatski (1869.) bavljenje starom hrvatskom, pa tako i starom slavonskom književnošću sporadično je i nesistematično što potvrđuju i rijetki radovi vezani uz ovo područje (npr. oni Josipa Jakošića ${ }^{1}$ ). Pri tome se kako u onim ranijim tako i u onim kasnijim radovima o hrvatskoj, odnosno o slavonskoj književnosti nezaobilazno govori o sljedećim činjenicama:

- posebnost hrvatske književnosti čini njezina „trojezičnost i tropismenost" (Hercigonja, 1994), zatim podjela na staru i novu književnost (dopreporodnu i postpreporodnu), kao i njezin regionalizam određen geografskim i povijesnim razlozima te stupanje Slavonije na književnu scenu tek u 18. stoljeću (Brešić, 2004: 9);

- u 18. stoljeću dolazi do pomicanja središta književnog života prema sjeveru zbog čega će se od 19. stoljeća hrvatska književnost u Dalmaciji ponašati kao periferija;

- u kontekstu nacionalne književnosti stara je slavonska književnost ${ }^{2}$ književnost atipičnoga razvoja, jer joj nedostaje medievalna, humanistička i renesansna dionica ${ }^{3}$;

\footnotetext{
Jakošićev je latinski rukopis objavio 1899. godine Milivoj Šrepel u Građi za povijest književnosti hrvatske, JAZU, knj. II, str. 116-153, a pod nazivom Jakošićev spis: Scriptores interamniae. Tekst Scriptores interamniae vel Pannoniae Saviae nunc Slavoniae dictae anno 1795 conscripti (cum continuatione anni 1830) - Pisci međurječja ili Savske Panonije sad zvane Slavonija, popisani 1795. godine (s nastavkom do 1830. godine) na hrvatski je preveo 1988. godine Stjepan Sršan u Reviji, 1, godište 28, str. 63-87.

2 Pojam slavonska književnost podrazumijeva sljedeće: „U književnoj historiografiji naziv slavonska književnost stekao je relativno ustaljeno značenje: knjige i rukopisi nastali od početka 18. stoljeća do 1855. godine, na području znatno širem nego što ga pokriva današnji pojam Slavonije (Interamnij - Međurječje: s istoka omeđeno Dunavom, sa zapada Ilovom, sa sjevera Dravom, s juga Savom). Stoga bi možda najuputnije bilo reći da je slavonska knjiga stvarana na prostoru koji je nekoć obuhvaćala Provincija sv. Ivana Kapistrana, odijeljena 1757. od Provincije Bosne Srebrene. Simbolično, otpočinje ona katekizmom Put nebeski đakovačkog župnika Ivana Grličića, tiskanim 1707. u Veneciji, a završava smrću Ignjata Alojzija Brlića 1855., kad prestaje izlaziti njegov Novouređeni ilirski kalendar iliti Svetodanik, čiji je prvi primjerak za 1836. otisnut u Budimu.“" (Tatarin, 2009: 495)

3 „Kad je u Dalmaciji pod utjecajem renesanse počela cvjetati hrvatska umjetna poezija,
} 
- atipičan je razvoj posljedica teškog društvenopolitičkog, gospodarskog i općeg kulturnog stanja u dopreporodnoj Slavoniji u kojoj se još uvijek sanjao barbarski san, a kroz magletinu se teško probijalo sunce ${ }^{4}$, kako je slikovito opisao stanje u Slavoniji Šime Ljubić, jedan od prvih šestnaest akademika ondašnje Akademije;

- odmah nakon oslobođenja od Turaka ne javljaju se književni tekstovi, jer nije bilo ni onih koji bi ih pisali, kao ni onih koji bi ih čitali ${ }^{5}$;

- autori su pretežno bili crkveni ljudi (franjevci, isusovci, svjetovni svećenici), a rjeđe svjetovnjaci;

- u književnosti je dominirala vjerska knjiga, didaktična ${ }^{6}$, utilitarna $^{7}$ i nadasve prosvjetiteljska: „Vjerski karakter hrvatske književnosti u Slavoniji u prvim decenijima osamnaestoga vieka poslije izgona Turaka bio je naravna posljedica osobitih prilika u zemlji: obrazovanih domaćih svjetovnjaka gotovo nije ni bilo, a redovnički i svjetovni kler u prvom

Slavonija pade pod turski igo (1524). Poradi toga nije se renesansa ni taknula Slavonije, a ne dugo nije mogla onamo doći ni bliža struja, izazvana reformacijom, koja je u užoj Hrvatskoj pokrenula književni život i rad oko narodne prosvjete, a susjednim je Slovencima udarila prve temelje književnosti na narodnom jeziku." (Drechsler, 1907: 3)

4 Stanje u Slavoniji nakon Karlovačkog mira (1699.) i odlaska Turaka Ljubić je slikovito opisao ovim riječima: „Ali se meni čini, da ova zemlja, makar ostala za to doba od turskoga kopita neoskvrnjena, nebi se ipak bila nipošto prenula s duševnoga mrtvila, ko što se pomakle nisu ni druge zemlje oko nje ležeće, a uživajuće bar njeku političku slobodu. Do osamnaestoga vieka cieli iztok a povećim dielom i siever jošte su mal da ne barbarski san boravili; a drugačije nije ni biti moglo, jer je na tih stranah još sasvim manjkalo onih sriedstava, koja su glavnom polugom i promicalom duševnog razvoja, naime, ne samo nije bilo mira i barem klicanja gospodarstva, nego ni javnih škola a kamo li učenih i književnih zavoda." (Ljubić, 1869: 481) Nastojanjem crkvenih ljudi i Marije Terezije situacija se počela mijenjati na bolje: „Tim načinom samo započela se je polovicom XVIII stolietja malo snebivati magletina, koja je do tada ovu zemlju držala pretisnutu, te sunce bolje budućnosti pomaljati.“(Ljubić, 1869: 482)

5 „Ni poslije oslobodjenja još dugo ne javlja se nova književnost, jer nije bilo za nju nikakove priprave ni temelja. Nije bilo ljudi sposobnih za književni rad, a pravo govoreći nije sada još bilo ni potrebe umjetne književnosti. Narod je u Slavoniji trebao još više decenija, da se sabere. Jedan savremenik rekao je za ovo doba, da Slavonac ne razlikuje dobro do zla, da ljude treba tjerati u crkvu, a za djecu graditi škole, da ne izrastu kao divlja životinja. Narod trebalo je dakle sada na slobodi podići od poludivljeg bojnika do pripitomljena čovjeka, kršćanina, a za ovo je dostajala sredovječna nabožna književnost.“ (Drechsler, 1907: 4)

6 „Po funkcijama koje je obavljala, tipu čitatelja kojemu je bila namijenjena, dominaciji stiha, no ne kao primarno literarnog medija u odnosu na prozu, ta je književnost ponajprije didaktična." (Tatarin, 2009: 495)

7 „Rad ovih pisaca lako se iscrpe s nekoliko riječi: tu se objašnjavaju istine katoličke vjere, pišu se nedjeljne propovijedi, pokazuje se vjernicima 'put nebeski', tumače se nedjeljna evandjelja, crta se život kojeg sveca. Knjige su nabožno-poučne, pisane stihovima ili prozom, ikavštinom, a štampane su uglavnom u Budimu i Pešti, jer u Osijeku još nema tiskare.“ (Drechsler, 1907: 5) 
je redu vrlo težko osjećao, što je narod za turske vlade jako bio zaostao, a vrlo često i zastranio u vjerskom životu.“ (Matić, 1945: 43)

- u njezinoj genološkoj slici prepoznatljiva su i starija genera (prenja i moraliteti), ali uz dominaciju naracije u stihu;

- stilski gledano u književnosti vlada pluralizam $^{8}$ u koji različiti autori ubrajaju različite sastavnice, od baroka, rokokoa, racionalizma, romantizma, sentimentalizma, latinizma do neoklasicizma i pseudoklasicizma. Hrvatsku književnost 18. stoljeća karakterizira bogatstvo tema i ideja što potvrđuju i ona djela koja nose epitet književnih umjetnina, ali i ona prigodničarskog i književnoznanstvenog karaktera (Bogišić, 1987: 157-158). Književnost ovog vremena, posebice ona nastala u Slavoniji, klasificira se najčešće tematski (dakle bez obzira na rod, vrstu ili žanr), a u novije vrijeme i žanrovski, i to posebice u odnosu na epiku ${ }^{9}$ (Fališevac, 1997a: 61-95). Tematsko razvrstavanje pri tome podrazumijeva: religioznokršćansku tematiku, tekstove s uputama za svakodnevni praktični život, prigodne tekstove, znanstveni rad različitih usmjerenja (Bogišić, 1987: 168-169), što nikako ne zadovoljava temeljito sagledavanje različitosti ove regionalne književnosti. S druge pak strane tipologija samo narativnih vrsta (bez lirike i dramskih tekstova) vrlo je razvedena, jer je književna praksa krajem 18. stoljeća (točnije na prijelazu iz 18. u 19. stoljeće, što podrazumijeva posljednjih dvadesetak godina 18. stoljeća i prvih dvadesetak godina 19. stoljeća $^{10}$ ) bila vrlo bogata upravo u Slavoniji. Njezinu žanrovsku strukturu čine epska djela u stihu (povijesno-ratnička epika /tj. ratna stihovana epika, junačke pohvalnice, politička epika, narativna djela u stihu sa suvremenom povijesnom tematikom/, stihovana kronika s religioznom tematikom, stihovane legende i životi svetaca, prosvjetiteljska satira, prigodnica, književne vrste s elementima komike), ali i izrazito svjetovni prozni žanrovi, po čemu ,(...) ova regija dobiva stanovitu prednost pred književnom kulturom dubrovačke regije“ (Fališevac, 1997a: 77), a što potvrđuju prijevodi pripovijetke-romana, pričica i anegdota, basni te političke biografije (Fališevac, 1997a: 73-82).

8 „Osamnaesto stoljeće u hrvatskoj književnosti prošlo je u znaku stilskog pluralizma. Interferirali su zakašnjeli stilovi, oni koji su već odavno ocvali u europskim književnostima, a neki od njih bili su već prošlost i za hrvatsku književnost.“ (Jelčić, 1997: 70)

9 Kada Dunja Fališevac piše o književnosti u Slavoniji na prijelazu iz 18. u 19. stoljeće, onda kaže da ona upravo u ovom vremenu "(...) zadobiva vrlo istaknuto mjesto u književnoj kulturi Hrvatske. Niz inovativnih poetoloških osobina, niz novih epskih vrsta i podvrsta, a osobito suvremene i moderne idejne i ideološke koncepcije mogu se, naime, uočiti upravo u ovom segmentu hrvatske epske književnosti." (Fališevac, 1997a: 62-63)

10 O epici upravo u ovom razdoblju u hrvatskoj književnosti piše vrlo iscrpno Dunja Fališevac (Fališevac, 1997a: 61-95; Fališevac, 2003: 79-105). 
U hrvatskoj se književnosti 18. stoljeća, pa tako i u slavonskoj pišu djela koja nose obilježja i književnog roda lirskog, i književnog roda epskog, i književnog roda dramskog.

Korpus slavonske osamnaestostoljetne epske produkcije potvrđuje uključenost $\mathrm{u}$ različite poetološke programe, svjetonazore i ideologije, a mogu se katalogizirati sljedeće njezine sastavnice:

I. epika u stihu (prema istraživanju Dunje Fališevac) ${ }^{11}$

1. didaktičko-prosvjetiteljski i satirični spjev sa suvremenom tematikom (M. A. Relković, Satir iliti divji čovik /1762./; V. Došen, Aždaja sedmoglava /1768./; A. T. Blagojević, Pjesnik putnik/1771./)

2. povijesni ep, epilij ili spjev sa suvremenom ratničkom tematikom (B. Bošnjak, Ispisanje rata turskoga pod Josipom cesarom II. /1792./; J. Pavišević, Kratkopis poglavitiji događaja sadašnje vojske među Marijom Terezijom kraljicom od Madžarske i Friderikom IV. kraljem od Brandiburske/1762./; A. Ivanošić, Pjesma od junačtva viteza Peharnika /s. a./, Pisma od uzetja Turske Gradiške iliti Berbira gada/s. a. /; Š. Štefanac, Pisma od Ivana Salkovića silnog viteza i junaka /1781./; J. Stojanović, Od slavne regimente gradiške složena u vrime rata turskog godine 1788.)

3. biblijski i/ili religiozni ep, epilij, spjev i poema (A. Kanižlić, Sveta Rožalija /1780./; A. Ivanošić, Svemogući neba i zemlje Stvoritelj; A. J. Knezović, Život sv. Ivana Nepomuka, Život sv. Genuveve, Život sv. Olive; A. Turković, Život sv. Eustahije; A. Ivanošić, Opivanje sličnorično groba Josipa Antuna Ćolnića od Ćolke /1786./)

4. šaljivo-komični ep, epilij, poema i pjesma (A. Ivanošić, Sličnorični natpis groba Zvekanovoga)

5. epske pjesme: poslanice, pohvalne prigodnice, panegirici o slavnim ratnicima i suvremnim ratnim ili drugim važnim društvenim događajima (neke pjesme iz Fructus auctumnales M. P. Katančića)

6. stihovana polemika i književna kritika (V. Došen, Jeka planine koja na pisme satira i tamburaša slavonskoga odjekuje i odgovara /1767./; A. T. Blagojević, Pjesnik putnik/1771./; Đ. Rapić, Satir obraćen /1776./).

11 Dunja Fališevac unutar hrvatske epske produkcije u stihu 18. stoljeća prema tematici razlikuje 19 zasebnih skupina, a u slavonskoj se ostvaruje njih šest (Fališevac, 2003: 82-83). 
II. prozna djela (prema istraživanju Dunje Fališevac) ${ }^{12}$

1. kronike, pučki kalendari, zbirke različitih štiva na hrvatskom jeziku (urednici pučkih kalendara: M. Lanosović, E. Pavić)

2. hagiografska proza, katekizmi, propovijedi (I. Grličić, Put nebeski /1707./; A. Kanižlić, Obilato duhovno mliko. /1754./, Mala i svakomu potribna bogoslovica /1766./; B. Leaković, Govorenja za sve nedilje godišnje na službu pripovidaoca, a na korist slišaoca /1795./ i brojni drugi autori)

3. basna (M. A. Relković prevodi Ezopove, Fedrove i Pilpajeve basne, ali su ostale u rukopisu)

4. prosvjetiteljska kraća proza (M. A. Relković)

5. biografija i autobiografija (A. Tomiković)

6. prijevodi fikcionalne proze (A. T. Blagojević, Kinki, nikoji kokinkinezijanski događaji /1768./)

7. latinska proza, memoari, govori, poslanice, pisma, rasprave, biografije, historiografija (svjetovna i crkvena), književna historiografija, poetika, estetika, filozofija (M. P. Katančić, De poesi illyrica libellus ad leges aestheticae exactus /1817./).

Slavonska epska djela 18. stoljeća ne postižu visoke estetske dosege, ali im ipak pripada značajno mjesto u povijesti nacionalne književnosti, jer je hrvatska ,(..) epika 18. stoljeća u poetološkom pogledu ostvarila onu puninu po kojoj se književnost 18 . stoljeća određuje kao pluralistička, kompleksna, a u idejnom pogledu - u jednom dijelu korpusa - inovatorska i moderna." (Fališevac, 2003: 86)

Isto se ne bi moglo tvrditi i za onodobnu lirsku književnu produkciju koja je i svojim stilom, i svojim izborom stiha kao i izborom dikcije još uvijek bila snažno vezana uz barokne ili srednjovjekovne poetološke modele (a dubrovačka latinska lirika uz programe akademskog klasicizma). U Slavoniji 18. stoljeća pisci su svoje neprosvijećeno i nepismeno čitateljstvo, tzv. „prosti sviet““ (Matić, 1945: 48), morali najprije zainteresirati za sadržaje koje su nudili u svojim knjigama. Prihvatljivim se pokazao katekizamski dijaloški model izlaganja i tumačenja građe, zatim su i ukomponirane pripovijesti činile vjersko štivo življim i prohodnijim, a građa prezentirana stihom i napjevima činila ju je privlačnijom i pamtljivijom: „Pjevanje je imalo od pamtivieka veliko značenje u vjerskom životu, pa je posve razumljivo, da je i u Slavoniji već

12 Dunja Fališevac u hrvatskoj književnosti 18. stoljeća navodi prema tematici osam zasebnih skupina proznih djela, a u slavonskoj je književnosti potvrđeno njih sedam (Fališevac, 2003: 84). 
od prvih početaka nastojanja oko vjerske prosvjete uz katekizme njegovana pučka crkvena pjesma: kršćanski je nauk bio namienjen razumnome shvaćanju, dok je pjesma govorila srdcu, a to je i u mladeži i u starijega svieta, osobito neobrazovanoga, lakši i sigurniji put do uspjeha." (Matić, 1945: 49) Potvrđuje to anonimno tiskana Knižica molitvena (Trnava 1724.), Mulihove Bogoljubne pisme (Trnava 1736.), a najljepšu je zbirku duhovnih pjesama u slavonskoj književnosti 18. stoljeća ostavio, kaže Tomo Matić, isusovac Antun Kanižlić.

Pri tome je pojam originalnosti shvaćen nešto slobodnije i na tragu razumijevanja funkcioniranja pučke književnosti, koja se na razini teksta razlikuje od pisane (visoke, elitne) umjetničke, jer se drugačije odnosi prema drugim književnim tekstovima ili, šire uzeto, prema tradiciji, ali i prema ulozi estetskih elemenata u tekstu. Prvi razlikovni element (odnos teksta prema drugim književnim tekstovima, odnosno prema tradiciji) govori o pučkoj književnosti kao o onoj kojoj nije do originalnosti i inovativnosti (sadržaja, stila, kompozicije, stiha, itd.), odnosno o visokoj literaturi kao o onoj koja teži individualnosti. O drugom razlikovnom elementu između pučke i pisane umjetničke književnosti (uloga estetskih elemenata u tekstu) Pavao Pavličić kaže: „U 'visokoj' literaturi estetski su elementi svrha, a u pučkoj sredstvo“. (Pavličić, 1991: 87) Umjetnička književnost, barem načelno, nema nikakve svrhe izvan sebe same; pučka književnost ne poznaje estetski doživljaj kao svrhu, jer je uvijek u pitanju neki praktičan cilj, neka korist. Djelo pučke književnosti ima za svrhu poučiti, informirati o svjetovnim ili religijskim stvarima, pri čemu, ali ne tako često, didaktičnost i utilitarnost mogu biti zasjenjeni i estetskom funkcijom teksta (npr. kod Kanižlića dotjeranim baroknim ornatusom, pojavom carminae figuratae, kod Mecića postupkom versus concordantes, kod Lipovčića akrostihom, itd.)

Da se djelo pučke književnosti prema drugim djelima odnosi kao prema nekom općem dobru (Pavličić, 1991: 87), potvrđuje, na primjer, Jaićeva crkvena pjesmarica Vinac boljubnih pisamah (1827.), taj "pučki književno-nabožni bestseler 19. stoljeća" (Zečević, 1988: 7) ${ }^{13}$ u koji su uključeni i Kanižlićevi i Mulihovi tekstovi (v. Šundalić, 1997: 417-455), dakle tekstovi pisaca koji su i sami prije Jaića u svoje molitvenike, pjesmarice i katekizme unosili i tekstove iz drugih knjiga, prerađujući ih pri tome ili ne: „Prema tome je Kanižlić - i ne uzimajući u obzir, da li je i koliko je pridonio novih pjesama - već samim prerađivanjem i konačnom redakcijom starijih pjesama snažno zahvatio u razvitak pučke crkvene pjesme u Slavoniji.“ (Matić, 1945: 50)

13 Jaićev Vinac bogoljubnih pisama doživio je od prvog izdanja iz 1827. do 1995. godine 25 izdanja (Hoško, 1996: 7). 
Kako je lirika vrlo ,rastezljiv pojam“ (Kravar, 1992: 198), katalog njezinih pojavnih oblika u slavonskoj književnosti 18. stoljeća ne može biti jednoznačan i konačan, ali se ipak može govoriti o sljedećim sastavnicama:

1. liturgijska lirika pisana u retoričko-poetičkome smislu u duhu stile acuto i sa statusom „potonuloga kulturnog dobra“14 (misli se na pjesme Antuna Kanižlića razasute po njegovim molitvenicima, od kojih neka budu spomenuti: Bogoljupstvo na poštenje s. Franceška Saverije /Trnava 1759./, Utočište Blaženoj Divici Mariji /Mneci 1759./, Primogući i srce nadvladajući uzroci /Zagreb 1760./, Mala i svakomu potribna bogoslovica /Trnava ${ }^{5} 1773$./ koja je žanrovski gledano istovremeno i katekizam, i molitvenik, i pjesmarica).

2. prosvjetiteljska i racionalistička lirika (započinje Relkovićevim Satirom /1762./, po kojemu je on ,prvi slavonski realist prije realizma“/Bogner, 1987: 114/, a zaključuje ju knjiga Relkovićeva sina Josipa Kućnik /1796./, kako piše Kravar /Kravar, 1992: 197/).

3. pjesme klasicističke struje (Franjo Sebastijanović, Poemata, sparsim antae edita, amicae memoriae caussa collecta recusaque /1805./, Matija Petar Katančić, Fructus auctumnales /1791./ u koje autor unosi antičku književnu topiku, klasične bogove, muze i nimfe, grčko-rimske lirske oblike, kvantitativnu metriku ${ }^{15}$ ).

Pri pokušaju katalogiziranja pojavnih oblika slavonske književnosti 18. stoljeća unutar književnog roda lirike u navedeni stilski pluralizam trebalo bi kao kriterije ukomponirati još najmanje dva čimbenika, tematiku (rat i druge pojavnosti svakodnevlja) i situacijsku deteminiranost pjesništva (prigodnost), što potvrđuje utemeljenim razmišljanje R. Bogišića koji kaže da „Kvaliteti pojedinih kategorija o kojima je ovdje bilo riječi (misli se na: religioznokršćansku tematiku, tekstove s uputama za svakodnevni praktični život, prigodne tekstove, znanstvene radove različitih usmjerenja, op. Z.Š.) međusobno se isprepliću i zadiru jedan u drugi. Tako se u književnoj praksi Slavonije 18. stoljeća kvaliteti religioznog, poučnog i prigodnog samo uvjetno mogu odvojiti i napose promatrati. U slavonskoj književnoj praksi 18. stoljeća ova tri aspekta

14 U hrvatsku je znanost o književnosti pojam „,potonuloga kulturnog dobra“ unio Zoran Kravar (v. Kravar, 1987) odredivši ga sljedećim riječima: „Pojam 'potonuloga kulturnog dobra' preuzimljem iz etnološke literature dvadesetih godina, a njime označujem slučajeve povezivanja baroka - kao književne mode izvorno afirmirane $u$ višim slojevima europske književnosti 17. stoljeća - s književnim djelima pretežno subliterarnoga nivoa i utilitarnoga karaktera." (Kravar, 1992: 196)

15 V. Fališevac, Dunja, 2007. Jesenski plodovi M. P. Katančića između klasicizma i predromantizma, u: Stari pisci hrvatski i njihove poetike. Drugo, prošireno izdanje, Hrvatska sveučilišna naklada, Zagreb, str. 289.-298. 
i odnosa redovito se dopunjuju i uvjetuju." (Bogišić, 1987: 169) Pri tome su vrijednosni sudovi rijetko superlativni, jer interpretacije književnih predložaka često zaključuju rečenice tipa „(...) stih mu je hrapav, a pripovijedanje suho i jednolično“ (Matić, 1945: 90) ili „(...) ostao je do kraja života prigodničar i ništa više" (Matić, 1945: 95).

Kako se za lirsku književnu produkciju 18. stoljeća nije moglo reći da je moderna tako se ni za onu dramsku ne bi moglo reći da je inovativna i moderna (idejno, politički, društveno). Ona je, uglavnom, neoriginalna i tradicionalna, a kao rijetke se vrijedne iznimke spominju tek dubrovačke frančezarije i kajkavska klasicističko-prosvjetiteljska građanska komedija (Fališevac, 2003: 85). U žanrovskom repertoaru hrvatske osamnaestostoljetne književnosti izdvajaju se:

- „frančezarije“, odnosno prijevodi/adaptacije francuskih djela, posebice Molièrea, jer se u stoljeću sveopćeg utjecaja Francuske na Europu osjeća njezin snažan utjecaj i u kulturnom životu Dubrovnika (bilo je poželjno govoriti francuski jezik, čitati francuske knjige i periodične publikacije, pratiti francusku modu, živjeti na francuski način). Dubrovačkim je miljenikom postao Molière (1622.-1673.), što potvrđuje i podatak da su od njegove 34 komedije u dubrovački prostor i vrijeme prenesene, "podubrovčene" (Bogišić, 1974: 352) čak $23^{16}$ (Deanović, 1972: 10; 1973), i to ponajbolja komediografova djela (Batušić, 1978:

16 Rafo Bogišić govori o 24 prevedene Molièreove komedije u Dubrovniku (Bogišić, 1974: 351), što je vjerojatno na tragu sljedećih Deanovićevih misli: „Sudeći po sačuvanim rukopisima, koji su svi mlađi prijepisi, taj se fenomen Molièreova teatra u Dubrovniku sastoji u tome da su u toku od nekoliko godina ili decenija prve polovice 18. vijeka od 34 Molièreova komada Dubrovčani preveli 23, dakle više od dvije trećine. Nijesu preveli one njegove komedije kojih sujeti nijesu odgovarali domaćim prilikama i kojih bi komičnost zato u nas promašila (npr. Les précieuses ridicules). Osim toga sačuvao se iz tog vremena još jedan prozni tekst komedije u mjesnom dijalektu Andro Stitikeca, koja je kontaminacija triju Molièreovih komedija. Imamo dakle danas ukupno 24 preradbe komedija toga autora gotovo iz istog doba." (Deanović, 1972: 10)

U odnosu na Andru Stitikecu zna se da nije riječ o samostalnu prijevodu određenoga predloška, nego da je riječ o kontaminaciji triju Molièreovih komedija: Škrca, Umišljena bolesnika i Ženidbe na silu. 
$161)^{17}$. Adaptacije $\mathrm{e}^{18}$ su ovih "frančezarija"19, uglavnom, vršene u prozi (s izuzetkom $P$ syche $)^{20}$, i to direktno s originala ${ }^{21}$.

- „talijanarije“, odnosno prijevodi nekih djela talijanskih autora, a pod utjecajem gostujućih družina iz Italije, kao što je na primjer Gleđevićev prijevod mletačke melodrame A. Zena I Rivali generosi (Belisario) ili Sorkočevićev prijevod Metastasijevih melodrama (Demetrio, Didone, Minteo).

- domaća autorska drama u Dubrovniku čiji su autori bili: Ferdinand Putica (Ciarlatano in motto), Marko Bruerević (Vjera iznenada), Vlaho Stulli/Stullić (Kate Kapuralica).

- školska drama u sjevernoj Hrvatskoj na latinskom i hrvatskom jeziku s, uglavnom, biblijskim temama, prijevodnog ili preradbenog karaktera (prevode se ili adaptiraju djela Charlesa de la Ruea, Molièrea, Goldonija, Kotzebuea, Ifflanda).

U Slavoniji 18. stoljeća dramska književna produkcija izgleda nešto drugačije, a određena je primarno svojom povezanošću s crkvom i njezinim nastojanjem oko vjerskog odgoja (Matić, 1945: 104). Stoga se u literaturi govori o sljedećim pojavnim oblicima:

17 „Najnovije analize Molièreova opusa u velike komedije ubrajaju Učene žene, Tartuffea i Mizantropa, pri čemu ovi naslovi visoku cijenu zaslužuju poštivanjem klasicističkih pravila: dakle, pisane su stihom i komponirane u 5 činova. Dopušteno je još u njih ubrojiti Školu za žene, premda ne slijedi pravila u cijelosti, te Dom Juana, iako pisanoga u prozi.“ (Pavlović, 2005: 65)

18 „U prvoj polovini 18. stoljeća u Dubrovniku su prevedene ili prerađene čak 23 Molièreove komedije, pri čemu su dramske radnje u najvećem broju adaptacija premještene u dubrovačku sredinu, a Molièreovi likovi pretvoreni u našijence raznih socijalnih statusa i tipično našijenskih mentaliteta.“ (Fališevac, 2001: 63-64)

19 Pojam frančezarije kod različitih autora podrazumijeva različite sadržaje, pa se tako pod tim pojmom podrazumijevaju preradbe Molièreovih komedija u Dubrovniku: „Te 'frančezarije', kako su ih Dubrovčani nazivali, s jedne strane su dokaz da je Dubrovnik i tada bio u izravnom kontaktu s Evropom, a s druge, i u njima je odražena dubrovačka svakidašnjica onoga vremena." (Fotez, 1967: 18)

Međutim, ovaj pojam može biti shvaćen i šire i kao takav podrazumijevati sklonost prema francuskoj kulturi: „Na tom tragu najuspjelija je odredba Hrvatske opće enciklopedije koja frančezarije tumači kao naziv kojim se u Dubrovniku potkraj XVII. i u prvoj polovini XVIII. st. obilježavali svi znakovi preuzimanja francuske kulture, među ostalim i skupina preradbi Molièreovih tekstova za dubrovačku pozornicu, pa se u potonjoj namjeni ustalio do danas.“ (Pavlović, 2005: 62)

20 „Dok je Molière stvarao svojim bogatim književnim jezikom (od ovih je komedija $10 \mathrm{u}$ stihovima, a 13 u prozi), dotle su naše preradbe, vidjeli smo, osim jedne, Psike, sve pisane dubrovačkim živim dijalektom i u prozi.“ (Deanović, 1972: 22)

21 Nada Beritić iznosi mišljenje „(...) da su se dubrovački prevodioci Molièrea doista poslužili francuskim izvornikom, a ne talijanskim prijevodom.“"(Beritić, 1965: 251) 
1. isusovačka crkvena drama i recitacije (prikazivana je Muka, tj. Tragedia hebdomadis sanctae /1734./, zatim požeški isusovci gimnazijalci odjeveni u anđele, angelici genii, na Brašančevo bi recitirali pjesme).

2. školska drama isusovačkih gimnazijalaca (izvodi se na latinskom, kazališne su predstave ponekad mogle biti i komedije i tragedije, i koje su kao novum bile dobro primljene kod gledateljstva. Latinskom se jeziku kasnije pridružio i hrvatski i njemački, a na sceni su se mogle gledati i preradbe francuskih dramatičara: Corneilla, Racinea, Molièrea, Voltairea.).

3. franjevačka školska drama (đaci franjevci su prikazali Tragoedia latina de S. Margarita de Cortona 1775. godine s umetnutim njemačkim i hrvatskim interludijima, zatim Ivan Velikanović izdaje na hrvatskom jeziku tri drame prema talijanskim predlošcima: Prikazanje raspuštene kćeri /1780./, Svetu Suzanu /1783./, Svetu Teresiju divicu /1803./, a Aleksandar Tomiković dramu Josip poznan od svoje braće /1791./, odnosno riječ je oslobodnom prijevodu Metastasijeva oratorija Guiseppe riconosciuto, zbog čega T. Matić zaključuje „(...) da uobće početcima hrvatske franjevačke duhovne drame u Slavoniji valja tražiti vrelo u talijanskoj književnosti“"Matić, 1945: 111/. Svemu treba pribrojati i Judit, victrix Holofernis, dramu koja se prikazivala oko 1770. godine $\mathrm{s}$ intermedijima sastavljenim u stilu komedije dell'arte /Columbina/ i njemačke lakrdije /Hanswurst/.)

4. predstave njemačkih putujućih kazališnih družina. ${ }^{22}$

5. Iako dramska književna produkcija u Slavoniji 18. stoljeća nije bila ni razvedena ni esteski dotjerana, ipak je pokazala stanovito uključivanje u književne tijekove onoga doba, što je bio pozitivan pomak.

\section{3.}

Pojam vjerska knjiga (T. Matić) odnosno vjerska književnost (K. Georgijević) u radovima različitih autora ima različite inačice, kao što su na primjer: crkvena literatura (J. Forko), religiozno-moralna književnost (B. Vodnik), vjerskopoučni rad (M. Kombol), vjersko i moralno poučavanje seljaka i građanina (S. Ježić), pobožna književnost (R. Bogišić), nabožno-poučna književnost (M. Kombol - S. P. Novak), vjerski pisci (A. Bilić), itd. O njoj se u

22 „Osim đačkih školskih prikazivanja inače vrlo malo znamo u to doba o kazalištnim predstavama u Slavoniji. Častnici vojničkih posada u slavonskim gradovima (u Osieku, Zemunu, a i drugdje) imali su uređene kazalištne dvorane, u kojima su se priređivale njemačke predstave, jamačno od diletanata, a možebiti su se već i tada zaletjele amo gdjekad također putničke glumačke družine.“ (Matić, 1945: 113) 
hrvatskoj znanosti o književnosti govori kao o subsistemu koji grade tekstovi različitih generičkih obilježja, a što pojednostavljeno izgleda ovako: „(...) i slavonska se religiozna literatura, slično kajkavskoj, dijeli na liturgijsku liriku, dulje pjesme djelomično ili u cjelini alegoričkoga karaktera i različita genera moralno-poučne proze.“ (Kravar, 1992: 199) Navedeni se književni subsistem može i detaljnije opisati te se može reći da ga u 18. stoljeću u Slavoniji čine pored već spomenute liturgijske lirike i duljih pjesama djelomično ili u cjelini alegoričkog karaktera i: molitvenici, katekizmi, životi svetaca i svetica, zbirke propovijedi, tumačenja evanđelja, lekcionari, pučka crkvena pjesma i pučke knjižice, prijevodi iz crkvenih otaca i prijevod Biblije, odnosno djela u kojima se jasno prezentira kršćanski svjetonazor, religiozna tematika i religiozno-moralna funkcija (Kravar, 1992). Njihovo uključivanje u povijest nacionalne književnosti tek predstoji, jer tek treba odraditi početne bio-bibliografijske dionice, a prije njih i prva čitanja u smislu sakupljanja građe. O ovom je zadatku hrvatske književne historiografije razmišljao još 1887. godine i Josip Forko zapisavši: „Naravno da bi tu trebalo ponajprije sakupiti sva tiskana djela te struke (propovijedi - op. Z.Š.), a rukopise tiskom izdati, (...). Tako bi se oteli zaboravnosti mnogi znameniti naši stariji radnici na polju crkvenog govorništva, (...).“ (Forko, 1887: 37) Da su i danas Forkove misli aktualne, svjedoče na primjer osamnaestotoljetne propovijedi koje i danas, nakon tristo i nešto više godina, čekaju svog strpljivog čitatelja i svoju prvu tiskanu inačicu. Da je riječ o nezanemarivoj baštini, rječitije od riječi govore sljedeće fotografije na kojima se nalazi samo dio nekatalogizirane rukopisne propovjedničke građe (v. Prilog 1.). 


\section{Prilog 1 .}

Rukopisne propovijedi u knjižnici Franjevačkog samostana Svetog križa u osječkoj Tvrđi
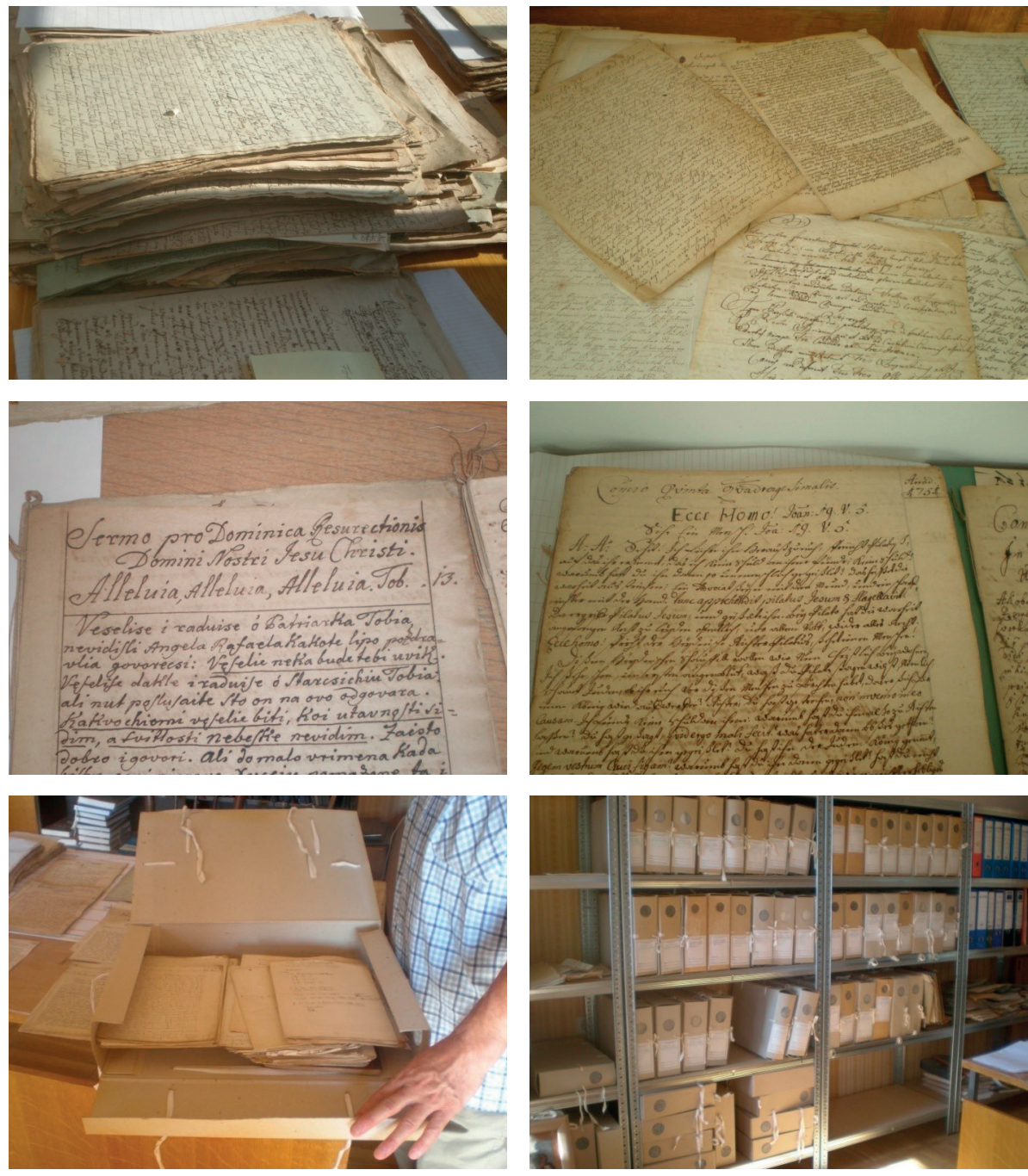
Da bi trebalo poraditi na sređivanju i objavljivanju starih tekstova podsjeća i F. E. Hoško: „Pisana ostavština hrvatskih franjevaca nije sva objavljena, a nemaju ni sva jednaku važnost.“

(http://www.ofm.hr/index.php/component/content/article/105-o-nama/iznase-povijesti/137-pregled-povijesti-hrvatske-franjevacke-provincije-svcirila-i-metoda-fra-emanuel-hosko; posjet: 7. 2. 2013.) Iako istraživanje vjerske knjige tek predstoji, ipak neki pomaci postoje pa se na temelju specijalistički usmjerenih radova i istraživanja mogu pribaviti i neki konkretni podatci. Tako su već danas dostupne informacije koje kažu da je na hrvatskom jeziku predilirskoga vremena napisano oko 120 molitvenika, među kojima su i oni Stjepana Adžića ${ }^{23}$ (Šundalić, 2003: 47), a da je tijekom 19. stoljeća tiskano i oko 50 novih naslova (Sertić,1943; Dugalić, 1989; Kolarić, 1996.). Isto tako postoje podatci i o tiskanim katekizmima koji često imaju ponovljena ili dopunjena izdanja i čiji broj prelazi preko stotinu naslova (Hoško, 1985). U novije se vrijeme posebna pozornost posvećuje iščitavanju i istraživanju propovjedničkoga žanra (Mihanović-Salopek, 2006).

Započeti se posao treba nastaviti i pri tome ne izgubiti iz vida činjenicu da pojavne oblike tzv. visoke/elitne književnosti prati i postojanje različitih oblika vjerske književnosti, da granica među njima nije strogo povučena, jer interakcija u oba smjera nije isključena ${ }^{24}$. Zbog ispreplitanja vjerskog, poučnog i prigodnog u slavonskoj osamaestostoljetnoj književnosti njezino je genološko katalogiziranje još uvijek otvoreno pitanje hrvatske znanosti o književnosti.

\section{4.}

Na kraju ovoga rada kao skroman prilog nastavku započeta posla „brisanja prašine" s baštinjene vjerske knjige koja se ne bi smjela prepustiti nepovratnom propadanju donosi se preslik jedne rukopisne propovijedi fra Petra „a Valcovarino“ iz 1754. godine s usporednom transkripcijom (v. Prilog 2.).

Na pitanje - tko je $P$. Petro á Valcovarino - odgovor nije jednostavan, jer ga povijesti stare hrvatske književnosti ne poznaju. Na temelju sačuvanih ruko-

23 Ovdje se posebice misli na njegovu Abekaviczu illyricsku (1779.) koja se žanrovski ne može jednoznačno odrediti kao abecevica, kako sugerira sam naslov djela, jer sadrži i molitvenički i katakizamski dio.

$24 \mathrm{O}$ interakciji kanonizirane literature i subliterature govori i A. Flaker kada se bavi pojmom funkcije književnog teksta: "Posebno mjesto pripada književnosti u funkciji zabavljanja (ludistička funkcija), kojom se redovito odlikuju djela što ih svrstavamo u trivijalnu književnost ili u subliteraturu, ali koja u književnopovijesnom procesu stoje u stanovitom suodnosu s književnim formacijama, pa su ruski formalisti (Šklovski) došli čak do zaključka da se novi oblici pojavljuju upravo kao rezultat interakcije tzv. kanoniziranih oblika i subliterature." (Flaker, 1976: 43) 
pisnih propovijedi u knjižnici Franjevačkog samostana Svetog križa u osječkoj Tvrđi može se uspoređivanjem rukopisa zaključiti da se P. Petro á Valcovarino potpisivao između ostaloga i kao P. Petro Dombay á Valcovarino, odnosno kao P. Petro á Valcovarino de Dombai. O Petru Dombaju iz Vukovara piše Josip Forko u svojim Crticama i pretpostavlja da se rodio početkom 18. stoljeća, a umro oko 1780. godine. Poznata mu je rukopisna Dombajeva Knjiga od različitih trava, prahova, pilula, melema, vina, balzama, drvja, različitih živina, stvari potajnih, bolesti različitih, svakojakih rana i voda, složena i skupljena iz različitih knjiga taljanskih $i$ u jezik ilirički obraćena i na svitlost dana za korist naših po o. P. Petru Dombaj iz Vukovara g. 1763. (Forko, 1887: 37) Forko donosi i podatak da se autor na kraju prvoga dijela knjige potpisao i kao Sabovljević, što nije podudarno s podtcima koji se mogu pronaći kod, na primjer, F. E. Hoška i R. Skenderovića. Tako na primjer u tekstu Pregled povijesti Hrvatske franjevačke provincije sv. Ćirila i Metoda Hoško donosi naprije povijesni pregled Hrvatske franjevačke provincije sv. Ćirila i Metoda, zatim opisuje područja djelatnosti hrvatskih franjevaca (pastoral, školstvo i odgoj, književna i znanstvena djelatnost), a u okviru karitativne djelatnosti spominje i franjevca Petra Dombaja-Saboljevića (a ne Sabovljevića, kako piše Forko) koji je bio i apotekar svećenik: „Pravilo franjevačkog Reda donosi ovu odredbu o bolesnicima: 'Ako tko od braće oboli, dužna su ga ostala braća dvoriti, kako bi željela da se njih dvori' (1). Ta je odredba, kao i običaj prvih franjevaca da rade u bolnicama, potakla braću da se bave medicinskom službom. I franjevci su se na području današnje Hrvatske provincije bavili medicinom i farmacijom. Jedni su bili bolničari, drugi ljekarnici, treći ranarnici ili kirurzi. Od 16. st. dalje medicinske službe bile su dopuštene samo samostanskoj braći, a ne i svećenicima. Ipak je bilo apotekara svećenika: Petar Dumbajj-Saboljević, Vuk Fraudendist, Ivan Gartner. Franjevci kirurzi i bolničari pružali su svoje usluge i građanima, premda su prvenstveno bili određeni za službu bolesnim redovnicima. (...) Samostanski su bolničari svoje znanje upotpunjavali, što nam svjedoče u samostanskim knjižnicama sačuvane medicinske knjige i medicinske upute za široke narodne slojeve. Petar Dombaj-Saboljević iz Vukovara, ostavio je u rukopisu djelo napisano 1763. 'Knjiga od različitih trava, praova, pilula, melema, vina, balzama, drvja, različitih živina, stvari potajnih, bolesti različitih i svakojakih rana i voda'. "'26

25 Ovdje je, vjerojatno, riječ o pogrješci, jer u nastavku teksta Hoško govori o Petru Dombaj-Saboljeviću.

26 Tekst Hoško, Emanule, Pregled povijesti Hrvatske franjevačke provincije sv. Ćirila i Meto$d a$ preuzet je sa stranice

http://www.ofm.hr/index.php/component/content/article/105-o-nama/iz-nasepovijesti/137-pregled-povijesti-hrvatske-franjevacke-provincije-sv-cirila-i-metodafra-emanuel-hosko (posjet: 6. 2. 2013.) 
U istom ga kontekstu i pod istim imenom spominje i R. Skenderović: „Franjevački i isusovački redovnici bili su u mnogim krajevima ne samo apotekari, nego često i jedini liječnici. Tako je, primjerice, u Vukovaru kao liječnik djelovao poznati franjevac Petar Dombaj Saboljević, koji je 1763. godine ostavio rukopis o narodnoj medicini. "“27

Godina rođenja Petra Dombaja može se odrediti prema podatku koji je zapisan u Nekrologiju Hrvatske franjevačke provincije sv. Ćirila i Metoda (Rijeka-Trsat, 1998, str. 163.) u kojemu stoji da je „o. Petar Sabovljević, duhovnik“ umro u Vukovaru 29. 5. 1781. godine u 60. godini života, što znači da je rođen 1721. godine. Navedenom se mogu dodati i podatci zapisani u Kronici Franjevačkog samostana u Brodu na Savi, I (1706-1787) (Slavonski Brod, 1995.) u kojoj se spominje Sabolević i Sabovljević Petar koji je 1744. godine bio student filozofije u Brodu (str. 103.) i za kojega se kaže da je na kapitularnoj skupštini fra Filipa Penića u Našicama (21. kolovoza 1757.) kao „velečasni otac Petar Sabovljević“ izabran za propovjednika u Brodu (str. 149.). ${ }^{28}$

U literaturi se, dakle, Dombaj spominje kao apotekar svećenik, a rjeđe i kao propovjednik, iako se samo u knjižnici Franjevačkog samostana Svetog križa u Osijeku nalazi nekoliko latinski naslovljenih rukopisnih propovijedi (npr. za godinu1754., 1756., 1758., 1760., 1761., 1762.) koje su bile izgovorene na hrvatskom jeziku u: Vukovaru, Cerniku, Osijeku.

Dombajeva propovijed koja se ovdje po prvi puta pojavljuje i u svojoj tiskanoj inačici ima također latinski naslov:

Pro festo visitationis Beatae Marie Virginis, | Facta et dicto Carloviczija a P. Petro de Alcantara, a | Valcovarino | Anno Dni $\mid$ 1754. | Die. 2. |.

Propovijed je izgovorena je 1754. godine u Srijemskim Karlovcima; broji 10 nepaginiranih stranica $\mathrm{s}$ ispisanih oko četrdeset redaka po stranici i uz napomenu da se na 5., 6. i 7. stranici pojavljuju kustode kao starinski način označivanja stranica. Na prvoj je stranici izvan redaka naslova dva puta napisano „Fala Bogu“ što bi se moglo razumjeti i kao komentar dobro obavljena posla, odnosno dobro, uspješno održane propovijedi povodom

27 Tekst Skenderović, Robert, Zdravstvene reforme Marije Terezije u Slavonskom provincijalu $i$ Generale Normativus Sanitatis iz 1770. preuzet je sa stranice

https://www.google.hr/\#hl=hr\&tbo=d\&output=search\&sclient=psy-ab\&q=Petar + Domba $\mathrm{j} \% 2 \mathrm{C}+18 .+$ stolje $\% \mathrm{C} 4 \% 87 \mathrm{e} \&$ oq=pet\&gs_l=hp.1.0.35i39j013.54783.55499.0.57903.3.3.0 .0.0.0.170.417.0j3.3.0...0.0...1c.1.2.hp.VgLavBffew4\&pbx=1\&bav=on.2,or.r_gc.r_pw.r_ qf.\&bvm=bv.41934586,d.Yms\&fp=fddbfe33ecc6cfdb\&biw=1049\&bih=584 (posjet: 7. 2. 2013.)

28 Za navedene podatke zahvaljujem se gospodinu Mati Batoroviću. 
pohođenja Blažene Djevice Marije njezine rođakinje Elizabete (blagdan se slavi 31. svibnja). ${ }^{29}$

U nastavku se rada donosi usporedno preslik izvornika i njegova transkribirana inačica, a intrpretacija same propovijedi ostaje kao zadaća za neki drugi rad. Dombajev je slovopis čitan na sljedeći način:

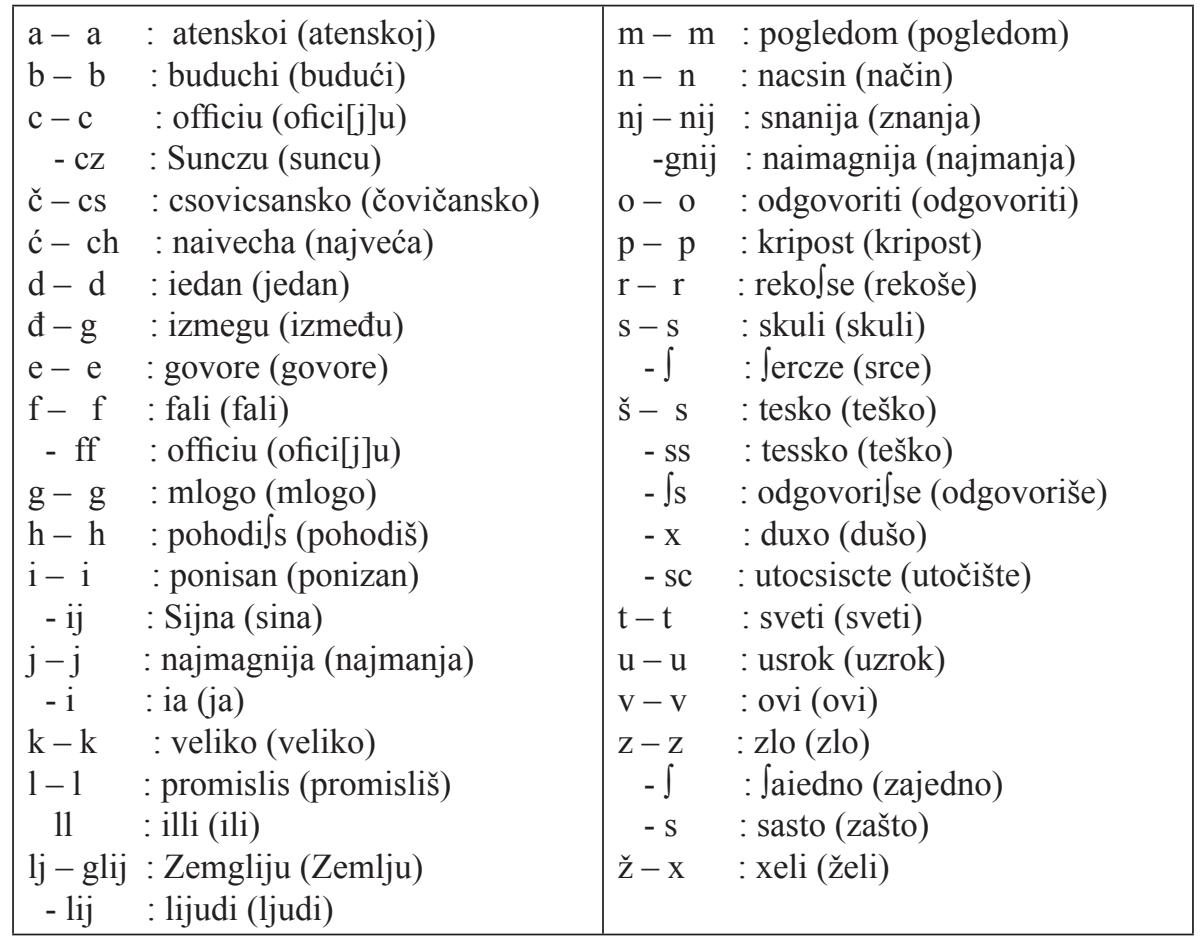

29 „Pohođenje Blažene Djevice Marije je katolički blagdan koji se obilježava 31. svibnja u spomen pohoda Djevice Marije svojoj rođakinji Elizabeti.

Prema Novom zavjetu Marija je dva mjeseca nakon bezgrešnog začeća pohodila svoju trudnu rođakinju Elizabetu, koju je Bog u dubokoj starosti blagoslovio potomkom. Elizabeta i njen muž Zaharija dobili su sina Ivana, koji je krstio Isusa u rijeci Jordan i koji je skončao život kao mučenik odrubljene glave.

Djevica Marija krenula je u posjet iz svog grada Nazareta u Elizabetino selo Ain Karim, nedaleko Jeruzalema. Put je bio oko $140 \mathrm{~km}$ dug, za što je trebalo pet dana pješačenja. Djevica Marija bia je siromašna pa nije mogla drugačije putovati. Nakon pet dana, Marija je konačno došla i pozdravila Elizabetu. Čim je Elizabeta čula Djevicu Mariju, zaigralo joj je dijete u utrobi. Osim što je to bio susret Djevice Marije i Elizabete, bio je i prvi susret Isusa i Ivana Krstiteljam, koje su trudnice nosile. Elizabeta se napunila Duha Svetoga i izjavila: "Blagoslovljena ti među ženama i blagoslovljen plod utrobe tvoje! (Lk 1, 42)." Taj Elizabetin zaziv postao je sastavni dio molitve 'Zdravo Marijo'.“

(http://hr.wikipedia.org/wiki/Poho\%C4\%91enje_Bla\%C5\%BEene_Djevice_Marije - posjet 6. 2. 2013.) 


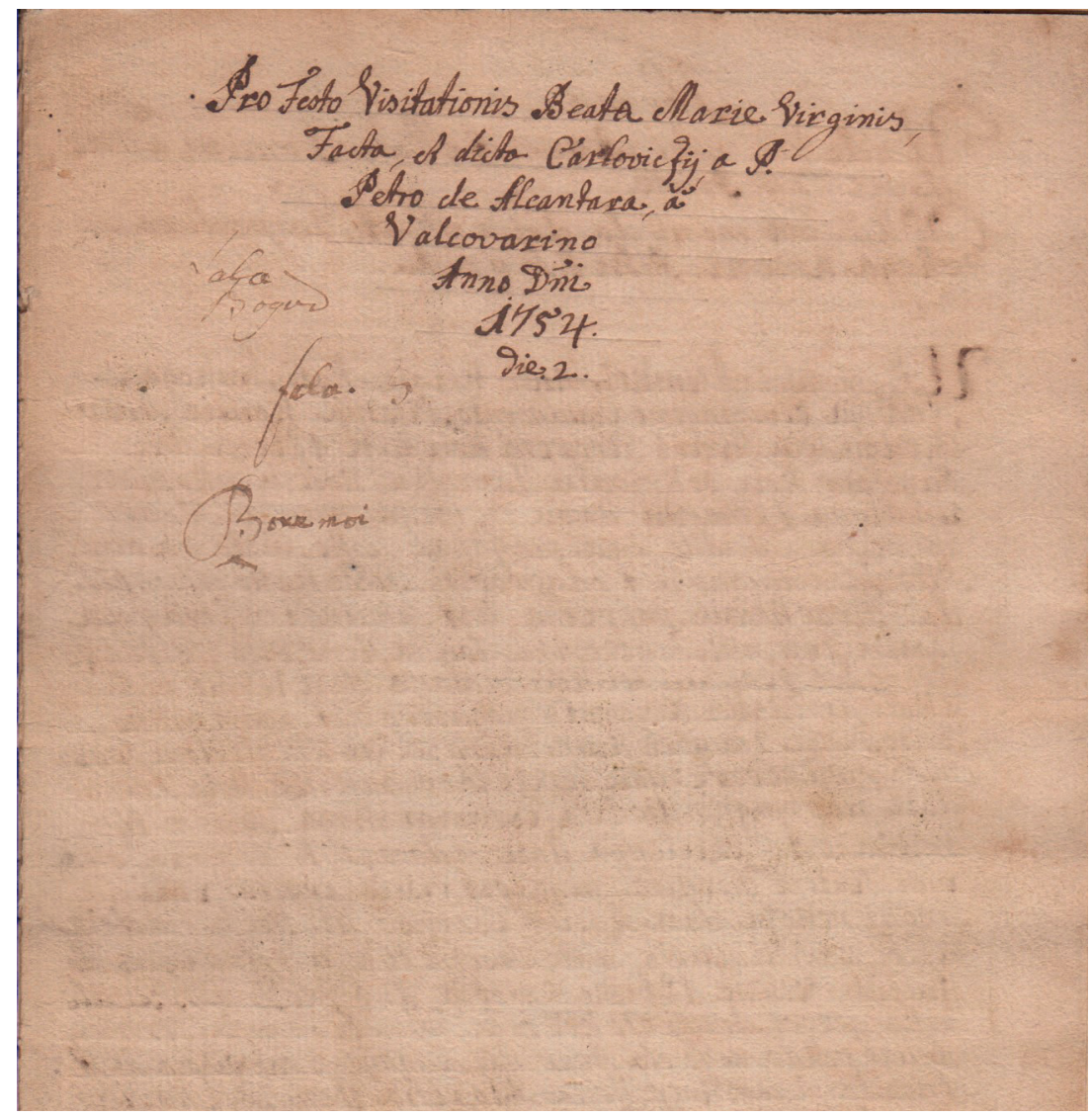

Prilog 2.

P. Petro á Valcovarino, Pro festo visitationis Beatae Marie Virginis,

Facta et dicto Carloviczija (1754.)

\section{Pro festo visitationis Beatae Marie Virginis, Facta et dicto Carloviczija a P. \\ Petro de Alcantara, a Valcovarino Anno Dni}

\section{4.}

Die. $2 .{ }^{30}$

\footnotetext{
30 Za nastanak ovoga teksta veliku zahvalu iskazujem gospodinu Mati Batoroviću koji je ne štedeći vlastito vrijeme zajedno sa mnom pregledavao rukopisne propovijedi u knjižnici Franjevačkog samostana u Osijeku i pomagao u rekonstrukciji nečitkih dijelova u tekstu.
} 
Vjerska knjiga u Slavoniji 18. stoljeća

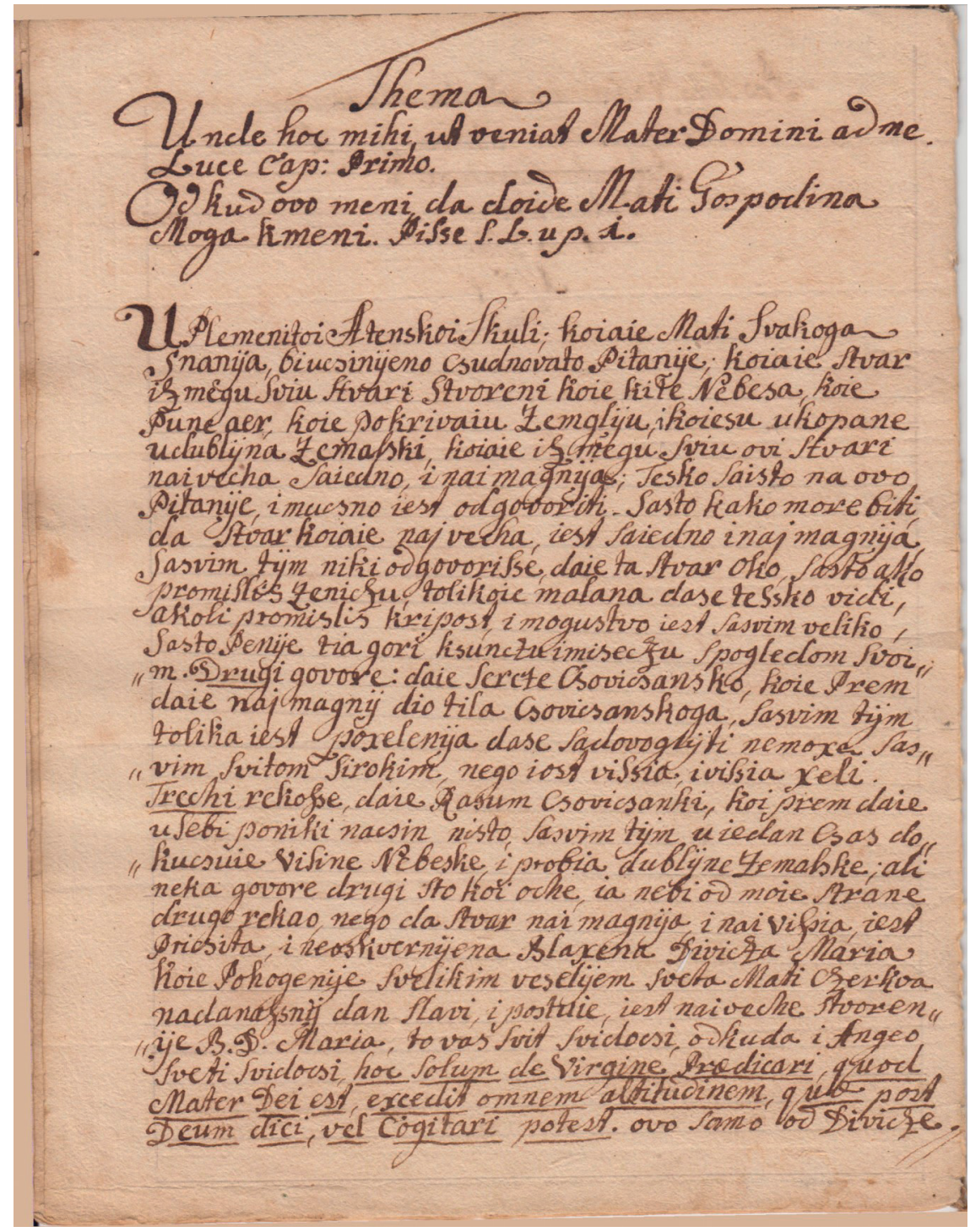


Thema

Uncle hoc mihi ut veniat Mater Domini ad me.

Luce cap: Primo.

Od kud ovo meni da dojde Mati Gospodina

moga k meni. Piše s. L. u p. 1.

U plemenitoj atenskoj skuli, koja je mati svakoga znanja, bi učinjeno čudnovato pitanje: koja je stvar između svi(j)u ${ }^{31}$ stvari stvoreni koje kite nebesa, koje pune aer, koje pokrivaju zemlju i koje su ukopane u dubljina zemalski, koja je između svi(j)u ovi stvari najveća, zajedno i najmanja. Teško zaisto na ovo pitanje i mučno jest odgovoriti. Zašto kako more biti da stvar koja je najveća, jest zajedno i najmanja.

Sa svim tim niki odgovoriše da je ta stvar oko, zašto ako promisliš zenicu, toliko je malana da se teško vidi, ako li promisliš kripost i mogustvo, jest sasvim veliko, zašto penje tja gori $\mathrm{k}$ suncu i misecu s pogledom svojim. Drugi govore da je srce čovičansko koje prem da je najmanj[i] dio tila čovičanskoga, sa svim tim tolika jest poželenja da se zadovoljiti ne može sa svim svitom širokim, nego jošt višja i višja želi. Treći rekoše da je razum čovičanski, koji prem da je u sebi po niki način ništo, sa svim tim u jedan čas dokučuje visine nebeske i probi(j)a zemalske. Ali neka govore drugi što ko(j)i oće, ja ne bi od moje strane drugo rekao nego da stvar najmanja i najviša jest priči[s]ta i neoskvrnjena Blažena Divica Mari(j)a koje pohođenje s velikim veseljem sveta mati Crkva na današnji dan slavi i poštuje, jest najveće stvoren je B. D. Mari(j)a, to vas svit svidoči, od kuda i Anđeo sveti svidoči: $\underline{\text { Hoc solum de Virgine praedicari, quod }}$ Mater Dei est, excedit omnem altitudinem, quae post Deum dici, vel cogitari potest. Ovo samo od Divice

31 U transkripciji se ubacuje intervokalno j u deklinaciji i konjugaciji i to tako da se ubačeno j stavlja u oble zagrade, a ostala umetnuta slova stavljaju se u uglatu zagradu kako bi se naznačilo da nisu napisana i u izvorniku, a na ovaj način ipak olakšavaju razumijevanje teksta. Odnosno, pogrešno napisana slova i očite tiskarske grješke ispravljene su i tako popravljene donijete u tekstu, a rekonstruirani je dio riječi naznačen uglatom zagradom. 


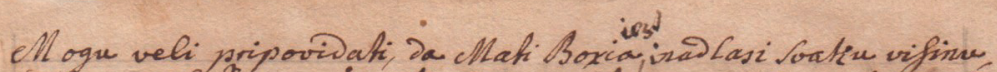

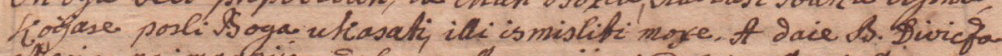

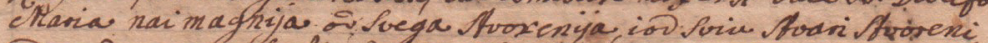

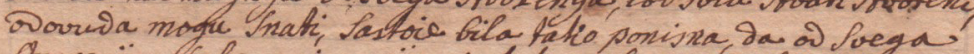

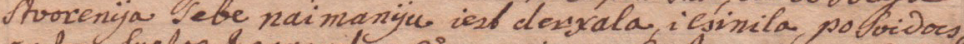

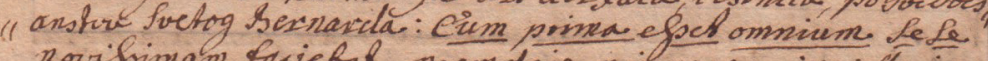
nowifimant facicbal, premdaie nil perva, inai taria

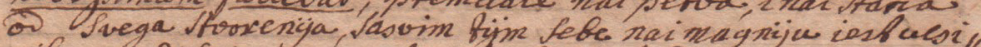

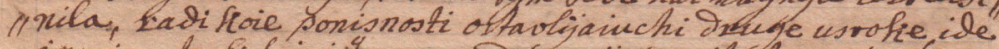

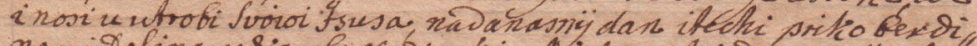

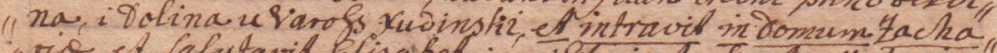
"roo, et alutavit clisabel iunigta iest ufuchutatiane"

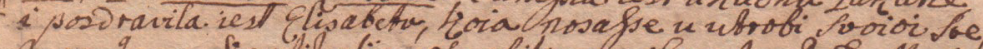
"toge furana herititeglija. O. velitia Sonifrensta. B. D. cllario".

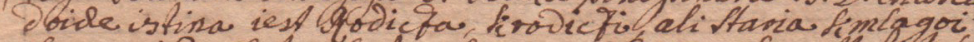

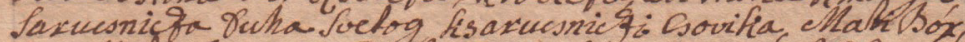

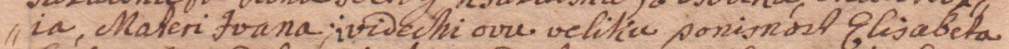

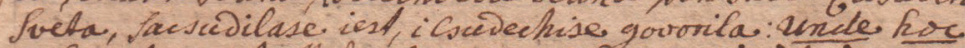

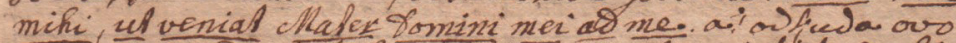

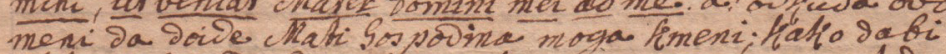
atila rechi, wige mioqo iest, intism inna ponisnos ta.

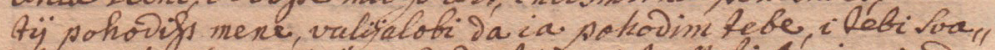
tio postenije vesinim Guduchi hasi ti llati Soxia, io

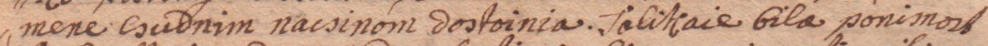
NiPS. D. Marie Da nijedan Joch nie bio uponisnosk priticsan njoi. ivsoof ovi iest asto nüjelan veti nie fio folifo velite a

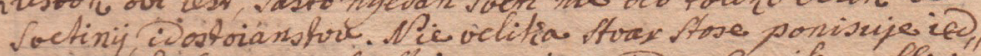

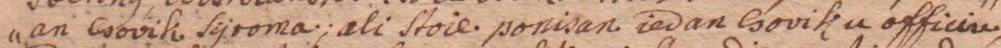

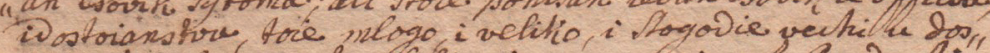

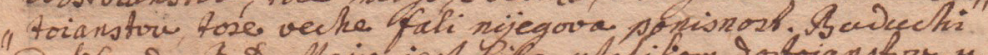
Dakle sa. S. D. Maria ient bila utatizom Sestoiansture, "e falforn nivisan webi nic. bio. asto nijeian nie meogeo holuto

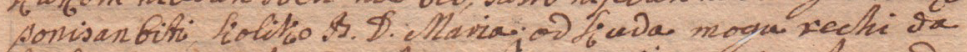

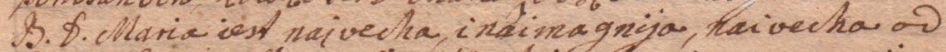

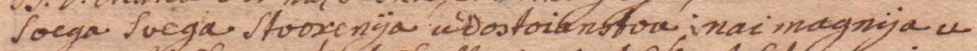
ponianosti. Da pati S. D. Maria iest fila tolite sonisna,

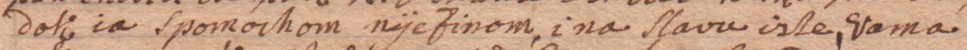

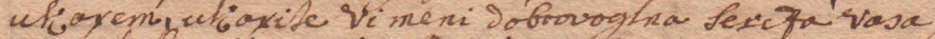
napostu Granije, a.ia porjimal. 
mogu, veli, pripovidati da Mati Božja nadlazi svaku visinu koja se posli Boga ukazati ili izmisliti može. A da je B. Divica Mari(j)a najmanja od svega stvorenja i od svi(j)u stvari stvoreni, odovuda mogu znati zašto je bila tako ponizna da od svega stvorenja sebe najmanju jest držala i cinila po svidočanstvu svetog Bernarda: Cum prima esset omnium se se novissimam faciebat, premda je najprva i najstari(j)a od svega stvorenja; sa svim tim sebe najmanju jest učinila, radi koje poniznosti ostavljajući druge uzroke ide i nosi u utrobi svojoj Isusa, na današnji dan ideći priko brdina i dolina $u$ varoš žudinski, et intravit in domum Zachariae et salutavit Elisabet, i unišla jest u kuću Zakari(j)e i pozdravila jest Elizabetu koja nošaše u utrobi svojoj svetoga Ivana Krstitelja. O! velika poniženst[v]a B. D. Mari(j)a dojde, istina jest, rodica $\mathrm{k}$ rodici, ali stari(j)a k mlađoj, zaručnica Duha Svetog k zaručnici čovika, Mati Božja materi Ivana i videći ovu veliku poniznost Elizabeta sveta začudila se jest i čudeći se govorila: Uncle hoc mihi, ut veniat Mater Domini mei ad me. A otkuda ovo meni da dojde Mati Gospodina moga k meni - kako da bi otila reći odviše mlogo jest i neizmirna poniznost da ti pohodiš mene; valjalo bi da ja pohodim tebe i tebi svako poštenje učinim, budući da si ti Mati Božja i od mene čudnim načinom dostojni(j)a. Tolika je bila poniznost [N.N. $]^{32}$ B. D. Mari(j)a, da ni jedan sveti ni(j)e bio u poniznosti priličan njoj. I uzrok ovi jest zašto ni jedan sveti ni(j)e bio toliko velik u svetinji dostojanstva. Ni(j)e velika stvar što se ponizuje jedan čovik siroma ali što je ponizan jedan čovik u ofici(j)u i dostojanstvu, to je mlogo i veliko, i što god je veći u dostojanstvu, to se veće fali njegova poniznost. Budući, dakle, da B. D. Mari(j)a jest bila u tolikom dostojanstvu, u kakom ni jedan sveti ni(j)e bio, zašto ni jedan ni(j)e mogao toliko ponizan biti koliko B. D. Mari(j)a, od kuda mogu reći da B. D. Mari(j)a jest najveća i najmanja od svega svega stvorenja u dostojanstvu i najmanja u poniznosti. Da, pak, B. D. Mari(j)a jest bila toliko ponizna, dok ja s pomoćom njezinom i na slavu iste, vama ukažem, ukažite vi meni dobrovoljna srca vaša na poslušanje, a ja počima.

32 Slova stavljena u uglatu zagradu u rukopisu su napisana na lijevoj margini teksta. 


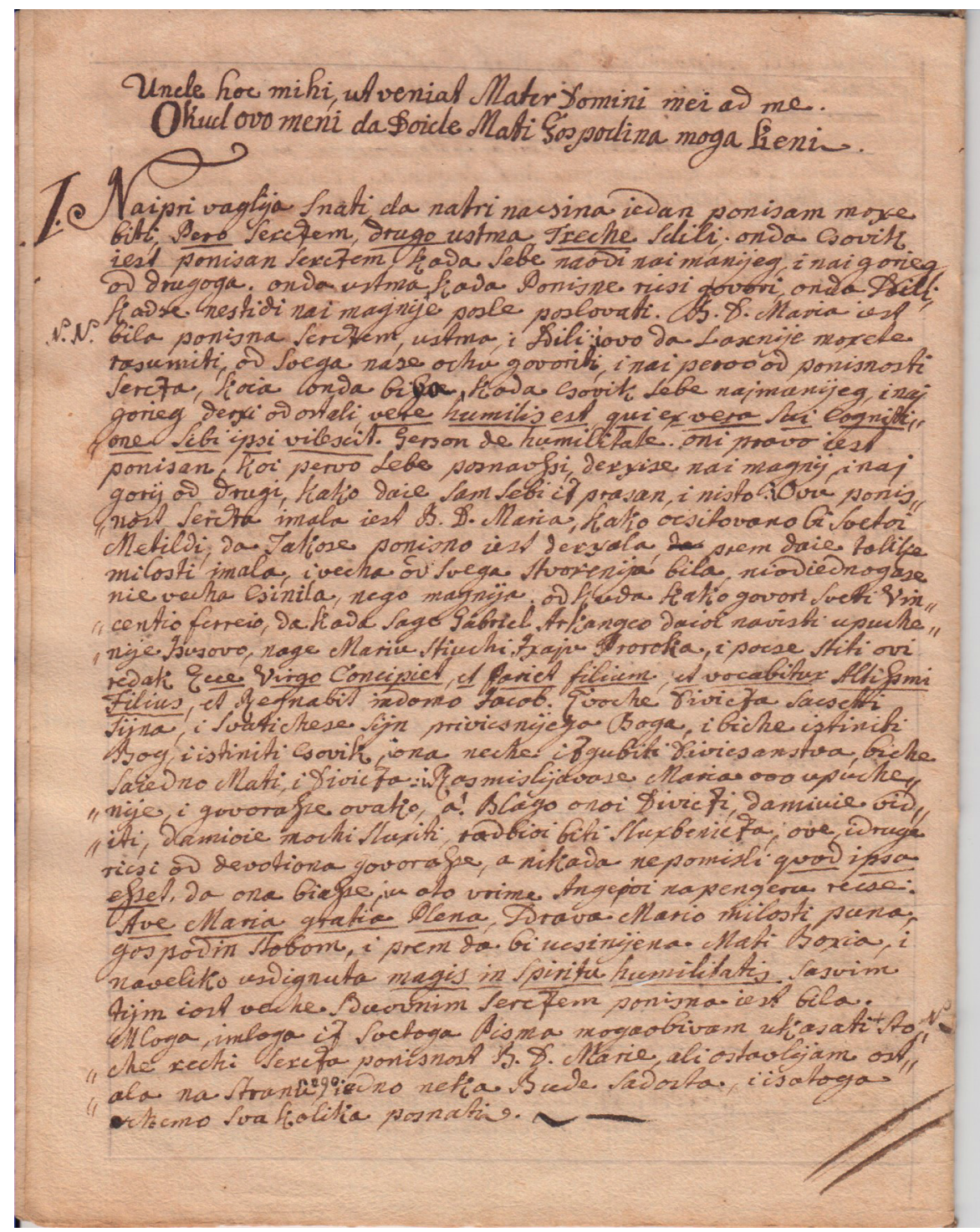


Uncle hoc mihi, ut veniat Mater Domini mei ad me.

Okud ovo meni da dojde Mati Gospodina moga k [m]eni.

I: Najpri valja znati da na tri načina jedan poniza[n] može

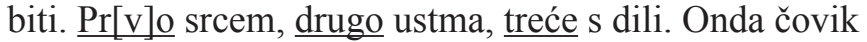
jest ponizan srcem kada sebe naodi najmanjeg i najgorjeg od drugoga; onda ustma kada ponizne riči govori; onda s dili kad se ne stidi najmanje posle poslovati. B. D. Mari(j)a jest [N.N.] $]^{33}$ bila ponizna srcem, ustma i dili. I ovo da lašnje možete razumiti, od svega na se oću govoriti i najprvo od poniznosti srca koja onda biva kada čovik sebe najmanjeg i najgorjeg drži od ostali, vere humilis est qui ex vero sui cognictione sibi ipsi vilescit. Gerson de humilitate. Oni pravo jest ponizan koji prvo sebe poznavši, drži se najmanji i najgori od drugi, kako da je sam sebi isprazan i ništo. Ovu poniznost srca imala jest B. D. Mari(j)a, kako očitovano bi svetoj Metildi da tako se ponizno jest držala prem da je tolike milosti imala, i veća od svega stvorenja bila, ni od jednoga se ni(j)e veća činila, nego manja, otkuda kako govori sveti Vincentio Ferreio, da kada sađe Gabri(j)el Arkanđeo da joj navisti upućenje Isusovo, nađe Mari(j)u šti[j]ući Ižai(j)u Proroka i poče štiti ovi redak: Ecce Virgo concipiet et poriet filium, et vocabitur altissmi filius, et regnabit in domo Jacob. To će divica začeti sina i zvati će se Sin privičnjega Boga i biće istinski Bog $i$ istiniti čovik i ona neće izgubiti divičanstva; biće zajedno Mati i divica razmišljavaše Mari(j)a ovo upućenje i govoraše ovako: O! blago onoj divici, da mi [j]u je viditi, da mi [j]oj je moći služiti, rad bi [j]oj biti službenica - ove i druge riči od devotiona govoraše, a nikada ne pomisli quod ipsa esset, da ona bijaše. I u oto vrime anđeo joj na penđeru reče: Ave Maria gratia plena, Zdrava Mari(j)o, milosti puna, Gospodin s tobom. I premda bi učinjena Mati Božja i na veliko uzdignuta magis in spiritu humilitatis. Sa svim tim jest velika s duovnim srcem ponizna jest bila.

Mloga i mloga iz Svetoga pisma mogao bi vam ukazati, što će reći srca poniznost B. D. Mari(j)e, ali ostavljam ostalo na stranu, nego jedno neka bude za dosta i iza toga ćemo svakolika poznati.

33 Slova u uglatoj zagradi su napisana na lijevoj margini teksta. 


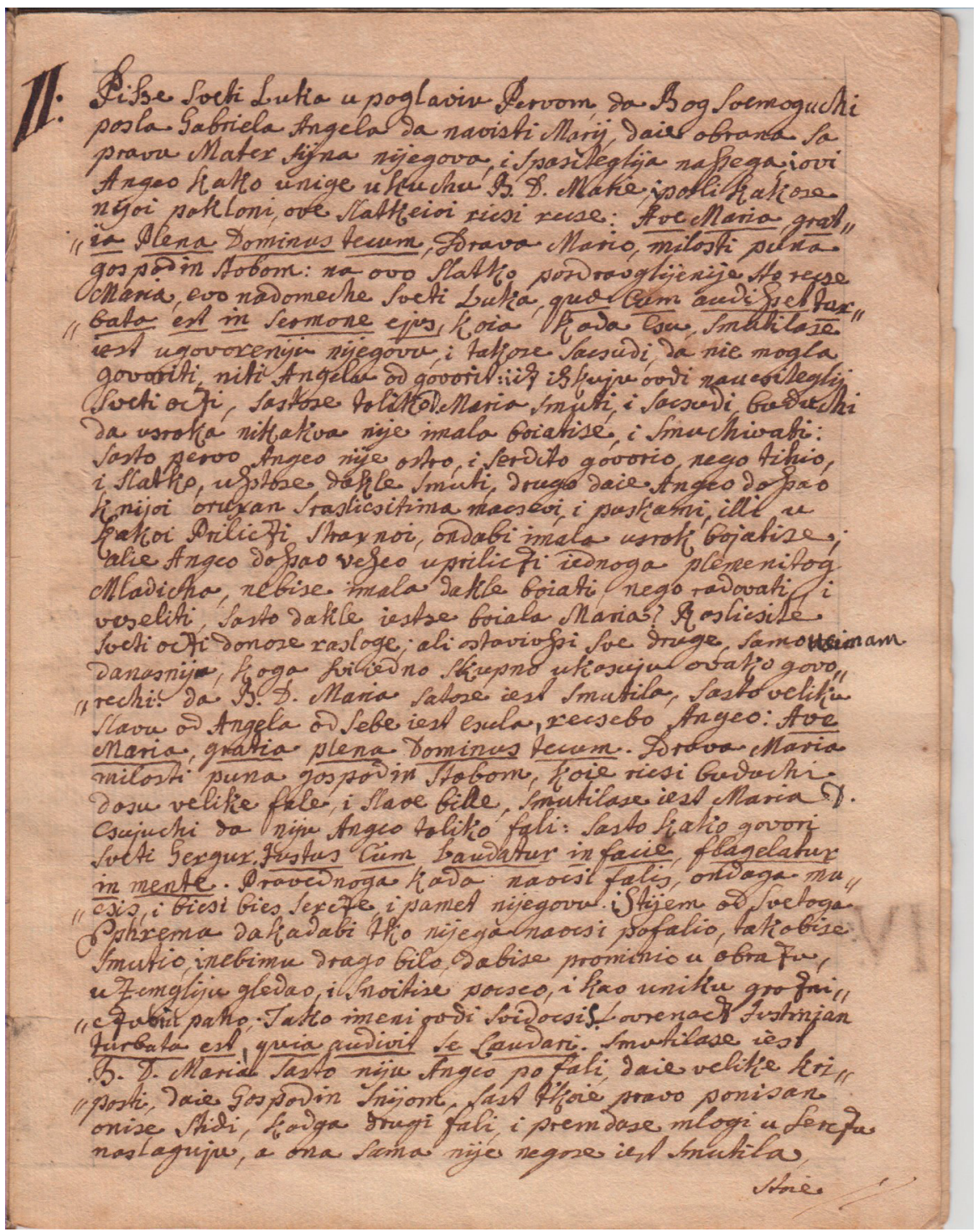

II: Piše sveti Luka u poglavju Prvom da Bog svemogući posla Gabriela anđela da navisti Mari(j)i da je obrana za pravu mater Sina njegova i Spasitelja našega. I ovi anđeo kako uniđe u kuću B. D. Mari(j)e i posli kako se 
njoj pokloni, ove slatke joj riči reče: Ave Maria gratia plena Dominus tecum, Zdrava Mari(j)o, milosti puna, Gospodin s tobom. Na ovo slatko pozdravljenje što reče Mari(j)a evo nadomeće sveti Luka, quo qum audisset tar$\underline{\text { bato }}^{34}$ est in sermone ejus, koja kada ču, smutila se jest u govorenju njegovu i tako se začudi da nije mogla govoriti niti anđelu odgovoriti, iziskuju ovdi naučitelji sveti oci, zašto se toliko D. Mari(j)a smuti i začudi, budući da uzroka nikakva nije imala bojati se i smućivati. Zašto prvo anđeo nije oštro i srdito govorio, nego tihio i slatko, u što se, dakle, smuti. Drugo da je anđeo došao $\mathrm{k}$ njoj naoružan $\mathrm{s}$ različitima mačevi i puškami ili u kakoj prilici stra[š]noj, onda bi imala uzrok bojati se. Ali [j]e anđeo došao veseo u prilici jednoga plemenitog mladića. Ne bi se imala, dakle, bojati, nego radovati i veseliti. Zašto, dakle, jest se bojala Mari(j)a? Različite sveti oci donose razloge, ali ostavivši sve druge samo imam današnji koga svi jedno skupno ukazuju ovako govoreći: da B. D. Mari(j)a zato se jest smutila zašto veliku slavu od anđela od sebe jest čula, reče bo anđeo: $\underline{\text { Ave }}$ Maria, gratia plena, Dominus tecum. Zdravo Mari(j)a, milosti puna, Gospodin s tobom, koje riči budući da su velike fale i slave bile, smutila se jest Mari(j)a D. Čujući da nju anđeo toliko fali, zašto kako govori sveti Grgur: Iustus cum laudatur in facie, flagelatur in mente. Pravednoga kada na oči fališ, onda ga mučiš i bi(j)eš i bi(j)eš srce i pamet njegovu. Štijem od svetoga Ephrema da kada bi tko njega na oči pofalio, tako bi se smutio i ne bi mu drago bilo, da bi se prominio u obrazu, u zemlju gledao i zno(j)iti se počeo, i kao u niku groznicu bi pano. Tako i meni ovdi svidoči s. Lovrenac Justinian: turbata est, quia audivit se laudari. Smutila se jest B. D. Mari(j)a zašto nju anđeo pofali da je velike kriposti, da je Gospodin s njom, zašt[o] tko je pravo ponizan, oni se stidi kad ga drugi fali i premda se mlogi u srcu naslađuju, a ona sama nije nego se jest smutila.

Što je

34 Nečitko napisan tekst zbog čega ni transkripcija nije pouzdana. 


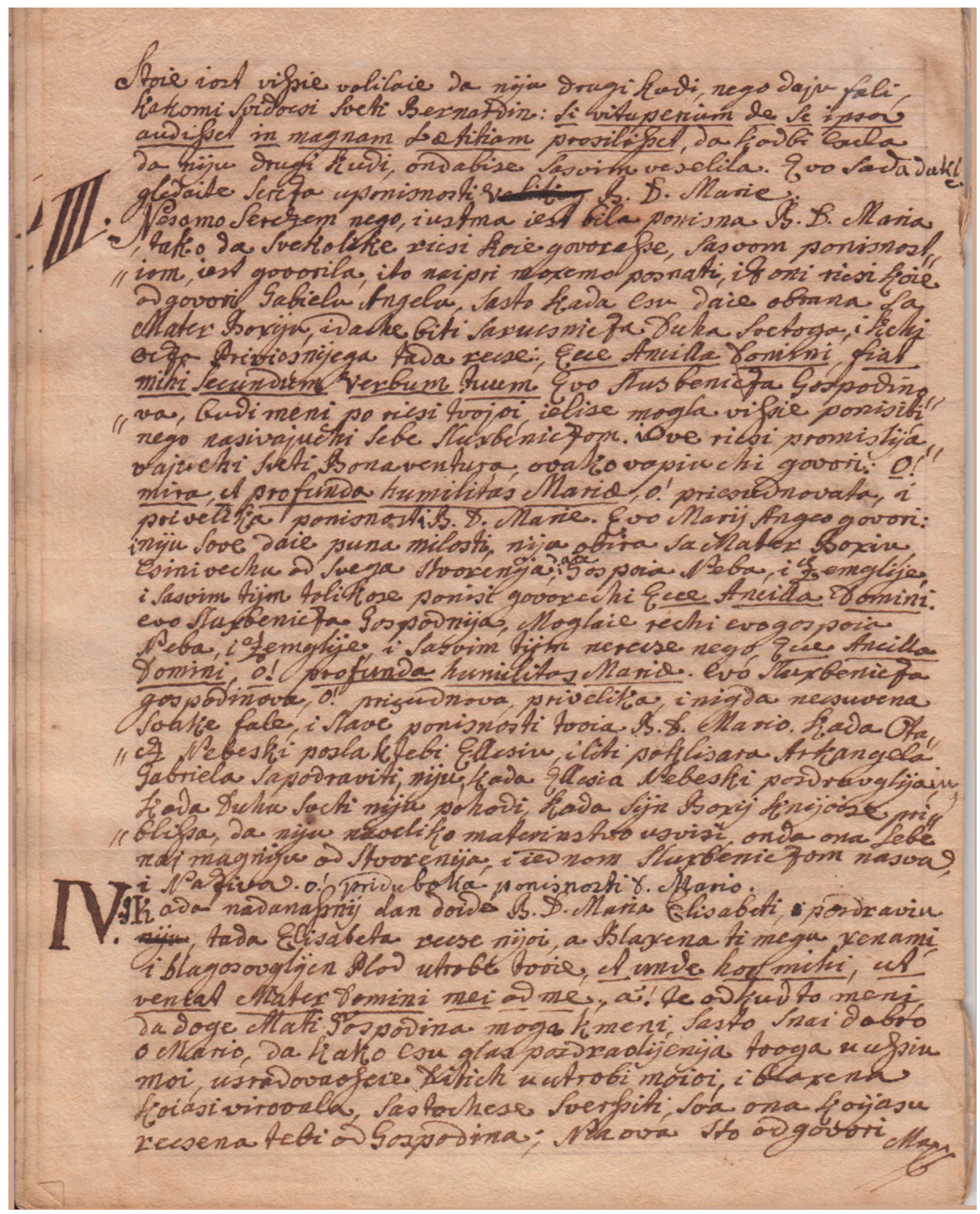

Što je jošt višje, volila je da nju drugi kudi nego da ju fali, kako mi svidoči sveti Bernardin: $\underline{\text { Si vituperium de se ipsorum }}{ }^{35}$ audisset in magnam laetitiam prosilisset, da kad bi čula da nju drugi kudi, onda bi se sasvim veselila. Ovo sada, dakle, gledajte srca u poniznosti B. D. Mari(j)e.

35 Nečitko u rukopisu. 
III: Ne samo srcem nego i ustma jest bila ponizna B. D. Mari(j)a tako da svekolike riči koje govoraše, sa svom poniznostjom jest govorila, i to najpri možemo poznati iz oni riči koje odgovori Gabrielu anđelu. Zašto kada ču da je obrana za Mater Božiju i da će biti Zaručnica Duha Svetoga i kći Oca Privičnjega, tada reče: Ecce ancilla domini, fiat mihi secundum verbum tuum. Evo službenica Gospodinova, budi meni po riči tvojoj. Je li se mogla višje poniziti nego nazivajući sebe službenicom. I ove riči promišljavajući sveti Bonaventura, ovako vapi(j)ući govori: $\underline{\mathrm{O}}$ mira et profunda humilitas Maria! O! pričudnovata i privelika poniznosti B. D. Mari(j)e. Evo Mari(j)i anđeo govori i nju zove da je puna milosti, nju obira za Mater Božju, čini veću od svega stvorenja i da je Gospoja neba i zemlje, i sa svim tim toliko se ponizi, govoreći: Ecce Ancilla Domini. Evo službenica Gospodnja. Mogla je reći evo gospoja neba i zemlje, i sa svim tim ne reče nego Ecce Ancilla Domini. O! profunda humilitas Maria. Evo službenica Gospodinova. O! pričudnova[ta], privelika i nigda nečuvena. Svake fale i slave poniznosti tvoja B. D. Mari(j)o, kada Otac Nebeski posla k tebi Ellesiu iliti poklisara arkanđela Gabriela za po[z]draviti nju, kada Ellesia nebeski pozdravlja ju, kada Duha Sveti nju pohodi, kada Sin Božji k njoj se približa, da nju na veliko materinstvo uzvisi, onda ona sebe najmanju od stvorenja i jednom službenicom nazva i naziva. O! priduboka poniznosti, D. Mari(j)o.

IV: I kada na današnji dan dojde B. D. Mari(j)a Elizabeti i pozdravi ju, tada Elizabeta reče njoj, a blažena ti među ženami, i blagosovljen plod utrobe tvoje, et unde hoc mihi, ut veniat Mater Domini mei ad me. A, te od kud to meni da dođe Mati Gospodina moga k meni. Zašto znaj dobro, o Mari(j)o, da kako ču glas pozdravljenja tvoga u ušim mo(j)i, uzradovaše se ditić u utrobi mojoj, i blažena koja si virovala, zašto će se svršiti sva ona koja su rečena tebi od Gospodina. Na ova što odgovori 


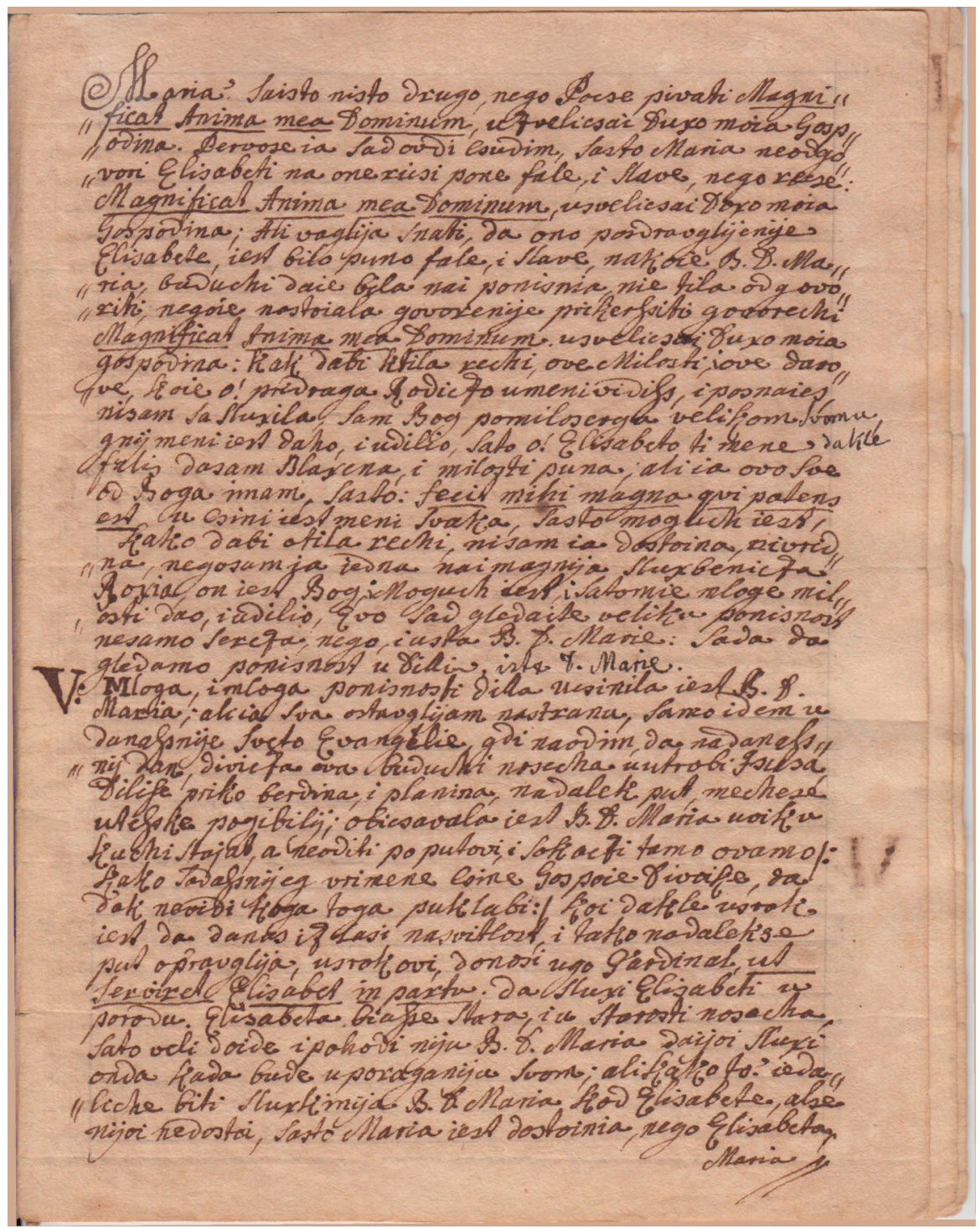

Mari(j)a? Zaisto ništa drugo nego poče pivati Magnificat Anima mea Dominum. Uzveličaj dušo moja Gospodina. Pervo se ja sad ovdi čudim zašto Mari(j)a ne odgovori Elizabeti na one riči $\mathrm{p}[\mathrm{u}]$ ne fale i slave, nego reče: Magnificat Anima mea Dominum. Uzveličaj dušo moja 
Gospodina. Ali valja znati da ono pozdravljenje

Elizabete jest bilo puno fale i slave na koje B. D. Mari(j)a, budući da je bila najponizni(j)a, nije tila odgovoriti, nego je nastojala govorenje prekršiti govoreći Magnificat Anima mea Dominum. Uzveličaj dušo moja Gospodina, kak da bi ktila reći ove milosti i ove darove, koje, o! pridraga rodico, u meni vidiš i poznaješ, nisam zaslužila, sam Bog po milosrđu velikom svomu nji meni jest dao i udilio. Zato, o, Elizabeto, ti mene, dakle, fališ da sam blažena i milosti puna, ali ja ovo sve od Boga imam, zašto: fecit mihi magna qui potens est, u čini jest meni svaka zašto moguć jest, kako da bi otila reći nisam ja dostojna ni vridna, nego sam ja jedna najmanja službenica Božja; on jest Bog i moguć jest i zato mi je mloge milosti dao i udilio. Evo, sad gledajte veliku poniznost ne samo srca nego i usta B. D. Mari(j)e. Sada da gledamo poniznost $\mathrm{u}$ dilim iste $\mathrm{D}$. Mari(j)e.

V: Mloga i mloga poniznosti dila učinila jest B. D. Mari(j)a, ali ja sva ostavljam na stranu; samo idem u današnje sveto Evanđelje, gdi na[h]odim da na današnji dan divica ova, budući noseća u utrobi Isusa dili se priko brdina i planina na dalek put meće se, u teške pogibilji; običavala jest B. D. Mari(j)a uvika kući stajat, a ne oditi po putovi i sokaci tamo ovamo /: kako sadašnjeg vrimena čine gospoje divojke da dok ne vidi koga toga, pukla bi:/ koji, dakle, uzrok jest da danas izlazi na svitlost $i$ tako na dalek se put opravlja, uzrok ovi donosi Ugo gardinal ut serviret Elisabet in parta. Da služi Elizabeti u porodu. Elizabeta bi(j)aše stara i u starosti noseća, zato oće da ide i pohodi nju B. D. Mari(j)a, da joj služi onda kada bude u porađanju svom. Ali kako to? Je da li će biti sluškinja B. D. Mari(j)a kod Elizabete, al' se njoj ne dosto(j)i, zašto Mari(j)a jest dostojni(j)a nego Elizabeta, Mari(j)a 


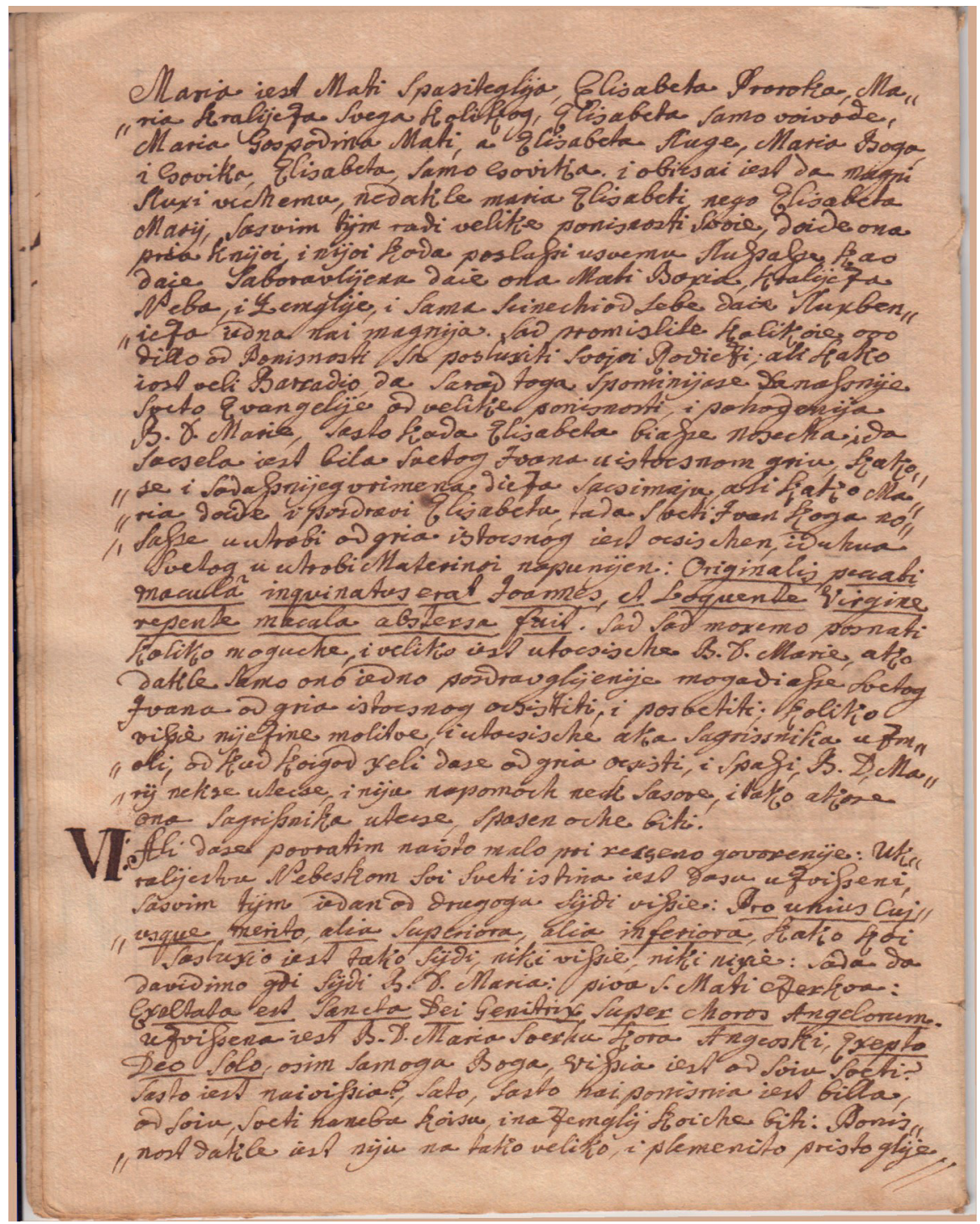

Mari(j)a jest mati Spasitelja, Elizabeta proroka, Mari(j)a kraljica svega kolikog, Elizabeta samo vojvode, Mari(j)a Gospodina mati, a Elizabeta sluge, Mari(j)a Boga i čovika, Elizabeta samo čovika i običaj jest da manji 
služi većemu, ne dakle Mari(j)a Elizabeti nego Elizabeta Mari(j)i. Sa svim tim radi velike poniznosti svoje dojde ona prva k njoj i njoj kada posluži u svemu služavka kao da je zaboravljena da je ona mati Božja, kraljica neba i zemlje i sama čineći od sebe da je službenica jedna najmanja. Sad promislite koliko je ovo dilo od poniznosti za poslužiti svojoj rodici, ali kako jošt veli Barcadio da zaradi toga spominja se današnje sveto Evanđelje od velike poniznosti i pohođenja B. D. Mari(j)e, zašto kada Elizabeta bi(j)aše noseća i da začela jest bila svetog Ivana u istočnom griu kako se i sadašnjeg vrimena djeca začimaju, ali kako Mari(j)a dojde i pozdravi Elizabetu, tada sveti Ivan koga nosaše u utrobi od gria istočnog jest očišćen i Duha Svetog u utrobi materinoj napunjen: Originalis pecabi macula inqvinatus erat Ioannes et loquente Virgine repente macula abstersa fuit. Sad, sad možemo poznati koliko moguće i koliko jest utočište B. D. Mari(j)e, ako dakle samo ono jedno pozdravljenje mogadi(j)aše svetog Ivana od gria istočnog očistiti i posvetiti; koliko više njezine molitve i utočište ako za grišnika uzmoli otkud ko(j)i god želi da se od gria očisti i spasi, B. D. Mari(j)i nek se uteče i nju na pomoć nek zazove i tako ako se ona za grišnika uteče, spasen oće biti.

VI: Ali da se povratim na isto malo pri rečeno govorenje: u Kraljestvu nebeskom svi sveti istina jest da su uzvišeni, sa svim tim jedan od drugoga sidi višje: Pro unius cuiusque merito alia superiora alia inferiora. Kako ko(j)i zaslužio jest, tako sidi, niki višje, niki nižje. Sada da da vidimo gdi sidi B. D. Mari(j)a. Piva sveta mati Crkva: Exaltata est sancta Dei genitrix super choros Angelorum. Uzvišena jest B. D. Mari(j)a svrhu kora anđeoski, exsepto Deo solo, osim samoga Boga višja jest od svi(j)u sveti. Zašto jest najvišja? Zato zašto najponizni(j)a jest bila od svi(j)u sveti na nebu koji su i na zemlji koji će biti. Poniznost, dakle, jest nju na tako veliko i plemenito pristolje 




uzvisila. Evo, dakle, u svi(j)u ozgo rečeni slidi da B. D. Mari(j)a jest bila najponizni(j)a, da nju Bog svemogući radi ove poniznosti obrao jest za mater svoju i svrhu svi(j)u sveti uzvisio. Drugo mi sada ne ostaje nego opominjam vas da mater ovu poštujete, da tko god se $\mathrm{k}$ njoj uteče, neće ga zapustiti kako štijem jednu istori(j)u. 
VI: Bi(j)aše jedna bludnica sasvim pristala i lipa, imenom Mari(j)a. Ova sedamnajst godina bludeći nepošteno ne samo jest živila nego mlogima uzrok jest bila pogubljenja, došavši posli u Jeruzolim, ne znam s kojim nadanućem, dojde i vidi gdi toliko mloštvo ulazi u crkvu. Zato ide i ona da uniđe, ali po kriposti Božjoj jedan i drugi put bi otirana. Smete ju Bog i ne dade unići. Smuti se i pristraši se. Sama sebe karaše da su uzrok tomu grisi, okreće se tamo ovamo radi opet unići u crkvu, ali zaludu. I evo s vr[h]u otara crkve ugleda priliku B. D. Mari(j)e, pada odma prid nju na kolina, prsa svoja udarati i ispovidati grie svoje, suzami lice svoje poliva, mrzi sasvim na grie, obećaje veće ne grišiti, moli milost da može u crk[v]u unići. I evo, pokripi se i usta, uniđe u crkvu, pokoru za grie zagrli, uniđe u jednu strašnu šumu anđeoski život provoditi i tolike bi svetinje da se vaskoliki svit čudi njezinoj svetinji. Evo, gledajte, o! grišnici i grišnice, da ovoj grišnici ne samo B. D. Mari(j)a otvori vrata crkvena, nego i vrata nebeska. Zato i vi koji ste po griu istirani iz raja, B. D. Mari(j)u na pomoć zovite koja vam vrata može otvoriti. Sa svom pomnjom nastojte na njezine dneve ispoviditi se, subotu na poštenje njezino postiti i svaki se dan njoj priporučivati, ako mislite s njom zajedno u kraljestvu nebeskom uživati i lice njezino gledati.

VIII: Višje ne govorim nego za dovršiti govorenje moje štijem od B[ri]gite svete, da joj bi od Boga očitovato da mloge milosti i darove primaju oni svi ko(j)i svaki dan one riči na poštenje B. D. Mari(j)e uzgovori: Monstra te esse Matrem summat per te praeces qui pro nobis natus $\underline{\text { tulis }}^{36}$ esse tuus. Ukaži se da si mati, neka primi po tebi molitve koji se od tebe jest rodio i dostojao se Sin tvoj biti. To i ja vičem i govorim, o!

36 Nečitko u rukopisu. 


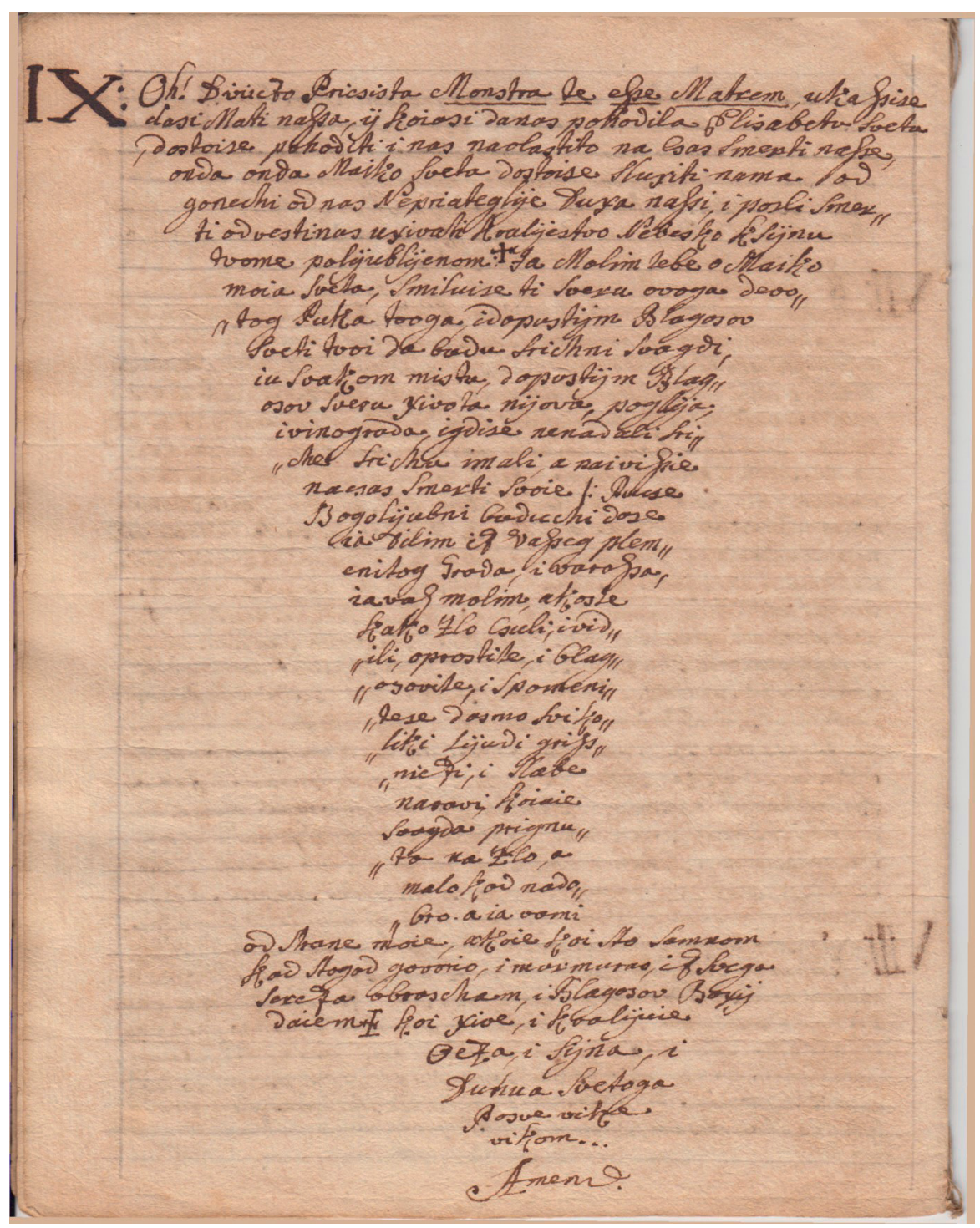


IX: Oh! Divico pričista Monstra te esse Matrem, ukaži se da si mati naša i koja si danas pohodila Elizabetu svetu, dostoj se pohoditi i nas, navlastito na čas smrti naše, onda, onda, Majko sveta, dostoj se služiti nama odgoneći od nas neprijatelje duša naši i posli smrti odvesti nas uživati kraljestvo nebesko $\mathrm{k}$ Sinu tvome poljubljenom. $\dagger$ Ja molim tebe, o Majko moja sveta, smiluj se ti svr[h]u ovoga devotog puka tvoga i dopusti im blagosov sveti tvoj, da budu srićni svagdi i u svakom mistu, dopusti im blagosov svr[h]u života njiova, polja i vinograda i gdi se ne nadali sriće sriću imali, a najviše na čas smrti svoje: Puče bogoljubni, budući da se ja dilim iz vašeg plemenitog grada i varoša, ja vas molim, ako ste kako zlo čuli i vidili, oprostite i blagosovite i spomenite se da smo svikoliki ljudi grišnici i slabe naravi, ko(j)im je svagda prignuto ka zlo, a malo kad na dobro. A ja ovmi

od strane moje, ako je ko(j)i što sa mnom kad zloga govorio i nečimurno, iz svega srca o[p]rašćam i blagosov Božji dajem, ko(j)i žive i kraljuje

Oca, i Sina, i

Duha Svetoga

Po sve vike vikom... Amen. 


\section{Literatura}

- Beritić, Nada, 1965. Franatica Sorkočević, dubrovački pjesnik XVIII stoljeća (1706-1771), Rad JAZU, Knjiga 338, Zagreb.

- Bilić, Anica, 2009. Stjepan Adžić (1730.-1789.), vjerski pisac u stoljeću prosvjećivanja i hrvatski latinist u ,galantnom “ stoljeću, u: Adžić, Stjepan, 2009. Sabrana djela I. Prozna djela, Duhovno hrašće, Drenovci, str. 155.-184.

- Bogišić, Rafo, 1987. Tragovima starih, poglavlje Jedan pogled na književnost Slavonije u 18. stoljeću, Književni krug, Split.

- Bogner, Ivo, 1987. Književni prikazi, Sveučilište u Osijeku - Pedagoški fakultet, Osijek.

- Brešić, Vinko, 2004. Slavonska književnost i novi regionalizam, Matica hrvatska, Ogranak Osijek, Osijek.

- Deanović, Mirko, 1972. Dubrovačke preradbe Molièreovih komedija, Knjiga prva, Stari pisci hrvatski, Knjiga 36, Zagreb.

- Drechsler, Branko, 1907. Slavonska književnost u XVIII. vijeku, Naklada knjižare Breyera, Zagreb.

- Dugalić, Vlatko, 1989. Pučka pobožnost u našim molitvenicima, Đakovo (rukopis).

- Dukić, Davor, 2002. Poetike hrvatske epike 18. stoljeća, Književni krug, Split.

- Fališevac, Dunja, 1997a. Epika na razmeđu 18. i 19. stoljeća, Dani hvarskog kazališta, XXIII - Hrvatska književnost uoči Preporoda, Književni krug, Split.

- Fališevac, Dunja, 1997b. Kaliopin vrt. Studije o hrvatskoj epici, Književni krug, Split.

- Fališevac, Dunja, 2003. Kaliopin vrt II. Studije o poetičkim i ideološkim aspektima hrvatske epike, Književni krug, Split.

- Flaker, Aleksandar, 1976. Stilske formacije, Sveučilišna naklada Liber, Zagreb.

- Forko, Josip, 1887. Crtice iz "slavonske" književnosti u XVIII. stoljeću, III, u: Izvješće o kralj. velikoj realci u Osieku koncem školske godine 1886/7; Tiskom Julija Pfeiffera, Osiek.

- Fotez, Mirko, 1967. Hrvatske komedije XVII. i XVIII. stoljeća, uvod u knjizi Komedije XVII i XVIII stoljeća, Pet stoljeća hrvatske književnosti, Knj. 20, Matica hrvatska-Zora, Zagreb.

- Georgijević, Krešimir, 1969. Hrvatska književnost od 16. do 18. stoljeća u sjevernoj 
- Hercigonja, Eduard, 1994. Tropismena i trojezična kultura hrvatskoga srednjovjekovlja, Matica hrvatska, Zagreb.

- Hoško, Franjo Emanuel, 1985. Negdašnji hrvatski katekizmi, Salezijanski provincijalat, Zagreb.

- Hoško, Franjo Emanuel, 1996. Marijan Jaić. Obnovitelj među preporoditeljima, Katehetski salezijanski centar; Zagreb.

- Hrvatskoj i Bosni, Matica hrvatska, Zagreb.

- http://hr.wikipedia.org/wiki/Poho\%C4\%91enje_Bla\%C5\%BEene_ Djevice_Marije (posjet 6. 2. 2013.)

- http://www.ofm.hr/index.php/component/content/article/105-o-nama/ iz-nase-povijesti/137-pregled-povijesti-hrvatske-franjevacke-provincijesv-cirila-i-metoda-fra-emanuel-hosko (Emanuel Hoško, Pregled povijesti Hrvatske franjevačke provincije sv. Cirila i Metoda posjet: 6. 2. 2013.)

- https://www.google.hr/\#hl=hr\&tbo=d\&output=search\&sclient=psyab\&q=Petar+Dombaj\%2C+18.+stolje \%C4\%87e\&oq=pet\&gs_l=h p.1.0.35i39j013.54783.55499.0.57903.3.3.0.0.0.0.170.417.0j3.3.0. ..0.0...1c.1.2.hp.VgLavBffew4\&pbx $=1 \& b a v=$ on.2,or.r_gc.r_pw.r_ qf. $\&$ bvm $=$ bv.41934586,d.Yms\&fp=fddbfe33ecc6cfdb\&biw $=1049 \& b$ $\mathrm{ih}=584$

- Jakošić, Josip, 1988. Scriptores interamniae vel Pannoniae Saviae nunc Slavoniae dictae anno 1795 conscripti (cum continuatione anni 1830) Pisci međurječja ili Savske Panonije sad zvane Slavonija, popisani 1795. godine (s nastavkom do 1830. godine), na hrvatski preveo Stjepan Sršan, „Revija“, 1, godište 28, str. 63-87.

- Jelčić, Dubravko, 1997. Povijest hrvatske književnosti. Tisućljeće od Baščanske ploče do postmoderne, Naklada P.I.P. Pavičić, Zagreb.

- Ježić, Slavko, 1993. (prema prvom izdanju iz 1944.) Hrvatska književnost od početka do danas. 1100.-1941., Grafički zavod Hrvatske, Zagreb.

- Kolarić, Juraj, 1996. Hrvatski kajkavski molitvenici i njihov utjecaj na duhovnost, ,Kajkaviana Croatica“, Hrvatska kajkavska riječ, Zagreb.

- Kombol, Mihovil - Novak, Slobodan Prosperov, 1992, Hrvatska književnost do narodnog Preporoda, Školska knjiga, Zagreb.

- Kombol, Mihovil, 1961. Povijest hrvatske književnosti do narodnog Preporoda, Matica hrvatska, Zagreb.

- Kravar, Zoran, 1987. Barok kao potonulo kulturno dobro, „Croatica“, br. 26-28, Zagreb.

- Kravar, Zoran, 1992. Barok u staroj slavonskoj književnosti, „Revija“, br. 3/4/5/6, god. XXXII, Osijek, str. 195.-231. 
- Kronika Franjevačkog samostana u Brodu na Savi, I (1706-1787), Za tisak priredio dr. Josip Barbarić, uredio p. Egidije Stjepan Biber, Matica hrvatska Slavonski Brod, Slavonski Brod 1995.

- Matić, Tomo, 1945. Prosvjetni i književni rad u Slavoniji prije Preporoda, HAZU, knj. XLI, Zagreb.

- Mihanović-Salopek, Hrvojka, 2006. Iz duhovnog perivoja, Naklada Ljevak, Zagreb.

- Pavličić, Pavao, 1991. Kamo pripada Reljkovićev S a t i r ?, u: Vrijeme i djelo Matije Antuna Reljkovića, urednik Dušan Čalić, JAZU - Zavod za zanstveni rad Osijek, Osijek, str. 85.-94.

- Robert Skenderović, Zdravstvene reforme Marije Terezije u Slavonskom provincijalu i Generale Normativus Sanitatis iz 1770.; posjet: 7. 2. 2013.

- Sertić, Nikola, 1943. Hrvatski kajkavski molitvenici, Zagreb (rukopis).

- Šrepel, Milivoj, 1899. Jakošićev spis: Scriptores interamniae, JAZU, knj. II, str. 116.-153.

- Šundalić, Zlata, 1997. Crtica o Vincu bogoljubnih pisamah ili ponešto o odnosu Jaić - Kanižlić - Mulih, u: Dani hvarskog kazališta. Hrvatska književnost uoči preporoda, uredništvo knjige: Nikola Batušić, Rafo Bogišić, Rudolf Filipović, Milan Moguš, Franjo Švelec, Josip Vončina, Književni krug, Split, str. 417.-455.

- Šundalić, Zlata, 2003. Studenac nebeski. Molitvenici u hrvatskoj književnosti od 16. Do kraja 18. Stoljeća (s posebnim osvrtom na Antuna Kanižlića), Književni krug, Split.

- Tatarin, Milovan, 2009. Književnost 18. stoljeća, u: Slavonija, Baranja i Srijem - vrela europske civilizacije, Prvi svezak, Galerija Klovićevi dvori, Zagreb, str. 495-501.

- Vodnik, Branko, 1913. Povijest hrvatske književnosti. Knjiga I. Od humanizma do potkraj XVIII. stoljeća. S uvodom V. Jagića o hrvatskoj glagolskoj književnosti, Matica hrvatska, Zagreb.

- Zečević, Divna, 1988. Hrvatske pučke pjesmarice 19. stoljeća, Osijek. 


\section{Zlata ŠUNDALIĆ \& Anela MATELJAK-POPIĆ}

\section{RELIGIOUS BOOKS IN $18^{\mathrm{TH}}$ CENTURY SLAVONIA}

The author of the present paper analyzes texts created from early $18^{\text {th }}$ century to 1855, when Ignjat Alojzije Brlić passed away and when his Novouređeni ilirski kalendar or Svetodanik ceased to be published. The above works make up the corpus of so-called Slavonian literature that was, territorially speaking, created in the area encompassed by the Province of St. Ivan Kapistran. The authors were mainly church people (Jesuits, Franciscans), while the genealogical image of $18^{\text {th }}$ century Slavonian literature is mainly made up of works of Enlightenment orientation (M. A. Relković, Satir or divji čovik, 1762; Đ. Rapić, Satir obraćen, 1765; V. Došen, Jeka planine, 1767; A. T. Blagojević, Pjesnik-putnik, 1771; J. S. Relković, Kućnik, 1769; etc.), as well as those of Baroque and Rococo (A. Kanižlić, Sveta Rožalija, 1780; A. Ivanošić, Opivanje sličnorično groba Josipa Antuna Ćolnića od Ćolke, 1786), and classicist orientation (M. P. Katančić, Fructus auctumnales, 1791), along with war chronicles in verse, as well as religious books, defined by N. Andrić as catholic truths (catechisms), divine ways (prayer books), mirrors of truth (various genres of moral-instructive prose), etc.

Key words: Slavonian pre-renaissance literature, stylistic pluralism, religious books, Dombaj 


\section{Novica VUJOVIĆ (Nikšić)}

UDK 811.163.4'373.2(497.16Piva)

Preliminarno saopštenje

Fakultet za crnogorski jezik i književnost - Cetinje

novica.vujovic@fcjk.me

\section{PRILOG IZRADI IMENOSLOVA PIVE}

Autor daje popis muških i ženskih ličnih imena toga dijela Crne Gore. U prilogu je naveden spisak monografskih studija i rodoslovnih knjiga na osnovu kojih je sačinjen registar. Građa potiče s terena durmitorskih govora (tako ih određuje dijalektolog Milija Stanić), odnosno śeverozapadnih crnogorskih govora.

Ključne riječi: muška $i$ ženska lična imena, imenoslov, Piva

Plemena razmještena oko velikoga durmitorskog masiva geografski, istorijski, etnografski itd. ispitivali su Svetozar Tomić (Drobnjak, antropogeografska ispitivanja, SDZb, knj. 4, Beograd, 1902), Andrija Luburić (Drobnjaci, pleme u Hercegovini, Beograd, 1930), Obren Blagojević (Piva, Srpska akademija nauka i umetnosti, 1971) i dr., a od mnogih drugih domaćih i stranih naučnika iz novijega vremena spomenućemo Slobodana Kasalicu, Milutina Lješevića, Branka Radojičića i Miroslava Doderovića. O durmitorskim plemenima ostavili su zapise i brojni putopisci, koji su najčešće s oduševljenjem i nadahnuto govorili o prirodi i ljudima koji tu žive.

Govori toga dijela Crne Gore u serbokroatistici najčešće su određivani kao hercegovački (naziv potiče još od Vuka Karadžića), međutim, jasno je da u ovome slučaju najznačajnije odlike toga govora žive van hercegovačkoga područja, pa je pravilno prihvatiti već afirmisani naziv śeverozapadni crnogorski govori. ${ }^{1} \mathrm{Na}$ samome početku naglašavamo da śeverozapadni crnogorski govori zahvataju veliki dio naše države, a mi ovđe za područje s kojega potiče izdvojena građa koristimo sintagmu Milije Stanića, te s tim u vezi nalazimo da durmitorskim govorima pripadaju: pivski, drobnjački, uskočki, šaranski i krnjojelski govori.

1 Detaljnije u: Adnan Čirgić, Crnogorski jezik u prošlosti i sadašnjosti, Institut za crnogorski jezik i književnost i Matica crnogorska, Podgorica, 2011. Posebno treba uputiti na poglavlje „Klasifikacija crnogorskih govora“, str. 51-93. 
Dijalektolog Jovan L. Vuković u monografiji Govor Pive i Drobnjaka ${ }^{2}$ veli i ovo: „Prirodno je bilo da ovaj planinski kraj, nepristupačan raznim tuđinskim uticajima, čuvajući i razvijajući rasne osobine našega naroda i njegova obeležja, čuva i razvija njegovo prvo obeležje - jezik“.

Vrijedno je podśetiti na značajnije karakteristike govora Pive i Drobnjaka (naravno, prema spomenutoj Vukovićevoj monografiji Govor Pive i Drobnjaka). Teritorijalna granica između ovih plemena, piše J. Vuković u svom doktorskom radu, nije spriječila njihov uži zajednički život, a u pogledu jezika „plemenska granica ne bi mogla biti granica i koje neznatnije jezičke crte“. Ispitivanja su pokazala da vokalska grupa ao daje sažimanjem $o$ (došo, reko). Međutim, u Breznima se javlja sažimanje u korist $a$, što se tumači uticajem doseljenika iz okoline Nikšića, čiji je govor tu osobinu primio od crnogorskih govora, kako veli Vuković s pozivanjem na Danila Vušovića. ${ }^{3}$ U Bezuju i Dubrovsku sažimanje u korist $a$ se rjeđe javlja, dok središnja sela Drobnjaka „većinom čuvaju svoju osobinu zamene a + o u o“. Sažimanje postoji u dodiru jednakih vokala kada su dio riječi koje akcenatski čine jednu cjelinu: „đavodnijo (đavo odnio: nemam đavodnijo brašna), dako (da ako: dako bide śutra lijepo), svedno (svejedno: radijo, ne radijo, svedno ti)" i sl. Karakteristike ovoga govora jesu nepoznavanje glasa $h$, koji se gubi (oću, ljeb, usanuti (usahnuti), sna (snaha), duovnik (sveštenik) i sl.) ili u znatno manjoj mjeri zamjenjuje drugim glasovima (stio (htio), onijeg, radik, držagu, orag i sl.). Uočljivo je nepoznavanje glasa $f$ umjesto kojega se javlja $v$ (vuruna, Sovija (Sofija), sovra (sofra) i sl.). Jovan Vuković je detaljno obradio nestalnost glasa $j$ u ovome govoru. Na taj dio njegove monografije ukazaćemo i nešto kasnije, kad riječ bude o statusu glasa $j$ u ličnim imenima Pive. Takođe, značajan dio rada posvećen je jotaciji. Suglasnici $t$ i $d$ jotacijom daju $c$ i $d$ : lećeti, đetelina i sl. (postoje i izuzeci: tješiti, tjelesni, djelo itd.), zatim kad se $j$ nađe iza $c$ : ćedilo, ćepanica i sl. te kad je između $d$ ili $c$ reducirano $v$ : međed, Ćetko, neđelja itd. Za ovu priliku izdvajamo Vukovićev zaključak da kao značajna odlika ispitivanoga govora dolazi „obrazovanje glasova $s ́$ i $z ́$ od $s j$ i $z j$, po najnovijem, delimično i po novom, jotovanju“. Primjeri su brojni: śesti, śeknuti, śeme, śutra, iźesti, ali Vuković bilježi i klasje, izjaloviti, izjednačiti. Materijali koji su obrađeni u pomenutoj monografiji u nekim primjerima potvrđuju da ,je najnovije jotovanje obuhvatilo i usnene suglasnike $\mathrm{p}, \mathrm{b}, \mathrm{v}$ i m“. Istraživanja na nivou morfologije potvrila su slaganja sa standardnim jezikom toga vremena ali i naglasila neke, kako Vuković veli, dijalekatske osobenosti govora Pive i Drobnjaka. O akcentu govora Pive i Drobnjaka pisao je takođe Jovan Vuko-

\footnotetext{
Jovan L. Vuković, Govor Pive i Drobnjaka, Južnoslovenski filolog, XVII, Beograd, 1940. Poznato je da su u tradicionalnoj serbokroatistici crnogorskim smatrani samo govori četiri nahije i Brda.
} 
vić. ${ }^{4} \mathrm{O}$ jeziku rečenoga područja istraživačima je vrijedne materijale ponudila i Radojka Cicmil-Remetić u monografiji Toponimija Pivske planine. ${ }^{5}$

Zanimljivo područje ispitivanja svakako jeste strana leksika u durmitorskim govorima. Vrijedan je osvrt na riječi koje su iz drugih jezika ušle u govor Pive u spomenutoj monografiji Radojke Cicmil-Remetić, kao i radovi Milice Radović-Tešić. ${ }^{6}$

Radi lakšega razumijevanja jezika toga dijela Crne Gore i onomastičkih materijala sakupljenih na širem prostoru oko Durmitora, vrijedi buduće istraživače uputiti, pored ostaloga, na radove Dragomira Vujičića i Branislava Ostojića, a neka na ovome mjestu bude spomenut i prilog Marijana Miljića: „Prilog bibliografiji radova o manastiru Piva"7 $\mathrm{s}$ popisom radova o bogatoj riznici Pivskoga manastira, knjigama, zapisima, natpisima, kao i mnogi drugi radovi.

Odlučujući se za literaturne izvore opredijelili smo se za nekoliko naučnih publikacija, dakle studija koje su radili stručnjaci i iza kojih su stale ugledne institucije, na primjer SANU, te nekoliko rodoslovnih knjiga u kojima onomastičari mogu pronaći značajne informacije. Nažalost, problem kod rodoslovnih publikacija je najčešće manji broj primjeraka te činjenica da je riječ o manje-više izdanjama autora ili zavičajnih udruženja, pa ih je nerijetko teško naći mimo porodičnih, odnosno privatnih biblioteka. Nastojali smo odabirom izvora da dobijemo ravnomjernu zastupljenost imena stanovništva Planine pivske i Župe pivske. Vrijedi radi onih koji će se baviti analizom

4 Jovan Vuković, „Akcenat govora Pive i Drobnjaka“, Srpski dijalektološki zbornik, knj. X, Srpska kraljevska akademija, Beograd, 1940, 185-417.

5 Radojka Cicmil-Remetić, Toponimija Pivske planine, Srpska akademija nauka i umetnosti, Odeljenje jezika i književnosti, Beograd, 2010. Na ovome mjestu možemo ponoviti da je ta monografija s dragocjenim fondom građe (str. 143-311) dobro prihvaćena od stručne javnosti, te i to da je ispitivanim primjerima autorka pristupila kao dijelu fonda srpskoga jezika i bezmalo svako objašnjenje podredila takvome pristupu. O pomenutoj monografiji iscrpno je pisao Vukić Pulević. Viđeti: Vukić Pulević, „Fitotoponimi i zootoponimi u toponomastičkim radovima Radojke Cicmil-Remetić", Lingua Montenegrina, br. 8, Institut za crnogorski jezik i kniževnost, Podgorica, 2011, str. 345-421.

6 Njen rad s naučnoga skupa Na izvoru Vukova jezika 1988. godine „Romanizmi u govoru Pive“ štampan je u knjizi: Durmitorski zbornik, Istorijski institut Crne Gore, Titograd, 1991. Analizom građe autorka dolazi do tri sloja romanizama:

1) tzv. balkanski latinitet (npr. loćika, papar, mramor, sapun, košulja, pogan i sl.);

2) tzv. dalmatinski period i

3) tzv. novoromanski. Milica Radović-Tešić zaključuje: „stočarsko-zemljoradničko stanovništvo pivskog sela preuzimalo je onu leksiku južnog primorja koja mu je nedostajala na počecima ekonomskog, kulturnog i društvenog razvitka. (...) Ono je prihvatalo termine za odeću, obuću, pokućstvo, posuđe, alatke i sl. - što je bio znak njegovog u to vreme skromnog materijalnog razvoja i napretka."

7 Marijan Miljić, „Prilog bibliografiji radova o manastiru Piva“, Četiristo godina manastira Piva, Stručna knjiga, Istorijski institut SR CG, Titograd, 1991. 
podśetiti da su lična imena preuzeta iz publikacija koje su poštovale normu nekadašnjega srpskohrvatskog, odnosno srpskoga jezika.

Uza sve rečeno potrebno je reći i ovo. Namjera nam je bila da akcente označimo prema izgovoru starijega govornog predstavnika s toga područja. Međutim, teškoće smo imali s manjim brojem imena koja ne žive u imenoslovu današnjih generacija Pivljana i svakodnevnoj komunikaciji, te ih je naša informatorka različito izgovarala pri čitanju. Među tim imenima su svakako i imena crkvenih lica. S obzirom na tu činjenicu, mi smo građu dali bez akcenata i tako ostavili priliku da se pokuša na terenu opisati akcenatsko stanje ovđe ponuđenih primjera.

Prema onome što se može čuti od starijih govornih predstavnika s tih terena našega jezika potvrđuje se da je glas $j$ u mnogim pozicijama dosta slab, odnosno slabo se čuje. Mi smo ovđe primjere navodili onako kako su dati u izvorima koje smo koristili. Međutim, naša je obaveza da ukažemo na pomenutu činjenicu u vezi s glasom $j$. Tako se u govoru starijih osoba čuje Blagoe, Radoe, Radoica, Voin itd. I dijalektolog Jovan Vuković konstatuje za govor Pive i Drobnjaka ,da se između tvrdih vokala i palatalnog $e$ i obrnuto $j$ potpuno gubi: (...) Dean, Radoe, Miloe, Zmaevic'“6 itd. Vuković primjećuje da je pravilna promjena Jovo - Jova Jovu, međutim na osnovu nekih rijetkih primjera u toponimiji, na čije su oblike vremenom mogli uticati različiti jezički i izvanjezički faktori, autor konstatuje „da i ovde nije bila nepoznata promena koju nalazimo zapadnije u Hercegovini: Đuro-Đure-Đuri““. ${ }^{9}$ Nama se čini, kad je riječ o antroponimiji, da se ta pitanja mogu objasniti unošenjen jezičkih elemenata sa strane, pa ovđe spomenimo i dijalektologa Miliju Stanića iz suśednih Uskoka, koji će na tu temu reći ovo: „Napominjem da sam u ovom radu (Uskočka antroponimija - N. V.) kraj formi Boro, Gajo, Rade, Vule itd. davao gen. (Boro, -a) da se te forme i njihove paradigme ne bi mešale sa pojavama: Boro - Bore - Bori itd., koje ovde, u Uskocima, ne postoje. "“10 Takvu situaciju na terenu zatiču i ostali proučavaoci naših govora.

Potvrde muških i ženskih ličnih imena koja dajemo u registru mogu se naći i u toponimima izvođenim prema antroponimu. Uz taj korpus leksike uvijek ide pitanje motivacije za izvođenje naziva. „Motivacija tih imena, aktuelnoj generaciji nesumnjivo sasvim prozirna, vremenom je sve više bledela i današnjem istraživaču kod mnogih slučajeva jedino je preostalo da nagađa o pozadini mnogih toponima toga tipa. "“11 I tako redom.

\footnotetext{
8 Jovan Vuković, „Govor Pive i Drobnjaka“, Južnoslovenski filolog, 1940, str. 43.

9 Jovan Vuković, n. d., str. 54.

10 Milija Stanić, „Uskočka antroponimija“ Onomatološki prilozi, knj. X, Srpska akademija nauka i umetnosti, Beograd, 1989, str. 505.

11 Radojka Cicmil-Remetić, Toponimija Pivske planine, Srpska akademija nauka i umetnosti, Odeljenje jezika i književnosti, Beograd, 2010, str. 129.
} 


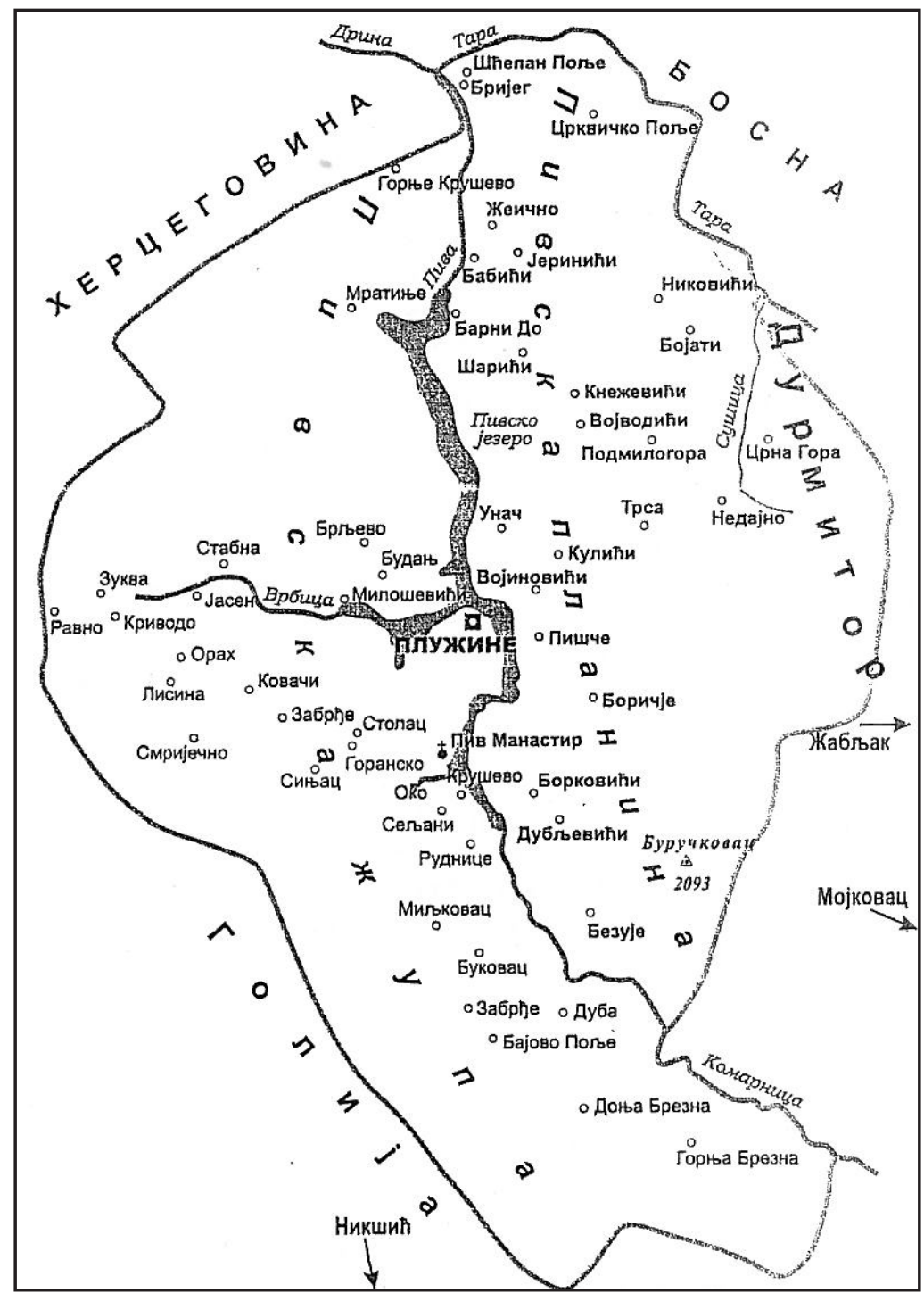

Preuzeto iz knjige Radojke Cicmil-Remetić Toponimija Pivske planine, Srpska akademija nauka i umetnosti, 2010. 
Građa data u prilogu ekscerpirana je iz ovih izvora:

- Dr Obren Blagojević, Piva, posebna izdanja, knjiga CDXLIII, Srpska akademija nauka i umetnosti, Beograd, 1971.

- Nenad Stevović i Slobodan B. Medojević, Crnogorci u Vojvodini - kolonizacija 1945-1948 (I-III), Matica crnogorska, Podgorica, 2010.

- Spasoje Cicmil i Milivoje Tripković, Pišče i Vojinovići, izdanje autora, Nikšić, 2003.

- Blažo Dubljević, Planina pivska, DRASLAR PARTNER, Beograd, 2006.

- Radivoje M. Tadić, Tadići, genealogija pivskog bratstva Tadić i druga bratstva prezimena Tadić, izdanje autora, Beograd, 1990.

- Momčilo Mićanović, Mićanovići u Pivi, Štamparija „Bajić“, Čačak Plužine, 2000.

Na kraju treba dodati i to da ponuđeni spisak ličnih imena ne možemo posmatrati kao konačan. 
MUŠKA IMENA

Amza

Anđelko

Aćim

Akso

Aleksa

Aleksandar

Aljo

Andrija

Anto

Antonije

Aranđel

Arsenije

Bajo

Bećo

Bećko

Bjelan

Blagoje

Blagota

Blažo

Bogdan

Bogić

Boris

Boriša

Božidar

Božo

Bojo

Branilo

Časlav

Čedomir

Ćetko

Damir

Damljan

Danilo

David

Dimitrije

Dragan

Dragić
Dragiša

Drago

Dražen

Dreka

Dušan

Đerasim (sveštenik)

Đerosim

Đevrosim

Đoko

Đoka

Đole

Đorđije

Đukan

Đurica

Đuriša

Đurko

Đuro

Filip

Gajo

Gale

Gavro

Gigo

Gavrilo

Gavro

Gligor

Gligorije

Gojko

Golub

Goran

Grujica

Igor

Ilija

Ivan

Jagoš

Jakov

Jakša

Janićije 


\begin{tabular}{ll} 
Janko & Mihailo \\
Jašo & Mijajlo \\
Jefimije & Mijat \\
Jevrem & Mijo \\
Jevto & Mijuško \\
Joco & Mikailo \\
Joko & Milan \\
Joksim & Mile \\
Jole & Milenko \\
Jovan & Mileta \\
Jovica & Milić \\
Jovo & Milija \\
Keka & Milika \\
Kiko & Milinko \\
Kojo & Milisav \\
Komnen & Milivoje \\
Kosta & Milo \\
Kostadin & Milosav \\
Kosto & Milomir \\
Krnjica & Milorad \\
Krsto & Milovan \\
Labud & Miloš \\
Lado & Milun \\
Lale & Milutin \\
Lazar & Miljan \\
Lazo & Mimo \\
Lekso & Minja \\
Luka & Minjo \\
Ljubo & Miodrag \\
Ljubomir & Miomir \\
Maksim & Mirko \\
Mališa & Miro \\
Marko & Mišo \\
Mašan & Mitar \\
Mašo & Miun \\
Mašut & Mladen \\
Matije & Mlađen \\
Mato & Momir \\
Mićan & Momčilo \\
Mićo & Mujo \\
440 & \\
\hline
\end{tabular}




\begin{tabular}{|c|c|}
\hline Munjica & Radosav \\
\hline Naod & Radoš \\
\hline Nebojša & Radovan \\
\hline Neđeljko & Radul \\
\hline Nenad & Radule \\
\hline Neša & Rajko \\
\hline Neško & Ranko \\
\hline Nešo & Ratko \\
\hline Niko & Risto \\
\hline Nikola & Samuilo \\
\hline Novak & Saša \\
\hline Novica & Sava \\
\hline Obrad & Savatije \\
\hline Obren & Savić \\
\hline Okica & Sekul \\
\hline Olica & Sekule \\
\hline Ostoja & Serafim (kaluđer) \\
\hline Pajo & Simat \\
\hline Pano & Simeun \\
\hline Panto & Simo \\
\hline Pavle & Slaviša \\
\hline Pejo & Slavoljub \\
\hline Peko & Slavko \\
\hline Perica & Slobodan \\
\hline Periša & Spasoje \\
\hline Perko & Srdan \\
\hline Pero & Sreten \\
\hline Petar & Staniša \\
\hline Petko & Stanko \\
\hline Piljo & Stanoje \\
\hline Polikarpa (sveštenik) & Stevan \\
\hline Predrag & Stojan \\
\hline Prokopije & Svetislav \\
\hline Rade & Svetozar \\
\hline Radenko & Šaban \\
\hline Radivoje & Šćepan \\
\hline Radoje & Šujo \\
\hline Radojica & Šule \\
\hline Radomir & Šundo \\
\hline Radomirko & Šurko \\
\hline
\end{tabular}


Novica VUJOVIĆ

\begin{tabular}{ll} 
Tadija & Vuko \\
Tanasije & Vukola \\
Teodor & Vukoman \\
Teodosije & Vukola \\
Tešo & Vukosar \\
Timotije & Vukota \\
Todo & Vuksan \\
Todor & Vule \\
Toma & Zdravko \\
Tomaš & Zeko \\
Tomislav & Zelen \\
Tomo & Zlatan \\
Tripko & Zoran \\
Trivko & Žarko \\
Tugomir & Željko \\
Vasilije & Živan \\
Vasilj & Živko \\
Vasko & \\
Vaso & \\
Vedran & \\
Velimir & \\
Veliša & \\
Veselin & \\
Veljko & \\
Vićentije & \\
Vidak & \\
Vidoje & \\
Vidomir & \\
Vilotije & \\
Vladimir & \\
Vlado & \\
Vlatko & \\
Vojin & \\
Vojislav & \\
Vučić & \\
Vujadin & \\
Vuk & \\
Vukadin & \\
Vukašin & \\
Vukić & \\
442 & \\
\hline
\end{tabular}


Aleksandra

Alena

Ana

Andreja

Anđelija

Anđelka

Anita

Anica

Anka

Aćima

Anđa

Aranđija

Biljana

Biserka

Bojana

Bosiljka

Božana

Božica

Branka

Brena

Bula

Cmiljana

Cvijeta

Daliborka

Danijela

Danila

Dara

Darinka

Desa

Desanka

Dobrica

Doka

Dostinja

Dragana

Dragica

Draginja

Dunja
Dušanka

Đuka

Đurđa

Gorana

Gordana

Gospava

Grozdana

Ivana

Ivanka

Ilinka

Jaglika

Jagoda

Janja

Jasmina

Jasna

Jaša

Jegda

Jevrosima

Jela

Jelena

Jelenka

Jelica

Jovana

Jovanka

Joka

Joša

Julka

Kanda

Kata

Kaća

Kara

Koviljka

Krstinja

Lela

Lenka

Lerka

Lidija 


\begin{tabular}{ll} 
Lucija & Olivera \\
Ljeposava & Pava \\
Ljerka & Pejka \\
Ljiljana & Petra \\
Ljubica & Petruša \\
Ljubinka & Rada \\
Maja & Radmila \\
Malina & Radojka \\
Manda & Rajka \\
Mara & Raka \\
Margareta & Ranđija \\
Marica & Ranka \\
Marija & Rista \\
Mijoljka & Ruška \\
Mikosava & Ruža \\
Mila & Sanda \\
Milena & Sara \\
Milenija & Sava \\
Milenka & Saveta \\
Mileva & Senija \\
Milica & Senka \\
Milijana & Simana \\
Milinka & Slavica \\
Milka & Slobodanka \\
Milojka & Smetana \\
Milosava & Snežana \\
Miluša & Sofija \\
Miljana & Sonja \\
Mitra & Stana \\
Nada & Stanica \\
Nadežda & Stanija \\
Nasta & Stanka \\
Nata & Stanuša \\
Natalija & Stevka \\
Nataša & Stoja \\
Nevenka & Stojanka \\
Nikica & Sulumija \\
Novka & Svetlana \\
Njegosava & Tanja \\
Olga & Tatjana \\
444 & \\
& \\
\hline
\end{tabular}


Tijana

Todora

Tomana

Tonka

Vanja

Vasilija

Vasiljka

Velika

Velimirka

Vema

Vemija

Veroslava

Veselinka

Vesna

Vida

Vidosava
Vidna

Vijoleta

Vinka

Višnja

Vjera

Vlatka

Vojka

Vukosava

Zagorka

Zdenka

Zdravka

Zlatana

Zorica

Zorka

Živana 


\section{Literatura}

- Cicmil-Remetić, Radojka: Toponimija Pivske planine, Srpska akademija nauka i umetnosti, Odeljenje jezika i književnosti, Beograd, 2010.

- Čirgić, Adnan: Crnogorski jezik u prošlosti i sadašnjosti, Institut za crnogorski jezik i književnost i Matica crnogorska, Podgorica, 2011.

- Miljić, Marijan: „Prilog bibliografiji radova o manastiru Piva“, Četiristo godina manastira Piva, stručna knjiga, Istorijski institut SR CG, Titograd, 1991.

- Pešikan, Mitar: „O imenoslovu durmitorskog kraja“, Durmitorski zbornik - Na izvoru Vukova jezika, Titograd, 1991, str. 13-20.

- Pulević, Vukić: „Fitotoponimi i zootoponimi u toponomastičkim radovima Radojke Cicmil-Remetić“, Lingua Montenegrina, br. 8, Institut za crnogorski jezik i kniževnost, Podgorica, 2011, str. 345-421.

- Radović-Tešić, Milica: „Romanizmi u govoru Pive“, Durmitorski zbornik - Na izvoruVukova jezika, Titograd, 1991, str. 49-57.

- Stanić, Milija: „Uskočka antroponimija“, Onomatološki prilozi, knj. X, Srpska akademija nauka i umetnosti, Beograd, 1989.

- Vuković, Jovan: Govor Pive i Drobnjaka, Južnoslovenski filolog, XVII, Beograd, 1940.

- Vuković, Jovan: „Akcenat govora Pive i Drobnjaka“, Srpski dijalektološki zbornik, knj. X, Srpska kraljevska akademija, Beograd, 1940, 185-417.

\section{Novica VUJOVIĆ}

\section{A CONTRIBUTION TO PIVA'S NOMENCLATOR}

The author of this paper provides a list of male and female first names of Piva, a region in northern Montenegro. The paper also contains a list of monographs and other studies on the basis of which the register was made. The material was collected in the area of Durmitor's speech patterns (as classified by Milija Stanić), i.e. north-west Montenegrin speech patterns.

Key words: male and female first names, nomenclator, Piva 


\section{PORTRETI}



UDK 821.163.4:929Stojović M.

Pregledni rad

\section{Aleksandar RADOMAN (Podgorica)}

Fakultet za crnogorski jezik i književnost - Cetinje

aleksandar.radoman@fcjk.me
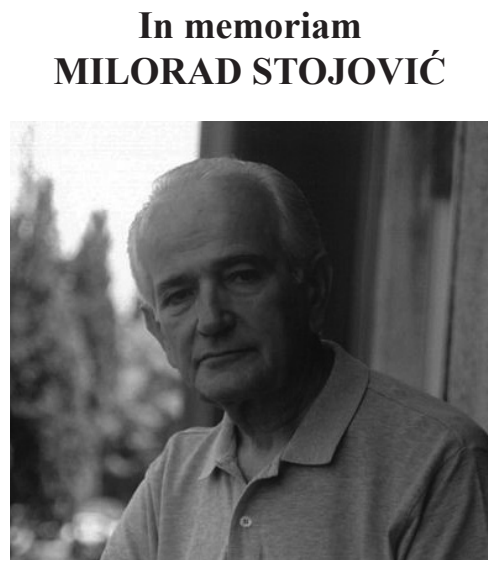

(1927-2015)

Smrću Milorada Stojovića, montenegristika je ostala bez još jednoga od svojih utemeljivača, a crnogorska kultura bez pregaoca koji je cijeli život ugradio u njene temelje.

Književni i pozorišni kritičar, istoričar književnosti, antologičar i urednik, Milorad Stojović pripadao je najužem krugu utemeljivača moderne montenegristike. Još od 1954. godine aktivno učestvujući u kulturnome i književnome životu Crne Gore, Stojović se ogledao u nekoliko oblasti koje su mu donijele i značajna društvena priznanja. Uz Boža Bulatovića, Sretena Perovića i Radoslava Rotkovića bio je pokretač poslijeratne književne kritike u Crnoj Gori, a uz Sretena Perovića neprikosnoveni autoritet u domenu crnogorske pozorišne kritike. Stojović je bio i jedan od pokretača izdavačke djelatnosti nekadašnjega Grafičkog zavoda, a kasnije Pobjede, izdavačkih preduzeća koja su postavljala nove standarde u izdavaštvu, namećući se i u jugoslovenskim okvirima a zaduživši crnogorsku kulturu ne samo neprevaziđenom bibliotekom-antologijom crnogorske književnosti „Luča“, već i nizom drugih biblioteka i izdanja, koje su crnogorsku nauku i kulturu obogatile novim pristupima 
i otvorile drugačije stranice istraživanja i tumačenja našega nasljeđa. Stojović ide $u$ red i naših prvih antologičara, rafiniranoga dara da prepozna i analizira specifičnosti književnoga teksta i strogih kriterijuma u odabiru i prezentaciji književne baštine. Nije se ni u domenu istorije književnosti zadržao na pukoj deskripciji i faktografskoj sintezi, već je i tu krčio nove puteve, priređujući izdanja zanemarenih i nedovoljno proučenih pisaca, otkrivajući nova djela i na nov način osvjetljavajući značajne pisce crnogorske književnosti. O toj bogatoj paleti Stojovićevih interesovanja i djelatnosti ponajbolje svjedoči nedavno publikovana bibliografija koja sadrži 1149 bibliografskih jedinica.

Milorad Stojović rođen je 11. 3. 1927. godine u Martinićima. Gimnaziju je završio u Podgorici. Diplomirao je na Grupi jugoslovenske književnosti i srpskohrvatski jezik Filozofskoga fakulteta u Beogradu. Od 1952. do 1963. godine radio je kao profesor podgoričke gimnazije. S pokretanjem izdavačke djelatnosti Grafičkoga zavoda u Titogradu 1963. godine postaje glavni i odgovorni urednik i direktor izdavačkog sektora toga preduzeća. Za rad na biblioteci „Luča“ njeni urednici, Milorad Stojović, Sreten Perović i Branko Banjević, kolektivno su 1970. godine dobili Trinaestojulsku nagradu. Od 1963. do 1987. Stojović je uredio čak 124 publikacije. Kao jedan od urednika časopisa Stvaranje, od 1963. do 1974. godine, dao je značajan doprinos profilisanju toga časopisa kao najznačajnijega crnogorskog i jednoga od najvažnijih jugoslovenskih književnih časopisa toga vremena. Nakon što je početkom sedamdesetih godina XX vijeka vlast kao nosioce ,nacionalističkih tendencija“ markirala i urednike Grafičkoga zavoda, Stojović prelazi da radi u Crnogorsko narodno pozorište, prvo kao direktor Drame od 1976. a potom i kao upravnik od 1981. do 1990. godine, kad je penzionisan. Za Antologiju pripovjedačke proze Crne Gore 1918-1965. dobio je 1966. godine Nagradu oslobođenja Titograda, dok je za knjigu Nadmoć ljudskosti dobio Nagradu oslobođenja Titograda 1968. i Trinaestojulsku nagradu 1969. godine. Bio je član Udruženja književnika Crne Gore iz kojega je, s grupom pisaca, istupio 1989. Jedan je od osnivača Crnogorskoga društva nezavisnih književnika, Matice crnogorske i Crnogorskoga PEN centra. Bio je predśednik Crnogorskoga PEN-a i Crnogorskoga udruženja pozorišnih kritičara i teatrologa. Preminuo je u Podgorici 6. 2. 2015 .

Pozicija pionira crnogorske književne kritike Stojoviću je nametala i obavezu posebne obazrivosti u odabiru i ocjeni književnih ostvarenja nastalih u Crnoj Gori od druge polovine 50-ih godina XX vijeka. Kao izuzetno plodan kritičar Stojović je imao mjeru u procjeni i ocjeni tekuće književne produkcije, pa bi se s ove distance moglo reći da su njegovi sudovi o savremenicima uglavnom opstali. Kao jedan od začinjavaca književnokritičke misli u Crnoj Gori svojim mnogobrojnim kritikama, prateći gotovo sve žanrove ondašnje 
crnogorske literarne produkcije, nije samo doprinio afirmaciji brojnih pisaca, već i uspostavljanju kriterija vrijednosti, kako u literaturi tako i u književnoj kritici.

U književnoj istoriografiji Stojović se realizovao u tri ravni - kao antologičar, kao priređivač te kao autor zapaženih studija i eseja o crnogorskoj književnosti.

Središnje mjesto u tome dijelu Stojovićeva opusa svakako pripada antologičarskome i priređivačkome radu. Već je knjigom Antologija pripovjedačke proze Crne Gore 1918-1965. iz 1965. godine skrenuo pažnju intelektualne javnosti. Bila je to, naime, prva poslijeratna antologija crnogorske proze. Koncipirana prema strogo estetskim standardima, ta je antologija ponudila panoramu crnogorske pripovjedne proze (u njoj su pored pripovjedaka zastupljeni i odlomci iz romana) u rasponu od gotovo pola stoljeća, notirajući, doduše izvan antologijskoga izbora, i brojne autore čiji se opus do toga trenutka nije činio dostatnim ulaska u antologiju. Svoj antologijski izbor Stojović je propratio i adekvatnim predgovorom, naslovljenim „Prozno kazivanje Crne Gore“ koji zahvata mnogo širi problemski kontekst od onoga najavljenog naslovom knjige i zapravo predstavlja preciznu, enciklopedijski sveobuhvatnu sintezu crnogorske prozne produkcije od Njegoša do sredine šezdesetih godina XX vijeka. No crnogorsku je kulturu Stojović posebno zadužio Antologijom crnogorske poezije: XX vijek, koju su objavili podgorički Grafički zavod i cetinjski Obod 1972. godine. Ta je antologija i u domenu identifikacije nacionalne literature učinila značajan iskorak u odnosu na Antologiju pripovjedačke proze Crne Gore, budući da je njenim naslovom otklonjena svaka moguća dilema oko statusa crnogorske književnosti. Neutralna formulacija naslova prethodne antologije, uzrokovana delikatnim kulturnim i političkim prilikama u kojima je nastala, izazvala je i neke dobronamjerne zamjerke, ${ }^{1}$ pa je s Antologijom crnogorske poezije Stojović postupio drugačije, već u naslovu ne ostavljajući mjesta nedoumicama oko statusa crnogorske književnosti. U atmosferi pažljivoga balansiranja međunacionalnih odnosa u socijalističkoj Jugoslaviji bio je to prilično hrabar iskorak. Stojović je time otvorio prostor novim izborima i antologijama u čijim će naslovima sintagma „,crnogorska književnost“ steći pravo naučnoga građanstva. No i izvan domena borbe za status nacionalne literature, Stojovićeva antologija ostaje kao izvanredan primjer savjesno i znalački pripremljena izbora koji nije samo panorama reprezentativnih poetskih glasova već i idejno-estetski čvrsto koncipiran autorski projekat.

V. Radoje Radojević, „Starodrevni tretman crnogorske književnosti“, Politika, br. 19144, 22. I 1967, str. IX. 
Zajedno s Brankom Banjevićem, Radoslavom Rotkovićem, Čedom Vukovićem i Sretenom Perovićem, Stojović je 1976. godine u Stvaranju priredio Antologiju crnogorske književnosti: IX-XX vijek, prvi antologijski poduhvat toga tipa u Crnoj Gori. Ta je Antologija izazvala značajnu pozornost, ali i oštre osude dijela javnosti. Kao glasnogovornik onoga dijela kulturne javnosti koji se nije mirio s konceptom prekohiljadugodišnjega kontinuiteta crnogorske književnosti, s prikrivenih pozicija unitarističkih učenja, Antologiju je u zagrebačkome $O k u$ oštro napao publicista Jevrem Brković, osporavajući joj s jedne strane to što je u crnogorsku književnost uključila starije, prednjegoševsko nasljeđe, a s druge strane što je prezentovala natkonfesionalni milje crnogorske književne tradicije. Kritikujući koncepciju antologije „koja počinje sa Andreacijem a završava se sa Zuvdijom Hodžićem“, Brković nudi svoj nacrt crnogorske literature: „Iznenadio me onaj deveti vijek i svi oni vjekovi do početka devetnaestog. Po meni crnogorska književnost počinje od Petra Prvog Petrovića Njegoša i njegovih Poslanica. “2 Na Brkovićevu paskvilu odgovorili su Milorad Stojović i Radoslav Rotković. Stojović u svojemu odgovoru, isuviše odmjerenom za registar koji je nametnula Brkovićeva paskvila, ukazuje na nivo ignorancije i deplasiranosti Brkovićeva pseudonaukovanja: „Odista je neprijatno i rekao bih beznadežno raspravljati sa čovjekom koji se, kako sam priznaje (...), prvi put srio sa našim književnim i kulturnim nasljeđem do XIX vijeka upravo u knjizi koju tako nemilosrdno napada. Nikad, eto, on ta naša ranija razdoblja nije proučavao i sve informacije o njima uzeo je iz bilježaka sastavljača Antologije, a i njih je, kako smo vidjeli, pogrešno navodio. (...) Po njemu nacionalna literatura otprilike počinje 'konačnim' konstituisanjem nacionalne svijesti, kao da svaka kultura i literatura nema svoje istorijske kontinuitete doprinoseći i sama konstituisanju te svijesti. Međutim, Jevremov marksizam dopušta svakoj literaturi, osim crnogorskoj, nacionalnu odrednicu za kulturno nasljeđe. On, dalje, smatra da 'IZ NAŠE ZAJEDNIČKE' književne riznice 's pravom može da uzima ko šta hoće'. To mu se već mora priznati kao čista nauka, mada se može desiti da neko to shvati kao šalu. Drugim riječima, djela nastala na crnogorskom tlu može da uzima i prisvaja 'ko hoće', samo ne Crnogorci! (...) Sa takvom 'dijalektikom' odista se nije lako sporazumjeti. I ja to ovdje neću pokušavati. Sagovornik je neprikladan za ozbiljan razgovor o temi koju nudi." ${ }^{3}$

Priređivačke aktivnosti Milorada Stojovića u tijesnoj su vezi s njegovim angažmanom u izdavačkome sektoru Grafičkoga zavoda. S pokretanjem

2 Jevrem Brković, „Ako se rodilo zdravo dijete zašto ćutimo ili o jednoj antilogičnoj antologiji“, Oko, Zagreb, br. 126, 13-27. siječnja 1977, str. 4.

3 Milorad Stojović, „'Neka uzima ko šta hoće'“, Oko, Zagreb, br. 127, 27. siječnja - 10. veljače 1977, str. 4. 
biblioteke-antologije crnogorske književnosti ${ }^{4}$ „Luča“, u okviru koje će od 1963. do 1987. godine biti publikovano 71 izdanje (od planiranih 100) iz oblasti crnogorske književnosti, a koju su osmislili i uređivali Milorad Stojović, Sreten Perović i Branko Banjević (na nekim izdanjima kao urednici su, uz pomenute, potpisani i Aleksije Obradović i Milo Kralj), percepcija crnogorske književnosti, njenoga identiteta, kontinuiteta i bogatstva, bitno je izmijenjena. Taj pionirski posao značio je ne samo prvi osmišljen projekat valorizacije i kritičke prezentacije crnogorskoga književnoga nasljeđa već i angažovanje svih raspoloživih snaga iz domena nauke o književnosti, kako u Crnoj Gori tako i u ondašnjoj Jugoslaviji. Tim delikatnim poslom uspjelo je decenijama, najprije kao glavni i odgovorni urednik, a nakon pada u političku nemilost kao urednik, rukovodio upravo Milorad Stojović.

Tek kad se sagleda nedavno publikovani izbor iz korespondencije Milorada Stojovića ${ }^{5}$, može se steći kompletnija slika o specifičnome duhovnom i kulturnom ambijentu šezdesetih i sedamdesetih godina XX vijeka. Ta bogata epistolarna građa svjedok je ne samo izdavačkih poduhvata, utemeljenja "Luče“ i drugih značajnih edicija, već i duhovne klime u kojoj se, uz poslovični oprez diktiran društveno-političkom svakidašnjicom, začinju ideje o dugoročnim, kapitalnim naučnim i kulturnim projektima, poput Enciklopedije Crne Gore, hrestomatije Crnogorska književnost u književnoj kritici, Istorije crnogorske književnosti i sl. Uredništvo i najbliži saradnici Grafičkoga zavoda te uprava ondašnjega Udruženja književnika Crne Gore postaju nukleus crnogorske kulturne i književne emancipacije, no taj krupni kulturni zamah zaustavljen je pojavom Bijele knjige 1973. godine, u kojoj će se kao „ideološki nepodobni“, pored nekoliko vodećih crnogorskih naučnih, kulturnih i književnih stvaralaca, obresti i urednici Grafičkoga zavoda. Već 1974. godine Grafički zavod je ugašen a njegova izdavačka djelatnost, u znatno smanjenom obimu, nastavljena u Pobjedi. Od početka 80-ih Biblioteka „Luča“ izgubiće kontinuitet izlaženja, pa će se umjesto 6 izdanja godišnje, kako je to od njenoga pokretanja bilo uobičajeno, svesti na svega 5 knjiga u intervalu od 1982. do 1987. godine, kad je objavljena i posljednja knjiga. Društveno-političke promjene koje su uslijedile onemogućile su njeno dalje izlaženje.

Šezdesete i sedamdesete godine XX vijeka period su stvaralačkoga zenita Milorada Stojovića. On ne samo da je jedan od pokretača književnoga života u Crnoj Gori, o čemu, pored njegovih uredničkih i priređivačkih aktivnosti svjedoči, recimo, i naslov koji je 1969. godine pripremio s Čedom Vukovićem i Radoslavom Rotkovićem, Građa i teze za razgovor o proble-

4 Biblioteka „Luča“ od 1975. godine nosila je podnaslov „Antologija crnogorske književnosti“".

5 Milorad Stojović, Pisali su mi, Izabrana djela, tom II, CID, Podgorica, 2012. 
mima crnogorske književnosti, već i neumorni književni povjesničar, koji nastoji da nadomjesti brojne propuste u tretmanu i vrednovanju crnogorskoga književnoga nasljeđa, da ispravi zablude i premosti lakune kojima obiluje tradicionalistička književna istoriografija, ali i da ponudi čvrste kriterijume revalorizacije književne baštine. Radovi kao što su „Prozno kazivanje Crne Gore“, „O periodizaciji crnogorske književnosti““, „Otpor kao utočište: o crnogorskoj poeziji od 1918.“, „Pogled na savremenu crnogorsku književnost“ i sl. svojevrsna su enciklopedijski precizna i vrijednosno utemeljena sinteza crnogorskoga književnoga iskustva i prvi pokušaji mnogostrukoga sagledavanja složenih literarnih pretpostavki koje tvore prekohiljadugodišnji identitet crnogorske književnosti.

Pored tih i drugih, parcijalnih, radova, od velikoga značaja za crnogorsku književnu istoriografiju je i Stojovićev priređivački rad. Počev od 1963. godine kad je u Biblioteci „Luča“, pod naslovom Sjaj legende, priredio izbor iz stvaralaštva Marka Miljanova, Stojović je priredio na desetine tomova izdanja iz crnogorske književnosti. Pored petotomnih Sabranih djela Marka Miljanova, objavljenih 1966. godine u izdanju Grafičkoga zavoda, priredio je izbore iz stvaralaštva Mirka Banjevića, Mihaila Vukovića, Aleksandra Lesa Ivanovića, Stevana Bulajića, Vojislava Vulanovića, Radovana Zogovića, dio ostavštine Nikole Lopičića te knjige Stanka J. Perunovića Likovi i karakteri Gorskog vijenca i Joksima Radovića Dobra nema đe ljudi nema: crnogorske narodne poslovice, izreke, klevete, blagoslovi (zajedno s B. Banjevićem). Bio je i jedan od saradnika na realizaciji antologija 100 romana književnosti jugoslovenskih naroda i 100 pjesnika književnosti jugoslovenskih naroda, koje je priredio Vlatko Pavletić.

Ipak, o Miloradu Stojoviću kao istoričaru književnosti cjelovit sud može se dati samo na osnovu njegovih autorskih knjiga iz te oblasti. S obzirom na prirodu njegova interesovanja, njegov stil i teorijski pristup, možda bi se preciznije moglo govoriti o jednoj knjizi, koja je nastajala u proteklih pet decenija. U osnovi te knjige bilo bi, zapravo, prvo njegovo posebno izdanje - zbirka studija i eseja iz 1968. godine Nadmoć ljudskosti. Već je rečeno da je njome Stojović zavrijedio najznačajnije crnogorsko državno priznanje, Trinaestojulsku nagradu. No i u uskostručnim krugovima ta je knjiga izazvala neobično veliku pažnju i gotovo jednodušnu pohvalu. Rijetke zamjerke nijesu se ticale njene metodološke i naučne utemeljenosti, već prepoznatljivog tradicionalističkog nemirenja pojedinih kritičara s njenom jasnom koncepcijom afirmacije crnogorske književnosti kao osobenoga književnoistorijskoga entiteta.

Posebno mjesto u krugu najužih interesovanja Milorada Stojovića pripada djelu Marka Miljanova Popovića. U razmaku od dvadesetak godina Stojović je priredio prvo petotomno izdanje Sabranih djela, a onda i jednoto- 
mna Djela toga pisca. Stojovićeva studija „Nadmoć ljudskosti: o djelu Marka Miljanova“ koja zauzima prološko mjesto knjige Nadmoć ljudskosti, a preštampavana je raznim povodima i u drugim publikacijama, nije samo prvi cjelovit književnoistorijski osvrt na djelo Marka Miljanova Popovića, već i kompleksna antropološka i idejno-estetska analiza društvenih pretpostavki u okviru kojih je to djelo i nastalo. Tradicionalističko svođenje Markova djela na plemensku dimenziju i ratnički svjetonazor, bilo u formi uzdizanja njegovih estetskih dometa bilo punog nipodaštavanja vrijednosti, u Stojovićevoj analizi dobilo je prvi i pravi kritički odgovor. Stojović pažljivom analizom temeljnih činilaca Markova pjevanja i mišljenja u njegovu djelu prepoznaje ponešto od „onih njegoševskih vidova i sinteza crnogorske epike i tragike“ i smatra ga specifičnim sublimatom etičke vrijednosti crnogorske tradicije. I u tekstu o Marku Miljanovu do izražaja dolazi, kako bi to rekao Krsto Pižurica, „konciznost izraza i ideal mjere estetskoga vrednovanja“, kao važna karakteristika stila Milorada Stojovića. Njegov tekst rasterećen je bespotrebnog verbalizma, kićenosti i glomazne teorijske aparature, i usmjeren na otkrivanje $i$ opis estetskoga fenomena i etičke dimenzije teksta.

Pisac kojem je Stojović posvetio posebnu pažnju je i pripovjedač Nikola Lopičić. Studija „Naš prvi moderni pripovjedač: o prozi Nikole Lopičića“, kao i publikovanje Lopičićevih neobjavljenih rukopisa, rezultat su Stojovićevih decenijskih napora da osvijetli lik i djelo Nikole Lopičića. Stojović je radio i na pripremi doktorske disertacije o djelu Nikole Lopičića, no njeno su finalizovanje onemogućile, u prvome redu, okolnosti njegova stalnog radnog angažmana u pozorištu. Prepoznavši u Lopičićevu pripovjednome opusu dragocjeni most između začetnika crnogorske proze Stefana Mitrova Ljubiše i savremenih Lalićevih proznih sinteza, Stojović njegovo djelo sagledava kao „potresan prolog jedne socijalno-moralno-psihološke drame“(V. Minić).

Stojovićeva knjiga Nadmoć ljudskosti svojom je koncepcijom otvorila prostor novom tumačenju i pozicioniranju crnogorske književnosti, koje će pogotovo tokom sedamdesetih i osamdesetih godina XX vijeka dobiti svoje puno opravdanje i književnoistorijsko utemeljenje knjigama Radoslava Rotkovića, Vojislava Nikčevića, Radoja Radojevića, Božidara Pejovića, Danila Radojevića, Vojislava Minića, Slobodana Tomovića, Sretena Perovića, Krsta Pižurice, Radomira Ivanovića, Slobodana Vujačića, Milorada Nikčevića i dr.

Izabrana djela Milorada Stojovića u dvije knjige, objavljena 2012. godine, donijela su nove vrijedne materijale za skiciranje portreta Milorada Stojovića u domenu književne montenegristike. Prva knjiga Izabranih djela, Tragom vremena, objedinila je Stojovićeve književnoistorijske, kritičke i teatrološke priloge i pružila najpotpuniju sliku njegovih istraživačkih interesovanja i stvaralačkih dometa. U njoj se nahodi većina radova objavljenih u 
Nadmoći ljudskosti, ali i značajan broj novih priloga, mahom kraćih eseja i prikaza, zapravo cjelovitih enciklopedijskih portreta pojedinih crnogorskih stvaralaca ili osvrta na njihovo djelo. Za književnu istoriju dragocjeno su svjedočanstvo i pisma, kako ona koje je Stojović slao drugima, tako i ona upućena njemu, objavljena u drugome tomu Izabranih djela. Ta su pisma u neku ruku hronika kulturnih i književnih zbivanja u Crnoj Gori šezdesetih, sedamdesetih i osamdesetih godina XX vijeka.

Neposredno pred smrt Stojović je pripremao za štampu knjigu svojih izabranih književnoistorijskih studija i ogleda koje će publikovati Fakultet za crnogorski jezik i književnost.

Milorad Stojović nije crnogorsku nauku i kulturu zadužio samo poslovima iz domena izdavačke djelatnosti, priređivačkim aktivnostima te književnokritičkim i teatrološkim radom, već i časnim i hrabrim djelovanjem na utemeljenju institucija i afirmaciji crnogorskoga nacionalnoga i državnoga identiteta. Kao član uprave Udruženja književnika Crne Gore Stojović je bio jedan od potpisnika „Saopštenja o jeziku“ kojim se tražilo ozvaničenje zasebne crnogorske jezičke varijante u okvirima ondašnjega standardnog jezika i protestovalo zbog koncepta jezičke unitarizacije nametnutoga Novosadskim dogovorom. Nije se stoga čuditi što je 1973. godine u Bijeloj knjizi izričito zahtijevano da se raspušti uprava Udruženja književnika Crne Gore. Stojović je bio i član Savjeta za standardizaciju crnogorskoga jezika i na tome je poslu pokazao dosljednost i apsolutnu posvećenost autentičnim crnogorskim nacionalnim vrijednostima.

U crnogorskoj književnoj istoriografiji Milorad Stojović prepoznatljiv je kao najbolji poznavalac i najposvećeniji proučavalac književnoga djela Marka Miljanova Popovića. Njegovi ogledi i studije o literaturi XX vijeka svojevrsna su neukoričena Istorija crnogorske književnosti XX stoljeća. Gotovo da nema značajnijega crnogorskoga pisca te epohe o kojemu nije pisao, bilo u formi cjelovitih književnoistorijskih sinteza, bilo kroz parcijalne oglede, prikaze ili osvrte na pojedine segmente njihova opusa. Stojović je, pored toga, uspostavljao neophodne kriterije vrednovanja, u književnu kritiku unosio duh objektivnoga i odmjerenoga pristupa tekstu, priređivao izbore iz djela i dragocjene antologije te svojim djelom uticao na formiranje svijesti o vjekovnome kontinuitetu i na definisanje kanona crnogorske književnosti. Time je Stojović zavrijedio posebno mjesto u krugu začetnika moderne književne montenegristike. 
Aleksandar RADOMAN

\section{In memoriam \\ MILORAD STOJOVIĆ \\ (1927-2015)}

In Montenegrin literary historiography, Milorad Stojović is recognized as the best and most dedicated connoisseur and researcher of literary works of Marko Miljanov Popović, while his essays and studies on the literature of the twentieth century are viewed as an unpublished History of Montenegrin Literature of the Twentieth Century. There are almost no significant Montenegrin writers of the epoch, whose work he did not analyze. In addition, Stojović has established the necessary criteria for the evaluation of literary works, brought the spirit of objective and restrained approach to the text in the literary criticism, and raised awareness about the centuries-long continuity and the definition of the canon of Montenegrin literature. This is how he earned a special place in the circle of the pioneers of modern literary Montenegristics.

Key words: Milorad Stojović, Montenegristics, history of literature, Montenegrin literature, Marko Miljanov Popović 

UDK 811.163.4'28(497.16):929

Vujičić D.

\section{Adnan ČIRGIĆ (Podgorica)}

Pregledni rad

Fakultet za crnogorski jezik i književnost - Cetinje

adnan.cirgic@fcjk.me

\section{DRAGOMIR VUJIČIĆ I CRNOGORSKA DIJALEKTOLOGIJA}

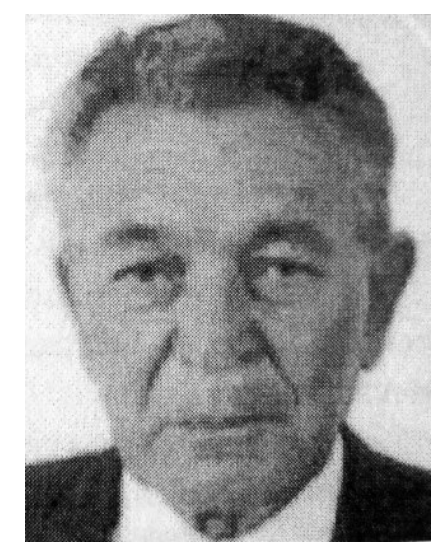

Autor ovoga priloga daje kratak osvrt na doprinos Dragomira Vujičića crnogorskoj dijalektologiji, ne ulazeći u leksikološka, leksikografska i onomastička pitanja kojima se bavio.

Ključne riječi: Dragomir Vujičić, dijalektologija, montenegristika

Crna Gora dala je više talentovanih lingvista koji su, uglavnom radeći i živeći izvan domovine, ostavili značajne rezultate prije svega u crnogorskoj dijalektologiji. Većina je sve svoje značajnije dijalektološke prinose posvetila crnogorskim govorima, a gotovo svi dali su i monografski opis jednoga od tih govora. O nekima od njih opširnije smo pisali na drugome mjestu. ${ }^{1}$ No ne treba zaboraviti ni one koji su ostavili značajne radove i o pojedinačnim pojavama u crnogorskim govorima. Jedan od takvih je i Dragomir Vujičić.

1 Viđeti: Adnan Čirgić, Dijalektolozi i crnogorski jezik, Zavod za udžbenike i nastavna sredstva, Podgorica, 2014. 
Osamdeset je godina od rođenja Dragomira Vujičića, crnogorskoga jezikoslovca čiji je život i rad uglavnom vezan za Sarajevo i za bosansko-hercegovačku dijalektološku problematiku. Rođen je 1935. godine u selu Šumatovac kod Žabljaka. Studirao je u Sarajevu, đe je 1959. godine diplomirao na Odsjeku za srpskohrvatski jezik i jugoslovenske književnosti. Najveći dio radnoga vijeka (1967-1992) proveo je u ANUBiH, đe je stekao i zvanje naučnoga savjetnika. Predstavljao je Dragomir Vujičić ANUBiH u Međuakademijskome odboru za dijalektološke atlase, Međuakademijskome odboru za onomastiku, Međuakademijskome odboru za leksikologiju i leksikografiju. Bio je rukovodilac projekta „Kompleksno ispitivanje bosansko-hercegovačkih govora“ pri Institutu za jezik u Sarajevu. Pet godina bio je i predśednik Odbora za jezik CANU, a pred kraj života i profesor na Filozofskome fakultetu u Nikšiću. Bibliografija mu zaprema 120 jedinica, mahom posvećenih bosansko-hercegovačkim govorima. ${ }^{2}$

Iako je, kako je rečeno, Dragomir Vujičić najznačajniji dio svojega dijalektološkog rada posvetio Bosni i Hercegovini, izvan njegovih interesovanja nije ostala Crna Gora i njena dijalektologija (u najširem smislu). Jedan dio svojih radova posvetio je crnogorskoj jezičkoj problematici, dijalektologiji, leksikologiji i onomastici. Ovaj se kratak osvrt odnosi isključivo na dijalektološke radove njegove. Većina tih radova sabrana je u knjizi Iz onomastike, leksikologije i dijalektologije (Unireks, Podgorica, 1996), koja je, kako sam autor u predgovoru ističe, objavljena na nagovor i podsticaj Branislava Ostojića.

Dvije su bitne razlike Dragomira Vujičića u odnosu na ostale crnogorske dijalektologe njegove i starije generacije. Crnogorski su govori za njega crnogorski. To je sasvim jasno iz svih njegovih studija. (Druga je stvar što je sve to posmatrao u okviru tzv. srpskohrvatskoga jezika i tzv. srpskohrvatske dijalektologije.) Tako recimo u tekstu naslovljenu Crnogorski govori istočnohercegovačkog tipa u svjetlu leksičkog materijala ${ }^{3}$ već u prvoj rečenici govore iz naslova precizno definiše kao sjeverozapadni crnogorski govori. I u cijelome ih tekstu naziva tako, a na jednome mjestu je sasvim decidan: ,„područje sjeverozapadnih crnogorskih govora, koji se nazivaju mlađim novoštokavskim ijekavskim govorima ili hercegovačkim..." Druga je njegova bitna razlika, ovim povodom manje zanimljiva, to što je značajnu pažnju posvetio

2 Biografski podaci dati su na osnovu nekrologa Miodraga Jovanovića: „Prof. dr Dragomir Vujičić (1935-1997)“, Riječ, III/1, Filozofski fakultet, Nikšić, 1997, str. 110-111. U nekrologu nije rečeno da li je Vujičićeva bibliografija objavljena, a mi je nijesmo mogli naći u Nacionalnoj biblioteci „Đurđe Crnojević“ na Cetinju.

3 Dragomir Vujičić, „Crnogorski govori istočnohercegovačkog tipa u svjetlu leksičkog materijala“, Iz onomastike, leksikologije i dijalektologije, Unireks, Podgorica, 1996, str. $175-182$. 
dijalektalnoj leksici, semantici i sintaksi, odnosno kako sam kaže „tvoračkoj snazi“ narodnih govora: „Nije se“, kaže Vujičić, ,ili ne sasvim dovoljno, ulazilo u suštinu onih najrazličitijih jezičkih sredstava kojima se običan čovjek zna vrlo umješno poslužiti da bi se izbjegle homonimnosti i da bi se označilo, odnosno imenovalo ono što se želi označiti, imenovati, kazati. Potrebno je marljivo slušati govor i govorenje, potrebno je barem približno sagledati onu širinu i bogatstvo frazeologizama, i onih ustaljenih i onih što odjedanput bljesnu i iznenade svježinom, jedrinom i originalnošću. "“4 Ili u vezi s leksičkim bogatstvom crnogorskih govora: „U stvari, u koju se god oblast djelatnosti zađe, uvijek se dolazi u situaciju da se sluša gotovo jedno razmetanje leksičkim blagom kakvo se rijetko na drugim područjima može sresti. Tamo se (u $\mathrm{CG}$ - prim. A. Č.) vrlo često može čuti da čovjek kaže: 'Pa ne kaže se to tako, to ima svoje ime' - ili će se reći: 'A znate li kako se zove to?"“5

Iz crnogorske dijalektološke problematike u pomenutu je Vujičićevu knjigu unijet i tekst o odnosu jezika Vuka Stef. Karadžića prema drobnjačkome govoru, kao govoru stare Karadžićeve postojbine, ${ }^{6}$ đe autor donosi zanimljive i logične stavove o Karadžićevu jeziku, tršićkome i drobnjačkom govoru, suptilno polemišući i s autoritetima kakav je bio Pavle Ivić. Takav je i tekst o upotrebi imperfekta i aorista u durmitorskome govoru, đe opet suptilno koriguje zaključke i građu Jovana Vukovića, zemljaka i starijega kolege i profesora iz Sarajeva. Ne ulazeći u interpretaciju teorijske rasprave o upotrebi imperfekta i aorista u crnogorskim govorima, ovđe ćemo navesti samo Vujičićevo dovođenje u sumnju primjera kojima se u literaturi ilustruje upotreba ta dva glagolska oblika u durmitorskome govoru, jer će to najbolje pokazati koliko je on zapravo bio upućen u crnogorsku dijalektologiju. A upravo je to, navođenje primjera za ilustraciju pojedinih dijalekatskih pojava jedna od većih boljki naše dijalektologije, na što je više puta skrenuo pažnju Vukić Pulević u svojim onomastičkim studijama. ${ }^{7}$ Tako Vujičić zapaža: „Tako, na primjer, nama su, po prirodi stvari, neprirodni Vukovićevi oblici: 'malo prije kosiše ljudi dolje u polju', - ili: 'malo prije razgovaraše naši ljudi o kosidbi', jer podvučeni oblici ovdje su mogli doći samo u imperfektu. Isto tako, neprirodna su nam i poređenja konstrukcija: pasijagu ovce u brdu i malo prije pasijagu ovce gore u brdu, jer će se samo u nekim prilikama, uz naknadno pitanje (Kad? - Malo prije...), durmitorski čovjek poslužiti priloškom odredbom, što

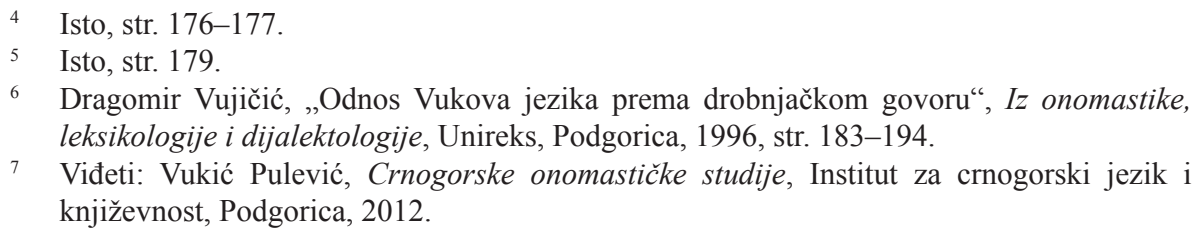

7 Viđeti: Vukić Pulević, Crnogorske onomastičke studije, Institut za crnogorski jezik i književnost, Podgorica, 2012. 
je ipak nešto drugo. (Navedena konstatacija mogla bi važiti i za cijelu Crnu Goru - prim. A. Č.) Ni ona druga upoređivanja s aoristom nisu takođe mnogo prirodna i adekvatna: 'Šta radiše oni tamo (...)? Siđeše i piše kavu'. Jer, toga nema u govorima, barem ne u onim koje mi poznajemo..." ${ }^{\text {"8 }}$

I još je po nečemu Dragomir Vujičić bio izuzetak od ostalih crnogorskih lingvista. Bio je jedini jezikoslovac u Crnoj Gori koji je sarađivao s Vojislavom P. Nikčevićem, od kojega su ostali, što zbog filološkoga tradicionalizma što iz drugih razloga, zazirali ili s njime nerijetko i neakademski polemisali. Kao potvrda za tu saradnju stoji Vujičićev tekst „Prilog proučavanju oaze starocrnogorskog govora na području istroromanskog jezika (na predlošku građe Josipa Ribarića, Branka Miletića i drugih - susreti i komparacije) ${ }^{\text {‘9 }}$ u kojemu na samome početku zahvaljuje Vojislavu P. Nikčeviću na podacima vezanim za iseljavanje Crnogoraca u Peroj. Ta studija nije plod terenskih ispitivanja niti donosi novu građu. Ona je plod komparativne analize građe koju je skupio Josip Ribarić s onom koju su publikovali Branko Miletić u monografiji o crmničkome govoru i Radosav Bošković \& Mječislav Malecki u pregledu „dijalekata Stare Crne Gore“. Ne smije se smetnuti s uma da je teško raditi bilo kakvo vjerodostojnije poređenje perojskoga govora s crnogorskim govorima jer su monografije o crnogorskim govorima odraz stanja u XX vijeku, a perojski je govor izgubio kontakt s maticom polovinom XVII vijeka - dovoljno dugo da neke današnje perojske osobine budu izgubljene u matici. Uostalom, odavno je poznato da dijalekatska periferija bolje čuva starije stanje, a perojski govor u datome slučaju ima sličan položaj. U svakome slučaju, ovđe Vujičićevu studiju o perojskome govoru ne navodimo samo kao potvrdu raznovrsnosti njegovih interesovanja no i kao pokazatelj da je u nauci sarađivao i s onima koji su bili nosioci zvanično nepoželjnih ideja, kakav je bio Vojislav P. Nikčević.

U vezi s time vrijedi pomenuti još jedan njegov značajan rad, iz oblasti crnogorske dijalektologije svakako najznačajniji. To je Vujičićev referat koji je izložen na skupu Crnogorski govori 1983. u Crnogorskoj akademiji nauka i umjetnosti u Titogradu (Podgorici) - „Jedan opštiji pogled na rezultate dosadašnjih ispitivanja crnogorskih govora“ ${ }^{10} \mathrm{~S}$ naučnom skromnošću i bez

8 Dragomir Vujičić, ,Neka zapažanja u vezi s upotrebom imperfekta u današnjem durmitorskom govoru“, Iz onomastike, leksikologije i dijalektologije, Unireks, Podgorica, 1996, str. 195-199.

9 Dragomir Vujičić, „Prilog proučavanju oaze starocrnogorskog govora na području istroromanskog jezika (na predlošku građe Josipa Ribarića, Branka Miletića i drugih - susreti i komparacije)“, In: Josip Ribarić, O perojskom govoru (leksikografski prinosi), Građu prikupio i priredio Milorad Nikčević, Osijek, 2004, str. 173-183.

10 Dragomir Vujičić, „Jedan opštiji pogled na rezultate dosadašnjih ispitivanja crnogorskih govora“, Iz onomastike, leksikologije i dijalektologije, Unireks, Podgorica, 2006, str. 200-215. Objavljen je i u zborniku Crnogorski govori, CANU, Titograd, 1984. 
pretenzija da iznosi kvalifikacije o studijama o crnogorskim govorima Dragomir Vujičić naveo je bezmalo sve značajnije radove o toj problematici od prvih sistematskih ispitivanja (tj. od rada Milana Rešetara) pa do 80-ih godina $\mathrm{XX}$ vijeka. Opet za razliku od ostalih crnogorskih jezikoslovaca, osobito onih koji su učestvovali na tome skupu, on nije preskočio da ravnopravno spomene i one koji svoje stavove nijesu na tome skupu mogli iznijeti, kakvi su bili recimo Radoslav Rotković i Vojislav P. Nikčević, čije studije nijesu bile čak ni iz oblasti crnogorske dijalektologije no iz istorije jezika, što i nije bilo direktno u vezi s temom. Za tu priliku naveo je Rotkovićevu studiju Tragajući za Ljubišom (Pobjeda, Titograd, 1982), a Nikčevićeve radove nije posebno navodio nego je samo naznačio da je riječ o radovima ,o narodnom jeziku u crnogorskoj književnosti različitih perioda“" ${ }^{\text {"s1 }}$ što je bila čak i hrabrost jer je riječ o Nikčevićevim radovima objavljenima u zagrebačkoj Kritici i Jeziku, koji su izazvali pravu lavinu polemika s pojedinim srpskim lingvističkim autoritetima, kakav je bio Pavle Ivić, što je bio učesnik i na tome skupu.

Na kraju još i ovo. Dragomir Vujičić bio je jedini učesnik na tome skupu koji je bez poruge i otpora spomenuo eventualnu standardizaciju crnogorskog „književnojezičkog izraza na temelju povezivanja njegovog s crnogorskim dijalekatskim izrazom. Naravno i o tome se smireno i naučno može

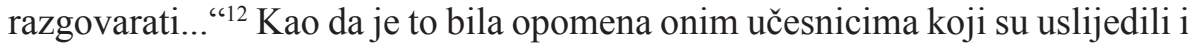
koji su nastojali obesmisliti svaki pokušaj crnogorske jezičke standardizacije. Dragomir Vujičić zaslužuje znatno širi osvrt od ovoga, osvrt koji bi morao obuhvatiti njegove radove iz oblasti crnogorske leksikologije, osobito dijalekatske, te radove iz oblasti crnogorske onomastike. Do tada neka ovaj osvrt bude samo podśećanje na njega, a povodom osamdesete godišnjice rođenja.

\section{Literatura}

- Čirgić, Adnan: Dijalektolozi i crnogorski jezik, Zavod za udžbenike i nastavna sredstva, Podgorica, 2014.

- Jovanović, Miodrag: „Prof. dr Dragomir Vujičić (1935-1997)“, Riječ, III/1, Filozofski fakultet, Nikšić, 1997, str. 110-111.

- Pulević, Vukić: Crnogorske onomastičke studije, Institut za crnogorski jezik i književnost, Podgorica, 2012.

- Vujičić, Dragomir: „Crnogorski govori istočnohercegovačkog tipa u svjetlu leksičkog materijala“, Iz onomastike, leksikologije i dijalektologije, Unireks, Podgorica, 1996, str. 175-182.

11 Isto, str. 209.

12 Isto, str. 200. 
- Vujičić, Dragomir: „Jedan opštiji pogled na rezultate dosadašnjih ispitivanja crnogorskih govora“, Iz onomastike, leksikologije i dijalektologije, Unireks, Podgorica, 2006, str. 200-215.

- Vujičić, Dragomir: „Neka zapažanja u vezi s upotrebom imperfekta u današnjem durmitorskom govoru“, Iz onomastike, leksikologije i dijalektologije, Unireks, Podgorica, 1996, str. 195-199.

- Vujičić, Dragomir: „Odnos Vukova jezika prema drobnjačkom govoru“, Iz onomastike, leksikologije i dijalektologije, Unireks, Podgorica, 1996, str. 183-194.

- Vujičić, Dragomir: „Prilog proučavanju oaze starocrnogorskog govora na području istroromanskog jezika (na predlošku građe Josipa Ribarića, Branka Miletića i drugih - susreti i komparacije)“", In: Josip Ribarić, $O$ perojskom govoru (leksikografski prinosi), Građu prikupio i priredio Milorad Nikčević, Osijek, 2004, str. 173-183.

\section{Adnan ČIRGIĆ}

\section{DRAGOMIR VUJIČIĆ AND MONTENEGRIN DIALECTOLOGY}

The author of the present paper makes a short reflection on the contribution of Dragomir Vujičić to Montenegrin dialectology, avoiding the discussion of lexicological, lexicographic and onomastic issues he dealt with.

Key words: Dragomir Vujičić, dialectology, Montenegristics 
UDK 811.163.4'373.2:929

Džogović A.

\section{Novica VUJOVIĆ (Nikšić)}

Pregledni rad

Fakultet za crnogorski jezik i književnost - Cetinje novica.vujovic@fcjk.me

\section{ALIJA DŽOGOVIĆ ONOMASTIČAR}

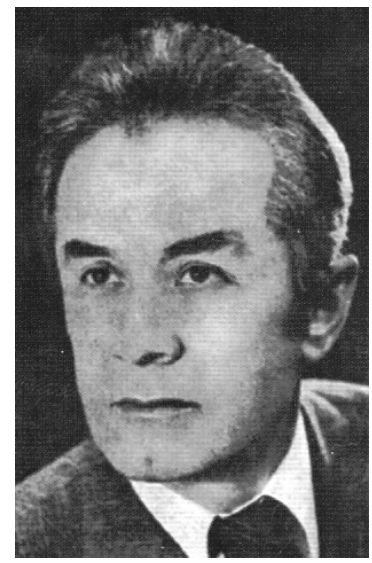

Rad ima za cilj da predstavi najznačajnije onomastičke radove Alije Džogovića i da ukaže na njegov doprinos crnogorskoj onomastici.

Ključne riječi: Alija Džogović, onomastika, crnogorski jezik

Montenegristika čuva uspomenu na Aliju Džogovića, crnogorskoga naučnika koji je višedecenijskim radom ostavio vrijedne onomastičke i dijalektološke priloge.

U osnovnim biografskim podacima nalazimo i ovo. Alija Džogović je rođen 1929. godine u Lahoru (Bijelo Polje). Diplomirao je 1955. na Filozofskom fakultetu u Beogradu. Radio je kao novinar, pisao eseje, bavio se dijalektologijom i onomastikom (više od pet stotina bibliografskih jedinica). Njegov dar za bilježenje i analizu onomastičkog materijala došao je do izražaja tokom saradnje sa Srpskom akademijom nauka i umetnosti kada je prikupljao nazive s prostora Kosova i Metohije. Zapažen je Džogovićev rad na publikovanju i tumačenju usmenih književnih tvorevina, a i sam je pisao umjetničke tekstove i objavio nekoliko knjiga poezije. Bio je član Bošnjačke akademije nauka i umjetnosti. 
Danas, dakako, s velikom sigurnošću treba reći da je Alija Džogović dao značajan doprinos razvoju crnogorske i jugoslovenske onomastike. Spomenućemo nekoliko studija i priloga, no prije svih vrijedi pohvaliti njegovu saradnju s časopisom Almanah. U Almanahu izlaze i ovi Džogovićevi radovi: „Porijeklo i značenje nekih toponima“,, „Toponomastika turskog porijekla i njena prilagođenost u sistemima južnoslovenskih jezika“, ${ }^{2}$, ,Šta nije a šta jeste u toponomastici“‘3 $\mathrm{i}$ dr.

$\mathrm{U}$ prilogu „Toponomastika turskog porijekla i njena prilagođenost $\mathrm{u}$ sistemima južnoslovenskih jezika“ Alija Džogović objašnjava karakter i motive imenovanja u periodu kad su Turci držali ove prostore. Dolaskom na ove prostore Osmanlije zatiču toponomastičku leksiku iz starobalkanskoga nasljeđa (tj. grčko-vizantijsku, ilirsku s elementima tračke i keltske i romansku) i jezički sloj slovenskoga porijekla. Osmansko društvo bilo je tolerantno, odnosno bez nacionalističkih zastranjivanja kakvih je bilo $\mathrm{u}$ istoriji prije turskih osvajanja i poslije njih, a takođe, zaključuje dalje Džogović, poštovana je kultura, tradicija i jezik pokorenih naroda. „Turci nijesu mijenjali stare (naslijeđene) nazive mjesta, kao što su to poslije njih činili drugi balkanski narodi. Starim toponomastičkim likovima oni su, po zakonitostima svoga jezika, dodavali samo relevantne morfološke strukture (finalna pozicija, kompozitni oblici, prefiksi i afiksi, atributivne lekseme) i fonetski ih modificirali prema duhu svoga jezika. “4 Baveći se rečenom temom autor je priložio i znatan broj toponima, među kojima su i primjeri vrijedni crnogorskim onomastičarima.

Konstatovano je da oni koji imenuju - ne griješe. Ne griješe zbog toga što je „,motivacija bila posljedica iskustva i sadržaja života, analoške metaforične slikovnosti, pa je iz jezika ulazila u pripovijednu usmenu kreaciju i folklor kao predanje, skaska, a često i kao bajkovita pripovijest. (...) U njihovom jezičkom sistemu ta imena imala su odgovarajuću funkciju i strukturu, u njima ništa nije bilo proizviljno i neadekvatno prirodnom sadržaju nekog reljefa. “"

U radu „Šta nije a šta jeste u toponomastici“ objašnjeni su i neki crnogorski toponimi. Toponim Rožaje pripada grupi primjera s bazom rog-za koju autor veli da je ilirskoga porijekla te da su zasvjedočene šrom Balkana. „Na mnogim

Alija Džogović, „Porijeklo i značenje nekih toponima“, Almanah, br. 27-28, Podgorica, 2004.

2 Alija Džogović, Toponomastika turskog porijekla i njena prilagođenost u sistemima južnoslovenskih jezika“, Almanah, br. 33-34, Podgorica, 2006, str. 127-145.

3 Alija Džogović, „Šta nije a šta jeste u toponomastici“, Almanah, br. 53-54, Podgorica, 2012, str. 13-47.

4 Alija Džogović, Toponomastika turskog porijekla i njena prilagođenost u sistemima južnoslovenskih jezika“, Almanah, br. 33-34, Podgorica, 2006, str. 145.

5 Alija Džogović, „Šta nije a šta jeste u toponomastici“, Almanah, br. 53-54, Podgorica, 2012, str. 13. 
terenima prokletijskog planinskog sistema, prilikom onomastičkih istraživanja, evidentirali smo veliki broj lokaliteta čiji je naziv Roge. To su alpske ledine i proplanci, kao oni oko Ibra, pa se sa sigurnošću može reći da je u osnovi toponimske strukture Rožaje apelativ roge. “6 Naziv Berane, ,izvodi se iz morfema bi + vrahos, čije je značenje voda i kamen, izvor u kamenu“". Toponim je grčkog porijekla, vremenom je slaviziran i prilagođavan govoru stanovnika.

Takođe, objašnjavajući postanak naziva Crčevo (selo kod Novog Pazara), autor daje korisne podatke o strukturi čevo u čijem je semantičkom polju „prisustvo kamena, krševitih strana i litica“ ${ }^{\text {“ }} \mathrm{i}$ koju smješta u inventar predslovenskoga leksičkog fonda. Pomenuti zaključak možemo uzeti kao utemeljen s obzirom na to da istoimena plemenske oblast (Čevo), odnosno selo nadomak Cetinja, naziv najvjerovatnije vezuje za taj elemenat. Potvrđena je ne samo u ovom slučaju, već u znatnom broju toponimskih struktura širom Balkanskog poluostrva. ${ }^{9}$ Analizira Džogović oronim Lovćen i veli da je naziv ilirskoga porijekla te da ga je pravilno vezati za brojna jezera na tom području, odnosno istraživače podśeća da u albanskome jeziku liqen // liqeni znači jezero. ${ }^{10}$ Ilirsko-grčki supstrat Džogović ne isključuje kada se bavi porijeklom toponima Neguše//Njeguše. „Po motivisanosti i etimološkoj logici nazivu mjesta Neguše//Njeguše prethodio je naziv rječice ili sličnog toka vode. (...) U leksičkoj strukturi ovih horonima i hidronima prepoznatljiv je apelativ guša, sa značenjem grlo, tijesnac kroz koji protiče voda. "“11 Hidronim i ojkonim Bistrica može se izvesti iz keltske, odnosno ilirske strukture. Potiče, dakle, iz predslovenske jezičke epohe, a ,izoglosa ovoga hidronima potvrđena je u prostoru između između Alpa, Tatra, Rodopa i Mediterana na kojima su boravili Kelti, Iliri, Goti..."..12

Autor je pokušao doprinijeti rasvjetljavanju zatamnjenoga porijekla toponima Crhalj (Bihor). Alija Džogović upućuje na crvenkastu boju terena i, uz to, odbacuje mogućnost izvođenja naziva od posesiva „srpski“13. Za Laholo, selo kod Bijelog Polja, dato je objašnjenje koje toponim ne vezuje

Alija Džogović, n. d., str. 17.

Alija Džogović, n. d., str. 43.

8 Alija Džogović, n. d., str. 15. Dodajmo ovđe da isti zaključak Džogović nudi kada ispituje formant - $\check{\mathbf{c}} / /$-oč, isto tako -ič // -ě - „upućuje na na prisustvo kamena na ovom terenu“ i navodi primjere: $B i$-oč- $a, G$-oč, Gori-oč, Por-oč-e itd. Rečeno možemo i mi potvrditi na primjeru toponimije čevskih sela.

9 Viđeti: Alija Džogović, n. d.

10 Viđeti: Alija Džogović, n. d., str. 22.

11 Alija Džogović, „Porijeklo i značenje nekih toponima“, Almanah, br. 27-28, Podgorica, 2004, str. 76.

12 Alija Džogović, n. d., str. 23.

13 Isto, str. 15. 
za „slovenski eho: hol-hol“"14, već da u strukturi naziva Laholo stoji etnik Vlah. Oronim Bjelasica takođe se naslanja na jezičke tragove iz perioda prije Slovena, tj. „dobijeno je od bi-lisa (lisa - neprohodna šuma, šuma straha i nepoznatosti, sa vododerinama i potocima). Sekvenca bi- upućuje na prisustvo vode na planinskim predjelima. Vrlo je frekventna u strukturama hidronima i oronima na Balkanu." ${ }^{\text {"15 }} \mathrm{U}$ toponimu Kovran prepoznaje se sekvenca kov- koja „upućuje na karakteristike reljefa (bregovi krševitog sastava)“. ${ }^{16}$

Dragocjen je i Džogovićev zaključak koji se tiče toponima Paśi vrh i Koźi brijeg (kod Džogovića Pas'i vrh, Koź i brijeg), odnosno fonema ś i ź u kojima su zasvjedočeni - „Ove toponimske strukture vrlo su stabilne u govoru lokalnog stanovništva“. ${ }^{17}$ Dodajmo ovđe i to da su strukture o kojima govori Alija Džogović stabilne u svim govorima crnogorskoga jezika.

Više puta je Alija Džogović objavljivao u Onomatološkim prilozima, renomiranom onomastičkom časopisu Srpske akademije nauka i umetnosti. Ne smetnimo s uma da su iza toga časopisa uvijek stajali istaknuti srpski lingvisti, te saradnju s Onomatološkim prilozima takođe vrijedi istaći kao značajan dio Džogovićeve naučne biografije. U tom časopisu našao se rad „Toponimija jugoslovenskog dela Prokletija“"18. Svojevrsni nastavak proučavanja toponimije Prokletija čini prilog „Onomastika severoistočnih ogranaka Prokletija“19. Džogović je obuhvatio veliku planinsku oblast, a kao istraživač usmjeren je na toponime u dijelu đe nije bilo stalnih naselja (,južni tereni ove oblasti“), dok je na ostalom prostoru bilježio i antroponime. U sakupljenom materijalu autor prepoznaje starije leksičke slojeve, međutim, kako sam uočava, zasvjedočeni su i „mlađi leksički slojevi“. Džogović konstatuje da su „forme slovenskog porekla (su), pored ostalog, dominantne“", kao i da je osnovna karakteristika „albansko-slovenska simbioza“ $u$ ispitivanim primjerima. Dodajmo i to da je znatan broj informatora Džogoviću saopštio predanje o porijeklu prema kojem njihova porodica vodi porijeklo iz Crne Gore.

U radu „Onomastika Dečana i okolnih sela“20 predstavljena je građa $\mathrm{s}$ prostora Dečana, Crnobrega, Loćana, Drenovca, Prilepa i Rastavice, kao i ono-

14 Isto, str. 16.

15 Isto, str. 26.

16 Isto, str. 35.

17 Isto, str. 28.

18 Alija Džogović, „Toponimija jugoslovenskog dela Prokletija“, Onomatološki prilozi, knjiga IV, Srpska akademija nauka i umetnosti, Beograd, 1983.

19 Alija Džogović, „Onomastika severoistočnih ogranaka Prokletija“, Onomatološki prilozi, knjiga VII, Srpska akademija nauka i umetnosti, Beograd, 1986.

20 Alija Džogović, „Onomastika Dečana i okolnih sela“, Onomatološki prilozi, knjiga VI, Srpska akademija nauka i umetnosti, Beograd, 1985. 
mastički materijal Pobrđa i Vokše u kojima 1977. godine, kad je Džogović obavljao ispitivanje, nije bilo „stanovništva čiji je maternji jezik srpskohrvatski“.

Alija Džogović je proučavao onomastičku građu planinske oblasti južno od Prizrena (,Onomastika Gore“"21). Kako se navodi u radu, u periodu kad je ispitivan taj dio današnje Republike Kosovo stanovnici su se „nacionalno deklarisali kao Muslimani“", dok su Srbi i Crnogorci (prema popisu iz 1981. godine) činili manju grupu radnika i službenika ,i to uglavnom u gradskom naselju Dragaš‘،. Zabilježena su brojna predanja o doseljavanju, narodna objašnjenja nekih naziva, a sva građa predstavljena je po naseljenim mjestima, ukupno osamnaest.

Crnogorskim naučnicima je, vrijedi i to upamtiti, najdragocjenija Džogovićeva monografija Onomastika plavsko-gusinjske dijalekatske oblasti. ${ }^{22}$ Autor se $\mathrm{s}$ velikom motivacijom usmjerio na śeveroistočni dio Crne Gore, konkretno na predio ispod Prokletija - gradove Plav i Gusinje s okolinom. Njegov rad na prikupljanju i obradi toponima i antroponima toga dijela naše države trajao je dvanaest godina, od 1988. do 2000. godine. Istraživana je oblast „,alpskog tipa“ s visokim vrhovima Prokletija, Plavskim jezerom i brojnim rijekama i potocima (Komorača, Đurička rijeka, Ljuča sa Vrujom, Grnčar i dr.).

Jasno je da su taj prostor i život ljudi koji ga nastanjuju višestruko odredili masivi Prokletija. O tome Alija Džogović govori iscrpno, pominjiću nekoliko naziva koje su narodi i plemena kroz istoriju, tj. od antičkih vremena, koristili da imenuju Prokletije. Zabilježeni su ovi nazivi: Monti Almoa, zatim Monti Beriseldi i samo Beriseldi, dok u XIX vijeku živi naziv Južne Alpe // Albanske Alpe. Džogović navodi da kod Vuka Karadžića postoji naziv Proklete planine // Prokletije ,(kako ih naziva stanovništvo slovenskog porijekla)“. ${ }^{23}$ Za Karadžićev oblik Srebrenica konstatuje se da je „,bila Vuku pogrešna informacija jer planine sa ovim imenom nema nigdje na Prokletijama, već se jedna planina zapadno od Rožaja naziva Bisernica“، ${ }^{24}$ Albanci za Prokletije imaju naziv Bjeshka e Nemna, što možemo prevesti kao proklete planine.

Kao što rekosmo, prostor oko Plavskoga jezera i Prokletija od najranijih vremena je naseljen, te je utemeljen Džogovićev zaključak da „današnji fond toponima posjeduje bogate supstratne resurse“ ${ }^{25}$ Džogović poseže

\footnotetext{
21 Alija Džogović, „Onomastika Gore“, Onomatološki prilozi, knjiga XII, Srpska akademija nauka i umetnosti, Beograd, 1996.

22 Alija Džogović, Onomastika plavsko-gusinjske dijalekatske oblasti, Almanah, Podgorica, 2009.

23 Isto, str. 8 .

24 Isto.

25 Isto, str. 9.
} 
za legendama, predanjima a nekad i prikupljenim laičkim tumačenjima te tako ulazi u etimološku sliku naziva svjestan činjenice da neki naši pokušaji, uprkos uloženom naporu, ipak ostaju samo interesantne ,etimološke pretpostavke“. Postoji mišljenje da je naziv Plav nastao prema imperatoru Flavijusu (Plavijus). Nauka, međutim, ovđe nije pokazala saglasnost, ali svakako ne treba smetnuti s uma da na tom području postoje ostaci popločanih puteva, mostova i utvrđenja iz antičkoga perioda. Tumači navode antroponim Plava, plavu vodu jezera, kao i poplave kao motivatacionu podlogu s koje je pošlo imenovanje u ovom primjeru.

Za izvođenje naziva Gusinje Džogović veli da je te prostore naseljavalo ilirsko pleme Piruste/i i s njim u vezi je naziv „Geusis (ime mjesta u uvali), pa je, vokalskom supstitucijom kasnije formiran lik Gusinje (na alb. je Gusis; ilirska vokalska sekvenca eu supstituisala se u vokal $\mathbf{u}$; po modelu Beusis = Buzet, Teuton $=$ Tutin i sl.). ${ }^{26}$

Hidronim Lim Alija Džogović povezuje sa strukturom „Ljuma (alb. rijeka) ${ }^{\text {“27 }}$ koja potiče iz starobalkanskoga fonda.

Uz građu sakupljenu na terenu ponuđeni su podaci s popisa stanovništva iz 1981. godine, te na osnovu toga imamo predstavu o zastupljenosti Muslimana, Albanaca, Crnogoraca, Srba, Hrvata i dr. na tom području.

Alija Džogović je na osnovu sabranih i analiziranih onomastičkih materijala ponudio i nekoliko zaključaka o govoru toga dijela Crne Gore. Pomenuta monografija je „od posebnoga značaja za crnogorsku dijalektologiju i osobito onomastiku". ${ }^{28} \mathrm{~S}$ obzirom na to da taj dio Crne Gore nije detaljnije dijalektološki ispitivan, ,vrlo je značajno što je on ovoj građi (i toponomastičkoj i antroponimskoj) pristupio prije svega kao dijalektolog. Mislim prije svega na bilježenje većine glasovnih pojava vezanih za plavsko-gusinjski kraj, a koje se lijepo očituju u objavljenoj građi. (...) Objavljivanjem građe poput one koju je sakupio i publikovao Alija Džogović stvoriće se uslovi za opis zajedničkih jezičkih karakteristika pripadnika islamske populacije u Crnoj Gori. Budući da takve osobine, kao uostalom i brojne druge osobine narodnih govora, sve više nestaju usljed ubrzane urbanizacije, rad Alije Džogovića na njihovu sakupljanju dobija još veću vrijednost. “29 Istaknute su specifičnosti govorne zone i objašnjen njen odnos sa suśednom ,gornjovasojevićkom govornom zonom“. „Te se razlike i specifičnosti najprije odnose na fonološki i fonetski sistem, leksički sistem, kao i na sintaksičke strukture. Ipak, međusobnih utjecaja ima

26 Isto, str. 9-10.

27 Isto, str. 10.

28 Adnan Čirgić, „Alija Džogović, 'Onomastika plavsko-gusinjske dijalekatske oblasti'“, Almanah, br. 48-49, Podgorica, 2010, str. 325.

29 Adnan Čirgić, n. d., str. 326. 
u sistemu govornih kontakata, gdje se u kontekstu sociolingvistike ovi odnosi manifestuju i žive u simbiozi i toleranciji. “630

Autor je pošao od činjenice da su toponimi građa ,primarnija u odnosu na antroponimiju“"31 te, s obzirom na to, prikupljeni onomastički fond Plava i Gusinja podijeljen je tako da se u prvom tomu našla toponimija, a za drugu knjigu Džogović veli da je ,u rukopisu“ i u njoj će se naći prezimena, lična imena, hipokoristici i nadimci.

Ime Alije Džogovića spominje se bezmalo u svim većim onomastičkim projektima u bivšoj Jugoslaviji. Bio je neumorni tragalac za izvornim oblicima koji čuvaju slojeve istorije, kulture i svakodnevnoga života nataložene u toponomastičkoj građi. U taj posao ulazio je smjelo, odlučno i argumentovano. Takođe, mnogo je hvaljen veliki trud i talenat Alije Džogovića uložen u afirmaciju, objavljivanje i tumačenje kulturnih sadržaja iz bošnjačke kulture i tradicije.

Na kraju, vrijedi uzeti kao primjer Džogovićevu istrajnost i pošten odnos prema građi koju proučava. On je lako prepoznavao vannaučnu motivaciju, stoga i veli: ,i u onomastici, kao i historiji, uvijek je bilo falsifikata, najčešće namjernih i zlonamjernih. U novije vrijeme falsifikati su postali strategija pojedinih učenih ljudi, nekih institucija, nekih političkih subjekata i režimskih projekata. Ta euforija proisticala je iz mašte nacionalista i njihovih namjera da izbrišu sa mape starih kultura sve što su stvarali oni prije njih. “32 Tako je ovaj naučnik, između ostaloga, veoma precizno locirao neke od problema s kojima se suočavala montenegristika.

Budući da je najmlađa grana slavistike te da se i dalje srijeće s brojnim teškoćama različite prirode, montenegristika s posebnom pažnjom mora brinuti o svima čije naučne rezultate baštini. Uza sve to, naša je potreba i objavljivanje knjiga i priloga, koji su zbog toga što se bave rasvjetljavanjem nekih pitanja jezičkoga i književnoga identiteta Crnogoraca tokom proteklih decenija zanemarivani ili zabranjivani. Neka i ovaj trenutak śećanja i zahvalnosti plodnome naučniku Aliji Džogoviću bude prilika da još jednom ukažemo na neophodnost upoznavanja novih generacija s bio-bibliografijama najznačajnijih istraživača crnogorskoga jezika i književnosti.

30 Alija Džogović, Onomastika plavsko-gusinjske dijalekatske oblasti, Almanah, Podgorica, 2009, str. 10.

31 Isto, str. 12.

32 Alija Džogović, „Šta nije a šta jeste u toponomastici“, Almanah, br. 53-54, Podgorica, 2012, str. 13. 


\section{Literatura}

- Čirgić, Adnan: „Alija Džogović, Onomastika plavsko-gusinjske dijalekatske oblasti“" (prikaz knjige), Almanah, br. 48-49, Podgorica, 2010.

- Džogović, Alija: „Šta nije a šta jeste u toponomastici“, Almanah, br. 53-54, Podgorica, 2012, str. 13-47.

- Džogović, Alija: „Porijeklo i značenje nekih toponima“, Almanah, br. 27-28, Podgorica, 2004.

- Džogović, Alija: „Toponomastika turskog porijekla i njena prilagođenost u sistemima južnoslovenskih jezika“, Almanah, br. 33-34, Podgorica, 2006, str. 127-145.

- Džogović, Alija: Onomastika plavsko-gusinjske dijalekatske oblasti, Almanah, Podgorica, 2009.

- Džogović, Alija: „Toponimija jugoslovenskog dela Prokletija“, Onomatološki prilozi, knjiga IV, Srpska akademija nauka i umetnosti, Beograd, 1983.

- Džogović, Alija: „Onomastika Dečana i okolnih sela“, Onomatološki prilozi, knjiga VI, Srpska akademija nauka i umetnosti, Beograd, 1985.

- Džogović, Alija: „Onomastika severoistočnih ogranaka Prokletija“, Onomatološki prilozi, knjiga VII, Srpska akademija nauka i umetnosti, Beograd, 1986.

- Džogović, Alija: „, Onomastika Gore“, Onomatološki prilozi, knjiga XII, Srpska akademija nauka i umetnosti, Beograd, 1996.

\section{Novica VUJOVIĆ}

\section{ALIJA DŽOGOVIĆ AS AN ONOMASTICIST}

The paper aims to present the most significant onomastic works of Alija Džogović, as well as to point to his contribution to the Montenegrin onomastics.

Key words: Alija Džogović, onomastics, Montenegrin language 


\section{PRIKAZI}



UDK 821.163.7.09:929Velev I.

Stručni rad

\title{
Aleksandar RADOMAN (Podgorica)
}

Fakultet za crnogorski jezik i književnost - Cetinje

aleksandar.radoman@fcjk.me

\section{KAPITALNA SINTEZA MAKEDONSKOGA KNJIŽEVNOG SREDNJOVJEKOVLJA}

\author{
(Илија Велев, Историја на македонската книжевност. \\ Средновековна книжевност, том I (IX-XIV век), \\ Гирланда, Скопје, 2014)
}

Prvi tom Istorije makedonske književnosti koji obrađuje srednjovjekovnu književnost od IX do XIV vijeka kruna je trodecenijskoga bavljenja prof. Ilije Veleva pitanjima makedonske medievalne književnosti, kulture i povijesti. Realizovana je kao iscrpna književnoistorijska monografija analitičko-sintetičkoga tipa što pored hronološkoga pregleda jedne nacionalne književnosti, koja istovremeno predstavlja istočnik ukupne slovenske kulture i pismenosti, nudi i žanrovski i tipološki pregled naznačene problematike te monografsku obradu znatnijih autora i djela makedonskoga književnoga srednjovjekovlja. Koncipirana u 24 poglavlja Velevljeva Istorija daje sveobuhvatnu sintezu ne samo pismenosti i književnosti, već ukupne makedonske srednjovjekovne kulture.

Ključne riječi: Ilija Velev, Istorija makedonske književnosti, srednjovjekovna književnost

Knjiga Istorije makedonske književnosti, I tom: Srednjovjekovna književnost (IX-XIV vijek) izdanje je koje u domenu monografske obrade jedne južnoslovenske srednjovjekovne književnosti postavlja nove metodološke standarde.

Prije nego se upustio u izradu voluminozne monografije o makedonskoj srednjovjekovnoj književnosti, Ilija Velev, redovni profesor i naučni savjetnik Instituta za makedonsku književnost Univerziteta „Sv. Kiril i Metodije“ u Skoplju, profilisao se kao jedan od vodećih makedonskih medievista i paleoslavista, publikujući na desetine monografija te oko 350 naučnih i stručnih radova iz oblasti srednjovjekovne književnosti i kulture. Navedimo samo neke od njih: Pregled srednjovjekovnih crkava i manastira u Makedoniji, Makedon- 
ska srednjovjekovna književnost, Makedonski književni XIV vijek, Sveti Gavril Lesnovski u književnoj tradiciji, Skriptorski centri srednjovjekovne Makedonije, Ćirilometodijevska tradicija i kontinuitet, Tvorci makedonske književnosti IX-XVIII vijek, Makedonski spomenici na glagoljskom i ćirilskom pismu, Makedonska književnost IX-XVIII vijeka, Beśeda protiv bogumila Prezvitera Kozme, Istorija makedonske srednjovjekovne književnosti i dr. Za knjigu Vizantijsko-makedonske književne veze Velev je 2006. godine dobio najvišu nagradu za naučna dostignuća u Republici Makedoniji „Goce Delčev“. U godini kad je publikovana monografija Istorija makedonske književnosti, tom I, iz štampe je izašla i knjiga Hronografija i roman o Aleksandru Velikom Makedonskom, koja pored obimne studije o tome značajnom srednjovjekovnom tekstu sadrži i tekstološku genezu toga spisa. Za izučavanje Aleksandride od posebnoga je značaja Velevljevo razgraničenje pojmova hronografije i romana, kao i lucidno poređenje s Biblijom, koja se u svijetlu novih Velevljevih istraživanja pojavljuje kao tekst bez čijeg se poznavanja srednjovjekovni $R o-$ man o Aleksandru ne može pojmiti na pravi način.

Knjiga koja je predmet naše pažnje zapravo je drugo izdanje monografije Istorija makedonske srednjovjekovne književnosti i prvi tom Istorije makedonske književnosti čiji će drugi tom obuhvatiti period od XV do XVIII stoljeća.

Prvi tom Istorije makedonske književnosti koji obrađuje srednjovjekovnu književnost od IX do XIV vijeka kruna je trodecenijskoga bavljenja prof. Veleva pitanjima makedonske medievalne književnosti, kulture i povijesti. Realizovana je kao iscrpna književnoistorijska monografija analitičko-sintetičkoga tipa što pored hronološkoga pregleda jedne nacionalne književnosti, koja istovremeno predstavlja istočnik ukupne slovenske kulture i pismenosti, nudi i žanrovski i tipološki pregled naznačene problematike te monografsku obradu znatnijih autora i djela makedonskoga književnoga srednjovjekovlja. Koncipirana u 24 poglavlja Velevljeva Istorija daje sveobuhvatnu sintezu ne samo pismenosti i književnosti, već ukupne makedonske srednjovjekovne kulture, čiji su počeci nerazlučivo povezani s vizantijskom kulturom i civilizacijom, čemu je Velev posvetio posebnu monografiju, već pomenute Vizantijsko-makedonske književne veze.

U prvome poglavlju monografije „Kontinuitet makedonskoga književnog razvoja“"Velev propituje odnos istorije, kulturne istorije i književne istorije, makedonski kulturnoistorijski identitet sagledava kroz prizmu makedonske književne istorije, a nakon tih početnih teorijsko-metodoloških uvida, nudi hronološki najprije preśek antičkih i ranohrišćanskih književnih tokova na tlu Makedonije, potom definiše makedonsku srednjovjekovnu književnost $\mathrm{u}$ kontekstu slovensko-vizantijske hrišćanske civilizacije i kulture te ćirilometo- 
dijevske slovenske tradicije. Autor monografije ne robuje tradicionalističkim romantičarskim kalupima no ispitivanju najośetljivijih pitanja „nacionalnoga“ razgraničenja srednjovjekovnoga nasljeđa pristupa iz ugla kulturnoistorijske rekonstrukcije čime se izbjegavaju pseudoistorijske konstrukcije kojima se najčešće savremene političke konstelacije projektuju u duboku prošlost. U poglavlju „O suštini i opsegu makedonske srednjovjekovne književnosti“ određena je suština i razvojni integritet makedonske srednjovjekovne književnosti od IX do kraja XIV vijeka i ponuđena periodizacija toga korpusa pri čemu se razlikuju tri istorijske i razvojne književne etape. Prva etapa hronološki je omeđena od 845. do 1018. godine, druga od 1018. do 1204/1261. a treća od 1261. do kraja XIV stoljeća, a u okviru svakoga od datih perioda ocrtane su pojedine istorijsko-razvojne faze. U poglavlju „Ćirilometodijevska tradicija i uspostavljanje slovenske civilizacije“ Velev iscrpno raspravlja o povijesnim i kulturnim pretpostavkama misije Svete braće, analizirajući slovenske, vizantijske i latinske izvore o životu i radu Sv. Ćirila i Metodija i detaljno rekonstruišući njihovo misionarsko djelovanje, $s$ posebnim osvrtom na $u$ istoriografiji osporavanu no novim interpretacijama izvora dokazanu Bregalničku misiju te Moravsku misiju i osobito njene političke i vojnostrateške tendencije. Panonskim legendama, kao primarnome izvoru o djelatnosti Sv. Braće, Velev pristupa s opravdanim oprezom, ukazujući na to da hagiografski tekstovi, nastali na osnovu ustaljenih žanrovskih obrazaca, ne mogu biti vjerodostojan izvor, kako se to u tradicionalističkoj nauci prihvatalo. Životi i rad Svete braće, Sv. Konstantina (Ćirila) Filozofa i Sv. Metodija Solunskog, dati su u zasebnim monografski koncipiranim poglavljima. Posebna poglavlja knjige Velev je posvetio i nastavljačima ćirilometodijevske tradicije, Ohridskoj književnoj školi i osobito njenim najznačajnijim predstavnicima, Sv. Klimentu Ohridskom i Sv. Naumu Ohridskom. Ličnosti Crnorisca Hrabra i njegovu filološkome traktatu „O pismeneh“ autor monografije poklanja posebnu pažnju, a u njegovoj se monografiji našlo mjesta i za opis djelatnosti Bregalničke književne škole, te poglavlja o književnoj djelatnosti Konstantina Prezvitera i bogumilstvu i bogumilskoj književnosti u makedonskoj srednjovjekovnoj tradiciji. Ilija Velev svoju književnoistorijsku monografiju ostvaruje kao sintezu dosadašnjih saznanja o naznačenoj oblasti, ali i svojih višedecenijskih istraživanja koja često nude i nove odgovore na davno postavljena brojna pitanja vezana za ovaj književnoistorijski korpus. Razvidno je to pogotovo u poglavlju o Prezviteru Kozmi đe pažljivom tekstološkom i kulturnoistorijskom analizom njegove Beśede protiv bogumila, poznate i u zetskoj književnoj tradiciji iz Zbornika Popa Dragolja, taj glasoviti spis datira u prvu polovinu XI vijeka. Kao i nekim drugim fenomenima makedonskoga srednjovjekovlja Velev je Prezviteru Kozmi posvetio i posebnu monografiju, objavljenu u Skoplju 2011. godine. 
U drugome dijelu knjige, Velev se vraća teorijsko-metodološkim i kulturnoistorijskim razgraničenjima kroz poglavlja „Istorijsko-razvojni kontinuitet makedonske jezičke i pismene tradicije“ i „Priroda i karakter makedonske srednjovjekovne književnosti“ đe nakon rasprave o istorijskim preduslovima kontinuiteta makedonske književne tradicije i opservacija o slovenskim pismima, ukazuje na terminološku uslovnost podjele na prijevodnu i originalnu srednjovjekovnu književnost te razgraničava pojmove književna škola, književni centar i skriptorski centar, kao ključnih toposa organizovanoga književnoga života, prosvjete, naučno-saznajnih i idejno-stvaralačkih aktivnosti srednjovjekovnoga perioda. Poglavljem „Klasifikacija žanrovskoga sistema makedonske srednjovjekovne književnosti“" Velev je ponudio model žanrovske klasifikacije prema kome bi se taj korpus mogao podijeliti na oficijelno-kanonske bogoslužbene tekstove, koji se dijele na biblijske i liturgijske tekstove, tekstove pravno-kanonske sadržine, u okviru kojih se javljaju crkveni i građanski pravno-kanonski književni zbornici, panegiričko-hagiografske, panegiričko-propovjedne i patrističke tekstove, potom neoficijelne, nekanonske tekstove, u koje spadaju i popularni apokrifi i, u okviru pete i najheterogenije grupe, tvoračko-funkcionalne prozne, retoričke i poetske književne tekstove, među kojima se razlikuju prozni književni sastavi, oratorsko-retorički književni sastavi, poetska književna djela, istorijsko-ljetopisni tekstovi, ljetopisi i ljetopisni zapisi i kratke književne forme. Svim naznačenim formama Velev je posvetio zasebna iscrpna poglavlja. Nakon tih književnoteorijskih, tipoloških razvrstavanja, Velev se vraća hronološkome književnoistorijskome modelu deskripcije posvetivši tri potonja poglavlja monografije književnim djelatnicima od XI do kraja XIV stoljeća, te fenomenima Svete Gore u makedonskoj srednjovjekovnoj književnoj tradiciji i isihazma i sholastičkog racionalizma kao duhovnoga mosta između istočne i zapadne tradicije. Svoju obimnu monografiju realizovanu na preko 500 stranica prof. Velev opremio je i uobičajenim dodacima, selektivnim pregledom konsultovane literature i bio-bibliografskom bilješkom.

Monografija Istorija makedonske knjiženosti, tom I: Srednjovjekovna književnost (IX-XIV vijek) cjelovita je književnoistorijska sinteza koja osvjetljava ne samo srednjovjekovni period makedonske književnosti već u širemu interkulturnom kontekstu i početke slovenske pismenosti i kulture. Kombinujući analitičko-sintetičke, književnoistorijske i književnoteorijske modele rekonstrukcije nacionalne literature, Velev je ponudio pouzdanu naučnu sintezu makedonskoga srednjovjekovnoga kulturnoga i književnoga nasljeđa koja je rezultat višedecenijskih istraživanja i vrijednoga rada na osvjetljavanju manje poznatih ili neproučenih segmenata nacionalne baštine. Time je ostvario ne samo reprezentativnu knjiženoistorijsku monografiju u okviru makedonistike već i dao značajan doprinos savremenoj slavistici. 
Aleksandar RADOMAN

\title{
CAPITAL SYNTHESIS OF MACEDONIAN LITERARY MEDIEVAL PERIOD
}

\author{
(Ilija Velev, History of Macedonian Literature. Medieval Literature, \\ Volume I (IX-XIV Century), Girlanda, Skopje, 2014)
}

The first volume of History of Macedonian Literature that deals with the medieval literature from the ninth to the fourteenth century is the crown of three-decade long work of Prof. Ilija Velev on issues of Macedonian medieval literature, culture and history. It is presented as an exhaustive historical and literary monograph of analytical and synthetic type, which in addition to chronological overview of a national literature - at the same time a source of entire Slavic culture and literacy, offers a genre and typological overview of the subject matter and a monograph-like reflection on major authors and works of the Macedonian literary medieval period. Conceived in 24 chapters, Velev's History provides a comprehensive synthesis of not only literacy, but of overall Macedonian medieval culture as well.

Key words: Ilija Velev, History of Macedonian Literature, medieval literature 

UDK 821.163.4.09:929Petrović Njegoš P. II

\title{
Nikola POPOVIĆ (Nikšić)
}

Stručni rad

Fakultet za crnogorski jezik i književnost - Cetinje

nikola.popovic@fcjk.me

\section{VRIJEDAN DOPRINOS CRNOGORSKOJ KOMPARATISTICI I NJEGOŠOLOGIJI}

\author{
(Vesna Kilibarda, Njegoš i Italija, \\ Institut za crnogorski jezik i književnost, Podgorica, 2014)
}

\begin{abstract}
Studija Njegoš i Italija rezultat je tridesetogodišnjega naučnoga rada prof. dr Vesne Kilibarde. Objavljena prošle godine u izdanju Instituta za crnogorski jezik i književnost, nakon velikoga jubileja, dvjestagodišnjice Njegoševa rođenja, studija Njegoš i Italija predstavlja cjelovitu sintezu o ,italijanskim temama“ $\mathrm{u}$ pjesničkome djelu i životu Petra II Petrovića Njegoša. Osim nesumnjivoga doprinosa njegošologiji, autor ovoga priloga ističe značaj Kilibardine studije i za afirmaciju komparatističkih istraživanja u okviru montenegristike.

Ključne riječi: Vesna Kilibarda, Petar II Petrović Njegoš, italijanske teme, njegošologija, komparativna montenegristika
\end{abstract}

Neosporna je povijesna činjenica da su temelji moderne književne montenegristike udareni šezdesetih godina prošloga vijeka. Tada je, uprkos snažnoj unitarističkoj koncepciji, na književnoistorijsku i književnokritičku scenu istupila plejada zaslužnih književnih istoričara i kritičara. Publikovanjem vrijednih književnoistorijskih monografija, rasvjetljavanjem tamnih mjesta iz bliže i dalje nam književne prošlosti, generaciji o kojoj je riječ treba prije svega odati priznanje da je na nov, metodološki savremen način otklonila brojne zablude koje su postojale u crnogorskoj nauci o književnosti, a budućim generacijama istraživača pripremila plodno tlo za raznovrsnije tumačenje zamršenih književnih pojava i procesa.

Dugo na marginama književnoteorijskih istraživanja, izgubljena $u$ moru različitih pristupa književnome tekstu, pionirske korake pravila je i oblast komparativne montenegristike. Prazninu u toj važnoj oblasti književne montenegristike, cjelokupnim naučnim angažmanom, već tridesetak godina uspješno popunjava crnogorska komparatistkinja i istoričarka književnosti 
prof. dr Vesna Kilibarda. Baveći se u prvom redu interkulturnim vezama, dr Kilibarda je u svojim naučnim radovima donijela pregršt novih saznanja koja dodatno osvjetljavaju duboke i složene odnose između dvije kontaktne kulture - crnogorske i italijanske. Njen rad na tome polju bez sumnje je nenadmašan. Dvosmjerno kanališući pravac svojega naučnog interesovanja, usmjerenoga na proučavanje italijanske književnosti i kulture u Crnoj Gori, kao i na recepciju Crne Gore i crnogorske književnosti u italijanskom književnom životu do 1918. godine, dr Vesna Kilibarda je značajno doprinijela unapređenju kulturnih veza Crne Gore i Italije. Prilog tome višegodišnjem naučnoistraživačkom radu jeste i studija koju ovđe predstavljamo - Njegoš i Italija.

Objavljena prošle godine u izdanju Instituta za crnogorski jezik i književnost, nakon velikoga jubileja, dvjestagodišnjice Njegoševa rođenja, studija Njegoš i Italija predstavlja, kako autorka u „Predgovoru“ ističe, pokušaj da se ,objedine 'italijanske teme' s kojima se dovodi u vezu crnogorski vladika i pjesnik Petar II Petrović Njegoš“. „Italijanske teme“ u ovoj studiji autorka je podijelila u dvije velike komplementarne cjeline. Prva, sastavljena iz tri posebna poglavlja, posvećena je Njegoševu poznavanju italijanskoga jezika, njegovoj italijanskoj lektiri, kao i mogućim uticajima Danteove Božanstvene komedije na Njegoševu Luču mikrokozma. Ovim dvama poglavljima, kao dio iste tematske cjeline, pridružuje se i poglavlje „Njegoš u italijanskom putopisu“, u kojem je dr Kilibarda dala detaljnu analizu putopisa italijanskoga botaničara Bartolomea Bjazoleta i njegova viđenja Njegoša i Crne Gore. Druga cjelina odnosi se na recepciju Njegoševa djela u Italiji i to kroz analizu prijevoda Njegoševih djela na italijanski jezik, dok zaključno poglavlje studije obuhvataju crnogorske teme italijanskih romantičara, s posebnim akcentom na prisustvo Njegoša u italijanskim romantičarskim tekstovima. Kao dodatak iscrpne studije autorka je naučnoj javnosti dala na uvid i bibliografiju prijevoda i napisa o Njegošu na italijanskom jeziku, i to prema hronološkom redosljedu pojavljivanja, a opremljena je anotacijama i registrima prevodilaca i autora.

Konsultujući brojnu tematski raznovrsnu i rasutu građu, namjera autorke je bila da ovom studijom ,razmotri(m) Njegoševe dodire s jednom velikom i starom evropskom kulturom - italijanskom - i da crnogorskog vladiku i pjesnika situira(m) u manje proučavani jadranski i mediteranski kontekst, kome je on suštinski pripadao i na koji je bio najviše, neposredno i neprekidno upućen i u ličnom životu i vladarskom djelovanju“.

Italijanska kultura i literatura su, prema mišljenju dr Vesne Kilibarde, trajno uticale na oblikovanje vladarske i pjesničke ličnosti Petra II Petrovića Njegoša. Budući da se Njegoš kao vrlo mlad susrio s italijanskom kulturom, u prvom redu s italijanskim jezikom, autorka je znatan prostor posvetila utvr- 
Vrijedan doprinos crnogorskoj komparatistici i njegošologiji

đivanju stepena Njegoševa poznavanja italijanskoga jezika. Iako ponajviše potreban za svakodnevnu komunikaciju s austrijskim vlastima u Boki Kotorskoj, odnosno za praktičnu upotrebu, italijanski je jezik, kako dr Kilibarda dokazuje, Njegošu služio i u „bogaćenju vlastite književne i filozofske kulture“. Tu činjenicu potkrepljuju i italijanski naslovi iz Njegoševe biblioteke, koju autorka bibliografski razvrstava, dopunjujući spisak djela navedenih u popisu Dušana Vuksana iz 1929. godine, ne ulazeći pritom u otvorena pitanja u vezi s današnjim sastavom Njegoševe biblioteke.

Upravo na temelju istraživanja Njegoševe biblioteke, autorka studije Njegoš i Italija u poglavlju „Njegoš i Dante“ ponovo pokreće pitanje odnosa Njegoševa filozofsko-religioznoga spjeva Luča mikrokozma i Danteove Božanstvene komedije. Iako nije u biblioteci Petra II Petrovića pronađeno djelo velikoga italijanskog pisca, već samo, kako dr Kilibarda ističe, „trotomni komentari Danteovog remek-djela Antonija Čezarija pod naslovom Ljepote Komedije Dantea Aligijerija“ ovaj podatak poslužio je mnogim autorima da pokrenu tezu o neoriginalnosti Njegoševa spjeva. Pored detaljnoga hronološkog pregleda najvažnijih studija i priloga u svijetlu navedenoga problema, radova Milorada Medakovića, Jovana Skerlića, Tihomira Ostojića, Pavla Popovića, Stjepa I. Kastrapelija, italijanskoga slaviste Artura Kronije i drugih, dr Kilibarda ističe značaj studija Alojza Šmausa, a posebno Mirona Flašara, koji je najargumentovanije dao odgovor na pitanje uticaja Dantea na Njegoša, zaključujući na kraju da je „mogućnost pronalaska tragova prisustva velikog italijanskog pjesnika u Njegoševom pjesničkom djelu bila inspirativna i za proučavaoce književnog djela najvećeg crnogorskog pjesnika“.

Uticaj koji su na mladoga crnogorskog pjesnika i vladiku ostavila putovanja u Italiju i upoznavanje s tamošnjom kulturom i civilizacijom, kao i prisustvo italijanskih tema i njihova refleksija u njegovu pjesničkom djelu, dr Kilibarda je, konsultujući obimnu literaturu i arhivsku građu, isrpno analizirala u poglavlju „Njegoš u Italiji, italijanske teme u Njegoševom djelu“. S obzirom na to da je izvan granica tadašnje Crne Gore Njegoš najviše vremena provodio u Italiji i mjestima na istočnoj obali Jadrana, koji su ostali u kulturnoj sferi nekadašnje Mletačke Republike, autorka je Njegoševa putovanja po Italiji hronološki izdijelila na putovanja u velike italijanske kulturne centre: Trst, Veneciju, gradove italijanskoga juga (Rim, Napulj), a poglavlje zaključila opisom njegovih pośeta italijanskim gradovima Livornu, Pizi i Firenci. Susreti s poznatim ličnostima onoga vremena, austrijskim i italijanskim zvaničnicima kao i brojnim predstavnicima ,ilirskoga pokreta“ uticali su na Njegoša državnika i proširila krug njegovih prijatelja, od kojih su pojedini, kako dr Kilibarda potcrtava, ubrzo postali njegovi „povjerenici za različite poslove“. Osim zanimljivih momenata iz Njegoševa života i rada, čuvene Bilježnice u 
kojoj se, između ostaloga, nalaze impresije s putovanja po Italiji, ova mediteranska zemlja trajno je uticala na njegovo pjesničko djelo, pa je uz poznatu epizodu „Draško u Mlecima“ iz Gorskoga vijenca, Njegoš u Italiji pronašao građu na osnovu koje je napisao svoje treće veliko djelo - dramski spjev Lažni car Šćepan Mali.

Krug „italijanskih tema“ u studiji Njegoš i Italija dr Vesna Kilibarda zatvara poglavljima „Njegoš u italijanskom putopisu“, „Italijanski prevodi Njegoševe poezije i napisi o pjesniku i vladici na italijanskom jeziku“ i „Njegoš u italijanskim romantičarskim mistifikacijama“. Počev od detaljne analize putopisa italijanskoga botaničara Bartolomea Bjazoleta, koji je Crnu Goru i Njegoša pośetio u maju 1838. godine, preko širega kulturološkog sagledavanja prijevoda Njegoševih djela na italijanski jezik, do interesantnoga priloga o književnim ostvarenjima „crnogorske inspiracije“ italijanskih književnika, u kojima se Njegoš pojavljuje čak i kao književni lik (sic!), na najbolji način pokazuju širinu i ozbiljnost istraživačkoga zadatka koji je preuzela dr Kilibarda.

Možemo već sada, bez svake sumnje, utvrditi da će studija Njegoš i Italija predstavljati nezaobilazno štivo u njegošologiji. Ona će, nadamo se, u isto vrijeme biti podsticaj za nove studije kojima će se afirmisati komparatistička istraživanja u okviru najmlađe grane slavistike.

\section{Nikola POPOVIĆ}

\section{A VALUABLE CONTRIBUTION TO MONTENEGRIN COMPARATIVE STUDIES AND STUDY OF NJEGOŠ}

\section{(Vesna Kilibarda, Njegoš and Italy, Institute for Montenegrin Language and Literature, Podgorica, 2014)}

Study entitled Njegoš and Italy presents the crown of thirty years of scientific work of Prof. Vesna Kilibarda. Published last year, by the Institute for Montenegrin Language and Literature, the study Njegoš and Italy constitutes a complete synthesis of the "Italian themes" in the poetic work and life of Petar II. Besides the undoubted contribution to the study of Njegoš, the author of this paper highlights the importance of Kilibarda's study for the affirmation of comparative research within Montenegristics as well.

Key words: Vesna Kilibarda, Petar II Petrović Njegoš, Italian themes, comparative Montenegristics 
UDK 821.163.4.09-31

Stručni rad

\title{
Marijana TERIĆ (Nikšić)
}

Fakultet za crnogorski jezik i književnost - Cetinje marijana.teric@fcjk.me

\section{POETIKA ROMANA MIHAILA LALIĆA KRSTA PIŽURICE}

\begin{abstract}
Pristupivši detaljnoj analizi najznačajnijih Lalićevih romana: Zlo proljeće, Lelejska gora, Hajka, Svadba i Ratna sreća, Pižurica je ukazao na različite mogućnosti percipiranja djela i tako svoje književnoteorijske poglede objedinio knjigom Poetika romana Mihaila Lalića. U tome smislu kratkim osvrtom na pet romanesknih ostvarenja iscrpno obrađenih u pomenutome djelu, izdvajamo samo neke od najznačajnijih stavova i zaključaka do kojih dolazi Krsto Pižurica. Detaljnom egzegezom u veoma razuđenoj naraciji teksta, Pižurica je ispitao gotovo svaki detalj literarnoga svijeta Lalićevih romana, posebno se zadržavajući na kompozicionim i strukturnim rješenjima, najistaknutijim pozicijama u tekstu, motivacionim kopčama, karakterizaciji likova, ali i intertekstualnim vezama s Njegoševim djelom i Njegoševom filozofijom života. Svježina Pižuričina jezičkoga tkanja proizilazi iz nove perspektive sagledavanja djela, koja autorovu interpretaciju romana čini aktuelnom.

Ključne riječi: Mihailo Lalić, književnoteorijska analiza, inovativan pripovjedački postupak, simboličnost, poetska izražajnost
\end{abstract}

Iako se izučavanjem Lalićevih djela bavio veliki broj književnih stvaralaca koji su bogatili crnogorsku književnost raznovrsnim kritičkim tekstovima, naučnim radovima, monografijama i zbornicima, najproduktivniji je naučnoistraživački rad književnoga kritičara i istoričara književnosti Krsta Pižurice. Posvetivši svoj radni vijek iscrpnome proučavanju literarnih ostvarenja Petra II Petrovića Njegoša i Mihaila Lalića, Pižurica se bavio različitim aspektima sagledavanja narativnih tekstova koje je upotpunjavao novim književnoumjetničkim tehnikama i metodama. Pristupivši detaljnoj analizi najznačajnijih Lalićevih romana: Zlo proljeće, Lelejska gora, Hajka, Svadba i Ratna sreća, Pižurica je ukazao na različite mogućnosti percipiranja djela i tako svoje književnoteorijske poglede objedinio knjigom Poetika romana Mi- 
haila Lalića. U tome smislu, kratkim osvrtom na pet romanesknih ostvarenja iscrpno obrađenih u pomenutome djelu, izdvajamo samo neke od najznačajnijih stavova i zaključaka do kojih dolazi Krsto Pižurica.

U uvodnoj studiji Dođe tako jedno zlo proljeće i sve pokosi (Struktura $i$ kompozicija romana 'Zlo proljeće'), autor navodi razloge zbog kojih se opredijelio da svoje djelo započne analizom drugoga po redu objavljenoga romana Zlo proljeće, ističući, između ostaloga, želju da hronološki isprati sudbinu čovjeka u različitim fazama ratnih zbivanja. Pišući o razuđenosti proznoga svijeta Lalićeva djela, autor ukazuje na značajan sloj istorijskih reminiscencija koji utiču na oblikovanje centralnoga književnog lika Lada Tajovića. Koncipirano po načelima klasičnoga romana, Zlo proljeće se, po riječima Pižurice, izdvaja inovativnim pristupom kompoziciji djela, tematskoj dvokolośečnosti, kao i razgranjavanju umjetničkoga postupka. Time se u fabularnoj ravni romana pojavljuje veliki broj motiva i asocijativnih niti kojima se konstituiše mnoštvo epizoda u djelu. Imajući u vidu kompleksnost psihološke strukturiranosti lika, autor objašnjava da Zlo proljeće u klasifikacionome smislu nadrasta okvire porodičnoga romana ili romana o đetinjstvu i mladosti Lada Tajovića, kako ga često ocjenjuje književna kritika, i tako postaje realističkim romanom širih dimenzija. Na to posebno ukazuju sociopsihološke slike djela s područja Lima koje se, kako konstatuje Krsto Pižurica, ubrajaju u najsnažnije i najživotnije koje crnogorska književnost pośeduje s toga geografskog područja. Zanimljivo je pomenuti i podjednako bitno Pižuričino zapažanje da književna kritika (izuzev Dragana M. Jeremića) nije prepoznala važnost socijalne komponente Zlog proljeća koju čini selo i život na njemu, kao nezaobilazni ambijent u sadržajnoj razuđenosti djela. Osluškujući ritam Lalićeva narativnog postupka, Pižurica posebnu pažnju poklanja poetizaciji teksta, pjesničkome jeziku i stilu proznoga djela, ne propuštajući priliku da se zadrži i na humoru i humornim situacijama kod pojedinih junaka koje detaljno karakteriše. Razgranjavanje centralnoga književnog lika - Lada Tajovića, kao i kompleksnost narativne strukturiranosti djela, u kojem se kao ni u jednom drugom Lalićevu romanu ne nalazi toliko zabilježenih smrti koje pominje glavni junak, navodi Krsta Pižuricu na zaključak da je Zlo proljeće melanholičan roman tmurnih boja, roman tragedije čovjeka u prostoru i vremenu.

Studijom o Lalićevoj Lelejskoj gori, Tragika i trijumf (objavljenoj u posebnoj knjizi u izdanju KPZP, Podgorica, 1996), Pižurica analitički rašćlanjuje strukturne elemente Lelejske gore, ukazujući na složenost tipološkoga određena romana, koji, po njegovome mišljenju, predstavlja sociopsihološko-istorijsku studiju protkanu ljubavnim doživljajima glavnog junaka. S obzirom na to da se u centru autorova istraživačkoga zadatka nalazi narator i glavni junak Lelejske gore, Pižurica se fokusira na motive koji imaju ključnu 
ulogu u konstituisanju proznoga svijeta djela (neprijatelj, glad, strah, podjela, izdaja i osveta), posebno se zadržavajući na osnovnome pokretačkom motivu samoće u Lelejskoj gori. Upravo se ovim motivom generišu brojna somnabulna i halucinantna stanja koja postaju osnova Lalićeva pripovjedačkoga postupka. Bez samoće glavnog junaka, naglašava Pižurica, fantastičnih scena ne bi bilo u Lelejskoj gori, a njen krajnji domet u romanu je đavo i susret Lada Tajovića s njim. U tome smislu znatan dio rada posvećen je funkciji đavola ne samo u Lalićevu već i djelu Dostojevskoga, od koga je i preuzet taj motiv. Komparativnim sagledavanjem njegove uloge u djelima dvaju autora, Pižurica zaključuje da pojava đavola kao ravnopravnoga lika u Lelejskoj gori i Braći Karamazovima predstavlja novinu, rjeđe prisutnu u literaturi. Pišući o višeslojnosti Lalićeva romanesknog ostvarenja, Pižurica ukazuje na međuknjiževni kontakt Njegoša i Lalića, o kojem u književnoj kritici nema značajnijih zapažanja. Određenim analogijama između Njegoševa Gorskog vijenca i Lalićeve Lelejske gore autor zatvara opsežnu studiju.

Ispitujući simboliku literarnoga svijeta Hajke, Pižurica prati sižejne tokove romana, koji se postepeno granaju dobijajući tako status tematskih cjelina koje mogu samostalno egzistirati. U tome pogledu Pižurica ističe da brojnost fabularnih nizova, obilje detalja i likova nije ugrozilo autorov umjetnički postupak. Svoje pripovijedanje Lalić je upotpunio lirskim nijansama, odnosno pjesničkim jezikom i uvijek zanimljivim tematskim činiocima, kojima je bogatio strukturu djela. Tema hajke, kao jedna od centralnih tema Lalićeva romansijerskog opusa, po mišljenju Krsta Pižurice, najsveobuhvatnije je obrađena u Hajci, pa iz toga razloga njegova studija predstavlja pokušaj da se upravo tema hajke na čovjeka prikaže onako kako je pisac zamislio kao simbolično postojanje odnosa u istorijskom procesu čovjekova trajanja... Sagledavajući polifonijsku strukturiranost romana, Pižurica želi ukazati i na određene manjkavosti Hajke, koje se odnose na raspričanost u pojedinim djelovima teksta, nedovoljnu srazmjernost u rasporedu i obradi nekih motiva, ali i na obim knjige koji bi mogao biti nešto manji. Na kraju zaključuje da ideja, tema i umjetnička obrada ovakve narativne tvorevine čine Hajku djelom evropske književnosti.

Crni gavrane ne nadleći često ( $O$ umjetničkoj strukturi i dometima Lalićeve 'Svadbe') naziv je četvrte cjeline Pižuričina istraživačkoga rada u kojoj se apostrofira umjetnički talenat Mihaila Lalića, nastao na prijelazu od pripovijetke ka romanu. Kroz temu Svadbe (četnički zatvor u Kolašinu u periodu 1942-1943. godine), Pižurica skreće pažnju na posebnu vrijednosti djela ispoljenu kroz objektivno sagledavanje događaja i likova, odnosno iskrenost kojom Lalić konstituiše literarni svijet djela. Ukazujući na ratnu atmosferu i sudbinu glavnoga junaka Tadije Čemerkića, brojnost epizoda i uvođenje 
novih likova, kompozicione elemente od kojih naročito izdvaja govor i san, Pižurica prepoznaje kontaktne veze s narodnom tradicijom, istorijom ali $\mathrm{i}$ Njegoševim Gorskim vijencem. Stoga, autor studije pravi paralelu Lalićeva i Njegoševa djela, akcentujući sličnost u umjetničkoj obradi lika Tadije Čemerkića i Njegoševih junaka, dijelom i vladike Danila, ali i drugih strukturnih elemenata prisutnih u djelima pomenutih pisaca. Time postaje jasno zašto se Svadba posmatra kao prolegomena u Lalićev svijet revolucije koja ujedno anticipira skoro sve odlike Lalićeva budućeg književnog oblikovanja društvene stvarnosti.

Analitičko sagledavanje romana Ratna sreća (Ratna sreća Mihaila Lalića i Ratna sreća nesrećnih Crnogoraca) poslužilo je Krstu Pižurici da ukaže na inovativnost u koncipiranju djela, koja se prvenstveno odnosi na osobenu tematiku i specifičan pripovjedački postupak. Kroz pričanje centralnoga junaka Peja Grujovića, Lalić organizuje zbivanja kroz dva narativna plana, od kojih prvi podrazumijeva pripovjedača kao učesnika u zbivanjima teksta, dok se drugi narativni plan razvija iz śećanja, memoara i zapisa. Pošto se u junakovim istorijskim reminiscencijama prepoznaje hroničarsko obilježje, Pižurica procjenjuje da se Ratna sreća može posmatrati kao roman-hronika, naglašavajući kako društveni roman društvene tematike do 'Ratne sreće' crnogorska književnost nije prepoznala. Iako primjećuje određene manjkavosti u romanu, poput nekompaktne fabule, odnosno fabule koja ne teče pravolinijski, digresivne epizode i neizdiferenciranost likova, Pižurica zaključuje da se radi o izuzetno kvalitetnome umjetničkom ostvarenju. Autor takođe uočava i deskriptivni manir u Lalićevoj poetici, eksplicitno navodeći i dvije pejzažne slike koje su po njegovome mišljenju antologijske vrijednosti. U poetskome iskazu posebnu važnost dobijaju pismo i citat, ali i putovanje kao model strikturiranja fabule. Prepoznatljivi motivi, folklorna građa, pjesnički jezik i naglašena simbolika, predstavljaju važne činioce Lalićeva pripovjedačkog umijeća.

Minucioznom analizom Lalićevih romansijerskih ostvarenja, Krsto Pižurica je osvijetlio ključne aspekte njegova narativnog prosedea. Registrujući naznačajnije segmente svakog od istraženih djela ponaosob, Pižurica plijeni jednostavnošću jezičkoga izraza. Temeljan, nedvosmislen i veoma precizan u iznošenju svojih zaključaka, ovaj autor se izdvaja sposobnošću sažimanja rečenične konstrukcije kojom proizvodi snažne stilske efekte. Svježina Pižuričina jezičkoga tkanja proizilazi iz nove perspektive sagledavanja djela te osobenih zapažanja koji autorovu interpretaciju romana čine aktuelnom. U tome smislu saglasni smo s konstatacijom Aleksandra Radomana koji primjećuje da Pižuričin naučnoknjiževni prosede karakteriše svojevrsni 
metodološki elekticizam. ${ }^{1}$ Detaljnom egzegezom u veoma razuđenoj naraciji teksta, Pižurica je ispitao gotovo svaki detalj literarnoga svijeta Lalićevih romana, posebno se zadržavajući na kompozicionim i strukturnim rješenjma, najistaknutijim pozicijama u tekstu, motivacionim kopčama, karakterizaciji likova, ali i intertekstualnim vezama s Njegoševim djelom i Njegoševom filozofijom života. Stoga, postaje jasno zašto su se i u ovom istraživačkome procesu našla dva velika autora: Mihailo Lalić i Petar II Petrović Njegoš. Monografijom Poetika romana Mihaila Lalića Pižurica je uspio da, na jednome mjestu, objedini najnovije književnoteorijske stavove do kojih je došao, potvrđujući time nemjerljivi značaj svoga prisustva u modernoj književnoj montenegristici.

\section{Marijana TERIĆ}

\section{POETICS OF MIHAILO LALIĆ'S NOVELS BY KRSTO PIŽURICA}

In a detailed analysis of the most important Lalić's novels: The Evil Spring, The Wailing Mountain, The Pursuit, The Weddings and The Fortunes of War, Pižurica points to various possibilities of perceiving them, gathering his literary-theoretical views in a book entitled Poetics of Mihailo Lalić's Novels. In this context, the author of the present paper provides a brief review of the five novels exhaustively analyzed in the above-mentioned study, pointing to some of the most important positions and conclusions taken by Pižurica. Through a detailed exegesis in a dissected narrative text, Pižurica examines almost every detail of the literary world of Lalić's novels, particularly emphasizing compositional and structural solutions, the most prominent positions in the text, motivational links, characterization, as well as inter-textual connections with the Njegoš's work and life philosophy. Freshness of Pižurica's linguistic weaving stems from a new perspective of looking at the text, which makes the author's interpretation of the novel contemporary.

Key words: Mihailo Lalić, literary-theoretical analysis, innovative narrative procedure, symbolism, poetic expressiveness

Aleksandar Radoman, „Lalićevi romani u interpretaciji Krsta Pižurice“, predgovor knjizi: Krsto Pižurica, Poetika romana Mihaila Lalića, FCJK, Cetinje, 2014, str. 24. 

UDK 821.163.4.09Petrović Njegoš P. II Stručni rad

\title{
Čedomir DRAŠKOVIĆ (Cetinje)
}

\section{NJEGOŠU JE MJESTO U RAJU POEZIJE, A NE U PAKLU POLITIKE}

\section{(Recepcija i novo čitanje Njegoševa djela, CKD „M-M“, HCDP „Croatica-Montenegrina“ RH, Fakultet za crnogorski jezik i književnost, Društvo hrvatskih književnika)}

\begin{abstract}
U referatima iz zagrebačko-cetinjskog zbornika Recepcija $i$ novo čitanje Njegoševa djela (2014), spontano i bez generičkih suprotstavljenosti prati se stvaralačka sinteza romantičarske, odnosno teorijske i književno-metodološke (šire) vizije Njegoševe, ali i autorski dometi Gorskog vijenca, Śćepana Malog, Luče mikrokozma kao kreativnih ostvarenja duha i bića crnogorskog: počev od ideje, forme, istorijske fabule podneblja i njegovog agonalnog podnebesja, autentične galerije likova, mentalne slike karaktera, jezičkog sublimata.

Ključne riječi: Petar II Petrović Njegoš, recepcija, zbornik
\end{abstract}

Kultura je, prije svega, etička kategorija - a onda, naravno, i estetska. S tim u vezi, najveći književnici su najpouzdaniji predstavnici naroda, njegovi tumači i posrednici, pa čak i svojevrsna „zavjetrina“ i utjeha u životu. Iako ne mogu da obezbijede duhovnu zakonomjernost, u našem šarolikom i proizvoljnom svijetu, oni značajno mogu da utiču na saznajne procese čitalaca, i (posebno) - da ih nadahnjuju dobrotom i krijepe moralnim dostojanstvom. Međutim, kako to često biva, poslije velikih književnih, pa samim tim i humanističkih stvaralaca, dolaze mali formati, sa svojim patetičnim, inhibitornim, ili politikanskim naumima. Kao i kod loših političara, i slabim književnicima - a posebno onim koji navodno tumače književnost - najvažnije je da smišljeno podilaze publici, odnosno čitaocima. S površnim provociranjem, traženjem odgovarajućih ličnih, političkih ili društvenih efekata, kojim se, upornim ponavljanjem, vješto pokreće, pa omamljuje i talasa narod. Tako se lako stvara zbrka - s kulturno, politički, društveno i istorijski rizičnim, dugoročno opasnim posljedicama. 
Njegoš je crnogorsku borbu za slobodu genijalno prenio u vječnost poezije, u jedinstvenu i svevremenu njenu poetsku imaginaciju. I to (svima je uvijek bilo znano) istorijski kao „sirak tužni, bez niđe nikoga“: u grču borbe i ropcu otpora crnogorskoga naroda! Nemaština, sa njom stalne suše, i isto tako česti ratni vihori - to je bila crnogorska stvarnost. I samo jedno nepregledno crnogorsko „toržestvo užasa“, i ,snoviđenje strašno“ - ,jedne slamke među vihorove“... Spartanski je ovjekovječio inokosne „božje narodne osvetnike", kako je Crnogorce okarakterisao predstavnik hrvatskoga naroda, Ljubo Perković - u predgovoru Mažuranićevu epu Smrt Smail-age Čengića (Ženeva, 1918). Recepcijom i novim čitanjem Njegoševa djela, u referatima iz zagrebačko-cetinjskog Zbornika (2014), spontano i bez generičkih suprotstavljenosti prati se stvaralačka sinteza romantičarske, odnosno teorijske i književno-metodološke (šire) vizije Njegoševe, ali i autorski dometi Gorskog vijenca, Śćepana Malog, Luče mikrokozma, kao kreativnih ostvarenja duha i bića crnogorskog: počev od ideje, forme, istorijske fabule podneblja i njegovog agonalnog podnebesja, autentične galerije likova, mentalne slike karaktera, jezičkog sublimata.

Kad se Crna Gora sama izborila sa svojim žrtvenim trajanjem i svetačkim odricanjem, u literarnu i političku klero-nacionalističku mobu vrlo ambiciozno se počeo uključivati suśedni „bracki“, srpski narod. A onda je grunula ukupna srpska politika, zaključno s konačnom aneksijom Crne Gore. Nakon tradicionalno pouzdanog crnogorskog savezništva i tokom tek završenog Prvog svjetskog rata! U međuvremenu, pokušali su da kulturološki glumataju Crnu Goru i Crnogorce, formalno i vještački ih svojatajući - radi prisvajanja svega onoga što može da upotpuni njihov kulturno-istorijski horizont! Čak su i Gorski vijenac, zbog teškog razumijevanja, prevodili u proznu priču. Pravili su rječnik nepoznate crnogorske leksike iz Njegoševa djela koji je, kako kažu pouzdani istraživači, brojniji od ukupnog leksičkog korpusa Šekspirovog! A onda, poslije uspješno ostvarene kulturne invazije, zadovoljni postignutim, krajnje razmetljivo i neuljudno, patetično i nemušto crnogorskog „vladaoca“ Petra II (tako je on sebe imenovao: poslije 1834. godine, samo u izuzetnim slučajevima oblačio je crkvenu odoru) - promovisali su u ,petog jevanđelistu“, a dugo i teško sricani Gorski vijenac - u „srpsku Bibliju“?! Iako su im po sopstvenom nacionalnom bitisanju bili strani - i spartanski nacion crnogorski, i Njegoševa enormna kreativna energija - jer su izrasli iz drukčije, njihove jedinstvene viševjekovne postojbine, odnosno zavičajne i kolektivne crnogorske duše, i njene ukupne usmenosti - što suštinski nema ništa s tom novokomponovanom i pseudo-kulturnom nadnacionalnom šatrom, pod kojom vašarski šenluče i pelivane, oni koji uporno i bez stida (u funkcionalnom sadejstvu posebnih „kulturnih“ podvižnika, bahate i nekontrolisano glagoljive 
Njegošu je mjesto u raju poezije, a ne u paklu politike

Srpske pravoslavne crkve, i u krilu ili prećutnoj toleranciji zvanične politike) - obmanjuju i lažima uljuljkuju sopstveni narod, navodeći ga na sračunate kulturne $\mathrm{i}$ istorijske konstrukcije, tragikomična nacionalna uznošenja. $\mathrm{S}$ tim u vezi se povremeno i uglavnom pojedinačno oglašavaju reagovanja Crnogoraca - mahom plasirana kao njihova identitetska negodovanja. Umjesto trajnog dizanja na najviši nivo mnogo kompleksnijih i svirepih posljedica: potpunog ignorisanja i negiranja Crne Gore? Da je nema, i ne bude - ni istorijski, ni kulturno, ni nacionalno, ni vjerski, ni državno, sem kao srpskog prostora $\mathrm{i}$ svetosavskog kulturnog entiteta!

Iskustvo nas uzaludno opominje: kad god se Crna Gora i Srbija vjerski smiješaju i zvanično „udruže“, odnosno „pijemontska“ Srpska pravoslavna crkva programski i metodološki, tj. politički vrši unitarno usisavanje svih južnoslovenskih pravoslavaca - velikosrpske posljedice su neminovne: još crnje je Crnoj Gori, a pogolemo crno biva i Srbiji.

\section{Njegoš biva „počašćen“ političkim prvačenjem na barjaku svakog istovjernog „balkanskog kasapina“}

Neuralgični srpski problemi i imaginarni klero-nacionalistički prohtjevi, odnosno zakašnjela i uvijek nanovo snažno podgrijavana srpska pravoslavna ekstaza - vrtložno zavlači i vjerski vandalizuje Njegoša. Patriotski ga lažno tetoši da bi ga ideološki lokalizovali i crkveno vezali za svoje kvazi-istorijske i post-političke, legendarne kosovske traume, satrapskom transformacijom transcedentalne poezije - $\mathrm{u}$ apsurdne crkvenjačke katakombe novovremenog posrtanja istorije! Velikom broju te apsurdne pravoslavne inteligencije i danas se pričinjaju snažno izmaštani odbljesci, vulkansko podrhtavanje u zraku od slobodarskog duha Njegoševa. Bez zdravog istorijskog rezona i minimuma građanske odgovornosti, inadžijski i autistično - drogiraju savremenost anahronizmima iz srednjeg vijeka!

Uljudni i obrazovani kulturni radnici jedino civilizacijski mogu da prate jedinstveni slobodarski duh $\mathrm{i}$ ista ili makar veoma slična etička rješenja kod, recimo, savremenika Njegoša i Ivana Mažuranića - kao uporednih i autoritativnih sudionika južnoslovenskog kulturnog ilirizma i globalnog književnog romantizma - a ne da u pseudonaučnom maniru, klonovskim ,artizmom“ obmanjuju i zavode javnost koještarijama raznim, između ostalog čak i podatkom da je Mažuranić podlo prevario Njegoša, ukrao mu i prisvojio djelo Smrt Smail-age Čengića?! Iako je Mažuranićevo djelo objavljeno 1846. godine, dakle prije Gorskog vijenca i Šćepana Malog! I niz godina prije Njegoševe smrti! Izmakao im veliki ilirski bard - a u dlaku bi ga željeli, kao recimo I. Andrića i M. Selimovića. Inače, kad su mogli ugrabiti i prisvojiti cijeloga Nje- 
goša, što da čaršijski ne pregnu da prigrabe i to jedno stvarno „primamljivo“ Mažuranićevo djelo. Po već viđenom ne ustežu se mnogo samo da bi zadobili još jedan veliki stvaralački Vijenac u svojoj fantazmagorički opterećenoj kulturi! Navodno, i lovćenskom Prometeju na čast, koju tako prljavo i dodatno ugrožavaju.

Brojnoj i tematski raznovrsnoj literaturi o Njegošu nedavno je dodata još jedna knjiga. Riječ je o zborniku radova s naučnog simpozija (održanog u Zagrebu 2013. godine): Recepcija i novo čitanje Njegoševa djela. Interdisciplinarni naučni skup je realizovan povodom dvije stotine godina od Njegoševa rođenja (u kontekstu istraživačkog i kulturno-edukativnog projekta Kulture u doticaju: stoljetni hrvatski i crnogorski književni identiteti koji je osnovan 1994. godine). Organizatori su bili Društvo hrvatsko-crnogorskog prijateljstva „Croatica-Montenegrina“ (u saradnji s Maticom hrvatskom), zatim Društvo hrvatskih književnika iz Zagreba, Institut za crnogorski jezik i književnost (danas Fakultet za crnogorski jezik i književnost). Po navodima iz „Predgovora" (autora Milorada Nikčevića, univerzitetskog profesora) ambicije su bile velike: „Cilj je bio da se (...) vrjednuje svekolika povijesna i kulturološka baština Petra II Petrovića Njegoša. Naime, željeli smo da se okvirno sagleda Njegoševo djelo u odnosu prema povijesno-kulturološkoj tradiciji Crne Gore i ostalih (ne)slavenskih zemalja te, ponajprije u književnom, jezičnom, povijesnom i kulturološkom okviru te u drugim komparativnim vidovima“. Osim što je ovaj naučni skup bio specijalistički i pozivni, da bi njegova istraživačka dimenzija, i ukupna saznajna i naučna akribija bila na nivou projektno ambiciozno zadatog cilja, organizator je definisao i potencijalnim saradnicima/ učesnicima simpozija sugerisao petnaestak posebno apostrofiranih istraživačkih cjelina, kako bi Njegoš i Crna Gora, kao i njihovo šire okruženje bili što kompleksnije i komplementarnije obuhvaćeni.

Listajući i iščitavajući ovu knjigu, svjesno sam nastojao da izbjegnem svoj inače negativan odnos prema sintagmi iz njena naslova: „,novo čitanje“. U zadnje vrijeme se sa takvim terminološkim određenjem sve češće srijećemo. U više navrata sam se uvjerio da se radilo o stilskoj pomodnosti i stvaralačkom licemjerju, kao i smišljenim simulantskim eufemizmima. Međutim, „novo čitanje“ Njegoša u ovom zborniku podrazumijeva odgovornu distancu od ideološkog i vjerskog tradicionalizma, agonalnog kvarenja poezije zarad prilagođavanja i prepravljanja istorije! Za dvadesetak autorskih priloga, koliko ih ima u Zborniku, primarno se nameće utisak da su oslobođeni onih toliko prisutnih prethodnih „kanona“ iz programskog manifesta s početka XIX vijeka: „Srbi svi i svuda“ (kasnije „,standardno“" nametnutih opštih mjesta vukovsko-belićke hibridne nauke), odnosno - bez emotivnih, vjersko-političkih i patriotskih dubioza načertanijevske kulturne istorije. 
Njegošu je mjesto u raju poezije, a ne u paklu politike

Ova knjiga se, između ostalog, na studiozan (koliko se to može) i egzaktan način bavi odnosima i simbioznostima crnogorske i Njegoševe intelektualne i literarne lične drame, njenim transponovanjem na viši nivo - ilirski i južnoslovenski. Da bi, zatim, pravoslavnu ravan tretirao kao jedinstveni i nacionalni - bolje reći oslobodilački i nadnacionalni - pojam, i njegovo koliko aktivističko, toliko i atavističko situiranje - u odnosu na sudbinski moćni i iscrpljujuće dominantni polumjesec Orijenta. Sve to, u konačnom, doživljavajući i u vaseljenskim dimenzijama generalnih kategorija dobra i zla, razmišljajući od posebnog ka opštem. Dok god pravda uspijeva da daje snažan otpor neslobodi i ugnjetavanju, ima nade da će pravda da nadvisi tiraniju. Da bi se odbranila ljudskost, njegovala humanost, poštovalo čojstvo...

Međutim, i u vrijeme sadašnje (a i ranije) Njegoša je poneko (uslovno rečeno) estetski i umjetnički htio sumnjičiti, pa i diletantski osporavati - zbog svakako izdašne zastupljenosti mita i mitologije u njegovu djelu!? - Kao da svi romantičarski preporoditelji nijesu koristili, i stvarali mitsku povijest, bez snebivanja će se naći tumačenja i odgovori na stranicama ovog zbornika. Ali i druge sublimirane i pouzdane analize: kako je Njegoš, kao jedan od vodećih romantičarskih preporoditelja - intuitivan i erudita, širokih interesovanja i u dometima univerzalne harmonije - stvaran i oplemenjivan na svojoj „kavkaskoj" podlozi, u autentičnom podneblju crnogorskom. Koje je dugo opstajalo i pretrajavalo zahvaljujući toj jedinstvenoj tradicionalnoj životnoj školi narodnoj. Zasnovanoj na jasnom životnom stavu: spontana spremnost na žrtvu za opstanak otačastva - Crne Gore, i spas bratstveničkog i plemenskog kolektiva!

Po desetak radova hrvatskih i crnogorskih autora čine štivo zbornika Recepcija i novo čitanje Njegoševa djela. S autorskim prisustvom još jednog značajnog naučnog radnika i slavističkog stručnjaka, Ukrajinke Ljudmile Vasiljeve: „Neke univerzalne posebnosti jezika poezije Njegoša, Ševčenka, Mažuranića i Janke Kupale (južnoslavenske i istočnoslavenske usporedbe)“". S tim u vezi, obavezno mi je spomenuti i Josipa Bratulića, Josipa Silića, Stjepana Damjanovića, Jakova Sabljića, Veru Blažević i Milicu Lukić, te Anu Bede, Ivanu Buljubašić i Tinu Vargu-Oswald, pa Sanju Nikčević, kao i Milorada Nikčevića (i sa hrvatske i sa crnogorske strane - čak je i zastupljen sa dva rada), ali i Božidara Petrača, koji je uzeo učešća u svojstvu predśednika Društva hrvatskih književnika. Od crnogorskih autora, stvaralačku saradnju nam nude Adnan Čirgić, Krsto Pižurica, Danilo Radojević, Radoslav Rotković, Vladimir Vojinović, Bojka Đukanović, Vesna Kilibarda, Aleksandar Radoman, Nela Savković-Vukčević, kao i posthumno Vojislav Nikčević (sa naučnim opserviranjem „Jezik Njegoševe Luče mikrokozma“). 
Uvijek se najneizvjesnije suočavati se sa istinom - jer je mnogo prijevarnih smutljivaca, onih pravih Sotoninih. Oni nasrtljivo siju i neumorno obnavljaju laž, što ima za posljedicu njeno infektivno i pandemijsko širenje. Knjiga kao „kulturno dobro od najvišeg značaja“ bi trebalo da daje veliku nadu za snaženje svijesti i ozdravljivanje savjesti. „Knjige, knjige braćo moja - a ne zvona i praporce, roditeljski je brižno, i mnogo davno svoju javnost upozoravao mudri Cincarin Dositej Obradović. Decenijama smo se nadahnjivali riječima ovog srpskog crkvenog velikodostojnika, ali uzaludno. Direktno ili indirektno, otvoreno ili posredno, velikosrpska strategija „,Zvona i praporaca" nadilazi ostalo. Jer što se kvalitetnih knjiga tiče, njih malo ko ferma, s obzirom na to da je oko 70\% ukupne populacije više ,usmeno“ nego pismeno. Po zvaničnoj statistici, njih čak toliko - u životu ne pročitaju ni po jednu knjigu! Od onih 30\% se, izgleda, većina ravna prema taktu „Zvona i praporaca“, pa nije teško procijeniti kakve su šanse za objektivnost i razložnost, $i$ istorijsku razumnost $-u$ našem ukupnom intelektualnom i demokratskom halaku. Makar da lakše dokučimo koliko je mozak sporije napredovao, te da je to samo jedan relativno razvijeni organ čovjekov...

S posebnim uvažavanjem treba doživljavati svaku nesebično pruženu ruku stvaralačke saradnje - kao u ovom slučaju odgovornog i stručnog valorizovanja i tumačenja Njegoša. S tim u vezi, borba za zdravu crnogorsku kulturnu i političku stvarnost ne bi se smjela olako shvatati, zanemarivati ili odlagati - neovisno koliko se protivnici formalno mijenjaju - ili vješto prilagođavaju. Ili (kako se ne prvi put moglo čuti): „Svaka čast Bogu, i iskrenom odnosu vjerničkom, ali u mantijama (i njihovim svjetovnim čaušima) ima mnogo naopakih i zlih ljudi, koje štiti njihovo preduzeće. 


\section{Čedomir DRAŠKOVIĆ}

\section{NJEGOŠ BELONGS TO POETRY PARADISE, NOT THE HELL OF POLITICS}

\section{(Reception and New Reading of Njegoš's Work, CKD "M-M", HCDP "Croatica-Montenegrina" RH, Faculty for Montenegrin Language and Literature, Croatian Literary Society)}

The papers from the Zagreb-Cetinje's Collection of Papers Reception and New Reading of Njegošs 's Work (2014) follow, spontaneously and without generic opposition, the creative synthesis of romantic or literary-theoretical and methodological Njegoš's vision, as well as the author's achievements in The Mountain Wreath, Śćepan Mali and The Ray of Microcosm as creative achievements of the Montenegrin spirit and being: starting from ideas, forms, historical fable, authentic gallery of characters, the mental image of characters, linguistic sublimate.

Key words: Petar II Petrović Njegoš, reception, collection of papers Reception and New Reading of Njegošs Work 

ARHIVA 



\section{Josip HAMM}

UDK 811.163.4'344.4(497.16)

\section{CRNOGORSKO T, D + JAT > Ć, Đ $^{*}$}

O tome se nejednom pisalo (Belić, Stevanović, Ivić, Pešikan, Vuković i drugi koji su se bavili crnogorskim dijalektima), pa će se nekomu možda činiti da su to repetita, no kako i repetita u nauci mogu placere, možda neće biti na odmet da se u tom pitanju čuje i moje mišljenje.

Mislim da ovdje imamo posla s problematikom koja je donekle - ali samo donekle - nalik na onu koja predstavlja odnos zapadnoslavenskoga $k v$, $g v$ prema istočnoslavenskom i južnoslavenskom $c v, z v$ (samo, razumije se, $\mathrm{s}$ drugim predznacima, u drugim kvadrantima i s drugim rezultatima). Kod $k v, g v$ radilo se o okluzivima velarnoga niza s prijelaznim $v(u)$ iza sebe, koje je inače dobro poznato iz tvorbe riječi u sufiksalnoj sekvenciji i derivaciji -ski $>$-stvo (s

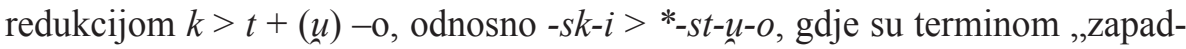
noslavenski“" obuhvaćeni i naši zapadni, npr. čakavski, govori sa svojom $f s e$, tfoj, sfoj, l'uctfo i sl.). Težište je na zapadu bilo na okluzivu, s odgovarajućim redukcijama ili punim oblicima u drugom dijelu (ispor. P. $k f$ 'jat : gv'jazda).

Kod istočnih Slavena i njihovih ogranaka, tako i kod nas kod štokavaca, ${ }^{*} u>v$ je morfolologizacijom ojačalo, težište je na nj preneseno te je, dosljedno, do redukcija dolazilo ne u drugom nego u prvom dijelu (i time do prelaženja $k, g, h \mathrm{u} c, z, s)$.

Problematika oko južnoslavenskoga $t, d+\breve{e}\left(\right.$ ili $\left.\breve{e}_{2}, \mathrm{i}_{2}\right)$, koje je u crnogorskim govorima dalo će, đe, samo je prividno i tek na prvi pogled nalik na onu o kojoj je malo prije bila riječ. Tu, u prvom redu, nije bilo prijelaznoga $v$ / $f^{1}$, što je po sebi značilo da je i cijeli proces morao biti ne samo jednostavniji i neposredniji nego da se i odvijao na drugom području s drugim tretmanom i $\mathrm{s}$ drugim predznacima. Ako se $\mathrm{kod} * \mathrm{sk} /{ }^{*} \mathrm{stf},{ }^{*} \mathrm{kv} /{ }^{*} \mathrm{kf}$ radilo o velarima koji su occasionibus dandis prelazili u dentale, ovdje se radi o dentalima koji su preko plozivnih alofona prelazili u afrikate; ako su ondje asimilacije bile progresivne, ovdje je trebalo očekivati da će biti regresivne, tako da jat po sebi utjecati na suglasnike (na $t, d$ ) ispred sebe.

\footnotetext{
Rad čuvenoga hrvatskoga jezikoslovca Josipa Hamma prilog je s naučnoga skupa Crnogorski govori koji je u organizaciji Crnogorske akademije nauka i umjetnosti održan u Titogradu 1984. godine (Josip Hamm, „Crnogorsko t, d + jat > ć, đ“, Crnogorski govori (rezultati dosadašnjih ispitivanja i dalji rad na njihovom proučavanju), Titograd, 1984, str. 79-82). Priredio ga je i strukturi časopisa prilagodio Adnan Čirgić.
} 
Tu su, međutim, mogle iskrsnuti - i iskršnjavalale su i iskršnjavaju neke razlike u shvaćanjima (i prije i danas). Jedna je od glavnih, da ě nije bilo iskonsko $e$ koje je tek poslije prelazilo u ${ }^{i} e$ (pisali ga mi ovako ili kao ${ }^{e} \ddot{a}$, ${ }^{i} \ddot{a}$ ili kako drugačije). Već je Križanić 1665. znao (v. Gram. Razd. 11) da je Konstantin Filozof (Ćiril) polazeći od grčkoga alfavita imao neprilika s bilježenjem slavenskoga fonema $e$ koje bi bilo bez jotacijskih kinema, ${ }^{1}$ a to se u još većoj mjeri odnosilo na jat koje je - možda i zbog toga - u glagoljici dobilo znak koji je bio nalik na (i izveden iz) uncijalnog A.

Što se crnogorskoga *tě, *dě > će, đe tiče, ja mislim da je tu na dioklijsko-zetskom području moglo dolaziti do sukobljavanja dviju tendencija, dviju smjerom i podrijetlom neovisnih, heterogenih artikulacija: zapadne suglasničke $\mathrm{i}$ istočne samoglasničke. One su tek zajedno dovodile do toga da je palatalni ploziv zajedno sa ě davao će, đe a ne *tje, *dje (*tie, *die) kao drugdje na jekavskom području gdje toga ploziva nije bilo. Cio proces bi, prema tome, bio običan, fonetski i alofonski, s pojačanjima u prvom dijelu i u skladu s isofonskom linijom koja se preko Stare Crne Gore protezala do područja na kojem je plozivno (dorzalno) $t$ ', $d$ ' bilo obična, u sistemu dobro motivirana, normalna pojava. Ovako bi se, uzgred govoreći, u malo riječi mogla predočiti i objasniti ova pojava koja crnogorskim govorima daje poseban značaj i posebnu draž.

$\mathrm{S}$ njom ne treba stavljati u isti red pojave ćio, ćeti za htio, htjeti (ekav. teo, teti) kod kojih kao punctum saliens ipak treba postavljati inicijalno $h$ (s retard. indikacijama i poslije njegova gubljenja) koje je u reduktivnom procesu aficiralo okluzivno $t$. Ono prema tome ne stoji ni u kakvoj, najmanje distributivnoj ili njoj sličnoj komplementarnosti s obzirom na ranije spominjano i prikazano crnogorsko *tě, *dě > će, đe.

A propos ,crnogorski“ kao termin u našoj dijalektologiji.

U Pregledu srpskohrvatskih dijalekata odobrenom kao stalni sveučilišni udžbenik za slušača Beogradskoga sveučilišta nema crnogorskih govora kao posebne dijalekatske grupe. Postoje šumadijski, šumadijsko-vojvođanski, vojvođanski i slavonski, no nema crnogorskih. Zašto? - Skiveni su pod nazivom ,zetsko-južnosandžački“. Mislim da je diskriminacija koja bi prije pristajala predratnoj malograđanštini nego progresivnom društvu kojemu je jedan od važnih zadataka da realno gleda na činjenice i da stvari postavlja na prava mjesta. Zašto onda krparenje koje ničemu ne vodi? Tko još danas (i od onih koji su pušači, i od onih koji to nisu) misli na historijsku Zetu (kako se od XI vijeka počela zvati Dioklea-Duklja)? I ako se u nju u dijalektološkom priručniku uključuju južnosandžački govori, šta je onda sa srednjosandžač-

Uzimljem ovdje kinem u značenju koje mu je dao Baudouin de Courtenay. 
Crnogorsko t, $\mathrm{d}+$ jat $>$ ć, d

kima i sjevernosandžačkima? Kuda su oni uključeni, i zašto to i u nazivima nigdje ne dolazi do izražaja. Mislim da bi najpoštenije i najpravilnije bilo, da se i crnogorski govori zovu crnogorskima, a to što oni jednim dijelom prelaze u južni Sandžak, to ne znači ništa. Opća je značajka dijalekatskih pojava da se one kod nas ne drže, i da se ni u prošlosti nisu držale administrativnih granica, mada se uvijek negdje - na nekim područjima i unutar nekih granica - nalazila njihova jezgra oko koje su se kretala žarišta lokalnih govora. U slučaju oficioznih ,zetsko-južnosandžačkih“ govora takvo je središte, nema sumnje, bila Crna Gora, pa i u tom pogledu mislim da nema razloga da se njezini govori ne nazovu „crnogorskima“ (tim više što u njima ima osobina kojih nema - ili barem strukturalno i sistemski uzeto nema - u drugim susjednim ili udaljenijim govorima).

Treba se uopće kloniti naziva i termina koje ne razjašnjavaju nego zamagljuju. Ja takvim smatram i opći naziv „srpskohrvatski/hrvatskosrpski dijalekti“ u Fonološkim opisima za OLA u izdanju ANU BiH godine 1981. Jedno je književni jezik koji u sebi može sadržavati i dva i tri standarda (kao što je to u engleskom, francuskom, španjolskom, pa i njemačkom), a drugo su dijalekti kao matice koje utječu na oblikovanje, razvitak i diferencijacije svojih - ističem „svojih - standarda. Kod nas govoriti o čakavskih i kajkavskim govorima kao o dijalektima srpskoga jezika više je nego nenaučno, a isto bi tako nenaučno bilo govoriti o torlačkim i šopskim govorima kao o prijelaznim dijalektima hrvatskoga jezika. Osim toga - obično se, kao što rekoh: s pravom - govori o tome da se dijalekti i govori ne drže administrativnih granica, pa kako to onda da se obilježja i simboli u spomenutim Fonološkim opisima i prema Sloveniji i prema Makedoniji točno drže političko-administrativnih granica? Zar tu nema baš nikakvih prijelaznih govora? Ili, ako ih ima, zašto i oni nisu ušli u mreže punktova, kada je sa općelingvističkog stajališta poznato da su upravo ona područja najzanimljivija na kojima dolazi do sukobljavanja i pronicanja jednih tradicija i osobina u druge. Čemu onda dvostruke mjere i dvostruki kriteriji? - Dovoljno je vidjeti i ispitati, kako je OLA maćuhinski predstavljena Vojvodina.

Kao što se vidi, u južnoslavenskoj je dijalektologiji još dosta pitanja koja bi mogla i trebala da budu predmet ozbiljne i objektivne naučne diskusije. 



\section{Miroslav ĐUROVIĆ}

UDK 821.163.4=(1.497.16)(091)

\section{OTKUD CRNOGORCI U ISTORIJI SRPSKE KNJIŽEVNOSTI JOVANA DERETIĆA?*}

U godini, koja je upravo zaminula, beogradski Nolit objavio je jednu tematski prijeko potrebnu i značajnu knjigu - Istoriju srpske književnosti, čiji je autor univerzitetski profesor i književni istoričar Jovan Deretić. Recenzenti knjige što se u biblioteci Sinteze pojavila pod uredništvom Borislava Radovića (glavni i odgovorni urednik Miloš Stambolić) su: dr Radmila Marinković, dr Nada Milošević-Đorđević, dr Vaso Milinčević, i dr Petar Milosavljević. Knjiga predstavlja ambiciozan poduhvat, na blizu sedam stotina stranica dat je pregled Srpske književnosti od najstarijih vremena do danas. Riječ je, znači, o knjizi koja se ne piše svake godine i iz koje će učiti sadašnje i buduće generacije učenika i studenata (i ne samo oni) pa je ukoliko potrebnije kritičko razmatranje ovog poduhvata. Naravno, unaprijed smo svjesni složenosti pisanja istorije književnosti jednog naroda, pa i ove Deretićeve. Međutim, ovom prilikom, nećemo se baviti vrijednostima ove knjige, ni brojnim pitanjima koja ona otvara. Niti nam to dopušta prostor dnevnog lista. Ukazaćemo samo na izvjesne aspekte u vezi sa Deretićevim određivanjem pisaca srpskoj literaturi.

U „Uvodu“ svoje Istorije srpske književnosti Deretić ukazuje na brojne teškoće koje vrebaju istoričara književnosti i, kritički se osvrćući na neka dosadašnja rješenja, pored ostalog, kaže: „Podela u okviru novih književnosti izvršena je po nacionalnom ključu, na novu srpsku, hrvatsku, slovenačku i makedonsku književnost. U poslednje vreme (podvukao M. Đ.) govori se i o crnogorskoj i o bosansko-hercegovačkoj literaturi“. Za prvi kriterij za razgraničenje među literaturama, Deretić uzima jezik, pa kaže: „Poznato je da na jeziku kojim se piše srpska književnost, tj. na srpskohrvatskom jeziku, postoje i druge književnosti“. Po njemu, novu srpsku književnost obilježavaju ekavski i ijekavski izgovor. Ističući da su zajedništvo i preplitanje literatura činjenica, on dalje piše: ,Jezičko jedinstvo naše literature nije ništa manje legitimno od nacionalnog. Prvo se, uz to, može sasvim egzaktno utvrditi što se za drugo ne može reći. Nama je danas sasvim lako utvrditi je li kakvo delo pisano na srpskohrvatskom ili nije, ali nam nije uvek lako odrediti kojoj književnosti ono

* Tekst „(Ne)jasni kriterijumi - Otkud Crnogorci u Istoriji srpske književnosti Jovana Deretića“ objavljen je u Pobjedi (god. 40, br. 6504, str. 9) 1984. godine. Priredio ga je i strukturi časopisa prilagodio Nikola Popović. 
pripada“. Drugi kriterij koji „obezbeđuje jedinstvo određene nacionalne literature jeste razvojni kontinuitet", u kojem je dominantna ,svest o nacionalnoj pripadnosti književnosti“. To su, uglavnom, Deretićeve odrednice za pripadnost (i nepripadnost) pisaca određenoj nacionalnoj literaturi, $u$ ovom slučaju srpskoj. Pisac Istorije ne govori o nacionalnoj pripadnosti i osjećanjima samih pisaca. Da vidimo sada, na nekolikim primjerima, kako je Deretić svrstavao i razvrstavao pisce u svojoj Istoriji srpske književnosti.

Nećemo govoriti o Ljetopisu Popa Dukljanina, ni o Starcu Miliji iz Kolašina (od koga je Vuk zabilježio četiri pjesme koje spadaju u najljepša ostvarenja naše narodne epike: Banović Strahinja, Ženidba Maksima Crnojevića, Sestra Leke Kapetana, i Gavran harambaša i Limo), ni o Starcu Rašku, takođe, ,rodom iz Kolašina“, „koji je dobežao u Srbiju“, od koga je Vuk zapisao deset epskih pjesama, ni o vojvodi i književniku Marku Miljanovu, koga on pominje u vezi sa tzv. herojskom anegdotom u retku i po: „Marko Miljanov dao je ovoj vrsti klasičan oblik u svom delu 'Primjeri čojstva i junaštva'“". Reći ćemo neku riječ o onim piscima o kojima u svojoj Istoriji srpske književnosti pisao Jovan Deretić i pomenuti neke od onih koje on nije spomenuo.

U svoju Istoriju srpske književnosti Deretić je unio i Petra I Petrovića Njegoša, Petra II Petrovića Njegoša, Rista Ratkovića, Mihaila Lalića, Radovana Zogovića, Mirka Banjevića, Janka Đonovića, Nikolu Lopičića, Dušana Đurovića, Dušana Kostića, i druge. Otkud ovi pisci onamo?

U pododjeljku Pokret socijalne literature XV odjeljka „Angažovana literatura i zaokret prema realizmu“, pisac Istorije na početku teksta o Radovanu Zogoviću kaže ovo: „Posebnu skupinu u beogradskom krugu čine crnogorski socijalni pisci. Više nego kod ostalih, kod njih su, uz zajedničke ideje i književne programe, delovali i drugi činioci, istorijski, folklorni, zavičajni“". O Laliću se takođe, govori kao o crnogorskom piscu. U pasusu o Mirku Banjeviću, Janku Đonoviću i Nikoli Lopičiću pisac pominje „etos Crnogoraca“, o Kostiću kaže da je „,crnogorski lirik“ itd. O Njegošu, naravno, ni o Petru Prvom, u tom smislu, ni riječi. Čak ni podsjećanja na riječi Svetozara Markovića od prije sto i više godina: „... naš ili upravo crnogorski pesnik Petar Petrović Njegoš“. Ali Svetozarovo vrijeme davno bješe...

Zanima nas po čemu je jedne crnogorske pisce uzeo u svoju Istoriju, istoričar književnosti Deretić a druge ne? Kamo su nestali crnogorski pisci (iliti pisci iz Crne Gore) o kojima u Deretićevoj knjizi nema ni pomena? Kamo je nestao Stevan Perović Cuca? Šta je, na primjer, sa značajnim jugoslovenskim pripovjedačem i romansijerom Ćamilom Sijarićem, jer je i on rodom iz Crne Gore, a živi u Sarajevu, kao i Đušan Đurović, koji je zastupljen? Čak je Sijarić i neke svoje knjige posvetio temama iz istorije srpskog naroda, ali mu to nije pomoglo. Po kriterijumu J. Deretića mogli su u Srbe da uđu i među- 
ratni crnogorski pisci Radosav Ljumović i Vukajlo Kukalj? Pjesnik i prozaist Radonja Vešović, koji od rata živi i stvara u Beogradu? Čedo Vuković, Blažo Šćepanović i Sreten Asanović, koji su djelovali i u Beogradu.

Kako da u Deretićevoj „skupini“" nema ni slova imena: Žarka Đurovića, Bogdana Šeklera, Ivana Cekovića, Miladina Ćulafića, Aleksandra Sekulića, Momčila Paraušića, Radoslava Pajkovića, koji žive i pišu u Beogradu? Gdje su još toliki crnogorski pisci koji su, ako ništa drugo, studirali i živjeli u Beogradu (i drugdje), učestovali i danas učestvuju u ondašnjem književnom životu kada se Deretić već služi „beogradskim ključem“. S druge strane, zanima nas šta o svojem mjestu u Istoriji srpske književnosti misle zastupljeni živi crnogorski pisci, a mrtvi su mislili šta su mislili.

Gdje su u Istoriji srpske književnosti, bože mi oprosti, beogradske noćobdije, pjesnici, megdandžije i hodočasnici: Antun Gustav Matoš, (koji u Istoriji nije ni spomenut), Tin Ujević, Gustav Krklec, pa i Miroslav Krleža, kada su već u ovoj knjizi obrađeni Vladan Desnica, Dušan Jerković, Stevan Galokaža i drugi pisci Srbi iz Hrvatske? Zašto uz bosanskohercegovačke pisce Borivoja Jevtića, Hamzu Huma i Isaka Samokovliju nijesu i Zija Dizdarević, Mak Dizdar i Izet Sarajlić? Kud se djenuo Novak Simić, rodom iz Bosne, koji je živio i stvarao u Hrvatskoj itd?

U svojem Uvodu Istoriji, Deretić, pored ostalog, kaže i ovo: „Mi možemo danas govoriti ne samo o jugoslovenskim nacionalnim literaturama kao o zasebnim pojavama, nego i o književnosti srpskohrvatskog jezika i o jugoslovenskoj književnosti kao i složenim celinama“. Zašto u kreiranju svoje Istorije Deretić nije bio dosljedniji meditacijama iz Uvoda? Onda bismo, možda, dobili Istoriju književnosti srpskohrvatskog jezika. Otkuda, inače, crnogorski pisci po drugi put među Srbima, u Deretićevoj Istoriji. Ili, možda greškom knjiga nije nazvana Istorija srpske i crnogorske književnosti? 



\section{KRITERIJUMI ZA PRIHVATANJE RADOVA I UPUTSTVA SARADNICIMA}

Časopis Lingua Montenegrina objavljuje prevashodno rezultate originalnih filoloških i kulturoloških naučnih ispitivanja, ali i preliminarna saopštenja te pregledne naučne i stručne radove. Pored toga, objavljuju se i recenzije i prikazi knjiga, časopisa, naučnih i stručnih skupova.

Radovi koji su prethodno objavljeni u drugim publikacijama, ili su u postupku recenzije za objavljivanje u njima, ne mogu biti prihvaćeni za objavljivanje. Ukoliko autor u ponuđeni rukopis uvrsti djelove materijala koji je prethodno objavio, takav sadržaj dužan je citirati ili označiti na drugi način. Autori su takođe dužni eksplicitno navesti izvore svih ideja u radu preuzetih od drugih, bez obzira na to radi li se o objavljenim, neobjavljenim ili elektronski dostupnim materijalima.

Odluku o tome da li će rukopis ponuđen za objavljivanje biti prihvaćen Redakcija zasniva na ocjeni recenzenata, na osnovu koje se vrši i kategorizacija radova. Objektivnost i anonimnost recenzije obezbjeđuju se time što recenzenti prilikom ocjenjivanja radova nemaju informacije o njihovu autoru, kao što ni autori nemaju podatke o recenzentima.

Časopis Lingua Montenegrina izlazi na crnogorskome ili drugom slovenskome jeziku, kao i na nekom od svjetskih jezika (engleski, njemački, ruski, francuski itd).

1. Izvorni naučni rad (Original scientific paper) sadrži neobjavljivane rezultate izvornih teorijskih ili praktičnih ispitivanja koje je autor korektno naveo tako da se mogu provjeriti njihova tačnost i tačnost analiza.

2. Preliminarno saopštenje (Preliminary communication) sadrži građu ili naučne podatke koji zahtijevaju brzo objavljivanje.

3. Pregledni rad (Review) jeste kritički i analitički pregled nekog područja ispitivanja ili jednog njegova dijela. U članku treba biti vidan autorov doprinos izučavanju izabrane problematike, a citirana literatura mora biti cjelovita.

4. Stručni rad (Professional paper) informiše i uvodi u problematiku struke bez pretenzija da bude plod naučnoga istraživanja.

U gornjem lijevom uglu potrebno je istaći: ime i prezime autora, instituciju u kojoj je zapošljen, grad i e-mail adresu. 
Naslov rada mora biti kratak i jasan. Rad treba da sadrži sažetak do 200 riječi i 4-8 ključnih riječi. Naslov rada, sažetak i ključne riječi potrebno je prevesti na engleski jezik.

Redakcija zadržava pravo da u bilo koji segment rada unese neophodne tehničke i slične izmjene.

Rukopisi i CD se ne vraćaju.

Redakcija 


\section{PAPER SUBMISSION AND ACCEPTANCE CRITERIA}

Lingua Montenegrina publishes primarily the results of original philological and cultural scientific researches, as well as preliminary communications, and scientific and professional papers. In addition, book reviews are published, as well as reviews of magazines, and scientific and professional conferences.

Papers that have been previously published or submitted for publication elsewhere may not be published in Lingua Montenegrina. Where the paper submitted contains materials overlapping with the previously published works of his/her own, the Author must cite these works in his/her paper. Authors are also obliged to explicitly state the origin of all the materials and ideas authored by others in their work, regardless of whether such materials were previously published or not.

The decision of the Editorial Board on whether the paper is to be accepted for publication, as well as the classification of papers accepted for publication, is based on the evaluation of Reviewers. Objectivity of the Reviewer's decision-making is ensured through a double-blind review process, whereby the Reviewers do not know the Authors and vice-versa.

1. Lingua Montenegrina is published in the Montenegrin and other Slavonic languages, as well as in internationally spoken languages (English, German, Russian, French, etc).

2. Original scientific papers contain unpublished results of original theoretical or practical researches. Its authors must list all the inputs and information in such a manner that the accuracy of the data provided and the analysis carried out may be verified.

3. Preliminary communications contain the materials or the scientific data that need to be published urgently.

4. Reviews are critical and analytical overviews of a field of study or a part thereof. Articles must contain author's contribution to the study of selected problem area, while the quoted literature must be comprehensive.

Professional papers aim to provide information and introduce a field of study or problem area, while the author does not aspire to conduct a detailed scientific research of the subject matter. 
In the upper left corner of a paper, all the authors should note: the author's first and last name, his/her affiliation, place of residence, and e-mail address.

Titles should be concise and clear. Each paper should contain an abstract of up to 200 words, and 4-8 key words.

The Editorial Board reserves the right to make any necessary technical and similar changes to the papers.

Manuscripts and CDs will not be returned.

The Editorial Board 


\section{SADRŽAJ}

\section{Илија ВЕЛЕВ}

Св. Константин-Кирил и Методиј како афирматори на словенската цивилизација, култура и писменост

Miomir ABOVIĆ

Ekstenzija značenja kod prijedloga; neprimarno

značenje prijedloga osim, pored, kod, kraj, mimo

i prijedloga $d o \mathrm{u} \mathrm{b/cg/h/s} \mathrm{jeziku}$

Novica VUJOVIĆ

Dijalekatski rječnici i njihov značaj

Miloš KRIVOKAPIĆ

Upotreba veznika u jeziku serdara i guvernadura

Radonjića (1706-1828) i u crnogorskim govorima

Milica LUKIĆ \& Vera BLAŽEVIĆ-KREZIĆ

Parčićeva koncepcija obnove staroslavenskih

liturgijskih knjiga u XIX stoljeću

Loretana FARKAŠ \& Silvija ĆURAK

Klaićevo Bizovačko narječje i današnji

podravski govori slavonskog dijalekta

Tanja BREŠAN-ANČIĆ

Pravopisna previranja u Dalmaciji

60-ih i 70-ih godina 19. stoljeća

Marijana TERIĆ

Rukopis dr Jovana Kujačića iz 1950. godine

Vukota BABOVIĆ

Beśede o Lelejskoj gori 125 
Danilo RADOJEVIĆ

Savić Marković Štedimlija

o Njegošu i Crnoj Gori njegova vremena

143

Sofija KALEZIĆ-ĐURIČKOVIĆ

Crnogorska književnost za djecu

i omladinu: odlike i predstavnici

Anka VUČINIĆ-GUJIĆ

Poetičke dominante Triptihona

iz nacionalne biblioteke Mladena Lompara 205

Lejla VESKOVIĆ

Nova crnogorska književnost kao

hronika posljednjih balkanskih ratova

Vladimir VOJINOVIĆ

Novo čitanje crnogorske usmene proze

Tijana RAKOČEVIĆ

Poslanice Petra I kao estetski proizvod

Sanja VOJINOVIĆ \& Marko DRAGIĆ

Značaj tradicije u prozi Mirka Kovača

Milorad NIKČEVIĆ

Teorijsko-metodološke refleksije o književnoj

tradiciji i teoriji literarnih / kulturoloških uticaja, veza i odnosa

Sreten ZEKOVIĆ

Je li Njegoševa mudrost eklektika, sinkretizam,

zvanično hrišćanstvo i u službi konzervativnog starog poretka? 307

Ethem MANDIĆ

Pojam igre u romanu Školice Hulija Kortasara

Lucijana ARMANDA

Kako vidimo druge: Amerikanci u hrvatskim dramama 
Marko EK \& Tina VARGA-OSWALD

Nádasev doprinos „retorici postmoderne“

u romanu Divna povijest fotografije 375

\section{GRAĐA}

Zlata ŠUNDALIĆ \& Anela MATELJAK POPIĆ

Vjerska knjiga u Slavoniji 18. stoljeća 393

Novica VUJOVIĆ

Prilog izradi imenoslova Pive 433

\section{PORTRETI}

Aleksandar RADOMAN

In memoriam: Milorad Stojović 449

Adnan ČIRGIĆ

Dragomir Vujičić i crnogorska dijalektologija

Novica VUJOVIĆ

Alija Džogović onomastičar 465

\section{PRIKAZI}

Aleksandar RADOMAN

Kapitalna sinteza makedonskoga književnog srednjovjekovlja 475

Nikola POPOVIĆ

Vrijedan doprinos crnogorskoj komparatistici i njegošologiji 481

Marijana TERIĆ

Poetika romana Mihaila Lalića Krsta Pižurice 485

Čedomir DRAŠKOVIĆ

Njegošu je mjesto u raju poezije, a ne u paklu politike 491 
ARHIVA

Josip HAMM

Crnogorsko t, $d+$ jat $>$ ć, d 501

Miroslav ĐUROVIĆ

Otkud Crnogorci u Istoriji srpske književnosti Jovana Deretića? 505 


\section{TABLE OF CONTENTS}

\section{Ilija VELEV}

St. Cyril and Methodius as Proponents

of Slavic Civilization, Culture and Literacy

Miomir ABOVIĆ

Extension of Meaning of Prepositions: Non-Primary Meanings

of Prepositions Osim, Pored, Kod, Kraj, Mimo and Do

in the Bosnian, Montenegrin, Croatian and Serbian Language

25

Novica VUJOVIĆ

Dialect Dictionaries and Their Significance

Miloš KRIVOKAPIĆ

Use of Conjunctions in the Language of Serdars

and Gubernators Radonjić (1706-1828)

and in Montenegrin Speech Patterns

Milica LUKIĆ \& Vera BLAŽEVIĆ-KREZIĆ

Parčić's Concept of Reconstruction of Old-Slavic

Liturgical Books in the $19^{\text {th }}$ Century

Loretana FARKAŠ \& Silvija ĆURAK

Klaić's Bizovačko Narječje and Contemporary

Podrava's Speech Patterns of the Slavonian Dialect

Tanja BREŠAN-ANČIĆ

Orthographic Turmoil in Dalmatia in 1860s and 1870s ............................. 97

Marijana TERIĆ

Jovan Kujačić's Manuscript of 1950

Vukota BABOVIĆ

Discussions of Lelejska Gora (The Wailing Mountain) 125 
Danilo RADOJEVIĆ

Savić Marković Štedimlija

on Njegoš and Montenegro of his Time

Sofija KALEZIĆ-ĐURIČKOVIĆ

Montenegrin Literature for Children and Youth

(Features and Representatives) 161

Anka VUČINIĆ-GUJIĆ

Poetic Characteristics of Mladen Lompar's

Triptych from the National Library

Lejla VESKOVIĆ

New Montenegrin Literature as a

Chronicle of Recent Balkan Wars

Vladimir VOJINOVIĆ

New Reading of Montenegrin Oral Prose

Tijana RAKOČEVIĆ

Epistles of Petar I as an Aesthetic Product

Sanja VOJINOVIĆ \& Marko DRAGIĆ

Importance of Tradition in Mirko Kovač's Prose

Milorad NIKČEVIĆ

Theoretical-Methodological Reflections on

Literary Tradition and Theory of Literary /

Culturological Influences, Relations and Correlations

\section{Sreten ZEKOVIĆ}

Does Njegoš's Wisdom Constitute Eclecticism,

Syncretism, and Official Christianity,

Supportive of Conservative "Old Order"? 307

Ethem MANDIĆ

Notion of Game in Rayuela by Julio Cortazar

Lucijana ARMANDA

How We See Others: Americans in Croatian Plays 
Marko EK \& Tina VARGA-OSWALD

Nádas's Contribution to Postmodern Rhetorics

in the Novel A Lovely Tale of Photography 375

\section{MATERIAL}

Zlata ŠUNDALIĆ \& Anela MATELJAK POPIĆ

Religious Books in $18^{\text {th }}$ Century Slavonia

Novica VUJOVIĆ

A Contribution to Piva's Nomenclator 433

\section{PORTRAITS}

Aleksandar RADOMAN

In memoriam: Milorad Stojović (1927-2015) 449

Adnan ČIRGIĆ

Dragomir Vujičić and Montenegrin Dialectology

Novica VUJOVIĆ

Alija Džogović as an Onomasticist 465

\section{REVIEWS}

Aleksandar RADOMAN

Capital Synthesis of Macedonian Literary Medieval Period 475

Nikola POPOVIĆ

A Valuable Contribution to Montenegrin

Comparative Studies and Study of Njegoš 481

Marijana TERIĆ

Poetics of Mihailo Lalić's Novels by Krsto Pižurica 485

Čedomir DRAŠKOVIĆ

Njegoš Belongs to Poetry Paradise, Not The Hell of Politics 491 
ARCHIVE

Josip HAMM

Montenegrin $\mathrm{t}, \mathrm{d}+\mathrm{jat}>\mathrm{c}, \mathrm{d}$ 501

Miroslav ĐUROVIĆ

How Montenegrins Were Found in

The History of Serbian Literature by Jovan Deretic?

505 
Lingua Montenegrina
časopis za jezikoslovna, književna i kulturna pitanja

lingua.montenegrina@fcjk.me

Izdavač

Fakultet za crnogorski jezik i književnost - Cetinje

Glavni i odgovorni urednik

Adnan Čirgić

Za izdavača

Milenko A. Perović

Lektura i korektura

Nikola Popović

Sanja Orlandić

Prijelom

Milutin Marković

Štampa

Grafo Bale

Tiraž

500 
Časopis Lingua Montenegrina uvršten je u međunarodnu bazu časopisa s otvorenim pristupom

DOAJ (www.doaj.org)

СIP - Каталогизација у публикацији

Централна народна библиотека Црне Горе, Цетиње

$81(497.16)$

LINGUA Montenegrina : časopis za jezikoslovna, književna i kulturna pitanja $=$ Lingua Montenegrina : the magazin of linguistic, literary and cultural issues / urednik Adnan Čirgić. - Br. 1 (2008) - . - Podgorica (Bulevar Mihaila Lalića 1) : Institut za crnogorski jezik i književnost, 2008 (Cetinje : IVPE). $-24 \mathrm{~cm}$

Dva puta godišnje.

ISSN 1800-7007 = Lingua Montenegrina (Cetinje)

COBISS.CG-ID 12545808

Časopis je registrovan u Ministarstvu kulture, sporta i medija Crne Gore (br. $05-2951 / 2$ ) 